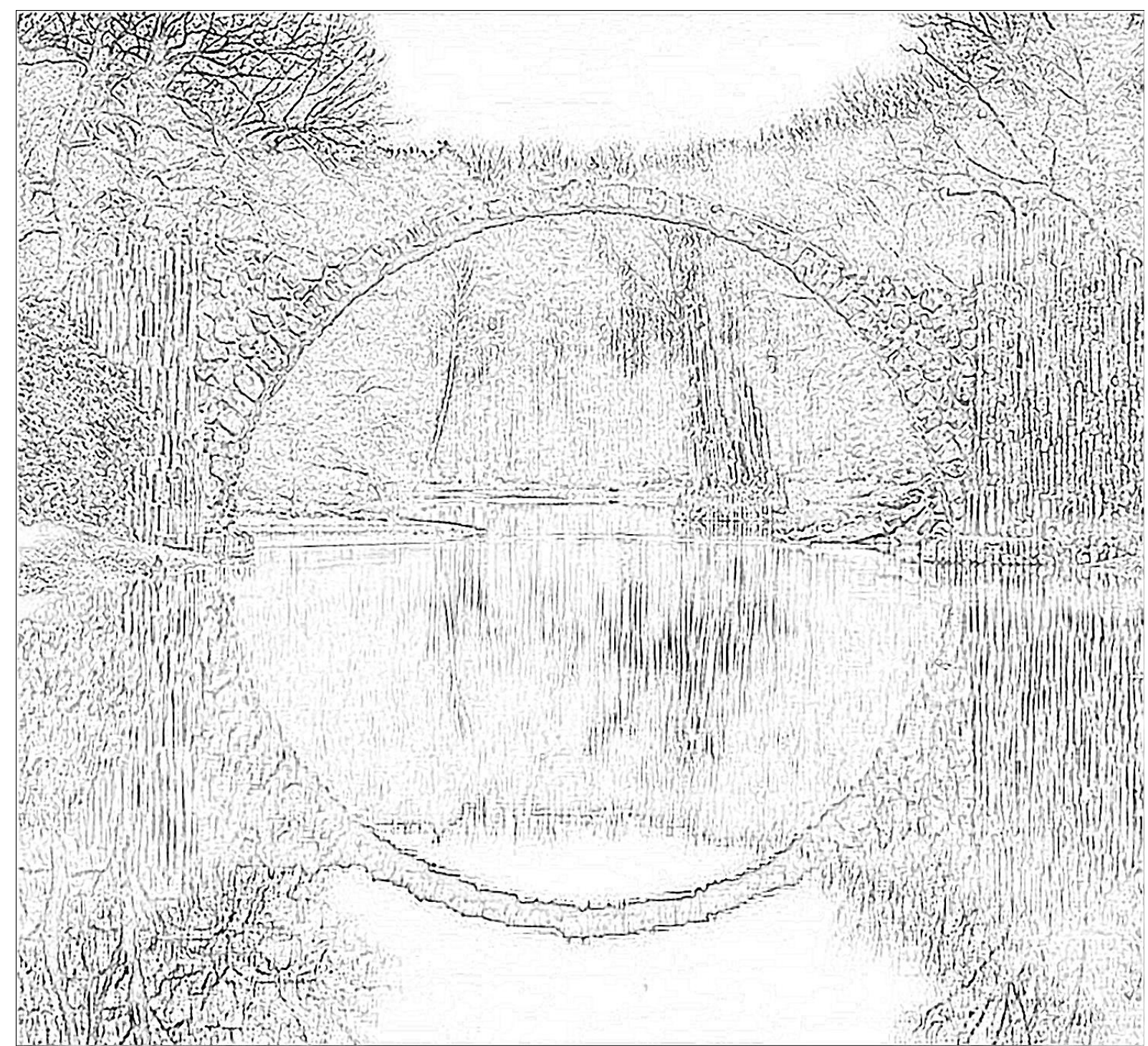

\title{
Estudos para uma definição de estética ecotécnica na arte, arquitetura e infraestruturas
}

\section{Guilherme Kujawski Ramos}

São Carlos

2019 

GUILHERME KUJAWSKI RAMOS

\section{Estudos para uma definição de estética ecotécnica na arte, arquitetura e infraestruturas}

(Versão corrigida)

Tese apresentada ao Instituto de Arquitetura e Urbanismo da Universidade de São Paulo para obtenção do título de Doutor em Ciências

Programa de Pós-Graduação em Arquitetura e Urbanismo Área de Concentração: Teoria e História da Arquitetura e Urbanismo Orientador: Prof. Dr. Ruy Sardinha Lopes 
Autorizo a reprodução e divulgação total ou parcial deste trabalho, por qualquer meio convencional ou eletrônico, para fins de estudo e pesquisa, desde que citada a fonte.

E-MAIL DO AUTOR: kujawski@gmail.com

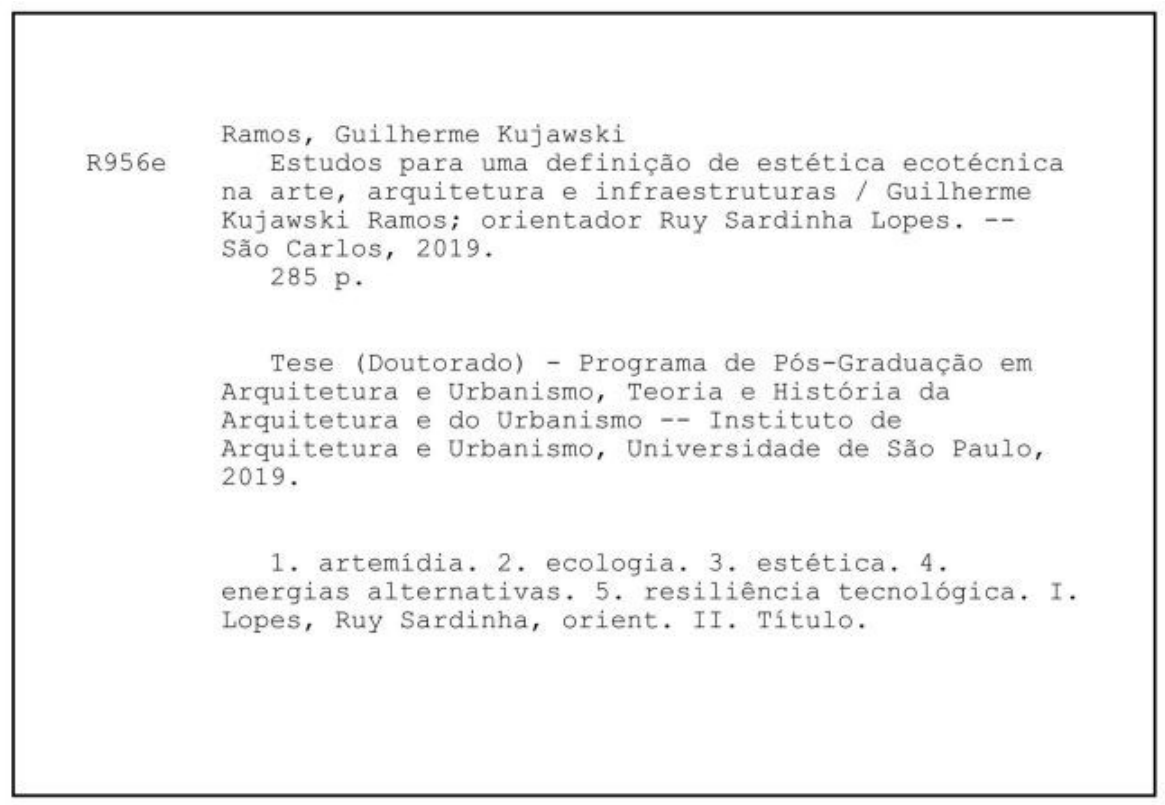




\section{FOLHA DE JULGAMENTO}

Candidato(a): Guilherme Kujawski Ramos

Título da tese: "Estudos para uma definição de estética ecotécnica na arte, arquitetura e infraestruturas"

Data da defesa: 06/08/2019

Orientador: Prof. Dr. Ruy Sardinha Lopes

Comissão Julgadora:

$\underline{\text { Resultado: }}$

in 217

Prof. Dr. Ruy Sardinha Lopes

Não votante

(IAU/USP)

Prof.Dr. João Marcos de Almeida Lopes

(IAU/USP)

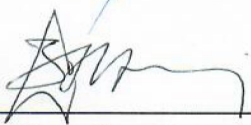

Profa. Dra. Luciana Bongiovanni Martins Shenk

$\operatorname{porada}$ (IAU/USP)
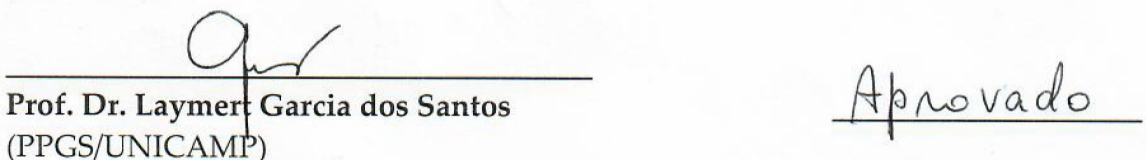

8) $920 \mathrm{~h} / \mathrm{O}$

Profa. Dra. Silvana de Souza Ramos (FFLCH/USP)

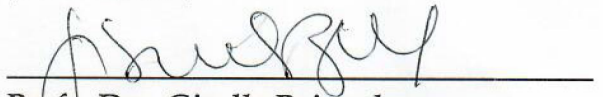

Profa. Dra. Giselle Beiguelman (FAU/USP)
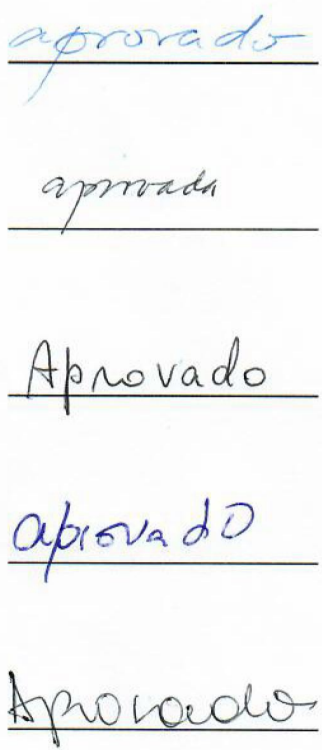

Coordenador e Presidente da Comissão de Pós-Graduação do Programa de PósGraduação em Arquitetura e Urbanismo: Prof. Dr. Tomás Antonio Moreira. 



\section{AGRADECIMENTOS}

À Coordenação de Aperfeiçoamento de Pessoal de Nível Superior (CAPES), pelo financiamento da pesquisa.

Ao meu orientador, Ruy Sardinha Lopes, por sua participação imprescindível na condução do presente trabalho.

Ao grupo de pesquisa NEC (Núcleo de Estudos das Espacialidades Contemporâneas), em especial Ruy Sardinha Lopes, David Sperling e Fabio Lopes de Souza Santos.

À Letícia Godoy, minha querida companheira de vida. 
"Devemos mudar nossa maneira de ver — para chegar finalmente, talvez demasiado tarde, a mudar nossa maneira de sentir" (NIETZSCHE 2008, A 103) 

RESUMO

O trabalho discute, por meio de método indutivo-descritivo, a hipotética existência de uma estética ecotécnica, dentro do horizonte das atuais discussões sobre sustentabilidade e resiliência. Em termos teóricos, compreende uma reflexão sobre a sua gênese, ponderando que ela seja o produto de uma comunhão entre os pensamentos tecnológico e ecológico. Em termos práticos, procura mapear não inovações, mas invenções em setores de infraestruturas, estruturas arquitetônicas e artemídias de cunho ecológico. A linha de investigação, portanto, engloba um amplo espectro estético, concentrando-se na produção de artistas, coletivos, teóricos de design e institutos acadêmicos envolvidos na pesquisa de suportes arquitetônicos vivos, redes autônomas de telecomunicações, sistemas computacionais não convencionais, eficiência energética, tecnologias de sensoriamento remoto de fenômenos naturais e revitalizações da chamada arte ecológica. Tem como objetivo geral proporcionar uma empatia com as técnicas low tech, sem subestimar os avanços tecnológicos da atualidade, mas preconizando o refreamento do uso intensivo de recursos, ou seja, a substituição da necessidade extensiva do crescimento econômico por um princípio de suficiência.

Palavras-chave: artemídia, ecologia, estética, energias alternativas, resiliência tecnológica 



\begin{abstract}
The thesis discusses, through a inductive-descriptive method, the hypothetical existence of an ecotechnic aesthetics, within the horizon of the current discussions about sustainability and resilience. In theoretical terms, it comprises a reflection on its genesis, considering that it is the product of a communion between the technological and ecological thoughts. In practical terms, it seeks to map not innovations, but inventions in sectors of infrastructure, architectural structures and media art expressions of ecological nature. The research line therefore encompasses a broad aesthetic spectrum, focusing on the production of artists, collectives, design theorists and academic institutes involved in the research of living architectural supports, autonomous telecommunication networks, unconventional computating systems, energy efficiency, technologies of remote sensing of natural phenomena and revitalizations of so-called ecological art. Its general objective is to provide an empathy with low tech techniques, without underestimating the current technological advances, but recommending the retention of the intensive use of resources, or, in other words, the substitution of the extension necessity of economic growth for a principle of sufficiency.
\end{abstract}

Keywords: media art, ecology, aesthetics, alternative energies, technological resilience 
SUMÁRIO

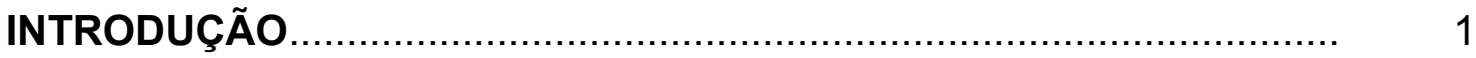

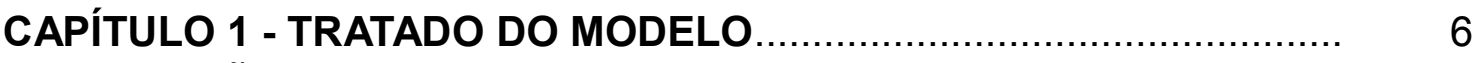

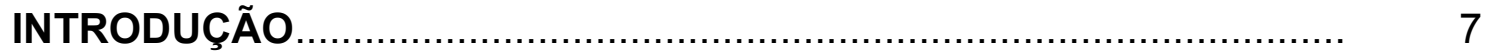

1.10 PENSAMENTO ECOLÓGICO............................................... 18

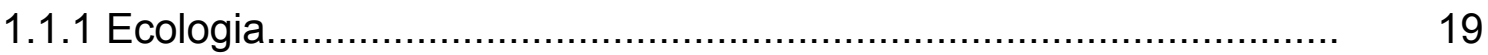

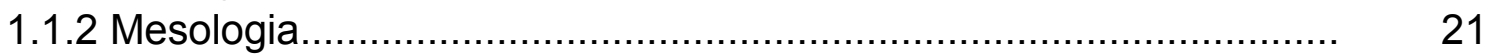

1.1.3 Teorias do meio............................................................ 23

1.1.3.1 Entorno............................................................................ 25

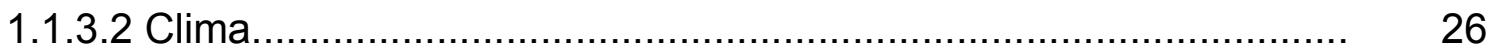

1.1.3.3 Paisagem ..................................................................... 27

1.2 O PENSAMENTO ESTÉTICO ............................................. 29

1.2.1 Construção e fenômeno...................................................... $\quad 30$

1.2.1.1 Construtivismo: forma e autoforma...................................... 31

1.2.1.2.1 Horizonte e profundidade.................................................. $\quad 35$

1.2.1.3 Fenomenologia: percepção e sensório.................................... 37

1.3 O PENSAMENTO TECNOLÓGICO............................................. 40

1.3.1 Tecnologia e cultura............................................................... 42

1.3.2 Tecnopoiética.................................................................... 44

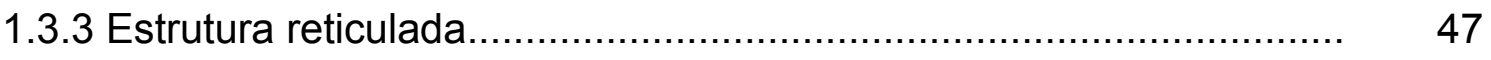

1.3.4 Limites dinâmicos..................................................................... 49

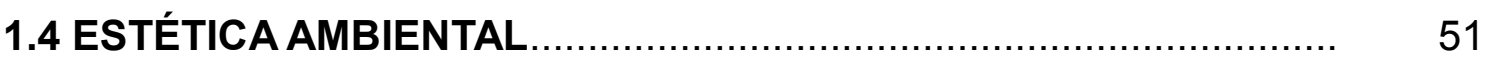

1.4.1 Novos modelos....................................................................... 52

1.4.1.1 Modelo cognitivo.......................................................... 54

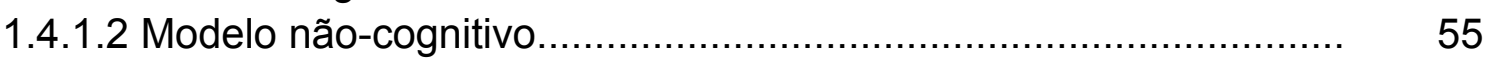

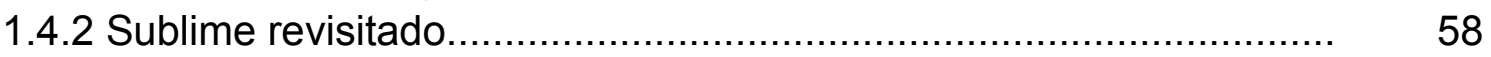

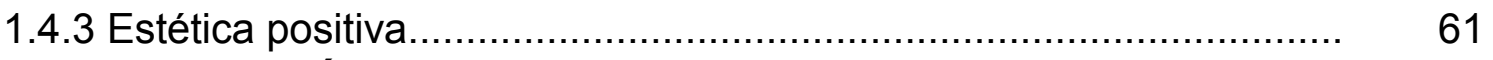

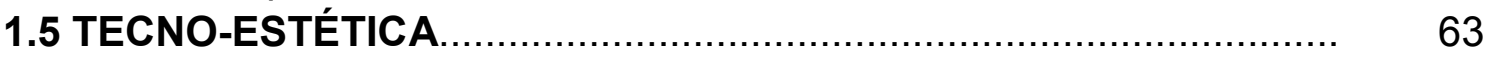

1.5.1 Categoria técnica.............................................................. 64

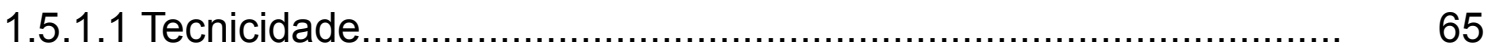



1.5.1.3 Indivíduos.................................................................... 67

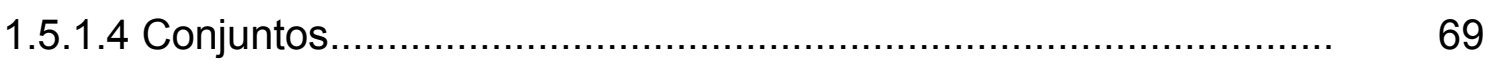

1.5.2 Categoria estética............................................................... 71

1.6 ESTÉTICA ECOTÉCNICA ...................................................... 74

1.6.1 Sistemas genéticos.............................................................. 77

1.6.2 Especificações................................................................. 79

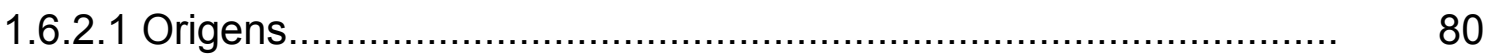

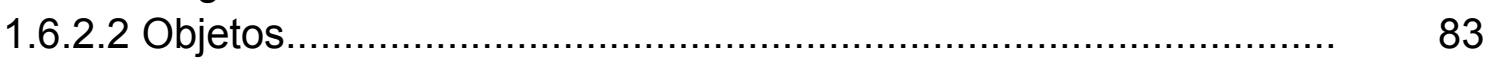

1.6.2.3 Funcionamento e função............................................... $\quad 85$

1.6.2.4 Estrutura figura-fundo................................................ 87 


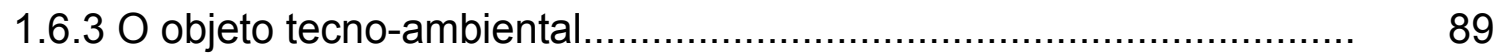

CAPÍTULO 2 - ESTÉTICA ECOTÉCNICA E ARTE................................. 93

INTRODUÇÃO....................................................................... 94

2.1 HIPOTÉTICA GÊNESE DE UM GÊNERO HIPOTÉTICO..................... 98

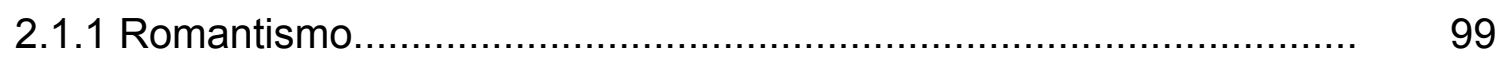

2.1.2 Environmental art................................................................... 103

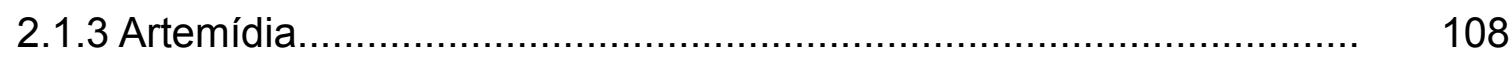

2.1.4 Considerações........................................................................... 114

2.2 O COMPLEXO ARTE-ARQUITETURA ......................................... 115

2.2.1 Arquitetura expandida.............................................................. 117

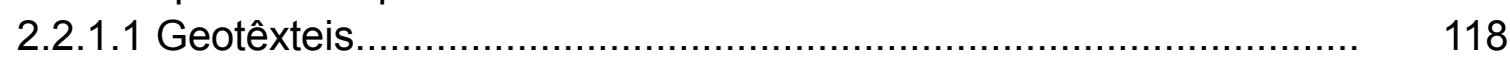

2.2.1.2 Choupanas....................................................................... 120

2.2.2 Arquitetura especulativa......................................................... 122

2.2.2.1 Arquitetura sistêmica............................................................... 124

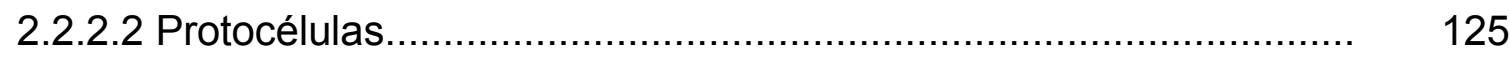

2.2.2.3 Biocalcários.......................................................................... 128

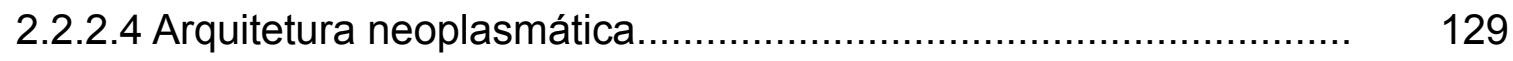

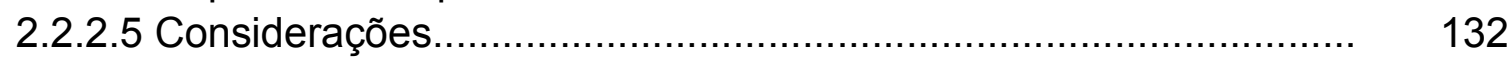

2.3 INFRAESTRUTURAS INVENTIVAS ................................................ 133

2.3.1 Critical Infrastructure ................................................................ 134

2.3.2 Infrastructure Fiction................................................................. 136

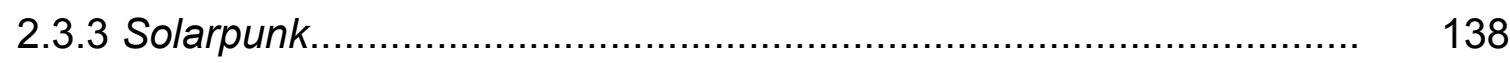

2.3.4 Setores infraestruturais.............................................................. 140

2.3.4.1 Comunicação..................................................................... 141

2.3.4.2 Informação .............................................................................. 143

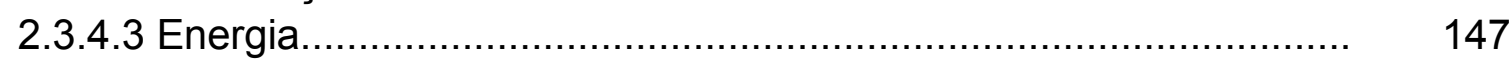

2.3.5 Considerações........................................................................ 148

2.4 EXPRESSIVIDADES GEOCIENTÍFICAS ...................................... 149



2.4.1.1 Atmosfera ............................................................................ 151

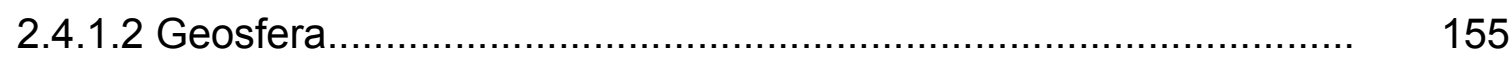

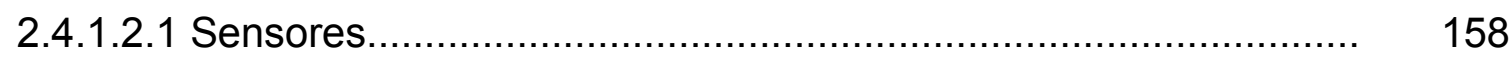

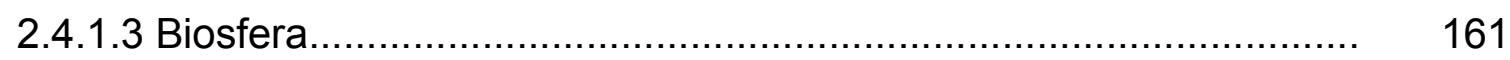

2.4.1.4 Hidrosfera........................................................................... 163

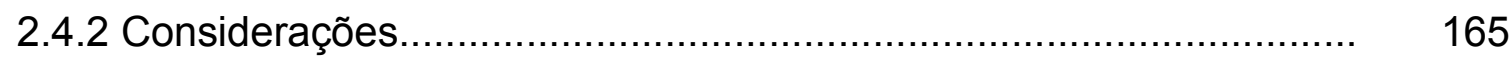

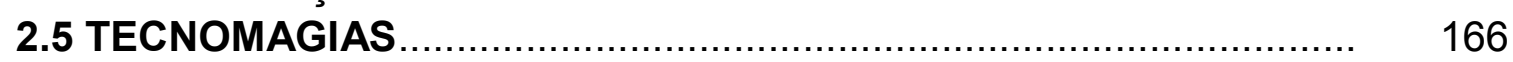

2.5.1 Geomancia aplicada............................................................... 167

2.5.2 Observatório psicogeofísico............................................................. 173

2.5.3 Alquimias hodiernas............................................................. 178

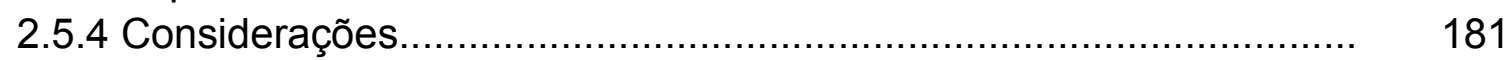



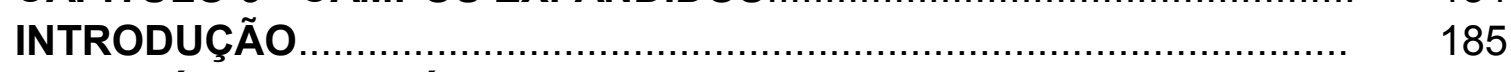

3.1 ESTÉTICA ECOTÉCNICA E ARQUITETURA ................................. 186 


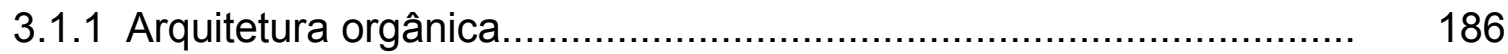

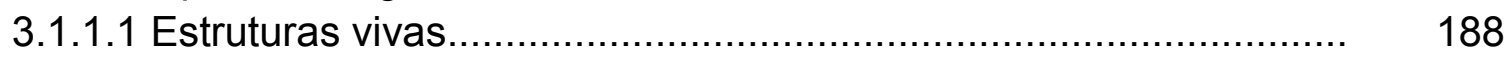



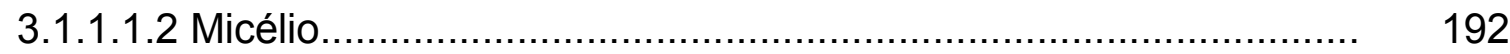

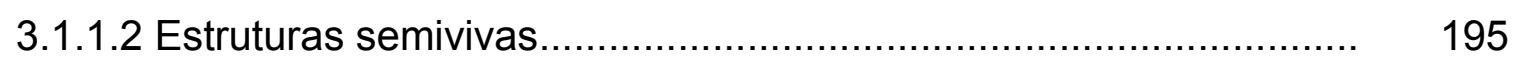

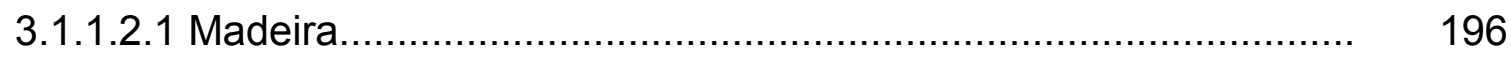

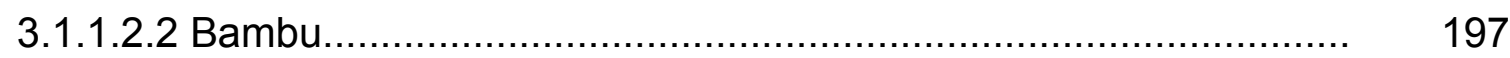

3.1.2 Arquitetura vernacular............................................................. 200

3.1.2.1 Elementos........................................................................... 201

3.1.2.1.1 Parede .......................................................................... 202

3.1.2.1.2 Torre de vento.................................................................. 204

3.1.2.2 Estruturas..................................................................... 205

3.1.2.2.1 Caixa-d'água.................................................................. 206

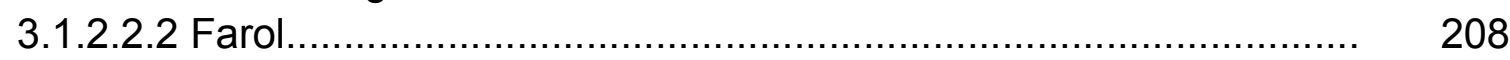



3.1.3 Arquitetura paisagista................................................................ 213

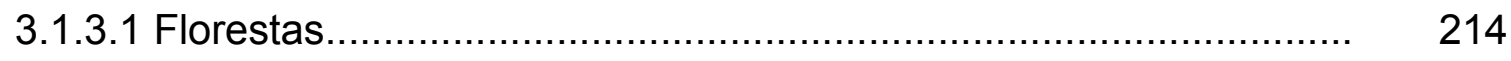

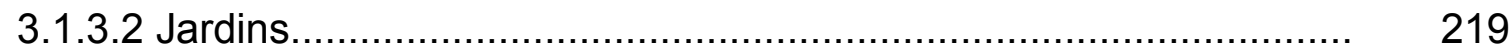

3.1.3.3 Parques.......................................................................... 223

3.2 ESTÉTICA ECOTÉCNICA E INFRAESTRUTURAS ......................... 227

3.2.1 Setor de engenharia................................................................ 228

3.2.1.1 Pontes pedonais.................................................................. 229

3.2.1.2 "Caminhabilidade".................................................................... 233

3.2.2 Setor de telecomunicações........................................................... 238

3.2.2.1 Computação natural................................................................. 239

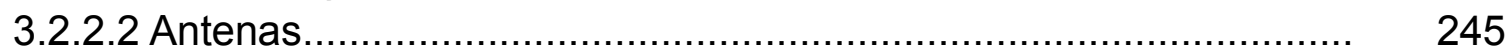

3.2.3 Setor energético................................................................... 249

3.2.3.1 Sistemas micro-hídricos........................................................ $\quad 249$

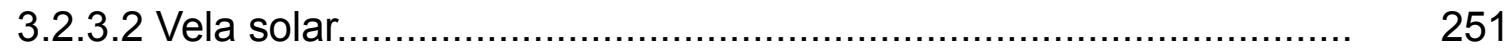

3.2.3.3 Energia biofotovoltaica...................................................... 254

3.2.3.4 Turbinas eólicas piezoelétricas.................................................. 257

3.2.4 Setor hídrico................................................................. 259

3.2.4.1 Cultura dos canais................................................................. 259

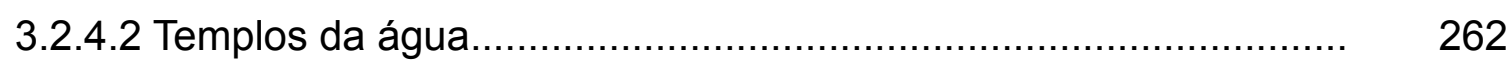

3.2.4.3 Linhas chaves..................................................................... 266

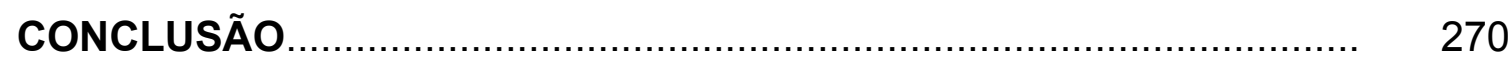

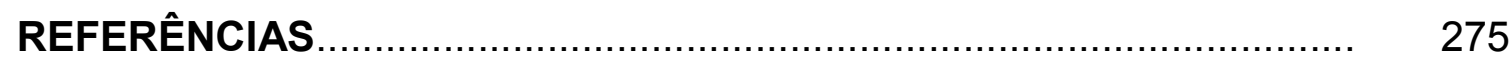


ÍNDICE DE ILUSTRAÇÕES

Figura 1 - Modos de pensar e ser no mundo.......................................... 13

Figura 2 - Sistema genético da estética ecotécnica................................ 15

Figura 3 - Jared Bark, "Untitled" (1973)............................................... 32

Figura 4 - A autoforma.....................................................................

Figura 5 - Ninho infinito de caixas de Kauffman...................................... 34

Figura 6 - Roden Crater (parte externa), de James Turrell........................ 57

Figura 7 - Ponte ferroviária de Garabit................................................... 64

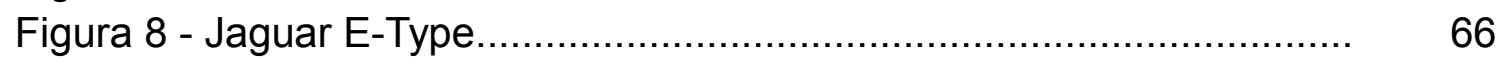

Figura 9 - Lâmina original de patente da turbina de Guimbal.................... 69

Figura 10 - Transmissor de Villebon..................................................... $\quad 70$

Figura 11 - 470 42' 03.6" N 7006' 50.1" W (2016), de Rougier................. 73

Figura 12 - "Zona de inclusão"........................................................... 90

Figura 13 - Old Bridge em Pontypridd, País de Gales............................. 102

Figura 14 - Lightning Field (1977), de Walter De Maria............................ 105

Figura 15 - Radioplanta (2015), de Paloma Oliveira e Mateus Knelsen.... 109

Figura 16 - LUCID (2016), de 3Hund..................................................... 111

Figura 17 - Outlandia, de London Fieldworks......................................... 121

Figura 18 - Lagoa de Veneza, por Christian Kerrigan.............................. 126

Figura 19 - Nausicaä do Vale do Vento (1984)...................................... 139

Figura 20 - Rechnender Raum (1967), de Konrad Zuse.......................... 145

Figura 21 - Rechnender Raum (2007), de Ralf Baecker.......................... 145

Figura 22 - Balões do Projeto Aeroceno................................................. 152

Figura 23 - Sensor instalado na geleira Similaun, 2016......................... 159

Figura 24 - Projeto para um rio em Nevada.......................................... 165

Figura 25 - Prototipagem do computador telúrico (2014)......................... 170

Figura 26 - Projetos na Caverna de Treak Cliff (2017)............................ 176

Figura 27 - The Crystal World Open Laboratory, 2012 ............................ 180

Figura 28 - A estrutura do Platanen-kubus................................................ 191

Figura 29 - Torre de tijolos de micélio no MoMA PS1 (2014).................... 193

Figura 30 - Bienal Internacional de Arquitetura de Bambu de Baoxi......... 198

Figura 31 - Parede Trombe em Santa Catarina, Egito.............................. 203

Figura 32 - Torre Warka projetada por Arturo Vittori e Andreas Vogler...... 207

Figura 33 - Farol de Adziogol, construído por Vladimir Shukhov............... 209

Figura 34 - Projeto para o festival SALT................................................ $\quad 212$

Figura 35 - O Meu Vizinho Totoro (1988)............................................. 217

Figura 36 - Jardim Suminoe, de Mirei Shigemori (1966)......................... 222

Figura 37 - Planta do Parque Centenário Chulalongkorn.......................... 226

Figura 38 - Ponte pedonal de Töss, de Robert Maillart............................ $\quad 230$

Figura 39 - Ponte de raízes vivas na vila de Nongriat.............................. 232

Figura 40 - Estreitamento de via pública em Oklahama City, EUA............ 236 
Figura 41 - Eletrodos ligados a um cacto Schlumbergera.......................... 243

Figura 42 - Antena Skywire Loop...................................................... 247

Figura 43 - Vela Solar da SunZilla..................................................... 252

Figura 44 - Ânodo do projeto Musgo Voltaico (IAAC)............................... 255

Figura 45 - Windstalk (Atelier DNA)..................................................... 257

Figura 46 - Canal de subak velado por divindade ................................... 265

Figura 47 - As "curvas estéticas" de keylines.......................................... 268 


\section{INTRODUÇÃO}

O estímulo que nos moveu a oferecer uma proposta de tese de doutorado ao Instituto de Arquitetura e Urbanismo da USP, nos idos de 2014, foi a percepção de que havia algo de errado com o conceito de sustentabilidade, e que valeria a pena rebatê-lo por meio de uma análise crítica. Empresas de diversas áreas o haviam adotado, como se isso pudesse dar a elas uma carta branca para ações de fato nada sustentáveis. A noção dava a "impressão de se ter convertido numa espécie de mantra... [sendo] repetida quase à exaustão em todo tipo de discurso relacionado com desenvolvimento (e crescimento) econômico", permitindo aos agentes fingirem ser possível algo como o "progresso material ilimitado ... como se nada, nenhuma ação humana alterasse a realidade biofísica do ecossistema em que se encontra inserido o sistema econômico".' Passamos então a investigar outra noção que, se não fosse capaz de substituir a de sustentabilidade, pudesse ao menos reexaminála. Foi assim que passamos a avaliar a teoria da resiliência, mais ajustada à realidade do mundo atual, considerando a impossibilidade da aplicação integral do modelo de crescimento sustentável no atual estágio do capitalismo industrial. Portanto, precisávamos de um posicionamento que fosse mais realista, que colocasse como inevitável o declínio do modelo, ou até mesmo de uma etapa da civilização. Um dos problemas despontados através dessa constatação foi o seguinte: a humanidade conseguiu construir a maior infraestrutura tecnológica de toda a sua história, mas continua sendo incapaz de realizar juízos acerca de sua própria condição sociotécnica.

Portanto, torna-se essencial estabelecer uma mudança de paradigma, não para enterrar de vez a noção de sustentabilidade, mas para tentar salvaguardá-la de um pensamento puramente mercadológico. Mudanças de paradigma são, no presente contexto, mudanças de visão de mundo, ou seja, mudanças ontoepistemológicas, alterações de modos de existência e de conhecimento, culminando em mudanças de modos de ação. Qual seria a melhor ferramenta conceitual para realizar tal tarefa? Havia a confiança de se optar por uma estratégia no campo da filosofia, em especial a estética, mas uma estética voltada exclusivamente ao campo

1 CAVALCANTI, Clóvis. Sustentabilidade: Mantra ou Escolha Moral? Uma Abordagem Ecológicoeconômica. Estudos Avançados, v.26, n.74, 2012, p. 35-50. 
da arte, ou seja, uma estética hegeliana preocupada apenas com a percepção de objetos artísticos (filosofia da arte). ${ }^{2}$ A tarefa implicava o estudo de gêneros com preocupações ecológicas, mostrando, por exemplo, a evolução da Environmental art, desde a Land art até a EcoArt, e especulando em paralelo como tais gêneros desembocaram em um tipo de arte que seria a própria extensão da natureza. Conjeturávamos, portanto, a existência de uma "estética da resiliência", mas não no sentido que o arquiteto holandês Matthijs Bouw dá ao termo: uma espécie de relação entre sistemas de proteção contra enchentes e paisagismo. ${ }^{3}$ As expressões que procurávamos seriam mais especulativas, estariam sugeridas em obras de arte ecológica com pretensões utópicas, mas ao mesmo tempo carregadas de pragmatismo.

Como o campo da resiliência é sobremaneira abrangente, consideramos realizar um recorte tópico. Em termos materiais, não queríamos focar a resiliência no que se refere a alimentos, transportes e situações insalubres na área de saúde, por exemplo. A meta inicial era concentrar a pesquisa na resiliência de sistemas de informação e comunicação, e quais artistas e designers tinham um interesse nessas áreas. Grosso modo, começamos a pesquisar três tipos de resiliência material:

a) resiliência de infraestruturas de comunicação (processos, microgrids, etc.);

b) resiliência computacional (computação não convencional, etc.);

c) resiliência energética (biológica, física, etc.)

Em termos materiais, o projeto inicial tinha como objetivo mapear quais seriam as novas arquiteturas computacionais, independentes da arquitetura digital elaborada por von Neumann; e quais seriam os tipos de tarefas computacionais que

2 No volume inicial dos Cursos de Estética, Hegel declara, no primeiro parágrafo do primeiro capítulo, que o programa "lida com Estética. Seu assunto é o amplo reino do belo, e, mais particularmente, sua província é a Arte - mas podemos restringi-la, na verdade, às Belas-Artes." (HEGEL 1993, p. 3; grifo do autor). Sob a sombra da tradição hegeliana, torna-se impreterível definir de antemão o que entendemos por "estética", sem lançarmos mão de um glossário. Reivindicaremos, em primeiro lugar, uma estética fenomenológica (DUFRENNE 1989), mas consoante o entendimento de Maurice Merleau-Ponty (apud CARROZZINI, Giovanni. How to Invent a Form: An Inquiry into Gilbert Simondon's Philosophy of Perception. In: SART 2015, pp. 33-48), para quem a fenomenologia é a "descrição direta da experiência". No caso, trataremos da experiência estética, ou do conhecimento através da percepção. Nesse sentido, a estética poderia adquirir o estatuto de uma "ciência", Wissenschaft, ou o estudo detalhado de algo (HEGEL, op.cit., sessão I, n.3, p. 98).

3 BOUW, Matthijs. Palestra proferida na PennDesign, Filadélfia (Pensilvânia), set. 2014. Vídeo disponível em: <https://vimeo.com/106315882>. Acesso em 31 mai. 2019. 
nos reservariam um futuro de escassos recursos materiais e energéticos. Por exemplo, como a humanidade se arranjaria em possíveis casos de colapso nas infraestruturas de telecomunicação? Seria possível programar um computador analógico para solucionar problemas básicos de comunicação por meio da teoria dos grafos (rotas de linhas de transmissão, por exemplo)? E, como consequência, quais seriam as formas alternativas de energia para alimentar uma infraestrutura criada a partir de outra colapsada? Aventamos a possibilidade de criar subtemas derivados das três formas de resiliência material para analisar, por exemplo, ferramentas, motores, máquinas, etc. Seria uma boa oportunidade para incluir em nosso projeto a cultura maker e os fablabs, além de atualizar a velha máxima "forma segue função" (no caso, em situações de resiliência, o antigo e desgastado conceito ganha significativa importância, já que a função é o elemento primordial em circunstâncias extremas, podendo inclusive adquirir o estatuto de uma forma estética).

Durante o processo de revisão bibliográfica, passamos a notar que a resiliência material era condição necessária, mas não suficiente, da estética que tínhamos em vista. Ou seja a resiliência material de nada vale se dissociada de um tipo de "resiliência existencial", uma forma de aceitar condições extremas de privação de recursos. Segundo o filósofo inglês John Foster (2014), o otimismo implicado na noção de sustentabilidade mascara processos de negação psicológica, comportamento verificado por exemplo em casos de transtorno do estresse póstraumático (TEPT). Mas, por outro lado, segundo o autor, não devemos descartar de imediato a esperança, não aquela pregada por religiões diversas, mas uma esperança fruto do aprendizado, uma que nos faça perceber as diversas possibilidades que temos à nossa disposição nesse momento decisivo. A humanidade talvez esteja fadada à um destino trágico, mas isso não impede que ela aprenda com seus próprios erros e não os reitere. Afora o fato de ainda haver alguma esperança, o expediente da negação tem um apelo poderoso e o atual estágio tecnológico contribui para tal situação, ocultando o quanto as nossas "tralhas" eletrônicas nada mais são que próteses dispensáveis em situações de colapso. Os deslumbrados com as promessas da realidade virtual, por exemplo, são como aqueles veteranos de guerra mutilados, vítimas da terrível "dor do membro 
fantasma". Ou seja, eles substituem o real por um virtual efetivamente real. Nessa linha, há os que hoje optariam por amputar o próprio braço, apenas para poder ingressar no exclusivo clube dos pós-humanos. Além da crítica à resiliência, passou ser importante denunciar também o problema da tecnofilia.

Nos anos de 2014 e 2015, a resiliência parecia ser a solução teórica mais apropriada e o ponto de partida ideal de nosso projeto. Mas, ao longo da pesquisa, o levantamento bibliográfico nos forneceu pistas de que a noção estava incorrendo em riscos significativos, tal como aconteceu com a sustentabilidade. ${ }^{4}$ Isto é, notamos que a noção estava sendo mal-entendida e, pior, cooptada, nesse momento não pelo mercado, mas pelo Estado, que ambiciona monopolizá-la e centralizá-la com o mesmo objetivo com o qual se dedica ao controle de pânico generalizado em populações sob ameaça de catástrofes, naturais ou não. A mudança de orientação acadêmica também contribuiu para que se desse um peso maior ao aspecto estético da hipótese original do que ao aspecto relacionado ao estudo da ética e à noção de resiliência (e à cultura cibernética propriamente dita). Uma nova hipótese foi elaborada em decorrência da remodelagem conceitual, mas sem que se abrisse mão do leitmotif original. Se de fato a ruptura entre natureza e cultura ainda inquieta a sociedade contemporânea, qual seria o recurso ideal para promover uma reaproximação dos dois termos? A própria persistência da clivagem não seria um problema de percepção ${ }^{5}$ Desta forma, passamos a nos empenhar em demonstrar que a recuperação de uma afinidade entre o pensamento tecnológico e 0 pensamento ecológico seria por via da estética e, a posteriori, da política e da ética. Por intermédio da obra do filósofo francês Gilbert Simondon, esboçamos em nossa tese um sistema individuante chamado de estética ecotécnica, um sistema o qual será esmiuçado no primeiro capítulo. Doravante, munidos com o caráter conceitual e

4 "A noção tão louvada de 'desenvolvimento sustentável' — não se pode negar as boas intenções de quase todos que a formularam e defendem - é, no fundo, apenas um modo de tornar sustentável a noção de desenvolvimento, a qual já deveria ter ido para a usina de reciclagem das ideias. Ela é uma contradição em termos. Não existe desenvolvimento capitalista sustentável." Ver VIVEIROS DE CASTRO, Eduardo. Desenvolvimento Econômico e Reenvolvimento Cosmopolítico: da Necessidade Extensiva à Suficiência Intensiva. Sopro, 51, 2011, pp. 3-10.

5 DANOWSKI, Débora. Palestra proferida no Colóquio Internacional Os Mil Nomes de Gaia: Do Antropoceno à Idade da Terra, 2015. Realização: Departamento de Filosofia da PUC-Rio e PPGAS do Museu Nacional - UFRJ. Vídeo disponível em <https://www.youtube.com/watch?v=yENRG9MZJjc>. Acesso em 17/03/2017. O mesmo argumento é também desenvolvido em MONBIOT, George. Our Selective Blindness is Lethal to the Living World. The Guardian, 2017. Disponível em: <http://www.theguardian.com/commentisfree/2017/dec/20/selective-blindness-lethal-natural-worldopen-eyes-environment-ecosystem>. Acesso em: 20 dez. 2017. 
diagramático do modelo, procuramos aplicá-lo, nos dois capítulos seguintes, à certas produções humanas, em princípio ligadas às artes, arquitetura e infraestruturas.

A metodologia, ou o método aplicado ao projeto é, como se verá, o indutivodescritivo, no qual parte-se de casos particulares, descritos com minúcia, para se chegar ao conceito geral. Cumpre adiantar ao leitor o emprego de análises genéticas, fenomenológicas e construtivistas ao longo do trabalho. Sintetizamos, contudo, que a estética pretendida, em suas especificações filosóficas, é o produto de duas outras: a tecno-estética de Simondon e a estética ambiental, de Carlson e Berleant; que o seu objeto é o que chamamos de "objeto tecno-ambiental", um híbrido de objeto técnico, objeto artístico e objeto natural (não necessariamente em porções idênticas); e, por fim, que ela ostenta caracteres subjetivos (esquematismo [figura/forma], significação [percepção + intenção cognitiva = sentido]) e objetivos (adequação tecnológica, privilégio de elementos materiais ao invés de abstratos, etc.). É preciso deixar claro de antemão que não pretendemos oferecer uma nova teoria estética ou um modelo fechado, mas estabelecer as diretrizes para a criação de um framework cabível em uma futura sociedade ecotécnica (GREER 2009). Um ponto importante é que pretendemos, ao demonstrar a hipótese, estabelecer os elementos básicos para a formação de um aparato crítico para a noção de sustentabilidade e, por extensão, para a teoria da resiliência, agora também sob quarentena. Também pretendemos estabelecer narrativas contrapostas às narrativas do progresso técnico irrestrito (por narrativa leia-se: conjunto de conteúdos que tornam um sistema mais transparente). Por último, uma das conclusões gerais expostas nas entrelinhas de nossa tese, e que está em conformidade com as reflexões de Regine Debaty em sua resenha do livro The Shock of the Anthropocene: The Earth, History and Us, de Christophe Bonneuil e Jean-Baptiste Fressoz, é que "o que precisamos agora não é um plano de resgate elaborado com as maravilhas da geoengenharia, mas de mais narrativas, saberes e uma variedade de iniciativas cívicas e alternativas populares que explorem os contornos de se viver melhor com menos". ${ }^{6}$

6 DEBATTY, Regine. The Shock of the Anthropocene. Or What Does it Mean to Have the Future of the Planet into our Hands? We Make Money Not Art, 10 set. 2015. Disponível em: <http://wemake-money-not-art.com/the_shock_of_the_anthropocene-2/>. Acesso em: 16 mar. 2017. 
INTRODUÇÃO

A relação entre estética, técnica e ecologia é complexa, apesar de se verificar eventuais campos harmônicos ao longo da história da arte, arquitetura, tecnologia e ciências. Ao analisá-la, o investigador deve primeiro procurar se ater não aos produtos e objetos manifestos, mas às relações entre os pensamentos dispostos na fundação de cada modo de pensamento isolado: o tecnológico, o estético e o ecológico. No capítulo de introdução de The Ecological Thought (2012), o filósofo inglês Timothy Morton nos apresenta, por exemplo, a sua versão do pensamento ecológico, colocando-o em contraste com o pensamento estético. Para ilustrá-la, ele se recorda de eventos em que moradores de diversas regiões da Europa se revoltaram contra a instalação de turbinas eólicas próximas de suas residências, com a argumento de os dispositivos de energia renovável não terem um aspecto "natural", destoando da paisagem. Os casos comprovam a existência de um pensamento estético (não do tipo ambiental) imperando sobre um pensamento ecológico, o que reforça a tese do livro de que, para se impor, a "ecologia deve prescindir da natureza" (op.cit.: 9-10), ou ao menos de uma natureza idealizada, irreal. Para agravar, os moradores citados por Morton promovem a refutação cabal do pensamento técnico, favorecendo a atual tendência de estetização de objetos técnicos, ao estilo das árvores eólicas que estão sendo instaladas em Paris. ${ }^{7}$ Afinal, seriam mais belas as tubagens que transportam petróleo e gás do que os aerogeradores? Não se trata de uma pergunta retórica...

A tese de Morton parece materialmente contraditória (haveria uma ecologia sem natureza?), mas faz sentido em situações nas quais o natural tornou-se "desnaturalizado", ou melhor, um princípio transcendental, quase um fetiche (MORTON 2007: 5). Segundo ele, além da integridade impossível das regiões selvagens, a noção de Natureza (com maiúscula) teria sido sequestrada por diversas ideologias e tornada por demais abstrata. O casos envolvendo turbinas eólicas apontam para a tensão existente entre modos de pensamento e como suas supostas diferenças colocam em risco uma possível aliança sinergética entre, por

7 Ver LAURENSON, John. Turbina Eólica em Forma de Árvore. Deutsche Welle, 7 abr. 2015. Disponível em: <http://www.dw.com/pt-br/turbina-e\%C3\%B3lica-em-forma-de-\%C3\%A1rvore/a18359728>. Acesso em: 17 jan. 2017. 
exemplo, esquemas técnicos e elementos naturais. Aerogeradores instalados na paisagem rural incomodam personagens díspares, de ideologias diversas, como 0 presidente dos EUA Donald Trump (que os quer distantes de seus campos de golfe na Escócia), ${ }^{8}$ assim como o ambientalista radical e fundador da marca de roupas e acessórios para montanhismo The North Face, Doug Tompkins, para quem uma turbina eólica é uma espécie de "logotipo" cartesianista, ou seja, simboliza a cultura tecno-industrial racionalista que pretende desenvolver-se de forma autônoma, à revelia da natureza. ${ }^{9} \mathrm{~A}$ defesa da ideia de que o desenvolvimento técnico e científico constitui-se em um processo autônomo já é uma tradição antiga entre os críticos da sociedade moderna, a qual se confunde, não sem razão, com um essencialismo de gene heideggeriano. Contudo, para a teoria geral do sistemas, ${ }^{10}$ a emancipação sem controle do meio técnico é tão-somente uma ilusão, fenômeno explicado pelo ponto de vista dos indivíduos internos ao sistema, uma perspectiva de inclinação subjetiva, ou seja, dos elementos sobre a totalidade que os contém (DUPUY 2011: 83-97).

É possível imaginar que a solução para o conflito entre tecnologia e ecologia emergirá sob a rubrica da estética, se considerarmos as visões do filósofo francês Gilbert Simondon (1969), para quem a reparação da clivagem entre técnicas e religiões ocorrida durante o processo relacional entre humanos e mundo só seria possível através de uma estética que conduzisse - simbolicamente, diga-se - os dois termos à sua unidade original: a um espaço-tempo primitivo e mágico regido pela interconectividade total. O anterior estado unificado, de acordo com o filósofo francês, não tem o caráter de uma mônada compacta, ou de um dualismo falsamente superado, e mais aparenta a uma retícula, por meio da qual as duas partes se tornam integrantes, como em uma justaposição de tons de diferentes intensidades que, quando observados a certa distância, compõem uma imagem. Em nossa interpretação do sistema simondoniano, as técnicas integrariam desde representações da trimensionalidade, como a perspectiva renascentista, até práticas

8 Ver SAMPATHKUMAR, Mythili. Wind Farm Opposed by Trump Opens Near His Golf Course in Scotland. The Independent, 7 set. 2018. Disponível em: $<$ https://www.independent.co.uk/news/donald-trump-scotland-golf-course-wind-turbines-renewableenergy-a8528231.html>. Acesso em: 26 mar. 2019.

9 Ver KINGSNORTH, Paul. Doug Tompkins Remembered. The Dark Mountain Project, 16 dez. 2015. Disponível em: <http://dark-mountain.net/blog/doug-tompkins-remembered/>. Acesso em: 16 dez. 2015.

10 Ver Teoria geral de sistemas. In: Wikipédia, a enciclopédia livre. [s.l.: s.n.], 2019. Disponível em: $<$ https://pt.wikipedia.org/w/index.php?title=Teoria_geral_de_sistemas\&oldid=54211345>. Acesso em: 26 mar. 2019. 
envolvendo ferramentas, máquinas automáticas, aparelhos e mídias em geral; e a parte religiosa teria o aspecto "panteísta" de uma ecologia espiritual, mas sem os traços do ambientalismo radical. ${ }^{11}$ De qualquer forma, se não for possível se chegar a uma resolução definitiva da ruptura, que a nossa proposta de estética ecotécnica consiga ao menos retirar o excessivo peso ideológico do pensamento ambientalista (que tende a nulificar o valor das técnicas) e do pensamento tecnófilo (que tende a menosprezar o movimento ecológico).

A estratégia de reconhecer a precedência dos três modos de pensamento sobre suas posteriores reificações é motivada por dois fatores. O primeiro é apontar que nossa análise estética apresenta características construtivistas e fenomenológicas, deixando transparecer que a "impressão estética" (SIMONDON 1969: 195-196) é formada conjuntamente por afinações subjetivas e qualidades objetivas; e que ela não seria tão somente um estado psíquico e nem um valor pertencente à coisa em si. A impressão estética, objeto do pensamento estético, seria o fruto de uma cogeração constituída pelo organismo sensível e o objeto percebido, ou seja, as qualidades não existiriam em função dos objetos, e nem existiriam como imagens pré-formadas na mente do espectador, como quer a Gestaltpsychologie; o objeto tornado estético é, antes de tudo, percebido, mas também é "inventado" dentro de um contexto que inclui objeto, sujeito e ambiente. Nesse sentido, podemos dizer que tratamos de uma fenomenologia de inspiração mais fenomenalista que ontológica. O segundo fator é inspirado na própria expressão "modo de pensamento", presente em diversos pontos da obra de Simondon. Segundo a exegese de Andrea Bardin (2015: 173), a concepção simondoniana de pensamento fundamenta-se na hipótese de um conjunto que, tanto no domínio teórico como no prático, é formado pelo humano e pelo mundo, tomando-se os dois como uma realidade completa. Ao dissertar sobre o pensamento mágico primitivo, Simondon chegava a desconectá-lo do sujeito, conjecturando que a semente do que depois viria a se tornar uma categoria de logos, era o protótipo de um campo unificado que incluía reflexão e ação desdobradas na physis. A noção simondoniana de um pensamento autônomo, como que desprendido do sujeito, ${ }^{12}$ ou

11 Ver TAYLOR, Bron. Resacralizing Earth: Pagan Environmentalism and the Restoration of Turtle Island. In: CHIDESTER \& LINENTHAL 1995, pp. 97-151.

12 Ver nota de rodapé 48 in: DANOWSKI \& VIVEIROS DE CASTRO (2015: 47) na qual os autores refletem sobre o "ser real do pensamento". 
ao menos irredutível ao mesmo, nos é profícua, tendo em vista a nossa posição contrária ao excepcionalismo humano na definição de uma estética ecotécnica.

Como já assinalamos, o conflito entre técnica e ecologia se dá em função de que a humanidade, em sua autoconfiança excessiva, insiste na distinção entre humanos e não-humanos, e esse é um dos problemas que pretendemos atacar nesse projeto. Somos seres que se julgam protegidos - tanto pelo destino favorável, como por divindades abstratas -, com controle de acesso à realidade, mas uma realidade de fundo neutro e opaco, e por efeito manipulável. Evocamos o fundo - e iremos discorrer largamente sobre esse termo ao longo do trabalho - "como o indefinido do horizonte sobre o qual se perfila a forma" (DUFRENNE 2015: 152), sendo a última traduzida pelas numerosas criações da humanidade, técnicas como via de regra, culturais no pormenor. Mas não seria paradoxal criticar o excepcionalismo humano por meio de um modo de percepção eminentemente humano? Não, se aplicarmos a tradição filosófica que investiga a percepção para justamente modificar a percepção em si, uma percepção contaminada pela impressão de que a figura - a forma - impera sobre o fundo, a "fonte inesgotável da realidade", na expressão simples e direta de Mikel Dufrenne. Daí o anseio de encontrarmos, dentro do pensamento ecológico - esse é o propósito da seção Pensamento ecológico - a noção de meio, um ambiente humanizado, é certo, mas de forma consciente, e isso na conotação mais ordinária da palavra "consciente", representada, por exemplo, na expressão "consciência ecológica". A palavra ambiente nos é um tanto adversa, tal como a palavra Natureza o é para Timothy Morton, tanto por sua indiferença em se servir como objeto de perscrutação científica, como por remeter-nos à posturas contraprodutivas do meio artístico: desinteresse, aura, autonomia e congêneres, posturas de distanciamento, em suma. No outro lado, o pensamento tecnológico não está dispensado de obrigações, devendo erradicar tudo que se refere ao tecnicismo, tecnocentrismo, tecnocracia e - por ironia - a autonomia da técnica. Tal pensamento, esforçarmo-nos por expressar na seção Pensamento tecnológico, deve ir de encontro a uma tecnicidade, um essencialismo de confirmação absoluta do modo de existir técnico, e não de renuncia a si mesmo. A tecnicidade (iremos refletir sobre a palavra muito em breve) é a técnica a serviço do meio, e por conseguinte, da humanidade, produto do meio. 
A escolha pelos três modos de pensamento para enriquecer a tecno-estética simondoniana com atributos ecológicos também nos assegura uma zona tampão ao redor dos modos de ser dos exemplos, os quais exigiriam a ginástica conceitual de uma abordagem ontológica (ou mesmo onto-estética). Se abríssemos uma brecha na "proteção", correríamos o risco de nos desviarmos das descrições de individuações de objetos tecno-ambientais e, pior, poderíamos ser cobrados para revelar o caminho de como tal ontologia poderia subverter as posições oficiais de se enfrentar os desafios tecnológicos e ecológicos da contemporaneidade. É sempre pertinente recordar que a relação entre os três pensamentos é analógica, expressão definida como uma identidade de relações, e não uma relação de identidade, que se consuma numa mera semelhança (SIMONDON 2008: 207). Apesar de suas características filosóficas, o presente trabalho anela primordialmente por estabelecer analogias (ou "transduções", no vocabulário simondoniano) entre os três modos de pensamento afim de mostrar que a ruptura entre técnica e religião na análise genética de Simondon é, antes de tudo, o princípio da divisão entre teoria e prática, e que, em nossa interpretação, quando combinadas por uma estética, podem estabelecer planos de ação, como estratégias de resiliência infraestrutural, poéticas da ambiência, técnicas de investigação em geociências, métodos de associação entre arquitetura e lugar, e assim por diante.

Nossa máxima inspiração, isso tornar-se-á patente ao longo do trabalho, é a classificação das fases da cultura de Simondon, ou a gênese da relação homemmundo, na qual, a partir da duplicação (dédoublement) original da unidade mágica primitiva, emergem duas novas fases: técnica e religião, coligadas pela estética, elemento de reminiscência da unidade perdida do pensamento mágico. Vê-se que, segundo o esquema diagramático proposto pelo exegeta Gilbert Hottois (ver Fig. 1), a ruptura entre técnica e religião origina disjunções sucessivas, sendo a imediatamente contígua, em ambas as fases, a que principia a notória divisão entre teoria e prática. A partir dessa segunda duplicação, Simondon expressa a origem dos métodos científicos, consubstanciando-os em teorias do conhecimento e práticas morais através da filosofia, a qual também remete à unidade mágica perdida. O que não se apresenta no diagrama de Hottois, porque talvez a completude do sistema genético dos modos de pensamento seja resistente a 
diagramações de todas as ordens, tem a ver com o operador estético e sua relação com o mundo da arte, mais especificamente com a arte sagrada e a arte profana. $O$ que Simondon coloca em jogo nesse momento, talvez sob a influência de Mikel Dufrenne, é o intercâmbio de valores entre as duas formas artísticas, da atitude presente no gesto ritualístico ao objeto místico que porta a verdade (SIMONDON 1969: 193). Em seu estilo bizantino, ele acaba por coordenar estética e filosofia, assinalando a estética como uma via privilegiada para a filosofia. ${ }^{13} \mathrm{O}$ que nos chama particularmente a atenção é a conclusão mais adiante de que a "impressão estética" se realiza no encontro entre as qualidades afetivas do objeto estético e a ação intelectual do sujeito que as exuma, entre o sensível e o senso da intelecção. "O objeto belo é aquele que realiza, no apogeu do sensível, a adequação total do sensível e do sentido e que, assim suscita o livre acordo da sensibilidade e do intelecto" (DUFRENNE 2015: 51). Cremos, de resto, ser praticamente impossível a esquematização completa do sistema genético proposto por Simondon, apesar do louvável empreendimento de Hottois. É indubitável, pode-se notar mesmo assim, que o sistema aspira a cobrir a totalidade das ações, sentimentos e juízos humanos. Destarte, faz-se necessário, no presente trabalho, escolher uma das linhas do primeiro desdobramento, lá mantendo o foco de nosso estudo; é a linha da técnica, e não religiosa, que seguiremos, portanto (nota-se, na figura 1 , tal disposição no círculo em torno da palavra "técnica").

13 Essa visão é sugerida na introdução à edição brasileira de Filosofia e estética (2015), assinada por Roberto Figurelli. 
Figura 1 - Modos de pensar e ser no mundo

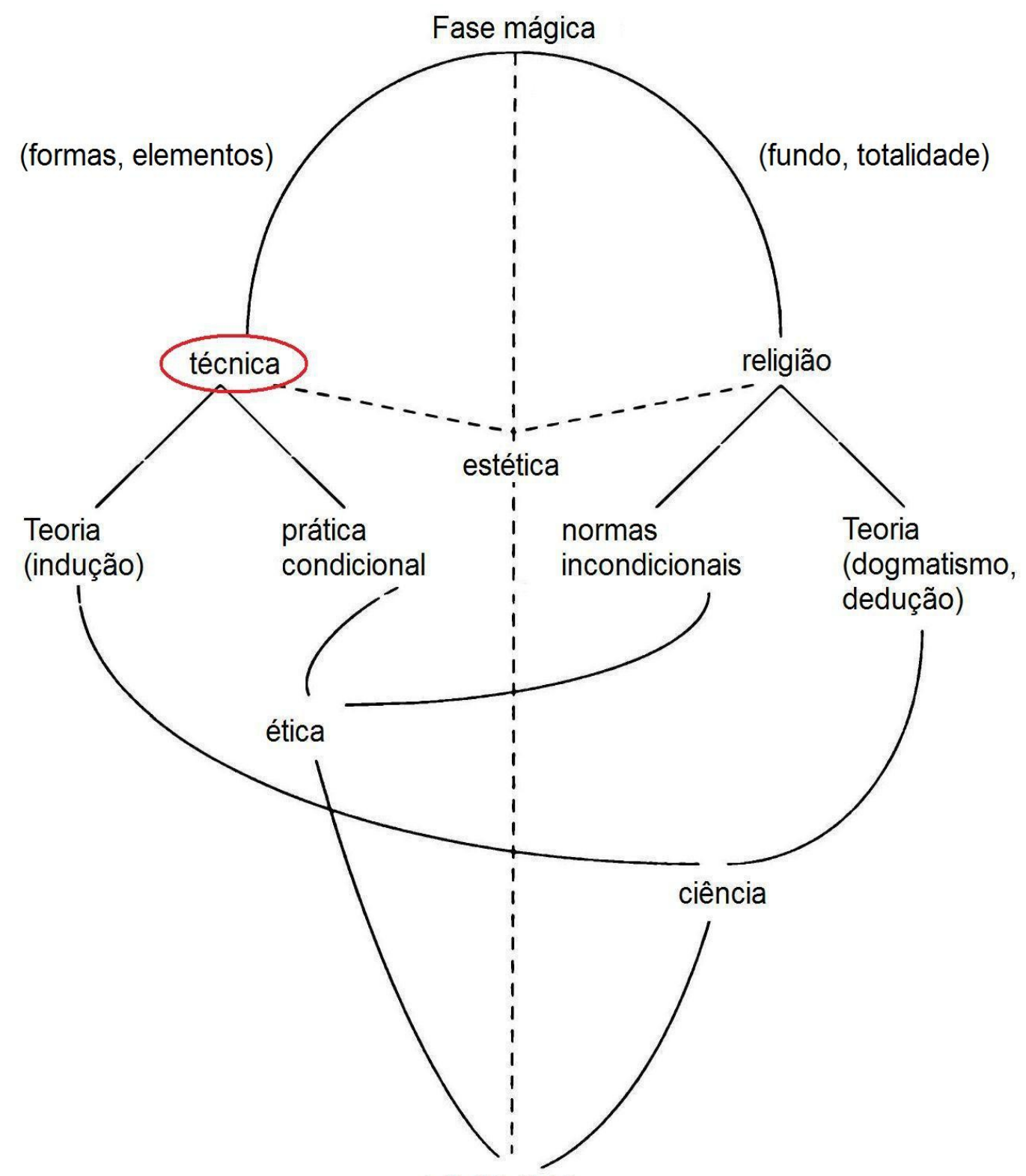

FILOSOFIA

Fonte: HOTTOIS 1993: 73

Em nossa proposta, algo sucede no interior da fase técnica: uma divisão entre tecnologia e ecologia e uma relação estética transcorrendo entre elas, sem que haja a interferência da fase religiosa. Os termos estão subordinados a um logos humano, a um pensamento, porque se a consciência é a lanterna que põe em evidência o sensível, a afirmação sensória dos objetos do mundo, é a razão que os "processa". 
Há, portanto, o pensamento ecológico destacado do pensamento tecnológico, ambos também sendo intermediados pelo pensamento estético, porque tal corte, semelhante ao sistema simondoniano, procede da desfocagem entre formas e fundo. Faz-se mister delinear aqui a racionalidade (logos) dos dois primeiros modos: por tecnologia entende-se o conjunto de métodos, técnicas e procedimentos de transformação do mundo natural; e, por ecologia, o projeto de síntese do último. Orientamo-nos por Simondon pois, segundo ele, "a oposição existente entre técnicas e religiões é, em uma primeira fase, inerente às técnicas de desenvolvimento do mundo natural, em contraste com as religiões, que pensam o destino do homem individual" (SIMONDON 1969: 214). ${ }^{14}$ No léxico pessoal do filósofo francês, a fase, vocábulo tirado da ciência, é a estruturação de uma porção do espaço-tempo que se dá a partir de dois campos, mas de acordo com intensidades distintas (a intensidade da religião difere da intensidade da técnica, por exemplo)..$^{15} \mathrm{Em}$ nosso modelo, pressentimos forças não constrangidas no campo da tecnologia, em proporção inversa às potências da ecologia, forças aquelas incitadas pela sabida vocação humana de maestria, controle e reorganização do ambiente natural (Heidegger, logo se verá, reflete em especial sobre esse tema). No diagrama (ver Fig. 2) os dois modos de pensamento são mediados por um pensamento estético, cuja intermediação seria por suposição capaz de resolver o desequilíbrio entre os dois termos "despegados". Mas verifica-se aqui disjunções sucessivas, assim como no sistema original de Simondon, porém com suas próprias necessidades. E elas se dão a partir do pensamento estético que, quando saturado em seu compromisso, desdobra-se, sob a regência do pensamento tecnológico, na tecno-estética de Simondon (1998); e sob a regência do pensamento ecológico, na estética ambiental, campo investigado pelos filósofos estadunidenses Arnold Berleant (1995) e Allen Carlson (2002). Uma combinação oportuna entre as duas, por sua vez, dá origem à estética ecotécnica, objeto crítico da presente tese.

14 Excerto no original: L'opposition qui existe entre techniques et religions est, dans une première phase, inhérente aux techniques d'élaboration du monde naturel dans le contraste qu'elles forment avec les religions qui pensent la destinée de l'homme individuel. (tradução nossa).

15 CARROZZINI, Giovanni. Esthétique et Techno-esthétique Chez Simondon. In: BARTHÉLÉMY 2011, pp. 51-70. 
Figura 2 - Sistema genético da estética ecotécnica

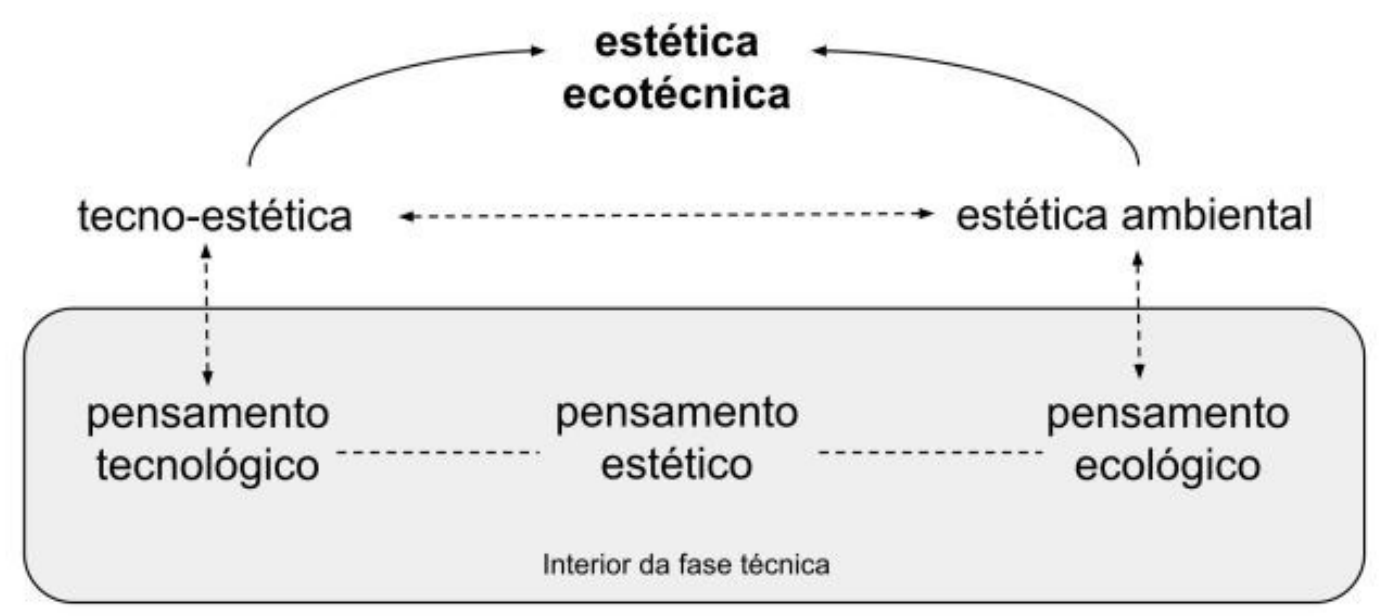

Fonte: autoria própria (2017)

Observa-se a diferença entre o sistema genético de Simondon e o sistema genético da estética ecotécnica, um sistema que, a começar do pensamento estético que intermedeia o pensamento tecnológico e o pensamento ecológico, faz irromper uma segunda relação, a que se dá entre um objeto técnico "sensível a transformações e mutações" (CHABOT 2013: 142) e um ambiente associado a ele. Em nosso caso, talvez seja possível afirmar que o sistema genético proposto representa, diagramaticamente, o acoplamento entre objetos tecnicizados e o seu meio (milieu), uma correlação efetuada através de uma determinada estética. Um dos intuitos de nosso sistema é compensar as "falhas" de ambas as estéticas previamente estipuladas por terceiros pensadores: uma tecno-estética, de caráter operativo, demasiadamente debruçada sobre o objeto técnico; e uma estética ambiental, de caráter contemplativo, inclinada sobretudo à apreciação de ambientes de diversas ordens. Enquanto a primeira é voltada ao resultado da operação técnica, sem atribuir o devido mérito ao espaço por onde se desdobra a ação ou o gesto, a segunda é ofuscada pelo brilho do termo "ambiente", sobremaneira problemático, muito em virtude do peso excessivo facultado ao ambiente natural objetivado e, principalmente, por sua aparente indiferença às fecundas conotações do termo milieu, uma combinação entre meio humano, natural e técnico (mais correto então seria estabelecer de partida uma ainda incriada "estética do meio", mas vamos nos ater ao cânone). Isto posto, o sistema sugere que um objeto tecno-ambiental (óbvia 
alusão ao objeto tecno-estético simondoniano) emerge da associação ótima entre um objeto técnico e seu meio. Mas seria o nosso sistema eminentemente "genético"? A questão é válida no âmbito metodológico e, por essa razão, faz-se necessário proferimos algumas considerações.

Se fossemos definir a metodologia empregada no tratado do modelo, no entendimento acadêmico que é outorgado ao conceito de método científico, diríamos, sem hesitação, que o modelo escolhido é o indutivo. Essa abordagem, deveras aplicada em teses científicas, é (abrimos as aspas à custa de incorrer em redundância), "um processo mental por intermédio do qual, partindo de dados particulares, suficientemente constatados, infere-se uma verdade geral ou universal, não contida nas partes examinadas" (MARCONI \& LAKATOS 2003: 86). Assim, partimos de uma série de constatações, pinçadas lá e cá da esfera das artes e das técnicas, e constatamos um esquema, ou o princípio de organização de uma forma, no início difusa, mas que, ao longo do processo de investigação, passou-se a cristalizar. Eis a metodologia oficial da tese. Contudo, tal reconhecimento seria insatisfatório sem a inclusão de um adendo sobre as análises empregadas ao método. Segue-se daí as nossas escolhas pela análise genética e fenomenológica, sem fecharmos os olhos para a possibilidade de um conflito, mas confiando que "essas escolhas não são, de forma nenhuma, exclusivas: não se pode estudar uma atividade sem examinar o que ela produz" (DUFRENNE 2015: 239). A análise genética de Simondon, faz-se necessário esclarecer, não condiz exatamente com a análise evolutiva do indivíduo, de seu devir, mas com a operação de estruturação das formas, de sua individuação, ou seja, ela é a descrição de um processo a praesenti, e não a posteriori, como supõe a indução. ${ }^{16}$ Acreditamos, como Simondon, que a melhor maneira de descrever os indivíduos técnicos é pela via genética, principalmente indivíduos situados na linde entre objeto técnico e objeto estético, em pleno processo de transformação. O fato de a análise genética se empenhar na descrição da composição de formas nos inspirou também a associá-la a um tipo de construtivismo - mais de inspiração epistemológica que radical - aprimorado pelo ciberneticista Heinz von Foerster e seus seguidores (em especial Louis $\mathrm{H}$. Kauffman). Voltaremos a esse assunto na seção Pensamento estético. Quanto à 
fenomenologia recordamos que ela, em seus primórdios, designava o método descritivo de pesquisa nas ciências da natureza e em psicologia. ${ }^{17}$ Compreendemos as incertezas implicadas na segunda e o valor de oportunidade da primeira. É certo que não existe o reconhecimento do objeto estético sem a presença do elemento humano, mas que tal imprescindibilidade não imponha um psicologismo de plantão. A percepção, em primeiro lugar, deve unir-se ao sensível, e não ao conceito. A intelecção (e os sentimentos) chega na esteira, podendo a partir daí suscitar novas percepções. Mas é a percepção do fenômeno - do mundo natural, diga-se, mesmo que humanizado - que tem a precedência. Uma ciência natural, ou uma filosofia da Natureza, como sugere Dufrenne (2015: 100), deve apelar sempre para uma fenomenologia.

O tratado do modelo, portanto, contém uma ponderação a respeito de cada um dos termos da relação inscritos no diagrama do sistema genético da estética ecotécnica. A seção Pensamento ecológico, simbolizada pela palavra grega physis, expõe uma coreografia de duas disciplinas: a ecologia e a mesologia. A primeira pauta-se pelo universal, o objetivo, a natureza em suas diversas encarnações, em especial o ambiente, bem como noções de conectividade e de rede. A segunda pauta-se pelo singular, o subjetivo e os nós das conexões ecológicas. Segue-se com uma breve reflexão sobre as teorias do meio, tais como entorno, clima e paisagem, com o propósito de traçar os contornos da noção de meio, uma condensação das antecessoras. A seção Pensamento estético, simbolizada pela palavra grega aisthesis, envereda-se pelos caminhos do construtivismo (na acepção que the deu a cibernética de segunda ordem), com a missão de descrever os processos de formação da figura e do fundo; e da fenomenologia da percepção - não precisamente a de Merleau-Ponty, mas de dois de seus seguidores, Dufrenne e Simondon - com o intuito de esclarecer a relação entre o sentido do objeto representado e o fenômeno do sensível, ou como o "objeto pode ter um sentido onde a forma vem informar a matéria" (op.cit.: 233). A seção Pensamento tecnológico, variada e tendo como símbolo a palavra grega techné, ruma em direção ao que Simondon chamava de tecnicidade, quase uma essência das técnicas (não apenas, como se verá). Variada porque procura esmiuçar as quatro causas de

17 Ver FISETTE, Denis. Fenomenologia e fenomenismo em Husserl e Mach. Scientiae Studia, v. 7,2009 , pp. 535-76. 
Aristóteles e ligar a noção heideggeriana de Gestell com a simondoniana de ensemble, concluindo com um arrazoado sobre os limites do progresso técnico, dinâmico em razão das invenções. Eis as seções dos três pensamentos aninhados na fase técnica; resta-nos em seguida examinar o que escoou para fora de suas bordas. Na seção Estética ambiental, empreendemos uma definição de duas vertentes da estética ambiental, filha pródiga da romântica estética da natureza: a estética cognitiva natural-ambiental de Carlson e a estética do envolvimento, proposta por Berleant. A seção Tecno-estética desfia a célebre carta de Simondon dirigida a Derrida, na qual ele, quase nos estertores de sua vida, esboça uma teoria estética das técnicas (parcial e ainda incompleta, diga-se), da qual trechos foram vislumbrados em outros recônditos de sua obra. Por fim, a seção Estética ecotécnica, tal como sugere o nosso diagrama, entrelaça os três modos de pensamento e as duas respectivas estéticas, definindo os conteúdos temáticos e lançando a pedra fundamental dos dois capítulos subsequentes, voltados ao mundo das artes e do que chamamos de campos expandidos (arquitetura e infraestruturas).

\subsection{O PENSAMENTO ECOLÓGICO}

A palavra natureza, provinda do grego physis, conexa preliminarmente ao cultivo de vegetais, deu origem a outra: física, ou a ciência da natureza, disciplina exata que culminou na revolução científica moderna, mas que começou a ser gestada muito anteriormente, com os pensadores da Escola de Mileto (século 6 a.C.), os quais, em um rompante inovador, propiciaram a separação dos relatos mitológicos dos fenômenos naturais, extirpando os últimos de seus fundamentos religiosos (BERQUE 2013: 24). Apesar de terem iniciado o processo de abstração do objeto "natureza", os gregos continuaram a associá-lo ao deus Pã, rebento nascido da união entre Zeus e uma dríade, habitante das florestas da Arcádia e protetor dos pastores e animais. A evidência para tal constatação foi dada pela dita classe ociosa, formada por "operários espirituais" domiciliados na polis, elite que mirava do cimo da acrópole o ambiente natural dos trabalhadores do campo, na longitude confortável do ambiente urbano. Um dos principais projetos do filósofo britânico Timothy Morton, explicitado no título de seu livro Ecology Without Nature (2007), é revelar a 
impropriedade de se associar um objeto tornado abstrato (sinonímia: natureza, ambiente, paisagem $)^{18}$ a uma disciplina objetivista e realista. Todos os recursos mobilizados pelos teóricos da paisagem, como por exemplo os autores ligados à nature writing e paisagistas em geral, servem apenas para provocar a falsa sensação de uma natureza retomada. Seria melhor, segundo o pensador inglês, deixar a tarefa nas mãos dos próprios ecologistas.

\subsubsection{Ecologia}

Assim como a palavra natureza, o termo ecologia, cunhado em 1866 pelo cientista alemão Ernst Haeckel (1834-1919), é sabidamente controvertido, primeiro por estar associado à ciência econômica (a palavra grega oikos - entendida como "habitação do núcleo familiar" - é prefixo de ambas as disciplinas), e, segundo, por sugerir que haveria uma lógica ou verdade por detrás da satisfação metabólica de diversos processos presentes na natureza, físicos e biológicos. ${ }^{19}$ Ademais, a palavra é hoje associada à principal área de interesse de movimentos ambientalistas de diversas ideologias, algumas até conflitantes. Uma diferença fundamental separa, por exemplo, os defensores dos movimentos preservacionista, fundado por John Muir, e conservacionista, lançado pelo engenheiro florestal Gifford Pinchot: enquanto os primeiros tendem a considerar os seres humanos como separados da natureza, como forasteiros indesejados (a atitude derrogatória é tamanha que alguns recorrem a analogias de doenças oncológicas), os segundos os consideram capazes de se valer dos recursos naturais de forma controlada e respeitosa. Aos que enxergam uma zona cinzenta entre um e outro movimento, há a possibilidade de abraçar uma "ecologia reconciliatória", ${ }^{20}$ na qual as intervenções tecnológicas seriam orientadas tanto por uma "estética da conservação" (LEOPOLD 1989) como por uma "tecnologia liberatória" (BOOKCHIN 1986: 107-161) - ou mesmo uma síntese entre

18 Além dos sinônimos, o significante em questão acolhe uma infinidade de definições e sentidos. "Natureza, um termo transcendental em uma máscara material, situada no final de uma série infinita de outros termos que se colapsam, também conhecida como lista metonímica: peixe, grama, ar da montanha, chimpanzés, amor, refrigerante, liberdade de escolha, heterossexualidade, mercados livres... Natureza." (MORTON 2007: 14)

19 Ver WARK, McKenzie. From 000 to P(OO). Public Seminar, 5 dez. 2015. Disponível em: <http://www.publicseminar.org/2015/12/from-ooo-to-poo/>. Acesso em: 31 jan. 2017.

20 Ver ANTONACCIO, Maria. Technology and the Humanisation of Nature: New Resources for Critical Assessment. In: DEANE-DRUMMOND \& BERGMAN, 2016, p. 31-46. 
os dois conceitos. De qualquer modo, a ciência que estuda o meio ambiente tornouse atualmente menos inabitual aos não iniciados, "porque as questões ecológicas se aproximaram tanto de 'nosso quintal' que ficou árduo tratá-las com a distância dos 'fatos objetivos da natureza': todas as informações agora devem ser encaradas como algo que ameaça o 'nosso lar'". ${ }^{21}$

Um dos temas mais essenciais da ecologia, tratada agora como ciência, é a relação entre partes e todo. A noção de holismo, ou como as propriedades de um sistema não podem ser explicadas somente pela soma dos seus componentes é, guardadas as proporções, o apogeu da ciência ecológica, tal a sua carga de inferências transcendentais (na acepção espiritual e não filosófica). O único estorvo de tal abordagem é que a relação entre as partes e o todo que as integra implica a imagem de uma máquina e, por conseguinte, de uma montagem (ou mesmo de um maquinista!). ${ }^{22} \mathrm{O}$ problema da palavra "montagem" (assemblage), segundo Timothy Morton, é o decorrente significado de que "grandes coisas são apenas agregados soltos de pequenas coisas", ${ }^{23}$ sendo melhor substituí-la por hiperobjeto, em que o fenômeno da emergência implicada no holismo seria sucedido por uma "subscendência", na qual o todo é sempre menor do que a soma de suas partes. Apesar do tom "ateísta", Morton faz com que seus hiperobjetos sejam impreterivelmente interconectados, formando uma malha (mesh) "onde não há substâncias, mas apenas coletivos de relações". ${ }^{24}$ Isto soa como algumas passagens com caracteres ontológicos de Simondon onde ele considera, por exemplo, "toda verdadeira relação como tendo estatuto de ser" (2005: 23-36), colocando como prioridade a realidade da relação sobre os diversos relativismos do real. O pensamento ecológico proposto por Morton nos dá também a oportunidade de correlacioná-lo com o pensamento técnico (não mecanicista) e o pensamento estético, pois tal pensamento, em última análise, ultrapassa o que tomamos exclusivamente por ambientalismo (2010: 3).

21 AIME (@AIMEproject). 18 de Dezembro de 2017, 5:00 AM. Tweet.

22 Ver a palestra proferida por Bruno Latour na Science Gallery, Trinity College Dublin, 2012. Vídeo disponível em: <https://www.youtube.com/watch?v=1_q_haTB_EA>. Acesso em: 11 fev. 2017.

23 Ver o artigo Of Course You Can do Something About Hyperobjects, postado no blog ECOLOGY WITHOUT NATURE, em 30 de janeiro de 2016. Disponível em: <http://ecologywithoutnature.blogspot.com.br/2016/01/of-course-you-can-do-something-about.html>. Acesso em: 9 fev. 2017.

24 Ver GRATTON, Peter. Tim Morton, The Ecological Thought. Speculations, v. 1, n. 1, 2010, pp. 192-99. 
A propósito, a evocação do ambientalismo e, por extensão, do radical ambiente, nos dá a oportunidade de meditar mais a seu respeito. A ciência ecológica investiu em um upgrade do polissêmico termo de origem grega ao se apropriar do termo "ambiente". Mas o problema persiste. O que seria o ambiente? Tudo o que está em nossa volta? Mas até onde vai essa adjacência? O teóricos da paisagem responderiam que o seu limite vai até onde a vista alcança. Timothy Morton não se contenta com os estetas e indaga qual seria o limite real do que os ecologistas chamam de ambiente: a atmosfera terrestre? O campo magnético? O sistema solar? A Via Láctea? (2010: 10). Nota-se aqui certa pregnância do espaço euclidiano, da coordenada cartesiana, do infinito, ou seja, de mais uma noção matematicamente construída, tão abstrata quanto natureza. Mas a autêntica sensação de contato com o meio real permanece ausente. A nossa metade animalesca, fisiológica, continua cingida de uma outra corporalidade, não menos importante, o "corpo medial", formado pelo mundo técnico, simbólico e, sobretudo, o natural (BERQUE 2013: 60). Artefatos como utilitários de luxo ainda são necessários para conduzir um corpo ao outro, ${ }^{25}$ mesmo que virtualmente (ou falsamente), como é visto no comercial ${ }^{26}$ do Jeep Renegade, no qual o mesmo texto de um voice-over surge primeiro no contexto urbano de uma academia de ginástica e, em seguida, no cenário de uma costa marítima (Você está na praia. Dá pra sentir a areia fria sob seus pés. A brisa da manhã traz o gosto salgado do oceano). Vê-se que até os profissionais da propaganda já assimilaram as técnicas exploradas pelos praticantes da arte ecológica e da nature writing. E ainda no campo dos utilitários, vale lembrar o alerta que Berque (op.cit.: 61) faz ao mostrar o problema psicológico de duplo vínculo entre adquirir um veículo desse tipo e manter uma conduta ecológica.

\subsubsection{Mesologia}

O termo criado pelo médico e naturalista francês Charles Philippe Robin $(1821-1885)^{27}$ para definir um ramo da biologia que estuda a relação entre seres

25 "A natureza não fala mais ao homem e ainda é necessário que ele tenha férias para a reencontrar", já dizia Dufrenne (2015: 220).

26 ARQUIVO DA PROPAGANDA. Jeep - Renegade 2017, 2016. Disponível em: <https://www.youtube.com/watch?v=hEIGtmZRNUc\&sns=em>. Acesso em: 20 fev. 2017.

27 Dado que não tivemos acesso à edição original de La Pensée Paysagère (2008), valemo-nos das edições espanhola (BERQUE 2009) e inglesa (BERQUE 2013). A análise comparativa entre os dois 
vivos e o meio em que vivem caiu em desuso no século 20 por dois motivos: o primeiro é a sua absorção pela sociologia; e o segundo é a sua substituição pura e simples pela ciência ecológica. Há, porém, os que defendem a sua preservação (e revitalização), como o geógrafo francês Augustin Berque, para quem o termo "ecologia" é por demais problemático devido a sua excessiva bagagem científica, desviando-se de questões subjetivas sem as quais não se poderia definir o meio ambiente em toda a sua completude. Para a ecologia, o meio ambiente é o reflexo de uma cosmologia newtoniana que principiou a era moderna, trazendo em seu rastro um legado de separações (mente e corpo, sujeito e objeto etc.). A ecologia, por exemplo, desconsidera a paisagem, noção fenomenológica, subjetiva, propícia a ser apoderada por projeções culturais e históricas. O senso de paisagem é culturalmente construído; não é um dado objetivo. E a sua "representação pictórica é apenas um dos seus vetores", ${ }^{28}$ como comprova o projeto Smellscape, da artista inglesa Kate McLean, uma constituição de "paisagens olfativas" a partir de diferentes ambientes urbanos. ${ }^{29}$ Historicamente, o primeiro esforço visual para se atingir uma "sensibilidade paisagística" surge na China da dinastia Han (206 a.C. - 220 d.C.), convergido para expressões caracterizadas por traços amplos e extensos espaços em branco que procuravam captar a "intenção" de um meio ambiente subjetivado. Tal objeto sensorialmente captado, para os chineses, significa "as montanhas e as águas" (shanshui), mas pode ser representado por outros elementos naturais (BERQUE 2013: 29).

\footnotetext{
textos nos revelou a replicação de uma discórdia interpretativa acerca da autoria do termo "mesologia". Na tradução espanhola, consta que seu autor é Louis-Adolph Bertillon (98), enquanto que na tradução inglesa menciona-se o nome de Charles Philippe Robin (55). Por inferência, concluímos que a tradução espanhola tomou a liberdade de alterar o nome do autor definido por Barque, enquanto a tradução inglesa foi literal, respeitando o autor grafado no texto original. A nossa indução se deu após a análise de um terceiro texto de Barque, Cosmophanie, Paysage et Haïku, publicado na revista Projets de Paysage em 2015, no qual ele mantém a autoria de Robin. Em termos cronológicos, Robin, fundador da Société de Biologie em 1848, foi o primeiro autor do termo - e Bertillon foi quem o sistematizou a partir de 1860. Ver também Historique du terme "mésologie" I Exposé de Mlle LEE Yichien. Séminaire "Questions de mésologie". Compte Rendu de la Séance du Jeudi 9 Décembre 2010. Mésologiques: Études des Milieux, 11 dez. 2010. Disponível em $<$ http://ecoumene.blogspot.com.br/2010/12/historique-du-terme-mesologie-expose-de.html>. Acesso em: 10 dez. 2017.

28 BERQUE, Augustin. Paysage, Milieu, Histoire. In: BERQUE (org.) ET AL., 1994. pp. 13-29.

29 Cf. TRAVERSO, Vittoria. Learning About Cities by Mapping Their Smells. Atlas Obscura, 8 dez. 2017. Disponível em: <http://www.atlasobscura.com/articles/art-mapping-smell-smellscapes-katemclean>. Acesso em: 9 dez. 2017.
} 
Mas é no Japão que a ciência de Robin se reconecta com o conceito de paisagem e com uma filosofia que a interpreta como uma entidade relacional. É progênito do pensamento do filósofo japonês Tetsuri Watsuji, o qual traduz a palavra mesologia para o neologismo fudogaku que, por sua vez, é traduzido por Berque (op.cit.: 55) para milieus, no plural, ou meios, no português, liberando-a das pretensões universalistas da ecologia científica e reconduzindo-a para diversas conotações não localizadas, a depender da cultura que a acolher. Pode-se, nesse esforço translativo (mas não no sentido antropológico do termo tradução), remeter a presente análise, primeiro, ao título da versão argentina do livro La Pensée Paysagère (2008), de Berque: El Pensamiento Paisajero (2009); e, segundo, à solução encontrada pelos tradutores ingleses para o título do mesmo livro: Thinking Through Landscape (2013). A intenção do filósofo japonês, relida pelo geógrafo francês, é revelada com o segundo exemplo, ao ser contrastado com a imperfeição do primeiro, já que a palavra paisagismo é problemática, não tanto pela sua associação com uma área da arquitetura que desenvolve projetos para espaços livres, mas pela sua ligação com técnicas de jardinagem encontradas até em revistas de bancas de jornais. Portanto, a expressão "pensar através da paisagem" é mais apropriada para transmitir o profundo significado do meio vital na releitura que Berque faz de Watsuji. E a função mesológica torna-se mais evidente com a substituição do substantivo pelo verbo: o pensar a realidade "ao vivo" tendo como contexto uma paisagem específica.

\subsubsection{Teorias do meio}

A discussão sobre a evolução da expressão "meio ambiente" ${ }^{30}$ é bastante ilustrativa sobre como viemos, ao cabo e ao final, associá-la com a ideia de "mídia". A palavra milieu, referida por Simondon em diversos trechos de sua obra, passou por modificações e apropriações, não sendo exagero dizer que seu processo de individuação ainda está em curso. De Aristóteles até a França renascentista, o termo manteve um significado geométrico, a zona central entre dois pontos, e, em menor medida, um significado moral, traduzido na doutrina do meio-termo. ${ }^{31}$ Mas pode-se

30 Ver o capítulo The Living Being and its Milieu. In: CANGUILHEM 2008, pp. 98-120.

31 Ver SPITZER, Leo. Milieu and Ambiance: An Essay in Historical Semantics. Philosophy and 
iniciar a genealogia da noção de milieu (meio) na mecânica do século 18, quando da disputa sobre a relação entre corpos e partículas, se transcorreria apenas por colisão ou também por atuações à distância. Se a segunda opção fosse verdadeira, então haveria a necessidade de se colocar "algo" entre os corpos, algo que exercesse uma influência entre eles. Esse "algo" foi denominado de éter, ou fluído, o vetor de uma força centrípeta entre dois corpos, o "veículo transmissor" (medium) proposto por Newton para resolver o problema das forças centrais, ou como os corpos exercem influências uns sobre os outros sem a necessidade de contato físico. No mesmo século, a palavra é associada a outra, ambiant, para designar não o entorno frio e sem vida da física, mas o meio ambiente que circunda todos os seres vivos, sendo que desta forma o termo perde um pouco suas denotações mecanicistas ("meio de ação distância") e é transposta para a biologia. Lamarck e Darwin precisavam de uma noção de exterioridade para fundamentar suas respectivas teorias, algo a partir do qual outros conceitos pudessem ser derivados, como clima, local e, claro, ambiente. Lamarck, por exemplo, fala em ambientes, no plural (milieus) - como água, ar, luz -, mas quando se refere a forças exercidas do meio externo em um determinado organismo, usa a expressão "circunstâncias de influência" (CANGUILHEM 2008: 100).

Um salto foi dado por Comte, que, pela primeira vez, concebeu uma relação dialética entre organismo e o ambiente, imediato ou não, no qual está inserido. A disputa segue até chegar em Saint-Hilaire que, em 1831, num relatório para a Academia de Ciências, grafou a expressão le milieu ambiant. Com a revolução industrial passou-se a encarar o meio ambiente como um suporte comunicacional e não mais apenas como um entorno ecológico. No caso isolado do termo ambiente (environnement), o adjetivo se destaca do qualificado, meio, substantivando-se, para tornar-se uma referência autônoma, extrapolando a área da ciência e invadindo outras tantas, como a da literatura (por ex. meio literário). Daí, é realizada a guinada definitiva para a teoria da comunicação, a começar com os populares conceitos de Marshall McLuhan. Mas agora, em tempos de crise ecológica, talvez seja preciso refazer o caminho da expressão, reduzir sua carga de abstração, materializá-la novamente e explicá-la por meio de definições vindas das disciplinas ambientais, "essa compreensão completamente diferente de meio, a mídia da terra, do ar e da Phenomenological Research, v. 3, n. 2, 1942, p. 169. 
água" (PARIKKA 2015: 19). É preciso interpretá-la não apenas em seu conteúdo informacional, mas também em seu aspecto elemental: "a mídia do mar, do fogo, das estrelas, das nuvens ..." (PETERS 2015: 14). Após a nossa breve genealogia e recordar que, para Nietzsche, a teoria do meio era tudo aquilo que exercia influência sobre o Homem $^{32}$ - talvez seja válido realizar uma espécie de "fracionamento" do "significante mestre" ambiente e explorar alguns de seus componentes, como por exemplo entorno, clima e paisagem, porque os três têm um papel formador do pensamento sobre o meio, ideia que nos parece mais relevante na ciência ecológica (assim como os termos técnica e tecnicidade está para a tecnologia).

\subsubsection{Entorno}

Pode-se evocar nesse momento que, na evolução diacrônica das noções de ambiente e meio, uma espécie de virada foi estabelecida pelo biólogo alemão Jakob von Uexküll, o qual passou a distinguir Umgebung, o ambiente geográfico, físico e universal, de Umwelt, o meio por onde seres vivos desempenham comportamentos estudados pela etologia, o espaço de suas ações de sobrevivência, o meio imediato de percepção, enfim. Uexküll resolve o desafio de uma antiga questão, promulgada por Auguste Comte, o de ser o meio indiferente - ou não - ao ser que envelopa, suscitando considerações acerca de um ambiente resistente às ações dos organismos, ou até mesmo hostil a elas. Um organismo controlado a partir do mundo externo configura uma situação catastrófica, porque viver é organizar o meio a partir de um centro de referência (CANGUILHEM 2008). É possível exorbitar poeticamente o conceito e dizer que não apenas indivíduos orgânicos se associam com seus entornos imediatos. Para Simondon, por exemplo, o Umwelt de um indivíduo técnico é seu meio associado (milieu associé), uma realidade imediata na qual se desenvolve o teatro da individuação técnica, ou a "concretização dos aspectos técnicos [tecnicidades] trazidos por todos os elementos [partes constituintes do indivíduo] em suas relações mútuas" (SIMONDON 1969: 74). ${ }^{33}$ Nesse sentido, um

32 Cf. SPITZER 1942, p. 184.

33 No original: ...le milieu associé est la concrétisation des technicités apportées par tous les éléments, dans leurs réactions mutuelles. (tradução nossa). A noção de tecnicidade [technicité] merece tratamento diferenciado e será abordada na seção Pensamento técnico. 
objeto técnico mereceria possuir as condições mínimas de subsistência, "porque tem valor intrínseco, que resulta de uma concretização originada no homem, mas destinada a tornar-se um análogo dos objetos naturais," ${ }^{34}$ concretos desde a sua concepção. É uma analogia parcial, portanto, diferente da analogia total promulgada pela ciência cibernética de primeira ordem.

\subsubsection{Clima}

Uma outra via de acesso à noção de meio, ou ao menos uma maneira de filtrá-lo de conteúdos objetivistas da ciência ecológica, descortina-se, como vimos, desde o Japão, na voz do filósofo Tetsuro Watsuji (2006), citado de relance em parágrafos anteriores. Discípulo motivado de Heidegger, em seu mestre constatou uma anomalia: o papel que Dasein realiza na estrutura subjetiva privilegia o tempo em função do espaço e, para ele, a estrutura ambiental deveria ser a peça-chave na existência humana. Sua filosofia, muitas vezes acusada de determinismo geográfico (erroneamente, ver seção 1.1.3.2), propõe três formas de ambientalidades climáticas: a umidade das monções, a sequidão dos desertos e as brisas das montadas europeias - cada uma definindo o devir e o hábito dos povos que as experimentam e as perpassam. "Na cultura, historicidade e ambientalidade são as duas faces da mesma moeda", reflete (op.cit.: 147). Mas um dos pontos que nos interessa em sua fenomenologia climático-ambiental são os vários níveis de percepção do corpo e seu meio, indo do fenômeno físico ao cultural, em como não é possível, a título de exemplo, "pressentir" o frio sem nunca tê-lo sentido e, quando se passa a senti-lo, percebê-lo transbordando para além da epiderme, indo existir interpessoalmente onde a comunidade existe, ou melhor, ex-siste. ${ }^{35} \mathrm{~A}$ filosofia poética de Watsuji, desta feita, deve ser comparada não com a de Friedrich Ratzel ou mesmo Marx, mas com os filmes de Yasujirō Ozu ${ }^{36}$ e os haiku de Bashō ("mar

34 Ver SANTOS, Laymert Garcia dos. Tecnologia, Natureza e a "Redescoberta" do Brasil. In: ARAÚJO 1998, p. 40.

35 Apesar da óbvia reminiscência heideggeriana, tal transposição remete, em nossa opinião, mais à transindividuação simondoniana, processo de individuação coletiva que demanda uma prévia desindividuação de cada um dos indivíduos.

36 Haveria uma curiosa relação entre a "abertura completamente desimpedida e abnegada" presente nos sistemas de ventilação das machiya (casas de madeira tradicionais que aparecem em praticamente toda a filmografia de Ozu) e a hospitalidade do povo japonês. Cf. BAEK, Jin. Fudo: an East Asian Notion of Climate and Sustainability. Buildings, v.3, n.3, 2013. 
sem sensação de mar"). ${ }^{37}$ Como prova de nosso conceito, o termo adotado para definir o espaço tangível sobre o qual disserta é fûdo, combinação de dois ideogramas de origem chinesa: vento e terra (WATSUJI 2006: 23). O que se pretende nesse projeto é regular a abstração do fenômeno concreto do ambiente, reconectando-o à existência humana e sem reduzi-lo meramente ao entorno físico e natural, objeto de estudo da ecologia (op.cit.: 31). De resto é atual porque, em tempos de mudanças climáticas, pode reativar coletivamente uma consciência sobre o clima do planeta em crise, diferenciando-o, antes de mais nada, do tempo da meteorologia. $^{38}$

\subsubsection{Paisagem}

Voltemos agora ao sintagma "pensar através da paisagem", tradução feliz de La pensée paysagère, uma das obras mais populares do geógrafo francês Augustin Berque (2013). O efeito de recuamento circular sugerido no título se dá ao admitirmos que a natureza produz o homem e se reflete através dele, no próprio espelho do pensamento humano, mas também é o homem que encontra a si mesmo em sua perseverança de pensar sobre a natureza. Contudo, o título não conta toda a história. O propósito de Berque é efetuar uma crítica aos que abusam da procuração formalizada pela ciência ecológica ou para arbitrariamente transfigurar a natureza em objeto, ou subjetivizá-la radicalmente, como se empenharam algumas eminências da arte visual romântica (op.cit.: 59). O problema de ambas as interpretações é que "ou se considera a paisagem em termos de processos físicos isolados ou como sistemas de sinais abstraídos de sua base no ecossistema: a história humana desacoplada da história natural" (loc.cit.). Berque se pergunta, mediante tal polarização, se seria possível reintroduzir uma antropologia que apelasse para uma filosofia da natureza. Sim, ele responde, se introduzirmos com sucesso um pensar sobre a paisagem que realize uma combinação mediadora de aspectos físicos, biológicos e simbólicos. Ele usa como exemplo a trajetória cruzada (trajection) de um raio de luz visível associado à cor vermelha (mundo físico) que, ao

37 Impressão de Watsuji sobre o mar Mediterrâneo. Ver op.cit.: 92.

38 Ver JANZ, Bruce. Watsuji Tetsuro, Fudo, and Climate Change. Journal of Global Ethics, v. 7, n. 2, 2011, pp. 173-184. 
atingir a biosfera (mundo do vivente), pode não ser percebida devido ao seu comprimento de onda específico (por um bovino, por exemplo) ou enxergada integralmente por seres humanos (mundo humano, ou ecúmeno, em sua terminologia), a partir daí podendo ser interpretada como "'pare!' para o motorista comum, [ou] 'avante!' para a Guarda Vermelha da Revolução Cultural" (BERQUE 2013: 58). Não é recomendável ignorar uma ou mais das três esferas, vedando-se os olhos para os processos materiais do planeta (Umgebung), a evolução da vida sobre a crosta terrestre (Umwelt) e a história geral da humanidade sob o prisma climático (fûdo). Há um compromisso inalienável, na escala da realidade, entre os três níveis; e o nome que se dá a esse relacionamento dinâmico é, segundo Berque, paisagem.

É notável a erudição empregada por Berque para diferenciar as duas abordagens de paisagem, buscando refiná-la ao máximo: o ancestral pensamento paisagístico - o pensar através da paisagem, e não sobre a paisagem, implantado por filósofos e poetas da China sob os Han - e a teoria da paisagem, elaborada inicialmente na renascença, depois vindo a ser saturada de conhecimentos sobre a natureza, conceito vago, mas estabelecido por convenção. A contradição exposta por Berque é que quanto mais destituída de pertences cientificistas, menos danos são infligidos à paisagem (ou como queiram chamar o ambiente), com a qual firmouse uma espécie de acordo de não agressão pelos antigos. Há mais contradições, contudo, no programa moderno de tornar o ambiente uma abstração controlável a todo o custo. A visão "ilustrada", oriunda da ciência (em especial a física), submetese ao determinismo materialista, na qual a natureza domina e define a cultura. Sua antípoda, capitaneada pelas ciências sociais e chamada por Berque de metabasismo (a palavra conota algo como uma estrutura infundada, sem alicerce), afirma ser a cultura e sociedade autônomas e, portanto, dominadoras da natureza. $\mathrm{O}$ óbice é que ambas as posições traduzem-se em um distanciamento do cosmos, um "a-cosmismo" desagregador da existência humana (op.cit.: 54). O componente faltante, em resumo, é uma cosmovisão que una o céu e a terra, ao estilo dos antigos chineses ou, quando menos, o determinismo e o metabasismo, típicos do pensamento moderno. Daí a persistência de se desmontar a "ecologia da paisagem" e substituí-la por uma mesologia que interprete a paisagem como um composto 
formado por humanos, técnicas e meio, numa correlação entrelaçada chamada por Uexküll de "emparelhamento" (Gegengefüge) e por Watsuji de "momento estrutural". Nesta última concepção, não é o ambiente que determina o humano (segundo os critérios do determinismo geográfico), mas é o humano que interpreta ativamente o meio ambiente através de suas percepções e ações, sendo o resultado desta compreensão o meio propriamente dito. ${ }^{39} \mathrm{~A}$ visão de paisagem de Berque, portanto, converge com a noção de meio, uma noção isenta das ambiguidades distintivas da ecologia. Vê-se que o pensamento paisagístico é, na verdade, o que entendemos por pensamento ecológico - ou melhor, o pensar através do meio, em sua versão definitiva.

\subsection{O PENSAMENTO ESTÉTICO}

É preciso definir de partida o que entendemos por "pensamento" na expressão "pensamento estético". Por certo somente o fato de estarmos analisando a ontogênese de formas e percepções já configuraria um processo mental, porém faz-se pertinente estabelecer que tal pensamento é orientado mais por um processo cognitivo, uma epistemologia - no caso uma epistemologia relacional - do que por um método, conceito associado ao pensamento puramente racional. Ademais, lembramos que a palavra "estética", introduzida por Baumgarten em 1750, deriva de percepção (do grego aisthanesthai, "perceber"), e que o recebimento de sinais sensoriais são ordenados, segundo a sugestão de André Leroi-Gourhan (1993: 272), de várias formas, tais como funções corporais (gosto, odor etc.); códigos sociais de comportamento; expressões simbólicas artísticas; e mesmo atividades técnicas, como os gestos empregados no exercício de um ofício. Com isso, a percepção é associada a um conhecimento, reciprocamente, redobrando-se em sua continuidade. O pensamento estético amplia-se ao infinito, malgrado as adversidades de tal extrapolação. O emprego de soluções estéticas para os problemas do mundo moderno, entretanto, corre o risco de resultar em formas comodificadas (MORTON 2007: 165), principalmente em processos de humanização

39 Ver BERQUE, Augustin. Anthropocene and Transhumanism. In: YANG, Andrew (org.). Designing Media Ecology, $\mathrm{n}^{\circ}$ 6, 2016. Publicado dentro do Anthropocene Curriculum, programa patrocinado pela Haus der Kulturen Der Welt, Berlim, Alemanha. 
(ou tecnicização) da natureza. Mas, por outro lado, o recurso estético também pode proporcionar uma aproximação sincera entre sujeito e objeto, através de uma sensibilização, sem que seja renunciada a marcação de fronteiras necessárias para o desenvolvimento de uma crítica das dicotomias. Uma comodificação parcial (ou incompleta, na teoria de Margaret Jane Radin $)^{40}$ de objetos tecno-ambientais pode estabelecer o equilíbrio entre a humanização universal e a não humanização universal da natureza - entre a adulteração indelével e a pureza total.

\subsubsection{Construção e fenômeno}

A propósito da referência aos objetos tecno-ambientais é útil esboçar o quadro contextual do universo estético sobre o qual iremos nos debruçar. Erige-se, logo de partida, uma tríade esquemática. No documentário de François Lagarde sobre Gilbert Simondon, ${ }^{41}$ assistimos a um diálogo a beira-mar, mais especificamente na costa adriática de San Cataldo (Lecce, Itália), entre Giovanni Carrozzini e Pascal Chabot, no qual o biógrafo italiano, abancado sobre as pedras das antigas ruínas do porto de Adriano, corrobora ao filósofo francês qual seria a principal influência filosófica de Simondon no campo da estética: Mikel Dufrenne. ${ }^{42} \mathrm{O}$ que nos interessa neste momento, já que discutiremos sobre o pensamento deste esteta francês ao longo do trabalho, é como Carrozzini pondera logo em seguida que, em sua leitura, o discurso estético de Simondon deveria ser segmentado em três níveis principais: pensamento estético, estética da tecnologia e tecno-estética. Vamos nos ater, nessa seção, tão somente ao primeiro nível, o pensamento estético, e examinar com mais detalhes os dois remanescentes na seção Tecno-estética. Simondon não colocava a percepção em posição elevada à da invenção, ao contrário do empirismo e de algumas variantes da fenomenologia. De fato, se a operação dos sentidos não é mais do que uma possibilidade de conhecimento da realidade, ela deve "ser sempre uma mistura de percepção e construção", ${ }^{43}$ ou seja,

40 Ver ANTONACCIO, Maria. Technology and the Humanisation of Nature: New Resources for Critical Assessment. In: DEANE-DRUMMOND ET AL. 2015, pp. 31-46.

41 SIMONDON du désert. Direção: François Lagarde. Edição: Mikaël Barre. Montpellier (FR). Hors CEil Éditions, 2012, 110 min.

42 Outra evidência é o texto de dedicação de Du Mode d'Existence des Objets Techniques: J'exprime, en terminant, ma gratitude à mes anciens Collègues André Doazan et Mikel Dufrenne, qui m'ont aidé au moment de ma soutenance à Paris.

43 Ver DUHEM, Ludovic. Thinking Aesthetic Reality (with Simondon), 2012. Segundo informações 
para nós, uma combinação de fenomenologia e construtivismo. Assim, começamos o estudo do pensamento estético com a investigação (a) sobre a forma e o fundo como se individuam e como se constituem em "unidades orgânicas perceptivas carregadas de informação"44 - e (b) sobre as faculdades perceptivas dos seres vivos, em particular aqueles inclinados a uma epistemologia do fenômeno.

\subsubsection{Construtivismo: forma e autoforma}

Entremos primeiramente na questão da gênese das formas. No senso comum, formas são aspectos (eidos) da matéria. ${ }^{45}$ Partimos de um exemplo do universo da arte com o intento de demonstrar o que são formas e como elas são constituídas. Tome-se como ilustração uma das abstrações geométricas de Jared Bark, artista estadunidense que criou uma série composta de imagens capturadas em antigas cabines fotográficas. Em uma obra específica de 1973, sem título, podemos reparar diversas linhas pretas contra um fundo branco, na verdade vinte e quatro registros de uma vareta negra fotografada em diferentes ângulos e que depois foram ordenados lado a lado, como se o artista se empenhasse em elaborar o esboço de uma partitura imaginária. A composição final apresenta-se como uma grade matricial, um tanto desfocada. O trabalho não é referência na crítica da arte e poderíamos ter elegido outros exemplos do vasto repertório da arte moderna e contemporânea, como as notórias formas geométricas do suprematismo russo ou mesmo as máquinas do artista-técnico futurista Fernand Léger. ${ }^{46}$ Porém, a obra de Bark se amolda em nossa análise por conter fragmentos autônomos, metáfora das "unidades orgânicas perceptivas", elementos básicos das formas. Como vimos, tais unidades morfológicas foram posteriormente arranjadas pelo artista em um único

obtidas em troca de mensagens com o autor na plataforma Academia.edu (2018), o texto citado, traduzido do francês para o inglês por Mark Hayward, foi encomendado, mas não publicado na SubStance: A Review of Theory and Literary Criticism, revista acadêmica da UW Press.

44 Ver CARROZZINI, Giovanni. How to Invent a Form: An Inquiry into Gilbert Simondon's Philosophy of Perception. In: SARTI ET AL., 2015, pp. 33-48.

$45 \mathrm{Um}$ alerta deve fazer-se ouvir após a leitura da frase "formas são aspectos de objetos": no paradigma da moldagem, expressado no esquema hilemórfico, a forma impõe-se à matéria. $\mathrm{Na}$ presente análise, eivada de tons simondonianos, tal esquema não é considerado. Para Simondon, a noção de forma deveria ser substituída pela de informação.

46 Exemplo citado por Simondon (1992) na célebre carta a Jacques Derrida sobre a criação de um Colégio Internacional de Filosofia. In: ARAÚJJ, 1998, pp. 253-266. 
objeto conceitual, gerando uma estrutura no transcurso de uma suposta "individuação harmônica". ${ }^{47}$

Figura 3 - Jared Bark, Untitled (1973), impressão por processo de prata coloidal

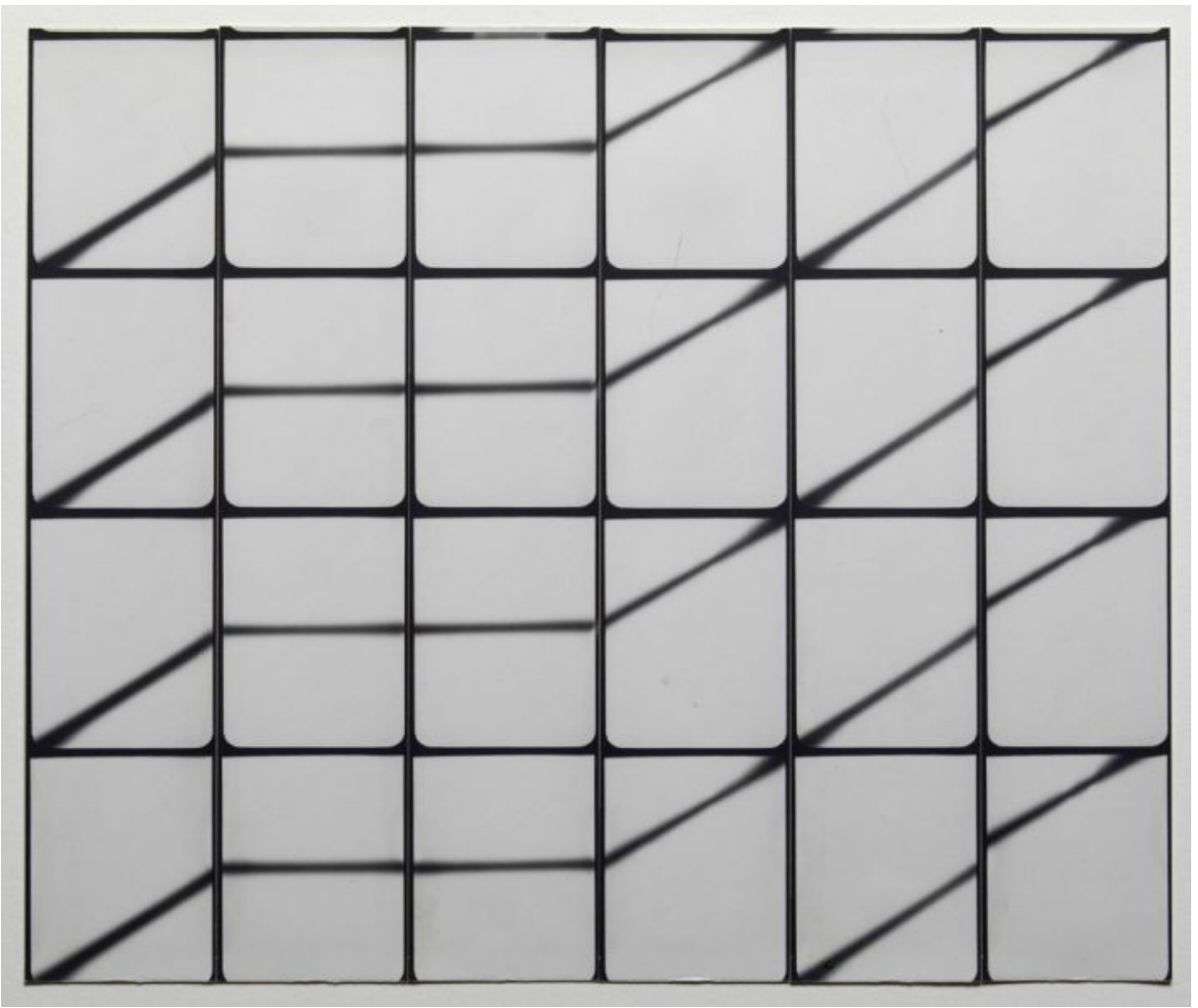

Fonte: https://hyperallergic.com/252712/an-artists-conceptual-photo-booth-compositions-from-the1970s

Ao destacarmos uma das vinte e quatro unidades que compõem a obra de Bark nos perguntamos como poderíamos descrever o processo de individuação desta forma/imagem em especial. Para tanto, já que assumimos uma posição construtivista, em paralelo à postura fenomenológica (analisada a seguir), recorremos à noção de autoforma (eigenform), ou processos matemáticos recursivos (autoprodutivos). A opção construtivista, familiar aos filósofos da cibernética de segunda ordem, ${ }^{48}$ é fundada no fato de que unidades orgânicas perceptivas são

47 Simondon chama de "ressonância" (excitações de frequências iguais) o efeito de uma forma em processo de individuação. Para ele, sistemas diversos garantem a sua existência através de uma condição de débil equilíbrio com o meio (ponto de equilíbrio metaestável), de tal maneira que, quando um equilíbrio total se concretiza, soluções para atingir o estado anterior tendem a assumir o controle. Ver SARTI, Alessandro; PIOTROWSKI, David. Individuation and Semiogenesis: An Interplay Between Geometric Harmonics and Structural Morphodynamics. In: SARTI ET AL. 2015: 49-73.

48 A cibernética de segunda ordem investiga como os observadores constroem modelos de outros sistemas cibernéticos. Ver HEYLIGHEN, Francis; JOSLYN, Cliff. Second-Order Cybernetics. Principia 
objetos que participam de uma rede de interações, assumindo uma aparente estabilidade a partir dessas mesmas relações. Nesse sentido, uma unidade de percepção (o elemento básico, o "morfema" de um objeto) é uma espécie de "anfíbio situado entre o mundo simbólico e imaginário da mente e o mundo complexo da experiência pessoal". ${ }^{49}$ Vamos ilustrar a noção de eigenform, à primeira vista hermética, por meio de diagramas, a começar por um de caráter simples, e até reducionista (ver Fig. 4), mas que atua como uma metáfora do processo pelo qual ações repetitivas podem levar à estabilidade de um estado qualquer. A execução operacional é: escolha um número qualquer e divida-o por 2 , adicionando 1 ao resultado final. Em seguida, repita o processo, ou seja, use a saída (resultado) dessa operação como a próxima inserção, e assim sucessivamente.

Figura 4 - A autoforma "calcula" uma saída e se aproxima recursivamente do valor 2

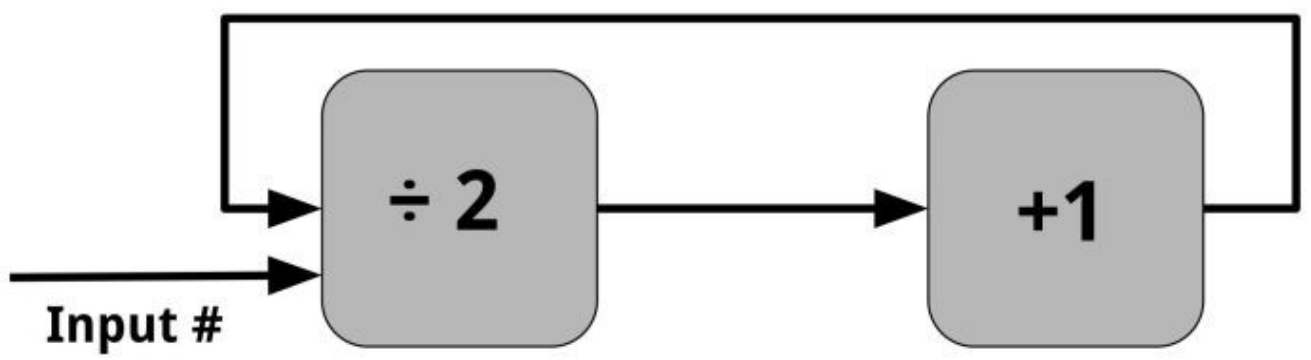

Fonte: GLANVILLE, Ranulph. Personal Wonder. In: MÜLLER \& MÜLLER, 2007, p.137

É perfeitamente viável traduzir o diagrama matemático da autoforma para um outro diagrama, menos abstrato e mais voltado ao sentido visual. Louis $\mathrm{H}$. Kauffman (2003) recorre ao físico austríaco Heinz von Foerster e apresenta-nos um modelo chamado de "ninho infinito de caixas", uma das autoformas visuais mais simples, segundo o matemático estadunidense. O princípio é o mesmo da autoforma recursiva operada com números, só que desta feita as operações são executadas com uma das formas geométricas padronizadas da Gestalten: o quadrado. Ou seja, cada passo no processo inclui os resultados da etapa anterior dentro de um quadrilátero preliminar $X$. Se a operação inicial $X=F(X)$ for continuada, cada etapa

Cybernetica Web, 3 set. 2001. Disponível em: <http://pespmc1.vub.ac.be/SECORCYB.html>. Acesso em: 4 abr. 2019.

49 Ver KAUFFMAN, Louis $\mathrm{H}$. Eigenforms - Objects as Tokens for Eigenbehaviors. Cybernetics And Human Knowing. Vol. 10, ns. 3-4, 2003, pp. 71-87. 
do processo inclui os resultados da etapa anterior e os sucessivos quadrados semelhantes vão se aninhando uns nos outros, até um limite "infinito". As aspas na última expressão indica que, ao assumirmos que é impossível construirmos um ninho infinito de quadrados durante o ato perceptivo, então é porque em algum ponto da recursão nós passamos a "completá-los", ou seja, passamos a imaginá-los (ou construí-los), para que eles alcancem uma estabilidade transitória (metaestabilidade) e se tornem um objeto passível de ser percebido, um quadrado propriamente dito. Certamente, o procedimento pode ser estendido para outros objetos, mais complexos, ou não, como a vareta negra de Bark.

Figura 5 - Ninho infinito de caixas de Kauffman

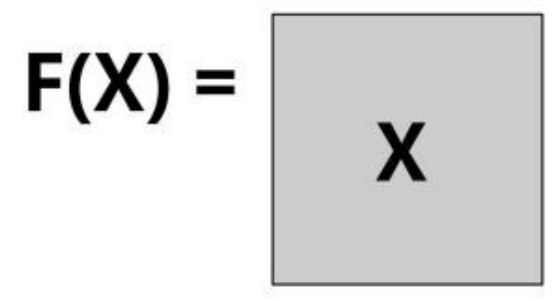

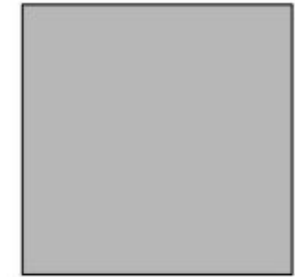

$\mathbf{X}$

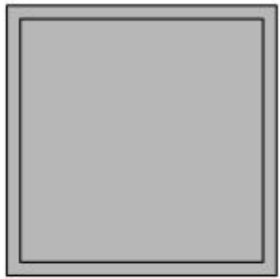

$\mathbf{F}(\mathbf{X})$

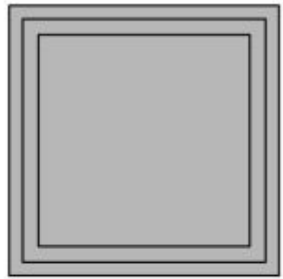

$F(F(X))$

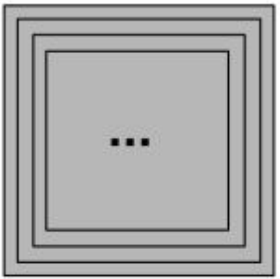

$F(F(F(X)))$

Fonte: KAUFFMAN 2003: 75

O diagrama de Kauffman demonstra como formas e imagens (as duas palavras são sinônimos para Simondon), durante o processo de percepção, passam de um estado de indivíduo individuante (operação) para o estado individuo individuado (estrutura), segundo condições que se situam entre o puro indeterminismo (casualismo) e o determinismo (causalismo). Esse processo de formação (prise de forme), na teoria alagmática ${ }^{50}$ proposta por Simondon, é um

50 "Considerando que cada ciência positiva é uma ciência de estruturas genéricas, a alagmática é a ciência das operações genéticas: 'a operação é aquela que faz aparecer uma estrutura, ou aquilo que modifica uma estrutura"' (SIMONDON 2005: 559). A expressão completa, incluída a citação de Simondon, é de autoria de Jean-Hugues Barthélemy. Ver Fifty Key Terms in the Works of Gilbert 
exemplo peculiar de individuação, já que se subordina a um ser individuado externo: o sujeito observador. É único, pois a individuação é antes de tudo um processo endógeno, sobretudo se transportarmos o conceito para outras denominações, também oriundas da ciência da física, como a passagem (temporária) de um estado metaestável, repleto de possibilidades, para um estado estável, estático. As abordagens determinista e não-determinista têm a função de trazer a dinâmica interna da individuação das formas para o campo do sensível e do conhecimento, caso contrário ela seria absolutamente incognoscível. ${ }^{51}$ Assim, o único recurso disponível é a descrição, em especial de seus vestígios e traços, formal ou diagramaticamente.

\subsection{Horizonte e profundidade}

É evidente, pela incidência de menções, a importância que Simondon dá à noção de figura-fundo, experiência perceptual investigada pela Gestaltpsychologie, tendo como exemplo mais famoso a imagem continua entre rosto e vaso, desenvolvida pelo psicólogo dinamarquês Edgar Rubin. Bem como é fato a sua crítica à psicologia da boa forma, devido à sua elevada subordinação ao conceito de representação, resultado de uma consciência não aberta ao mundo, mas detida em um circuito fechado (DUFRENNE 1973: 336). Ainda assim, a noção é aplicada extensivamente em sua obra, inclusive sendo o fundamento da célebre gênese da relação homem-mundo, com as funções figurativas da técnica operando sobre as figuras de fundo criadas pela religião. Em sua reflexão estética, adquire ainda mais relevância, pois a beleza de um objeto técnico se dá quando ele "encontra um fundo adequado, do qual pode ser a figura apropriada, isto é, quando alcança e expressa o mundo" (SIMONDON 1969: 185). Um objeto técnico, portanto, não é belo em qualquer circunstância: "um trator na garagem é apenas um objeto técnico; quando ele está arando e se inclina sobre o sulco enquanto espalha a terra, pode ser percebido como belo" (loc.cit.). ${ }^{52}$ Induzimos que a relação entre o esquema figural do objeto técnico e o fundo indiferenciado do meio sobre o qual opera é também uma

Simondon. In: BOEVER ET AL. 2013, p. 204.

51 Ver CARROZZINI 2015, p. 36.

52 No original: Un tracteur, dans un garage, n'est qu'un objet technique; quand il est au labour, et s'incline dans le sillon pendant que la terre se verse, il peut être perçu comme beau. (tradução nossa). 
relação parte-todo, sem recorrermos a um sistema holístico nem cibernético, mas sim a um princípio monodológico. A lei gestáltica reinterpretada por Simondon parece entremear-se no famoso diálogo entre Sócrates e Hípias, no qual o primeiro afirma ser o Belo aquilo que é mediado pelos sentidos da visão e audição, admitindo paradoxalmente em seguida uma "qualidade ou essência que possa pertencer a um par de objetos sem pertencer a cada um em particular" (PLATÃO 1980: 301c). De modo especulativo, poderíamos resolver o impasse final de Hípias Maior com uma solução sinestésica, aconselhando aos dois filósofos que considerassem uma qualidade inerente ao som e a cor: a tonalidade..$^{53}$

É simples aplicar o método construtivista, vagamente inspirado no formalismo lógico, na compreensão do princípio de organização das formas, ou como elas se constituem. E a Gestalt, independente do fato de ser uma psicologia, oferece indícios de como funciona esse "truque", a construção interna de um esquema fundado em um sensível externo, sendo imprudente mencionar os termos "interno" e "externo", pois isso resultaria em um distanciamento mediado. "O esquema ... é um modo de nos colocar em contato com o dado: é um cubo, uma escada, um antílope... O importante é que essa estruturação do campo é imediata, espontânea" (DUFRENNE 2015: 94). Mas deixemos de lado, por um instante, a forma, e cuidemos do plano de fundo, componente da composição fotográfica, por exemplo, quando o fotógrafo obtém a profundidade de campo ao ajustar os planos da imagem. O fundo, ao menos para psicologia da forma, é indiferenciado, convindo apenas como objeto secundário de onde se destacará a imponente figura, a qual dáIhe sentido. Mas o fundo pode ser também portador de sentido?, se pergunta Dufrenne (op.cit.: 152). Para Berleant (1992), sim, porque a paisagem, em relação ao ambiente, transforma-se numa unidade perceptiva essencial se o apreciador deixar de percebê-la tão-somente como um cenário, e a assumir como matrizes de qualidades perceptivas configuradas por humanos ("os contornos do solo, as espécies e a distribuição da vegetação, a vida dos animais e das aves, mesmo a fertilidade, a umidade e o clima" [op.cit.: 155]). Perceber o fundo como um meio, em suma. O fundo tem vários sentidos, todos solicitando por uma construção. Para Dufrenne, o "Grund também designa a potência da fonte: aquilo que está na origem,

53 A tonalidade é uma questão de quantidade, seja de ritmo ou de imagens: estritamente falando, a amplitude das vibrações (MORTON 2007: 45; tradução nossa). 
e que talvez seja um Logos primordial, ou que queira ter acesso, pela operação do homem, à consciência e à representação" (loc.cit.). E é nesse sentido que o fundo, sob uma ótica construtivista, torna-se uma quase-figura.

\subsubsection{Fenomenologia: percepção e sensório}

Como assinalamos na abordagem construtivista, a noção de forma desempenha um papel funcional constante: o de ser uma semente estrutural dispondo de certo poder de direção e organização (SIMONDON 2005: 531). Nessa visão, o fenômeno da percepção não é o ato de recuperar formas temporariamente armazenadas do mundo exterior, fazendo-as intercalar com imagens prédeterminadas na mente do observador; também não é um processo absolutamente não-determinista, em que esteja ausente quaisquer formas de controle construtivo. Percepção é um work in progress, no qual a solução para a resolução de uma forma em estado primitivo é resolvida pelo observador em um ato de invenção, isto é, um ato de individuação restrita. Não devemos, porém, entrever o construtivismo, por ser contrário ao objetivismo, como uma forma de solipsismo ou de idealismo subjetivo, no qual a coisa-para-nós tem precedência sobre a coisa-em-si. Cumpre recordar que inclinações idealistas e psicologistas de origem kantiana possibilitaram o surgimento de uma filosofia que pudesse recuperar a coisa-em-si, sem a exumação do objetivismo ou de um realismo puro: a fenomenologia. ${ }^{54} \mathrm{~A}$ começar pelo modelo de Edmund Husserl, de se estabelecer uma espécie de "suspensão de juízo" do mundo objetivo (epokhé) com a finalidade de descobrir uma zona primordial de constituição da percepção, uma camada pré-individual, distinta das sensações mediadas pela ciência ou outras formas de conhecimento. ${ }^{55} \mathrm{Em}$ seguida, temos Martin Heidegger, que sugere como ponto de partida para qualquer percepção da dimensão ôntica (entes objetivos) a facticidade ontológica, concreta, do ser situado (Dasein, ou seraí). ${ }^{56} \mathrm{E}$, para completar o nosso breviário de modelos fenomenológicos, chegamos finalmente a Maurice Merleau-Ponty, o qual adota como estratégia a superação do

54 PINTO NETO, Moysés. Derrida e a Fenomenologia Francesa. Filosofia em Transe, 2017. Vídeo disponivel em: <https://www.youtube.com/watch?v=g_BT9ZUSku4>. Acesso em: 15 nov. 2017. 
dualismo entre corpo e alma, ${ }^{57}$ integralizando a ação perceptiva como um evento multissensorial e refutando, ao que parece, o monopólio dos dois sentidos elencados na última resposta de Sócrates a Hípias em sua tentativa de definição do que é o Belo em si (PLATÃO 1980).

Dentre todas as abordagens fenomenológicas descritas, é a de MerleauPonty que fará o papel de contraparte completiva ao construtivismo no processo perceptivo, de acordo com o nosso modelo de estética ecotécnica. Mais precisamente, a fenomenologia desenvolvida por um de seus discípulos, que a vincula a uma relação entre objetos exógenos pertencentes ao meio e um estado especial de reflexividade intuitiva, que tem a imaginação como um de seus motores. Em Imagination et invention, Simondon segmenta o ciclo genético da configuração imagética em três fases distintas, mas integradas: antecipação (a priori), experiência (a praesenti) e sistematização (a posteriori) (2008b: 19). A primeira guarda certa semelhança com a protensão de Husserl que, ao contrário da retenção efetuada pela memória, atua como um "futuro vivido", como projeção finalista que prepara o sujeito a ações a serem motivadas por estímulos externos (ou seja, é anterior ao processo de estímulo e resposta). A diferença é que, para o filósofo francês, a antecipação é uma experiência pré-temática, pré-objetiva, na forma de uma imagemmotriz condutora da motricidade, ou seja, da capacidade cinética dos seres vivos. Para os seres vivos mais primitivos, orienta a locomoção em um meio sem muitos gradientes; para os superiores, providos de um sistema nervoso central, a antecipação é a antessala da sensorialidade propriamente dita, a que transcorre em tempo real. A primeira fase do ciclo nos é particularmente oportuna, pois além de ela facultar a autonomização da imagem com relação ao sujeito, reforça a relação entre estética e técnica, uma vez que a antecipação, como salienta Bernard Stiegler (1998: 6), propiciou aos primeiros hominídeos o desenvolvimento do sentido de temporalização, a raiz do cálculo, ou seja, um dos caráteres das técnicas. Não obstante seu aspecto primevo, tal senso é regido por uma tendência à externalização, ao seu complemento protético. Nesse sentido, formas alcançam a condição de "mídias", pois "tudo o que intervém como intermediário entre sujeito e objeto pode adquirir valor de imagem e desempenhar um papel protético que é 
adaptativo e restritivo."58 Mostra-se aí a justificativa de se vincular o imediato da percepção com o mediato do intelecto imaginativo sob a regência de uma intencionalidade cognitiva. ${ }^{59}$

Uma das mais fecundas contribuições da fenomenologia, a propósito da intermediação descrita acima, é problematizar a relação entre sujeito e objeto e propor substituí-la pela relação entre fenômeno e fluxo de consciência. ${ }^{60}$ Convém avaliá-la, nesse caso, não como dois termos distintos, mas como continuados, ou, no máximo, permitir que haja uma transclusão ${ }^{61}$ do primeiro no âmago do segundo, e vice-versa. O fenômeno é o sensório propriamente dito, um objeto em si eventualmente desprovido de seu substrato material (DUFRENNE 1973: 87); e o fluxo é a consciência do vivido, com o preenchimento de seus devidos conteúdos. A consciência é o veículo dos pensamentos, incluso o pensamento que dá coesão ao suposto "eu" (o ideal da unidade, ou o "eu" transcendental, possui o caráter de pensamento, o que o coloca em igualdade de condições com os demais). A fenomenologia, portanto, desfaz a separação absoluta entre a fenomenalidade dos objetos e a consciência perceptiva, concentrando-se em como o mundo sensorial se apresenta perante a consciência. Porém, como nos explica Bernard Stiegler, ao almejar uma unidade coerente, um "eu" centrífugo, a consciência acaba por autorrealizar-se e, ato contínuo, idealizar os objetos do mundo fenomenal, tornandoos eidéticos (imagens mentais). E é nesse ponto que a fenomenologia se interpola de forma não premeditada com o construtivismo, pois "esta eidética é transcendental na medida em que ela e as ideias / unidades que a compõem (eidé) não existem no mundo (mais do que um ponto geométrico)"; ou, em outras palavras: "o real

58 No original: En ce sens, tout ce qui intervient comme intermédiaire entre sujet et objet peut prendre valeur d'image er jouer un rôle de prothèse à la fois adaptatrice et restrictive (SIMONDON op.cit.: 12). 59 Sobre o conceito husserliano de intencionalidade cf. SPEAR, Andrew D. Edmund Husserl: Intentionality and Intentional Content. Internet Encyclopedia of Philosophy. [s.d.] Disponível em: <https://www.iep.utm.edu/huss-int/>. Acesso em: 23 abr. 2019.

60 Não confundir com a técnica literária chamada por alguns críticos de stream of consciousness, empregada, entre outros, pelo escritor irlandês James Joyce. Os acadêmicos das letras deveriam chamá-la, em nossa opinião, apenas de monólogo interior, já que se trata de uma narrativa de conteúdos internos, ora gerados por um estímulo externo, ora incitados pela própria memória do personagem. O fluxo de consciência da fenomenologia ocupa-se prioritariamente com o processo de realização de tais conteúdos.

61 Aqui nos valemos de uma metáfora provinda da ciência da computação: "transclusão é a inclusão de parte ou de tudo de um documento eletrônico em um ou mais outros documentos por hipertexto referência". Ver definição em Transclusão. In: Wikipédia, a enciclopédia livre. [s.l.: s.n.], 2017. Disponível em: <https://pt. wikipedia.org/w/index.php?title=Transclus\%C3\%A3o\&oldid=50460141>. Acesso em: 11 jan. 2018. 
existente assim é construído para e pela consciência, assim como o ponto geométrico inexistente constitui o espaço puro que integra o espaço empírico" (STIEGLER 2011: 64; grifo nosso). A consciência, portanto, não seria uma "caixa preta" dentro da qual são depositados os conteúdos do percebido; ela e os conteúdos são a mesma coisa.

Voltamos agora, após feita a análise da percepção, ao objeto da mesma, ou aquilo que se apresenta ao sentidos, o que surge através das formas - em suma, o sensório. Contamos, para a realização de tal tarefa, com as reflexões de Mikel Dufrenne (que também se deixa influenciar, em parte, por Merleau-Ponty) em razão de suas influências procedentes da fenomenologia estética e, acima, de tudo, por ter sido um dos autores de inspiração para Gilbert Simondon (na concepção de Carrozzini). O método empregado por Dufrenne (1973) para definir o objeto estético é compará-lo com outros objetos do mundo, tais como o objeto de uso cotidiano (objets usuels) e objetos do mundo natural (les choses naturelles). Em princípio, todos os objetos são estéticos, por estimularem a consciência perceptiva de alguma maneira, sendo o objeto artístico o único não incidental e/ou acidentalmente estético (op. cit.: 73). A capacidade perceptiva é uma virtude natural por excelência, donde se conclui o interesse particular do filósofo francês pelo objeto natural e sua relação com o objeto artístico. "O objeto estético não repudia a natureza, mas está em harmonia com ela, como uma igreja no coração de uma aldeia ou uma fonte em um jardim" (op. cit.: 84). A diferença entre uma obra de arte (oeuvre d'art) e uma obra de engenharia (ouvrage d'art) é que, enquanto a primeira eventualmente estetiza a natureza, a segunda é estetizada por ela, mesmo sob a pena de sofrer violações da parte da humanidade desafiada. Antes de tudo, o objeto estético - e o arquitetônico o é por excelência, segundo Michelangelo - se acomoda à natureza, tornando-se integral com o ambiente, "como o Parthenon na Acrópolis ou Notre Dame, nas margens do Sena" (op. cit.: 85).

\subsection{O PENSAMENTO TECNOLÓGICO}

A reflexão sobre as técnicas não é atual e origina-se no período áureo da filosofia grega, em uma época em que não havia distinções conceituais entre 
conhecimento (episteme) e técnica (techné), sendo muitas vezes os dois termos intercambiáveis. ${ }^{62}$ Até o aparecimento de Platão, a palavra técnica estava associada a uma racionalidade, a um logos, a um conhecimento que precede e orienta a realização de uma ação no mundo (PINTO 2005: 138). A ruptura foi suscitada, segundo a descrição de Bernard Stiegler (1998: 1), por questões políticas: pelo fato de os sofistas terem transformado a retórica dos cidadãos da assembleia em uma técnica discursiva, instrumentando-a e tornando-a independente do conhecimento, ao contrário do que prescreviam os filósofos da época. O que nos conduz à transfiguração léxica, esta mais recente, do adjetivo técnica (por ex. habilidade técnica, conhecimento técnico) em um substantivo, representado pelo quase místico termo Técnica, com maiúscula, e seu derivativo, Tecnologia, simbolizado pela midiática expressão "tecnologia de ponta". O que antes era entendido como a prefiguração para a atualização do virtual, um modo de conhecimento para se realizar algo - tornou-se a abstração do sistema técnico como um todo, originando um significante no papel do oposto do que deveria significar: a teoria global da evolução das técnicas (STIEGLER 1998: 2). Ao ser mencionada a palavra "tecnologia" nos meios de comunicação conjura-se mais do que uma tendência universal difratada em diversas culturas e etnias; idealiza-se praticamente a religião da era moderna. O pensamento tecnológico deve, portanto, ser dirigido à tecnicidade, para assim contradizer os sofistas clássicos e reaver o potencial poético e cultural das técnicas.

É necessário, à vista disso, partir do pensamento tecnológico para se chegar à precípua noção de tecnicidade. Mas o que ela abarca? E como defini-la? A título introdutório, pode-se recorrer a um dicionário qualquer e averiguar que a palavra significa o "caráter, qualidade ou condição do que é técnico". É um começo. Um tanto essencialista, é verdade, mas não deixa de ser um ponto de partida. Caso fosse exigido maior rigor, seria mais prudente recorrer à Gilbert Simondon, malgrado os usos polissêmicos que o filósofo faz do termo. Para ele, tecnicidade é o "instrumento da evolução técnica" (1969: 70), a "intermediária entre forma e matéria (op.cit.: 72) e o "grau de concretização do objeto técnico" (loc.cit.). Pode-se inferir

62 Ver PARRY, Richard. Episteme and Techne. In: ZALTA, Edward N. (org.). The Stanford Encyclopedia of Philosophy. Outono 2014. [s.I.]: Metaphysics Research Lab, Stanford University, 2014. Disponível em: <https://plato.stanford.edu/archives/fall2014/entries/episteme-techne/>. Acesso em: 25 out. 2017. 
várias conclusões a partir dessas definições, mas a mais significativa, sem dúvidas, é a que se reconhece nas entrelinhas: o inescusável esquecimento, na tão famigerada "era da tecnologia", de um traço primordial dos objetos técnicos, em benefício do uso que se faz deles: o seu funcionamento. ${ }^{63}$ Pode-se, a partir dessa negligência, se tecer uma crítica à tecnologia começando com a apropriação do famoso dito atribuído ao arquiteto estadunidense Louis Sullivan - forma segue função - e estabelecendo um ampliamento no qual, no universo da tecnicidade, forma, associada incondicionalmente à função, segue o funcionamento. Uma guinada que retoma a dignidade perdida dos objetos técnicos e põe sob nova perspectiva a tal religião da era moderna. A tecnicidade, desvelada por entre as frestas da tecnologia, é o que nos concerne na busca por uma definição de estética ecotécnica. Particularmente, na próxima seção, em como ela se reveste na cultura humana ${ }^{64}$ e em complexos técnicos de maior abrangência, sistemas que evoluem sob determinadas condições e dentro de certos limites. O topos acerca do funcionamento intrínseco aos objetos técnicos será analisado mais detidamente nas seções Tecno-estética e Estética ecotécnica.

\subsubsection{Tecnologia e cultura}

Gilbert Simondon sempre manifestou seu desgosto com a discórdia entre tecnologia e cultura, exortando uma reaproximação entre os dois domínios. ${ }^{65}$ Para ele, os dois são gêmeos monozigóticos, nascidos da mesma célula-ovo. A cultura seria um desdobramento, quando não um sinônimo, da tecnologia. Mas a divisão foi consagrada, talvez devido o despeito mantido pelo universo cultural à certa predominância do conhecimento técnico ao longo da História, principalmente ao modo como a sociedade em geral permitiu uma intrusão excessiva do tecnicismo na vida humana após as revoluções tecnológicas da era moderna. A sobrevalorização da técnica fez com que os objetos técnicos fossem vistos com certa desconfiança pelos guardiões das superestruturas, o que contribuiu para que eles fossem

63 Cf. BARTHÉLÉMY, Jean-Hugues. Fifty Key Terms in the Works of Gilbert Simondon. In: BOEVER ET AL. 2013, p. 215.

64 "A cultura técnica é um elemento necessário da experiência estética". Cf. DUFRENNE 2015, p. 251.

65 Ver SIMONDON, Gilbert. Cultura e Técnica. Revista Nada, n 11, maio 2008, pp. 169-175. 
relegados a funções meramente utilitárias, dentro de um modo de produção escravista. Daí a necessidade, segundo o nosso autor, de se instaurar uma cultura técnica, na qual os objetos técnicos retomassem a gênese de seu desenvolvimento natural e sua importância cultural. É nosso pressuposto de que a descrição de uma estética ecotécnica seja uma das formas de tomada de consciência cultural dos objetos e conjuntos técnicos (SIMONDON 2008: 245). A intuição perceptiva fundamental, aisthesis, também faz parte de uma cultura, o que se confirma, no campo da percepção gustativa, na aversão ou dileção a certos tipos de alimento, de acordo com a sua aparência ou mesmo a sua constituição. ${ }^{66}$

Portanto, um pensamento tecnológico autêntico debruça-se sobre fatores culturais, o que propiciaria o nascimento de uma cultura técnica. A época atual não comporta mais beligerâncias entre determinismos, seja na versão cultural ou tecnológica. Tomemos como caso negativo o desdém com que o antropólogo estadunidense Marshall Sahlins (2003: 93-5) trata o exemplo do gesto técnico executado por um lenhador descrito por outro antropólogo, Gregory Bateson, um "processo efetivado por um sistema total, árvore-olhos-cérebro-músculos-machadogolpe-árvore" (BATESON 2000: 317). O "funcionalismo ecológico" da descrição seria comparável, segundo o determinismo cultural de Sahlins, ao comportamento de qualquer outro animal, isento de significados, como os deparados na escultura de um totem ou de uma canoa. Em nossa visão, o gesto técnico do lenhador, mesmo que culturalmente desmotivado, já está imbuído de um pensamento, mesmo que puramente técnico. Além disso, uma analogia entre o pensamento tecnológico e o pensamento ecológico evidencia que não existe apenas a forma externa da madeira; haveria uma pré-forma, uma forma implícita "precondicionada" que conduziria o gesto do lenhador. Para ilustrá-la, Simondon faz a distinção entre o corte de uma árvore por um elemento técnico ferramental, o machado, e por um objeto técnico, a serra elétrica (SIMONDON 2005: 53). ${ }^{67} \mathrm{Em}$ uma serralheria, por exemplo, a "forma

66 Simondon (1992) usa como exemplo o empresário francês que tentou em vão distribuir um alimento a base de arroz para uma população da Índia acostumada a alimentos a base de grãos de trigo.

67 Excerto no original: Mais la différence consiste en ce que la scie mécanique coupe abstraitement le bois selon un plan géométrique, sans respecter les lentes ondulations des fibres ou leur torsion en hélice à pas très allongé : la scie coupe les fibres, alors que le coin les sépare seulement en deux demi-troncs : la fissure chemine en respectant la continuité des fibres, s'incurvant autour d'un noeud, suivant le coeur de l'arbre, guidée par la forme implicite que l'effort des coins revele. [Mas a diferença é que a serra mecânica corta a madeira abstratamente segundo um plano geométrico, sem respeitar as lentas ondulações das fibras ou sua torção helicoidal não muito alongada: a serra corta as fibras 
explícita produzida pela operação técnica não respeita, neste caso, a forma implícita" (loc.cit). A analogia pode, ainda, tornar sem efeito uma eventual motivação econômica, ilustrada pela história do lenhador que, quando vê uma árvore, enxerga "capital", e não um ser vivo (GRAUGAARD 2014: 29).

\subsubsection{Tecnopoiética}

A noção de forma implícita está em íntima relação com o popular senso comum sobre como se dá o resultado final de um trabalho de cinzelagem, a ação produtora (poiesis) que traz à tona uma figura tridimensional a partir de um bloco de pedra maciço. Em terminologia heideggeriana a ação do escultor apenas desocultaria a verdade da imagem, cujo ser estaria previamente inscrito na forma implícita. A ideia de desocultamento é cara ao pensamento técnico de Heidegger, mas não sem riscos. Em princípio, é a essência da técnica, manifesta na produção de algo - seja de modo instrumental, finalista, utilitarista; ou não. A verdade dos objetos revelada por técnicas manuais é mais acessível, não sendo o caso das técnicas modernas, por demais multiformes. Daí que a nova realidade tecnológica insta os humanos a revelar objetos na condição de um desafio que se coloca, um apelo às armas de caráter irresistível, como o canto de uma sereia mecânica. Mas assim que, aceito o desafio e finalmente desocultado, isto é, revelado como testemunho do excepcionalismo humano, o surgido em questão perde a titularidade de objeto (em alguns casos, técnico) e torna-se não mais que um artigo de estoque, o qual deve se sujeitar e atender às demandas, conforme solicitado, para a conveniência dos humanos. Entretanto, não apenas os objetos técnicos são vistos como recursos, alvos de exploração e controle, mas também a própria natureza, a base material que os condicionam. Em seu seminal ensaio sobre a questão técnica ${ }^{68}$ Heidegger introduz que a complexidade técnica moderna só pode ser apreendida por meio de seu enquadramento em um sistema, conjunto expresso no termo Gestell (armação, segundo a tradução de Marco Aurélio Werle). ${ }^{69}$ Em uma

do tronco, enquanto a lâmina do machado somente o separa em dois semitroncos: a fenda avança de acordo com a continuidade das fibras, curvando-se sobre um nó, segundo o núcleo da árvore, guiado pelas formas implícitas que a força da lâmina revela.] (grifo do autor; tradução nossa).

68 Cf. HEIDEGGER, Martin. A Questão da Técnica. Scientiae Studia, 2007, v. 5, n. 3, 2007, pp. 375398.

69 A semântica da palavra não é estranha à de sistema e, na visão de Bertrand Gille, o conceito de 
construção sintática ao estilo do filósofo alemão, poderíamos dizer que o perigo do modo de desocultamento latente em Gestell, o desabrigar da técnica moderna, seria o ocultamento do modo anterior de desocultamento, o desabrigar da técnica manual antiga, na qual a forma, a finalidade e o agente se comprometem com a matéria. Perde-se, nessa transição, a essência autêntica da técnica e, como consequência, a dignidade dos objetos produzidos. A salvação estaria no lançar-se em uma espécie de engenharia reversa, na recuperação da poiesis da produção técnica, na restituição da "faculdade tecnopoiética" (VIEIRA PINTO 2005: 137) dos que a efetuam.

Em sua ferrenha crítica, o filósofo brasileiro Álvaro Vieira Pinto, materialista dialético que é, questiona qual ser estaria oculto e por que não se faria visível ao pensamento, posto que está ao alcance dos humanos, em toda a sua evidência material. Honramos a crítica e compreendemos a inquietação de Vieira Pinto diante da hermeticidade bizantina e da "química lexicológica" (op.cit.: 152) presente na reflexão de Heidegger, repleta de especulações metafísicas idealistas. O ser em questão, respondemos intuitivamente, é a verdade da matéria transformada, seja o produto da fabricação o bronze esculpido de Formas únicas de continuidade no espaço (Umberto Boccioni, 1913) ou o minério de ferro extraído e acomodado em uma usina. Seja dito de passagem, na menção ao segundo, a diferença que o filósofo germânico estabelece entre o desocultamento poético do solo arado pelo camponês tradicional e o desocultamento desafiante do solo por uma mineradora de grande porte (HEIDEGGER 2007: 381-82). Apesar de sua análise sobre a técnica ser por demais hermética e estar por um triz de ingressar na esfera da poesia pura (notar as citações de versos de Hebel, Hölderlin...), ao menos ela deixa entrever um alerta sobre a crise ecológica provocada pelo confronto entre técnicas e meio ambiente, avaliação essa obviamente estranha a um materialista dialético voltado ao desenvolvimentismo e ao progresso da sociedade (capitalista ou socialista). Outrossim, a certa altura do texto sobre a questão técnica, Heidegger afirma ser a produção manual análoga à produção consumada pela natureza, sendo a "physis inclusive poiesis no mais alto sentido" (op.cit.: 379). Para Vieira Pinto, trata-se de uma confusão de origem kantiana; em nossa visão, a frase é positiva por sugerir 
uma convergência (ou uma complementação) ausente no sistema técnico vigente, ou seja, a produção em si mesma da natureza sendo auxiliada pela produção intencional dos humanos, ambas em mútua concordância.

Confessamos nossas reservas em relação ao essencialismo do pensamento técnico de Heidegger, mas insistimos ainda, em proveito próprio, no avanço da comparação entre o objeto trazido-à-tona e o objeto trazido-à-tona-mediante-umdesafio; entre a fabricação manual, de caráter instrumental, e a produção realizada por um sistema técnico mais amplo e complexo. Aludimos em um primeiro momento aos críticos do pensador germânico, os quais observam, não sem razão, que a produção do modo Gestell poderia ser aplicada a uma produção mais primitiva, instrumental, na qual as quatro causas de Aristóteles ainda estariam em comprometimento mútuo. Nesse sentido, seria possível, por exemplo, o moleiro feudal ampliar as velas da cúpula do moinho para aumentar a sua eficiência, armazenando mais grãos para assim comercializá-los mais vantajosamente em períodos de menor prosperidade. ${ }^{70}$ Nota-se nesse caso a aplicação de um traço do modo Gestell em um domínio alheio ao das atuais técnicas de geração de energia elétrica em grande escala. Referimo-nos certamente a uma analogia disposta no seminal ensaio, a da central hidroelétrica que "não está construída no rio Reno como a antiga ponte de madeira, que há séculos une uma margem à outra", mas que, "pelo contrário, é o rio que está construído na central elétrica" (HEIDEGGER 2007: 382). Usinas de grande porte, sabemos, dependem de extensas barragens, as quais implicam em obras de revegetação e drásticas alterações topográficas. Ora, se é possível deslocar a disposição do desabrigar da técnica moderna para o contexto do desabrigar da técnica manual antiga, como no caso do moinho, então deduzimos que o vetor contrário também é factível. Por exemplo, ao invés de construir uma usina de grande porte no Reno, seriam construídas nas vazões de seus ribeirões secundários pequenas centrais que não dependem de barragens e cujos exemplos típicos são as usinas a "fio d'água" e as hidrocinéticas. ${ }^{71}$

70 Ver o exemplo em WADDINGTON, David I. A Field Guide to Heidegger: Understanding 'The Question Concerning Technology'. Educational Philosophy and Theory, v. 37, n. 4, 2005, pp. 567-583. 71 Cf. KOCK, Juliana. Micro Central Hidrelétrica com Turbina Hidrocinética. 2014. Trabalho de Conclusão de Curso 2, do Curso de Engenharia Elétrica da Coordenação de Engenharia Elétrica COELT - da Universidade Tecnológica Federal do Paraná - UTFPR, Campus Pato Branco. 


\subsubsection{Estrutura reticulada}

Por motivos de ordem temática, ainda não correlacionamos a noção de Gestell, o espaço de "desenvolvimento global de técnicas modernas" (STIEGLER, 1998: 8) e a ideia, repleta de potencial, de "conjunto técnico" (ensemble), inventada por Simondon. Há vasos comunicantes entre elas, mas seria por demais especulativo estipulá-los formal ou diagramaticamente. A noção de Gestell é uma maneira de o filósofo germânico retirar a densa pátina metafísica da operação técnica material, e trazê-la mais para o mundo das "coisas postas em conjunto" (VIEIRA PINTO 2005: 152). Nesse caso, não estaríamos mais concentrados em como o pensamento logra acessar o ser por meio da técnica, mas sim em como a técnica em si extrapola o singelo contexto das ferramentas manuais e projeta-se em uma organização tecnológica de maior estatura. Não seria mais a técnica associada aos objetos utilitários, mas a uma trama de ações humanas e reações maquínicas codependentes. Nesse sentido, Heidegger e Simondon convergem, pois ambos tinham como ambição retirar o peso excessivo do utilitarismo instrumental dos objetos técnicos, cada um por motivos diferentes. Enquanto o primeiro buscava por uma qualidade técnica alheia à funcionalidade utilitarista, dada pelo destaque à causa eficiente, o segundo procurava desconstruir no mundo técnico o hilemorfismo, a teoria segundo a qual todos os seres principiam a sua existência a partir do encontro entre matéria e forma, sendo a segunda a que se impõe sobre a primeira por meio da causa final. Há, contudo, o perigo de se atribuir as duas causas à imanência: ao buscar neutralizar as tendências finalistas com os valores normativos do mundo técnico (COMBES 2013: 61-3), recobra-se o essencialismo de sua autonomia absoluta.

A pergunta que se faz é: haveria, na visão de Simondon, uma compatibilidade entre a rede de pontos privilegiados do mundo natural e a rede de conjuntos técnicos - entre as duas redes? Primeiro é preciso notar que a reticulação técnica de conjuntos concretos proposta por Simondon, o conjunto de conjuntos técnicos, seguramente não se vincula diretamente com as chamadas Novas Tecnologias de Informação e Comunicação (NTIC), nem com as redes telemáticas informacionais. Além disso, aconselha-se uma certa precaução para não vinculá-la com a 
computação em escala planetária consubstanciada na rede mundial de computadores, da qual protótipos começaram a ser oferecidos ao público muito antes da morte de Simondon, em 1989, como a rede Minitel, serviço de videotexto implementado na França pela PTT, em 1982. O que está em discussão são estruturas, complexos e canais que compõem uma rede de técnicas universais, um sistema técnico planetário industrial que vem se prolongando dinamicamente ao longo do espaço e do tempo desde a gênese da linguagem, a primeira "tecnologia". O domínio de conjuntos técnicos sobre o qual fala Simondon tem como modelo os laboratórios, ou, mais especificamente, o "laboratório de fisiologia das sensações" (1969: 61), como por exemplo um voltado aos exames de audiologia. O que é mais significativo nessa análise é a necessária coerência entre os elementos e indivíduos que compõem o conjunto, interação que adquire um "valor axiológico" (op.cit.: 62). E mais: deve-se conservar a individualidade ambiental de cada elemento ou indivíduo (como a recepção de frequências de um determinado oscilador, por exemplo), mas sem que haja uma disjunção estrutural, visando a autorregulação total do conjunto. E talvez seja aí que o caráter reticular das técnicas converge com o caráter reticular da natureza: ambas englobam unidade e pluralidade (conectividade) ao mesmo tempo.

Assim, constatada a analogia entre a rede de pontos-chave da natureza tropo que será analisado sob o aspecto estético em outra ocasião - e a rede de técnicas universais, resta-nos ainda a tarefa de sondar uma possível analogia entre o aparato estrutural da contemporaneidade, alcunhada por Heidegger de armação, ou o "princípio organizador, de abrangência existencial, puramente 'antropo-télico', concebido para saciar o apetite e a vontade homocrática da maneira mais eficiente, produtiva e amplamente possível"72 - e a rede (réseau) de conjuntos (ensemble) técnicos de Simondon. A primeira pista que temos à mão é: ambos os tropos anseiam por uma visão de mundo na qual o trabalho tecnicizado não exploraria a natureza de forma tão brutal. ${ }^{73}$ Para Heidegger, tal visão seria alcançada por meio da desmistificação da essência da técnica moderna; ${ }^{74}$ para Simondon, através de uma

72 Ver BENNETT, Fionn. Artefactualising the Sacred: Restating the Case for Martin Heidegger's 'Hermeneutical' Philosophy of Technology. In: DEANE-DRUMMOND ET AL. 2016, p. 51.

$73 \mathrm{lbid}$.

74 "Porque a essência da técnica moderna reside na armação, esta necessita empregar a ciência exata da natureza. Desse modo, nasce a aparência enganadora de que a técnica moderna é uma ciência da natureza aplicada. Esta aparência se sustentará até que a proveniência essencial da 
"realidade reticular, o meio que oferece a possibilidade de reconstruir uma relação com a unidade mágica do mundo analógico" (COMBES 2013: 70; grifo nosso). uso da palavra "analógico" pela exegeta francesa nos remete, em uma primeira instância, à representação contínua dos fenômenos físicos, somente possibilitada pela fusão efetiva entre humanos e mundo, ou na completa reconfiguração da relação Sujeito-Objeto; ${ }^{75}$ e, numa segunda instância, ao anverso do digital, dos processos de quantização, por exemplo, tão em voga hoje em dia. Vamos nos deter na primeira opção, posto que a segunda exigiria um tratado à parte. Em nossa busca por uma definição de estética ecotécnica estamos dando enfoque às operações técnicas analógicas que resultam em mudanças qualitativas, diferente das operações técnicas digitais, que resultam em contagens quantitativas. Enquanto Simondon direcionava seu olhar a um "modo de evolução originário de uma unidade mágica perdida", ${ }^{76}$ Heidegger reportava-se a um modelo tecnológico helênico, um modo de ser-no-mundo preocupado, por exemplo, com a metalurgia e a construção de templos. ${ }^{77}$ Os dois estavam discorrendo, em seus respectivos estilos, sobre operações técnicas analógicas, que resultam em mudanças qualitativas, a contrario das operações técnicas digitais. Em resumo, a relação entre os sistemas técnicos reticulados imaginados pelos dois filósofos estaria na busca por uma coexistência de técnicas (techné) e natureza (physis), as duas integradas por uma humanidade solícita.

\subsubsection{Limites dinâmicos}

Para exemplificar como a evolução tecnológica dos conjuntos se depara eventualmente com limites de diversas ordens emprestamos a noção de sistema

ciência moderna e a essência da técnica moderna sejam adequadamente questionadas". Nos valemos aqui da tradução de Marco Aurélio Werle de um parágrafo de A questão da técnica para a Scientiae Studia (São Paulo, v. 5, n. 3, 2007, p. 387). Por mais essencialista que seja Heidegger, o paradoxo é que, para a humanidade escapar do perigo do modo de desvelamento característico das técnicas desenvolvidas depois da revolução científica, faz-se necessário "des-essencializá-las", para que uma verdadeira essência eleve-se delas. Na edição inglesa (HEIDEGGER 1977), traduzida por William Lovitt, há uma relevante nota de rodapé (p. 4) na qual o tradutor elenca as diversas conotações que o filósofo alemão dá à palavra Wesen (essência), tais como "ser", "presente" e "habitar".

75 Cf. BENNETT 2006, pp. 50-2.

76 Ver LEMOS, André. The Critique of Essentialist Critique of Cyberculture. Matrizes, v. 9, n. 1, p. 29, 2015.

77 Cf. BENNETT op.cit., pp. 54-9. 
técnico, criada pelo historiador francês Bertrand Gille (1986). Ela foi concebida para demonstrar a passagem de um sistema técnico para outro, no esforço de propor uma teoria geral da tendência evolutiva das técnicas, e como um sistema técnico se relaciona com outros sistemas, em especial o econômico e o político. Por exemplo, a economia pode constituir um freio para a expansão de um sistema técnico, seja "através de um sistema de regulamentações aduaneiras ou de investimento público" (STIEGLER 1998: 32). É uma noção que ampara o progresso técnico como força inelutável da inventividade e marca existencial da humanidade. Evangeliza a vetorialização unidirecional da progressão técnica, recolhida no âmago da própria progressão histórica, insinuando a impossibilidade de retrocessos a fases anteriores, assentindo no máximo com dilações contingenciais. ${ }^{78}$ Tem o mérito de esboçar com alguma antecedência o processo de crescimento sustentável do progresso técnico ao especificar a dinamicidade de suas constrições evolucionais, consistindo de um "sucessivo deslocamento de seus limites" (loc.cit.). Um dos aspectos relevantes da noção é de como sistemas técnicos, ao serem constrangidos, propiciam a eclosão de invenções, principalmente quando o progresso ocasiona a desestabilização do sistema anterior, estabelecendo novos limites e avançando de forma descontínua. ${ }^{79}$ O efeito colateral maior da limitação do progresso de sistemas técnicos seria a sua não homogeneidade com o progresso humano propriamente dito, fragmentando-se em centros de excelência separados e não incidindo na humanidade como um todo. ${ }^{80}$

Se o sistema econômico é um dos fatores limitantes do progresso tecnológico, questionamos se os ecossistemas naturais assim também o seriam, como sugeriu en passant Simondon. ${ }^{81}$ Elaborar uma réplica, porém, não é tarefa trivial. O próprio Gille tinha reservas com relação ao impedimento do progresso

78 Stiegler (1998: 33) transcreve o caso das locomotivas a vapor, cada vez mais pesadas, que passaram a deformar os frágeis trilhos de ferro; a inovação ferroviária viria a ser retomada após a invenção do conversor de Bessemer, recipiente empregado na produção industrial de aço.

79 A noção de descontinuidade de Gille coincide, não sem surpresas, com a palavra da moda entre os gurus contemporâneos da inovação, o anglicismo "disrupção", empregado, como aponta o tecnólogo paraibano Silvio Meira em Tweet de 21 de setembro de 2017, de modo negligente, sendo o correto dizer "ruptura". Ver MORISSO, João Gabriel D. Ser ou não ser disruptivo, afinal o que é disrupção? Disponível em: <https://medium.com/@joao.morisso/ser-ou-n\%C3\%A3o-ser-disruptivoafinal-o-que-\%C3\%A9-disrup\%C3\%A7\%C3\%A3o-2541dcac5f8a>. Acesso em: 1 nov. 2017.

80 Ver SIMONDON, Gilbert. The Limits of Human Progress: A Critical Study. Cultural Politics: an International Journal, v. 6, n. 2, 2010, p. 229-236.

$81 \mathrm{lbid}$. 
imposto pelo mundo natural (STIEGLER 1998: 33), asseverando que tais limites exógenos teriam um lado negativo, mas de igual maneira um positivo, como o estímulo à invenção. De nossa parte, honramos a postura de Gille, desde que a ação inventiva admirada por ele reconstitua um novo ponto de equilíbrio do progresso técnico, um novo ponto de mutação e uma transformação de longo prazo que não seja apenas uma fugaz inovação. Por exemplo, no campo da ciência computacional, uma alteração do paradigma digital por um paradigma analógico, sem obviamente abrir mão do avanço de tecnologias digitais conquistado (ao invés de se investir somente em computadores quânticos, por exemplo, permitir o desenvolvimento de uma linhagem de computadores eletroquímicos ou biológicos). O limite pode ser também de ordem cultural: uma cultura que privilegie o conhecimento acerca do mundo natural é uma cultura que reconhece os limites exploratórios da técnica sobre a natureza. O modelo cognitivo da estética ambiental proposto por Carlson pode inclusive propiciar regulações oriundas do sistema político, não obstante a constatada objeção da indústria tecnológica ao aumento líquido de marcos regulatórios. ${ }^{82}$ Ademais, segundo Simondon (1969: 227), uma cultura alheia à realidade intrínseca dos objetos técnicos, normativos por natureza, é uma cultura avessa a uma "normatividade regulatória", o que a torna vulnerável a um tipo de liberalismo econômico sem restrições.

\subsection{ESTÉTICA AMBIENTAL}

A estética ambiental é procedente da estética da natureza, ou o estudo filosófico acerca da apreciação de objetos naturais, ramo da estética pujante no decorrer do século 19 e início do 20. Tendo Kant como um de seus principais formuladores, a estética da natureza tinha como fundamento a noção de desinteresse, a qual impele a não associação de conceitos e preconceitos (utilitaristas, morais etc.) durante $o$ ato da experiência estética. Uma das características mais marcantes da estética predecessora era a importação de posturas e elementos da arte para a natureza: o meio natural deveria ser apreciado

82 MANJOO, Farhad. Silicon Valley's Politics: Liberal, With One Big Exception. The New York Times, 2017. Disponível em: <https://www.nytimes.com/2017/09/06/technology/silicon-valleypolitics.html>. Acesso em: 28 set. 2017. 
tal como uma obra de arte é apreciada. Há dois modelos de apreciação da natureza influenciados pelo direcionamento artístico: um que se orienta pelo princípio do objeto (a natureza como "escultura"); e outro que se orienta pelo princípio paisagístico (a natureza como "pintura de paisagem"). Enquanto o primeiro endereça um tipo de arte ambiental que despega objetos naturais de seu local de origem, colocando-os em outros contextos, ${ }^{83}$ o segundo assume que, por exemplo, deve-se observar uma vista panorâmica tal como se fosse uma pintura de paisagem, aplainando-a em duas dimensões, ou mesmo utilizando o recurso do espelho negro de Claude Lorrain, dispositivo semelhante a um pequeno espelho convexo, levemente tingido por uma cor escura, o qual servia para "objetificar" uma determinada paisagem natural, dando-lhe o aspecto de pintura.

\subsubsection{Novos modelos}

Ao ser desprezada pela filosofia analítica do século 20, a estética da natureza foi condenada ao ostracismo e foi apenas retomada no penúltimo quartel, desta vez por pensadores não satisfeitos com o exclusivismo da filosofia da arte. Foi assim que a estética da natureza se transmutou em estética ambiental, também em função do avanço do movimento ambientalista, dando origem a novas orientações e visões. Uma das mais exóticas, associada inclusive à proposição de uma "nova estética", ${ }^{84}$ é a ideia de atmosfera desenvolvida pelo fenomenologista alemão Herman Schmitz, espécie de aura de livre flutuação, que emana do objeto e "tinge" esteticamente o ambiente circundante, tornando-o mais sensível às percepções "autonomizadas" do

83 Carlson (2002: 44) oferece o exemplo de uma pedra que terá diferentes qualidades estéticas se vista sobre um mantel branco ou em seu "ambiente de criação". No mesmo tom, tome-se as ilustrações do livro sobre pedras do sociólogo surrealista francês Roger Caillois, uma coleção lítica cujos objetos, destacados de seu meio natural, tornam-se verdadeiros suportes de inscrições estéticas. $\mathrm{O}$ arquivo de Caillois desnaturaliza objetos naturais, tornando-os objetos de arte, talvez "para fazer com que uma pedra seja sentida como pétrea". Ver SHKLOVSKY, Viktor. Art as technique. In: RIVKIN \& RYAN, 2004, pp. 15-21.

84 Não confundir com a expressão homônima criada por James Bridle, que dá nome a uma estética imbuída em representações de media art que tratam da aparência da linguagem visual da tecnologia digital no mundo físico. Ver New Aesthetic. In: Wikipedia. [s.l.: s.n.], 2017. Disponível em: $<$ https://en. wikipedia.org/w/index.php?title=New_Aesthetic\&oldid=814643178>. Acesso em: 20 jan. 2018. 
sujeito. Mas, como aponta seu intérprete e conterrâneo Gernot Böhme ${ }^{85}$ tal descolamento sensorial é parcial e tampouco seriam as atmosferas sensíveis produtos de um estado psíquico. A impressão estética definitiva se realizaria, nesse sentido, no encontro das afeições "destacadas" do sujeito com a atmosfera emanada do objeto, uma união concebida como êxtase (ou epifania, como diria Dufrenne). Tal reunião em um ponto equidistante entre sujeito e objeto seria assim efetivada sem a necessidade de uma combinação constrita entre os dois termos, praticada mediante, por exemplo, uma dialética.

Outros modelos, menos extravagantes, que vem contribuir para o renascimento da estética ambiental, são os cognitivos e não-cognitivos. ${ }^{86} \mathrm{O}$ senso comum poderia dar a crer que uma visão não-cognitiva da estética ambiental seria a mais apropriada, seja por meio do envolvimento, modelo defendido por Arnold Berleant (1995), uma abordagem mais fenomenológica e extensiva aos cinco (ou mais) ${ }^{87}$ sentidos, seja através do modelo que preconiza a natureza como sendo incognoscível, misteriosa, eternamente refratária ao olhar subjetivo da humanidade. Mas a visão cognitiva, defendida por Allen Carlson (2002), também deve ser examinada, pois uma apreciação apropriada da natureza, segundo o filósofo estadunidense, implica em um certo tipo de anteconhecimento a respeito de sua composição e elementos particulares. Em contraposição direta ao formalismo abstrato do universo da arte e à doutrina do desinteresse que, como vimos, não está sujeita a informações secundárias ao objeto em si, a visão cognitiva de Carlson, chamada por ele de natural-ambiental, sobrepõe o conhecimento racional ao conhecimento perceptual, sem deixar de reconhecer que o meio natural possui certa resistência em ser conceitualizado, devido à sua carga de indeterminação (op.cit.: 37). Subverte o fato de que, no domínio da estética, a razão está sempre subordinada à percepção (KOREN 2008: 18), mas não resolve por completo a

85 Ver BÖHME, Gernot. Atmosphere as the Fundamental Concept of a New Aesthetics. Thesis Eleven, v.36, n.1, 1993, p.113-126.

86 Ver TOADVINE, Ted. Ecological Aesthetics. In: SEPP \& EMBREE, 2009, v. 59, p. 85-91. Disponível em: <http://www.springerlink.com/index/10.1007/978-90-481-2471-8_17>. Acesso em: 22 set. 2017.

87 Berleant procura suplantar os mais populares órgãos receptivos e é respaldado pela neurociência, a qual reconhece que os cinco sentidos definidos por Aristóteles em De Anima não são os únicos. Por exemplo, além dos sentidos implicados no fenômeno da cinestesia, a capacidade de reconhecimento da localização espacial do corpo, existem milhares de receptores associados aos sentidos convencionais. Ver MAS, Kimberly. You Have More Than Five Senses. Vox, 2017. Vídeo disponível em: <https://www.youtube.com/watch?v=9W0WPPpCFaM> 
questão de como se engajar com a natureza em seus próprios termos. O ideal seria promover um composto entre a visão cognitiva e a não cognitiva, ou mesmo colocálas em uma relação dialética.

\subsubsection{Modelo cognitivo}

O principal argumento para tornar relevante a abordagem cognitiva da estética ambiental é que o conhecimento prévio de seres bióticos e abióticos enriquece a experiência sensória. Carlson disserta que é possível categorizar elementos da natureza, assim como categorizamos objetos artísticos (esta pintura é cubista, aquela outra é impressionista, e assim por diante). A diferença é que os objetos naturais são categorizados mediante o conhecimento das ciências naturais, e não da crítica e da história da arte. Diferentes elementos naturais demandam diferentes atos de aspecção (acts of aspection), pois a "apreciação é um conjunto de atividades que não só respondem ao objeto, mas incorporam o conhecimento como um componente essencial" (CARLSON 2002: 106). Carlson oferece o exemplo das baleias rorquais (op.cit.: 90), mamíferos majestosos que, fossem percebidos como espécies de peixes, pareceriam desgraciosos. Ter ciência sobre a entrada de pragas florestais vindas de outros países pode definir a apreciação estética de um determinado animal, como o besouro-do-pinheiro (Dendroctonus frontalis), chamado em inglês de southern pine beetle, mas que está cada vez mais deixando o sul, inscrito em seu nome, e invadindo áreas ao norte dos Estados Unidos, inclusive o Canadá, devido ao fenômeno do aquecimento global. ${ }^{88} \mathrm{O}$ mesmo vale para paisagens: saber diferenciar um karoo sul-africano de um cerrado brasileiro, por exemplo, pode influenciar a apreciação estética de determinadas extensões da natureza com traços semelhantes, considerando que categorias adequadas determinam propriedades perceptuais adequadas. Tal posição contradiz o argumento de que objetos naturais não são passíveis de gerar uma reação estética, ou melhor, um julgamento estético, pois não foram desenhados para esse fim, tal qual um objeto artístico. Elementos da natureza, por assim dizer, não foram

88 Ver COLE, Laura. Beetlemania as Invasive Species Spreads North. Geographical, 7 set. 2017. Disponível em: <http://geographical.co.uk/places/forests/item/2387-invasive-southern-pine-beetles>. Acesso em: 25 set. 2017. 
projetados por ninguém, não podem ser criticados (a menos que se pressuponha a hipótese pseudocientífica do design inteligente). Porém, assim como é possível enquadrar um objeto artístico dentro de uma escola, relacionando-o a um movimento ou a um estilo, também é possível avaliar um objeto natural, "julgando-o quanto ao que é, colocando-o dentro de sua categoria, sua espécie, gênero, etc., localizando-o em sua história natural e em seu meio ambiental" (CARLSON 2002: 79). Em suma, a natureza da apreciação estética de objetos naturais não é tão diferente da natureza da apreciação estética objetos artísticos.

A apreciação da natureza pura, se orientada exclusivamente ao objeto pode fazer irromper uma não desejável versão positiva ou teísta da estética ambiental (op.cit.: 82), ou mesmo potencializar assertivas pseudocientíficas que revestem de valor científico hipóteses de cunho religioso. A posição de Carlson convoca o conhecimento científico para contribuir com a apreciação estética do mundo natural, já que o método científico invoca certos tipos de qualidades inerentes à natureza, tais como "ordem, regularidade, harmonia, equilíbrio, tensão, resolução e assim por diante" (op.cit.: 93). Um exemplo atual: tem-se observado que o conhecimento de ciências climáticas, facilitado pelas tecnologias de sensoriamento e a quantidade cada vez crescente de dados, influenciam na percepção de que fenômenos naturais catastróficos não são tão somente "naturais". ${ }^{89}$ Pode-se também apreciar esteticamente a formação de um furacão no Atlântico norte sem obscurecer o conhecimento das consequências de seu landfall. Isso pode influir na marcação de posições contrárias às dos negadores do clima e, por extensão, na percepção de que certos artefatos são responsáveis pelo aumento de intensidade dos furacões, estimulando o movimento de transição para tecnologias alternativas.

\subsubsection{Modelo não-cognitivo}

O modelo não-cognitivo é desenvolvido pelo filósofo estadunidense Arnold Berleant (1995) e iremos vinculá-lo ao modelo cognitivo de Carlson, supondo-se que "os dois relatos podem ser combinados de forma fecunda para uma compreensão

89 Ver GUSKIN, Emily DENNIS, Brady. Majority of Americans Now Say Climate Change Makes Hurricanes More Intense. Washington Post, 28 set. 2017. Disponível em: $<$ https://www.washingtonpost.com/news/energy-environment/wp/2017/09/28/majority-of-americansnow-say-climate-change-makes-hurricanes-more-intense/>. Acesso em: 30 set. 2017. 
mais rica do nosso compromisso estético e holístico com o mundo". ${ }^{90}$ Berleant chama a sua estética ambiental não-cognitiva de estética do envolvimento, vocábulo que primeiro faz uma clara objeção quanto a adequabilidade da ideia do desinteresse como forma de apreciação estética e, segundo, sugere a sua submissão à filosofia fenomenológica. Para ele, a descrição da experiência de um ambiente natural ou construído teria de passar obrigatoriamente por uma abordagem fenomenológica, mas "não com a intenção de identificar as estruturas essenciais dessa experiência, mas sim de discernir os padrões de seus processos de temporalidade e movimento" (BERLEANT 1995: 149). Ou seja, a fenomenologia do filósofo estadunidense, ao menos no caso de seus exemplos na arquitetura, limita a predominância do sujeito na experiência perceptiva. Vestígios de subjetivismo, entretanto, são detectados por ele em quem menos se esperaria, como a sua maior influência, Merleau-Ponty, para quem o corpo seria o "ponto zero da espacialidade" (op.cit.: 150), e não uma das partes extensivas da inter-relação. Ora, tal sujeito (kantiano, presume-se) não teria nenhuma relação originária com o mundo, apenas com um espaço apriorístico ${ }^{91}$ - porém é o ser-no-mundo que condiciona o senso de cardinalidade espacial, e não o contrário. Para a estética do envolvimento, o mundo deve vibrar mais que o espaço que o coordena.

90 Ver TOADVINE 2009, p. 90.

91 Segundo Alexis Philonenko (apud STIEGLER 2011, p. 162). Obs.: a citação de Philonenko por Stiegler, sem referência direta, alude a um livro de Kant traduzido para o francês como Qu'est-ce que s'orienter dans la pensée? 
Figura 6 - Roden Crater (parte externa), de James Turrell

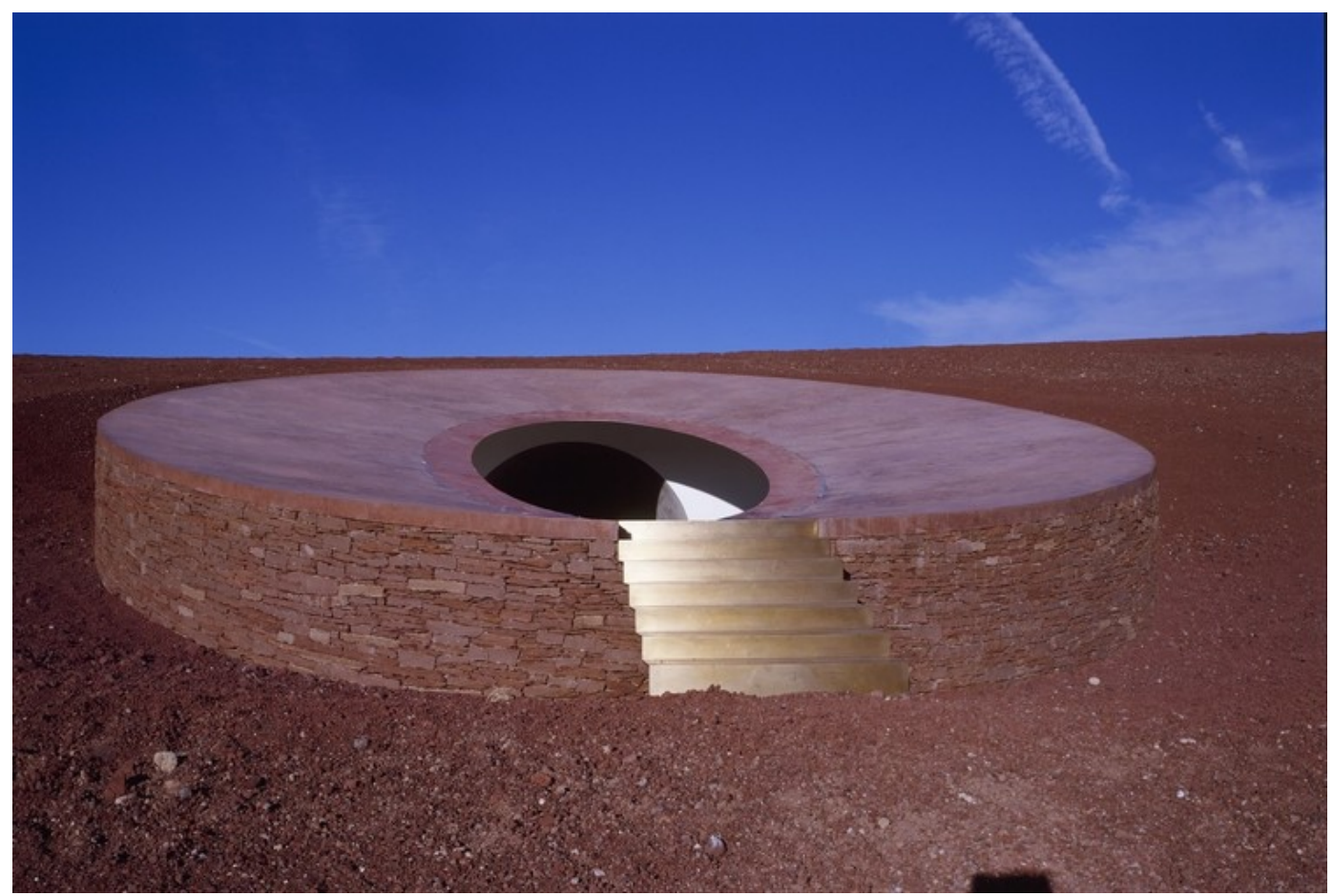

Fonte: https://www.archdaily.com/910086/james-turrells-roden-crater-set-to-open-after-45-years

O projeto de reformulação de Berleant preconiza que a apreciação da natureza é uma necessidade interna dos sentidos, que é ela, e não o objeto artístico, o centro das atenções estéticas. Logo, a importação mencionada em parágrafos anteriores deve ser revista: as obras de arte devem ser apreciadas como se fossem elementos do mundo natural, e não o contrário. Ora, no atual contexto cultural, não nos parece tão delirante tal inversão. O confrontamento da teoria do desinteresse deve ser, segundo o filósofo, inexorável. Por mais que a noção de participação já tenha sido assimilada em proposições da arte contemporânea, o art world parece manter-se agrilhoado à teses obsoletas, como as que insistem em enquadrar a apreciação estética dentro do universo exclusivista da arte. Por mais que se negue isso e mesmo com a difusão cada vez maior de recursos participativos (diferentes dos interativos, segundo Claire Bishop), ${ }^{92}$ o foco da operação estética permanece sendo dirigido aos "atributos internos do objeto de arte, como a sua autossuficiência, completude e unidade" (op.cit.: 162). O projeto de Berleant propõe ainda uma estética única que englobe a arte e a natureza, uma "estética universal", inclusiva e

92 A historiadora e crítica britânica distingue a ativação participativa em obras de arte interativas (artemídia) das práticas artísticas que se apropriam de formas sociais para aproximá-las da vida cotidiana. Ver BISHOP, 2006. 
abrangente. Não seria Roden Crater o modelo perfeito?, pergunta Barelant. $\mathrm{O}$ artista estadunidense James Turrell está construindo no norte do Arizona, Estados Unidos, um complexo de túneis e galerias no interior de um vulcão extinto, de mesmo nome, uma obra de earthwork projetada para a visualização de fenômenos luminosos solares e celestiais (ver Fig. 6). O projeto de Turrell coloca em evidência a alteridade da natureza, mas sem torná-la "alienígena". Nesse sentido, objetos inseridos dentro de uma estética universal poderiam estar sendo usufruídos em qualquer recôndito do globo terrestre, ou mesmo em outro planeta.

\subsubsection{Sublime revisitado}

Entrevistado para uma matéria do The Guardian, ${ }^{93}$ o famoso naturalista britânico David Attenborough deu a entender que, se quisermos salvar o planeta da atual crise ecológica, haveremos de resgatar o "senso de deslumbramento" que a natureza sempre nos aguçou. Não seria então o caso de a estética ambiental tentar manter acesa a chama do sublime, ideia popular no período romântico, desenvolvida a partir das teorias de Burke e Kant (CARLSON 2002: 79), e que preconizava uma maneira de se extirpar o aspecto ameaçador da natureza selvagem e indomável por meio de sua subjetivação e "domesticação" representacional? Se conseguirmos erradicar do sublime da ideia que Ihe prenunciou, o desinteresse, que distancia o sujeito desejante do objeto apreciado, deslocando-os da interconexão ecológica, talvez seja possível recuperá-lo para uma nova finalidade. Bruno Latour já havia notado a "evaporação" do conceito do sublime na contemporaneidade, para ser preciso, no momento em que passamos a nos ver não como seres humanos insignificantes, dominados pela natureza, mas, pelo contrário, como um gigante coletivo que molda o planeta. ${ }^{94} \mathrm{~A}$ estética ambiental de Carlson e Berleant não contempla esse anacrônico estado de espírito, mas colocá-lo em foco novamente pode contrabalançar a imprudência dos projetos prometeicos da humanidade. Ela terá a incumbência de restabelecer, perante a natureza, um senso de

93 Ver HARVEY, Fiona. David Attenborough on the Scourge of the oceans: "I remember being told plastic doesn't decay, it's wonderful". The Guardian, 25 set. 2017. Disponível em: $<$ http://www.theguardian.com/tv-and-radio/2017/sep/25/david-attenborough-on-the-scourge-of-theoceans-i-remember-being-told-plastic-doesnt-decay-its-wonderful>. Acesso em: 25 set. 2017.

94 Ver LATOUR, Bruno. Waiting for Gaia Composing the Common World Through Arts and Politics. In: YANEVA \& ZAERA-POLO, 2015, pp. 21-33. 
estranhamento, ocultar as semelhanças e inverter as relações de causa e efeito, tornando estranho o familiar, operações que dão vazão ao que Morton (2016: 7) chama de strange of appearance. A remodelagem da noção de sublime exigiria transformar a Terra em Marte, não geologicamente, por certo, mas conceitualmente, esteticamente. O protótipo para uma nova interpelação da noção de sublime se encontra em uma descrição contida no primeiro livro da celebrada trilogia marciana, ${ }^{95}$ de Kim Stanley Robinson:

O sol tocou o horizonte e as cristas da duna desvaneceram-se nas sombras. O pequeno botão solar mergulhou em direção ao oeste sob a linha escura. Agora o céu era uma cúpula marrom, as nuvens altas rosadas como o musgo campion. As estrelas estavam aparecendo por toda parte, e a cor marrom do céu mudava para uma vívida violeta escura, uma cor elétrica que era apanhada pelas cristas de dunas, de modo que parecia que as penumbras do crepúsculo líquido estavam espalhadas pela planície negra. De repente, Nadia sentiu uma brisa rodopiar através de seu sistema nervoso, correndo por sua coluna até sua pele; suas bochechas tingiram-se, e ela podia sentir a vibração de sua medula espinhal. O belo pode fazer tremer! Foi um choque sentir uma resposta tão física à beleza, uma emoção semelhante a do sexo. E essa beleza era tão estranha, tão alienígena. Nadia notou que nunca tinha visto isso antes, ou nunca havia sentido; ela estava gostando de sua vida, como se estivesse em uma Sibéria mais bem arranjada, de modo que realmente ela estava vivendo uma enorme analogia, compreendendo tudo em termos de seu passado. Mas agora ela estava debaixo de um alto céu violeta e na superfície de um oceano negro petrificado, tudo era novo, tudo era estranho; era absolutamente impossível comparar isso com qualquer coisa que ela tinha visto antes; e, de repente, o passado se afastou de sua cabeça e ela girou em círculos, como uma garotinha tentando ficar tonta, sem pensamentos na cabeça (ROBINSON 1995: 171-72; tradução nossa).

95 A três novelas que compõem a trilogia marciana são: Red Mars (1993), Green Mars (1994) e Blue Mars (1996). 
Como deslocar tal senso carnal para o planeta Terra? Um senso de espanto que, segundo Aristóteles, é nada mais que a origem da filosofia (thaumazein)? Antes é preciso expor alguns axiomas acerca do ambicioso projeto literário de Robinson. Em sua análise sobre a trilogia, o filósofo australiano McKenzie Wark (2015) detalha as diversas visões - e, sobretudo, projetos - que cada um dos primeiros exploradores nutre a respeito do planeta vermelho recém-empossado. Duas facções majoritárias - e antagônicas - se destacam ao longo da narrativa: a que pretende iniciar o quanto antes o processo de terraformação, ou seja, a modificação do sistema planetário com o intuito de deixá-lo semelhante ao habitat terrestre (facção dos Greens); e a que evangeliza o mínimo de interferência possível (facção dos Reds). Para os primeiros, a natureza é o que resiste ao trabalho, e principalmente à organização do trabalho; para os últimos, trata-se de uma questão de deferência, de contemplação de um estado natural a ser estimado (e sobretudo conservado). A disputa, que no fundo é estética, fica patente em um diálogo no qual uma personagem da facção Green tenta convencer uma personagem da facção Red sobre a desnaturalização do ato contemplativo, agora aberto à alteridade geofísica:

As pessoas podem tentar mudar o planeta, mas o tempo todo o planeta também está mudando-as. O senso de lugar, uma estética da paisagem, todas essas coisas mudam com o tempo. Você sabia que as pessoas que viram pela primeira vez o Grand Canyon acharam aquilo feio como o inferno porque não parecia com os Alpes? Demorou muito tempo para elas enxergarem a sua beleza (ROBINSON 1995: 300-1; tradução nossa).

Porém, como assinalamos no caso da personagem Nadia, o efeito da beleza na grandiosidade arrebatadora de uma natureza estranha (no caso de nosso argumento, da natureza terrena), o próprio sublime romântico revisitado, independe de um processo de terraformação, ou de uma terraformação a posteriori no caso de o planeta Terra estar no caminho de se transformar em Marte, devido à ultrapassagem de várias fronteiras planetárias ${ }^{96}$ por ações antropogênicas.

96 Cf. Fronteiras planetárias. In: Wikipédia, a enciclopédia livre. [s.l.: s.n.], 2017. Disponível em: $<$ https://pt. wikipedia.org/w/index.php?title=Fronteiras_planet\%C3\%A1rias\&oldid=49362513>. Acesso em: 14 nov. 2017. 
Suponhamos que seja possível, através de uma bem confeccionada estética ambiental, reativar o efeito do sublime, em paralelo com o reconhecimento de que a humanidade se encontra em relação metonímica com a physis, com o desígnio de anular a necessidade de uma terraformação a posteriori de nosso planeta em um futuro não muito distante. Talvez o sublime convocado nessa reedição não tenha o mesmo teor do efeito estudado por estetas do início do século 18, e é aí que devemos solucionar um paradoxo: como cancelar, no novo sublime, o desinteresse não desejante típico do sublime original? Sim, pois o sublime exigido pelas novas condições deverá despertar o fascínio distanciado, mas ao mesmo tempo aproximar os humanos de não humanos (e da matéria inumana). Uma das soluções possíveis seria "cientificar" o efeito do sublime, condicionando-o ao entendimento do que está sendo apreciado e observado, desbravando um novo campo de avaliação (CARLSON 2002: 86). Não se enquadraria em uma estética positiva, ansiosa por uma natureza intocada e virgem; mas em uma estética aberta para intervenções técnicas adequadas. O retorno do sublime na contemporaneidade dependeria, portanto, de uma ressonância entre as posições dos Reds e dos Greens.

\subsubsection{Estética positiva}

Se quisermos reivindicar a origem ideológica da estética da natureza seríamos obrigados a atribuí-la ao movimento ambientalista, como já sugerimos. Uma natureza íntegra, ainda isenta da marca humana, seria bela por princípio, não sendo aplicável a ela um julgamento "negativo". Daí a expressão "estética positiva", analisada por Carlson, para designar a apreciação estética de uma natureza intocada. Antes de tudo é preciso relevar alguns pontos. Se se conceitualiza o meio natural por meio do significante Natureza (natura naturans), somos tentados a interpretá-lo como um "objeto", como uma escultura de topiária, por exemplo. Se ele é conceitualizado como "paisagem", somos tentados a interpretá-lo como cenário, semelhante às representações românticas de paisagem. Uma cláusula deveria ser aqui adicionada à descrição do termo "paisagem", diferenciando-o de conotações geográficas e antropológicas levantadas por Berque e Watsuji; para a crítica de Carlson, a paisagem tem o sentido de "pintura de paisagem", de um cenário neutro 
sobre o qual se dirige o olhar distanciado e seguro. Em outras palavras, é uma interpelação imprópria, assim como a objetal. Assim é convocada uma terceira via: a estética positiva. Mas não incondicionalmente. Primeiro, a apreciação estética da natureza é tão-somente infensa a um julgamento crítico em teoria, porque sempre ocorrerá uma reação estética da parte do sujeito (vide o exemplo do assombro provocado por seres das zonas abissais). Com efeito, a estética ambiental de Carlson não professa subliminarmente uma concepção inestética. Segundo, se a estética positiva se apropriar da posição romântica do sublime em um determinado julgamento estético da natureza, ela deve embarcar sentimentos como espanto, maravilhamento e admiração - e não o temor, suscetível a julgamentos negativos. Para evitar conflitos e ambiguidades das abordagens anteriores, Carlson sugere a via cognitiva, uma estética positiva "positivista", mas com nuances ecológicos: "Os defensores contemporâneos da estética positiva têm consideração pela ciência. $A$ principal diferença é que agora as ciências relevantes não são principalmente geografia e geologia, mas sim a "biologia e a 'ciência' inclusiva da ecologia" (CARLSON 2000: 86). Perguntamos de resto se o pitoresco prestar-se-ia mais do que o sublime para a formação de uma estética voltada a objetos tecno-ambientais, mas aquele pitoresco com evidências da presença humana, tendo em vista que tais interferências já correspondem a quase a totalidade da área planetária. $E$ ademais compreende-se que a estética positiva contemporânea sobre a qual se refere Carlson deva incluir além de um "sublime rebaixado", ${ }^{97}$ um sentido que avalie "uma natureza já humanizada, impregnada pelo trabalho ou pela arte, e já suscetível de ser percebida através de uma tradição estética". ${ }^{98}$ Por fim, uma estética positiva que incorpore um real recriado pelo homem e pelas máquinas, uma fenomenologia mediada pela tecnologia, ou mesmo uma "fenomenotécnica". ${ }^{99}$

97 "O pitoresco é um sublime rebaixado, uma expressão diminuída do sublime" (DUFRENNE 2015: 74). $98 \mathrm{lbid}$. 99 Ibid., p. 220. Aqui emprestamos o termo cunhado por Bachelard, concebido para amparar sua reflexão sobre a racionalidade científica, para propor uma suposta "fenomenologia das técnicas". 


\subsection{TECNO-ESTÉTICA}

A ponte Garabit, no rio Truyère, é, para Gilbert Simondon, o exemplo perfeito de obra tecno-estética, uma estrutura que, apesar de ser um artefato construído, se encontra em "plena natureza", sem que sua presença entre em conflito com o entorno, associando-se a ele de modo inconsútil (ver Fig. 7). É uma obra "perfeitamente funcional, inteiramente bem sucedida e bela, simultaneamente técnica e estética, estética porque técnica, técnica porque estética. Há fusão intercategórica" (SIMONDON 1992). A axiologia intercategórica a qual se refere Simondon se estende para exemplos congêneres, alguns deles retirados de projetos de Le Corbusier e Xenakis, sugerindo a introdução de uma arquitetura híbrida, de modo que "arte e natureza possam interferir uma na outra" (op.cit.). O que talvez esteja em desvantagem na definição de tecno-estética de Simondon, ao menos no exemplo da ponte Garabit, é a noção de ambientalidade (WATSUJI 2006), elemento indispensável na composição entre objeto técnico e realidade estética, ausência que pode ser compensada com modelos contemporâneos de estética ambiental, renegada por estetas da arte e pela tradição analítica. Adiantamos uma ressalva, a de que a tecno-estética sobre a qual versaremos em seguida tem apenas uma relação transversal com a chamada new media art, bastante em voga no circuito da arte contemporânea, integrada por expressões artísticas de tal maneira dependentes de procedimentos tecnológicos e algorítmicos que "uma simples disfunção técnica não significaria apenas o impedimento do efeito estético, mas a própria aniquilação da obra". ${ }^{100}$ Feita esta advertência de carácter conceitual, ingressamos na análise da proposta estética de Simondon propriamente dita, mas não sem antes verificar separadamente as duas categorias fundidas no caso da ponte Garabit - ou seja, especularemos a respeito do que o filósofo francês entende por categoria estética e por categoria técnica. Uma vez que existe um "espectro contínuo que liga a estética à técnica" (op.cit.), observar-se-á nos interstícios de nossa análise sobre a primeira uma insinuação a respeito da segunda, e vice-versa.

100 Ver DUHEM, Ludovic. Introduction à la techno-esthétique. Archée : cyberart et cyberculture artistique. [s.d.] Disponível em: <http://archee.qc.ca/ar.php?page=article\&no=343>. Acesso em: 28 out. 2017. 
Figura 7 - Ponte ferroviária de Garabit



Fonte: http://mieux-se-connaitre.com/2012/02/ponts-suite-le-viaduc-de-garabit/

\subsubsection{Categoria técnica}

Se a ponte Garabit é o exemplo perfeito de tecno-estética para Simondon, podemos concluir então que o caso da ponte Tacoma Narrows, nos Estados Unidos, seria exatamente $\mathrm{o}$ seu oposto. Até hoje fonte de controvérsias entre engenheiros, ${ }^{101}$ o fato é que esta ponte pênsil, construída sobre o Estreito de Tacoma, Washington, colapsou em 1940 devido a uma forte ventania. Em princípio, a oscilação natural da estrutura entrou em ressonância com os vórtices dos ventos, ampliando as frequências e proporcionando a vibração torcional da estrutura. Não obstante se a causa do fenômeno destrutivo pode ser descrita tecnicamente como uma ressonância forçada ou uma oscilação autoexcitada (flutter), o que é importante ressaltar à luz de uma visão simondoniana é que trata-se de uma falha humana, pois os engenheiros não levaram em conta a ambientalidade do local, como suas singularidades geofísicas e meteorológicas. Os construtores deveriam ter pensando 
na associação entre objeto técnico e meio, buscando formar um sistema acoplado. Curioso é que Simondon emprega a palavra acoplamento, ${ }^{102}$ outro termo extraído do vocabulário científico, para descrever o sistema mundo-sujeito na operação perceptual, na qual há a ressonância na relação entre a heterogeneidade indeterminada das formas externas e a solução inventiva do sujeito-receptor em busca de uma unidade coerente. O colapso da ponte Tacoma Narrows, nesse sentido, é resultado de um projeto calculado com exatidão, mas isento de elementos naturais não determinados (periodicidade dos vórtices dos ventos). O projeto era mais técnico do que estético, uma instabilidade não concebível na acepção da tecno-estética.

\subsubsection{Tecnicidade}

Um dos principais tópicos da filosofia da tecnologia de Simondon, já o dissemos, não é a técnica em si, mas o que ele denomina de tecnicidade, conceito complexo, de difícil explanação, mas que ao mesmo tempo é familiar ao ser humano, posto que é um dos componentes originários de sua condição e, mais importante, de sua relação com o mundo. Segundo o filósofo francês (1969: 72), trata-se da capacidade de um objeto técnico se concretizar (ou seu "grau de concretização", em suas palavras), prolongando-se além das circunstâncias espaciais, materiais e temporais que o engendraram. Neste sentido, a tecnicidade "interliga as dimensões geográficas, ecológicas, energéticas, econômicas e históricas sem ser redutível a nenhuma delas" (MACKENZIE 2006: 11). Ela engloba não apenas habilidades manuais, mas também o desejo de transmiti-las a futuras gerações. Ressalta os atributos de materiais à disposição do artífice em uma determinada localidade. Em uma imagem lírica, mantém aceso o fogo furtado dos deuses, em nome da coletividade e das etnias. Em termos estruturais, dispõe de objetos que vão do simples ao complexo, como elementos, indivíduos ${ }^{103}$ e conjuntos

102 Esta palavra é tomada aqui no sentido que a física lhe dá, especialmente na teoria das trocas de energia entre oscilador e ressonador (SIMONDON 2005, p. 244, nota de rodapé 7). Excerto no original: Ce mot est pris ici au sens que la Physique lui donne, en particulier dans la théorie des échanges d'érnergie entre oscillateur et résonateur. (tradução nossa).

$103 \mathrm{Em}$ metafísica e estatística, a palavra "indivíduo" habitualmente descreve qualquer coisa numericamente singular, embora por vezes se refira especificamente a "uma pessoa". Usada em muitos contextos, tanto "Sócrates" como "a Lua" são indivíduos. Ver o verbete Indivíduo. In: Wikipédia, a enciclopédia livre. [s.I.: s.n.], 2017. Disponível em: <https://pt.wikipedia.org/w/index.php? 
técnicos. Aumenta proporcionalmente se articulada a fatores como simplicidade e transferência. No exemplo da indústria automotiva, os elementos técnicos tradicionais (por ex. molas, correias) têm mais potencial de tecnicidade que um indivíduo formado por eles (por ex. motor) e muito mais que o conjunto técnico da cadeia produtiva. A sua vinculação com a percepção estética se encontra em sua exigência, no processo de concretização, por figuras adequadas (formas), funções robustas (funcionalidade) e funcionamentos inteligíveis (execução transparente da função). Um objeto técnico como o Jaguar E V12 (ver Fig. 8) encontra-se numa situação algo paradoxal, porquanto the falta uma funcionalidade importante em termos de aerodinâmica (SIMONDON 1992). Descrito como "o carro mais belo já feito" por Enzo Ferrari, o automóvel, porém, não deixa de ser "estético" por essa falha funcional, sendo um exemplo não bem-acabado de uma tecno-estética (como o alicate de corte Facom), pendendo mais para o campo da estética da tecnologia, na expressão de Giovanni Carrozzini. Analisemos agora os componentes da genealogia da tecnicidade - elementos, indivíduos e conjuntos -, tendo os últimos sido também objeto de exame na seção Pensamento técnico.

Figura 8 - Jaguar E-Type, automóvel fabricado pela Jaguar britânica entre 1961 e 1974

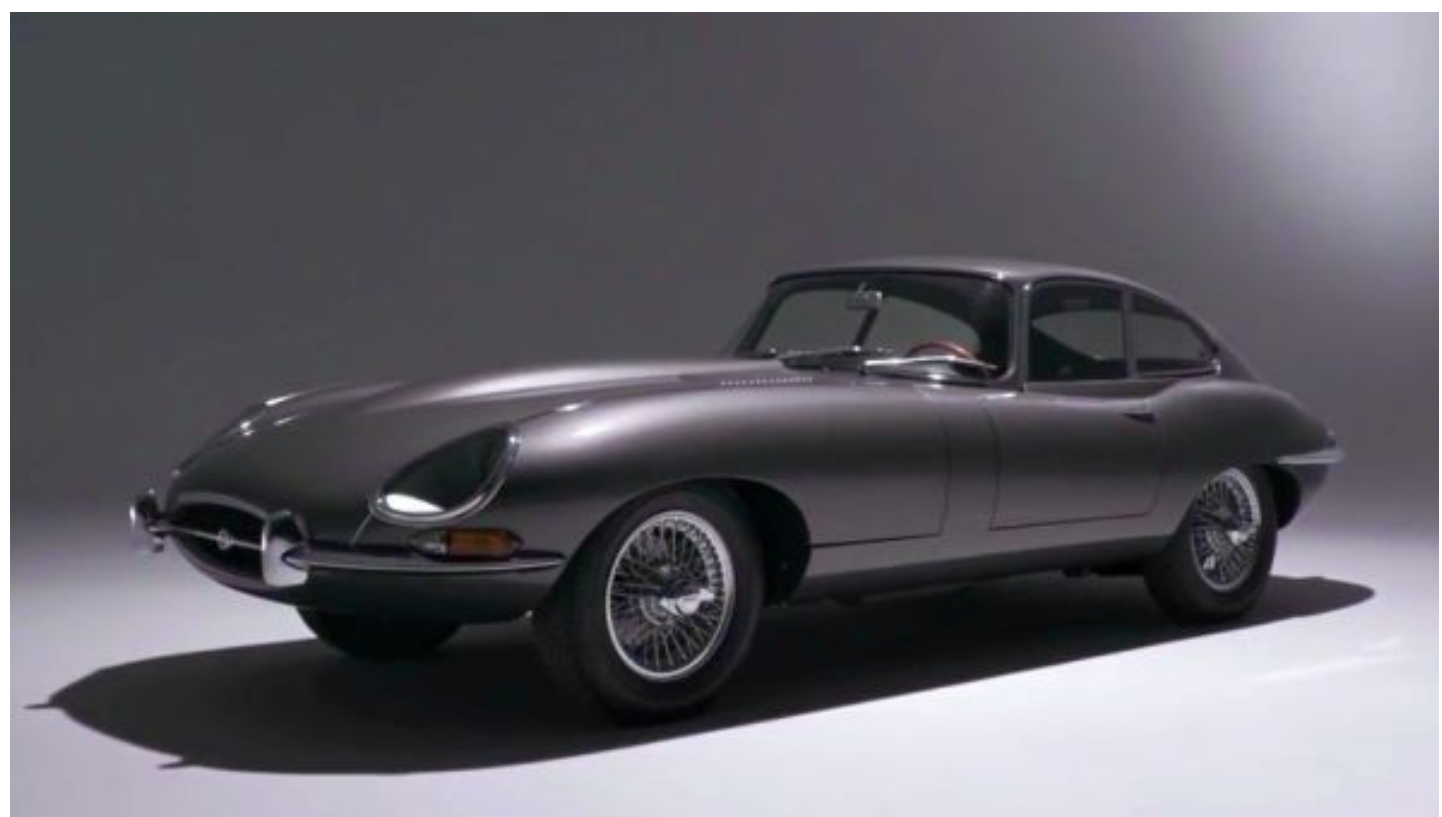

Fonte: https://www.jaguar.com/about-jaguar/jaguar-classic/etype-reborn.html

title=Indiv\%C3\%ADduo\&oldid=50594921>. Acesso em: 26 abr. 2019. 


\subsubsection{Elementos}

Em virtude da alusão ao popular alicate de corte, temos agora o pretexto para estabelecer uma relação entre tecno-estética e ferramentas em geral, objetos de uso e elementos técnicos por excelência. Para começar, Simondon confere-lhes valências práticas, dando ao manuseio do tesourão Facom, por exemplo, a "impressão de facilidade que não está longe do prazer sensório-motor" (SIMONDON 1992). Ainda no campo morfológico, a descrição detalhada da evolução de um modelo de chave para ciclistas, com a culminância resolutiva de sua empunhadura, nos faz especular se os desenvolvedores de técnicas de lascado do período Paleolítico - como a de Levallois - também se compraziam esteticamente com a progressão de suportes mais adequados para suas lâminas talhadas em seixos. Mas a contemplação de um elemento técnico não exaure seu aspecto estético. "É no uso, na ação, que ela se torna de certa forma orgásmica, meio tátil e motor do estímulo" (op.cit.). A deleitação descrita faz Simondon avantajar-se de Heidegger ao atribuir às ferramentas um papel maior do que estarem simplesmente "à mão"; elas contam com toda uma gama sensorial. O elemento técnico induz à ação ao invés da intelecção, e é por esse motivo que a exterioridade utilitarista pode servir de porta de entrada para a experiência estética, por sua proximidade com o sensível. Por certo é um objeto cultural tecnicamente interiorizado (STIEGLER 1998: 176) e eivado de normas (um martelo pode ser usado para pregar ou destruir - notória asseveração pronunciada tanto por técnicos como por religiosos). E a familiaridade do uso pode "nos levar a uma conivência em que a percepção é perdida nos gestos" (DUFRENNE 1973: 83). Mas a tecno-estética pode resolver o problema do automatismo do uso ferramental através de uma economia singular onde o "corpo do operador dá e recebe" (op.cit.). As ferramentas são o retrato de uma sinergia.

\subsubsection{Indivíduos}

Um dos impedimentos para o rendimento robusto dos "seres que funcionam", os indivíduos técnicos, é a hipertelia, ou a sua sobredeterminação funcional, o que os encerram em especializações contrárias à possíveis e proveitosas 
indeterminações - problema que afeta os elementos técnicos do mesmo modo. Para reduzir tal impropriedade há de se ocorrer, no caso de um indivíduo técnico descrito como a associação concordante de diversos elementos técnicos - uma espécie de autocondicionabilidade de seu funcionamento, sendo ele condicionado concomitantemente pelo meio geográfico no qual está inscrito (STIEGLER 1998: 80). Essa causalidade circular se eventualiza no exemplo paradigmático de indivíduo técnico convocado por Simondon (1969: 54): a turbina de Jean Guimbal (ver Fig. 9), patenteada na década de 1950 pelo inventor homônimo, híbrido de turbina hidráulica e gerador elétrico para usinas hidrelétricas. ${ }^{104} \mathrm{~A}$ substância usada na lubrificação do indivíduo e a água ao seu redor passam a desempenhar múltiplos papéis: a água é fonte de energia, mas também dissipa o aquecimento da turbina; o óleo transporta o calor, mas também isola e lubrifica o gerador, e, devido ao diferencial de pressão, acaba por evitar infiltrações. ${ }^{105}$ Haveria um duplo mutualismo de potencialidades. Contingentemente, é a natureza naturante que "toma a iniciativa" e passa a se sobredeterminar em hipertelias, neutralizando a sobredeterminação da natureza naturada. "[A turbina de Guimbal] é, portanto, a condição de si mesm[a] como condição de existência desse meio misto, técnico e geográfico ao mesmo tempo" (SIMONDON 1969: 55).

104 Cf. CLAUDE, G.J. Combined Turbine and Generator Unit. [s.l.]: Google Patents, 1953. Disponível em: <https://www.google.com/patents/US2634375>. Acesso em: 24 abr. 2019. 105 Ver BOEVER, Arne De; MURRAY, Alex; ROFFE, Jon. 'Technical Mentality' Revisited: Brian Massumi on Gilbert Simondon. In: BOEVER ET AL. 2013, pp. 19-36. 
Figura 9 - Lâmina original de patente da turbina de Guimbal instalada em hidroelétrica Filed Nov. 3, 1950

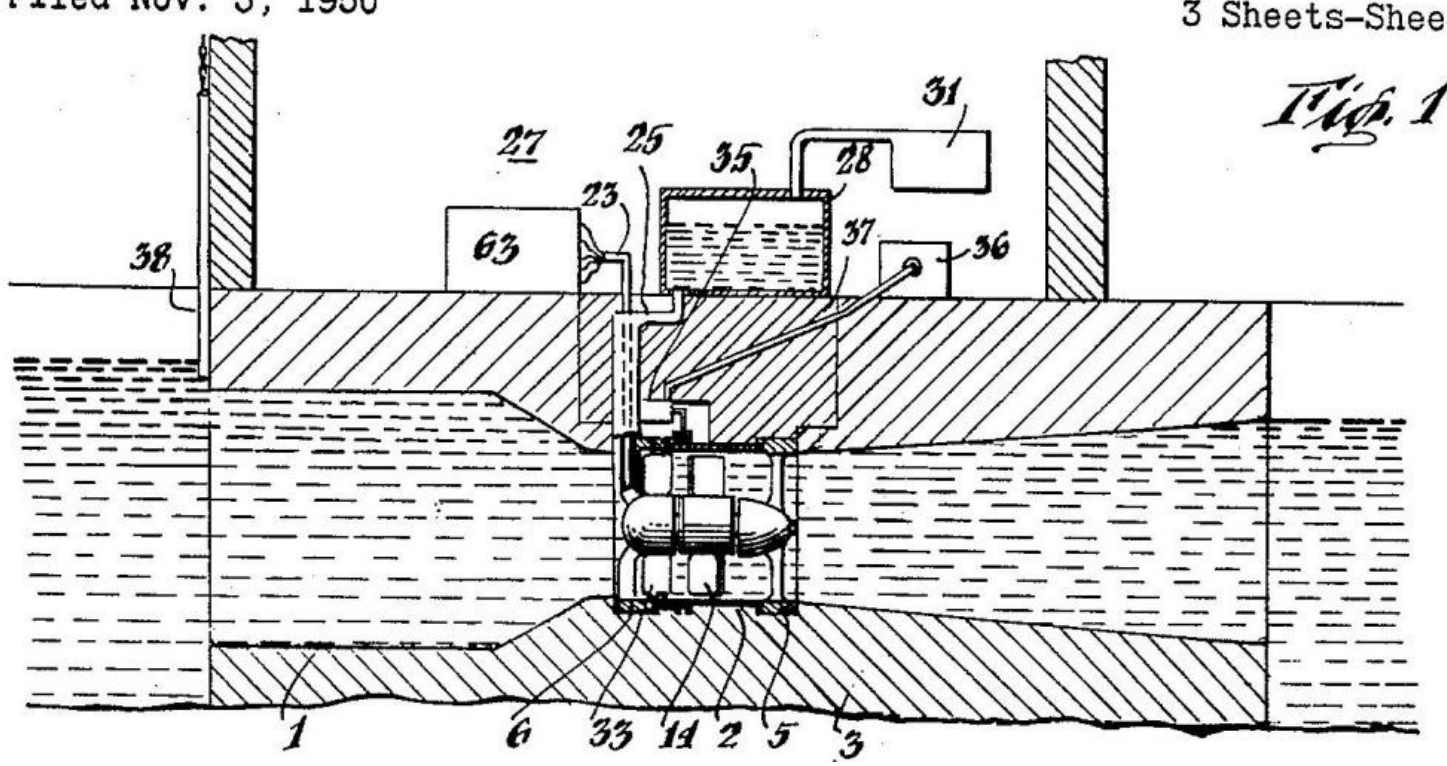

Fonte: https://www.google.com/patents/US2634375

\subsubsection{Conjuntos}

Para Simondon, a verdadeira estética industrial de um conjunto situa-se nos lugares de emissão de rádio, e ele se vale como exemplo o campo de antenas do centro de transmissão de Villebon-sur-Yvette (ver Fig. 10), construído próximo à Paris, em 1934, e operado pela Télédiffusion de France (TDF). Uma das estruturas de alta tensão "é digna de nota especialmente porque não se encontra na natureza. Ela é completamente artificial, exceto talvez se pensarmos na figueira da Índia, que busca apoio e subsistência em vários pontos do solo" (op.cit.: 262), podendo tal analogia de conteúdo naturalista se acomodar com exatidão aos "pilares geralmente atados várias vezes por cabos" (loc.cit.). Em termos estéticos, Simondon concede dois tratamentos aos conjuntos de emissão. O primeiro, mais material, abrange a estrutura física das antenas, uma "floresta de metal" na qual cada componente "se recorta sobre as nuvens ou sobre o fundo mais claro", imagem evocativa do "intenso poder semântico" suscitado pelo contraste figura-fundo. Mikel Dufrenne recorda que, na "função de totalidade" descrita por Simondon, parece existir um protagonismo não apenas da forma, mas também do fundo, uma circunstância na qual "em vez da forma estetizar o fundo, é o fundo que estetiza a forma" (DUFRENNE 2015: 159). O 
segundo tratamento abarca não o objeto concreto, mas o que dele se desprende. As ondas médias transmitidas com frequência de $695 \mathrm{kHz}$ pelas antenas de Villebon, assim como a eletricidade, não são objetos, mas podem ser percebidas através de um objeto técnico e se tornar fonte de percepção estética. Por certo reportamo-nos aos instrumentos, como galvanômetros e osciloscópios, que mediam o mundo invisível aos órgãos do sentido. Isso suscita uma primeira questão, sobre a qual voltaremos em outra oportunidade, se a relação ruído-sinal não seria uma variante incorpórea, em contraponto direto com a tradição visual da Gestaltpsychologie, da relação figura-fundo. E também a singular questão filosófica se uma qualidade estética estaria reservada não ao aparato em si, justaposto ao fundo, mas às suas "renderizações", ou seja, aos semblantes de um mundo não elegido de ser mostrado aos humanos (WARK 2015: 177). Invoca-se, nesse sentido, a obra The Lightning Field (1977), de Walter De Maria, quatrocentos postes pontiagudos instalados em um deserto no Novo México, um conjunto concebido para atrair as descargas de relâmpagos. Aludiremos a essa obra de arte, a título de exemplo de objeto tecnoambiental, no segundo capítulo.

Figura 10 - Transmissor de Villebon

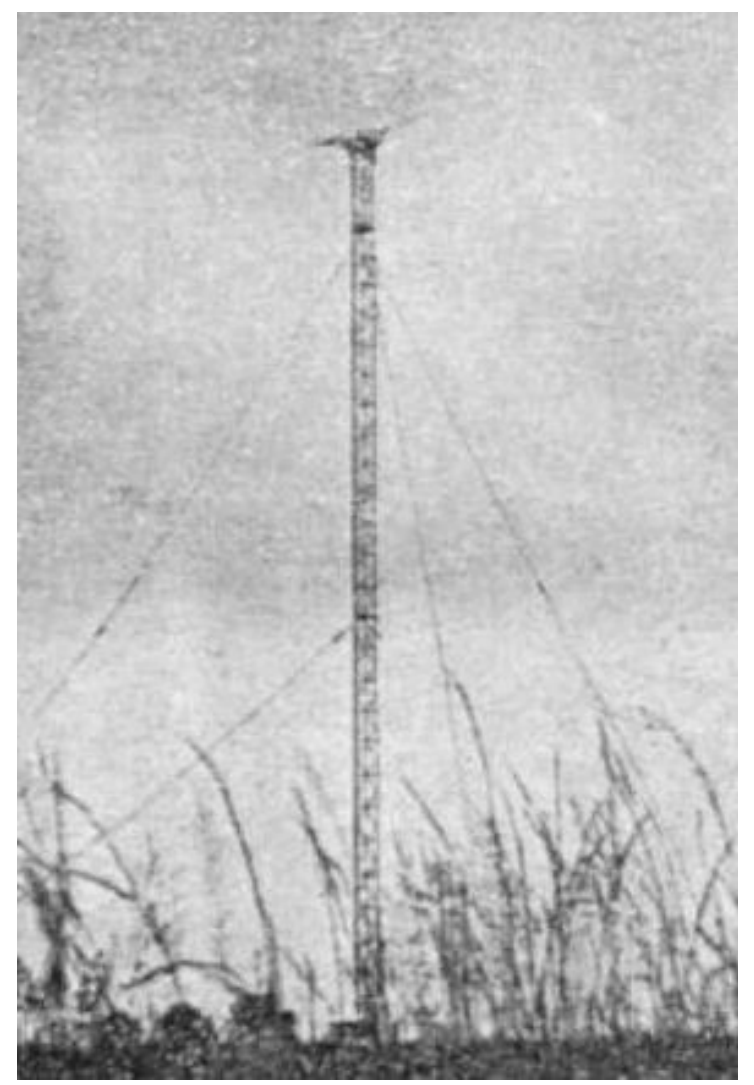

Fonte: https://tvignaud.pagesperso-orange.fr/galerie/am/75villebon.htm 


\subsubsection{Categoria estética}

A concepção de estética de Gilbert Simondon tende a tornar-se o arcabouço de uma autêntica teoria estética e está expressa em textos esparsos, como na referida carta a Derrida, na qual ele desenvolve parcialmente a sua noção de tecnoestética, na quarta parte do curso Imagination et invention (2008b: 90-91), na qual ele investiga a invenção artística e o papel do objeto estético no ciclo da sensorialidade, e principalmente na terceira parte de sua tese complementar de doutorado, Du mode d'existence des objets techniques (1958), intitulada Essência da tecnicidade. Vamos analisar agora mais detidamente, nessa mencionada parte, a primeira seção do capítulo II, Rapports entre la pensée technique et les autres espèces de pensée (Relações entre o pensamento técnico e outras espécies de pensamento), intitulada Pensée technique et pensée esthétique (Pensamento técnico e pensamento estético). Como lembra Yves Michaud, ${ }^{106}$ um dos poucos autores a se debruçar sobre as concepções estéticas de Simondon, é uma seção com alto teor especulativo, mas que pode contribuir de forma original com a filosofia da estética, principalmente se for realizada como complemento a uma crítica da estética marcada pela tradição analítica, que se ocupa exclusivamente com a filosofia da arte, sem abarcar outros domínios.

Em um breve sumário da primeira seção do capítulo II, recordamos que na gênese da relação entre o homem e o mundo, em um espaço-tempo primitivo, mítico, existia um pensamento mágico que não contemplava, em sua visão de mundo, a separação entre sujeito e objeto, entre natureza e cultura, entre figura e fundo e assim por diante. Ou seja, havia uma unidade primordial e os primeiros objetos criados pela técnica não destoavam do fundo infinito ${ }^{107}$ totalizante. A partir do desenvolvimento do pensamento primitivo para um pensamento pré-moderno, as unidades do dualismo mais elementar, porque sensorial - figura e fundo -, se separam, criando contrastes até então desconhecidos. Interessante que, para Simondon, a única forma de o pensamento pré-moderno e moderno articular figura e fundo é por meio de uma estética, por meio de uma composição entre os dois

106 Ver MICHAUD, Yves. The Aesthetics of Gilbert Simondon: Anticipation of the Contemporary Aesthetic Experience. In: BOEVER ET AL. 2013, pp. 121-132.

$107 \mathrm{Em}$ alusão à técnica fotográfica. Também confere o aspecto cósmico do universalismo. 
elementos em concorrência. Mas essa união parcial, alerta ele, não resolve por completo o problema da cisão original. Por exemplo, um objeto estético não é um fim em si mesmo; é apenas um índice, um apontamento em direção a uma visão de mundo primitiva; é o resquício de um pensamento mágico e sagrado. Os novos modos de pensamentos surgidos após a cisão, então, são como vestígios de uma unidade mágica perdida. Pode-se concluir pelo texto da seção que tais formas de pensamento são como "mídias", no sentido de mediarem os humanos e a imagem de um "mundo perdido".

Ainda no espaço-tempo primitivo, em um dado momento do processo genético da relação humano-mundo, a unidade mágica da realidade, consistentemente enredada, defasou-se ${ }^{108}$ em duas partes principais: as técnicas, subsumidas pela figura e pelos elementos "figurativos"; e as religiões, subsumidas pelo fundo, uma espécie de cortina cósmica de fundo, de cunho contemplativo. $O$ pensamento técnico é representado por figuras, elementos, partes, esquemas. Já o pensamento religioso é representado pelo fundo, pelo universal, pelo todo. Segundo a concepção de Simondon, podemos inferir que o pensamento técnico é a soma do conceito (teoria, indução) com a eficácia (prática). Se para Hegel a religião e a arte eram etapas para se atingir o pensamento filosófico superior, aquele cujo destino era apenas e tão-somente o Absoluto (JAMESON 2006: 132), para Simondon o caminho era mais sinuoso: o pensamento filosófico seria a resolução temporária de um segundo desdobramento, que teria originado o pensamento científico e o pensamento ético. No presente trabalho nos deteremos apenas ao primeiro desdobramento, aquele que provocou a separação entre técnica e religião, uma polaridade parcialmente mediada por uma estética, ou melhor, por uma tendência estética, mais importante que objetos e gestos concretizados, pois repousa sobre uma presumível necessidade do pensamento mágico.

A análise estética de maior relevo é, em nossa opinião, a que gravita em torno da complexa análise sobre figura e fundo, em razão da proposição que define o traço distintivo entre dois modos de pensamento. Um deles é marcado pela

$108 \mathrm{Em}$ toda a sua obra, Simondon "canibaliza" palavras e expressões extraídas do vocabulário científico, principalmente física e química. A expressão "mudança de fase" (defasear ou defasar), que significa quando uma substância perde ou cede energia térmica para o meio externo, é uma delas. Segundo a exegeta Muriel Combes (2012: 83), o filósofo francês ocasionalmente glosa o termo no sentido de "duplicação" (dédoubler), indicando a sua disposição de não dispensar contrastes ou conflitos e conceber métodos de resolução de contraposições distintos da dialética. 
tecnicidade, enquanto o outro é marcado pela religiosidade; o primeiro é de natureza analítica, a qual exorta o destaque de elementos figurais e esquemas do segundo, de natureza sintética, pano de fundo de uma totalidade não fragmentada. Os esquemas, que podem ser, por exemplo, virtualidades, clamam por uma ação técnica que, por sua vez, devem encontrar um meio propício de atualização. No contexto estético, "o esquema é, propriamente, princípio de organização do sensível" (DUFRENNE 2015: 94), ou figuras percebidas imediadamente sem a intervenção de conceitos. Já o fundo, semelhante ao cenário situado atrás do proscênio, ou melhor, ao fundo infinito dos estúdios fotográficos, é o suporte dos elementos figurais, que surgem por um gesto humano, um fazer poético, conceito que curiosamente remete à ideia de aparência de Heidegger, do desocultamento, da produção poética, do gesto técnico que é desafiado pelo mundo natural. Talvez, para Simondon, a diferença entre o "trazer à tona" da técnica e o "trazer à tona" da arte resida na sutil diferença entre $o$ ato de fazer $\mathrm{e} o$ ato de criar.

Figura 11 - 47 42'03.6" N 7006' 50.1" W (2016), de Bertrand Rougier

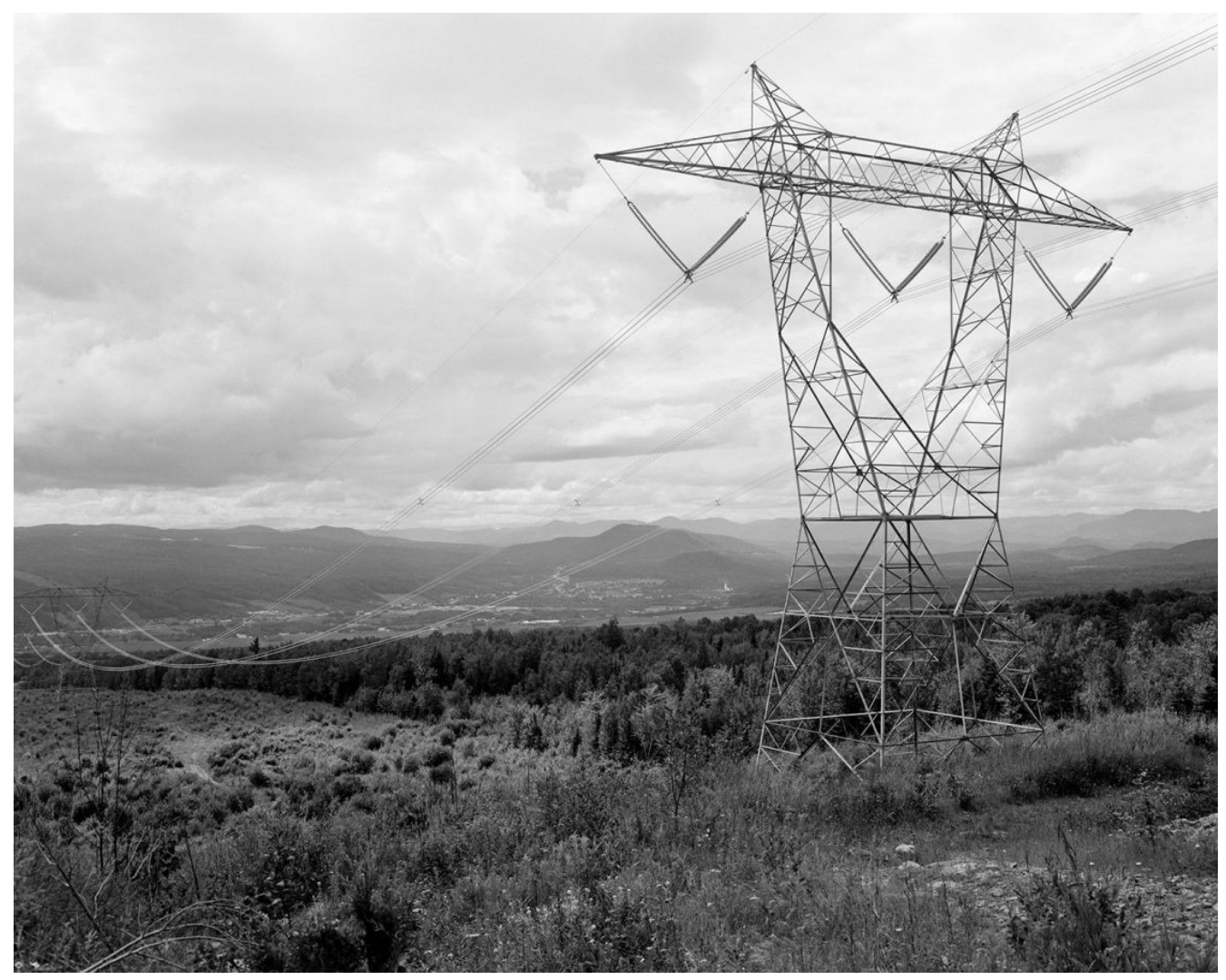

Fonte: http://forty-five.com/papers/132 
É na relação entre figura e fundo, por conseguinte, que a nossa atenção se volta nesse projeto, porque é nela que a ideia dos pontos-chave se exprime com maior eloquência. Estes são como que pontos privilegiados na geografia, um conjunto formado por figuras singulares inseridas no meio das coisas naturais ( $\mathrm{mi}$ lieu, literalmente, "meio lugar"), ${ }^{109}$ conferindo um sentido renovado à topografia dos locais. As torres de linha de energia que atravessam os vales é, parece-nos, o exemplo mais paradigmático de tecno-estética, porque equivale a um dos índices mais ubíquos do trânsito do homem pelas regiões do mundo, autênticas "pegadas técnicas" de sua passagem. Após a cisão da unidade primitiva, identificada pelo entrelaçamento de zonas energéticas e nós de comunicação, "os pontos-chave tornaram-se os objetos técnicos, fragmentos desprendidos do mundo, abstratos e transportáveis e, em toda parte, eficazes" (DUFRENNE 2015: 240). As torres de energia representam a essência da tecnicidade, com o perdão do pleonasmo, em razão de seu funcionamento eficaz (suportam cabos em condições extremas) e flexibilidade de transposição e montagem. E conseguem se impor sem constrangimento, disseminando a sua própria ambientalidade, traço distintivo de um objeto de arte que, ao proclamar a sua presença, solicita a sensibilidade alheia para fazer cumprir sua posição de objeto estético. Mais ainda quando são objetos representados, ou seja, arrogam-se modelos para expressões de artes visuais, como fica patente na fotografia ao estilo fine art de Bertrand Rougier (ver Fig. 11). As torres de transmissão são objetos técnicos edificados em pontos de expressão do mundo, merecendo o estatuto de objetos estéticos, ou melhor, tecno-estéticos.

\subsection{ESTÉTICA ECOTÉCNICA}

Aqui no Brasil, a palavra "ecotécnica" é empregada em manuais de sustentabilidade patrocinados pelo Ministério da Educação, porém a nossa apropriação tem um caráter mais filosófico. Segundo o governo federal, ecotécnicas "correspondem a um conjunto de intervenções tecnológicas no ambiente que se baseia na compreensão dos processos naturais e tem como foco a resolução de problemas com o menor custo energético possível e com uso eficiente de bens Research, 24 jan. 2016. Disponível em <http://forty-five.com/papers/132> Acesso 23 Jan. 2018. 
naturais" (BRASIL 2012: 15). O termo se refere aos métodos e processos das chamadas tecnologias sociais - soluções de baixo custo e impacto ecológico voltadas para comunidades vulneráveis - mas a sua semântica carrega consigo um aspecto sintático, expressado na aglutinação do prefixo "eco" (ecologia, ecossistemas) ao substantivo "técnica", o que reforça o nosso propósito de reagrupar natureza e técnicas por meio de uma estética. Uma estética, portanto, seria conclamada a resolver uma "ruptura metabólica" entre a humanidade o resto da natureza, remetendo os que a ela se dedicassem para a "rede mágica do universo" e neutralizando o fato de que a tecnologia moderna não molda a natureza, mas a transforma e, no extremo, a substitui. ${ }^{110}$

O termo desenvolvido pelo Ministério da Educação é esclarecedor, mas gostaríamos de incrementá-lo com o conceito de ecotécnica desenvolvido pelo historiador estadunidense John Michael Greer, o qual prevê o surgimento de uma nova forma de civilização humana, uma sociedade ecotécnica "que vai respaldar tecnologias relativamente complexas, mantendo ao mesmo tempo relações ricas e sustentáveis com o resto da biosfera" (2009: xiv). Para ele, a crença atual de que a ciência e a tecnologia libertaram a humanidade da dependência da natureza é uma ilusão perigosa, passível de ser desmontada por uma materialidade latente. A sociedade industrial moderna seria, então, a mais primitiva forma de sociedade técnica, dependente em grande escala de energias não renováveis, como o carvão e o petróleo. Greer lamenta o fato de a maioria dos futuristas imaginar o porvir com elementos do presente, sendo mais acertado chamá-los de presentistas. É preciso imaginar um futuro profundo, inspirado no conceito de tempo profundo, o tempo geológico usado como referência para estabelecer acuradamente a idade da Terra. As sociedades ecotécnicas do futuro profundo terão disponíveis recursos de energia renovável e "talvez outros ainda inexistentes". ${ }^{111}$ O programa de Greer engloba orientações para a transição e propostas de recursos para uma verdadeira praxis futurista (alimentação, energia, trabalho etc.), mas a partir daqui o insinuaremos sem o professar.

110 Ver SCOTT, Peter Manley. Technology in a Postnatural Condition? Concepts of Nature and Meanings of Technology. In: CANDLIN \& GUINS 2009.

111 Ver GREER, John Michael. 2016: Toward the Deep Future. The Dark Mountain Project, 19 jan. 2017. Disponível em: <http://dark-mountain.net/blog/2016-toward-the-deep-future/>. Acesso em: 31 jan. 2017. 
Se as definições anteriores não configuram o quadro ideal, nem a institucional e nem a futurista, de quais ecotécnicas estamos tratando? Ora, não negligenciaremos por completo ambas, porque queremos abordar as tecnologias sociais e, por extensão, os modos alternativos de produção de energia, por exemplo. Assim como formas de preparação e enfrentamento de efeitos das mudanças climáticas nas infraestruturas, táticas do movimento de transição e tecnologias livres para um futuro não muito distante. Todavia, parece-nos que existe um ponto fulcral que, sem desatender as duas definições anteriores, as excede ao destilar seus princípios, que é precisamente a relação conflituosa entre técnicas e natureza. As ecotécnicas que divisamos, é certo, têm de impor uma relação renovada, a começar pela produção material, regida por uma "praxis técnica que, longe de fazer, em sua essência, violência à natureza, trava amizade com ela, conhece-a e a aperfeiçoa; e como ela não desnatura a Natureza, também não aliena necessariamente o homem" (DUFRENNE 2015: 30). Outrossim, a estética sobre a qual dissertamos procura um sentido técnico e ecológico em objetos estéticos, mas não apenas no art world, na expressão do sociólogo Howard S. Becker, porque um objeto técnico, quando se ordena à natureza, é suscetível de estetização, tornando-se um objeto apreciável através de uma estética ecotécnica: "uma estrada, indiferente quando a seguimos, pode ser bela vista de longe se esposa felizmente as inflexões do terreno e comensura a espacialidade do espaço natural; um quebra-mar, se prolonga espontaneamente a costa; uma aldeia, se se adapta ao solo; um jardim, se corresponde tanto ao céu, quanto à terra" (DUFRENNE 2015: 70-1). Há de haver uma conaturalidade da necessidade programada ao objeto tecno-ambiental com a necessidade natural, tendo a segunda o potencial de ser inclusive a necessidade da primeira, "pois a necessidade social da ecologia é também, sob certos aspectos, uma necessidade natural" (op.cit.: 72). Se o objeto tecno-ambiental - o mesmo podendo suceder aos objetos estéticos - se destaca eventualmente do mundo, pode encarnar o filho pródigo que retorna ao lar natural sem fazer-lhe violência. É a partir daí que todas as definições adquirem sentido. 


\subsubsection{Sistemas genéticos}

Parece-nos adequado, então, começarmos, daqui para a frente, a descrever com mais detalhes o que entendemos por estética ecotécnica, tomando como fonte inspiradora o sistema genético de Simondon, no qual uma estética intermedeia as particularidades dos esquemas técnicos e as qualidades universais das religiões, reestruturando a economia entre o homem e o mundo ao recriar uma nova relação entre artefatos e a teologia. Reconhecemos, desde então, as motivações ideológicas tanto dos arautos do progresso tecnológico inovador, avessos ao que chamam de "tribalismo tecnológico", como dos seguidores de uma visão de mundo ecoteológica. Sugerimos que tais encantos sejam quebrados com um tipo de dissenso estético, no sentido que Jacques Rancière dá ao termo: uma reconfiguração da experiência sensória coletiva. ${ }^{112}$ Uma das estratégias talvez seja enfatizar, em um primeiro momento, a incompatibilidade teórica entre técnica e natureza, contrastando os dois polos com o objetivo de fortalecê-los sincronicamente, como na colagem ${ }^{113}$ de Valerio Recchioni em que o observador da pintura romântica Caminhante sobre o mar de névoa (1818), do artista alemão Caspar David Friedrich, se depara não com uma paisagem majestosa e sublime, como no original, mas com o que parece ser um projeto arquitetônico pós-moderno de Rem Koolhaas. O trabalho sugere, entre outras coisas, que a palavra-chave na teoria estética não é o belo (ou o sublime etc.), como tem sido sugerido pela tradição, mas o sentido, ou seja, uma das qualidades da experiência perceptiva. ${ }^{114}$ Mas, por enquanto, nos restringimos a descrever o esquema inspirado no sistema genético simondoniano.

Em nossa versão, o sistema genético da relação entre tecnologia e ecologia remete eventualmente à unidade mágica primitiva, pois é em direção a ela que os

112 Ver The Paradoxes of Political Art. In: RANCIÈRE 2015, p. 134-151.

113 A série Genius Disloci, de Valerio Recchioni, estuda a relação entre arquitetura e meio ambiente através da técnica da colagem. Ver a peça citada em <http://loves.domusweb.it/geniusdisloci/nggallery/image/lovesdomus-genius-disloci-09/>. Acesso em: 18 jan. 2017.

114 A experiência estética não implica somente na percepção do belo, como em Hegel (1993), mas também na apreensão de um sentido (insight). "De acordo com a Gestaltpsychologie, as regras de proximidade e de similaridade dos elementos em uma configuração determinada (em uma organização modelada) imprimem ao agrupamento um maior grau de pregnância, isto é, tornam-no mais significativo" (CARROZZINI, Giovanni. How to Invent a Form: An Inquiry into Gilbert Simondon's Philosophy of Perception. In: SART 2015, pp. 33-48; tradução nossa). Mas o que é o sentido? A mais razoável definição origina-se de Lévi-Stauss, apud Mikel Dufrenne: "É um sabor específico percebido pela consciência quando degusta uma combinação de elementos dos quais nenhum, tomado em particular, ofereceria um sabor" (2015: 167). 
sucessivos desdobramentos se orientam. Imaginemos que a concepção simondoniana de primitivismo não tem nada a ver com o retorno à natureza de Rousseau ou com a aversão às técnicas contemporâneas dos anarcoprimitivistas; a unidade mágica seria uma malha de vértices técnicos conectados por arestas naturais, uma retícula na qual a tecnologia primitiva de Prim ${ }^{115}$ convive perfeitamente com ferramentas e máquinas modernas; e a primeira natureza não entra em choque com a segunda. Ela anula, portanto, o jogo de soma zero entre técnica e natureza. Como reflete Adorno, "o carácter errôneo da antítese vulgar de técnica e natureza reside manifestamente no fato de [um]a natureza não-contaminada pela intervenção humana e sem nenhuma marca do seu domínio" (ADORNO 2008: 84). Se a tecnologia é a mediação entre homem e o espaço do mundo, então a ecologia seria a mediação entre o homem e o tempo, pois ela nos torna conscientes de uma temporalidade não imediata (deep time). O diferencial de nosso esquema é que priorizamos o espaço (ao invés do tempo) e implantamos um conteúdo ecológico ao aspecto tecnológico, não sendo dificultoso realizar, por extensão, um vínculo entre o pensamento religioso e o pensamento ecológico, basta um olhar mais atento para notar a associação entre antigas religiões e as divindades sagradas da natureza. Não há uma permuta, salientamos isso na Introdução, da fase da religião por uma "fase ecológica"; o que há é a intensificação da realidade ecológica no centro da fase técnica. Na progressão do modelo, a ponte entre os pensamentos tecnológico e ecológico continuaria sendo efetivada pelo arco de um pensamento estético, por analogia ao sistema original. Por fim, a estética ecotécnica seria o resultado da combinação entre duas outras estéticas que a precedem: a estética ambiental (CARLSON 2002; BERLEANT 1995) e a tecno-estética de Simondon (1992).

Essas relações complexas instituem um pálido recorte das concebidas por Simondon em seu sistema genético, concebido para ser uma espécie de Teoria de Tudo da interação entre humanos e mundo, uma teoria da vida, enfim. Em nosso sistema genético o que se pretende é demonstrar o que é concretizado na relação entre esquemas técnicos e elementos naturais, tendo como agente de intermediação a estética, antigo ramo da filosofia. Nota-se a anteposição de um pensamento em

115 Prim é um anônimo de Far North Queensland, Austrália, autor de Primitive Technology, um canal no YouTube com vídeos sobre projetos criados a partir do zero, sem ferramentas e materiais modernos. Disponível em: <https://www.youtube.com/channel/UCAL3JXZSzSm8AIZyD3nQdBA>. Acesso em: 28 abr. 2017. 
cada um dos três elementos, sugerindo mais um terreno epistemológico que ontológico. Além disso, acrescentamos a disposição de problematizar uma antiga questão filosófica, que provém desde Aristóteles, a da distinção radical entre a produção humana, a atividade manual, e a produção da natureza, a vida ordenada nela mesma - a separação entre entidades da techné, "poiéticas", e entidades da physis, autopoiéticas. Também se faz necessário ressaltar mais uma vez que a presença de uma realidade ecológica na fase técnica não caracterizaria uma usurpação indevida do sistema simondoniano, mas apenas a sua conformação a um programa manifestadamente estético. Pretendemos, através de nossa proposta, apontar, por exemplo, o tênue intervalo entre o processo de formação de cristais (physis) e os procedimentos internos de um computador eletroquímico (techné). Ou, em outras palavras, propor uma analogia entre a matéria viva (physis) e a matéria inorgânica organizada (techné), tendo em conta que ambas se transformam em suas interações com o meio (STIEGLER 1998: 49). E, por fim, o nosso sistema indaga se haveria uma espécie de poiesis no próprio processo de aesthesis, assim como há na physis e na techné.

\subsubsection{Especificações}

No processo evolutivo de nosso modelo, além de agregá-lo a elementos identificados em produtos resultantes do gesto técnico, orientada por uma estética tecnológica simondoniana, é preciso do mesmo modo fazê-lo absorver componentes representativos de um tipo de estética da natureza (em nosso caso, uma estética inspirada na filosofia de Carlson). Assim, na busca pela definição de uma estética ecotécnica, teríamos como ponto de partida o binômio composto pela soma de uma estética ambiental e uma tecno-estética, como vimos na estrutura de nosso diagrama derivado - em parte - do sistema genético da relação humano-mundo, fundado por Simondon. O esquema de nossa estrutura, disposto em detalhes na introdução ao capítulo (ver Fig. 2), sugere de forma evidente que a estética ecotécnica é o resultado de duas importantes correntes tributárias da filosofia estética: a tecno-estética e a estética ambiental. Assim, é possível concluir que a confluência decorrente, concretizada em nossa proposta contém, em maior ou 
menor medida, elementos constituintes de ambas as doutrinas estéticas (ver Quadro 1). É também admissível conjecturar, como se verá doravante, que a "acareação" de tais elementos delineia, como resultante, uma espécie de síntese. Iniciamos o itinerário conceitual com um breve relato sobre as origens históricas e culturais de ambas as estéticas e uma discussão sobre a provável beleza de objetos intermediários, situados entre os objetos de arte e os nomeados técnicos e naturais; em seguida retomamos a discussão sobre funcionamento e função, considerando que a "descoberta da beleza dos objetos técnicos não pode ser deixada unicamente à percepção" (SIMONDON 1969: 186 apud DUFRENNE 2015: 251), mas que, "inversamente, só o conhecimento da função e do funcionamento não basta para despertar o sentimento de beleza" (loc.cit.). Concluímos as especificações das duas estéticas com um breve arrazoado sobre o sentido da estrutura figura-fundo, atentando obviamente aos perigos do subjetivismo e psicologismo e tendo como orientação, via Simondon, a ideia da congruência entre locais geográficos singulares e os objetos integrados a eles.

Quadro 1 - Especificações da tecno-estética e da estética ambiental

\begin{tabular}{|c|c|}
\hline TECNO-ESTÉTICA & ESTÉTICA AMBIENTAL \\
\hline estética industrial, maquínica & estética da natureza, romantismo \\
\hline objeto técnico intermediário & objeto natural intermediário \\
\hline funcionamento & função \\
\hline figura (forma), elementos & fundo, totalidade \\
\hline
\end{tabular}

Fonte: autoria própria

\subsubsection{Origens}

É corrente admitir que a tradição da apreciação estética da natureza provém de longa data, iniciando-se, por exemplo, na fase mágica, porém é mais razoável precisar seu advento oficial com a figura de Petrarca (século 14) (CARLSON 2012: 3) e sua paixão por escalar montanhas, em especial o Monte Ventoux. Desde então a prática passou a ser vista com desconfiança pelas religiões, atemorizadas por suas implicações físicas, vindo a ser ignorada no todo por estetas, agora com seus 
pensamentos exclusivamente voltados para as obras de arte. Em nome da brevidade - e para transpor a parte na qual até o Absoluto e o devir tornaram-se objetos da filosofia estética (op.cit.: 4) - sintetizamos que a história da estética da natureza é retomada, na contemporaneidade, pela chamada estética ambiental. Já o termo estética industrial filia-se à estética técnica que, lateralmente, filia-se ao construtivismo russo, vocábulos e representações ameaçadas de ser ideologicamente facciosas. Somos tentados a compartilhar o termo à luz de Dufrenne (2015: 238-56), para quem a estética industrial é um modo fundamental de praxis, vinculado às atividades de produção de objetos de uso por objetos técnicos, objetos estes que eventualmente aspiram auferir o estatuto de objetos estéticos (o exemplo da arquitetura é definitivo). Por adição, dispomos ao lado da estética industrial - na interpretação de Dufrenne e também a título de experimento - a estética da máquina, corrente inserida no notório fluxograma ${ }^{116}$ elaborado em 1936 por Alfred H. Barr, primeiro diretor do Museu de Arte Moderna (MoMA), por ocasião de Cubismo e Arte Abstrata, exposição que procurou remontar as origens do modernismo europeu e suas vanguardas. A estética da máquina de Barr tem mais a ver, ao menos em tese, com a estética tecnológica sobre a qual discursa Simondon do que com o verbete "estética industrial"117 publicado em 1979 na Grande Enciclopédia Soviética, sobretudo se acompanharmos a seta vermelha indo da estética da máquina ao "futurismo de Marinetti, [que] deu lugar ao carro de corrida" (SIMONDON 1992), a expressão material da velocidade por meio de linhas aerodinâmicas.

Dissertamos, na seção Pensamento tecnológico, sobre o porquê de artefatos técnicos não lograrem acesso à esfera cultural, ou o que estaria por detrás da resistência de se combinar a cultura técnica com a cultura simbólica. Especula-se que tal interdição tenha sua origem no momento em que a linguagem da beleza, tomando consciência de si mesma, deixa de ser a língua franca da técnica e da arte,

116 Os organizadores da exposição Inventing Abstraction, 1910-1925, patrocinada pelo MoMA em 2012, reinventaram o fluxograma de Barr, por demais linear e categorizado, e o transformaram em um mapa de rede, vinculando os nós não a movimentos, mas a indivíduos. Ver o gráfico em $<$ https://www.moma.org/interactives/exhibitions/2012/inventingabstraction/?page=connections $>$. Acesso em: 3 fev. 2018.

117 O termo significa, sobretudo, a estetização do espaço de trabalho (cores, ergometria etc.). Cf. The Great Soviet Encyclopedia, $3^{\mathrm{a}}$ edição, s.v. Verbete em inglês disponível em $<$ https://encyclopedia2.thefreedictionary.com/Industrial+Aesthetics>. Acesso em: 3 fev. 2018. A investigação de Denis Huisman e Georges Patrix, citados de passagem por Dufrenne (2015: 252), segue em conformidade com a dos soviéticos. Ver HUISMAN \& PATRIX 1967. 
transfigurando-se em linguagem própria e tornando vulnerável as duas esferas a ocupações de tecnicistas e formalistas. É chegado o momento de retorná-los ao mundo da cultura, seja por meio de uma educação técnica, ou mesmo por "uma ciência das correlações e transformações, que seria uma tecnologia geral, ou uma mecanologia" (SIMONDON 1969: 48; grifo nosso). É certo que há contrariedades como a especialização, a complexificação e a abstração - inerentes ao meio técnico contemporâneo. O sentido dos objetos técnicos não é imanente à suas formas (DUFRENNE 2015: 244): um motor de automóvel não fala a um não-mecânico; trata-se de "um sistema de signos cuja significação é necessário conhecer de antemão" (loc.cit.). Por analogia, a educação técnica para o público em geral, se e quando for aditada a uma base curricular, seria o equivalente ao que representa a educação estética na formação de pesquisadores da história da arte. Há uma simetria singular entre a apreciação estética de um objeto técnico (estética industrial) e a apreciação estética de um objeto natural (estética da natureza), porque ambos os objetos não são objetos estéticos por definição. Mas ambos podem tornar-se belos espontaneamente, sob determinadas condições. $\mathrm{O}$ objeto natural mais ainda se a sua captação perceptual for reforçada por conhecimentos das ciências naturais, como argumenta Carlson. Segundo o filósofo, categorias como biologia e geologia (entre outras disciplinas) equivalem a autênticas categorias artísticas e estilos. Nesse sentido, saber a diferença entre uma pedra de quartzo de outra de feldspato seria o mesmo que saber a diferença entre uma obra cubista da fase analítica e outra da fase sintética. A natureza da apreciação potencializa-se de acordo.

Um dos truísmos da primeira fase da arte Romântica, origem secundária da estética ambiental, é de que a arte deveria representar um meio natural imaculado, ou melhor, de que a apreciação da arte deveria ter o mesmo peso que a apreciação da natureza. Entretanto, a partir de um dado momento do movimento, a arte deixou de apenas representar a natureza em si - o belo e o sublime - e passou a representar uma natureza humanizada, pitoresca. Ou seja, uma natureza não mais independente, mas correlacionada com a cultura humana, mais precisamente, com os objetos técnicos elaborados por diversas culturas, com suas respectivas realidades técnico-sócio-culturais. Carlson descreve bem o ponto de inflexão: "Assim, enquanto o desinteresse e o sublime despojaram e objetificaram a natureza, 
o pitoresco vestiu-a em um novo conjunto de imagens subjetivas e românticas: um precipício acidentado com um castelo em ruínas, um vale profundo com uma ponte arqueada, a casa de um pequeno agricultor sobre um estéril afloramento rochoso" (CARLSON 2002: 4). Logo, inferimos que é no pitoresco, com suas formas rústicas sobre paisagens acidentadas, que se localiza a origem de uma trégua na competição entre cultura e natureza no campo representacional. Nesse sentido, é possível vincular uma das várias definições e usos do termo "pitoresco" com o espaço reticulado formado por objetos técnicos e elementos naturais: "As técnicas, após ter mobilizado e separado do mundo as figuras esquemáticas do mundo mágico, voltam-se ao mundo para com ele se aliar pela coincidência do cimento e da rocha, do cabo e do vale, do pilar e da colina; uma nova rede se institui dando um privilégio a certos lugares do mundo, numa aliança sinérgica dos esquemas técnicos e dos poderes naturais" (SIMONDON 1969: 181). ${ }^{118}$ A despeito da polissemia do termo "pitoresco" e de suas múltiplas aplicações e interpretações, parece-nos que ele disseminou o germe do que depois veio a se chamar de estética ambiental.

\subsubsection{Objetos}

É necessário apontar a diferença, no processo de identificação do belo em objetos técnicos e naturais, ou seja, objetos sem o propósito estético. Tal diligência se dá em razão de nos encontrarmos em um domínio retirado do mundo exclusivo da arte, ao menos em primeira instância. "O objeto estético é a obra de arte que pretende exclusivamente a beleza e que provoca a percepção estética onde essa beleza será realizada e consagrada", medita Dufrenne (2015: 242-43). Já o objeto belo não pleiteia o ato de estetização da obra de arte, não foi produzido para esse fim e, quando eventualmente inclina-se para esse efeito, não perde suas outras virtudes, tais como "encanto, funcionalidade [e] inteligibilidade" (loc.cit.). Donde se conclui que tanto objetos técnicos, como objetos naturais, são perfeitamente passíveis de constituir o que o bom senso (ou o bom sentido?) entende por belo.

118 No original: Les techniques, après avoir mobilisé et détaché du monde les figures schématiques du monde magique, retournent vers le monde pour s'allier à lui par la coïncidence du ciment et du roc, du câble et de la vallée, du pylône et de la colline; une nouvelle réticulation, choisie par la technique, s'institute en donnant un privilège à certains lieux du monde, dans une alliance synergique des schèmes techniques et des pouvoirs naturels. (tradução de Roberto Figurelli). 
Como argumentamos na seção Tecno-estética, a beleza de um objeto técnico não é oferecida tão-somente por sua forma ou função, mas por seu funcionamento, cujo rendimento e robustez depende da interação ótima dos dois esquemas antecedentes. Todavia a questão do belo se intrinca no mundo da natureza, em especial no confrontamento entre o objeto artificial e o objeto natural. Recorremos, com alguma esperança, ao espírito da autenticidade, pois "uma obra de arte autêntica conserva sempre uma aparência de natureza" (op.cit.: 69) e uma "tecnicidade autêntica" (op.cit.: 242) recusa sempre a relação inumana entre homens e máquinas e, por conseguinte, entre homens e natureza. Ademais, a autenticidade é sempre esposada com a espontaneidade: objetos técnicos, assim como os objetos naturais, não se pretendem objetos estéticos, mas podem tornar-se belos, não por acaso, mas por necessidade.

Vê-se a importância de se traçar, nesse momento, contornos demarcados entre os objetos em questão: técnicos, naturais e de arte. Contudo, lançar um certo tipo de casticismo sobre eles seria contraproducente, sobretudo se quisermos refletir, no âmbito de uma estética ambiental, sobre o que Carlson a Dufrenne chamam de objetos intermediários, situados na "Terra do Nunca entre a natureza e a arte", e qual seria, por conseguinte, a estética apropriada para se apreciar, por exemplo, "estradas, campos de milho, jardins ... igrejas e prédios de escritórios" (CARLSON 2000: 133). Se fosse suscetível a um tipo de formalismo, a estética da natureza tradicional teria contratempos em apreciar objetos que são "intermediários entre a arte e a natureza, como uma paisagem urbana ou um parque em torno do castelo" (DUFRENNE 2015: 64), ou assuntos que não fossem chancelados por uma estética positiva. No que concerne aos objetos técnicos, existem do mesmo modo os objetos de transição, a contar com os que pareiam com os objetos naturais, porque "incorporam uma parte do mundo natural que intervém como condição de [seu] funcionamento" (SIMONDON 1969: 47). Ao descrever o processo de invenção, por meio do qual elementos são agrupados em indivíduos técnicos, Simondon entrevê a capacidade imaginativa do inventor de "perceber nos objetos certas qualidades que não são práticas, que não são diretamente sensoriais nem completamente geométricas, que não estão relacionadas à matéria pura ou à forma pura, mas que estão nesse nível intermediário dos esquemas" (op.cit.: 73-4). ${ }^{119}$ Por fim, o objeto de 119 O excerto no original: L'imagination n'est pas seulement faculté d'inventer ou de susciter des 
arte, declaradamente estético, objeto representado que aspira, sem caução, ao estatuto de belo. Sua índole é tanto mais voltada ao sentido, quanto os objetos intermediários, técnico e natural, são orientados ao funcionamento e à função, respectivamente. Pode-se conjecturar, então, que a função e o funcionamento são, de certa forma, sentidos ("o sentido de um templo é, primariamente, ser um templo") (DUFRENNE op.cit:: 160). Nota-se, por fim, a constituição de uma "zona de inclusão", uma triangulação formada pelos três objetos e seus intermediários, por onde circula livremente um quarto elemento, sobre o qual retornaremos.

\subsubsection{Funcionamento e função}

Um dos problemas abordados por Carlson em seu estudo sobre estética ambiental diz respeito ao tema da relevância estética, ou se a inclusão de referências relativas a um objeto sensível particular é adequado ou não na prática perceptiva do espectador. Ao mediar posições formalistas e pós-modernistas (dito de outra forma: essencialistas e excessivamente liberais), ele as resolve colocando a ênfase não no sujeito, mas no objeto. É uma solução orientada ao objeto que coloca em segundo plano os "transportes" subjetivos do sujeito que poderiam conduzi-lo a uma atitude desinteressada. Pode-se afirmar, diz ele, que um objeto "faz exigências" (CARLSON 2002: 133): no caso de um objeto do mundo da arte, a vindicação de informações históricas, culturais e artísticas a seu respeito; no caso de um objeto do mundo da natureza, informações filiadas à sua história natural, à sua evolução, à sua inserção na cadeia ecológica. Mas e um objeto situado entre os dois mundos, localizado em um espaço indefinido entre natureza pristina e arte pura, centro de interesse da estética ambiental? Como, por exemplo, entidades extraídas da arquitetura de paisagem e do design industrial? Carlson identifica a solução no conhecimento da função do objeto intermediário, já que objetos naturais e artísticos, os últimos ao menos em sua maioria, são isentos de alguma intenção funcional (op.cit.: 134). ${ }^{120}$ Dispor como relevante o fator funcional para a apropriada

représentations en dehors de la sensation; elle est aussi capacité de percevoir dans les objets certaines qualités qui ne sont pas pratiques, qui ne sont ni directement sensorielles ni entièrement géométriques, qui ne se rapportent ni à la pure matière ni a la pure forme, mais qui sont à ce niveau intremédiaire des schèmes. (tradução nossa).

120 Para os antigos chineses, uma paisagem seria investida de intenção, no sentido de propensão, de como ela permitiria o surgimento de coisas que a integram - mas sem caracterizá-la como 
apreciação estética de objetos estéticos intermediários - nomeados de naturaisambientais por Carlson - põe em evidência a impropriedade de se destinar a sensibilidade perceptual instadas por obras de arte à experiência sensorial de objetos belos, porém não explicitamente estéticos. Ademais, a despeito da renúncia da centralidade do sujeito, a estratégia de Carlson não exclui o intelecto no processo da experiência estética ambiental, incrementando o valor da percepção preliminar solicitada pelas aparências: percepção $\rightarrow$ intelecção $\rightarrow$ percepção++. ${ }^{121}$

Como se estivesse em sintonia com Simondon, Carlson imprime qualidades estéticas a objetos situados entre a natureza e o mundo da arte, valendo-se do argumento contido no famoso slogan modernista "forma segue a função" (2002: 135), atribuído ao arquiteto estadunidense Louis Sullivan, conceito concebido por ele para atacar o excesso de decoração em projetos arquitetônicos de seu tempo. Segundo Carlson, as informações agregadas pelo sujeito à objetos intermediários não suscitam peguntas do tipo "o que é isso e como chegou a se tornar o que é?", emblemáticas de objetos naturais e artísticos, mas do tipo "o que isso faz e por que faz isso?". Se incluído na discussão, Simondon iria mais além, e colocaria a ênfase não tanto na forma ou na função do objeto, mas em seu funcionamento, ${ }^{122}$ suscitando perguntas do tipo "como tal objeto faz isso?". Ou seja, a forma não deveria somente seguir a função de um produto, mas sobretudo estar integrado a ela, em nome de um funcionamento mais robusto. Hoje, no meio técnico, forma e função estão divorciadas novamente, não em razão do combate ao ornamento, como nos tempos de Sullivan, mas para se ocultar o hermetismo do funcionamento de objetos técnicos. ${ }^{123} \mathrm{~A}$ indústria atual tende a produzir cada vez mais objetos inacessíveis, não consertáveis e inadaptáveis, obstruindo a compilação de

funcional. Ver BERQUE, Augustin. Paysage, Milieu, Histoire. In: BERQUE, 1994, pp. 13-29.

$121 \mathrm{Na}$ introdução à edição brasileira de Estética e Filosofia, Roberto Figurelli entabula um primoroso comentário sobre a relação entre percepção bem sucedida e intelecção: "No terceiro momento noético [sentimento], o Autor [Dufrenne] procura caracterizar a função do intelecto na percepção estética, função importante mas que não deve ser exagerada sob pena de transformar a experiência estética em mero exercício racional. O mesmo ocorre com o sentimento: sua posição, no ápice da percepção, não deve levar ao erro de tudo sacrificar em favor do sentimento. Na atitude estética há uma espécie de oscilação entre atitude crítica e atitude sentimental." Cf. DUFRENNE 2015, p. 12.

122 Para Simondon, a função (ou funções) está subordinada a um funcionamento integral de um objeto "maduro". L'essence de la concretisation de l'objet technique est l'organisation des sousensembles fonctionels dans le fonctionnement total. [A essência da concretização do objeto técnico é a organização dos subconjuntos funcionais no funcionamento total.] (SIMONDON 1969, p. 34; tradução nossa).

123 Ver MICHAUD in: BOEVER ET AL. 2013, p. 130. 
informações ao seu respeito e, consequentemente, de acordo com a visão cognitiva de Carlson, o seu fruir estético. Ao menosprezar a função e o funcionamento em razão de um novo formalismo, a indústria propicia a naturalização da polissêmica (e problemática) palavra "funcionalidade", ou seja, a maneira de assegurar que um produto funcione tal como foi especificado pelo fabricante, suscitando perguntas do tipo "o que isso pode fazer?", mas sem oferecer respostas claras aos que o utilizam. Essa estética da tecnologia substitui a autenticidade da função, translúcida por exemplo nos objetos de uso, por uma funcionalidade simulada, contrária aos projetos de mecanologia.

\subsubsection{Estrutura figura-fundo}

Em certo momento do filme Afterimage (2016), último trabalho dirigido por Andrzej Wajda em vida, o pintor vanguardista polonês Wladyslaw Strzeminski (18931952) analisa com toda a pompa e circunstância acadêmica, numa sala de aula na Escola de Belas Artes de Lodz, o quadro Champ de blé vert avec cyprès (1889), de Vincent van Gogh. Diz ele: "A natureza tem seus próprios centros de interesse, os quais atraem a nossa atenção". Nos slides de apresentação aos alunos, o professor mostra uma versão esquemática do notório quadro do pintor holandês, dividida em quatro partes e explica as razões pelas quais ele o segmentou com finalidade instrutiva: "Não que o 'formalista' Van Gogh assim o desejava por obscuros motivos subjetivos, mas porque ele procurava reproduzir de maneira precisa o processo de mirar a paisagem". Um processo influenciado, deduzimos, pelos focos de atenção conclamados pela própria natureza. Percebe-se aqui uma semelhança (ou analogia) entre os centros de interesse detectados por Strzeminski no quadro de Van Gogh e a noção de ponto-chave (point-clef) de Simondon, lugar privilegiado na trama matricial do mundo, que assim o é por "resumir e conter a força de uma massa compacta de realidade" (SIMONDON 1969: 165). O topo de uma montanha é o exemplo por excelência (e não só metaforicamente, segundo a nota de rodapé). Mas também a parte mais impenetrável de uma floresta. Aparentemente, os pontos-chave são localidades inacessíveis e, por uma razão paradoxal, são pontos em que o "ser humano encontra-se irremediavelmente vinculado ao mundo" (loc.cit.). Eles são 
como que lugares sagrados, ideais para a edificação de templos (temenos) e, como é de bom tom, templos não devem ser erguidos em qualquer lugar.

Os pontos-chave, portanto, não se reduzem à figura, nem ao fundo, mas constituem uma totalidade. O que é esperado é a colocação em primeiro plano, ao menos por algum momento, do plano de fundo, "a pátria comum das imagens e dos conceitos" (DUFRENNE 2015: 168), fonte geradora dos seres e do mundo, a ponto de ser associado por Simondon à noção de apeiron, parte integrante da cosmogonia de Anaximandro, que a considerava como o llimitado, diferenciando-o do espaço infinito euclidiano (SELIGMAN 1962: 34). De fato, o filósofo pré-socrático sustentava ter tudo se principado dessa "matéria" indefinida, e não de elementos particulares, como o fogo e água, essa última na concepção de Tales de Mileto. A pensadora francesa Muriel Combes nos lembra em boa hora que Simondon ligava também o termo tanto ao pré-individual, a primeira fase de toda e qualquer individuação, como à natureza, physis, mas uma natureza como reserva de potências (COMBES 2013: 46). Nas pinturas renascentistas, fato conhecido, o fundo era empregado como apoio da projeção perspectiva e, na sétima arte, como cenografia inerte, com algumas exceções que o destacam. A título de exemplo, encontramos no filme Banshun (Pai e Filha, na tradução brasileira), de 1949, diversas imagens do fundo primordial (florestas, oceano etc.) inseridas cá e lá na sequência fílmica, aparentemente sem nenhum propósito. Mestre do shomingeki - gênero de filmes que retrata a vida das classes trabalhadoras japonesas - o diretor Yasujiro Ozu como que nos faz lembrar que, na retaguarda dos esquemas figurais cotidianos, existe um fundo inesgotável de realidade, uma potência perene que vivifica e impulsiona o destino da humanidade. Por fim, Dufrenne defende a tese de ser o fundo detentor de sentido, assim como as formas, pois o "sentido que elas carregam em si remete a um horizonte de sentido o qual atesta, ele mesmo, que o sentido visa uma realidade inexaurível" (DUFRENNE 2015: 168). Essa ambivalência do fundo, a de ser imaterial ("céu profundo") ${ }^{124}$ e material ("magma primordial") ao mesmo tempo, é o que atesta a sua significância, não apenas para a estética ambiental, mas similarmente para a tecno-estética.

124 Ver MARTY, Emília Marty. Simondon, um Espaço Por Vir. Revue Multitudes, n 18, outubro, 2014; (tradução de Carla Ferro). Disponível em <https://pontodevistabrblog.wordpress.com/2016/11/09/simondon-um-espaco-por-vir>. Acesso 19 fev. 2018. 


\subsubsection{O objeto tecno-ambiental}

O gênero "tecno-ecológico", criado pelos artistas e pesquisadores Rasa Smite e Raitis Smits, refere-se ao conjunto de práticas na arte contemporânea que tendem a "abordar e trabalhar questões de sustentabilidade a partir de perspectivas variadas - sociais, culturais, ecológicas e tecnológicas". ${ }^{125}$ Ao contrário do que se sugere, a dupla de letões não tem como bandeira principal a causa ecológica, mas a condição "pós-midiática" das expressões artísticas em uma época em que as redes de telecomunicações, em especial os computadores que a compõem, subsumiram todas as mídias precedentes. Nessa perspectiva, as práticas emergentes atentam às questões e dinâmicas ecológicas, sem se desenraizarem das novas mídias. Reconhecemos de bom grado os projetos desenvolvidos em torno da Renewable Network (Rede Renovável, a gravitar em torno do conceito de "futuros renováveis", outro termo de autoria da mencionada dupla) - como as células solares feitas a partir de suco de arônia, do artista Bartaku, e mesmo a bateria de bactérias em água residual, de Smite \& Smits - no entanto torna-se frustante observar a sua recente mudança de rota, agora mais direcionada aos aspectos tecnocientíficos que ecológicos das expressões. É por esse motivo que optamos pelo termo "tecnoambiental" para designar os objetos que se apresentam aos sentidos como formas de uma experiência estética ecotécnica. É-nos francamente mais propício, sobretudo por evocar indiretamente o objeto intermediário da estética ambiental de Carlson, nomeado por ele de natural-ambiental.

125 Ver SMITE Rasa; SMITS Raitis. Emerging Techno-Ecological Art Practices: Towards Renewable Futures. In: APPRICH 2013, pp. 142-159. 
Figura 12 - "Zona de inclusão" por onde circula e converge o objeto tecno-ambiental

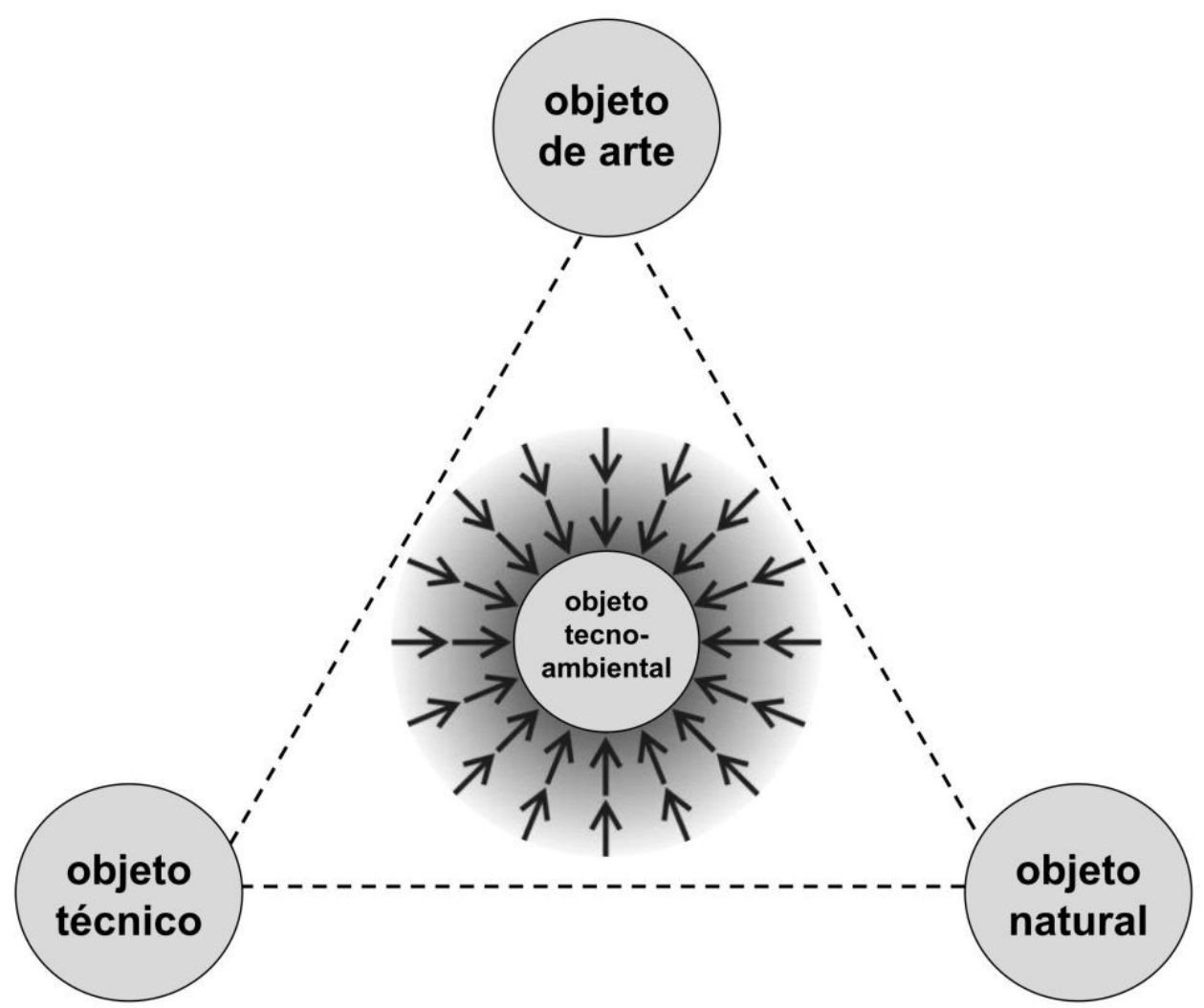

Fonte: autoria própria

Consideremos, portanto, o objeto tecno-ambiental. Uma análise apressada assentaria que tal objeto é um híbrido, uma quimera incongruente - ou se situaria, geometricamente, no ponto cêntrico do triângulo da figura 12, não sendo-lhe facultado propender-se para nenhum dos três vértices. Porém, veremos ao longo do trabalho que não se trata de um ponto médio; logo, valemo-nos da geometria analítica, da demarcação de pontos e suas respectivas coordenadas, porque o ponto no qual se situa o objeto tecno-ambiental é um ponto que "circula" pela área interior. Existem expressões que definem a área de uma região triangular valendo-se apenas das coordenadas dos vértices de um triângulo plano, mas o ponto em questão é um "alvo móvel" encontrado na matriz das coordenadas internas da figura. Tanto os vértices, como os objetos intermediários - rememoremos: o natural-ambiental de Carlson, entre o de arte e o natural; o tecno-ecológico de Smite \& Smits, entre o 
técnico e o natural; e algumas manifestações da artemídia, ${ }^{126}$ entre o objeto de arte e o técnico - configuram-se tão-somente pontos de referência, ou "atratores". (Há ainda, no caso do objeto técnico, o objeto de uso, como as habitações, as quais enquadram-se, sob determinadas circunstâncias, na categoria dos objetos intermediários situados entre o objeto de arte e o objeto técnico). Vê-se que o ponto do objeto tecno-ambiental, devido a sua alternância, expor-se-ia ao cálculo integral de uma função, contudo esta não é a ocasião para tais detalhismos. O que se releva, como particularidade, é que a função do objeto intermediário naturalambiental tem mais a ver com o sentido perceptivo do que para a sua finalidade (social, por exemplo) (ARGAN 1992: 288), característica do funcionalismo arquitetônico, ensimesmado com conteúdos funcionais (a função de um templo, antes de ser um local de culto, é de ser um templo). E a finalidade técnica de um objeto técnico é seu funcionamento, dando-se a forma como o destaque qualitativo do objeto de arte. E quanto ao objeto tecno-ambiental? Ora, a nossa expectativa é de que ele componha forma, função e funcionamento, seja em equilíbrio, como em oscilação.

O objeto tecno-ambiental pode assumir vários papéis, a depender de seu contexto. O motor elétrico de um trem, por exemplo, um objeto técnico por excelência, pertence a dois meios: o meio técnico e o meio natural. Seu funcionamento pode ser descrito, em termos gerais, como uma transformação de energia elétrica em energia mecânica, por meio do campo magnético gerado por três bobinas. O fascínio de Simondon não se direcionava a um dos meios isolados - o meio técnico ou o meio natural - mas por sua integração, chamada por ele de meio associado (milieu associé), e traduzida, no caso de uma locomotiva, por uma força que se adapta a uma estrutura geográfica - quando da tração empregada em declives - e meteorológica - quando do encontro com a neve nos trilhos ou com o

126 Artemídia é um termo criado para "designar formas de expressão artística que se apropriam de recursos tecnológicos das mídias e da indústria do entretenimento em geral, ou intervêm em seus canais de difusão, para propor alternativas qualitativas". Compreende "as experiências de diálogo, colaboração e intervenção crítica nos meios de comunicação de massa" e "abrange também quaisquer experiências artísticas que utilizem os recursos tecnológicos recentemente desenvolvidos, sobretudo nos campos da eletrônica, da informática e da engenharia biológica ... Inclui também artes visuais e audiovisuais, literatura, música e artes performáticas ... a criação colaborativa baseada em redes, as intervenções em ambientes virtuais ou semivirtuais, a aplicação de recursos de hardware e software para a geração de obras interativas, probabilísticas, potenciais, acessíveis remotamente, etc. ... Engloba e extrapola expressões anteriores, como 'arte\&tecnologia', 'artes eletrônicas', 'artecomunicação', 'poéticas tecnológicas', etc." Cf. MACHADO 2010, pp. 7-8. 
vento. O objeto técnico é, portanto, "a condição de si mesmo como condição de existência nesse meio mesclado, ao mesmo tempo técnico e geográfico" (SIMONDON 1969: 55). E, ao condicionar a sua existência, ele condiciona, é certo, seu funcionamento. Contudo, devido ao grau de indeterminação do ambiente, o funcionamento de um objeto técnico não pode ser excessivamente condicionado por seu projetista, evento conhecido como hipertelia. É possível concluir que, se um objeto técnico (não sobredeterminado) consegue condicionar-se, é porque ele possui uma certa margem de indeterminação, assemelhando-se, de certa forma, às qualidades formais do meio natural. Infere-se também que se a natureza possui formas indeterminadas, incorporando a própria indeterminação (CARLSON 2000: 37), ela é afetada por objetos que tenham as mesmas qualidades. No processo de individuação de um objeto tecno-ambiental uma dança de indeterminações é formada, com a condição de a palavra final ser a do fundo, o verdadeiro esteio das formas (SIMONDON 1969: 58). 
CAPÍTULO 2

ESTÉTICA ECOTÉCNICA E ARTE 
INTRODUÇÃO

De que modo exatamente a estética ecotécnica está relacionada com a arte, ou mesmo com a filosofia da arte? Em outras esferas, a indefinição sobeja. Por exemplo, a beleza de um aerogerador não é tão evidente, ao menos para os partidários da atitude "não em meu quintal". Em uma posição contrária, Gilbert Simondon constata reminiscências de uma rede mágica universal em objetos técnicos inseridos de forma afirmativa (mas não violenta) na natureza: torres de transmissão de energia ao longo de vales, faróis sobre promontórios (SIMONDON 2008: 199-203). Ou seja, não como artefatos dissimulados, mas integrados de forma contínua na paisagem; não como objetos de um remorso, marcados pela culpa da intervenção em uma natureza imaculada. A estética proposta por Simondon busca por pontos-chave, não obras-primas; fosse um artista contemporâneo, o filósofo francês buscaria o local perfeito para uma instalação site-specific, ou para a construção in situ de um earthwork, ao modo daquelas expressões discutidas na seção Hipotética gênese de um gênero hipotético. A localização para ele tem quase a importância das linhas Ley, os míticos centros de poder do planeta Terra, alinhamentos místicos que funcionam como meridianos geofísicos, como pontos energéticos do "corpo" de Gaia - locais inspiradores inclusive de um dos projetos de Shift Register, sobre o qual falaremos na seção Tecnomagias. Ao invés da distinção entre objeto técnico e natureza, de um objeto inserido como arte institucional na natureza, Simondon propõe uma relação entre o elemento figural do primeiro plano e seu pano de fundo, a qual remete a uma forma primitiva de percepção: o da distinção entre figura e fundo, tão investigado por psicólogos da Gestalt. Junte-se então um objeto técnico inserido de forma apropriada em uma localização, em um ponto específico do mundo natural (segundo Simondon, do "mundo geográfico"), para se ter a prolongação de um objeto técnico na natureza, um objeto tecnoambiental, centro da estética ecotécnica.

O que está em questão em nossos estudos para uma definição desta estética no campo da arte é, preliminarmente, a correspondência entre técnica - aqui, na acepção de ars (techné) - e natureza, entendendo que tal relação não é tão trivial o quanto se imagina. Na Grécia antiga já se fazia a distinção entre natureza e técnica, 
entre a physis, na qual a vida é ordenada por ela mesma, e techné, em que os elementos naturais são operados por meio de atividades humanas (a palavra ars em latim remete a techné, assim como a árthra, articulação). A própria etimologia sugere o seguinte raciocínio: se o homem tecnicisa a natureza (PINTO 2005: 141), então ela é também suscetível a uma espécie de "artealização", ${ }^{127}$ queremos dizer, a uma atitude de estetização estimulada pelo pensamento estético, uma tendência que converte objetos diversos, não limitados a determinados domínios ou espécies, em objetos estéticos. Nesse sentido, pode-se "artealizar" um instrumento ou até o gesto técnico que o manuseia. Ou seja, a ação técnica, ou qualquer outra atividade manual, se inscreve no mundo natural tal qual um típico fazer artístico, ${ }^{128}$ seja tal realização motivada por um projeto exclusivamente estético, ou por princípios artesanais, como o trabalho do cuteleiro estadunidense Bob Kramer, que confecciona facas a partir de meteoritos. ${ }^{129}$ A diferença entre as pinturas de natureza-morta representando utensílios de cozinha (como as de Jean-Baptiste Siméon Chardin) e o instrumento de corte esculpido em aerólitos é de grau, não de gênero: ambos os produtos são o resultado de uma histórica reconfiguração da natureza (no caso da faca de Kramer poderíamos dizer: de uma xenonatureza). À essa história soma-se outra: o nascimento da arte com o "arqui-cinema"130 das pinturas rupestres (BATAILLE 1955 apud STIEGLER 2018: 220), expressões primitivas que, de um lado, deram aos hominídeos do Paleolítico superior o poder de captura simbólica e, de outro, os impeliram a fabricar diversos instrumentos manuais destinados à artealização da natureza.

Este é um capítulo, portanto, que trata das condições materiais técnicoecológicas sob o prisma da arte, particularmente a que cria objetos tecno-ambientais percebíveis através de uma estética que poderíamos chamar de ecotécnica. De início, tomamos como fundamento a relação entre seres humanos e a natureza, um comércio em geral mediado por artefatos tecnológicos, os quais se reservam o direito de proceder em ciclos de dualidade (pharmakon), quer no papel de remédio,

127 Ver MICHAUD in: BOEVER ET AL. 2013, p. 124.

128 Ibid., p. 131.

129 RAW CRAFT. Anthony Bourdain \& The Balvenie. Episódio quatro: Bob Kramer, 2015. Vídeo disponível em <https://www.youtube.com/watch?v=4x0f2b_0kn0>. Acesso: 29 mar. 2017.

130 Termo criado por Bernard Stiegler para fundamentar o argumento de que a forma primordial de reprodução de apreensões externas (chamada por Husserl de "retenção") do ser humano é a imagética (e não a escrita, como propôs Derrida). Ver STIEGLER 2011, passim. 
quer no de veneno. Essa imagem é projetada desde os primórdios da filosofia e é esmiuçada por pânditas tão díspares quanto o cineasta e animador japonês Hayao Miyazaki (uma fonte de referência em outras seções) e o filósofo Martin Heidegger, um e outro delatores da força destrutiva da tecnologia, mas também da sua possibilidade de renovação e sacralização da natureza. ${ }^{131}$ Talvez essas sejam visões românticas que não seriam absolutamente contrariadas por Gilbert Simondon, um dos mentores intelectuais de nossa tese. Para o filósofo francês, a physis não é algo a que devemos retornar ou adequar; "é uma construção pura". ${ }^{132}$ Daí a nossa ênfase no construtivismo da cibernética de segunda ordem, em particular os estudos sobre a individuação de formas. Na seção sobre a gênese da arte ecotécnica, especulamos sobre quais períodos e movimentos ela começa a agregar-se de forma estruturada, ou quais seriam os possíveis trajetos de sua linha de fuga (ligne de fuite). Essa hipótese começa, então, pelo Romantismo. A bem da verdade, pode-se dizer que a busca pela natureza selvagem constitui um dos traços marcantes desse movimento no campo das artes visuais, tendo excepcionalmente como ponto de inflexão o advento do pitoresco, onde os temas técnicos superpõem-se ao fundo da natureza primitiva, sem que haja divergências de assunto. Veremos que, numa possível linha diacrônica, o programa Land art coloca-se como o sucedâneo lógico desse conceito de estética, podendo tal sucessão ser estendida, prontamente, até expressões contemporâneas de artemídia, em especial aquelas não totalmente submetidas ao fetiche da tecnologia digital.

Para seguir adiante na segunda parte da tese, será necessário interpelar dois "campos ampliados" excepcionais no panorama da arte contemporânea: arquitetura e infraestruturas, domínios que, no terceiro capítulo, receberão um tratamento mais técnico que artístico. A seção $O$ complexo arte-arquitetura assume o caráter estético e prototípico do movimento conhecido como arquitetura especulativa, averiguando a sua capacidade de colocar em questão questões definitivas da atualidade, como a natureza do habitar e as mudanças climáticas. Esse questionamento do próprio ato de questionar é suscitado pela pesquisadora britânica Rachel Armstrong, uma das

131 Ver MCDOUGALL, Edward. Spirited Away Meets Heidegger: We Killed the Gods with Technology. IAI TV - Philosophy for our times: cutting edge debates and talks from the world's leading thinkers, 2 jul. 2018. Disponível em: <https://iainews.iai.tv/articles/spirited-away-meetsheidegger-we-killed-the-gods-with-technology-but-the-sacredness-of-life-is-continuous-auid-1104> . Acesso em: 17 jul. 2018.

132 Ver DEBAISE, Didier. What is Relational Thinking? Multitudes, 2004, n.18, pp. 15-23. 
referências chaves da seção: "seremos capazes de ir além das práticas industriais urbanas, moldando de forma diferente as questões acerca dos desafios do milênio?", questiona. ${ }^{133}$ Uma das funções da arquitetura experimental, ela deduz, é libertar a vida do espírito criativo; e, nós acrescentaríamos, exaltar antes as maquinações da invenção do que as imposições do mercado, preferencialmente aquelas que beiram ao oximoro das fantasias exequíveis. Por certo que o foco de Armstrong é o planejamento urbano e o futuro das cidades, contudo as confabulações de sua "arquitetura-viva" dispõem de valências tecno-ambientais em diversos âmbitos, sustentando em geral o equilíbrio entre forma, função e funcionamento. Tal é, na seção Infraestruturas e invenção, o caso dos objetos decorrentes dos programas Infraestrutura Crítica ${ }^{134}$ e Infraestrutura Ficcional, ${ }^{135}$ bem como o caráter tecno-ecológico de expressões do Solarpunk, movimento cultural proposto pelo ideólogo Adam Flynn que, em um manifesto de 2014, preconiza as "infraestruturas como uma forma de resistência". ${ }^{136}$ No setor de energia, por exemplo, artistas voltam-se para fontes alternativas aos obtusos combustíveis fósseis, buscando decerto por princípios ancestrais de movimento sem desgaste, como o "sentido da palavra yi (mutação), que evoca a ideia de 'facilidade' e exclui a de trabalho[;] [a]s realidades ... se transmudam, e são transmudad[a]s sem que para isso haja um gasto, sem que para isso se despenda qualquer espécie de energia" (GRANET 2004: 204-05; grifos do autor). Veremos que as bactérias, e não as máquinas de movimento perpétuo, afirmam-se como fortes candidatas à uma composição energética dessa natureza.

A propósito, a subsunção da magia às técnicas - e vice-versa - é tema da seção Tecnomagias, orientado a princípio, diríamos nós, pela incursões filosóficas de Gilbert Simondon e Alfred Gell a respeito do pensamento mágico e, em igual medida, por trabalhos representativos do Encontro de Tecnomagia - Nuvem,

133 ARMSTRONG, Rachel. Palestra proferida no TEDx Talks, TEDxCERN (Genebra), 9 out. 2015. Vídeo disponível em: <https://www.youtube.com/watch?v=LX8aT-Hb5FE\&feature=youtu.be>. Acesso em: 26 jul. 2018.

134 Expressão formulada por Jamie Allen, artista canadense empenhado na aplicação do design crítico no domínio das infraestruturas.

135 Expressão criada por Paul Graham Raven, pesquisador em futuros da infraestrutura na Universidade de Sheffield.

136 Ver FLYNN, Adam. Solarpunk: Notes Toward a Manifesto. Hieroglyph, 4 set. 2014. Disponível em: <http://hieroglyph.asu.edu/2014/09/solarpunk-notes-toward-a-manifesto/>. Acesso em: 26 jul. 2018. 
hacklab rural realizado em Visconde de Mauá, em 2012. ${ }^{137}$ O significado do título da seção é amplo, ramifica-se em diversos planos preternaturais, até mesmo xamânicos, obtendo a sua potência nominal ao sugerir a conexão do humano à técnica e ao mundo natural por intermédio de temas míticos. Como aponta o professor da Unicamp Pedro Ferreira, na contagem da história do xamã que surpreendeu um antropólogo ao fazer de uma recém-conhecida tecnologia - o submarino - a metamorfose de uma "cobra mítica", é "através da imitação de procedimentos míticos que a tecnologia é transferida para os homens, atualizada em cada sociedade". ${ }^{138}$ No ponto de partida para uma estética ecotécnica, a seção trata das intersecções entre tecnologia e magia natural, forma de magia revelada na physis. E é aqui que o trabalho do artista Martin Howse adquire relevo, uma espécie de mago-poeta contemporâneo que canta as virtudes da alquimia na recristalização de terras-raras incrustadas em computadores e da arqueoastronomia como a "origem da geometria e de todas as artes do mapeamento e da medição". ${ }^{139}$ As expressões artísticas tecnomágicas são pontos fora da curva dentro do art world contemporâneo, esfera de conhecimento em sua maior parte confinada ao reino do neoliberalismo. Questiona-se, nesse contexto, qual a predisposição das expressões atuais acerca de temas alheios ao mercado da arte, como o das mudanças climáticas. O esboço de uma resposta acha-se na seção Expressividades geocientíficas, na qual investiga-se objetos tecno-ambientais neguentrópicos que emergem do fundo entrópico que se transformou a biosfera.

\subsection{HIPOTÉTICA GÊNESE DE UM GÊNERO HIPOTÉTICO}

É comum afirmar que a genética é, segundo Gilbert Simondon, a filosofia da individuação, ${ }^{140}$ a saber, as atividades operacionais de uma pessoa, sociedade, tecnologia, estrutura, em suma, de qualquer indivíduo, vivo ou não, real ou irreal (uma imagem mental, por exemplo). À vista disso, seguiu-se uma substituição léxica

137 O encontro resultou em uma publicação. Cf. BELISÁRIO 2014.

138 Ver FERREIRA, Pedro P. Os Xamãs e as Máquinas. Revista Alegrar, n. 2, 2005.

139 shift register (@shiftregister_). "Astronomy: an origin to geometry and to all the arts of mapping and measurement, a moon's phase gives the circle bringing the stars and planets down to earthy symbol, the muddied and rattle-snaked cycles". 27 mar. 2018, 1:46 AM. Tweet.

140 Ver BARTHÉLÉMY in: BOEVER ET AL. 2013, pp. 203-231. Especificamente os verbetes Individuation/disindividuation e Ontogenesis. 
no título da presente seção. Por certo consideramos o valor da área de estudos que aborda as manifestações artísticas desde os primórdios até o presente, contudo optamos por redigir a palavra "gênese" ao invés de "história" porque o nosso objeto não se encontra devidamente formado e, sobretudo, por tratar-se de um hipotético gênero de arte, diluído em outros gêneros e narrativas críticas. Quando nos referimos a uma suposta "arte ecotécnica", convém dizer, não sancionamos a sua existência nem pretendemos inaugurar um novo estilo, contentando-nos, por ora, com a identificação de alguns de seus genes matizados no fluxo do fazer artístico. Primeiro, nota-se o entrecruzamento de juízos tecnológicos e ecológicos, ou melhor, o tingimento recíproco de duas estéticas estabelecidas: a maquínica e a natural. É possível concluir que a primeira remete ao Manifesto Futurista, embora compatibilize-se mais, em nossa concepção, com o Arts \& Crafts, mas um tanto diferente do movimento que floresceu na América do Norte e Europa entre 1880 e 1920, tendo-se aberto ao exercício de um revisionismo construtivo, no qual os ofícios da cultura técnica são estimulados em conjunto com o artesanato e o que poderia ser enquadrado no atual movimento Faça-Você-Mesmo. E podemos supor que a segunda estética, por força do nome, reduz-se em objetos de representação do mundo edênico (ou mesmo pré-adamita), uma natureza sem a presença de marcas humanas, mas, como veremos ser em diversos casos, ela serve-se também de imagens de intervenções técnicas. Assim, na busca da relação entre a estética ecotécnica e a arte, analisaremos alguns possíveis antecedentes artísticos nos quais os objetos naturais e os objetos técnicos tornam-se complementares, e não antagônicos. Por motivos de abreviação, a operação genética proposta aqui passa pelo Romantismo, em particular pelo conceito estético de pitoresco, direciona-se para alguns programas da arte ambiental, como a Land art, em voga nas décadas de 1960 e 1970, e aproxima-se, por fim, da arte contemporânea, especificamente de certas expressões da artemídia (media art), gênero eivado de celebrações tecnológicas, mas que, em alguns casos, retribui à natureza a sua devida magnitude. 


\subsubsection{Romantismo}

A representação da natureza sempre esteve presente no mundo da arte, desde tempos imemoriais. Haja vista, por exemplo, a chamada pintura de paisagem, as cenas bucólicas presentes em diversos estilos da história da arte, das pinturas tradicionais chinesas - como as do estilo shan shui (água e montanha), ou paisagens imaginárias com cenas de espinhaços e rios - até as obras produzidas pelos artistas viajantes que passaram pelo Brasil a partir do século 17. Entretanto é no período romântico que a representação da natureza ganha um sentido "ecológico", ${ }^{141}$ sendo suas produções até consideradas a origem de um movimento que, na década de 1970, ficou conhecido como ambientalismo. Porém, tal relação nunca foi infensa a um simplismo barato, sendo reduzido o topos àquelas nostalgias da unidade perdida entre homem e natureza, ou pior, como mera celebração poética de belas paisagens. ${ }^{142}$ Salvo o intuito nobre e pitoresco de exaltação do mundo natural, outro aspecto da representação da natureza vinculava-se ao próprio ato de constituição da paisagem, prática que, no caso do colonialismo brasileiro, implicou em resultados não tão nobres. O pesquisador paraibano Rondinelly Medeiros lembrou, em sua palestra para o simpósio Os Mil Nomes de Gaia, ${ }^{143}$ como o fundamento axiológico do projeto colonial era baseado na pretensão política de ocupação do espaço para determinar materialmente e de forma unidirecional a constituição da paisagem. Assim como os artistas românticos, o princípio "estético" das entradas e conquistas do século 17 no Brasil era tornar a natureza transcendente, mas ainda maleável, só que dessa vez com o objetivo de aplacar os efeitos morais de sua brutalização e exploração. ${ }^{144}$

Os pintores românticos baseados na Europa talvez fossem mais ingênuos. A natureza constituída por eles não era antagônica, mas tinha como conteúdo um

141 Ver HARRISON, Gary. Romanticism, Nature, Ecology. University of Maryland: Romantic Circles, 2006.2 Disponível em <https://www.rc.umd.edu/pedagogies/commons/ecology/harrison/harrison.html>. Acesso: 28 mar. 2017. 142 Ibid.

143 MEDEIROS, Rondinelly. Palestra proferida no Colóquio Internacional Os Mil Nomes de Gaia: Do Antropoceno à Idade da Terra, Casa de Rui Barbosa (Rio de Janeiro), out. 2014. Vídeo disponível em <https://www.youtube.com/watch?v=f8YQEzQsubY>. Acesso: 17 set. 2015.

144 Temos aqui um contraste entre duas formas: a idealização da pintura romântica e o realismo da pintura de paisagem, com seus respectivos vínculos com as missões artísticas francesa e holandesa no Brasil. A diferença, especulamos, reside no aspecto "ecológico" da primeira. 
imperativo de separação, que vai no sentido do distanciamento exigido pelo sublime. ${ }^{145} \mathrm{O}$ que está em jogo nesta forma de representação do mundo natural é o que o filósofo inglês Timothy Morton chama de ecomimesis, uma técnica estética que não se limita a imitar a natureza, mas a fantasia "como uma atmosfera envolvente, palpável, porém disforme" (2007: 77), um idílico locus amoenus. Em algumas situações, segundo Morton, tal prática ganha contornos estetizantes, se considerarmos a diferença entre estética e estetização: enquanto a primeira é o campo da filosofia preocupado com as formas de percepção e apreensão sensorial da realidade, a segunda é resultado de uma construção sensória (por vezes ideológica). A técnica da ecomimesis proporciona um falso sentido de ambiência, cujo objetivo é despertar uma sensação de imersão, por meio de imagens de uma natureza que está "do lado de fora", externa, chamando o observador para um pretenso envolvimento. Pode-se dizer que a ecomimesis estaria oposta à noção de situatedness, elaborado por fenomenologistas, um termo de difícil tradução, significando geralmente a maneira de perceber exatamente quais as circunstâncias conjunturais do entorno, algo relacionado também à inserção, localização e contextualização do sujeito em relação ao seu meio. É saber, enfim, quais os limites da própria noção de limite entre exterior e interior. Pintores de paisagem britânicos, como contraponto, passaram a criticar tais construções românticas com a ideia de "fidelidade à natureza" (truth to nature), expressão cunhada pelo crítico John Ruskin para descrever as práticas de desenho da natureza ao ar livre, forma de arte que tinha conexões com a objetividade mensurável das ciências naturais.

145 O filósofo anglo-irlandês Edmund Burke opunha o prazer tranquilo proporcionado pelo belo ao poder de arrebatamento da natureza (sublime). Ver o catálogo da exposição A paisagem na arte: 1690-1998. Artistas britânicos na coleção da Tate, organizada pela instituição britânica em associação com a Pinacoteca do Estado de São Paulo, 2015. 
Figura 13 - Old Bridge em Pontypridd, País de Gales

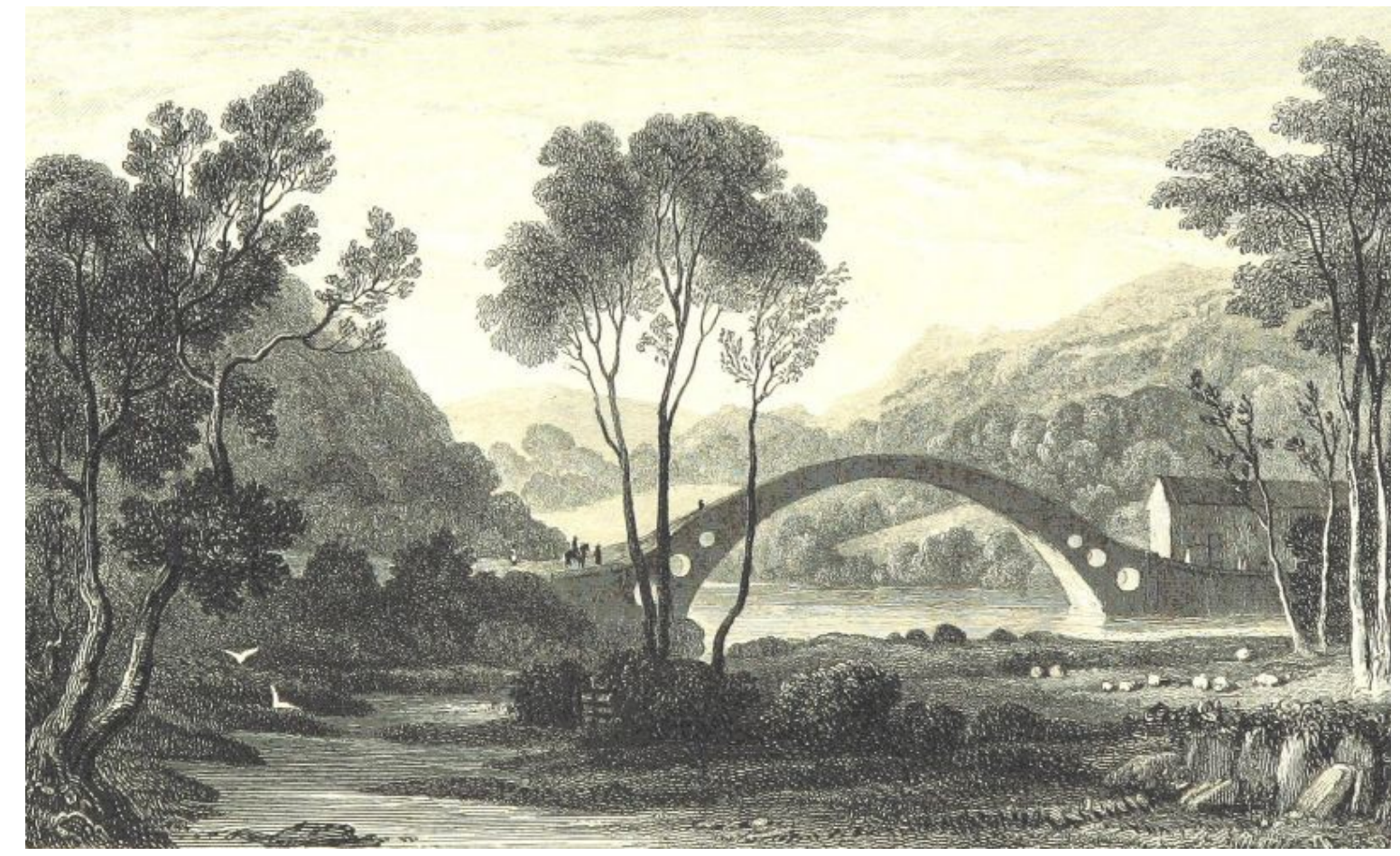

Fonte: http://www.oldphotos.org.uk/glamorgan.html (Direitos autorais: Croeso Network)

E ainda são os românticos ingleses que nos dão o código para decifrar a nossa hipotética arte ecotécnica, porque foram eles que aperfeiçoaram o conceito de pitoresco, uma interpolação linear a meio caminho entre o belo (pleno espontâneo) e o sublime (temor admirável). Tem-se por convenção atribuir o termo ao artista inglês William Gilpin, grafado em obra de 1770 , época na qual se discutia acaloradamente se o único acesso sensorial à natureza seria por via de sua estetização pictórica. Gilpin, ao contrário de seus pares defensores do belo castiço, admitia as imperfeições do mundo natural. Segundo seu relato, a natureza "é uma colorista admirável, capaz de harmonizar suas tonalidades com infinita variedade e inimitável beleza; contudo, poucas vezes é igualmente correta na composição, ao extremo de que dificilmente chega a produzir um conjunto harmonioso. Há uma desproporção dos planos, ou algum traço desajeitado atravessa o conjunto ou, inclusive, alguma árvore está mal localizada ... ou existe alguma coisa que não é como deveria ser" (GILPIN 1800: 31). ${ }^{146}$ Vê-se que a diferença reside, além do fator acabamento, no enquadramento. Um objeto natural "não é delimitado exatamente como o quadro é delimitado pela moldura", a vista é multidirecional, "isso não só porque o seu 146 Excerto traduzido por Pablo Diener. 
contorno não é nítido mas porque, em si mesmo ele não está fixado e imutável" (DUFRENNE 2015: 61-2). Contudo, os assuntos de Gilpin não se esquivam dos mesmos objetos retratados por seus coetâneos, tendo como ingredientes elementos como "árvores, rochas, terrenos íngremes, matas, rios, lagos, planícies, vales, montanhas e distâncias". ${ }^{147}$ Faz-se mister adiantar que a ideia de pitoresco não é invariante e única. As teorias do ensaísta Uvedale Price, por exemplo, encontram-se mais em concordância com a nossa hipotética arte ecotécnica, em razão dos motivos e oposição aos cânones, o que fica patente em sua "paixão pelas ruínas góticas, por cabanas rurais isoladas, preferencialmente atingidas por temporais", ${ }^{148}$ digressões acerca de jardins italianos (PRICE \& LAUDER 1842: 297-ss) e estruturas arquitetônicas intrincadas (op.cit.: 339). Denota-se, assim, o entroncamento de objetos técnicos e objetos naturais e prenuncia-se a sua necessária convivialidade nas representações (ver Fig. 13). E, para além das artes plásticas, não seria a descrição pitoresca do farol de Penrith, na Cumbria, realizada pela memória adolescente do poeta inglês Wordsworth, ${ }^{149}$ uma descontextualização das rotas de guias de turismo, reinserindo-o na categoria de objeto técnico militar (BROGLIO 2008: 77), como se fosse um objeto estético intermediário entre arte e natureza?

\subsubsection{Environmental art}

Quando as estratégias políticas de enfrentamento da crise ecológica perdem a sua eficácia, recorre-se à percepção, na esperança de ativar o sujeito por meio de uma apresentação diferente do problema e, por conseguinte, de sua significação. Assim o fez, por exemplo, o socialista utópico Charles Fourier, a quem importava, para além das mudanças sociais, uma espécie de aperfeiçoamento estético da biosfera (WARK 2015: 96). O problema é: como transformar a fria e distante paisagem romântica em algo vivo e íntimo, isto é, em ambiente (ou melhor, meio)? Foi inspirada por esse princípio que uma forma de arte começou a surgir no final da década de 1950, a qual se valia da área pública (urbana ou rural) como suporte: era

147 Ver DIENER, Pablo. The Picturesque as an Aesthetic Category in the Art of Travelers: Notes on J. M. Rugendas's Work. Historia (Santiago), Santiago, v.40, n.2, 2007, pp. 285-309. 148 Ibid.

149 Cf. o excerto do poema referente ao Penrith Beacon em Wordsworth's Prelude, 1850. Disponível em: <http://homes.Imc.gatech.edu/ broglio/1102/penrith.html>. Acesso em: 24 abr. 2018. 
o programa Land art. Apontava para o que depois passou a ser chamado genericamente de environmental art, ou arte ambiental, termo que passou a englobar várias outras expressões, a maioria apostando em um tipo de arte política de cunho denunciatório e conscientizador, mas todas ligadas direta ou indiretamente aos temas ecológicos (lembrando que o Relatório do Clube de Roma, no qual foi exposta a questão dos limites do crescimento econômico, só veio a ser publicado em 1972). Primeiro, o programa pretendia retirar a pátina romântica da natureza a todo o custo; era preciso, então, "desestetizá-la". Em seguida, era preciso escapar da armadilha do processo de estetização da paisagem - um processo kitsch por excelência, basta constar aqueles quadros rústicos com belas vistas pastorais, quase artificiais, que vemos nas casas do interior. Por fim, era mandatório resgatar o sentido de ambiência, de percepção sensorial do entorno, mas agora sem os artifícios da ecomimesis.

Os artistas cujos nomes são mais ligados à Land art, tais como Robert Smithson, Walter De Maria e Robert Morris, refutavam a ideia romântica de contemplação e retorno à natureza. Para eles, o planeta Terra é primordialmente uma mídia adicional, ou melhor, uma imensa tela sobre a qual pode-se riscar, traçar, compor e recompor elementos ao bel prazer, como se os criadores fossem verdadeiros demiurgos. Segundo depoimentos compilados no documentário Troublemakers: The Story of Land Art, ${ }^{150}$ do historiador de arte James Crump, muitos artistas de Land art foram fortemente inspirados por aquela célebre foto do nascer da Terra (em inglês Earthrise), tirada por William Anders durante a missão Apollo 8 à Lua, em 1968. A primeira fotografia da Terra tirada do espaço colocou em perspectiva a diminuta dimensão de nosso planeta em contraste com o infindável espaço cósmico, mas, inversamente, o encolheu o suficiente para que passasse a ser uma totalidade (algo parecido com uma natureza), ou mesmo um objeto (ou hiperobjeto) palpável e passível de manipulação estética. Finalmente, o Aufklärung científico da corrida espacial havia "domesticado" uma natureza recalcitrante e imprevista ao colocá-la ao "alcance de nossas mãos".

150 Ver uma entrevista com o diretor do documentário em <http://hyperallergic.com/235006/adocumentary-mines-the-stories-of-three-pioneers-of-land-art/> Acesso: 22 out. 2015. 
Figura 14 - Lightning Field (1977), de Walter De Maria

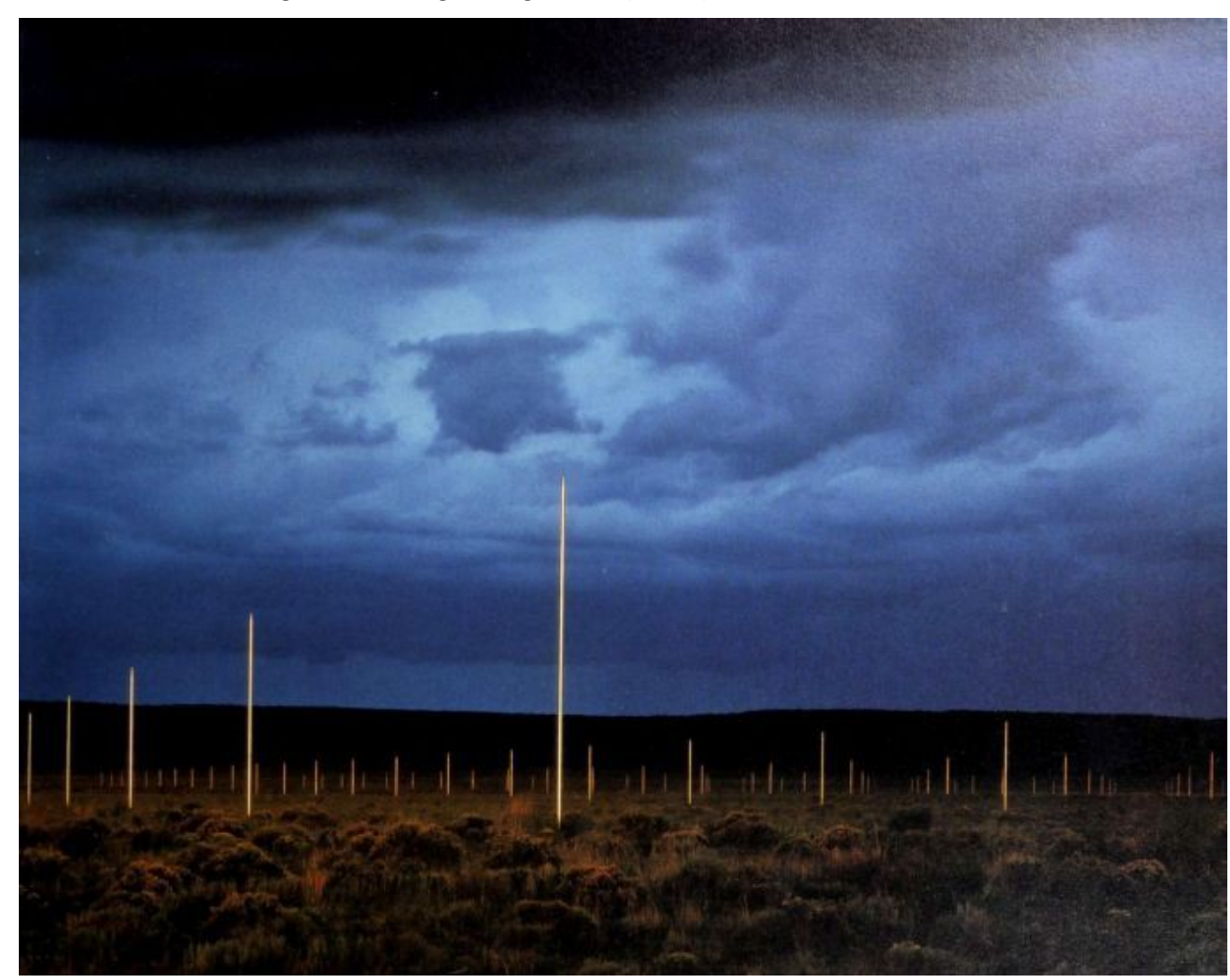

Fonte: KASTNER \& WALLIS 2010

Robert Smithson, em particular, não era diretamente inspirado pelo movimento ecológico e são famosos os seus conflitos com ambientalistas que, em certa ocasião, conseguiram convencer as autoridades canadenses a impedir a materialização do projeto Island of Broken Glass, um earthwork que implicava o despejo de cem toneladas de vidro quebrado em uma pequena ilha rochosa, cobrindo completamente a sua superfície com o material destruído. Igualmente, obras como Asphalt Rundown (1969), uma de suas geologias abstratas, não apresentavam nenhum conteúdo ecológico (eram talvez até anti-ecológicas); o artista queria antes desconstruir os cânones do mercado de arte e realizar projetos que não estivessem de acordo com os sistemas de valor das galerias, além de discutir questões como entropia, controle tecnológico e a crise do capitalismo. Mas, nas entrelinhas, a crítica de Smithson era contra o mito do progresso ilimitado, e isso Ihe chancelava certo pendor ecológico. Apesar disso, ele não tinha a atitude reverencial em relação à natureza de artistas como Walter De Maria, Michael Heizer 
e James Turrell, e ainda procurava desconstruir o discurso ecológico que, para ele, não passava de um panegírico ao progresso científico (URSPRUNG 2013: 254). escultor britânico David Nash é o seu antípoda, acoplando o físico e o espiritual em seus projetos arbóreos, como Ash Dome, de 1977, vinte e duas árvores plantadas no interior do país de Gales na forma de um vórtice circular, remetendo à técnica da topiária, mas desta feita com toda a estrutura das plantas, e não apenas com seus arbustos. Assim, então, teríamos um earthwork com qualidades pitorescas. Ao que comentamos antes, o pitoresco não se reduz a uma paisagem vista sob a ótica pictórica, não somente "reintroduz a arte na natureza", não é definitivamente um conceito estético elementar no qual a "natureza se exprime por meios que a arte pode reproduzir porque são naturais: jogo das cores, das linhas, dos equilíbrios e desequilíbrios, das harmonias e desarmonias" (DUFRENNE 2015: 74). Ele contém, como uma de suas premissas, a neutralização da uniformidade e da stasis, elementos valorados pelo belo e o sublime. Diante disso, há um princípio de concordância entre Smithson e Uvedale Price, no sentido de ambos admitirem a realidade das alterações contínuas da natureza e seus eventuais desastres, a sua transfiguração radical, as oscilações pendulares entre matéria e energia, seja por necessidade natural ou mãos humanas. Em seu seminal ensaio para a revista Artforum, ${ }^{151}$ Smithson evoca a entropia da técnica processando-se em um espaço sem contentores, onde as manifestações tecnológicas não são "extensões" do homem (de acordo com Marshall McLuhan), mas um agregado de elementos: "Em vez de usar o pincel para fazer sua arte, Robert Morris prefere o trator". ${ }^{152}$ Contudo, segundo ele, é preciso desconfiar da "ideologia da tecnologia", na qual a ferrugem comporta um valor estético inferior ao do aço inoxidável e a deterioração dos materiais é vista com maus olhos. Em suas práticas espaciais, Smithson tece a analogia entre as erosões do solo e as convoluções da mente, propugnando o valor estético das patologias geológicas e a libertação do pensamento sob o jugo do formalismo greenberguiano. De todo modo, há manifestações dentro do programa Land art em que não se reveste a tecnociência de ambiguidades. Tome-se The Lightning Field (1977), de Walter de Maria (ver Fig. 14), um earthwork composto por

151 Ver SMITHSON, Robert. A Sedimentation of the Mind: Earth Projects. Artforum, Setembro 1968, p. 44.

152 Ver SMITHSON, Robert; LEWITT, Sol. Towards the Development of an Air Terminal Site. Artforum, v. 5, n. 10, 1967, pp. 36-40, cit. in: KASTNER \& WALLIS, 2010, p. 20. 
400 vigas de aço inoxidável polidas, erigidas simetricamente em área do deserto do Novo México (EUA), exatamente sobre a Divisória Continental da América do Norte. Resumindo: é uma matriz de para-raios, precisamente alinhada. Uma máquina de relâmpagos, especulamos dizer, dependente da eletrificação de nuvens sobre a região, da consequente separação de partículas negativas e positivas por ventos, e do chamado fogo de santelmo, ${ }^{153}$ descarga eletroluminescente provocada pela ionização do ar, formando um forte campo elétrico e criando uma "guia" que tem origem nas pontas das vigas. É uma obra, presume-se, que invoca a apreciação estética de cunho ecotécnico.

Mas nem só de earthworks monumentais e interruptores ambientais vive a environmental art. O artista brasileiro Cildo Meireles, em um projeto de 1969, Mutações Geográficas: Fronteira Vertical, retirou um centímetro do Pico da Neblina, no Amazonas (o ponto mais alto do Brasil), e encrustou em seu lugar um minério de dois centímetros, "aumentando assim a altura do Brasil". ${ }^{154}$ Já o artista húngaro György Kepes - o qual, anos mais tarde, em 1969, convidaria Smithson para participar de uma sala de arte e tecnologia na $10^{a}$ Bienal de São Paulo - organizou em 1951 uma exposição intitulada $A$ nova paisagem, na qual apresentou exemplos de afinidades entre artes visuais e visualizações geradas por instrumentos científicos (basicamente, microscópios e telescópios). As expressões da natureza, segundo o conceito do evento, não seriam mais mediadas pelas ferramentas da techné, mas pelos instrumentos da episteme, da ciência. Na exposição, figuras de Lichtenberg, imagens produzidas por descargas elétricas, ficavam dispostas ao lado de instalações site-specific cujo suporte era a própria luz. O micro e o macro, grandezas dispostas lado a lado, por via da ciência, insinuam-se em franca discordância com a posição segundo a qual, na experiência estética da natureza, o insignificante e o pequeno não são estetizáveis (DUFRENNE 2015: 66). Ao constituir uma outra paisagem, Kepes encampa um tipo de arte ambiental avant la lettre, mas com ingredientes contemplativos, quase despertando o renascimento de alguns valores da pintura de paisagem e provocando o surgimento de uma espécie de protoambientalismo.

153 Ver CAMPBELL, Christopher D. Walter De Maria's Lightning Field and McCarthy's Enigmatic Epilogue: "Y qué clase de lugar es éste?" The Cormac McCarthy Journal, v. 2, n. 1, 2002, pp. 40-55. 154 Ver CYPRIANO, Fabio. Panorama da Arte do MAM Ousa ao Mesclar Antigos e Atuais. Folha de São Paulo, São Paulo, 27 out. 2015. 


\subsubsection{Artemídia}

Não é o caso refutar radicalmente a técnica (ou a tecnociência), mas entender seus modos de existência e sua relação com a biosfera. É no rastro desse princípio que surge na contemporaneidade um híbrido entre arte tecnológica ${ }^{155}$ e arte ecológica, uma arte que passaremos a chamar tentativamente de artemídia ecotécnica. Caso tal arte exista, um de seus princípios teóricos seria o de reformular a noção de "natureza", e não eliminá-la por completo, como querem, por exemplo, alguns representantes da Ontologia Orientada a Objetos (OOO), escola de pensamento que rejeita o privilégio da existência humana sobre os objetos nãohumanos. A noção revisitada pela artemídia ecotécnica se distanciaria da physis e se aproximaria da noção de apeiron que, como vimos, significa o ilimitado, sentido mais apropriado para os reformistas, porque estabelece uma extensão entre seres e seus entornos; ou seja, sugere uma continuidade "sem costura" entre seres e o seu meio ambiente. Em relação aos seres, extensões do Ser, é preciso observar que os mesmos não apenas abarcam os seres vivos, mas também seres não vivos, todos gravitando uns em torno de outros, exercendo influências e estabelecendo relações.

Além de privilegiar a noção de apeiron sobre physis, a artemídia ecotécnica também valoriza a união entre episteme e techné. Mas haveria realmente uma divisão? Em princípio, sim. Mas se a poiesis (não natural) é o fazer que demanda uma técnica, então a episteme, que é um tipo de mentalidade criada por aquela técnica, seria uma espécie de racionalidade técnica voltada a um determinado desempenho. Portanto, a técnica se dá na poiesis enquanto o conhecimento ocorre em domínio cognitivo. A divisão é, sim, ilusória e o campo da tecnologia depende tanto da técnica como da epistemologia. Em acréscimo, algumas produções da artemídia ecotécnica acrescentam um quarto elemento, também oriundo da Grécia antiga, tyche, palavra comumente traduzida por acaso. Os objetos tecno-ambientais resultantes desta forma de fazer artístico não mais controlariam o acaso, mas o deixariam se adentrar e constar entre as suas variáveis, entre os programas dos agentes internos "tomadores de decisão". Os produtos de tal arte estariam então

155 A existência ou não do gênero é amplamente debatida na teoria e na crítica de arte atual. A título de resumo, chamaremos aqui de arte tecnológica (ou artemídia) todas as produções que se utilizam de novas mídias e tecnologias em suas expressões. 
condicionados a funções não-determinísticas, contrárias às presentes, por exemplo, nas atuais arquiteturas computacionais, inspiradas no antigo modelo digital sugerido pelo matemático húngaro John von Neumann, na década de 1950. Os dispositivos não-determinísticos são abertos em todas as acepções, principalmente abertos a uma margem de indeterminação, como diria Simondon, podendo se ajustar às contingências do meio ambiente, ou mesmo resolver problemas no-analog, termo que, em paleoecologia, significa a recorrência de climas pretéritos sem equivalentes aos atuais. ${ }^{156}$

Figura 15 - Radioplanta (2015), de Paloma Oliveira e Mateus Knelsen

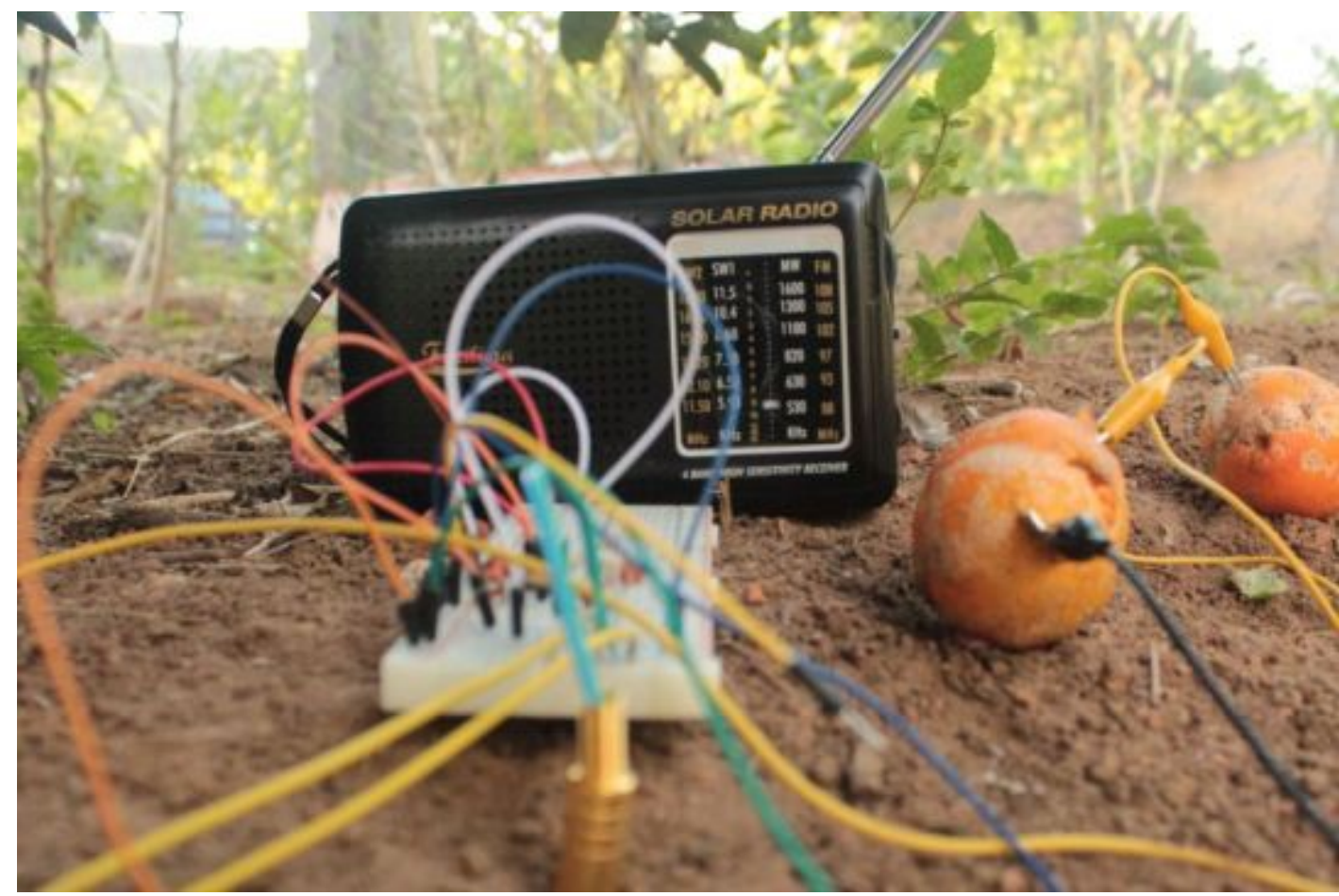

Fonte: http://www.discombobulate.me/en/projetos/radioplanta/ (Foto: Manoela Cardoso)

Tome-se, por exemplo, o projeto Radioplanta (ver Fig. 15), de Paloma Oliveira e Mateus Knelsen, resultado de rural.scapes, ${ }^{157}$ residência artística ocorrida durante o ano de 2015 na fazenda Santa Tereza, próxima a cidade de São José do Barreiro, Rio de Janeiro. Na descrição, os dois artistas se perguntam: se pelo rádio ouvimos a história narrada em músicas e notícias, como seria ouvir os pleitos de quem não tem voz, no caso, as plantas? Em termos técnicos, eles aplicam um sensor galvânico 
(semelhante ao usado no inefável detector de mentiras) em folhas de plantas locais da fazenda. Por meio de circuitos transmissores e receptores de sinais FM de baixa potência, é possível escutar uma rudimentar conversação entre os vegetais, uma sonoridade ininteligível aos humanos, mas que, mesmo assim, poderia produzir sentido em um hipotético Parlamento das Coisas. Além disso, servindo como um alerta à falência da matriz energética sobre a qual está assentado o capitalismo contemporâneo, todos os circuitos são desenvolvidos sobre suporte de papel e alimentados com bio-baterias a partir de limões-cravo, mandiocas, carás, bananas e outros alimentos locais, referência implícita às batatas ligadas por eletrodos e conectadas a um voltímetro na instalação Analogía I (1970/1971), do artista argentino Víctor Grippo. ${ }^{158}$ Radioplanta é um trabalho performativo que junta duas tecnologias "semivivas" (rádio e polígrafo) a um sistema aberto ao incerto.

Aos olhos mais atentos, essa linhagem da artemídia ecotécnica, com sua "estética tosca", ${ }^{159}$ estaria extrapolando o mundo da arte e ingressando na agenda de designers ansiosos por resolver o problema das energias renováveis, como pode ser verificado nos projetos desenvolvidos durante o POC 21, ${ }^{160}$ laboratório em residência concebido para anteceder (como antítese e contraponto) a $21^{a}$ Conferência do Clima (2015), em Paris. Diferentemente do movimento romântico e das práticas da environmental art, tal corrente teria uma visão menos contemplativa e mais "operacional" da natureza, prescindindo de um programa de ação e controle e com uma disposição de coexistir e coevoluir com as partes discretas que, juntas, compõem o que nós, ocidentais, chamamos de natureza. Mas além da proposta de reforma da noção de natureza, seria também preciso investir em uma reforma da própria noção de tecnologia. Qual poderia ser essa outra visão? Certamente, ela seria mais plural (técnicas, tecnologias), enciclopédica, naturalista (na linha das ciências naturais), não quantificadora e, por certo, decentralizada. Uma tecnologia onde a técnica da cutelaria fosse igual a do rapsodo, ao menos no instante da inspiração (PLATÃO 2011). Enfim, técnicas e saberes que, ao concretizarem a comunhão entre res cogitans e res extensa, entre a história humana e a história

158 Ver MATOS, Diego. Víctor Grippo. In: REBOUÇAS \& VOLZ 2016, p. 368.

159 Ver o contexto da expressão em MCKIBBEN, Bill. Being Good Enough. In: CANN \& KINGSNORTH, ETAL., 2015.

160 O trabalho mais próximo de uma estética ecotécnica, segundo a nossa concepção, são os canteiros da AKER, projetados para impressoras 3D. Disponível em <http://www.poc21.cc>. Acesso: 21 out. 2015. 
natural, retirariam o véu de externalidade da natureza, acomodando-a ao lado de seu consorte: o mundo técnico.

Figura 16 - Fotograma do curta-metragem LUCID (2016), de 3Hund

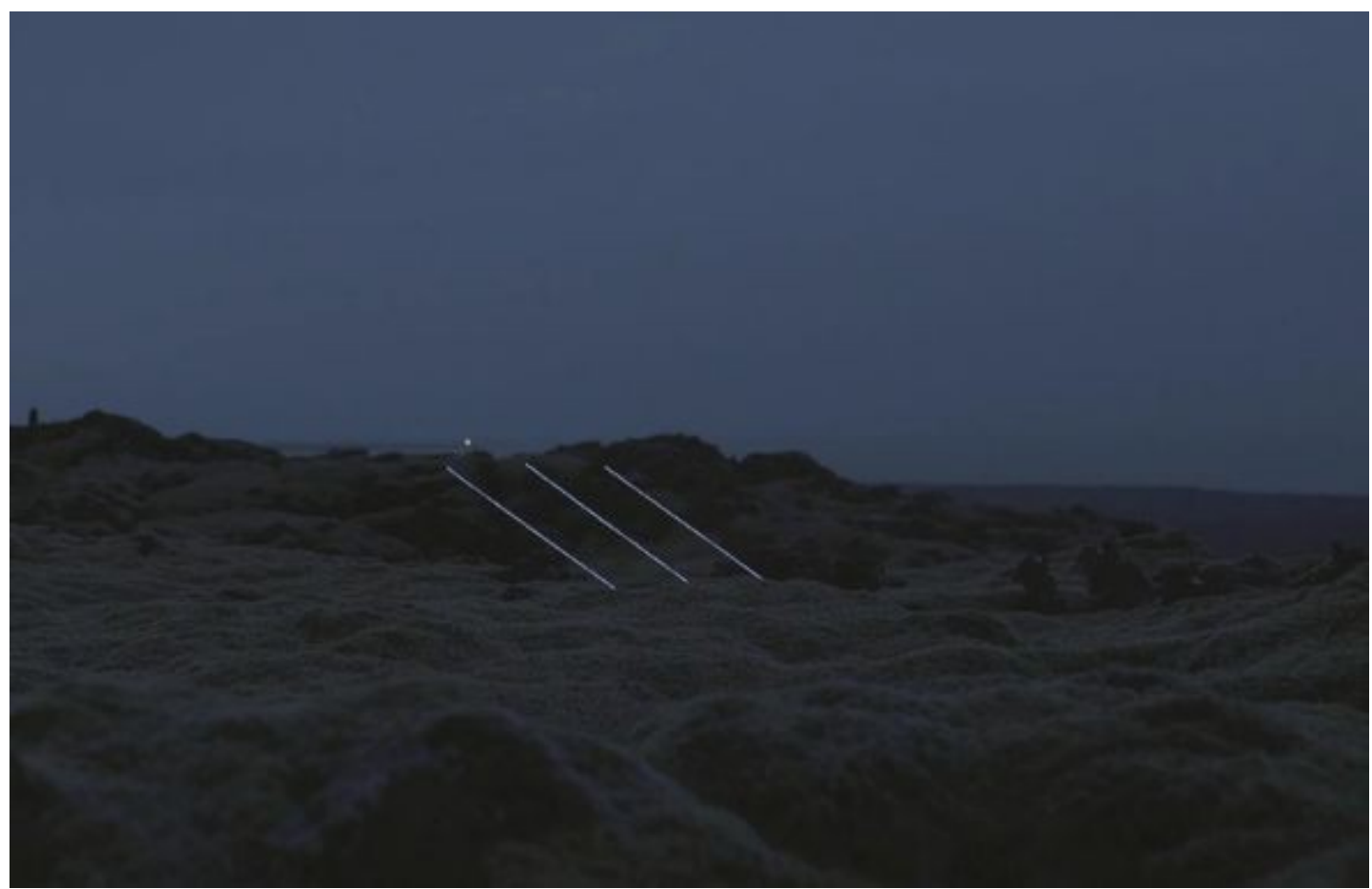

Fonte: https://www.3hund.com/lucid/

Uma outra corrente, mais condescendente com as tecnologias de ponta, poderia também enquadrar-se no campo da artemídia ecotécnica, porém sem que recaia na euforia prometeica da era digital. Evoca projetos clássicos de Land art e algumas obras de arte site-specific, em especial o trabalho Metafore, acervo construído entre 1972 e 1979 pelo arquiteto e designer italiano Ettore Sottsass, uma série de estruturas dispersadas pelos Pirineus, referida como um conjunto de formas em que a "arquitetura é reduzida a um contorno frágil que alude à presença do homem, mas o que aparece é, em vez disso, o pano de fundo imutável da paisagem". ${ }^{161}$ Tome-se como exemplo um dos projetos do 3Hund (coletivo composto pelos artistas alemães Friedrich van Schoor e Tarek Mawad) titulado LUCID (2016), obra que agrega esculturas fabricadas com objetos mais técnicos, como fios eletroluminescentes, material flexível que emite uma tênue luz em resposta à paesaggio/>. Acesso em: 22 jun. 2018. 
correntes elétricas - e outros mais insólitos, como luminárias esféricas da loja IKEA. O pano de fundo sobre o qual os objetos cintilantes da dupla justapõem-se - sejam elas fincadas em pedras ou suspensas por drones e kites - é quase irrealista, e todas as esculturas quase sempre afiguram-se no lusco-fusco, algumas por entre a névoa rasteira (chamada de o "gato do vale" no dialeto islandês), irrompendo no que parece ser o panorama de um planeta distante (na verdade trata-se do interior da Islândia), semelhante aos cenários de clima metafísico encontrados em algumas polaroides do cineasta russo Andrei Tarkovsky (GUERRA 2006). As instalações de LUCID foram cinematografadas digitalmente e convertidas em um curta-metragem, sem a incorporação de recursos gráficos de pós-produção (a única inclusão é uma trilha musical do gênero "paisagem sonora"), ${ }^{162}$ contudo olvidemo-nos por alguns instantes do produto audiovisual resultante e detenhamo-nos nos objetos em si. Primeiro, eles sobrelevam a espessura argêntea e azulada dos planaltos e glaciares islandeses, pontos-chave de um "ponto quente" assentado no Atlântico Norte, termo da geociência que expressa um determinado foco de anomalia termal no interior do planeta. Logo em seguida, revelam-se como portadores de uma atmosfera melancólica, porventura sagrada, ou mesmo como marcadores dos chamados thin places que, na tradição celta, são lugares onde o céu e a terra conectam-se intimamente. ${ }^{163}$ Por último, esses objetos técnicos, espalhados sobre paisagens intocadas, possuem a marca indelével da intervenção humana, mas não se limitam "a criar uma mediação entre homem e natureza; [são] uma mistura estável de humano e natural, contém algo de humano e natural; [dão] ao seu conteúdo humano uma estrutura semelhante à dos objetos naturais e permite[m] a inserção desta realidade humana no mundo das causas e efeitos naturais" (SIMONDON 1969: 245). ${ }^{164}$

Seguindo os passos da dupla 3Hund, outros artistas de artemídia investem na inserção de objetos técnico-ambientais em sítios abertos específicos, filtrando, do

162 Vídeo disponível em: <https://vimeo.com/186269874>. Acesso em: 23 jun. 2018.

163 Ver WEINER, Eric. Thin Places, Where We Are Jolted Out of Old Ways of Seeing the World. The New York Times, 9 mar. 2012. Disponível em: <https://www.nytimes.com/2012/03/11/travel/thinplaces-where-we-are-jolted-out-of-old-ways-of-seeing-the-world.html>. Acesso em: 23 jun. 2018.

164 Excerto no original: L'objet technique, pensé et construit par l'homme, ne se borne pas seulement à créer une médiation entre homme et nature; il est un mixte stable d'humain et de naturel, il contient de d'humain et du naturel; il donne à son contenu humain une structure semblable à celle des objets naturels, et permet l'insertion dans le monde des causes et des effets naturels de cette réalité humaine. (tradução nossa). 
imenso universo das obras site-specific, uma especificidade espacial particular, a de uma paisagem remota, sendo portanto conveniente enquadrá-las na categoria informal landscape installation. ${ }^{165}$ Invariavelmente, tais obras de arte são sedimentadas em registros audiovisuais ou fotográficos, o que não é o foco de nosso interesse, e sim um dado funcionamento de suas operações quando ainda na condição de instalações. Em uma sucinta panorâmica de obras que se valem da luz como mídia, listamos a série Marche Celeste, ${ }^{166}$ do artista e designer francês Alexis Pichot, a qual faz justiça aos elementos e elementais noturnos da floresta de Fontainebleau, banhando-os na luz de dispositivos eletroluminescentes e canhões refletores; Relativity (2018), ${ }^{167}$ do artista visual David Ogle, que nos adverte sobre os perigos da centralidade urbana, deslocando-nos, por intermédio de feixes de laser, para o mundo plural da wilderness; e, por fim, o artista estadunidense Kevin Cooley, que nos guia, com a série At Light's Edge (2009), aos remotos territórios das nações indígenas de Idaho, Montana e Wyoming, onde as "forças orgânicas colocadas em primeiro plano são usadas para questionar sistemas de conhecimento". ${ }^{168}$ Além de sua lucidez (em todas as suas acepções) o que as três obras têm em comum é o fato de suas linhas luminosas e fosforescentes riscarem a geografia do segundo plano, como se fossem uma versão extemporânea do sinalizador de Wordsworth, ou a expressão mais funcional de um sistema maquínico-luminoso, sendo que, por sistema, entenda-se: "qualquer ... processo dinâmico delimitado (isto é, limitado) que sempre surge de certas condições de fundo (de um ambiente pré-individual), alcançando uma relativa estabilidade". ${ }^{169}$ Referem-se, obviamente, ao funcionamento pulsante dos faróis marítimos, agigantando-se sobre a potência infinita do apeiron, mas sem ofuscá-lo ou desfocá-lo. Deste modo, as obras fundem, simultaneamente, os variados planos, chegando a adulterar algumas leis da psicologia da boa forma (como a aplicada ao vaso de Rubin). Por exemplo, em um dos fotogramas de LUCID

165 Ver o contexto do termo em GELIOT, Emma. David Ogle Sublimely Exploits Remote Landscapes in Loomings. Culture Colony, 26 jan. 2016. Disponível em: <https://www.culturecolony.com/news/david-ogle-sublimely-exploits-remote-landscapes-loomings>. Acesso em: 23 jun. 2018.

166 Ver Marche Céleste. Alexis Pichot. Disponível em: <https://www.alexispichot.com/marcheceleste/>. Acesso em: 23 jun. 2018.

167 Ver Relativity. David Ogle. Disponível em: <https://www.davidogle.co.uk/relativity/>. Acesso em: 24 jun. 2018.

168 Ver Lights Edge. Kevin Cooley. Disponível em: <http://www.kevincooley.net/lights-edge/>. Acesso em: 24 jun. 2018.

169 Ver a introdução de Daniel Ross in: STIEGLER 2018, p. 12. 
(ver Fig. 16), no qual três linhas eletroluminescentes em primeiro plano sobressaemse em relação a um ponto luminoso no horizonte (provavelmente o feixe de um farol distante), o segundo plano torna-se a própria figura que, por sua vez, conduz o foco de nosso olhar para o real plano de fundo.

\subsubsection{Considerações}

Muitas declarações ${ }^{170}$ atuais estão repletas de tecnoutopia, a noção de que a "tecnologia nos salvará", e isso remete aos sonhos progressistas de socialistas da época de Marx e mesmo de ambientalistas desafetos de Smithson. Em outras palavras, para muitos, a solução para os problemas criados pela tecnologia é a promoção de mais tecnologia, recurso alcunhado por alguns filósofos atuais de aceleracionismo. Seria, assim, a apoteose e o paroxismo do mito de Prometeu. Mas o mito de Epimeteu sugere exatamente o contrário, o que, sim, os artifícios de seu irmão podem até salvar a humanidade, mas salvarão tarde demais, quando já não restarão mais recursos materiais que hoje sustentam a cultura digital. $\mathrm{O}$ atraso de Epimeteu, segundo o filósofo francês Bernard Stiegler (1998), resultou em déficits de origem, presentes em todos os seres humanos, falhas compensadas com variados artifícios, principalmente aqueles voltados para a fabricação de próteses de memória. O problema do excesso de confiança nas técnicas se torna mais complexo quando nos esbarramos nos limites dos recursos naturais, composto por matériasprimas fundamentais para o funcionamento da máquina tecnológica (principalmente as chamadas terras raras). Daí o sentido de, no campo da arte, abrir mão de formas de contemplação e de experiências estéticas fundadas em uma natureza mediada, para então partir para uma "tecnicização" e "artealização" da natureza em um cenário de mudanças climáticas. Hoje nos deparamos muito com artistas e exposições de arte que exploram temas distópicos da ficção científica; mas parece que a ficção deixou de ser mera ficção, e o que era antes uma remota possibilidade vem se afirmando, a cada dia, com a força e legitimidade de um fato real. Aliás, é preciso reformular também o gênero ficção científica, ${ }^{171}$ já que não faz mais sentido

170 Ver em especial o The Ecomodernist Manifesto, assinado pelos membros do Breakthrough Institute. Disponível em <http://www.ecomodernism.org>. Acesso: 17 set. 2015

$171 \mathrm{Ver}$, nesse sentido, EVANS, Claire L. Climate Change is So Dire We Need a New Kind of

Science Fiction to Make Sense of It. The Guardian, 20 ago. 2015. Disponível em 
falar sobre exploração espacial nos laboratórios de um planeta ecologicamente devastado. Precisamos de algo inovador: uma forma de ficção científica que aborde as mudanças radicais do planeta $e$, consequentemente, de nossa realidade premente.

O campo das artes visuais passa pelo mesmo desafio do gênero ficção científica. Talvez não seja mais conveniente, e nem eficiente, recuperar as disposições de artistas românticos ligados ao pitoresco, as estratégias "além do cubo branco" da environmental art ou o caráter meramente denunciatório das mazelas ambientais observado em recentes trabalhos de artemídia. Está claro que uma das alternativas é alterar a percepção que temos da própria percepção, bem como é preciso assumir que as mudanças climáticas, que nos jogam na incerteza de um futuro selvagem, podem alterar os parâmetros e os termos da percepção em si. ${ }^{172}$ A palavra "percepção" é indicativa de que a estética e suas respectivas produções de sentidos adquire, então, uma dimensão política, caso elas consigam subverter estabelecidas visões de mundo ("Então, a fenomenologia se torna política", nas palavras de Stanley Cavell). ${ }^{173}$ Faz-se necessário, de saída, abrir mão de noções como "alta tecnologia", "progresso", "sustentabilidade" e "natureza" e substituí-las por "bricolagem", "entropia", "resiliência" e "floresta" (a palavra entropia, tão cara a Robert Smithson, ironicamente faz sua reentrada em produções "toscas" de artemídia ecotécnica). E, com distinção, investir numa forma de arte que traga o plano de fundo ao primeiro plano, mas sem que seja excluída a relevância técnica da figura. Nota-se que, nos exemplos explorados aqui, a figura não se destaca do fundo distorcido, como na técnica fotográfica alcunhada de bokeh; em todos os casos, arriscamos a dizer, a figura é o fundo - ou, quando menos, a sua mandatária.

<http://www.theguardian.com/commentisfree/2015/aug/20/climate-change-science-fiction>. Acesso: 22 set. 2015.

172 Ver BOETZKES, Amanda. Ecologicity, Vision, and the Neurological System. In: DAVIS \& TURPIN 2015, pp. 271-281.

173 Ver ROSS op.cit., p. 19. 


\subsection{O COMPLEXO ARTE-ARQUITETURA}

As experiências arquitetônicas no mundo da arte, e, inversamente, a inserção de teses artísticas no campo da arquitetura, põem duas fórmulas em constante vaivém (sempre em relação analógica, como se dá no domínio dos signos), a saber: arte na arquitetura e arquitetura na arte. A preposição de lugar "na", em ambos os casos, não tem a função de subordinação, mas de assimilação. E, quanto à primeira fórmula, não sem resistências: arquitetos da escola Bauhaus, como Gropius, não acreditavam na universalidade da arte (ARGAN 1992: 269). Além disso, há a relação conflituosa entre funcionalismo e ornamento, os esquisses décoratives de Binet, a Art Nouveau... Não cabe aqui, portanto, pronunciar-nos a respeito da primeira fórmula. Compreende-se, então, que versaremos sobre a segunda, a impregnação paulatina, mas determinada, do pensamento arquitetônico no domínio artístico, mas sob a forma de projetos integrais, e não como acessórios, expressões a que aludiremos doravante pela palavra composta arte-arquitetura. Se fôssemos elaborar uma lista de modelos desse suposto "gênero", teríamos que incluir, no mínimo, o Merzbau de Kurt Schwitters (com suas reconstruções) ${ }^{174}$ e os building cuts de Gordon Matta Clark. Contudo, um objeto de arte-arquitetura, à luz de uma estética ecotécnica, pleiteia outros traços, por certo alheios às instalações dos dois artistas citados. Mas que, em alguns casos, são também instalações. Elas estariam mais em conformidade, por exemplo, com Desert Cloud, ${ }^{175}$ imenso inflável pneumático projetado em 1972 pelo artista Graham Stevens. Flutuando sobre o deserto da Arábia, o involucro de poliéster transparente transforma-se, numa leitura conceitual, em uma metáfora do metabolismo energético e, numa leitura técnica, em um condensador de ar atmosférico, espécie de cisterna voadora para regiões desérticas. Uma outra vertente da arte-arquitetura, afora as instalações, poderia estar vinculada à arquitetura especulativa, de inspiração neofuturista, tão em voga na década de 1960. Veremos, contudo, que as atuais expressões pouco têm em comum com as de seus antepassados, inclinando-se, em alguns casos, para uma

174 Ver ORCHARD, Karin. Kurt Schwitters: Reconstructions of the Merzbau. Tate Papers, n.8, 2007. Disponivel em: <http://www.tate.org.uk/research/publications/tate-papers/08/kurt-schwittersreconstructions-of-the-merzbau>. Acesso em: 18 abr. 2018.

175 Ver HOFBAUER, Lucy. Desert Cloud, 1972-2004. Frac Centre-Val de Loire [s.d.]. Disponível em: $<$ http://www.frac-centre.fr/_en/art-and-architecture-collection/stevens-graham/desert-cloud-317.html? authID=183\&ensembleID=589 > . Acesso em: 18 abr. 2018. 
tecnociência de reabilitação, preocupada com a solução de problemas causados pela tecnocracia autodestrutiva. Tanto as instalações da arquitetura expandida, quanto os projetos de arquitetura especulativa, respondem, em proporções diversas, à atividades técnicas em sintonia com operações da natureza.

\subsubsection{Arquitetura expandida}

Em um texto controvertido da década de $1970,{ }^{176}$ a crítica de arte Rosalind Krauss propõe uma forma de esquematizar a superação da especificidade de mídias ao referenciar as experiências pioneiras em escultura expandida, a começar com a desaparição do pedestal, principal elemento de localização e contextualização do objeto artístico tridimensional. Segundo ela, a monumentalidade foi o primeiro atributo a ser expurgado da produção escultórica modernista. Não é para menos. $\mathrm{O}$ escritor austríaco Robert Musil já havia observado, no primeiro quartel do século 20, que "não há nada mais invisível no mundo que os monumentos" (MUSIL 2013: 19). Para Krauss, por meio de uma operação de espelhamento diagramático, tal negatividade transfigura-se em positividade, uma não-paisagem e uma nãoarquitetura torna-se de fato paisagem e arquitetura nesse novo campo ampliado da escultura. Essa compreensão possui implicações diretas no surgimento da arte pública, em suas diversas encarnações, como arte-em-lugares-públicos, arte-comolugar-público e arte-de-interesse-público (KWON 2004: 60), formas de instalação que foram classificadas e reclassificadas à exaustão por teóricos da arte, os quais passaram a forjar em seguida conceitos mais complexos, como site-specific, no qual o entorno do local é parte integrante do objeto, e a sua versão antitética: o filledspace, uma mera justaposição de planos, sem que haja relação direta entre figura e fundo. De qualquer modo, no mundo da arte contemporânea, os influxos ornamentais do mundo natural presentes na Art nouveau, como as famosas mechas de gavinhas, perderam o status de representação e se tornaram a própria instalação, ou, dependendo do enfoque, a própria morada. Em prol de Krauss,

176 Ver KRAUSS, Rosalind. A Escultura no Campo Ampliado. Tradução de Elizabeth Carbone Baez. Revista do Curso de Especialização em História da Arte e Arquitetura no Brasil, PUC-Rio, 1984, pp. 87-93. 
examinaremos duas formas de "escultura expandida", uma na linha tectônica (materiais) e outra na de habitação (rupestre).

\subsubsection{Geotêxteis}

Ao imaginarmos uma estética estrategicamente posicionada entre 0 pensamento tecnológico e o pensamento ecológico, insinuamos outras oposições, se é que seja possível alegá-las como produtos inevitáveis da dualidade primordial. Como vimos, a união complementar entre figura e fundo (ou sua "síntese disjuntiva", como diria Deleuze apud Viveiros de Castro), ${ }^{177}$ contraste característico de um pensamento primitivo, pode converter-se em oposições diversas, sendo lugar e espaço a complementaridade mais intuída na área de arquitetura. A presença da arquitetura na arte explora justamente tais jogos binários, mas as instalações do arquiteto canadense Philip Beesley, por exemplo, os excede para explorar seus interstícios, ou membranas, como ele prefere dizer. Sabe-se que as membranas não apenas regulam fluxos metabólicos, por isso são da ordem dos afetos, porque a "afetividade ocorre entre o dentro e fora, assim como entre a sensação e a ação". ${ }^{178}$ O conjunto de oposições que nos é familiar, no universo de Beesley configura-se em "Terra e mundo, horizonte e solo, objeto e meio, organismo e mecanismo, superfície e profundidade, pele e recipiente, instrumento técnico e cifra simbólica". ${ }^{179}$ Tome-se, por exemplo, Haystack Veil (1997), um véu de tripés feitos com mais de trinta mil galhos e dispostos na forma de uma estrutura triaxial sobre um penhasco em Deer Isle, Maine, nos EUA. Apesar do desgaste natural causado por intempéries e animais nativos, a malha está erguida até os dias de hoje, fazendo com que a ancoragem resiliente se comporte como uma segunda pele de Gaia. É um dos protótipos de futuros trabalhos ecotécnicos do arquiteto canadense que preconizam o papel dos geotêxteis como os verdadeiros intermediários entre natureza e cultura.

O geotêxtil é uma manta geossintética utilizada em obras de drenagem de solo, filtração e reforço no controle de erosão. A sua aplicação em ambientes

177 Ver VIVEIROS DE CASTRO, Eduardo. Filiação Intensiva e Aliança Demoníaca. Novos Estudos - CEBRAP, n.77, 2007, p. 91-126.

178 Ver SHAVIRO, Steven. Simondon on Individuation. The Pinocchio Theory, 16 jan. 2006. Disponível em: <http://www.shaviro.com/Blog/?p=471>. Acesso em: 15 mar. 2017.

179 Ver PAYNE, Andrew. Surface: Between Structure and Sense. In: BEESLEY 2010b, p. 51. 
externos, por vezes de difícil acesso, requer a intervenção de um designer, tal é a importância da interação do artefato com a natureza. Philip Beesley é conhecido por seu pioneirismo na fabricação digital, mas são suas experiências com estruturas têxteis e processos de formação de membranas em campos abertos o que mais se aproxima de uma estética ecotécnica na arte-arquitetura. As primeiras instalações de sua série Geotextiles (1998-2007), em grande débito com a Land art, exploram de maneira inventiva o conceito de biomimética, um processo de design que imita a maneira como a natureza opera (e não como ela aparenta) para criar novas tecnologias (BONNEMAISON \& EISENBACH 2009: 84). A prática da biomimética por Beesley é cuidadosa e não deixa transparecer nos trabalhos uma versão abstrata e idealizada da Natureza, como a atual aplicação indiscriminada da parametrização por arquitetos "sustentáveis". O uso sem critério da biomimética é equivalente ao recurso da ecomimesis (MORTON 2007), uma "poética da ambiência" que procura simular artisticamente o meio ambiente (e seus elementos) com o intuito de conduzir de forma segura o observador a um entorno fora de seu alcance imediato. Em uma crítica dura ao livro Architecture Follows Nature: Biomimetic Principles for Innovative Design (2013), de llaria Mazzoleni, a pesquisadora britânica Rachel Armstrong alerta para os perigos de uma "atenção seletiva para as atividades do mundo natural", em que apenas exemplos esteticamente atrativos são incorporados em projetos arquitetônicos biomiméticos, sem que haja a consideração de aspectos "não higienizados" da natureza (p. ex.: "abutres, a ratazana-toupeira e abominações da zona abissal dos oceanos"). ${ }^{180}$ Simondon lembra também que é a "inserção que define o objeto estético, e não a imitação" (2008: 201), ou seja, é preciso que haja um prolongamento do objeto com o mundo ao seu redor: uma estátua não é um objeto estético por imitar a forma de um humano; ela o é por estar inserida na arquitetura da cidade. É preciso combater as inclinações decorativas, as camuflagens, e investir em uma fanerotécnica que revele os materiais usados nas construções e a lógica de sua inscrição no local em que elas foram instaladas.

180 Ver ARMSTRONG, Rachel. Rachel Armstrong on Biomimicry as Parametric Snake Oil. Architectural Review, 11 jul. 2013. Disponível em: <http://www.architecturalreview.com/rethink/reviews/rachel-armstrong-on-biomimicry-as-parametric-snake-

oil/8650000.fullarticle>. Acesso em: 15 jan. 2016. 


\subsubsection{Choupanas}

O legado deixado por Martin Heidegger ao discurso arquitetônico é marcante, a ponto de se insinuar a existência de uma arquitetura "heideggeriana" (SHARR 2006: xii-xiii). É possível entrever traços de sua fenomenologia ontológica - na qual todos os entes tem caução no Ser (DUFRENNE 2015: 79) - em literaturas referenciais de arquitetura, ${ }^{181}$ de preferência o escrito ${ }^{182}$ que define a concepção de espaço ou diferencia a habitação de ocupação física. Mas há um fato de sua vida, ligado diretamente à disciplina, pouco explorado: suas estâncias em uma modesta cabana - chamada por ele de die Hütte - próxima à vila de Todtnauberg, na Floresta Negra. Exegeses interpretam a disposição do filósofo como uma resistência à modernização tecnológica e suas artimanhas para distrair o pensamento elevado; outras, como uma busca do sentido de moradia por intermédio de um ato de distanciamento e reclusão. Contudo é-nos estimada a contribuição do filósofo na discussão acerca da distribuição de locais no espaço, ou seja, em como o local, dividido em bordas, torna-se a personificação da figura - e, por conseguinte, como o espaço assume o papel do fundo (o Grund como physis) (DUFRENNE 2015: 152). ${ }^{183}$ É restaurada, por somatória, a ideia da posição física e geográfica dos sítios (pontos-chaves), de sua força no cenário, encarnando um tipo de verdade, tão memorável como a localização do Templo de Apolo ao lado do monte Parnaso (SHARR op.cit.: xvi-xvii). A cabana de Heidegger influencia, direta ou indiretamente, uma produção que liga a noção de arte-arquitetura aos abrigos de refúgio, tanto os de turismo, quanto os que simbolicamente se conectam à desobediência civil, como o fez Thoureau em Walden. Pertence ao primeiro grupo, por exemplo, a cabine ${ }^{184}$ erguida pelo artista George J. Steinmann ao longo de uma trilha próxima a Saxeten, comuna suíça que conta com cerca de 132 habitantes. Ao segundo, Outlandia (ver Fig. 17), do coletivo britânico London Fieldworks.

181 Ver, por exemplo, a epígrafe em FRAMPTON 1985, p. 280.

182 Ver HEIDEGGER, Martin. Building Dwelling Thinking. In: HEIDEGGER 1993, pp. 343-364. 183Cf., especificamente, a nota de rodapé 2.

184 Ver STEINMANN, George. Das Werk Saxeten: Eine Wachsende Skulptur von George Steinmann, 2002-2006. Disponível em: <http://www.george-steinmann.ch/15saxeten.html>. Acesso em: 22 abr. 2018. 
Figura 17 - Outlandia, choupana criada pelo coletivo London Fieldworks e projetada pelo escritório Malcolm Fraser Architects.

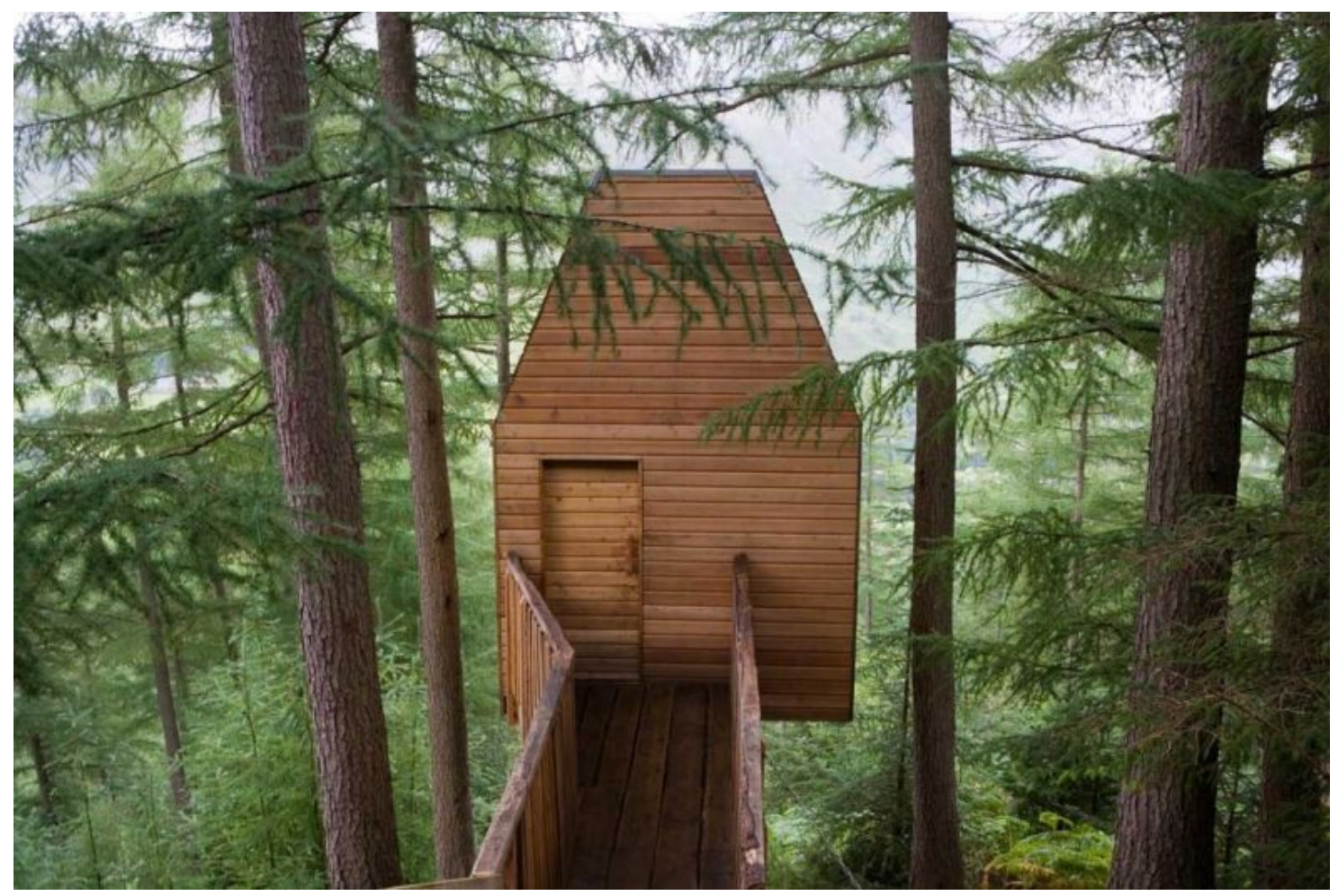

Fonte: https://londonfieldworks.com/Project-87-Outlandia

Segundo o artista escocês Bruce Gilchrist, um dos integrantes da dupla London Fieldworks, as descrições na mídia do projeto Outlandia tem um quê de erráticas: ora seria uma estação de pesquisa de campo para artistas em residência, ora um estúdio construído como se fosse uma daquelas casas na árvore tão presentes na memória da infância e, como se aventou anteriormente, um projeto de arquitetura criativa pertencente à tradição dos estudos de refúgios florestais. ${ }^{185}$ Contudo, o duo (a artista inglesa Jo Joelson compõe a outra metade) segue por outra via, imputando ao projeto a particularidade de um experimento de "arquitetura performativa", onde os agentes, humanos e não humanos, decidem as práticas que melhor lhes convém. A choupana, erguida nas escarpas de uma ravina (glen) das Terras Altas escocesas, diante de Ben Nevis, a mais elevada montanha do Reino Unido, é por certo o emblema de um ponto-chave, o sítio apropriado para se erguer um retiro civilizacional à maneira de die Hütte. Sabemos, por via do pensamento chinês, que a escolha de um local para se construir uma habitação (desde uma 
cabana rústica até o palácio de um imperador), deve se valer de técnicas de divisão de terras empregadas por agrimensores-geômetras (GRANET 2004: 119, § 5): é a Unidade Suprema que dispõe na localização conveniente o posicionamento de um Centro (op.cit.: 121, § 4). ${ }^{186}$ Contudo, Outlandia evoca também a questão filosófica sobre o significado existencial das regiões remotas na contemporaneidade, e como se dá a conexão de um centro urbano aos Degraus do Mundo, às franjas das regiões vagas (op.cit.: 69, § 1). Nesse sentido, eventuais artistas residentes em Outlandia tem ao seu dispor um serviço de Internet por satélite, cuja infraestrutura funciona graças a um gerador de célula de combustível movido a gás hidrogênio puro. Discute-se, então, a partir disso, qual a validade, em uma época na qual o humano alcançou a posição de uma força geológica, da ideia de wilderness, "aqueles espaços cada vez mais restritos de uma natureza pura, incorrompida pela presença humana, horti conclusi que dão testemunho de um passado que teria conseguido sobreviver 'intocado' desde tempos primigênios até o presente" (DANOWSKI \& VIVEIROS DE CASTRO 2014: 37). Seria então o conceito, tão caro entre os ambientalistas, uma construção mental?, pergunta-se Gilchrist. Como seria um "mundo-sem-nós", mas fortemente mediatizado e escrutinado por uma tecnologia cada vez mais sofisticada de sensores?

\subsubsection{Arquitetura especulativa}

A arquitetura especulativa saiu da berlinda após décadas e nota-se, pelas atuais composições, como evoluiu dos megaprojetos brutalistas para a esfera molecular, das cidades robóticas caminhantes para as cidades vivas (como no projeto de salvação de Veneza, o qual referenciaremos em breve), da abstração pura do ambiente construído para o estudo de materiais metabólicos - contudo sem que, no processo de transição do passado para o presente, fosse descartado os rudimentos ficcionais característicos. Pressente-se o novo espírito, por exemplo, no projeto Growing A Ship In A Yew Forest Over 200 Years (2005-6), do arquiteto e artista irlandês Christian Kerrigan, no qual ele subordinou o imperativo evolutivo de um bosque de teixos (Taxus baccata L.) à modelagem de uma embarcação - o

186 O ponto mencionado é o centro do quadrado mágico Lo Shu, representado pelo número 5 , índice da Terra, cuja forma é quadrada. 
mesmo navio relatado no poema Rime of the Ancient Mariner, de Samuel Taylor Coleridge - que se desenvolveria, in silico, ao longo de dois séculos. A disposição de se criar uma síntese relacional entre sistemas naturais e artificiais resultou em um trabalho de "nanotecnologia especulativa", ${ }^{187}$ no qual os parâmetros de crescimento das árvores são alterados em um modelo digital, como se os vegetais estivessem sendo comprimidos por cintas de metal, do mesmo modo como é executado um projeto de arboescultura. No mundo real, o artista extrai resinas periodicamente das árvores como uma forma de medição de tempo, produzindo uma coreografia estética entre o meio selvagem e o meio digital. Por certo que é um experimento mental, mas um que questiona os padrões imediatistas de espaço-tempo da arquitetura convencional.

O antigo formato da arquitetura especulativa, brandido por arquitetos radicais das décadas de 1960 e 1970, reabilitou-se em tempos presentes, mas agora vinculado ao factível (não imediato) com a introdução de procedimentos científicos. Pode-se dizer que o renascimento teve origem com a expressão "arquitetura híbrida", surgida pela primeira vez em 2005 em um ensaio ${ }^{188}$ de Georges Teyssot, mas definitivamente incorporada e sublimada por Philip Beesley em vários de seus projetos recentes que agregam tecnologia geotêxtil, microcontroladores e, entre outros dispositivos orgânicos, bolsas de gel contendo levedura, por exemplo. Além de ser apenas um experimento mental, de caráter unicamente artístico, ele pretende com isso propor outros métodos de se recuperar aterros sanitários com 0 "xenoenxerto" de "próteses terrenais" ${ }^{189}$ que evoluem e se adaptam de modo autoorganizado. O alcance dessas implicações é ampliado com as pesquisas do Science and Engineering of Natural Systems (SENSe), grupo da Universidade de Southampton liderado pelo Dr. Klaus-Peter Zauner, para quem a "prospecção da fina camada que separa o mundo animado do inanimado é recente na ciência ... e [os dois mundos] estão prestes a se confundir mais ainda com o advento de sistemas de

187 Ver ARMSTRONG, Rachel. Systems Architecture: a New Model for Sustainability and the Built Environment Using Nanotechnology, Biotechnology, Information Technology, and Cognitive Science with Living Technology. Artificial Life, Massachusetts Institute of Technology, n.16, 2009, pp.1-15. Cf. as imagens renderizadas do projeto de Kerrigan em <http://200yearcontinuum.com/Growing-A-ShipIn-A-Yew-Forest-Over-200-Years-2005-6>. Acesso em: 8 mar. 2017

188 Cf. TEYSSOT, G. Hybrid Architecture: An Environment for the Prosthetic Body. Convergence: The International Journal of Research into New Media Technologies, v.11, n.4, 2005, p. 72-84.

189 Ver MANAUGH, Geoff. Synthetic Geology: Landscape remediation in an age of benign geotextiles. In: BEESLEY 2010a, p. 42-49. 
engenharia que incorporam componentes biológicos funcionais, como moléculas, células e tecidos". ${ }^{190}$ Novas metodologias que acoplam o pensamento tecnológico com o pensamento ecológico facultam novas abordagens, abandonando as mimeses biológicas e proporcionando uma guinada em direção a formas alternativas de matéria vital. Edifícios de protocélulas, estruturas artificiais encarnadas em algas e o desenvolvimento computacional de mecanismos de coordenação indireta (estigmergia) encontrados em colônias de insetos são alguns dos exemplos que fundam uma arquitetura híbrida conectada ao meio ambiente por intermédio de trocas de informação e energia. Analisaremos em seguida duas derivadas da arquitetura híbrida: Arquitetura Sistêmica e Arquitetura Neoplasmática.

\subsubsection{Arquitetura sistêmica}

Durante uma oficina ministrada na Bartlett School da Universidade de Londres, em 2009, Rachel Armstrong, professora de arquitetura experimental da Universidade de Newcastle, definiu a arquitetura sistêmica como um "novo modelo para a geração de arquitetura sustentável que combina a disciplina do estudo do ambiente construído com o estudo científico da complexidade, ou ciência dos sistemas, adotando a perspectiva da teoria dos sistemas". ${ }^{191}$ É a injunção, na prática da arquitetura, do pensamento ecológico da interconectividade (MORTON 2012: 7), a admissão de que os humanos e suas máquinas não formam um reino separado da natureza e, acima de tudo, o reconhecimento do fator impermanência (conceito empregado quase em sua acepção budista) ao invés da obsessão moderna por objetos perenes, que supostamente não se contorcem, ou desgastam-se, como se fosse possível a ausência de fricções nos sistemas físicos, desejo em total afronta aos preceitos da tribologia, o estudo dos atritos e fricções. Para a pesquisadora, os atuais métodos empregados pela arquitetura e engenharia, apesar de teoricamente blindados por expedientes de "sustentabilidade", são vestígios da "Era Vitoriana", 192 devido a sua enorme dependência de materiais agregados, inertes. As novas matérias-primas estudadas por ela, ainda inexistentes na prática arquitetônica,

190 Cf. ARMSTRONG 2009, p. 79. 
deverão apresentar as "propriedades da matéria viva, como auto-organização, capacidade de resposta, crescimento ou movimento, e constituiria essencialmente uma nova geração de insumos inteligentes". Os arranha-céus futurísticos sustentando fazendas verticais representam, em sua visão, um modelo falido, descendente de um ambientalismo de fachada e uma cadeia produtiva viciada na manufatura industrial. Uma solução com um viés mais ecotécnico seria erguer prédios com frontais de pedra calcária, formando uma estrutura dinâmica que, além de poder ser continuamente "cultivada" por cianobactérias, assimilam o carbono da atmosfera, procedendo como uma tecnologia de geoengenharia do tipo CCS (sigla da expressão em inglês carbon capture and storage, ou captura e armazenamento de gás carbônico).

\subsubsection{Protocélulas}

Com a fusão entre ciência de borda, arte e arquitetura especulativa, arrisca-se a uma "transcendência" ainda maior em um domínio onde a linha entre a vida e a não vida é de fato tênue, ou melhor, onde o que é não vivo comporta-se como vivo, ou ainda, como na brilhante exegese que Jean-Hugues Barthélémy faz da obra de Simondon, começa-se a trilhar uma seara na qual "supõe-se que a vida dos vivos vem do que não é". ${ }^{193}$ Introduzimos, então, o que os arquitetos, cientistas e artistas Rachel Armstrong e Neil Spiller chamam de "arquitetura das protocélulas", prática que agrega em um mesmo cadinho a arquitetura de sistemas (o estudo do ambiente construído descrito no contexto da ciência de sistemas), a pléctica (o estudo da simplicidade e da complexidade, conceito criado por Murray Gell-Mann) ${ }^{194}$ e a biologia sintética, cujas pesquisas incluem, entre outras coisas, a programação direta da matéria, e não por via da computação digital, mas com técnicas de computação não convencional (conceito explorado no terceiro capítulo: a relação entre estética ecotécnica e infraestruturas). Grosso modo, protocélulas são semelhantes aos coacervatos ("coágulos líquidos"), uma concentração de partículas

193 Ver BARTHÉLEMY, Jean-Hugues. 'Du Mort qui Saisit le Vif': Simondonian Ontology Today. Artigo escrito para o colóquio Actualité de Simondon, acontecido em 16 de Junho de 2007 e organizado pelo Centre Georges Canguilhem da Universidade Paris 7. In: BOEVER ET AL. 2013, pp. 110-120.

194 Ver mais detalhes no verbete Plectics. In: Wikipedia. [s.l.: s.n.], 2017. Disponível em: <https://en. wikipedia.org/w/index.php?title=Plectics\&oldid=777648387>. Acesso em: 9 jul. 2018. 
de coloide que, acredita-se, originou a vida na Terra, servindo de matéria-prima na constituição de células orgânicas. Armstrong as reproduz por meio de bolhas de óleo imersas em fluído aquoso que, por serem sensíveis à luz e a diferentes componentes químicos, podem ser "programadas" por meio de quimiotaxia, processo de atração de células em direção a um estímulo químico. É uma forma de tropismo que, no âmbito dos estudos de vida artificial, pode ser interpretado como um modo de autopropulsão, discriminador imanente de seres vivos. Além disso, protocélulas isoladas agrupam-se formando colônias, comportamento inusual em se tratando de corpúsculos sintéticos destituídos de DNA, fato que ainda lhes permite expandir de modo ilimitado. Daí provém, associado à ideia de se instituir uma arquitetura metabólica conectada à natureza, o desejo de Armstrong de recuperar a cidade de Veneza (ver Fig. 18), hoje ameaçada pelas progressivas enchentes, fenômeno conhecido como acqua alta e que tem se agravado com o aquecimento global.

Figura 18 - Lagoa de Veneza com recife de calcário em crescimento

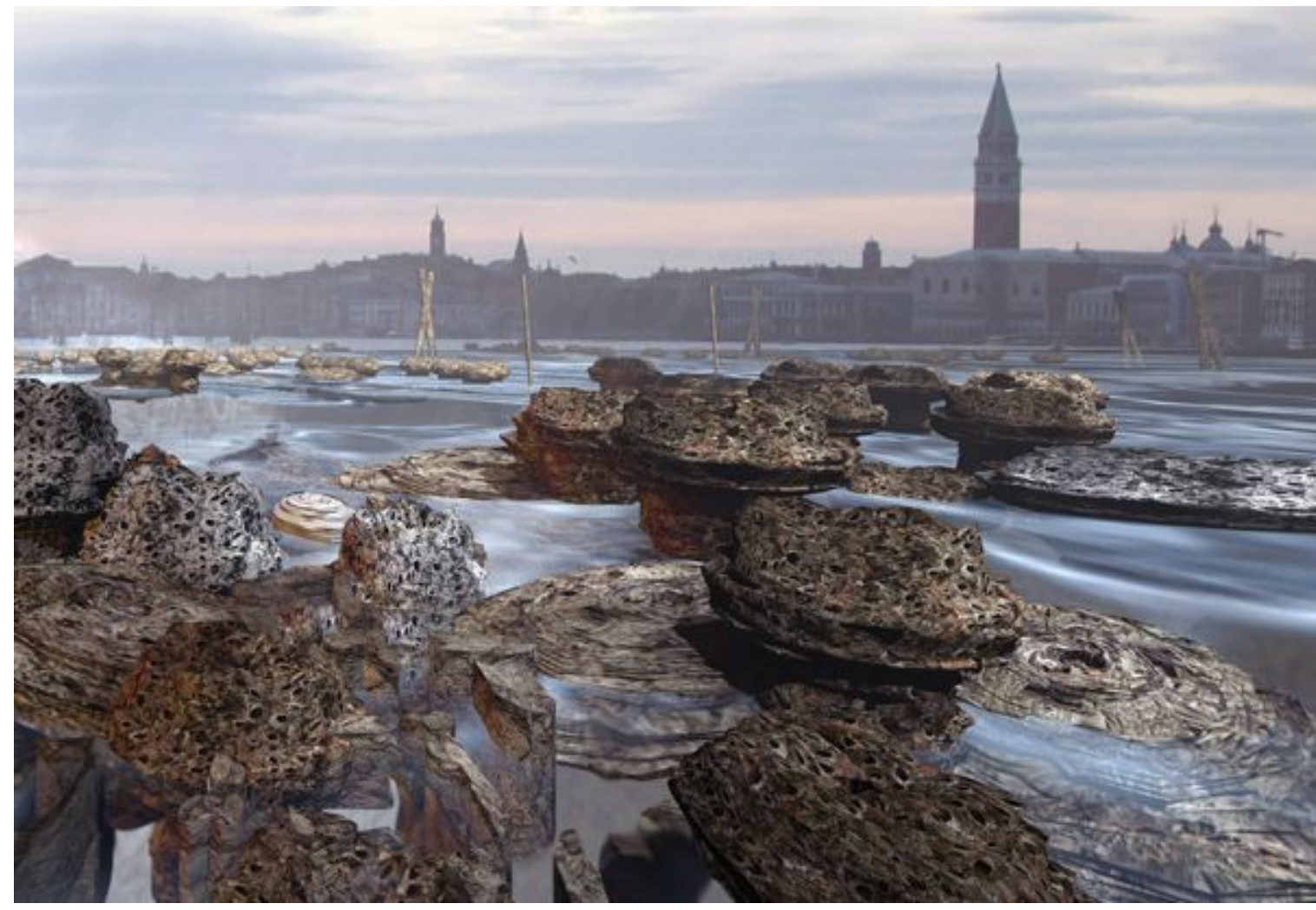

Fonte: http://200yearcontinuum.com/Saving-Venice-2009 (Imagem computadorizada por Christian Kerrigan) 
A solução encontrada pelo Ministério da Infraestrutura italiano traduz-se num dos maiores projetos de engenharia civil que se tem notícia: a instalação de barreiras móveis nas três aberturas da Lagoa de Veneza para o Mar Adriático, um conjunto técnico batizado de MOSE, acrônimo que significa Modulo Sperimentale Elettromeccanico (Módulo Experimental Eletromecânico). ${ }^{195}$ Um projeto dessa magnitude, contudo, não está infenso a adversidades. Por exemplo, quando finalizadas, as barreiras se retrairão, por efeito de força hidráulica, no momento em que as marés subirem 110 centímetros, porém a praça São Marcos já é atualmente inundada com 80 centímetros de elevação do nível do mar. ${ }^{196}$ As barreiras são coligadas por túneis submersos, os quais têm a função de facilitar o trânsito de técnicos de manutenção, atividade cuja periodicidade vai depender do número de acionamentos dos portões: a maior frequência de elevação das marés significa um maior uso das dobradiças e, por consequência, o maior desgaste dos materiais. A pergunta que se faz é: ao invés de aço e concreto, por que não empregar materiais metabólicos? Por que investir em uma obra faraônica com um prazo de validade de 50 anos se, ao invés, fossem cultivados recifes de calcário sob a cidade, uma solução mais perene? Poder-se-ia "cultivá-los", por exemplo, com a tecnologia das protocélulas, programando-as a depositar carapaças de carbonato sobre os pilares de madeira, uma estrutura escorada desde o ano 810, sabemos, no caranto (como é conhecida a camada subterrânea de argila sedimentada e extremamente compacta formada no Pleistoceno), com a finalidade de expandir as ilhas naturais da lagoa. Com isso, a estrutura original seria petrificada e, sobre ela, novos recifes e novos aterros cresceriam naturalmente ao redor dos canais e edifícios, protegendo-os das marés. ${ }^{197}$ Trata-se de uma tecnologia telúrico-química, ainda inexistente, por isso especulativa, mas não completamente inexequível, fossem destinados os 7 bilhões de dólares para a construção do MOSE a pesquisas de objetos tecno-ambientais com finalidades arquitetônicas e infraestruturais.

195 Ver HangarDesignGroup. The Sea Meets MOSE. Consorzio Venezia Nuova. Disponível em: <https://www.youtube.com/watch?v=0G6S-8-1VWc\&feature=youtu.be>. Acesso em: 17 abr. 2018. 196 Ver ROSSI, Marcello. Why Venice's New Flood Gates May be Insufficient. CityLab, 3 abr. 2018. Disponível em: <https://www.citylab.com/environment/2018/04/will-a-huge-new-flood-barriersave-venice/556226/>. Acesso em: 17 abr. 2018.

197 Ver ARMSTRONG, Rachel. Palestra proferida no PICNIC, set. 2009. Vídeo disponível em: $<$ https://www.youtube.com/watch?v=nAMrtHC2Ev0>. Ver também ARMSTRONG, Rachel. Palestra proferida no TEDGlobal, jul. 2009. Vídeo disponível em: <https://www.youtube.com/watch? v=nAMrtHC2Ev0>. Acesso em: 17 abr. 2018. 


\subsubsection{Biocalcários}

Rachel Armstrong é, informalmente, uma escritora de ficção científica. Em um de seus $\operatorname{contos}^{198}$ ela concebe uma cidade batizada de Mossville (Vila Musgo), pontuada por habitações encobertas por uma substância metabolicamente ativada pela ação da luz solar: o biocalcário. Os cientistas da narrativa manufaturam tal material pingando gotículas de óleo em uma emulsão simples que, ao absorver o dióxido de carbono da atmosfera, formam um composto de sal parecido com o carbonato, uma rocha comumente conhecida como calcário. No enredo, após o episódio de uma votação em plenário, a prefeitura aprova, com recomendações, a implementação do biocalcário no combate ao aquecimento global, persuadindo os residentes a revestirem as fachadas de suas habitações como o novo material sintético. Um aspecto estético, somado à pauta de planejamento, começa a tomar conta da paisagem urbana em Mossville, porque "as áreas que haviam sido pulverizadas com a solução começam a se transformar e produzir uma rocha esbranquiçada, altamente estampada e úmida". O conto especulativo, encomendado por um centro de pesquisa da Universidade do Sul da Dinamarca, tem como função servir de ferramenta de apoio no ensino de sustentabilidade em escolas públicas, mas pode-se interpretá-lo, heuristicamente, como uma reflexão sobre a urgência de se pesquisar e desenvolver materiais inovadores para a arquitetura e a construção civil. Além disso alude, em certos trechos, às fantasias vitalistas de Bruno Schulz, como as suas descrições de "seres amorfos, desprovidos de estrutura interna, produtos da tendência imitadora da matéria, que, dotada de memória, repete por hábito as formas já adotadas uma vez" (SCHULZ 2012: 54). Essa "pseudofauna" e "pseudovegetação" imaginadas pelo escritor polonês são, coincidentemente, criadas nos mesmos moldes que os seres protocelulares de Armstrong, podendo "ser obtidos pela suspensão de certos coloides mais complexos numa solução de sal de cozinha" (op.cit.). Em nosso livre exercício de literatura comparada é possível analisar como os dois autores sublinham o mérito de uma natureza "desnaturada", de como tudo o que parece intacto e dado é o efeito de uma longa cadeia de modificações intencionais, como os pastos abertos da Inglaterra, que sucederam as

198 Ver ARMSTRONG, Rachel. Biolime: Mock Rock. In: ARMSTRONG 2015, pp. 189-193. 
milenares florestas temperadas devido à ação de desmatamentos e incêndios. ${ }^{199}$ Nesse quadro, Armstrong descreve a resistência dos adeptos da permacultura em admitir a coexistência entre processos artificiais e naturais e, por conseguinte, compreender a natureza "não natural" do biocalcário de Mossville.

\subsubsection{Arquitetura neoplasmática}

Essa concepção foi proposta em uma edição da Architectural Design, ${ }^{200}$ revista arquitetônica publicada pela John Wiley \& Sons. O vocábulo "neoplasia", segundo a literatura médica, denota o crescimento anormal de tecido orgânico ( $p$. ex. tumores), contudo, conforme sugerido no editorial da publicação, seguiremos o bioartista australiano Oron Catts, que reinterpreta o neoplasma como uma "entidade semiviva". A mesma inflexão é, diremos, traço constituinte da bioarquitetura, sem que isso signifique incluí-la na tipologia da arquitetura verde que, a despeito de amparar-se em noções da estética arquitetônica contemporânea - tais como materiais impuros e superfícies irregulares - não pressupõe questionamentos radicais como, por exemplo, o estudo de habilidades protocognitivas de certas moléculas e seus conjuntos. ${ }^{201}$ Especulemos, portanto, se será possível plantas e edifícios assimilarem-se mutuamente. Opondo a resposta aos conhecidos jardins implantados em coberturas, os chamados "telhados verdes", ou mesmo os populares jardins verticais, como paredes de cultivo e muros verdes, a nossa abstração envolve ou incorpora organismos vivos diretamente às armações construtivas (scaffolding). Um dos impedimentos práticos de se extrapolar o campo da arquitetura sustentável tradicional é o grau de imprevisibilidade que materiais vivos impõem-se ao controle absoluto pretendido pelo arquiteto, profissional habituado a projetar edificações como se fossem estruturas narrativas aristotélicas, atendendo a uma forma de composição integral com começo, meio e fim. $\mathrm{Na}$

199 THOUSANDS of Years Ago, This Was a Forest. See What Remains. Direção de Burnham Arlidge. National Geographic, Short Film Showcase, 2018. Vídeo disponível em $<$ http://video.nationalgeographic.com/video/short-film-showcase/thousands-of-years-ago-this-was-aforest-see-what-remains>. Acesso em: 9 jul. 2018. 200 Ver Architectural Design, v. 78, n. 6, Novembro/Dezembro 2008.

201 Ver o texto de apresentação de Protocognition, oficina parte da ALIFE, conferência internacional sobre síntese e simulação de sistemas vivos ocorrida em Tóquio, Julho de 2018. Disponível em: <http://uncomp.uwe.ac.uk/Protocognition/Protocognition2018.html>. Acesso em: 7 jul. 2018. 
mencionada edição da $A D$ é Rachel Armstrong quem assinala ${ }^{202}$ como modelo singular de arquitetura viva o The Molecular House (2000), dos arquitetos estadunidenses John M. Johansen e Mohamad Alkayer, projeto especulativo que tem a forma de um diário de anotações, datado do ano de 2200 , escrito pelo proprietário de uma habitação manufaturada por um processo de engenharia molecular. ${ }^{203}$ A técnica é derivada das propriedades das plantas, contudo as suas qualidades autônomas não pertencem exclusivamente ao reino vegetal. ${ }^{204}$ Ao longo dos dias, por exemplo, somos informados de que as fundações de apoio, desenvolvidas como se fossem um sistema vascular arterial, têm a forma de radículas, emergidas de tanques de composto químico dispostos ao largo da construção. Similarmente, as áreas vazias das vigas transversais da superestrutura, alcunhada de "treliça", são preenchidas por pequenas nervuras de conexão, cujas densidades podem ser espessadas ou afinadas de acordo com um programa. Por intermédio de sinais pré-programados, as membranas da cobertura alteram-se do opaco para o transparente, proporcionando aos moradores um desempenho térmico, luminoso e enérgico. Em nove dias, a operação é finalizada. Qual será, no interior da diegese que Ihe foi atribuída, o seu futuro? Imaginemos que, caso não seja demolida ou reciclada (possibilidades aventadas pelo próprio escritor do diário), a casa molecular possa ter a mesma duração que a dos cedros da ilha japonesa de Yakushima, árvores com idade superior a 2200 anos. ${ }^{205}$ É, como o projeto nanotecnológico de Christian Kerrigan, um olhar incisivo ao deep time do porvir e um desafio aos imperativos imediatistas da arquitetura moderna.

Os mesmos princípios de ecologia biossintética, segundo Armstrong, ocorre em Homeostatic Membrane (2008), projeto de nanotecnologia de Anders Christiansen, graduado da Bartlett School. Propõe-se, nesse exemplo, a transferência do conceito de homeostase - equilíbrio dinâmico entre o indivíduo e seu meio; e uma das ações de sobrevivência do Umwelt - para o campo da arquitetura, proporcionando o balanceamento do sistema interno da edificação

202 Ver ARMSTRONG, Rachel. Artificial Evolution: a Hands-off Approach for Architects. Architectural Design, op.cit., pp. 82-85.

203 Ver ONA. Disponível em: <http://www.ona.vg/vision/growthhouse.html>. Acesso em: 7 jul. 2018. 204 Cf. ARMSTRONG 2008.

205 Ver YANAGIHARA, Hanya. A Real-life Enchanted Forest. The New York Times, 17 mai. 2018. Disponivel em: <https://www.nytimes.com/2018/05/17/t-magazine/yakushima-japan-hayao-miyazakiprincess-mononoke.html>. Acesso em: 7 jul. 2018. 
(umidade, temperatura, etc) a despeito de variações nas condições externas. Tratase de associar materiais semivivos e não vivos ao invólucro construtivo, como se fizessem parte de um "sistema vascular" que conecta "sistemas de coleta e purificação de água, biorreatores de microalgas e células fotovoltaicas", elementos assimilados à própria "carne da membrana". ${ }^{206}$ Como é sugerido pela pesquisadora britânica, manifesta-se uma inquietude relacionada aos materiais tradicionais contemplados por projetistas do mercado. Essa conclusão é inferida, por exemplo, dos testes da parede de concreto autorrecuperáveis realizados por Henk Marius Jonkers na Universidade de Tecnologia de Delft, na Holanda. ${ }^{207}$ A reparação de rachaduras em concreto armado tornou-se um problema clássico na história da ciência da computação, tendo sido solucionado, em parte, pelo engenheiro soviético Vladimir Lukyanov que, em 1936, projetou um computador hidráulico para calcular a "distribuição dos fluxos de calor" e as "relações complexas entre a temperatura e as propriedades variáveis implicadas na duração do concreto", uma operação expressa pelas chamadas equações diferenciais parciais. ${ }^{208}$ No caso de Jonkers, desconsidera-se o aspecto computacional e matemático do problema e recorre-se ao campo da biologia, sendo a reparação realizada por uma espécie de bactéria inofensiva à saúde humana, dando ao convencional concreto um aspecto de "bioconcreto". Fato que, contingentemente, insere o concreto - o material de construção mais aplicado no mundo - na esfera biopolítica, com base na qual pode-se pensar numa bioestética. Bernard Stiegler, propositor de tal categoria, nos demonstra que toda forma de produção, seja mental ou manual, pode ser descrita como uma exosomatização (a "gramatização" do pensamento em mídias externas ou a externalização do gesto laboral em máquinas industriais) e que tais concretizações técnicas são suscetíveis a processos de "seleção artificial", grau estrito de biopolítica e, em última análise, de fazer artístico, motivo "pelo qual traduzimos o grego techné para o latim ars" (STIEGLER 2018: 99). Passa-se, deste modo, dos materiais convencionais aos materiais neoplasmáticos sonhados pelos arquitetos da arte contemporânea, próximo estágio biopolítico da estética arquitetônica.

206 Ver ARMSTRONG, Rachel. Designer Materials for Architecture. Architectural Design, op.cit., pp. 86-89.

207 Ibid.

208 Ver SOLOVYEVA, O. Water Computer Machines. Science and Life, n. 4, 2000. Disponível em russo: <http://www.nkj.ru/archive/articles/7033/>. Acesso em: 8 jul. 2018. 


\subsubsection{Considerações}

O título da seção 2.2, por certo, é idêntico ao nome de obra de Hal Foster (2015). A nomeação, admitimos, não é exatamente uma homenagem ao crítico de arte estadunidense, posto que, na medida em que ele estreita a relação entre artistas e a esfera arquitetônica, tal convergência se dá no vetor que vai da arte para a arquitetura (não obstante a segunda seção do livro dedicar-se a "arquitetos para quem a arte era um ponto de partida essencial") (op.cit.: 6-7). De todo o modo, parece-nos que a ênfase do crítico reside na primeira fórmula, a saber, a assimilação da arquitetura pelo mundo da arte, o oposto de que nos propomos na introdução. Mas consideremos novamente o título do livro. No prefácio, ele descreve que optou pelo termo "complexo" - após o descarte de "encontro" e "conexão" - por três razões, sendo a principal delas, em nossa visão, "para designar os vários conjuntos em que a arte e arquitetura são justapostas e/ou combinadas" (op.cit.: 12-13). É essa complexificação entre as duas disciplinas que evocamos em nosso título, tanto na reflexão sobre alguns exemplos do que chamamos de arquitetura expandida, quanto nos hibridismos da arquitetura especulativa contemporânea, ditada por sonhos de organismos complexos, não mais plenamente orgânicos, mas organológicos, na palavra de Bernard Stiegler, porque a "exosomatização começa como um novo estágio na organogênese através do qual os viventes se complicam, combinando-se originalmente com os não-vivos" (STIEGLER 2018: 132). A respeito da inclusão de geotêxteis e choupanas, o propósito é amplificar algumas das características objetivas e subjetivas da estética ecotécnica, como a adequação tecnológica e a percepção fenomenológica, porque fiamo-nos que a "arquitetura proporciona algo como uma epoché ambiental, um espaço de projeto destinado a produzir efeitos no sujeito", ${ }^{209}$ similar à Academia de Platão, espaço concebido para ser um "colchete" do mundo externo, quase um local de meditação (e, óbvio, de pensamento).

209 Ver ROBBERT, Adam. Architecture and Epoché. Knowledge Ecology, 22 out. 2016. Disponível em: <https://knowledge-ecology.com/2016/10/22/architecture-and-epoche/>. Acesso em: 9 jul. 2018. 


\subsection{INFRAESTRUTURAS INVENTIVAS}

A noção de resiliência em infraestruturas, para além do campo das ciências dos materiais e econômicas, vem conquistando relevância no campo acadêmico, principalmente na literatura de planejamento e desenvolvimento urbano, bem como no estudo de conjuntos técnicos que dão suporte ao funcionamento das sociedades. O problema é que o conceito vem cada vez mais sendo cooptado pelo oficialismo, definido como a dependência do Estado para a resolução de todos os problemas. Parece-nos que uma das estratégias para evitar que ele seja colonizado e universalizado em um único projeto é considerá-lo esteticamente, ${ }^{210} \mathrm{em}$ particular através de uma estética politizada, um tanto ao modo de Jacques Rancière, cujas teorias implicam, entre outras coisas, que encantos ideológicos dominantes sejam quebrados por um "dissenso estético": a reconfiguração da experiência sensória coletiva. A título de exemplo, as políticas públicas que definem como a realidade das infraestruturas de energia, e sua permanência, é percebida ("distribuição do sensível", segundo o filósofo francês) são influenciadas por uma indústria dependente de combustíveis fósseis, equipada com elevado capital político. E se essa visão de mundo, ou sensibilidade, fosse subvertida por um outro pensamento estético? Por exemplo, o movimento Arts and Crafts, surgido na segunda metade do século 19 foi, em essência, uma resposta crítica e estética à revolução industrial e seus objetos kitsch, bem adequados ao gosto da classe burguesa emergente. $\mathrm{Na}$ esfera das figuras de linguagem, ao invés de associar o pensamento de resiliência com metáforas do tipo "pilha de areia" e "queimada controlada", ${ }^{211}$ propomos ligá-lo às imagens intuitivas do Zen budismo ${ }^{212}$ (ondas, água ${ }^{213}$ etc.) e a uma estética

210 Ver ADEY, Peter; GROVE, Kevin. Security and the Politics of Resilience: an Aesthetic Response. Politics, 2015, vol.35(1), pp. 78-84.

211 Ver PETRILLO, Adriana Scotti; PROSPERI, David C. Metaphors from the Resilience Literature: Guidance for Planners. In: SCHRENK, Manfred; POPOVICH, Vasily V.; ZEILE, Peter. CORP 2011 Proceedings/Tagungsband, 2011.

212 Ver RAMÍREZ, Rafael; RAVETZ, Jerome. Feral Futures: Zen and Aesthetics. Futures, v.43, n.4, 2011, pp. 478-487. Nesse estudo, os autores propõem uma abordagem estética e Zen budista para se lidar com as incertezas contemporâneas acerca do futuro, item relevante nas análises de risco.

213 É de autoria de Bruce Lee, artista e instrutor de artes marciais, uma frase de inspiração Zen que se encaixa perfeitamente ao pensamento de resiliência propenso às dinâmicas de sistemas complexos: "Esvazie sua mente de modelos, formas, seja amorfo como a água. Você coloca a água em um copo, ela se torna o copo. Você coloca a água em uma garrafa, ela se torna a garrafa. Você coloca ela em uma chaleira, ela se torna a chaleira. A água pode fluir, a água pode destruir. Seja água." 
ecotécnica que faça a ponte entre o pensamento tecnológico e o pensamento ecológico. E pode-se efetuar essa mesma estratégia com relação à acepção geral que particulariza o termo infraestruturas - obras, redes, sistemas - destituindo-o de significados "oficiais".

\subsubsection{Critical Infrastructure}

Uma das terminologias criadas por Martin Heidegger se refere ao modo de existência dos objetos do nosso cotidiano, em especial dos instrumentos que usamos de forma natural, sem tecermos maiores teorias a seu respeito. $O$ célebre exemplo é o do martelo: usamo-lo como se fosse a extensão de nossas mãos, sem concentrar a nossa atenção para o objeto em si, pois, caso contrário, correríamos o risco de perder o controle do gesto laboral e nos ferirmos. "Em consequência, normalmente não percebemos ou focalizamos o martelo como tal. Aquilo de que estamos conscientes primeiramente é o lugar de trabalho; dentro dele, dentro da 'totalidade instrumental', instrumentos particulares são enfocados à medida que se tornam necessários" (INWOOD 2002: 113-15). Pode-se dizer que o martelo, quando plenamente funcional, torna-se invisível, uma "prontidão à mão", um intermediário prático que silenciosamente ajuda-nos a cumprir uma determinada tarefa. Mas, quando inutilizado, quando quebrado, muda o seu modo de ser, passa a ser visível, torna-se uma incômoda "presença à mão". A noção poderia ser ampliada para fora do universo das ferramentas, dos elementos técnicos (na terminologia de Simondon) e expandir para as máquinas, para o conjunto formado por elas, incluindo infraestruturas completas, como as de telecomunicações, por exemplo. É preciso, então, desvelar a engenharia dos conjuntos técnicos, esmiuçando os tecidos e ligamentos de seus órgãos internos, ainda que à guisa do design crítico, ou mesmo das ficções especulativas.

O projeto Critical Infrastructure, do artista canadense Jamie Allen, comissionado para o festival de arte e tecnologia alemão transmediale 2014, apropria-se dessa incumbência. Composta por uma instalação elaborada com instrumentos geotécnicos e tecnologias de medição da paisagem, o projeto, que conta também com oficinas e produção de textos, faz uma reflexão sobre como as 
"infraestruturas são imediatamente detectadas, mas são também indiscerníveis; elas estão ao mesmo tempo em toda parte e em parte nenhuma". ${ }^{214}$ Allen se refere especificamente às infraestruturas de informação e comunicação, com seus alicerces inscritos em uma ordem materialista, geológica, mas que operam em camadas numéricas cada vez mais abstratas. Esses sistemas banais e hipernormalizados supostamente independem de nossa preocupação, de nossa atenção, e não foram criados para serem notados. Normalmente não percebemos o que os fazem funcionar, e quando notamos tais estruturas subjacentes é porque algo aconteceu, geralmente algo de terrivelmente errado, como um alastrado blackout. Segundo Allen, as infraestruturas de telecomunicações são "transparentes em termos de como as usamos, mas opacas no que diz respeito a como funcionam", exatamente como no exemplo do martelo de Heidegger. É preciso, portanto, fazê-las adentrar no espaço sensório humano por meio de uma estética. ${ }^{215}$

O mérito do projeto é delatar o excesso de abstração da era digital e exortar o regresso ao físico, ao que é concreto. Conta-se, para isso, com o auxílio de mantenedores e técnicos. O primeiro artigo do manifesto do engenheiro crítico, declaração prescritiva elaborada pelo artista neozelandês Julian Oliver e seus irmãos de armas, dispõe que a engenharia é "a linguagem mais transformadora do nosso tempo, moldando a maneira como nos movemos, comunicamos e pensamos. É função do engenheiro crítico estudar e explorar esta linguagem, bem como expor a sua influência." ${ }^{216} \mathrm{De}$ acordo com o manifesto, é recomendada a revisão do imperativo invisível das infraestruturas, revelando-as e tornando-as aparentes por meio de uma "virada estética". ${ }^{217}$ No caso das infraestruturas de comunicação, separar o ruído do sinal seria o mesmo que separar o joio do trigo, mas, na

214 Ver ALLEN, Jamie. Critical Infrastructure. A Peer-Reviewed Journal About [s.d.]. Disponível em: <http://www.aprja.net/?p=1677>. Acesso em: 12 jan. 2017.

$215 \mathrm{Em}$ nossa visão, a infraestrutura crítica de Allen complementa-se nos estudos literários ecológicos (ecocriticism ou crítica ambiental), um modo de investigação que explica as maneiras através das quais os textos culturais descrevem o mundo natural e as forças que o definem. Assim como o ecocriticism esquadrinha expressões ecológicas nas artes, a infraestrutura crítica revestir-seia de igual vocação, mas agora com o foco em infraestruturas conciliadas com o ambiente natural.

216 Ver OLIVER, Julian; SAVIČIĆ, Gordan; VASILIEV, Danja. The Critical Engineering Manifesto. The Critical Engineering Working Group, 2011-2016. Disponível em: <https://criticalengineering.org/pt>. Acesso em: 13 jan. 2017.

$217 \mathrm{lbid}$. O artigo primeiro estabelece que "qualquer tecnologia de que dependemos constitui um desafio e uma ameaça. Quanto maior é a dependência em relação a uma tecnologia, maior é a necessidade de analisar e expor seu funcionamento interno, independentemente de direitos ou questões legais." 
realidade, há sempre um meio associado mascarando nuances entre os dois termos. O meio associado é a prova da materialidade, quase no sentido jurídico do termo. $O$ documentário The Russian Woodpecker (2015), ${ }^{218}$ de Chad Gracia, é sobre a misteriosa torre de transmissão localizada próxima da região de Chernobil, na Ucrânia. Ao longo da Guerra Fria, Duga-3, como era denominada, emitia um padrão de transmissão repetitivo, cuja função, desconhecida por décadas, foi motivo de dezenas de teorias conspiratórias. A verdade é que essa engenhosa obra de infraestrutura, hoje desativada, era na verdade um radar Over-The-Horizon (OTH) de monitoramento do espaço aéreo, capaz de fornecer um aviso prévio em possíveis eventos de lançamento de mísseis balísticos inimigos, dando o tempo ao alvo de planejar uma resposta. A complexa e corpulenta armação constituída de gaiolas cônicas, plataformas suspensas e tubulações encurvadas é uma obra fanerotécnica por excelência, que apesar de ter ocultado a função de seus sinais durante décadas, sempre desvelou a sua potência estrutural aos olhos do mundo. Nesse sentido, Duga-3 poderia quase fazer-se passar por uma instalação ao ar livre de Takis, escultor do pós-guerra conhecido por explorar a energia do campo magnético em suas obras semelhantes a antenas.

\subsubsection{Infrastructure Fiction}

O design de infraestruturas requer hoje a introdução de uma condicionante estética e, por conseguinte, de elementos imaginativos e especulativos. É preciso partir, talvez, de um ponto biomimético, mas sem recorrer aos recursos de uma grotesca camuflagem, uma "mentira materializada". ${ }^{219}$ Ao invés de aplicar modelos antropocêntricos e racionais como se fossem um "significante mestre" na elaboração de estruturas de telecomunicações, por que não espelhar as operações que já existem na natureza? Por exemplo, há um canal sonoro presente nas profundezas

218 Ver o trailer do documentário em <https://www.youtube.com/watch?v=9rd4ARsbg_0>. E também a série fotográfica HAЯP, do artista norueguês Øystein Sture Aspelund, na qual ele contrasta a estrutura metálica de Dunga-3 com um cenário enevoado, realçando a impressão estética, em <http://oysteinaspelund.com/projects-2/\#h-a-\%d1\%8f-p>. Acesso em: 13 jan. 2017.

219 As torres de celular travestidas de árvores são justamente a versão contemporânea do exemplo de Simondon (2002: 202): o reservatório de água travestido de ameias. Ver BROOK, Pete. Cellphone Towers Disguised as Trees Are a Puzzling Attempt at Aesthetics. Wired, 26 mar. 2013. Disponível em: <https://www.wired.com/2013/03/dillon-marsh-invasive-species/>. Acesso em: 14 jan. 2017. 
do oceano, chamado de SOFAR (Sound Fixing and Ranging Channel), que ocupa uma determinada camada oceânica onde é mínima a velocidade do som. Neste canal, sons de baixa frequência podem viajar milhares de milhas sem perder a sua qualidade, o que o torna ideal para o intercâmbio comunicacional de certos animais marinhos, como as baleias. É patente que não seria o caso substituir as atuais tecnologias de comunicação por uma infraestrutura puramente ficcional ou mesmo refazer os primeiros testes de cabos telegráficos transatlânticos. O que vale é a analogia, o método de se criar uma identidade de relações entre modos de pensamento (e não relações de identidade, segundo Simondon), noção que também nos faz lembrar da sempiterna função social das infraestruturas.

Tome-se a ideia de Infrastructure Fiction (Infraestrutura Ficcional, em tradução livre), modo livre de se inventar visões do futuro, com um viés de futurecraft, método descrito pelo futurólogo estadunidense Alex Stefen como uma caixa de ferramentas mentais para se construir um futuro técnico mais resiliente, dinâmico e equitativo. ${ }^{220}$ Suas fontes de intuição e referência são o design crítico - forma de design na qual o conceito prevalece sobre o objeto materializado - e o método futures thinking no domínio específico das infraestruturas. O criador do termo, o acadêmico inglês Paul Graham Raven, recomenda que a solução proposta em um projeto de design fiction (parte integrante do design crítico) deve ser antes de tudo factível, deve fazer-se crível. ${ }^{221} \mathrm{Na}$ perspectiva da filosofia das técnicas de informação, o nosso exemplo do canal SOFAR funcionaria como uma banda de transmissão ampla, que resolve em parte um problema técnico: para que haja uma maior variação do sinal que carrega informação (ou seja, significação), maior deve ser a largura de banda, o que demanda mais índices de energia para ampliar o seu espectro. Em um futuro não muito distante, a banda submarina poderia ser empregada, com o mínimo de sacrifício energético, para transmitir informação não como estereotipia pura, como a regularidade dos sinais de sincronização das redes de televisão, mas como algo infinitamente variável (SIMONDON 2008a: 153). No campo estético, são proficientes os instrumentos de comunicação com cetáceos criados pelo artista Ariel Guzik

220 Ver STEFFEN, Alex. Retro-futurecraft and Rethinking Tomorrow. Alex Steffen, 19 nov. 2015. Disponível em: <http://www.alexsteffen.com/retro_futurecraft_and_rethinking_tomorrow>. Acesso em: 13 fev. 2017.

221 Ver FENLON, Wesley. Infrastructure Fiction: Sci-fi with a Realistic Goal. Tested, 8 nov. 2013. Disponível em: <http://www.tested.com/tech/concepts/458957-infrastructure-fiction-sci-fi-realisticgoal/>. Acesso em: 15 nov. 2016. 
(2015): cápsulas de quartzo fundido integradas por mecanismos de cabos e circuitos. Afora a descrição técnica, tais dispositivos seriam como identificadores de "culturas" de outras espécies.

\subsubsection{Solarpunk}

É de praxe, entre os praticantes do gênero literário da ficção científica (ou subgênero, a depender do círculo acadêmico que o chancela), descrever o futuro da humanidade sob o prisma da distopia, ou a utopia negativa, um lugar que ainda não existe, mas que, ao o fitarmos como se fosse um espelho negro, não desejaríamos que existisse. A distopia é o apanágio do movimento Cyberpunk, surgido na década de 1980 para paralisar o fluxo de imagens de um futuro perfeito reproduzidas durante os Trinta Anos Gloriosos. Tinha-se uma agenda, mas ela foi superestimada. Mas propor um horizonte obscuro e niilista acabou tornando-se uma comodidade. Perdeu-se o élan. À espreita, o Steampunk, um verdadeiro exercício de anacronias tecnológicas, logrou impor-se. Mas o seu retrofuturismo continha algo de tenebroso. Era indispensável o uso de uma força mais drástica para quebrar o encanto da destruição e do apocalipse. Introduz-se, então, o Solarpunk, outra subdivisão do predecessor Cyberpunk, mas que imagina um mundo de prosperidade, resiliência e estética tecnológica. Não obstante seus preceitos otimistas, como que elaborados pelo personagem de Voltaire, Dr. Pangloss, o movimento tem um caráter fortemente político, com influencias do anarquista Murray Bookchin (1986) e suas noções de tecnologia liberatória e ecologia social. Em termos de período histórico, seus correlegionários poderiam sequestrar algumas imagens do Steampunk e incluir em suas expressões objetos da literatura vitoriana, repleta de menções às novas infraestruturas da época. Todavia, uma outra estética era iminente. Propôs-se - e o prefixo configura uma ideia diretiva - não o anacronismo, mas o sincronismo, como painéis solares de vitral em estilo Art Nouveau; ${ }^{222}$ ou a descoberta fortuita de qualidades high-tech em dispositivos low-tech; ou a convivência da permacultura com a biotecnologia. E assim por diante. Com efeito, a tendência adequa-se

222 Ver WILK, Elvia. Is Ornamenting Solar Panels a Crime? e-flux Architecture / Positions [s.d.]. Disponível em: <http://www.e-flux.com/architecture/positions/191258/is-ornamenting-solar-panels-acrime/>. Acesso em: 9 abr. 2018. 
plenamente à ficção infraestrutural. O tema e os casos são amplos, mas vamos nos deter aqui em algumas narrativas ecofuturistas de Kim Stanley Robinson e animações de Hayao Miyazaki.

Figura 19 - Esboço de produção da animação Nausicaä do Vale do Vento (1984)

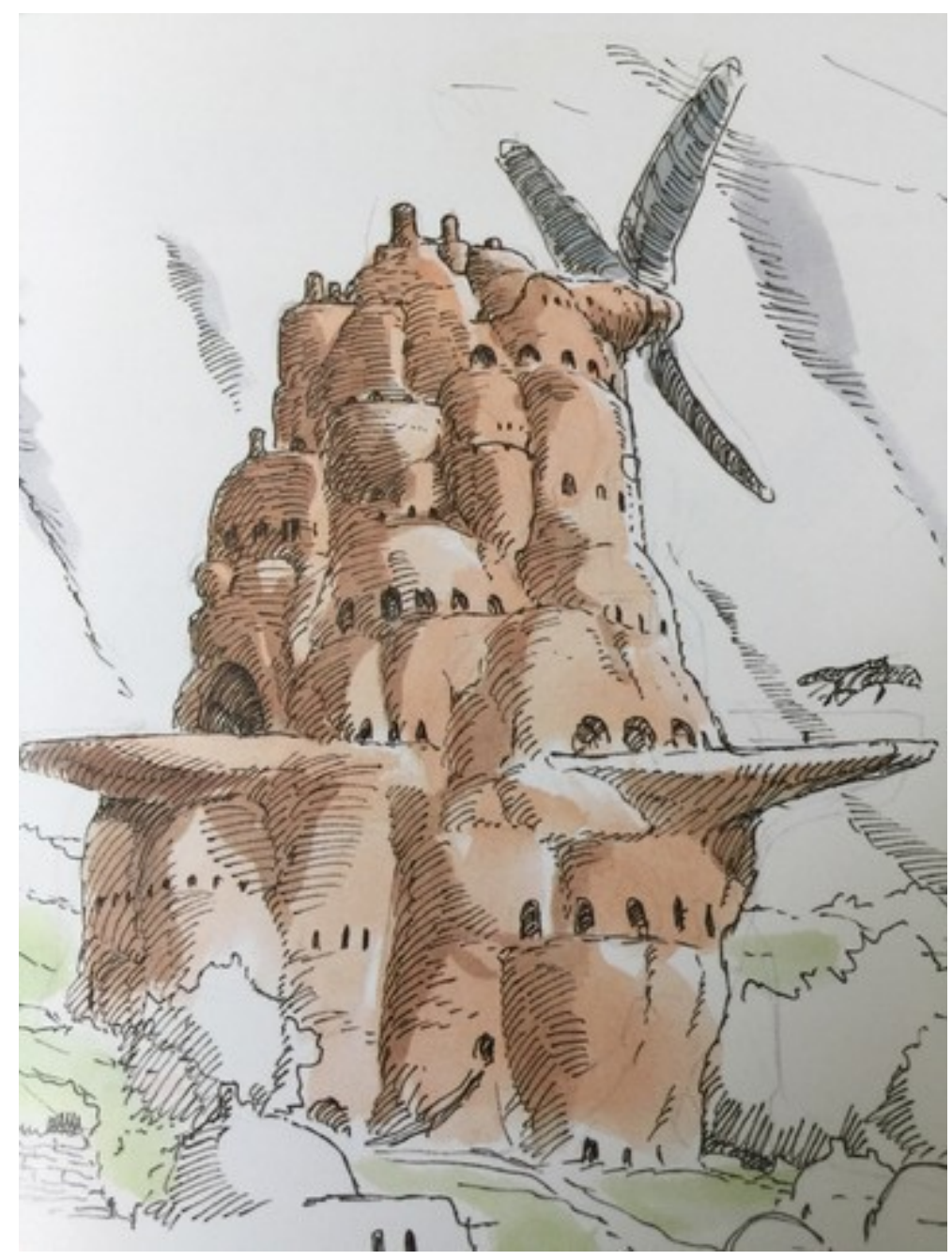

Fonte: https://www.pinterest.com/pin/491877590537005195/ (Direitos autorais: Studio Ghibli, 1984)

O cinema é uma mídia que explora com alguma frequência tais enlevos ficcionais nas infraestruturas. Em uma primeira leitura, os filmes de animação do diretor japonês Hayao Miyazaki colocam em evidência o valor intrínseco da natureza, em contraste direto com o seu valor de uso, como na animação Avatar (2009); mas a sua força inventiva está nos detalhes dos apetrechos. A principal obra que consegue se adequar mais aos parâmetros da ficção infraestrutural é Nausicaä do Vale do Vento (1984), história sobre um pequeno país de aldeões com uma 
população de aproximadamente quinhentas pessoas. Ele está localizado na borda do Mar da Corrupção, mas o vento limpo constante do Oceano de Sal protege o vale fértil de seus miasmas e esporos. O vento é idolatrado pela comunidade e movimenta diversos moinhos (ver Fig. 19), alimentando as infraestruturas da comunidade, inclusive as de irrigação. Em termos políticos e econômicos, a narrativa futurista incorpora em retrospectiva um modelo feudal de vassalagem, na qual lealdades ao reino de Tolmekia são trocadas por proteção bélica. Salvo a curiosa retroatividade histórica da narrativa, são as disparidades de fontes energéticas empregadas pelos personagens que chamam a atenção: enquanto a carismática princesa Nausicaä se locomove por meio de um planador (chamado de Mehve) equipado com um motor de propulsão movido a energia eólica armazenada, os aviões de carga e de caça do reino de Tolmekia dependem de motores a combustão, necessitando de grandes quantidades de propelentes, provavelmente combustíveis fósseis. Outra denotação sobre os prejuízos de antigas formas energéticas materializa-se nos Deuses Guerreiros, gigantescos seres biomecânicos com capacidade de disparar devastadores feixes de energia atômica, daí sendo considerados em grande parte responsáveis pelos Sete Dias de Fogo, epíteto de um antigo holocausto nuclear.

\subsubsection{Setores infraestruturais}

Como já vimos, partimos do pressuposto, desenvolvido em pormenores na filosofia de Gilbert Simondon, de que todo o tipo de conhecimento (percepções, conceitos etc.) é essencialmente um conjunto de relações que, em princípio, pode ser explicado através de um sistema que organiza e coordena uma relação do tipo figura-fundo, a mais elementar e primitiva forma de estruturação do mundo alcançada por humanos (BARDIN 2015: 6-7). No caso de uma estética ecotécnica aplicada a projetos artísticos de infraestrutura, a gestalt fundante é levada, em alguns casos, para a dimensão da relação sinal-ruído, investigada nas técnicas de transmissão de informação, mas também para a dimensão da relação entre energia potencial (armazenada) e energia cinética (movimento), considerando que a "estética e, principalmente, as distinções metafísicas, envolvem discriminações entre 
[por exemplo] dentro e fora" (MORTON 2007: 48). Não que no processo histórico haja uma evolução de uma operação de distinção mais básica para uma mais complexa; o que está em jogo é uma marca distintiva que surge em todas as relações, uma "marca especial (ou uma série delas) que nos torna cientes de que estamos na presença de marcas (significativas)" (loc.cit.). No caso da relação entre ruído e sinal haveria a distinção, segundo Simondon (2008a: 154), de três termos: puro acaso (ruído), a forma (o canal e o sinal que o trafega) e a informação (significação). Da descontinuidade entre um esquema figurado artificial e a natureza física externa, surge a diferença. Esse é o princípio da distinção, o qual presta também às infraestruturas críticas e ficcionais. $E$, entre elas, há os setores, assim como os há entre as infraestruturas reais. É necessário enfatizar que as configurações setoriais e técnicas propostas aqui têm um ar especulativo: atendem ao receituário da ficção infraestrutural.

\subsubsection{Comunicação}

Segundo o Departamento de Segurança Interna dos Estados Unidos (DHS em inglês), infraestruturas críticas são "patrimônios, sistemas e redes, sejam eles físicos ou virtuais, de tal forma vitais para o país que, caso sejam incapacitadas ou destruídas, poderão acarretar um efeito debilitante na segurança pública, segurança econômica nacional, saúde pública, ou qualquer combinação desses itens". ${ }^{223}$ Portanto, a interrupção dos serviços da rede mundial de computadores, seja por motivos naturais ${ }^{224}$ ou não, é motivo de temor constante por parte da elite responsável pela securitização dos EUA, pois supostamente teria um efeito mais devastador que um ataque nuclear. Nessa linha, a experiência performática da Südthüringer-Wald-Institut (REIZNER 2012), organização de pesquisa independente cuja sede foi instalada temporariamente em uma caverna situada a 200 metros de profundidade sob uma floresta da Turíngia, na antiga Alemanha Oriental, reestrutura o imaginário do DHS em um cenário pós-apocalíptico e com uma estética constituída

223 Cf. What Is Critical Infrastructure? Homeland Security, 2016. Disponível em: <https://www.dhs.gov/what-critical-infrastructure>. Acesso em: 2 mai. 2019 (obs.: página desativada). 224 LO AND BEHOLD, Reveries of the Connected World. Direção: Werner Herzog. Chicago, Illinois, EUA: Saville Productions, 2016. Documentário (98 min). Ver o trecho em que a astrônoma estadunidense Lucianne Walkowicz alerta sobre os riscos de uma tempestade solar de maior intensidade incapacitar por completo a internet. 
por dispositivos pessoais autônomos e aplicativos de arquivo de código aberto. A moção reconstrutora do grupo de engenheiros e espeleólogos revive de certa forma os encargos de Milcíades, personagem de novela futurista de Gabriel Tarde (1974) na qual a população do planeta, única espécie viva após uma catástrofe solar, é compelida a viver em galerias e salões cavernosos. O "neo-trogloditismo" subterrâneo implantado pelo novo líder da humanidade pretende reinaugurar uma civilização que "começou nas cavernas, e estava destinada a retornar a esses abrigos subterrâneos, mas a um nível muito mais profundo" (op.cit.: 78-79). A marcha a ré, porém, não possui traços anarcoprimitivistas. Na análise de Déborah Danowski e Eduardo Viveiros de Castro, a regeneração proposta por Milcíades não é um "retrocesso a uma condição de primitividade natural, mas ... uma interiorização técnica do mundo ... [E] a natureza, não mais experimentada como um entrave à liberdade humana, é completamente estetizada, e se torna um mito" (2014: 81). É como se, no fundo daquelas furnas, preenchidas por estalactites esculpidas artificialmente, a physis se auto-organizasse com o auxílio de uma techné.

Assim como os subterrâneos de Tarde abrigam uma filosofia, praticada por devotos da beleza e da psicologia molecular (TARDE op.cit.: 161-194), a caverna na Turíngia abrange um pensamento, produto conjunto de uma filosofia da decentralização e de uma estética da resiliência. A configuração de um sistema de telecomunicações da estaca zero só é possível graças ao avanço tecnológico das redes ad-hoc, ${ }^{225}$ um tipo de rede que não possui um nó ou terminal especial, mas é desenhada a partir de uma malha de dispositivos autônomos, sem fio ou cabeados. A infraestrutura de rede do instituto é baseada no OSI (acrônimo do inglês Open System Interconnection), modelo de rede de computadores dividido em sete camadas de funções que permitem a comunicação entre máquinas heterogêneas, a saber: física, dados, rede, transporte, sessão, apresentação e aplicação. Há uma hierarquia de dependência que avança da camada mais concreta (física) em direção à mais abstrata (aplicação). Para evitar uma possível falha da topologia de rede, o modelo do instituto se vale apenas das duas camadas mais extremas do modelo, a camada física, chamada de Autonomous Node Device (Dispositivo de Ponto Autônomo) e a camada de aplicativo, chamada de Archive Platform (Plataforma de Arquivos), centrada em um banco de dados aberto, o Apache CouchDB, codificado 225 Principalmente na área de roteamento. Cf. SHERIF 2013. 
em Erlang, uma linguagem de programação tolerante a falhas devido ao tempo de execução de seus módulos, recurso típico de equipamentos de telecomunicações para missões críticas. Além disso, a estrutura executa tarefas em uma camada de apresentação virtual, renderizando uma interface gráfica simples, mas com recursos de navegação e gerenciamento de arquivos. Em termos de resiliência, a opção por uma topologia diagramática, mais operacional e menos hierárquica, ao invés de uma topologia representacional, derivada de um esquema do tipo centro-periferia, tem motivações técnicas, mas é no fundo uma opção estética (ADEY \& GROVE 2015: 81). A primeira expedição da equipe de campo do instituto, realizada no dia 23 de junho de 2012, passou com sucesso por uma bateria de testes que simulam o rigoroso evento do Final dos Tempos, tendo sido prognosticada a estabilidade relativa do sistema para os próximos "50 a 70.000 anos" (REIZNER op.cit.: 36).

\subsubsection{Informação}

Ora, o que seria de uma infraestrutura de comunicação sem o apoio de uma infraestrutura de informação? Um sistema de telecomunicação sem "inteligência"? É nesse sentido que adicionaremos uma camada computacional ao sistema de comunicação, embora não se contemple aqui o funcionamento efetivo e robusto do objeto tecno-ambiental, porque nos ancoramos na esfera da engenharia crítica e não da engenharia oficial. As máquinas sobre as quais iremos discorrer, é verdade, não foram projetadas para "funcionar" nos termos de um computador real, o qual é concebido para resolver problemas de diversas ordens, sendo os mais primários as operações básicas de matemática - até os mais complexos, como os problemas indecidíveis e intratáveis. O que se pergunta é: quais são as capacidades fundamentais e limitações dos computadores atuais? Deixemos de lado a linguagem formal dos algoritmos e tratemos do desempenho material em si. Não é o funcionamento "instrumental", portanto, que abordaremos, mas a própria atividade do funcionamento - e sua respectiva transparência. Demonstra-se isso com rigor em computadores de brinquedo, como o Digi-Comp II, ${ }^{226}$ comercializado durante a década de 1960, uma máquina que usa bolinhas de gude rolando em um plano

226 Ver uma réplica em EVIL MAD SCIENTIST. Digi-Comp II: First Edition. [s.l.: s.n., s.d.]. Vídeo disponivel em: <https://www.youtube.com/watch?v=_tZdE-3nR3w>. Acesso em: 11 maio 2018. 
inclinado para realizar cálculos básicos. À medida que avançam, as bolinhas movem cambotas (peça que faz um movimento de vaivém, como as alavancas do fliperama) para cima e para baixo, como se fossem portas lógicas, as quais permitem - ou não - que elas passem por determinadas vias. Outro exemplo são os autômatos celulares, modelos clássicos da teoria da computabilidade, descritos como máquinas evolutivas, as quais materializam-se física ou mentalmente, impondo-se como um elo perdido entre natureza e técnica, suscitando indagações milenares: seriam as operações da natureza discretas ou contínuas, analógicas ou digitais? "As configurações produzidas por autômatos celulares nos ajudam a entender melhor a mecânica de formação de padrões, propagação e interação em sistemas naturais: ... proteínas de membrana bacteriana, reatores químicos, permeação de água no solo, gás comprimido, divisão celular, dinâmica populacional e comportamento coletivotrivial, sistemas de reação-difusão e auto-organização" (ADAMATZKY \& MARTíNEZ, 2016: v). Pode-se verificar, visualmente, a evolução temporal de tais autômatos: começa-se desenhando no papel uma grade simples, bidimensional, composta por "máquinas de estados finitos", ou, em linguagem coloquial, "células". Dá-se como regra que o valor verdade de sua condição - apagada ou acesa, clara ou escura, vazia ou cheia (e, no formalismo computacional, 1 ou 0 ) - depende do estado das células vizinhas imediatas. Por exemplo, qualquer célula viva com menos de duas vizinhas vivas morre de "solidão"; ou qualquer célula viva com mais de três vizinhas vivas morre em virtude de "superpopulação". Ou vive, em nenhum desses dois casos. E assim, sucessivamente, repetidamente. Mostra-se assim um padrão, imprevisível e organizado, a partir de preceitos simples. A linguagem, nota-se, é das ciências naturais, todavia situamo-nos no mundo técnico. Então, diremos, a técnica imita a natureza, porque os padrões das conchas de gastrópodes do gênero Conus formam-se exatamente pelo mesmo procedimento! 
Figura 20 - Rechnender Raum (1967), de Konrad Zuse (sob o pseudônimo Kuno See)

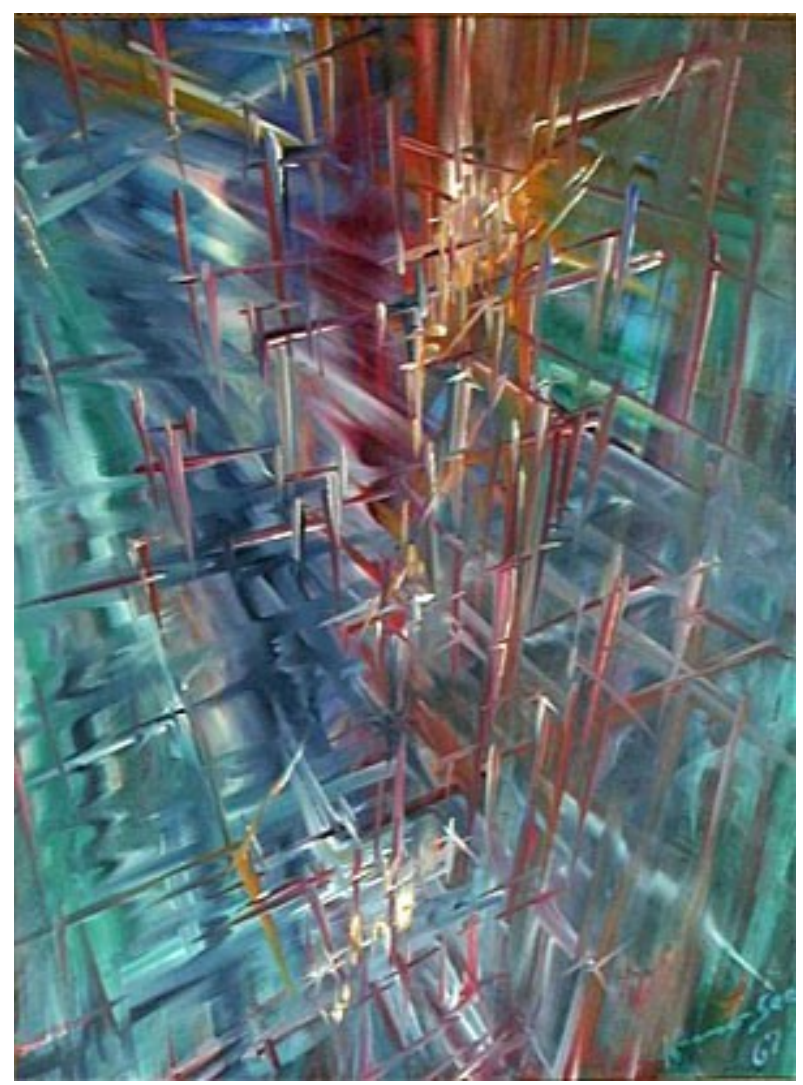

Fonte: http://www.kgms2.com/zuse/

Figura 21 - Rechnender Raum (2007), de Ralf Baecker

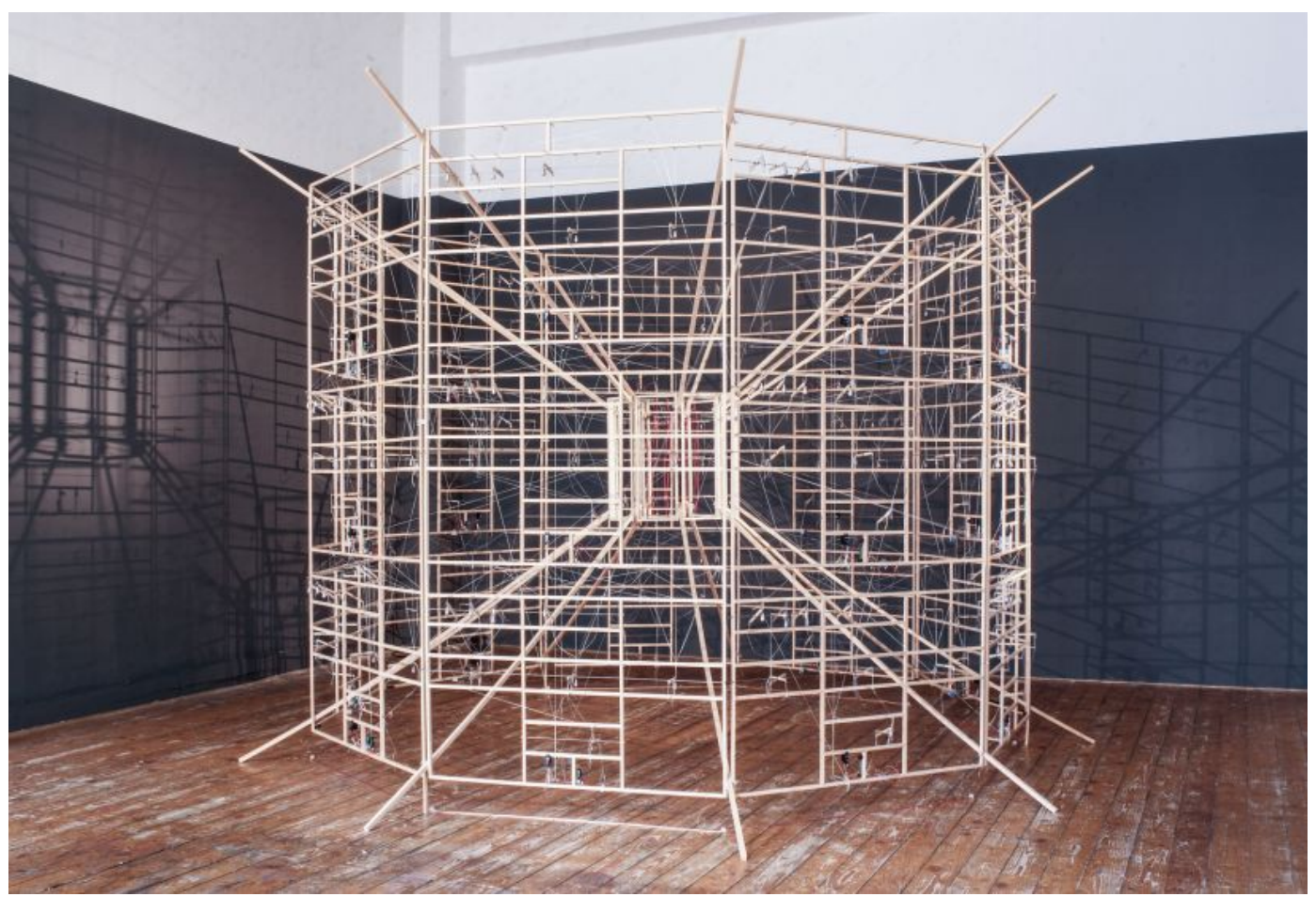

Fonte: http://www.rlfbckr.org/work/rechnender-raum/ 
As operações de conexão e as regras de cálculo dos autômatos - a sua associação aos robôs não é por acaso - podem ser vistas como as operações elementares do processamento da informação. O que matemáticos, físicos e teóricos da computação colocam em evidência, em curvas de enunciação e visibilidade, é a afinidade entre os processos físicos e os cálculos numéricos, mesmo que o primeiro incline-se para o sentimento $e$, o segundo, para o pensamento formal; o que importa é que ambos dirigem-se ao mundo (DUFRENNE 2015: 27-8). É significativo que o engenheiro alemão Konrad Zuse, um dos propositores dos autômatos, dedicava-se nas horas vagas às artes plásticas, retratando, entre outras coisas, o Rechnender Raum ("espaço de cálculo"), teoria sobre a condição determinística do universo ou, antes, uma refutação da incerteza exposta em ligações interindividuais, sendo aquela uma ilusão explicada pelo ponto de vista do observador interior ao sistema (DUPUY 2011: 84). A sua pintura mais famosa (ver Fig. 20), parte do acervo do Museu de Tecnologia de Berlim, representa um dos processos elementais do seu espaço de cálculo, no qual duas partículas digitais, ao se chocarem, produzem uma terceira entidade. Foi inspirado nessa pintura, e em seus conceitos subjacentes, que o artista alemão Ralf Baecker forjou uma escultura homônima (ver Fig. 21), "uma estrutura de treliça aberta feita de cordas, polias e alavancas manipulando um estranho 'mostrador' elástico em seu núcleo". ${ }^{227} \mathrm{O}$ objeto é tecno-ambiental porque dá legibilidade a um evento computacional (no caso, a regra 110, introduzida por Stephen Wolfram em 1983, uma operação de reconhecimento de padrões para autômatos celulares) através de um processo cinético, continuo na natureza. Porém, ao contrário de Digi-Comp II, a máquina de Baecker "nunca oferece uma 'interface' aos humanos, mas se afasta constantemente, e para dentro, em direção a si mesma". ${ }^{228}$ Além disso, ela nunca está ociosa, "trabalha devagar, incansavelmente, num processo interminável", 229 como as máquinas de Turing, do célebre matemático britânico, experimento de imaginação para verificar a computabilidade de números, mas que, em alguns casos, "podem iludir o examinador, fazendo com que [sigam] funcionando, desempenhando suas operações inescrutáveis, jamais interrompendo sua atividade,

227 Ver BAECKER, Ralf; WHITELAW, Mitchell. Epistemological Machines and Protocomputing. In: ADAMATZKY \& SCHUBERT 2015. pp. 1-17. 
nunca se repetindo de maneira óbvia, e deixando o observador para sempre no escuro quanto à possibilidade de interrupção de seu funcionamento" (GLEICK 2013: 219; grifo do autor). O autômato de Turing é a prova de conceito que atesta a limitação das máquinas "pensantes", mesmo os computadores quânticos. Já a obra de Baecker assinala a premência de se instaurar uma autêntica cultura mecanológica na sociedade contemporânea, uma sociedade cada vez mais oprimida por dispositivos com interfaces amigáveis, mas tecnicamente ininteligíveis.

\subsubsection{Energia}

Uma obra "tecno-ecológica", gênero lançado pelos artistas letões Rasa Smite e Raitis Smits, faz justiça ao setor energético de nossa ficção infraestrutural, a despeito de a dupla imputá-la antes como um modelo pós-midiático de percepção de dados. Trata-se de Pond Battery (2014-2015), um desdobramento de Biotricity (2014-2015), pesquisa de ciência e tecnologia sobre a produção de eletricidade por micro-organismos, notadamente bactérias. Nessa continuação, seis células de combustível microbianas são instaladas na lagoa do Jardim Botânico da Universidade da Letônia, em Riga, subsistindo lá ao longo de seis meses. Para os artistas, o ponto-chave do projeto assenta-se a posteriori, na quantização de produtividade das células, tanto na forma de sonoridade, como na de visualização de informação, uma das diversas técnicas de processamento de dados por meio de imagens. Grosso modo, a medição contínua da voltagem produzida pelas bactérias são codificadas, tornando audível e visível uma atividade invisível da natureza. A partir daqui consignamos o projeto, sem endossar a visão "tecno-ecológica" e pósmidiática da dupla, porque entendemos que o seu ponto-chave reside na dinâmica do ecossistema local e sua relação com os aparatos de energia renovável. A estética situa-se, em nossa visão, na própria geração de eletricidade por bactérias da espécie Geobacter, consumada pela oxidação de compostos e mecanismos extracelulares de transferência de elétrons. A transformação de eventos contínuos em paisagens de dados no espaço da galeria tem uma função cognitiva, por certo, mas a quantização do sistema contínuo em um sistema distinto é um modo de redução, não aquela fenomenológica, que interdita o julgamento das coisas, mas 
uma de caráter reducionista. Elegemos por praticar a epoché segundo a singular fórmula sugerida por Dufrenne segundo a qual, na atitude estética, o espectador é levado a suspender a crença espontânea no mundo (sentido amplo), sem que o mundo da obra (sentido estrito) seja neutralizado (2015: 191), o que nos conduz, paradoxalmente, à suspensão de descrença, no sentido que o poeta Samuel Taylor Coleridge the atribui, qual seja, a crença na aparência de verdade de uma narrativa fantasiosa. Sem desmerecer o conceito do projeto letão, a sua essência situa-se, de acordo com a estética ecotécnica, nas células sobre o lago, bem como no conceito, ainda em gestação, de "tecnologia viva", que "herda inevitavelmente a imprecisão da própria vida". ${ }^{230}$ Para além do que é factível ou não, a fórmula de Dufrenne nos faz crer, parafraseando a terceira lei de Clarke, que qualquer tecnologia suficientemente avançada é indistinguível da natureza. ${ }^{231}$

\subsubsection{Considerações}

Alguém dirá que, em tempos de crise energética e das infraestruturas em geral (inclusive de telecomunicações), é dispensável falar sobre uma estética ecotécnica no setor. É preciso apostar, anunciam os tecnocratas de plantão, na extração de combustíveis líquidos e gasosos do subsolo e demonstrar a necessidade de modernização das infraestruturas existentes, caso contrário seremos tragados para um crise sem precedentes. Respondemos: não corroboramos! É preciso, em nossa opinião, arriscar em um trajeto oposto, em um caminho que nos leve em direção ao que John Michael Greer chama de "sociedade ecotécnica", etapa civilizatória que sucederia o "industrialismo da escassez" - a fase posterior (ou descendente) do Pico de Hubbert ${ }^{232}$-, e a "sociedade de recuperação", fase de total esgotamento das fontes de energia não-renováveis, durante a qual a população se utilizará de processos de reciclagem e retrofit de matérias-primas abandonadas por gerações anteriores. Mas isso não acontecerá de hoje para

230 Ver BEDAU, Mark A. Living Technology Today and Tomorrow. Technoetic Arts, v. 7, n. 2, 2009, pp. 199-206.

231 Ver ARMSTRONG, Rachel. Any Sufficiently Advanced Civilization is Indistinguishable from Nature. Next Nature Network, 18 fev. 2012. Disponivel em: <https://www.nextnature.net/2012/02/anysufficiently-advanced-civilization-is-indistinguishable-from-nature/>. Acesso em: 17 maio 2018.

232 Ver o verbete Pico do petróleo. In: Wikipédia, a enciclopédia livre. [s.I.: s.n.], 2015. Disponível em: <https://pt.wikipedia.org/w/index.php?title=Pico_do_petr\%C3\%B3leo\&oldid=43486112>. Acesso em: 29 mar. 2017. 
amanhã; demorará séculos. Como complemento da noção de "dissenso estético" de Rancière, Greer evangeliza o "dissenso técnico", uma postura contra qualquer consenso infraestrutural que, para ele, "reduziria as opções num momento em que o leque de potenciais escolhas deve ser o mais amplo possível" (GREER 2009: 9497). Portanto, ao invés de investir em tecnologias de fraturamento hidráulico, o mais sensato seria reconquistar a afinidade com o movimento da tecnologia adequada (SCHUMACHER 2010), popular na década de 1970, descrita como uma tecnologia "intermediária, de baixo custo, alternativa, socialmente apropriada, popular, comunitária, radical, emancipadora, libertária, utópica, doce, não-violenta, ecológica, de vila, suave, poupadora de capital etc.". ${ }^{233}$ Greer não considera possível prever exatamente como será a sociedade ecotécnica do futuro, tamanha a temporalidade que nos separa dela; daí a necessidade de se imaginá-la agora, mesmo que por meio de ficção. Nesta futura sociedade, por exemplo, a noção de Tecnologia da Informação e Comunicação (TIC) será completamente reformulada, a começar pela própria noção de informação que, para além das três instâncias fechadas de Luciano Floridi, ${ }^{234}$ poderá ser qualquer sinal inusitado, como ondas eletromagnéticas e vibrações digestivas de anelídeos.

\subsection{EXPRESSIVIDADES GEOCIENTÍFICAS}

No campo da análise de cenários, o futuro é visto como previsível, imprevisível ou, no extremo, como uma entidade selvagem, sendo esta um futuro que ilide a nossa capacidade de interpretá-lo como previsível ou imprevisível: é um animal que, outrora domesticado, escapou para a mata e lá recuperou toda a sua ferocidade. O futuro selvagem não pode ser mais enquadrado sob a metodologia da análise de riscos, pois os riscos são prováveis ou não prováveis, isto é, estão sujeitos ao acerto (ou erro) do cálculo de probabilidades. Portanto, devemos encarar o futuro selvagem com outros enquadramentos metodológicos, não-ortodoxos, como o Zen, prática filosófica e religiosa que nos permite abandonar preconceitos e assim

233 Ver ROSA, Cláudio Porto da. Tecnologia Apropriada: um Conjunto Homogêneo? Revista de Administração de Empresas, v.29, n.1, 1989, p. 47-51.

234 Para colocá-la sob uma ótica de distinção, Floridi divide o conceito de informação em três formas: informação "como" realidade (noção física), a informação "para" a realidade (noção instrumental) e informação "sobre" a realidade (noção semântica). Cf. FLORIDI 2010, p. 75. 
responder a situações emergentes sem precedentes; e a estética, que articula uma maneira particular de perceber e apreciar a realidade de forma intuitiva. ${ }^{235}$ As situações condicionadas por um futuro selvagem não emergem "naturalmente", ou seja, reclamam a força motriz de uma ação humana, isto é, são antropogênicas. No presente, o exemplo mais contundente é representado pelo fenômeno das mudanças climáticas, alterações do Sistema Terra causadas, entre outras coisas, pela emissão não natural de gás carbônico na atmosfera. É consenso entre os cientistas que tal conjuntura coloca a humanidade frente a um futuro absolutamente incerto, ou seja, um futuro selvagem. Além da tradicional racionalidade expandida para lidar com os desastres causados por mudanças climáticas, a abordagem estética pode ser útil como uma forma de meta-racionalidade para se ajuizar tais incertezas. Investigamos assim, nessa seção, qual o papel da arte e da estética não apenas em projeções acerca do futuro físico do planeta Terra mas, principalmente, na articulação do conhecimento científico envolvido nesse processo, em particular o obtido por dispositivos das ciências de Terra, um conjunto de disciplinas que atualmente direcionam-se ao esquadrinhamento minucioso da atividade de quatro esferas do planeta: geosfera, biosfera, hidrosfera e atmosfera. Afora os sensores ubíquos, há de se incluir no rol da ecotécnica geocientífica artefatos de biologia sintética, estudo de ervas e micologia, sistemas de manejo de recursos hídricos, técnicas de geoquímica, entre outros. Para tanto, usamos como inspiração metodológica a estética ambiental, ou uma de suas abordagens, desenvolvida por Allen Carlson (2002: 6), o modelo ambiental, o qual recomenda a apreciação da natureza à luz do conhecimento proporcionado pelas ciências naturais, especialmente as ciências ambientais, como a geologia, a biologia e a ecologia.

\subsubsection{As quatro esferas}

É difícil determinar qual a origem da ideia por meio da qual se argumenta que o planeta Terra é um "ser vivo", para não dizer um sujeito senciente, ou mesmo consciente, como o planeta aquático da novela Solaris, lançada pelo escritor de ficção científica polonês Stanislaw Lem em 1961. A propósito, tudo leva a crer que tal percepção tenha sido iniciada no próprio ato da palavra, em um regime 235 Cf. RAMÍREZ \& RAVETZ, supra. 
circunscrito às fábulas. Como "prova de conceito" da evidência, a dupla Deleuze e Guattari se valeu de um antigo conto de Arthur Conan Doyle, ${ }^{236}$ em que um cientista contrata um perfurador de poços artesianos para ajudá-lo em um desafio: introduzir uma broca no solo o mais profundamente possível, no que viria a ser o maior projeto de escavação da história. O resultado é que o grupo atinge um estrato misterioso, composto por elementos desconhecidos, aguilhoando o "corpo sem órgãos da Terra", uma entidade "desterritorializada, glacial, uma molécula gigante" (DELEUZE \& GUATTARI 1987: 40), que, ato contínuo, solta um grito de agonia audível em toda a sua superfície. Já a apropriação do conceito pela ciência foi indolor. É hoje conhecida a Hipótese de Gaia, proposta pelo pesquisador britânico James Lovelock e a bióloga estadunidense Lynn Margulis, na qual são comparados os componentes físicos da Terra a um sistema vitalista, sujeito a condições de equilíbrio e "pirexia" (atividade vulcânica como febre), tal qual o corpo de um autêntico vivente. Portanto, a perfuração imaginada por Doyle seria tão invasiva quanto a mais delicada das cirurgias, podendo atuar também como um termômetro. Atualmente, há à disposição de geocientistas sofisticados instrumentos de medição e sensoriamento do planeta, capazes de "sentir" com detalhes as "pulsações" das esferas. Alude-se aqui aos principais estratos de Gaia - atmosfera, biosfera, hidrosfera e geosfera - e como os mesmos foram devassados pelo olho científico e, agora, por outros sentidos das ciências humanas. É possível ainda deslindar traços de uma estética ecotécnica pertinente a este grande laboratório planetário, no qual a Terra "percebe" estar sendo percebida.

\subsubsection{Atmosfera}

Tomemos como índice da geociência atmosférica, sob o ponto de vista da estética ecotécnica, o Projeto Aeroceno (ver Fig. 22), do artista argentino Tomás Saraceno, discutido na segunda edição de Anthropocene Curriculum, projeto multidisciplinar promovido pela Casa das Culturas do Mundo (Haus der Kulturen der Welt, ou HKW), centro cultural sediado em Berlim. ${ }^{237}$ Uma das temáticas do evento

236 Mundialmente famoso por suas histórias sobre o detetive Sherlock Holmes.

237 Cf. ENGELMANN, Sasha. The Aerocene Campus. Anthropocene Curriculum [s.d.]. Disponível

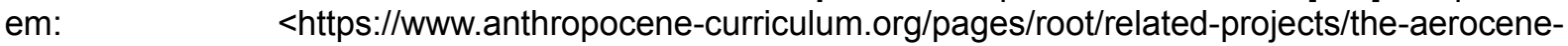
project/aerocene-campus/>. Acesso em: 28 jun. 2018. 
foi explorar uma quinta esfera planetária, a tecnosfera, definida como "uma composição de entidades técnicas, bióticas e abióticas que emergiu em determinado planeta e adquiriu um grau de autonomia autopoiética em relação a outros subsistemas planetários" ${ }^{\text {"238 }} \mathrm{e}$, portanto, apta a engendrar conhecimentos, como as suas quatro irmãs. Mas já que estamos tratando de uma estética ecotécnica, a qual implica em um enredamento inconsútil entre técnica e natureza, seria recomendável substituir a palavra "autopoiética" da definição pela terminologia simbólica "simpoiética", ${ }^{239}$ proposta por Donna Haraway, cujo prefixo remete a simbiose, relação mutuamente vantajosa, coisas feitas-juntas-com, de preferência em comunidades de prática compostas por humanos e não-humanos abertos para negociações cosmopolíticas. O projeto de Sarraceno tem como orientação conceitual os balões meteorológicos de grande altitude e se manifesta na forma de esculturas feitas com materiais simples, capazes flutuar na atmosfera sem precisar de propulsores químicos.

Figura 22 - Balões do Projeto Aeroceno



Fonte: http://aerocene.org

238 Ver TADDEI, Renzo. Conhecendo (n)o Antropoceno. ClimaCom Cultura Científica - Pesquisa, Jornalismo e Arte, v. 3, 2016, pp. 156-162.

239 Ver a gênese do termo na entrevista de Martha Kenney com Donna Haraway in: DAVIS \& TURPIN 2015, pp. 256-270. 
O projeto é parte de um série da qual fazem parte outras esculturas aéreas, como o Museo Aero Solar (2007-), obra que é incrementada em tamanho a cada local que descende, convocando a comunidade a inserir emplastros em suas junturas. Sarraceno afirma que "tais esculturas podem revelar a forma interna da atmosfera através de seu movimento; rodar o globo em correntes de jato próximas a troposfera; monitorar a química atmosférica, convecção e dinâmica de fluidos; e expandir as zonas críticas da nossa percepção acerca do Sistema Terra". ${ }^{240}$ A filosofia básica por detrás da série é a do código aberto, o que abre a possibilidade de suas esculturas capturarem imagens de alta definição da superfície do planeta, democratizando o acesso a dados estratigráficos aéreos. Mas a maior contribuição de Sarraceno é a concepção teórica de uma nova visão de mundo, livre dos combustíveis fósseis, que conduza a humanidade a imergir em uma ambiência nãoterrena, pontuada por "cidades-cirriformes" cujos habitantes, nas palavras do nosso Alberto Santos-Dumont, movem-se na velocidade das correntes de ar.

Outro projeto artístico-científico com balões atmosféricos tem como força inspiradora a ética ecológica de Aldo Leopold, condensada na expressão "pensar como uma montanha". Em Thinking Like a Cloud ${ }^{241}$ (Pensar como uma nuvem) a artista polonesa Karolina Sobecka correlaciona ecologicamente as esferas atmosférica e biológica ao reconduzir ao nível do solo a microbiota dispersa em nuvens de alta altitude, como as cirro-estratos. Análises recentes indicam que ao menos 17 tipos de bactérias vivem em ambientes extremos da troposfera, região assolada por ventos áridos e raios ultravioleta. Cientistas também descobriram que tais seres integram o núcleo de condensação das nuvens, uma zona repleta de materiais orgânicos e inorgânicos, sobre os quais ocorre o fenômeno da transição do vapor d'água para as gotas de chuva. ${ }^{242} \mathrm{O}$ balão de Sobecka, munido com um coletor - uma tela de polipropileno de alta densidade - refaz o processo natural, capturando as gotículas de água, condensando-as e fazendo-as fluir para um recipiente protegido por uma válvula de refluxo (a malha de Raschel consegue

240 Ver SARRACENO, Tomás; ENGELMANN, Sasha; SZERSZYNSKI, Bronislaw. Becoming Aerosolar: From Solar Sculptures to Cloud Cities. In: op.cit., pp. 57-62.

241 Ver mais informações sobre o projeto em: <http://cargocollective.com/karolinasobecka/ThinkingLike-a-Cloud>. Acesso em: 3 mai. 2019.

242 Cf. SHEN, Helen. High-flying Bacteria Spark Interest in Possible Climate Effects. Nature News, 28 jan. 2013. Disponível em: <http://www.nature.com/news/high-flying-bacteria-spark-interestin-possible-climate-effects-1.12310>. Acesso em: 25 jun. 2018. 
extrair $30 \%$ da umidade da nuvem, cerca de 0,7 a 1,75 litros de água por hora). A segunda parte do projeto é fazer com que voluntários ingiram o líquido celestial, aumentando, em suas células, a porcentagem de microflora (a média é de 95\%). É relevante o sistema maquínico-meteorológico em si, o que John Durham Peters (2015) classifica como "mídias celestes", objetos tais como os balões, dirigíveis e satélites que sondam a atmosfera com o intento de prospectar o tempo variável do clima (kairos), oposto ao tempo cíclico dos corpos celestes (cronos) (op.cit.: 165). Consideremos, aqui, dilatar a noção de Peters, ao convertermos em mídia as próprias nuvens, agora no papel de canais de informação - ensejando um mundo técnico com novas estruturas, exatamente como o ideado pelos argumentos da estética ecotécnica. É o que se vê em CloudServices, ${ }^{243}$ um dos projetos apresentados no CRISPR.kitchen, espaço aberto de inovação para biohackers localizado em Berlim. O grupo propositor considera agrupar bactérias do tipo Pseudomonas syringae (que figura em primeiro lugar no "cardápio" de Sobecka) para armazenar dados em seus genomas, valendo-se de técnicas de engenharia genética. ${ }^{244}$ A partir daí, os portadores vivos de informação são aspergidos em folhas de plantas como o trevo vermelho, crescidas em topografias propícias à movimentos turbulentos e convectivos, favorecendo a sua elevação em direção às nuvens. Um projeto de computação natural dessa magnitude tem, por enquanto, traços especulativos, no entanto nos oferece um novum, ou ao menos uma visão alternativa da teoria da informação, em alto grau utilitarista e quantificadora, em conformidade com os serviços de armazenamento e computação em nuvem oferecido por empresas como a Amazon. Atende ao ajuste proposto por Simondon, entre a forma do objeto técnico e a forma do pensamento de quem o opera, concluindo que a informação não passa de uma significação que emerge quando as duas são combinadas relacionalmente (SIMONDON 1969: 257). Nessa proposta para uma biogeografia de difusão de dados em hidrometeoros, determinados saberes seriam exigidos dos que a implementassem, erradicando por completo um tipo de alienação que se verifica nas atuais atividades técnicas.

243 Ver mais detalhes (inclusive um curioso infográfico) em: <http://www.crispr.kitchen/microbiomeediting-scenarios/scenario-i-cloudservices>. Acesso em: 25 jun. 2018.

244 Filamentos de DNA são sintetizados, sendo cada uma das bases (TGAC) representada por um valor binário ( $\mathrm{T}$ e $\mathrm{G}=1, \mathrm{~A}$ e $\mathrm{C}=0$ ). Um único byte (ou 8 bits) pode representar 4 pares de bases de DNA. Para ler os dados armazenados no DNA, simplesmente sequencia-se cada uma das bases do TGAC, convertendo-as de volta para o binário (op.cit.). 


\subsubsection{Geosfera}

Quando descobrimos quais minerais estão presentes nos dispositivos eletrônicos que compõem as mídias envolvidas na visualização, sonorização, mapeamento, cálculo e simulação das esferas do planeta, percebemos que o que era apenas geográfico foi deslocado para o campo da geologia e da geofísica, o estudo da composição das propriedades que formam o planeta. Como vimos anteriormente, o materialismo implicado na geologia das mídias (PARIKKA 2015) reinterpreta os já sobrecarregados conceitos de territorialização, desterritorialização e reterritorialização; mas não apenas isso, insere-os em uma reflexão "geofilosófica"

e "geontológica", acrescentando à recomposição territorial de Deleuze e Guattari um ingrediente freático, uma atividade de enterramento, desenterramento e mineração constante da crosta terrestre, processo verificado em seus diversos estratos durante escavações estratigráficas, um permanente brotar e revirar de dentro para fora do solo e seus minerais e metais constituintes. Nessa perspectiva, a abordagem química dos artistas britânicos Andy Webster e Jon Bird se enquadra em uma "estética do imanente". ${ }^{245}$ Indagando o excesso de intervenção e ausência de incerteza em Skullcracker, de Richard Serra, obra de 1969 construída por empilhamento de peças de aço, a dupla a reconfigura em um dispositivo chamado célula eletroquímica, onde uma corrente elétrica passando entre dois eletrodos imersos em sulfato de cobre acarreta o contínuo depósito de material metálico em sua base, formando uma "escultura" por microerosão. Outra obra de Serra, Scatter Piece, de 1967, na qual o artista dispersa de forma aleatória espuma de látex no assoalho de seu estúdio, é repetida pela dupla, mas agora por meio de uma célula de Hele-Shaw, sistema elaborado para estudar o escoamento de fluidos imiscíveis infiltrados no estreito espaço entre duas placas planas. ${ }^{246} \mathrm{O}$ projeto eletroquímico do duo britânico é de fato a variação de um "jardim químico" (ou "jardim de cristais"), experiência estético-química que vem fascinando cientistas desde o século 17.

245 WEBSTER, Andy; BIRD, Jon. Better Living Through Electrochemistry? In: MONTAG 2008, p. 121-130.

246 MY BREATH Are My Lungs. Direção de Andy Webster. Inglaterra, 2011. Vídeo disponível em: <https://vimeo.com/29922250>. Acesso em: 22 mar. 2017. 
Essa peculiar forma de jardinagem foi descrita pela primeira vez por Johann Glauber, em 1646, despertando a curiosidade de outros químicos e até escritores, como Thomas Mann, que a mencionou no clássico Doutor Fausto (1947). Pesquisadores de diversas áreas, como dinâmica não-linear, formação de padrões, automontagem e dinâmica de fluidos, associam tais jardins a questões de maior dimensão, como equilíbrio termodinâmico e auto-organização de sistemas. ${ }^{247} \mathrm{O}$ biólogo francês Stéphane Leduc, por exemplo, chegou a compará-los com entes vivos, incentivando a produção de novas teorias sobre o surgimento da vida na Terra e aproximando a biosfera da geosfera. Eventualmente, eles desvencilharam-se dos laboratórios científicos e apoderaram-se de programas educativos, chegando mesmo a figurar nos tradicionais kits de química para crianças. A receita para se produzir estes arbustos ornamentais cristalinos é simples: em uma solução de silicato de sódio (vidro líquido), despejar cloreto de níquel (sal verde), sulfato de cobre (sal azul), cloreto de sódio (sal de cozinha), cloreto de cobalto (sal vermelho) e dois sais de ferro: sulfato ferroso e sulfato férrico. Percebe-se quase imediatamente uma reação química inusitada, na qual forma-se sobre cada grão de sal uma membrana semipermeável que, através do fenômeno da osmose, permite a entrada de moléculas de água e íons hidróxido, aumentando a pressão interna e provocando o seu rompimento. À medida que o grão liberto emerge na solução metálica, a membrana "cura-se" por conta própria, partindo para uma nova etapa e proporcionando no processo a formação sucessiva de "caules" coloridos. A membrana continua a formar-se enquanto o contraste químico persistir entre as soluções, replicando de certa forma o contraste entre figura e fundo, um dos atributos da estética ecotécnica que, como vimos, se expressa em outros pares mutantes, como exterior e interior.

A maior parte dos minerais existentes hoje na Terra surgiu durante o Grande Evento de Oxidação, que começou cerca de 2,3 bilhões de anos atrás. Um recente estudo $^{248}$ analisou que, dos 5.208 minerais oficialmente catalogados pela Associação Mineralógica Internacional, 208 são decorrentes de processos de cristalização disparados por atividades antropogênicas iniciadas com a Revolução Industrial: os

247 Ver STEINBOCK, Oliver; CARTWRIGHT, Julyan H. E.; BARGE, Laura M. The Fertile Physics of Chemical Gardens. Physics Today, v.69, n.3, 2016, pp. 44-51.

248 Ver HAZEN, Robert M.; GREW, Edward S.; ORIGLIERI, Marcus J.; et al. On the Mineralogy of the "Anthropocene Epoch". American Mineralogist, v.102, n.3, 2017, pp. 595-611. 
"cristais do Antropoceno". Para Simondon (2005), a forma mais primitiva de individuação é representada pela formação dos cristais, a epítome da individuação física. O assunto é explorado no segundo capítulo de L'individuation à la lumière des notions de forme et d'information, ao tratar da relação entre estruturas e energia potencial, através do princípio da alotropia, a propriedade que alguns elementos químicos têm de se transformar em uma ou mais substâncias diferentes, como o diamante e o grafite, que formam um retículo cristalino, no interior do qual os átomos unem-se por ligações covalentes. Como se vê, a noção da retícula aqui também está presente, revelando pontos e suas coordenadas integrais, as tensões ideais, a multiplicidade de direções que deve seguir cada molécula, uma representação que, apesar de ser abstrata (periódica, infinita), se coloca em posição antitética aos corpos amorfos (SIMONDON 2005: 73). ${ }^{249}$ Mas o que importa para Simondon é como a operação estruturante do cristal é desengatilhada por um inesperado "corpo estranho", oriundo do meio externo, mas que adquire a capacidade de compatibilizar as condições materiais e energéticas, orquestrando uma relação entre um estado ordenado e um estado amorfo, transformando-se numa semente estruturadora, um germe que ativa a tomada de forma do indivíduo físico, mas que ao mesmo tempo não é propriamente o indivíduo, é apenas um ponto singular, uma singularidade que surgiu como a silhueta de uma informação. Além disso, existe um prolongamento no tempo e no espaço das condições desta compatibilidade realizada, nivelando germe e estrutura. Aqui se apresenta um fenômeno que vai além do esquema hilemórfico, para o qual só existem a matéria (átomos) e a forma (retículos de Bravais), sem considerar o aspecto energético da relação entre os dois termos e, por conseguinte, a relação dos dois termos com o meio em que estão inseridos.

249 Excerto no original: Si l'on se représente un corps amorphe comme un corps dans lequel les particules constitutives sont disposées de façon désordonnée, on pourra supposer que le cristal est, au contraire, un corps dans lequel les particules élémentaires, atomes ou groupes d'atomes, sont disposées selon des arrangements ordonnés, nommés réseaux cristallins. [Se representamos um corpo amorfo como um corpo no qual as partículas constituintes são dispostas de forma irregular, pode presumir-se que o cristal é, pelo contrário, um corpo no qual as partículas elementares, átomos ou grupos de átomos, são dispostos em arranjos ordenados, chamados redes cristalinas.] (tradução nossa). 


\subsection{Sensores}

No campo da geofísica, o papel dos sensores é crucial. Eles espalham-se por toda a superfície do planeta e exercem uma significante função, sendo verdadeiras extensões prostéticas do aparelho sensório humano. É inevitável antes questionar qual a qualidade perceptiva de tais dispositivos, se é propositado relacioná-los analogamente com a percepção humana, nesse caso, se seriam suscetíveis à temporalidade, ou mesmo a capacidade de retenção ou protenção, no linguajar de Husserl, ou seja, se seriam apenas captadores de dados em tempo real, ou se teriam alguma faculdade de memorização e predição. Mas essa conjectura sobre tais poderes dos sensores não está no escopo de nossa indagação, já que estamos prospectando uma feição estética das técnicas voltadas às geociências. Por certo que os dados captados e analisados pelo conjunto técnico formado por sensores, satélites e algoritmos são relevantes - inclusive em forma de objetos artísticos, como se pode verificar em variadas amostras da artemídia contemporânea. Mas é a materialidade do dispositivo que nos conduz a uma estética, ao que parece, ecotécnica. Os dados (sobre o clima da Terra, por exemplo) apreendidos por essa "infraestrutura de conhecimento" é variável, dinâmica, desliza-se em controvérsias, faz-se fluída. E uma parte do conjunto técnico que os produz está "constantemente se expandindo, reexaminando cada datum e grupo de dados, reanalisando-os, adicionando-os aos seus metadados" (EDWARDS 2013: xviii). Trata-se, no limite, da mais abrangente e complexa infraestrutura tecnocientífica da história da humanidade. Porém, tal conhecimento produzido por esta vasta infraestrutura, sem pôr em prática medidas políticas corretivas, corre o risco de tornar-se somente a imagem em alta resolução de um "planeta doente", na expressão de Guy Debord: "Uma tal ciência não pode mais do que nos acompanhar rumo a destruição do mundo que a produziu e que a mantém; mas ela é forçada a fazê-lo com os olhos abertos. Ela mostra, assim, em um grau caricatural, a inutilidade do conhecimento sem uso". ${ }^{250}$ Nossa atenção volta-se, então, à arte dos dispositivos de sensoriamento, aos objetos tecno-ambientais propriamente ditos, qual a sua "forma

250 Ver DEBORD, Guy. O Planeta Doente. Tradução de Emiliano Aquino. Ensaios e Textos Libertários, 24 abr. 2015. Disponível em: <https://arlindenor.com/2015/04/24/o-planeta-doente-2/>. Acesso em: 6 maio 2018. 
sensível dada como Gestalt significante" (DUFRENNE 2015: 28) em contraste com um planeta em pleno processo de transformação.

Figura 23 - Sensor instalado na geleira Similaun, 2016

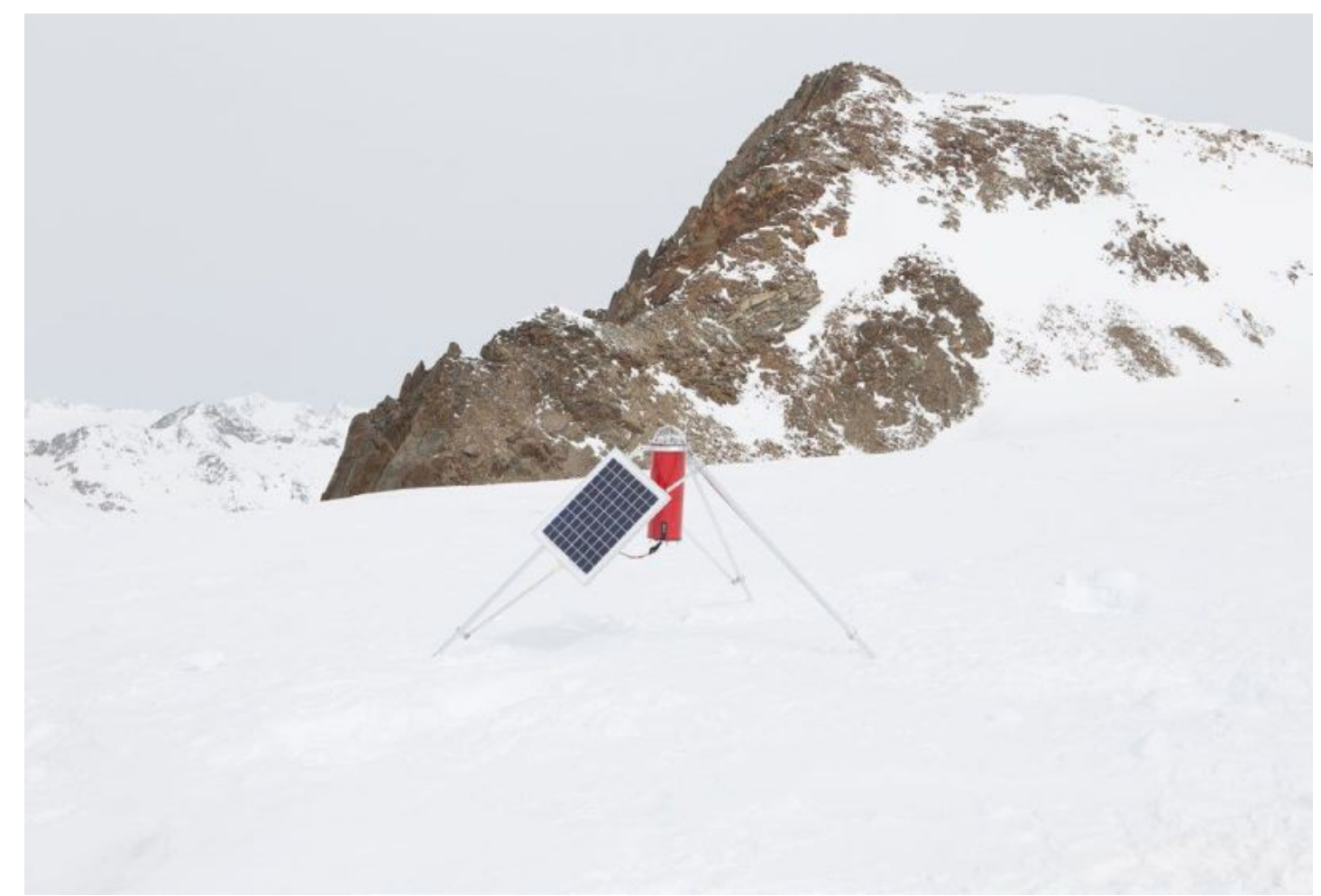

Fonte: http://www.italianlimes.net/ (Foto: Delfino Sisto Legnani)

Consideremos, pois, uma amostra da série de artefatos autônomos do projeto Italian Limes, de autoria do Studio Folder, um "consórcio" composto por artistas e cientistas. Em latim, a palavra limes quer dizer "fronteiras", e o título declara assim de antemão a finalidade do empreendimento: "explorar como as divisas naturais aparentemente inquestionáveis e autoevidentes - estão, de fato, expostas à complexidade dos processos ecológicos de longo prazo, revelando o problema da representação territorial e suas implicações políticas". ${ }^{251}$ A partir de uma pesquisa nos arquivos do Istituto Geografico Militare em Florença, começada em 2014, observou-se alterações na fronteira austro-italiana, em especial os marcos demarcatórios entre os dois países situados nas geleiras alpinas. Decidiu-se, então, por monitorar tais mudanças através de sensores concebidos especificamente para o projeto, todos construídos com ferramentas de levantamento topográfico de código 
aberto (ver Fig. 23). As coordenadas das agrimensuras, como resultado, são periodicamente apresentadas em instalações montadas em diversos espaços culturais da Europa. Trata-se, indubitavelmente, de um projeto de arte política, no qual é apontada a inocuidade do controle rígido de fronteiras em tempos de mudanças climáticas, e isso apoiando-se em uma tecnologia de origem sabidamente militar, o GPS. Desse arcabouço retórico, reteremos aqui, somente, as formas do aparelho receptor móvel e sua relação com a geometria do panorama glaciar. É como se fôssemos lançar um olhar a um ponto distinto de um vasto conjunto técnico (e sociotécnico), quase à maneira de um discípulo do pitoresco (e não do sublime). Pode-se adicionar a esse olhar, em razão de sua disposição apolítica, a primeira lei do tecnólogo Melvin Kranzberg: "A tecnologia não é boa nem má; e nem é neutra". ${ }^{252}$ Não é, enfatizamos, um olhar desinteressado, mas não aquele eivado de teses políticas ou dados de estímulos físicos, mas de conhecimentos científicos acerca das causas do recuo de bacias glaciais. Um entendimento é constituído por dois inputs, como no exemplo dado por Simondon relacionado à integração da informação visual na percepção binocular: "As imagens de cada olho estão em relação de disparidade, mas ela é a condição necessária para o surgimento de planos sucessivos, sem que isso signifique que os elementos díspares sejam fundidos". 253 Nesta amplificação organizadora, o sentido é formado por duas intencionalidades à primeira vista conflitantes: a percepção sensória e a atitude cognitiva. A combinação não debilita a experiência sensória, porque na atitude estética há uma espécie de vaivém entre o juízo estético e o juízo de conhecimento. ${ }^{254}$ Vê-se que, nesse caso, o sensor deixa de ser apenas um sensor; torna-se um objeto tecno-ambiental que nos interpela esteticamente.

252 Ver KRANZBERG, Melvin. One Last Word - Technology and History: 'Kranzberg's Laws'. In: CUTCLIFFE \& POST, 1989, pp. 248-249.

253 Ver RODRÍGUEZ, Pablo E. Comunicación e Información: la Refundación de la Tecnología, las Ciencias Naturales y las Ciencias Sociales en Gilbert Simondon. Texto apresentado no encontro Informação, tecnicidade, individuação: a urgência do pensamento de Gilbert Simondon. CTeMe/IFCH/Unicamp, 2012.

254 Ver a nota de rodapé 121 do capítulo 1, p. 86. 


\subsubsection{Biosfera}

A teoria da biosfera, na qual a rede de viventes é mais do que um filme biológico envolvendo as outras esferas, é de lavra do mineralogista russo Vladimir Ivanovich Vernadsky (1863-1945), figura que durante décadas ficou à margem das bibliografias científicas. Seus cálculos sobre a quantidade de matéria viva na camada batizada por ele (VERNADSKY 1998: 72) manifestava a essência de seu interesse: os fatores de multiplicação da vida independente da noção de abiogênese (criação direta de um organismo vivo a partir de matéria inerte), viabilizada, por exemplo, pela transmissão de energia geoquímica e dispersão aérea de esporos e sementes. Mas é no animismo radical de Emanuele Coccia que a totalidade biológica prevista por Vernadsky se manifesta em toda a sua intensidade: a biosfera na forma de uma "mente total", constituída pela integração dos sistemas natureza e cultura, devendo a última ser criada por indivíduos não escravizados por uma "consciência intencional" (BATESON 2000: 440). Para Coccia, "voltar a pensar sobre a natureza significará formular de outra forma a fenomenologia do espírito", uma forma não exclusiva dos foros humanos, considerando que a

produção de modificações permanentes e transmissíveis de geração em geração do próprio ambiente não é uma prerrogativa humana: modificando os que foram definidos como "nichos" ambientais, todos os viventes, também os mais elementares, produzem cultura, que pode assim ser definida como uma espécie de herança exossomática. Uma herança não anatômica, mas ecológica. ${ }^{255}$

O curioso é que, ao decentralizar o monopólio humano da fenomenologia, Coccia dá ênfase especial à vida das plantas, categoria de viventes distantes do que poderia ser enquadrado no sistema de uma mônada enclausurada, uma forma de vida não limitada à sua interioridade, aberta integralmente e sem intermediários às trocas energéticas e físicas com o seu entorno. Tal postura vai além de meras condicionantes ecológicas, pois "[n]enhum outro ser vivente contribui tanto quanto 
[as plantas] para a qualidade estética do cosmo." ${ }^{256}$ É como se não fizesse diferença, para os viventes do reino vegetal, em sua relação inconsútil com o externo, as diversas interpretações de meio ambiente tão caras ao pensamento ecológico. Organismo e Unwelt seriam uma coisa só; e tal contato "sem contato" definiria uma "cultura vegetal", a epítome singular de uma "cultura total":

Se a vida vegetal é também uma vida cultural, esta pressupõe a atividade de uma mente que se exercita antes de tudo e, quase exclusivamente, na forma do próprio corpo. Pensar a vida vegetativa desta forma corresponderia a tudo aquilo que a tradição aristotélica tinha chamado psuchê trophukê, ou seja, nem tanto ou não somente uma unidade taxonomicamente distinta e separada das outras, mas um lugar compartilhado por todos os viventes, indiferente à distinção entre plantas, animais e homens, o princípio pelo qual, segundo o logion aristotélico, "a todos pertence a vida" (ARISTÓTELES, De anima 414 a 25). ${ }^{257}$

A humanidade perde a sua majestade perante tamanho poder de comunhão performado na biosfera. Talvez seja por isso que "as plantas representam a ferida sempre aberta do esnobismo metafísico", 258 o nítido sinal de derrocada da espécie que se imaginava espiritualmente dominante. Nas metrópoles modernas são persona non grata, "hóspedes ingratos - ervas daninhas - ou objetos de produção de massa para conseguir proventos sempre mais escassos". ${ }^{259}$ Mas há os que não as veem assim, como a pesquisadora e artista estadunidense Ellie Irons, exploradora diligente das chamadas "paisagens selvagens" citadinas. Um determinado lote inserido em uma cidade que não seja um parque público, um jardim particular ou uma área de conservação pode ser classificado como paisagem selvagem, ou tecnicamente como um espaço verde urbano informal, ${ }^{260}$ o ambiente propício para se experimentar novas formas de ocupação (ou desocupação) que não

256 Ibid., p. 211.

257 Ibid., p. 212; grifos do autor.

258 Ibid., p. 207.

259 Ibid., p. 211.

260 Ver RUPPRECHT, Christoph D.D.; BYRNE, Jason A. Informal Urban Greenspace: a Typology and Trilingual Systematic Review of its Role for Urban Residents and Trends in the Literature. Urban Forestry \& Urban Greening, v.13, n.4, 2014, pp. 597-611. 
seja puramente cultural ou biológica, mas que tenha um traço socioecológico. Irons é responsável pelos projetos Sanctuary for Weedy Species ${ }^{261}$ e Next Epoch Seed Library, ${ }^{262}$ o último uma versão condensada do Silo Global de Sementes de Svalbard, bunker localizado a cerca de mil quilômetros ao sul do polo norte que preserva cerca $90 \%$ das sementes conhecidas existentes no mundo (uma espécie de arca de Noé da biologia vegetal). Em espaços limites da cidade, Irons lavra plantas urbanas espontâneas (descritas popularmente como ervas daninhas) em espaços públicos intersticiais e até mesmo em galerias de arte, tendo gerado uma polêmica sobre a pertinência ou não de se plantar plantas não nativas ao lado de plantas nativas, uma discussão que reflete uma outra entre ambientalistas, as posições antagônicas da preservação (áreas naturais não devem sofrer interferência da ação humana) e conservação (manejo controlado). O dois projetos não tomam partido de nenhuma das duas posições, mas no entanto deixa entender que os métodos tóxicos ou de uso intensivo de recursos utilizados para erradicar ervas daninhas no contexto urbano acabam por suprimir também ervas medicinais e plantas alimentícias não convencionais (Panc). É possível analisá-los como uma crítica ao modo de vida imposto pela Monsanto e/ou um panegírico ao futuro alvissareiro das fazendas urbanas, área que já conta com uma aceleradora de empreendimentos. ${ }^{263}$ Mas isso é insuficiente. É melhor colocá-los sob a ótica do animismo fenomenológico de Coccia, deslocando, por exemplo, a ora-pro-nóbis (Pereskia aculeata) de um terreno baldio para o nicho de um templo mágico.

\subsubsection{Hidrosfera}

Cabe dizer que o conhecimento da hidrosfera, no contexto da elevação do nível do mar e da rotina cada vez maior da escassez de água, faz-se hoje uma das principais áreas do sistema Terra. Com efeito, nota-se a emergência de artistas com pesquisas sérias acerca de bacias hidrográficas, desenhando projetos emanados da

261 Ver IRONS, Ellie. Sanctuary for Weedy Species: a Winter Respite for Urban-dwelling Plants and Humans. Feral Landscape Lobby, 2015. Brochura parte da exposição Social Ecologies, com curadoria de Greg Lindquis.

262 Este projeto, feito em parceria com Anne Percoco, é de fato um repositório com mais de 5000 espécies de sementes. Cf. THE NEXT Epoch Seed Library. Direção de Candace Thompson, 2016. Vídeo do documentário disponível em: <https://vimeo.com/195514276>. Acesso em: 27 mar. 2017. 263 Ver detalhes do projeto em <https://squarerootsgrow.com>. Acesso em: 06 mai. 2019. 
Environmental art, mas certamente sem as pretensões e os anseios de autonomia ou vanguardismo, à guisa de seus antecessores. Nota-se, em suas trajetórias, não somente o rompante estético, mas um sentido de remediação e solidariedade. São assim, por exemplo, as esculturas para zonas ribeirinhas dos artistas Daniel McCormick e Mary O'Brien, que edificam, tais como dois habilidosos castores, enormes "cascas de vagens" feitas com galhos de salgueiro e as ajustam ao longo de bancos de cursos d'água e corredores ribeirinhos. As estruturas foram até tipificadas, sendo chamadas por eles de watershed sculptures, tais os detalhes das especificações. Atualmente, eles estão ajudando a restauração da zona ribeirinha do rio Truckee, em Nevada, em áreas afetadas pelo escoamento de dejetos de erosões, articulando arte ambiental e serviço público (ver Fig. 24). O desmatamento de mata ciliar, prática verificada ao longo de rios de todo o mundo, acarreta, como se sabe, a erosão do solo e, mais grave, o rebaixamento do nível do lençol freático. Daí o papel mais que simbólico das Esculturas para Bacias Hidrográficas. Antecedem as construções de tais "linhas de defesa" uma densa fase de pesquisa, incluindo em seu roteiro o entendimento de princípios e leis naturais (gravidade, capilaridade, hidráulica, dinâmica de fluidos, etc.), ornitologia, geomorfologia fluvial e técnicas da permacultura para conter o escoamento agrícola e enchentes. ${ }^{264} \dot{E}$ assim que a dupla reúne três fatores na esquematização de projeto - estética, funcionalidade e processo -, atendendo às características do modelo ambiental de Carlson e harmonizando juízo estético e juízo de conhecimento.

264 Ver a entrevista com Daniel McCormick and Mary O'Brien no Re:sculpt, blog do International Sculpture Center (ISC), 15 jun. 2016. Disponível em: <https://blog.sculpture.org/2016/06/15/designingliving-sculture/>. Acesso em: 8 maio 2018. 
Figura 24 - Projeto para um rio em Nevada

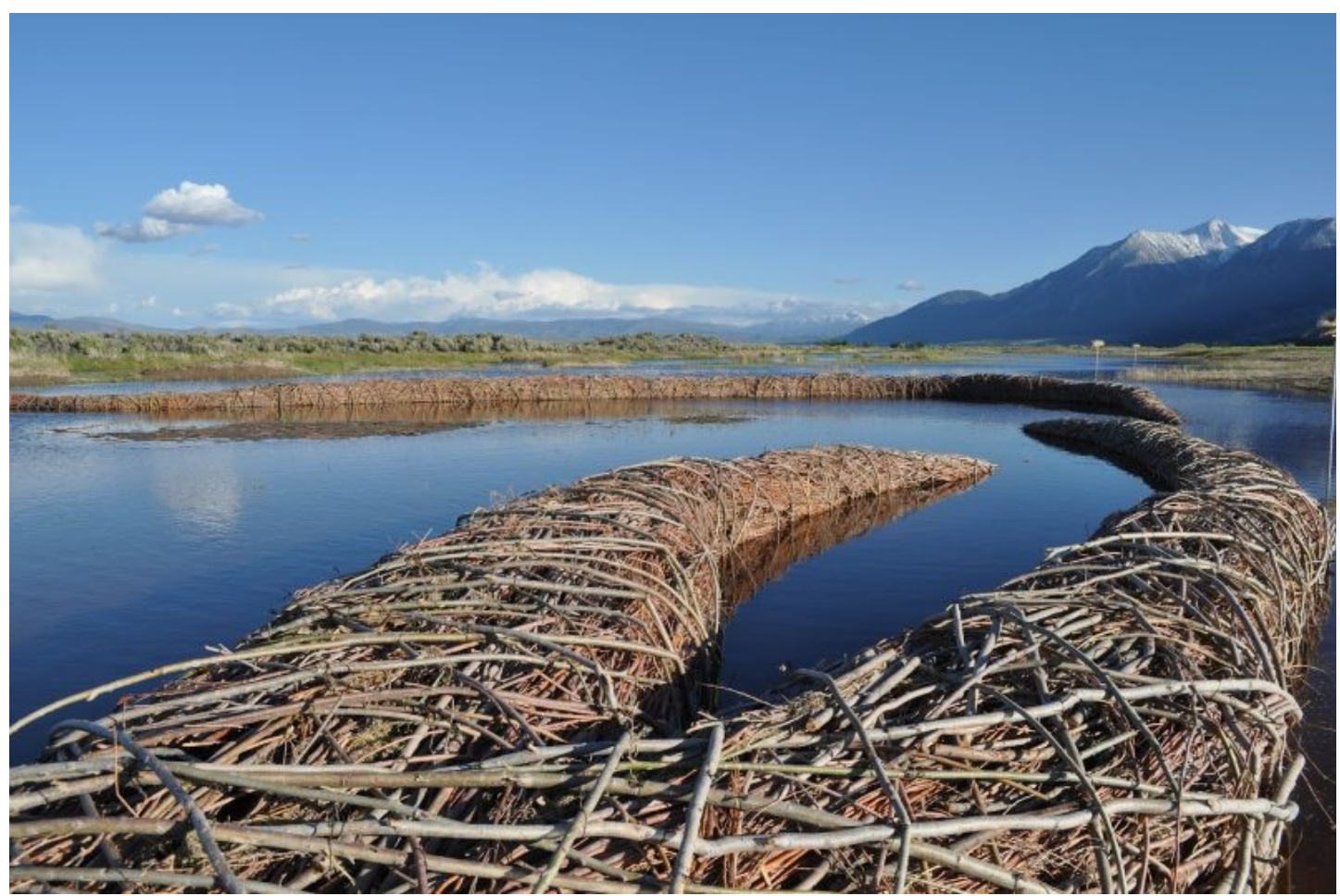

Fonte: http://www.watershedsculpture.com

\subsubsection{Considerações}

De tudo o que foi dito sobre as quatro esferas das geociências e sua relação com o mais recente período geológico, marcado por atividades antrópicas irreversíveis, conclui-se que está em curso algo que poderia ser descrito como a artefatualização do mundo (STIEGLER 2011) e, por correspondência, um pensamento estético e ecológico à altura da recente tecnoesfera. As práticas artísticas, de cunho científico, parecem ser um dos anteparos psicológicos à dinâmica escatológica da história atual, nas perspectivas humana e planetária. Sabe-se que a desesperança caminha junto com a ausência de ideações, e que, para lidar com o futuro trágico que se anuncia, é preciso, antes de tudo, imaginá-lo e, fundamentalmente, "mobilhá-lo". Provavelmente, a proposta que "desmetaforiza" a computação em nuvem e propõe que supercélulas de tempestade sejam canais de circulação de informações insertadas em bactérias geneticamente modificadas, surtirá o descrédito no mais convicto dos futuristas. Mas devemos lembrar, como aconselha Hans Jonas, que não vivenciamos mais os tempos da Grécia clássica, 
nos quais a techné ligava-se a projetos mais artesanais e geométricos; a nossa epocalidade é a das complexas estruturas da Gestell, uma etapa civilizatória que, a despeito de seus traços entrópicos, tudo parece ser possível, porque o "poder tecnológico transformou aquilo que costumava ser exercícios hipotéticos da razão especulativa em esboços concorrentes para projetos executáveis" (JONAS 2006: 63). Contudo, a transformação do devir humano em um futuro menos selvagem depende da reciprocidade equilibrada entre a individuação de processos psíquicos, técnicos e sociais, ou seja, de um devir organológico com nuances ecológicos. Outro interesse colateral de nossa investigação é compreender como as possíveis retenções efetuadas por tecnologias geocientíficas influem nas protenções (projeções imaginativas) de futuras mídias terrestres, aéreas, hídricas e biológicas. E ao falarmos de compreensão, não nos restringimos à científica, mas também à humanística, porque, como confessou Julien Oliver em recente seminário, "arte e design podem desempenhar um papel central na propagação de uma nova subjetividade planetária". ${ }^{265}$ Cremos, por fim, que o modelo ambiental de Carlson, ao reclamar por uma sabedoria ampla (arriscamos a dizer: geocientífica) na apreciação estética, seja o que mais se aproxima da organologia neguentrópica proposta por Stiegler (2018: 43), uma renovação da mecanologia de Simondon.

\subsection{TECNOMAGIAS}

O pensamento mágico, outrora engenho principal da mediação humana, recolheu-se em um canto do progresso tecnocientífico, com o pesar dos ensinamentos da epistemologia. Todavia, como aponta Simondon, é a partir dele que o mundo apareceu ao homem, com todas as suas incertezas, mas também com todo o seu poder de encantamento e de encantar. Apesar disso, a relação entre o pensamento mágico e a atividade técnica nunca expirou completamente, mesmo sob a égide do racionalismo mais obstinado, para o qual tal pensamento é desprovido do método de se controlar as incertezas da natureza. Ora, o que é incerto não são as atividades do mundo natural, mas o próprio conhecimento a seu

265 Ver OLIVER, Julien; REVELL, Tobias. Palestra proferida no Mapping Festival, Paradigm_Shift \#2 Forum, 2018. Vídeo disponível em: <https://vimeo.com/271213836>. Acesso em: 29 jun. 2018. 
respeito. ${ }^{266} \mathrm{O}$ pensamento mágico persiste, ao contrário do que propugnam os teóricos das commodities, no centro dos modelos operatórios inventados pela técnica, porque a tecnologia ideal é, ao menos aos olhos de seus beneficiários, aquela que produz objetos sem a imposição do labor manual e, sobretudo, a que Ihes desobriga do ônus do custo de oportunidade, ${ }^{267}$ simbolizado pela utópica automação integral da "Idade do Ócio", um momento-chave no qual, "no dizer de Aristóteles, 'os fusos trabalham sozinhos'" (ANDRADE 1990: 106). É, em suma, o encantamento da técnica a serviço da técnica do encantamento. ${ }^{268}$ No contexto "selvagem", o entendimento da conexão entre produção técnica, magia e arte é realizado plenamente pelos habitantes das ilhas Trobriand, mais especificamente na configuração de suas hortas de inhame, descritas, segundo o relato do antropólogo polonês Malinowski, como "jardins" (bagula): uma área quadrangular capinada e delineada em suas extremidades por "prismas mágicos" (kamkokola), pilares de madeira não confeccionados para fins técnicos, mas sim para a obtenção de uma transcendência da produção técnica. ${ }^{269}$ No mundo ocidental, se verifica o resgate da tradição mágica do período helenístico durante o renascimento, em especial a noção de que todas as coisas do mundo natural estão conectadas por uma mágica simpatia (ZIELINSKI 2006: 57-59). E no estado de coisas do presente tecnocientífico, o pensamento mágico está expresso na famosa terceira lei do autor britânico de ficção científica Arthur C. Clarke, conforme a qual "qualquer tecnologia suficientemente avançada é indistinguível da magia."270

\subsubsection{Geomancia aplicada}

Ocultismo e adivinhação, praticados por antigos magos e feiticeiros, já foram reconhecidamente formas de conhecimento, chegando a igualar-se às da ciência racional. Índices que também remontam à labiríntica produção tecnoesotérica de Martin Howse, programador, escritor, artista performático e explorador de mundos 266 GELL, Alfred. The Technology of Enchantment and the Enchantment of Technology. In: CANDLIN \& GUINS 2009, pp. 208-228.

$267 \mathrm{Ibid}$. Esse é custo de se renunciar a uma potencial vantagem.

$268 \mathrm{lbid}$.

269 Ibid.

270 Ver o verbete Clarke's three laws. In: Wikipedia. [s.l.: s.n.], 2018. Disponível em: $<$ https://en.wikipedia.org/w/index.php?title=Clarke\%27s_three_laws\&oldid=827806068>. Acesso em: 25 mar. 2018. 
mágicos - atributos vagos e não peremptórios, sendo mais cabível classificá-lo como um artista-alquimista ou um filósofo da natureza da era contemporânea. Mas voltemos aos índices das práticas divinatórias e sua relação com a obra de Howse. É a terra o elemento clássico de sua predileção, substância por vezes trêmula, mas sem cessar firme, porque é "a fundação de todos os elementos ... o objeto, sujeito e receptáculo de todos os raios e influências celestiais" (NETTESHEIM 2008: 89). Um fenômeno de grau superior, a hylé em seu mais alto grau de substanciação, para a qual todos os significados do mundo convergem, já que "é dela que brotam todas as coisas" (op.cit.). Contudo, não seriam suas qualidades a "escuridão, espessura e quietude", na visão de Platão apud Agrippa (op. cit.), mas sim a vibração da vida e do movimento (assim como o fogo, diga-se de passagem). Além do mais, para Howse, a terra teria as qualidades de um objeto técnico, sendo em princípio o envoltório de uma espécie de memória computacional ancestral, bem como o proscênio arquetípico de cerimônias esotéricas, todavia tecnológicas, como a que um "viajante temporal" executa ao enterrar no solo da floresta "uma única memória de núcleo magnético" para passar todo o "conteúdo de seu disco rígido, através ou dentro desse núcleo, como se fossem dados binários." Sua missão seria "liberar essa mesma informação como uma série de impulsos elétricos que podem mover-se para dentro do planeta Terra através de diferenciais induzidos entre duas placas de metal". ${ }^{271}$ Vê-se que o tecido da ficção de Howse, respaldado laboriosamente por centenas de textos herméticos (ancestrais e modernos), entrelaça-se de forma inconsútil aos assuntos plásticos e sonoros de sua obra.

Os artífices da geomancia se valiam de material terroso na prática mântica de previsão do futuro - contudo, não estariam restritos às superfícies da crosta, ao aspecto da camada externa do solo. Em conjunturas contemporâneas, o pó, a terra batida, o barro e a argila excedem as suas atribuições na aparência, seu papel de "suporte midiático", destituindo-se dos objetos atirados ao léu sobre o seu manto para abarcar outras formas mágicas, como a entrada e saída de informações, naturais e artificiais, processadas em suas entranhas. A terra batida, a "unidade central de processamento" de Gaia, ou, na perspectiva de Howse, o Intérprete das

271 Ver o contexto das citações em HOWSE, Martin. Returned to Earth. Continent, n.4.2, 2015, pp. 45-48. 
Trevas (Dark Interpreter), ${ }^{272}$ é mais do que uma tela ou um imã dinâmico, é um transdutor natural que, à semelhança de sua contraparte artificial, o computador, é capaz de "sujeitar palavras a mudanças (materiais)". ${ }^{273}$ É possível estender tal analogia, porque, na ciência da computação, os interpretadores são programas especiais que decifram o código fonte de outros programas e os convertem em códigos executáveis; encontram-se mais próximos da linguagem de máquina (o código com menos grau de abstração), e mesmo dos circuitos mais elementais, das partes físicas, como semicondutores, constituídos de metais de terras raras, minerais obscuros, com nomes obscuros (p. ex.: monazita, bastnaesita e xenotima). Operações simbólicas - e lógicas - acabam por igualar-se, assim, ao substrato material. Daí o impulso da reificação do simbólico, de uma refundação do excesso de abstração distintivo da terceira revolução industrial, a digital. Simondon (2008b: 183) consagrava a aproximação íntima do objeto técnico da realidade natural, devido à relação estreita entre a causalidade do mundo e a funcionalidade da máquina, dessemelhante dos objetos da categoria estética, enviesados à autonomia do em-sipara-si (DUFRENNE 1973: xxvii). Todavia, reverenciamos a encantação intemporal do filósofo hermético inglês John Dee, na qual a relação entre arte (técnica) e natureza é de espécie familiar, e não filial. ${ }^{274}$ Dessa união simpática aflora um objeto

272 O título, extraído de obra de Thomas De Quincey, refere-se, em análise temática, ao lado obscuro da alma humana, mas também, pelo artifício de Howse, ao "mais avançado processador de ruído autônomo, sensível a dedos, sensível a pragas, um sintetizador granular e gerador de som, que mescla processamento digital e analógico". Ver uma demonstração do sintetizador de ruídos em HOWSE, Martin. The Dark Interpreter 001. [s.l.: s.n., s.d.]. Vídeo disponível em: $<$ https://www.youtube.com/watch?v=sSnc-_tvjBc>. Acesso em: 24 mar. 2018. Cf. a fonte em DE QUINCEY, Thomas; JAPP, Alexander H. (Alexander Hay). The posthumous works of Thomas De Quincey. Ed. from the original mss., with introductions and notes. by Alexander H. Japp. Londres: William Heinemann, 1891.20 Disponível <http://archive.org/details/posthumousworkso01dequ>. Acesso em: 24 mar. 2018.

273 Ver HOWSE, Martin. Occulted Energies: Earth, Alchemy, Electronics and Technology. Energies in the Arts Conference, National Institute for Experimental Arts (NIEA), UNSW Art \& Design, Sydney, 2015.

274 Provide by Arts, for the hardnesse of Nature, for one Sister weepeth without the other. Epígrafe do texto de introdução do sintetizador ERD/y, da série ERD Modular Eurorack 2019. Cf. fonte em DEE, John; CASAUBON, Meric; KELLY, Edward. A true \& faithful relation of what passed for many yeers between Dr. John Dee ... and some spirits: tending (had it succeeded) to a general alteration of most states and kingdomes in the world: his private conferences with Rodolphe Emperor of Germany, Stephen K. of Poland, and divers other princes about it : the particulars of his cause, as it was agitated in the Emperors court, by the Pope's intervention: his banishment and restoration in part : as also the letters of sundry great men and princes (some whereof were present at some of these conferences and apparitions of spirits) to the said $D$. Dee : out of the original copy, written with Dr. Dees own hand, kept in the library of Sir Tho. Cotton ... : with a preface confirming the reality (as to the point of spirits) of this relation, and shewing the several good uses that a sober Christian may make of all. Londres: Printed by $D$. Maxwell for T. Garthwait..., 1659. Disponível em: <http://archive.org/details/truefaithfulrela00deej>. 
com várias camadas, sendo a mais intermediária delas metade técnica, metade linguagem (como é o caso dos computadores).

Figura 25 - Prototipagem do computador telúrico em ambiente externo (2014)

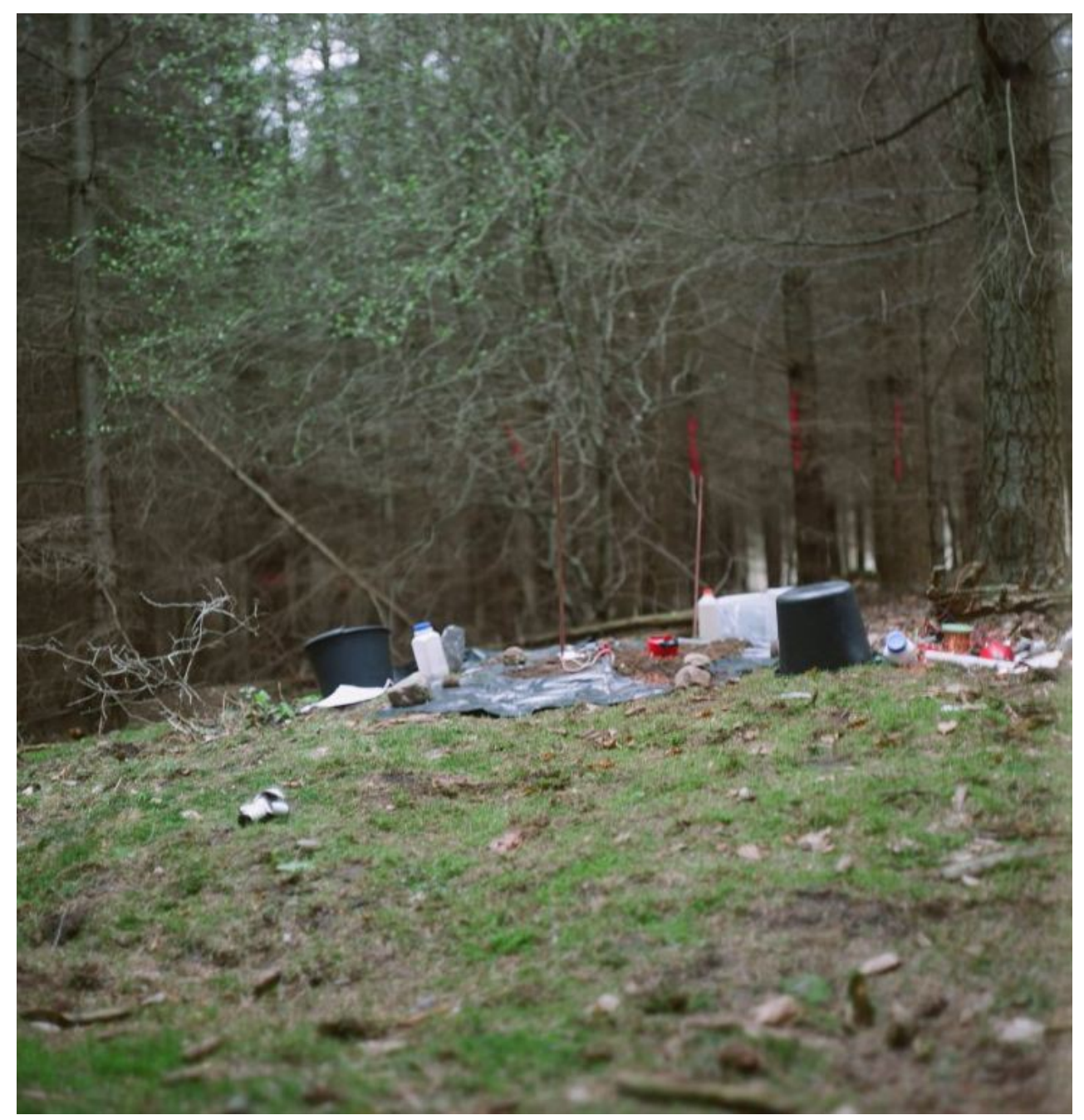

Fonte: http://www.1010.co.uk/org/sketches.html

A analogia é incorporada em outros projetos de Howse por meio de um processo de amplificação que não se circunscreve a uma finalidade precondicionada, sendo-lhe assim bastante amplas as possibilidades de invenção. Tome-se as duas variações de The Earthcodes Project: earthboot e earth computer. Formado por uma série de laboratórios ao ar livre (ver Fig. 25), a principal indagação suscitada pelo projeto é a possibilidade de se construir um computador telúrico, e a primeira experiência, realizada na reserva florestal de Schorfheide-Chorin, 
Alemanha, é subverter a operação convencional de reinicialização do sistema principal de um computador a partir de um disco rígido (ou de um pendrive), primeiro soterrando um frasco contendo uma bobina mergulhada em solução de sulfato de cobre, e depois o conectando a um "dispositivo de gerenciamento de material terroso" - um transdutor, na verdade - que, por sua vez, é conectado à porta USB de um computador portátil. A proposta de Howse é substituir as tradicionais correntes elétricas por correntes telúricas com o intuito de compreender as relações comunicacionais entre o código simbólico humano e o sentido emanado por minerais não consolidados: "Às vezes, três a cada cem vezes, aparecem caracteres estranhos piscando na tela, indicando que a terra não está interessada pelo código sendo executado em meu computador". Por contradição, a linguagem não-humana da terra não se mostra compatível, ao menos em primeira instância, com o sistema de notações humano. Como se dedicar, então, a uma métrica difundida, a um padrão mínimo que seja, a um sistema de compatibilidade entre o gesto técnico e os limites do mundo natural (SIMONDON 1969: 206)?

A solução se deu a partir de uma descoberta fortuita. Ao notar que a terra seca impedia o fluxo de sinais em earthboot, sendo os solos úmidos e com mais atividade micelial e animal, os mais adequados, Howse se deu conta de uma compatibilidade até então subestimada, entre produtos humanos e não humanos. Foi então que concebeu mais uma das derivações de The Earthcodes Project, a qual implica no registro comunicacional de uma classe de seres invertebrados, os vermes anelídeos decompositores de húmus, popularmente conhecidos como minhocas. Uma das fascinações de Howse é ouvir a voz da História Natural, libertar-se do diálogo interior, do eterno embate conceitual entre fala e linguagem humana, para dedicar-se à identificação de "jargões" que circulam pelo bioma, em especial o subterrâneo. Sabe-se que uma espécie de nematódeo, o Caenorhabditis elegans, emprega sinais químicos para trocar informação com seus pares, ${ }^{275}$ indicando que, sejam quais forem os códigos trocados entre os animais, eles seriam intraduzíveis para a linguagem humana. O que não deixa de ser uma constatação alvissareira, porque balda a imposição de situar a linguagem humana como referente universal,

275 Ver CALIFORNIA INSTITUTE OF TECHNOLOGY. Decoding Worm Lingo. EurekAlert! 12 abr. 2012. Disponível em: <http://www.eurekalert.org/pub_releases/2012-04/ciot-dwl041212.php>. Acesso em: 22 mar. 2018. 
ou como a linguagem que traduz todas as outras linguagens, franqueando a introdução de, se ousarmos dizer, uma Linguagem Universal Nematódea. No início, Howse modificou sua série de sintetizadores modulares ERD (Earth Return Distortion) para lograr a montagem de ERD/WORM, dispositivo eletrônico que decodifica um vocabulário de mais de 4000 palavras e frases, incluindo alofones básicos ou fonemas, em "locuções" proferidas por vermes anelídeos. ${ }^{276}$ Diversos dispositivos eletrônicos foram incorporados ao aparelho e modificados, inclusive os seus títulos; por exemplo, o sintetizador de fala Speak \& Spell, popular brinquedo da Texas Instruments, um sistema texto-fala (TTS, na sigla em inglês) que converte textos ortográficos em fala, torna-se, na transmutação alquímica de Howse, Speak \& Worm. O ímpeto transformador atinge inclusive a epígrafe do manual apensado ao dispositivo, uma frase escrita pelo alquimista alemão Michael Maier: "O verme ficou por muito tempo desejoso de falar, porém a regra e a ordem do Tribunal ordenou-lhe o silêncio, mas agora se pavoneando e tumeficando, impaciente de mais delongas, ele irrompeu assim...", ${ }^{277}$ expressão seguida de especificações detalhadas do algoritmo e da maquinaria envolvida na criação e simulação de vozes e vocalizações não humanas.

Por fim, em uma espécie de salto da fé, Howse transmite impulsos magnéticos e ultrassônicos ao solo, e os sinais distorcidos, "decodificados" por vermes anelídeos, são registrados e publicados em um documento com mais de 3500 páginas, versos do que ele chama de worm poetry, ${ }^{278}$ representação da

276 Escutar as locuções extra-humanas em ERD/WORM pre release [016]. Disponível em: <https://soundcloud.com/martin_howse/erdworm-pre-release-016>. Acesso em: 21 mar. 2018.

277 A epígrafe (não referenciada por Howse) consta em livro de Meier no qual é contada a história de oito representantes dos reinos animal, vegetal e mineral, competindo para provar quais são os mais benévolos para a humanidade. A modificação mencionada é a substituição da palavra silkworm (bicho-da-seda), um dos concorrentes, por worm (geralmente traduzida por "verme"). Os outros participantes do concurso são: bezerro, ovelha, ganso, ostra, abelha, linho e o deus Mercúrio, simbolizando provavelmente a prata líquida, elemento vital para os alquimistas. Ver Lusus serius: or, serious passe-time. A philosophical discourse concerning the superiority of creatures under man. [Traduzido por J. de la Salle, pseud., i.e. John Hall.]. Oppenheim, 1654 [1616], p. 56. Ainda sobre animais conversadores, a psicóloga suíça Marie-Louise von Franz recorda a jornada (peregrinatio) de Meier em busca da ave Ortus, uma versão alemã do Simurgh (folclore persa), pássaro com rosto e voz humana. Contudo, segundo Jung, ela tem também uma conexão com a Fênix, ave que obtém vida nova surgindo das cinzas, primeiramente na forma de um verme. Ver FRANZ, Marie-Louise von. Individuation in Fairy Tales: Revised Edition. Boulder, Colorado: Shambhala Publications, 2017.

278 Cf. HOWSE, Martin. Worm in July. Disponível em: <http://1010.co.uk/worms.pdf>. Acesso em: 21 mar. 2018. Excerto da sintaxe críptica dos vermes transposta para o alfabeto fonético ASCII (American Standard Code for Information Interchange): ctrdûïœus'ymanofèrdsps $s$ uarén'Écarine,...êvin'âômucl.)ùêpprégéns pel tr qs népe sièr,ômmonfoce.iïq,œumyaran,...'â——'yx- 
comunicação nematódea, ilegível, indicando a primazia da semântica sobre a sintaxe, de um sentido revelado da alteridade sobre a tentadora análise estrutural ou linguística.

Supõe-se, assim, o argumento central do projeto (ou quase-programa) de Howse: estabelecer uma aliança sinergética entre esquemas técnicos e forças naturais, podendo ser os primeiros abstratos (códigos, simbolismo) ou concretos (dispositivo, nominalismo); e os últimos, paranormais ou científicos. A respeito ainda da instauração do canal com o mundo animal subterrâneo, incluímos mais uma analogia, a que se dá entre composição (musical) e compostagem (decomposição de materiais orgânicos), a qual é perfeitamente demonstrada na performance Composting The City. Composting The Net (2013), de Martin Howse e Shu Lea Cheang, exibida em Riga, Letônia. O som de um dos sintetizadores de Howse é gravemente modulado quando a sua mão remexe uma porção de terra orgânica dentro de um tanque, repleta de micróbios e minhocas, como se ela estivesse lendo, ao estilo de um maestro, uma partitura geomântica. ${ }^{279}$ Evento que nos leva de encontro a uma das características da estética ecotécnica, a noção de esquematismo, "princípio de organização do sensível" (DUFRENNE 2015: 94), mas só que, desta feita, o contraste expressivo, carregado de sentido, é exposto não apenas por uma disparidade visual, mas também por uma sonora, englobada no ruído, comumente a "tela de fundo", agora na qualidade de som em destaque. Contudo, ao apreendê-los, os planos não se anulam na apreciação estética, e sim se reforçam. Outra hermenêutica possível da performance é a discussão acerca da mediação tecnológica de fenômenos naturais, se, ao serem mediados, se extinguiriam na artificialidade. Cremos que não, porque o sentido dos pulsos eletromagnéticos exumados por Howse, fenômeno natural, reside no comércio de duas formas de energia estudadas pela física clássica: a mecânica acústica e o electromagnetismo - o som e o sinal. 


\subsubsection{Observatório psicogeofísico}

No empenho de se compatibilizar estudos de arqueoastronomia, psicogeofísica $^{280}$ e tecnologias de teledetecção aplicadas no sensoriamento do planeta, Jamie Allen, Martin Howse e Jonathan Kemp propõem juntos o Shift Register, projeto de pesquisa e arte que investiga como atividades tecnológicas e de infraestrutura acarretam marcas indeléveis na face da Terra. O título, traduzido para "registrador de deslocamento", termo emprestado da eletrônica digital, remonta à uma atividade da memória computacional na qual bits são trocados no circuito (à direita ou à esquerda da trajetória elétrica), sendo a dinâmica, no caso da proposta feita originalmente para o festival de arte alemão transmediale, consumada não por bits, mas por corpos "humanos, terrestres e planetários". A ação central do projeto é o mapeamento de "pontos-chave" evidenciados por atividades antropogênicas zonas de exclusão, "fazendas de servidores", rotas da poluição - redirecionando a noção simondoniana de points-clés para o que os artistas chamam de "pontos de condensação", locais favoráveis ao conhecimento e percepção da mecânica terrestre, seus vapores e espíritos. Como parte do Megaobservatório da Terra (Earth Observatory Array, ou EOA), prevê-se a realização de publicações de pesquisa (READER) e oficinas (RESPONSE) para congregar valências da "estética industrial e das ciências de observação, land art, aparelhos alquímicos e maquinaria simbólica do esotérico contemporâneo". ${ }^{281}$ Cada uma das ações consumadas em várias partes do mundo é chamada, apropriadamente, de reação, compondo em suas longitudes um conjunto de vestígios in situ (Earth Observatory Array Elements, ou EOAE), marcadores estratigráficos ${ }^{282}$ sem intencionalidade científica, mais propensos ao papel de "cravos dourados" estéticos, ou registros da alvorada da era dos humanos.

Resumo da tese proposta: o esforço de estruturação da realidade excede o mundo imediato, abarcando todo o universo. Em um dos cerimoniais reativos da

280 Paródia do procedimento psicogeográfico, definido pelo pensador francês Guy Debord, em 1955. Ver psycho [psychogeophysics]. Disponível em: <http://www.psychogeophysics.org/wiki/doku.php>. Acesso em: 4 abr. 2018.

281 Cf. as definições no blog Shift Register Tumblr. Disponível em: <http://shiftregister.info/info>. Acesso em: 26 mar. 2018.

282 Sobre os atuais candidatos ao papel de marcador do Antropoceno, ou, no jargão dos geólogos, Seção e Ponto de Limite Global de Estratotipo (GSSP, na sigla em inglês), ver WATERS, Colin N.; ZALASIEWICZ, Jan; SUMMERHAYES, Colin; et al. Global Boundary Stratotype Section and Point (GSSP) for the Anthropocene Series: Where and How to Look for Potential Candidates. EarthScience Reviews, v. 178, 2018, pp. 379-429 
série global de observações Earth Observatory Array Elements (algo como Megaobservatório da Terra e seus Elementos), este sucedido na caverna de Treak Cliff, Castleton, Inglaterra, buscou-se, de partida, instituir o entendimento acerca da natureza dos raios cósmicos, na verdade partículas extremamente penetrantes, dotadas de alta energia, que se deslocam a velocidades próximas à da luz no espaço sideral. Deslocar o céu para dentro da terra, virando do avesso a astronomia e revirando-a em geologia, já se configura uma espécie de operação mágica de reticulação de dois polos analógicos - arqueologia e astronomia, dois campos totalizados no documentário Nostalgia da Luz (2010), de Patricio Guzman (ALLEN \& HOWSE, 2017b: 19) -; e sabemos que a prática de observar estrelas durante o dia, de dentro de poços de minas abandonadas e chaminés, não é assunto estrito a contos folclóricos, tendo sido intuído ao longo de um amplo arco temporal que vai de Aristóteles ao naturalista alemão Alexander von Humboldt. ${ }^{283} \mathrm{E}$ ainda que a operação binomial garanta que ambas as disciplinas, em mútuo acordo spinozista, celebrem o tempo profundo do passado, regulando um ponto de vista sub specie aeternitatis, a que olha para o céu reflete a teoria e a que olha para a terra reflete a prática. Ciências puras e ciências aplicadas; artes e ofícios: a antiga disputa epistêmica. Daí a entonação unificadora dispersa na publicação preparada para o festival Abandon Normal Devices (2017) - conjunção viabilizada, oportuno registrar, pela ciência de borda, ou, se ousássemos dizer, pela ciência infra-mince do entredois - e no sentido dos três dispositivos elaborados especialmente para o cerimonial.

Analisemos agora os três objetos tecno-ambientais utilizados em Treak Cliff (ver Fig. 26), a começar pelo elemento intitulado de DESCIDA. Trata-se de um instrumento para medir a ressonância cristalina e a radiação eletromagnética emitida pela fluorita, mineral que compõe parte significativa da caverna, daí ele ser chamado localmente de Blue John, devido às ligas de cor púrpura-azulada. O segundo, DECAIMENTO, é um instrumento de detecção do fluxo de raios cósmicos ultraenergéticos, as chamadas "chuvas" de múons, recordando que, por decaimento, leia-se reações que ocorrem no núcleo de elementos radioativos. O terceiro, PROFUNDEZA, é um detector Cherenkov construído - em consonância com os 
outros dispositivos - sob o estatuto da filosofia Maker e que serve para comparar velocidades de partículas oriundas do espaço profundo com as da luz. Tal é, portanto, a breve descrição técnica dos dispositivos, cujos detalhes, enviados e ponderados por pares das ditas Ciências Duras, aguçaram o escárnio, ou, no caso do conselheiro municipal do burgo de Derbyshire, a ameaça sumária de detenção (ALLEN \& HOWSE 2017b: 35). O jogo binomial, neste momento, é entre arte e magia, não mais convindo aos autores e espectadores o valor de verdade de uma lógica bivalente (verdadeiro ou falso), com a chancela científica. Técnica e magia, nesse caso, dependem das evocações hic et nunc do âmbito subterrâneo, tendo em conta que a "arte reconstitui o universo, ou melhor, reconstitui um universo, enquanto a magia parte de um universo para estabelecer uma estrutura que já o diferencia e o divide em áreas carregadas de significado e poder" (SIMONDON 1969: 193; grifo nosso).

Figura 26 - EOAE-TC \#1 Descent, EOAE-TC \#2 Decay e EOAE-TC \#3 Depth, Caverna de Treak Cliff (2017)

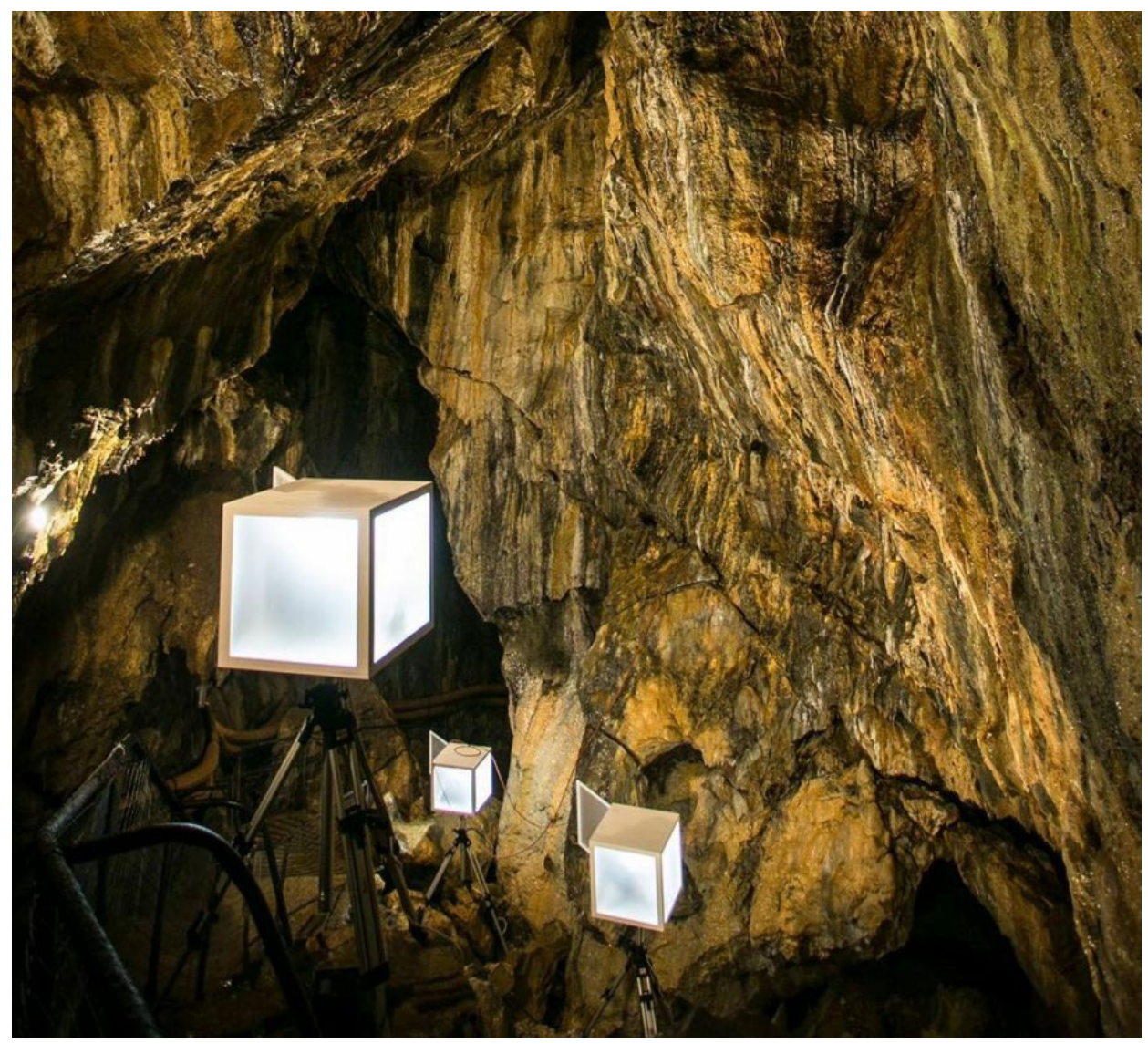

Fonte: ALLEN \& HOWSE, 2017b: 36 
Uma das pesquisas da série Earth Observatory Array Element, realizada na cidade de Pequim, envolveu a análise de material particulado e a percepção fenomenológica do smog, nevoeiros contaminados por poluentes aéreos, fenômeno que, na China, alcançou níveis alarmantes, a ponto de suscitar, na mídia, a palavra aglutinada "arpocalipse". ${ }^{284} \mathrm{O}$ que se pretende nesse projeto, sem que isso seja mandatório ou definitivo, é a introdução da estética do smog, ${ }^{285}$ sob a perspectiva dos indicadores da qualidade do ar. ${ }^{286}$ Contudo, o que se nota nas entrelinhas dos textos reunidos na publicação de referência, é a presença de dois eixos temáticos: o elemento ar - e, por efeito, o sopro $(k i)$ - e os elixires da vida eterna, receitados por fangshis (alquimistas taoistas) a uma gama de imperadores e suseranos. A respeito do primeiro eixo, introduz-se a título de prefácio uma reflexão de Hipócrates relacionando o vento exterior (ar) ao vento interior (respiração), e como as doenças dão-se como consequência de suas más circulações. Mas é na história da China, e não da Grécia, que o ar tem um papel primordial, sendo mesmo a substância de todos os seres. É lá, por exemplo, onde a chamada magia dos sopros, ou a arte do discurso com ritmo escandido, se revela como culminância (GRANET 1997: 36). Mas também na fala do universo, sendo o sopro o emblema do número um, o número do uno, ou ki (op.cit.: 107, § 3). A estrutura do universo, semelhante à casa do soberano, é sustentada por colunas, os pilares do Céu, "relacionadas com as Oito Direções, as Oito Montanhas e as Oito Portas que dão passagem às Nuvens de chuva e aos Oito Ventos" (op.cit.: 214, § 4). Um pensamento harmônico, como o chinês, daria corpo a um vento maligno? No sistema taoista, sim: no mito da grande inundação: "Durante a batalha que travou contra o Soberano Zhuanxiu, Kung-kung, o espírito do Vento, a quem a Morada Sombria serve da abrigo, conseguiu abalar o [monte] Pou-zhou. Seguiu-se um dilúvio. O mundo só fica em ordem ao ser fechado à maneira de uma residência" (loc.cit.: § 6). A Casa do Chefe é também a casa do Universo. Começa-se com os compostos químicos nos tempos do império; e

284 Ver "Arpocalipse" na China: Poluição Coloca Meio Bilhão de Pessoas em Alerta Vermelho. BBC Brasil, [s.d.]. Disponível em: <http://www.bbc.com/portuguese/internacional-38393259>. Acesso em: 16 abr. 2018.

285 Os autores enquadram nesse "gênero" o "parque" limpo da artista Amy Balkin, uma escultura que flutua na atmosfera e está sujeita aos ventos dominantes e à circulação de longo alcance dos gases. Ver Public Smog. Disponível em: <http://www.publicsmog.org/>. Acesso em: 16 abr. 2018. Ver também BALKIN, Amy. Public Smog. In: DAVIS \& TURPIN 2015, pp. 341-46.

286 Ver PARIKKA, Jussi. FCJ-219 The Sensed Smog: Smart Ubiquitous Cities and the Sensorial Body. The Fibreculture Journal, n. 29, 2017. 
termina-se com os aerosóis e partículas expelidas por uma das maiores potências econômicas do mundo atual. Com relação aos elixires, os autores da pesquisa apontam que o chumbo (princípio Yang) e o mercúrio (princípio Yin), dois onipresentes particulados atmosféricos, constituíam os ingredientes principais de um dos métodos de preparação do elixir da imortalidade, o qual teria envenenado o primeiro imperador, Qin Shihuang. Deveras, a virtude do Tempo, para os chineses, tem uma natureza cíclica e procede por revoluções (GRANET 1997: 67).

\subsubsection{Alquimias hodiernas}

Um dos projetos de Howse que mais faz comércio fronteiriço com a alquimia milenar é The Crystal World ${ }^{287}$ (O Mundo de Cristal), série de oficinas coordenadas em conjunto com os artistas britânicos Ryan Jordan e Jonathan Kemp. Realizadas em Londres e em Berlim, as atividades laboratoriais abertas ao público procuram sistematizar, segundo as documentações, ${ }^{288}$ "precipitações de terras raras ou minerais, geologia sintética de alta temperatura, cristalografia indutiva, fossilizações antropogênicas, criptografia baseada em cristais de água, fotografia Kirlian, ${ }^{289}$ construção de fulguritos ${ }^{290}$ e forças ódicas ${ }^{291}$ difratadas". As ações e práticas se complementam em cadeia, como por exemplo, o processo de reciclagem de metais encravados em peças descartadas de computadores resultam na obtenção de material escultórico para a exposição. Ao contrário de tempos de antanho, fornos de micro-ondas realizam o papel de cadinhos refratários, de onde os artistas extraem o pó de silício, derivado da areia de quartzo aquecida com pó de magnésio, e o ferrogusa, produzido a partir da hematita triturada e fundida a cerca de 1200 graus

287 Ver HOWSE, Martin; KEMP, Jonathan. The Crystal World. Mute, 26 set. 2012. Disponível em: <http://www.metamute.org/editorial/articles/crystal-world>. Acesso em: 5 maio 2018.

288 Cf. o wiki documental e conteudístico em: <http://crystalworld.org.uk/wiki/doku.php? id=the_crystal_world:space:postdescription>. Acesso em: 5 maio 2018.

289 Método fotográfico descoberto acidentalmente pelo cientista russo Semyon Davidovich Kirlian em 1939 ao colocar um objeto sobre uma chapa fotográfica submetida a campos elétricos de alta voltagem. Ver o verbete Kirlian photography. In: Wikipedia. [s.I.: s.n.], 2018. Disponível em: $<$ https://en. wikipedia.org/w/index.php?title=Kirlian_photography\&oldid=837092780>. Acesso em: 5 maio 2018.

290 Corpos vitrificados devido à fusão da sílica por descarga elétrica.

291 Potência vitalista investigada pelo barão Carl von Reichenbach no século 19, uma força situada por ele na mesma hierarquia do ki chinês e do prana indiano, porém oriunda não da respiração, mas de campos eletromagnéticos biológicos. Ver o verbete Odic force. In: Wikipedia. [s.l.: s.n.], 2018. Disponível em: <https://en. wikipedia.org/w/index.php?title=Odic_force\&oldid=837147325>. Acesso em: 5 maio 2018 
centígrados. Trata-se, em outras palavras, da reciclagem de resíduos eletrônicos, atividade de alto teor tóxico, porém rentável, desempenhada em vários países da Africa, geralmente em condições de trabalho degradantes e insalubres. Howse, ciente dos males da externalização capitalista, conduz em suas oficinas o que ele chama de "decristalização/recristalização", ou a extração por eletrólise de metais de placas de circuito impresso - tais como como nitrato de prata, ferro, cobre, fósforo, boro e tântalo - e empregá-los em seguida na confecção de pequenas esculturas metálicas, os "fósseis do Antropoceno". Assim como no projeto Shift Register, os artistas reúnem uma copiosa documentação de apoio às atividades práticas, tendo como destaque um livro de história da química na Índia medieval, ${ }^{292}$ no qual designase os méritos de inúmeros elementos químicos, por exemplo o mercúrio (ele aquecido remove a pobreza; já a sua versão confinada faculta a habilidade humana de "alar-se"), bem como ensina-se receitas tibetanas de formação de metais. O símbolo mágico da reciclagem de metais do lixo eletrônico, para Howse, é a água régia, mistura de ácido nítrico e ácido clorídrico que converte o ouro numa solução de ácido cloroáurico (a página inicial do Wiki de documentação é a capa de Aula Subterranea [1574], do metalurgista germânico Lazarus Ercker, uma gravura do artefato de produção da aqua regia). Mas, de acordo com outras referências na extensa obra de Howse, digamos que o símbolo onipresente é o oroboro, o dragão que devora a própria cauda, presente em diversos manuscritos alquímicos, como o Atalanta Fugiens, livro emblemático composto de 50 ilustrações, cada uma das quais é acompanhada por um verso epigramático e uma fuga musical. ${ }^{293}$ 
Figura 27 - Myco-logical, The Crystal World Open Laboratory and Exhibition,

The White Building, Londres, 2012

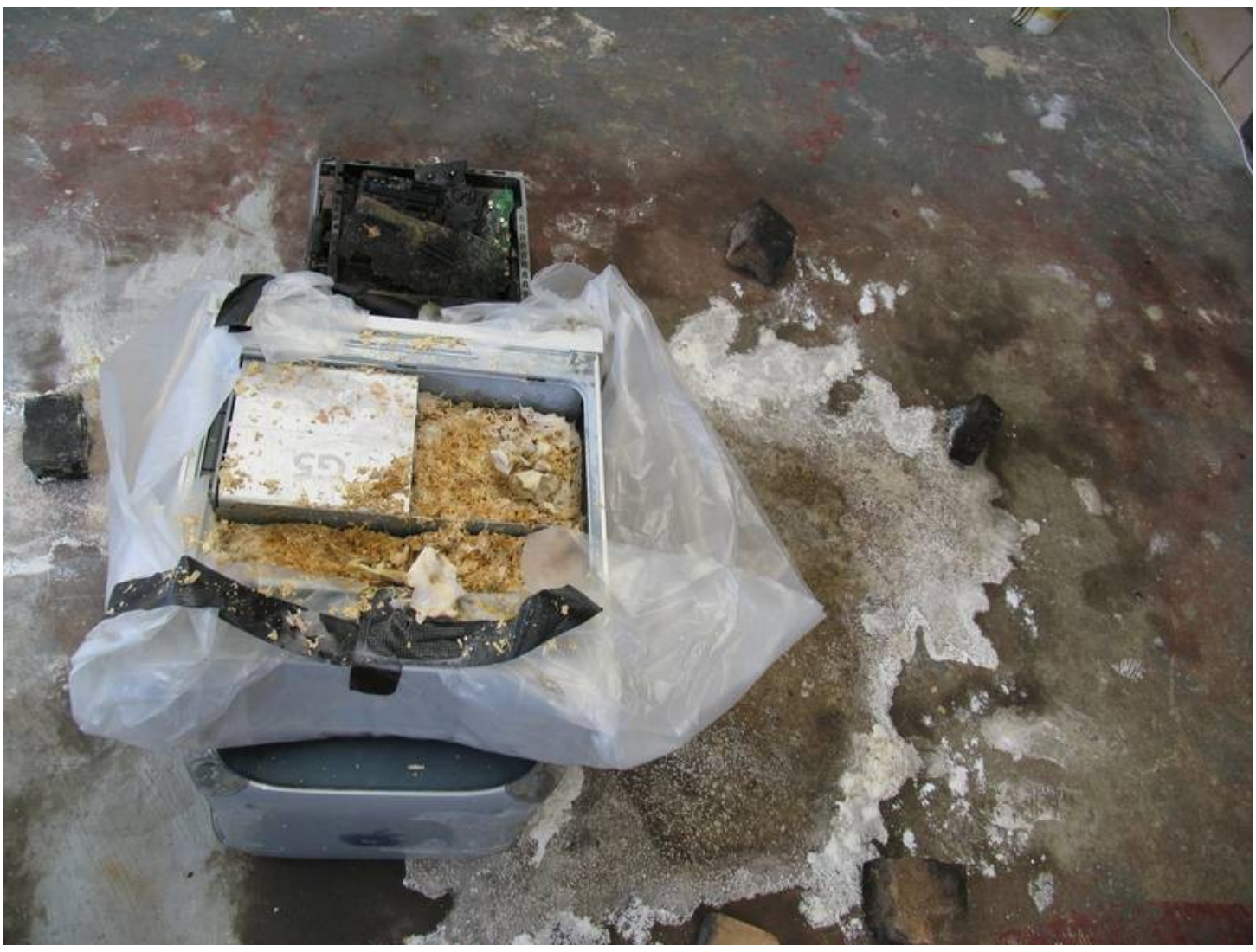

Fonte: http://crystalworld.org.uk/wiki/doku.php?id=the_crystal_world:space:postdescription

Portanto é oroboro um dos símbolos mais vigorosos da transmutação alquímica, seja do corpo ou de metais, e objeto-imagem da série de oficinas capitaneada por Howse. Assim como da ciência, porque é August Kekulé quem, ao sonhá-lo durante uma dormitada em seu gabinete, esquematiza a estrutura molecular do benzeno, inaugurando a Teoria Estrutural do Carbono. No relato ficcional de Thomas Pynchon, mencionado por Howse em diversas passagens, o químico alemão "sonha com a Grande Serpente que morde a própria cauda, a Serpente sonhadora que contorna o Mundo... A Serpente que anuncia: 'O mundo é uma coisa fechada, cíclica, ressoante, que eternamente retorna', será entregue a um sistema cujo único propósito é violar o Ciclo" (PYNCHON 1998: 426). Ao versar sobre a "violação", o autor estadunidense refere-se aos valores adulterados do capitalismo, um sistema que toma "sem dar nada em troca, ... retirando do resto do Mundo imensas quantidades de energia para manter sua pequena fração desesperada ..." (loc.cit.). Pode-se associá-la, colateralmente, à cibernética de 
primeira ordem, disciplina que distancia-se da engenharia eletrotécnica e aproximase da engenharia de comunicações, ramo "cujo principal interesse não é a economia de energia, mas a reprodução acurada de um sinal" (WIENER 1961: 39). Contudo, Howse readmite a ideia da violação do Ciclo ao mundo dos seres vivos, evocando como lhes é essencial transgredir - ou ao menos deferir por intermédio de uma diferença, quer dizer, por um processo metabólico - a forte atração entrópica, "tendência natural das coisas de passarem à desordem" (SCHRODINGER 2012: 69), ou seja, de dissolverem-se no perecer de um equilíbrio constante e estático. A operação que está por detrás de tal violação é, por certo, a da recursividade, força motriz do construtivismo da cibernética de segunda ordem (implicado, como vimos no primeiro capítulo, na esquematização de formas) e, como recorda Howse, da engenharia eletrônica, em especial no caso do amplificador operacional, cujo diagrama remete à imagem de uma "serpente [que] se une a partir do interior sob o sinal de feedback negativo". ${ }^{294}$ Um exemplo de concretização envolvendo os planos vital e técnico, no sentido que Simondon dá ao termo, transcorre na exposição derivada das oficinas (ver Fig. 27), na qual, após o banho eletrolítico de uma placamãe G5, propõe-se a recristalização dos metais lixiviados no interior de cogumelos ostra (Pleurotus ostreatus). Consubstancia-se, assim, a biologia e a "vida técnica" (Georges Canguilhem 2008 apud STIEGLER 2018: 59), ambas lançando-se agora em conjunto em direção à entropia negativa, ou neguentropia.

\subsubsection{Considerações}

A fase mágica, na concepção de Simondon, bifurca-se em técnicas e religiões, sendo portanto, fenomenologicamente, a mais vital relação entre homem e mundo (BARDIN 2015: 170), ou mesmo a ponte de transição evolucionária entre natureza e cultura (loc.cit.). Nesse sentido, foi responsável por realizar, em épocas distintas, a passagem do corpo simbolizado (tatuagens, escarificações etc.) para o objeto simbólico, permitindo com que a consciência se projetasse (como protensão e imaginação) em objetos, fato constatado nas práticas religiosas do vodu (voults) (op.cit.: 166). A magia de Simondon engloba também elementos ligados ao fundo da realidade pré-individual, sobre o qual sobressaem-se as figuras dos sistemas (vivos, 294 Ver HOWSE 2015. 
ou não), uma fonte carregada de energia que os mantém em sua metaestabilidade. ${ }^{295}$ Independentemente de eventuais orientações hermenêuticas acerca da complexa noção simondoniana de pré-individual - sejam aquelas de caráter bioantropológico (COMBES 2013: 69) ou tecnológico ${ }^{296}$ - sabemos da importância de classificá-la, no âmbito da tecnomagia de Martin Howse, como uma espécie de princípio ilimitado e indissolúvel, a partir do qual as coisas limitadas seriam distribuídas num determinado Espaço-Tempo. Pode-se querer explicar o ilimitado como uma das várias faces da physis, "onde a palavra natureza poderia ser usada para designar o que permanece de original, antes mesmo da humanidade constituída no homem" (SIMONDON 1969: 248); e é, provavelmente, a causa eficiente de todos os suplementos técnicos, porque o "homem inventa levando a cabo o seu próprio suporte natural, esse apeiron que permanece ligado a cada ser individual" (loc.cit). ${ }^{297}$ Talvez seja lícito afirmar que os objetos tecno-ambientais de Martin Howse pretendam imbuir-se daquele fundo ilimitado, sem que isso signifique que eles sejam produtos do Vazio absoluto: "A invenção, é bom que humildemente se diga, não consiste em criar a partir do nada, mas a partir do caos; em primeiro lugar, os materiais precisam estar à mão: podemos dar forma a substâncias obscuras e informes, não trazer à luz a substância em si".. ${ }^{298}$ Ademais, o funcionamento de tais produções contém em si uma margem de indeterminação,

295 lbid.

296 "Um escritor, um músico ou um cineasta mobiliza, em cada caso, um fundo retencional e protencional comum, constituído por protorretenções e protoprotensões, típicas de uma região cultural e de uma época, e que ele próprio adota com base em um fundo arquiretencional e arquiprotencional, isto é, com base em elementos arcaicos que derivam do que Simondon chamou de 'pré-individual' (sob a influência de Jung e sua teoria da individuação)". Ver STIEGLER 2018, p. 162; tradução nossa. Pode-se concluir, nesse registro, que a obra de Martin Howse alicerça-se em protorretenções (marcas, resíduos, rastros) e protoprotensões (sonhos e projeções ancestrais), como se seus conteúdos fossem extraídos diretamente de um arquivo universal (arquirretencional), depósito de conhecimentos herméticos, formas imaginárias ainda não completamente desvinculadas dos anseios despertados pela suprema forma da entropia, a morte (arquiprotencional).

297 O excerto completo, no original, é: L'objet qui sort de l'invention technique emporte avec lui quelque chose de l'être qui l'a produit, exprime de cet être ce qui est le moins attaché à un hic et nunc; on pourrait dire qu'il y a de la nature humaine dans l'être technique, au sens où le mot de nature pourrait être employé pour désigner ce qui reste d'originel, d'antérieur même à l'humanité constituée en l'homme; l'homme invente en mettant en œuvre son propre support naturel, cet apeiron qui reste attaché à chaque être individuel. (tradução nossa).

298 Cf. o prefácio a terceira edição (1831) in: SHELLEY, 2013. A propósito, Martin Howse inspira-se com mais paixão não em Shelley, mas em Bram Stocker, criador de outro célebre monstro da literatura gótica de horror. Os blocos de terra que controlam (e distorcem) os sinais de áudio da série de sintetizadores modulares ERD (Earth Return Distortion) são equiparados à carga de "areia prata" transportada em caixões para Londres, para que o vampiro pudesse aperceber-se, na distância, em sua terra natal: a Transilvânia. Ver ERD Modular Eurorack Series 2018. Disponível em <http://www.1010.co.uk/org/ERD.html>. Acesso em: 18 jul. 2018. 
sendo-lhes autorizada certa liberdade comportamental perante os cisnes negros da contingência. Ao contrário da Big Science e sua precisão para mensurar o que necessariamente não pode ser diferente do que é (STIEGLER 2011: 187), a tecnociência "amadora" de alquimistas e magos contemporâneos é plenamente favorável às tecnologias naturais que lidam com o inesperado; e, como reconheceu Aristóteles, as técnicas, em geral, "amam o acaso" (op.cit.: 189). 
CAPÍTULO 3

CAMPOS EXPANDIDOS 
INTRODUÇÃO

Ao deixarmos o campo da arte analisaremos as relações da estética ecotécnica com dois "campos expandidos", ${ }^{299}$ sendo eles os da arquitetura e infraestruturas, mutuamente interligados. Vamos subdividir em conformidade, portanto, esse terceiro e último capítulo em dois subcapítulos. Já sugerimos, no segundo capítulo, acerca da inserção de teses artísticas no campo da arquitetura e o desenvolvimento de disposições ficcionais no das infraestruturas. Aqui, diversamente, iremos contemplar o processo por meio do qual objetos não deliberadamente artísticos são estetizados por um intencionalidade cognitiva, convertendo-se em objetos estéticos e, sob condições particulares, em objetos belos. Quais condições?, pergunta-se. Em primeiro lugar, cumpre salientar de que tratamos de objetos tecno-ambientais, associação de objetos técnicos ao seu respectivo meio. Equilibra-se, em proporções variáveis, forma, função e funcionamento e, em plano superior, figura e fundo. Feita a combinação, identificamse neles características objetivas - tais como adequação tecnológica e propensão à desabstração - e subjetivas - tais como esquematismo (tomada de forma) e significação (produção de sentido). No subcapítulo voltado à arquitetura, veremos como o tradicionalismo, paradoxalmente, faculta a consecução de projetos inovadores em tempos de mudanças climáticas. Bem como a chamada arquitetura paisagística recobrando de forma inesperada a fórmula "pensar através da paisagem", proposta por Augustin Berque. No subcapítulo sobre as infraestruturas, vamos preterir o olhar assoberbado e datado que Brian Hayes (2006) dirige ao complexo infraestrutural legado, porque o que está em jogo é precisamente a mudança desta percepção. Por exemplo, dotaremos não as cidades com o poder de caminhar, como sonhavam os arquitetos radicais do século passado, mas os próprios pedestres, nesta hora tomados pela ideia-valor de "caminhabilidade". Segue-se na ordem outros setores, como telecomunicações, energético e hídrico.

299 A expressão "campo expandido" é vagamente inspirada no termo criado por Rosalind Krauss (ver seção 2.2.1, Capítulo 2), bem como no vocábulo "cinema expandido", o qual inclui formas de expressão que abrangem outras dimensões da imagem em movimento. Cf. Expanded Cinema Monoskop. Disponível em: <https://monoskop.org/Expanded_cinema>. Acesso em: 16 abr. 2019. Em nossa significação, a expressão parece implicar na extrapolação da análise estética para além da esfera da arte propriamente dita. 


\subsection{ESTÉTICA ECOTÉCNICA E ARQUITETURA}

A inserção de um pensamento estético-ecotécnico no domínio da arquitetura teve como ponto inicial o contexto dos artistas da Art Nouveau que, na virada do século 19 , tentaram reconciliar a relação entre o homem e a natureza, tomando inspiração estética do mundo natural. Os meticulosos desenhos de radiolários, feitos pelo biólogo alemão Ernst Haeckel (criador do termo ecologia), iriam paulatinamente influenciar 0 arquiteto francês René Binet, conhecido por projetar a Porte Monumentale para a Exposição Universal de 1900, feira mundial realizada em Paris, França. Além dos arcos fortemente inspirados nos esqueletos minerais de protozoários ameboides postos em seu "portão monumental", outros organismos marinhos de Haeckel foram insinuados em outros projetos, notadamente as águasvivas tropicais, que tornaram-se lâmpadas domésticas; os próprios organismos unicelulares do projeto da feira mundial foram transmutados em interruptores de luz e padrões de papel de parede. Arquitetos e designers, segundo Binet, deveriam "recorrer ao grande laboratório da Natureza" (WULF 2015: 312) com o intento de mimetizá-la. Veremos, entretanto, que a pura mimese das formas caracteriza uma espécie de conformismo perante a mimese do funcionamento espontâneo da physis; mais que a mimese, nos interessa a solidariedade constitutiva entre objetos técnicos e objetos naturais. Independente das costumeiras discussões sobre a conexão entre forma e função na arquitetura, são nos projetos na área da eficiência energética em edificações, por exemplo, que notamos com maior clareza a relação mutualística entre estética e funcionalidade. Neste primeiro subcapítulo seremos guiados, inter alia, pelo espírito do fabuloso arquiteto Eupalinos, o qual nos conduzirá por três terrenos "acidentados": variantes da escola orgânica, reduplicação de técnicas tradicionais e construção de lugares (e não espaços) públicos.

\subsubsection{Arquitetura orgânica}

A expressão "arquitetura orgânica", para os ortodoxos, é essencialmente aquela influenciada pelo pensamento de Frank Lloyd Wright, um pensamento dominado pela oposição à escola racionalista. Sua grande virtude foi inspirar-se na 
natureza e servir-se dela como base de projetos, mas o arquiteto estadunidense não foi capaz de inverter a tendência técnica da inovação que reforça a primazia da causa eficiente, desatendendo as outras três previstas por Aristóteles, em especial a causa material. ${ }^{300}$ Por exemplo, foram empregados em seu projeto mais célebre, Fallingwater House (1936), produtos com elevada pegada de carbono, como o aço e o concreto armado. É fecunda, não obstante, a influência do pensamento organicista, como em Case Study Houses, ensaios de arquitetura residencial pósguerra patrocinados pela revista Arts \& Architecture. ${ }^{301}$ No último quartel do século 20, tais experimentos foram reencenados. Porém mais que organicistas, tais exemplos são representativos de um novo paradigma holístico que revolucionaria as aspirações dos programas habitacionais nos Estados Unidos (RYKER \& HALL 2007). Eles alçam-se a uma linhagem arquitetônica que se houvesse atribuído o compromisso de desvincular-se das redes de energia elétrica (off-grid) e das tecnologias tradicionais do ambiente construído, incorporando novos materiais ao processo, como o calcrete de Pliny Fisk, substituto do concreto desenvolvido a partir do caliche e das cinzas volantes (op.cit.: 26). Seja como for, a arquitetura orgânica através da qual iremos especular uma estética identifica-se por sua literalidade, isto é, a organicidade deixa de ser uma qualidade ou o anseio de uma mera relação com a natureza e recobra a forma de um órgão propriamente dito. Ademais, a arquitetura orgânica com traços ecotécnicos não é biomimética, como já asseveramos, mas busca "inventar inovações compatíveis com a vida e até mesmo regeneradoras dela - no sentido mais amplo do termo 'Vida'". ${ }^{302}$ Em vez de investir no ímpeto mimético das formas da natureza, optamos pela reprodução de seus processos, sendo assim mais acertado apropriar-nos dos protocolos e preceitos da bioarquitetura e do biodesign do que da arquitetura orgânica clássica.

300 Sobre o confisco dos processos de inovação pela racionalidade econômica e a decorrente compressão da criteriologia causal aristotélica, ver STIEGLER 2015, p. 189.

301 Ver Arts \& Architecture: Case Study House Program. Notadamente o case \#23, assinado pelo escritório Killingsworth, Brady, Smith, and Associates, projeto que leva em conta o ambiente integrado. Disponível em: <http://www.artsandarchitecture.com/case.houses/index.html>. Acesso em: 20 jan. 2019.

302 Ver SCHEFFER, Olivier. From Biomimicry to Ecomimicry: Reconnecting Cities - and Ourselves - to Earth's Balances. The Nature of Cities, 30 nov. 2016. Disponível em: $<$ https://www.thenatureofcities.com/2016/11/30/from-biomimicry-to-ecomimicry-reconnecting-citiesand-ourselves-to-earths-balances/>. Acesso em: 7 jan. 2019. 


\subsubsection{Estruturas vivas}

Segundo a pesquisadora britânica Rachel Armstrong (2015), um outro método para a produção de arquiteturas ecológicas, supostamente dentro de nossa proposta de estética ecotécnica, seria o chamado biodesign, entendido como a incorporação de materiais vivos na arquitetura. Ao contrário dos que acreditam ser o tipo de vida pastoral, ou árcade, incompatível com um modelo de tecnologia intensiva, ${ }^{303} \mathrm{o}$ uso que alguns setores de construção civil faz atualmente do mundo vegetal é mais sofisticado do que parece. Para começar, estruturas e sistemas técnicos conectados à natureza de forma inconsútil não são vistos mais como um retrocesso, mas como um avanço tecnológico significativo. Talvez seja extravagante construir habitações a partir de enxertos e fungos, mas a sua pertinência é tão somente uma questão de mudança de paradigma cultural. É preciso primeiro abrir mão, em primeiro lugar, do hilemorfismo, teoria filosófica na qual o ser ocorre após o encontro entre forma e matéria, dando origem a uma substância, a um indivíduo já individuado, pronto e acabado. Em vez da palavra "indivíduo", Simondon preferia o substantivo "individuação", que dá a ideia de ação, de processo, ou melhor, de operação. A individuação de um ser já individuado ocorreria "em pleno voo", logo, durante, e não antes ou depois de sua constituição. As duas formas consagradas de pensamento a forma arquétipo de Platão e o modelo hilemórfico de Aristóteles - fundamentam o "princípio" da individuação a partir de um indivíduo já formado, seja no mundo das ideias ou no mundo real, sem levar em consideração a relação entre o individuado e a individuação, entre a estrutura e a operação. Tal relação, nesse caso, adquire uma qualidade ontológica, de ser. A filosofia clássica tende a pensar o ser na forma de indivíduo; Simondon propõe a individuação, ao invés de indivíduo; e a operação, ao invés de seu princípio constitutivo. Trata-se de, com o perdão do pleonasmo, uma "gênese volante". O processo é interpretado, na visão clássica, como uma forma de progresso: linear, evolutivo, do simples ao complexo. Mas, na verdade, deveria ser

$303 \mathrm{Em}$ entrevista, o escritor anglo-canadense Cory Doctorow revela a sua faceta ecomodernista ao afirmar que o "futurismo pastoral é genocida". Nas entrelinhas, reside a noção de que a tecnologia, ou melhor, a alta tecnologia da agroindústria, deve ser acelerada o máximo possível para a salvação de bilhões de pessoas. Mostra um preocupante desconhecimento sobre outros modos de existência das técnicas, como aqueles voltados à computação natural. Ver em WOODBURY, Mary. Interview with Cory Doctorow, Walkaway. Eco-Fiction, 3 mar. 2016. Disponível em: <http://ecofiction.com/interview-cory-doctorow-walkaway/>. Acesso em: 6 mar. 2017. 
visto como uma resolução de forças oponentes (mas não discordantes) de diferentes ordens de magnitude, operadas de forma semelhante, mas descontínuas. O biodesign segue na contramão das formas ideais e perenes.

\subsubsection{Baubotanik}

Tomemos o conceito de baubotanik, técnica criada pelo arquiteto alemão Ferdinand Ludwig, processo que une o componente vegetal a andaimes de metal por meio de poda e técnicas de enxertia. Apesar de ainda permanecer no limiar entre uma earthwork de Andy Goldsworthy e uma arboescultura de Marcel Kalberer (por ex. Palácio do Salgueiro, Auerstedt, Alemanha), já é possível observar casos concretos, como o Platanen-kubus, localizado em Nagold, Alemanha, maior edifício baubotanikal já construído, uma malha de troncos e ramos de plátanos interligados por um sistema de vigas autossustentáveis (ver Fig. 28). Mas apesar de comentaristas descreverem a técnica como uma "fusão" entre configuração antropogênica e produção natural, o que se verifica no baubotanik é a demarcação de diferenças e não um aglomerado que anula as duas instâncias, mas que as ressaltam em uma reticulação, lembrando que o termo, mencionado diversas vezes por Simondon para descrever a maneira como o mundo era percebido pela humanidade em sua fase mágico-primitiva, não tem nada a ver com as retículas da impressão gráfica, mas com o enredamento formado pela articulação primordial entre a figura e o fundo. No caso da edificação de estruturas vivas (e, como se verá, de semivivas), podemos realizar, em alguns casos, a "transdução" do par figurafundo para o par espaço (objetivo) e lugar (subjetivo).

A estética arquitetônica do baubotanik é ecotécnica por excelência, indo além das edificações com envolventes vegetais (coberturas e fachadas verdes). Em termos filosóficos, consideramos que a técnica de Ludwig refuta a metafísica substancialista, principalmente aquela nomeada hilemórfica, a qual presume uma dualidade e, no atacado, induz o pensamento do ser único: uma mônada sem clinâmen, a emergência de um suposto terceiro após a síntese de um dualismo, ou uma multiplicidade sem totalidade e sem relacionalidade. Citamos especificamente o substancialismo dualista, aquele que deu origem ao embate entre corpo e alma 
(Descartes) e à dialética. Teve como ponto alto, insistimos, o hilemorfismo, o qual concebe a substância como um composto de matéria e forma. Simondon não recusa o esquema, considera-o apenas incompleto. Propõe a inclusão de um termo suplementar, a energia, porque a "própria aquisição de forma demanda matéria, forma e energia, singularidade" (SIMONDON 2005: 52) ${ }^{304}$ Ademais, como vimos em outra ocasião, não há apenas uma forma externa, aparente; haveria uma pré-forma, uma forma implícita que deve ser computada. Para a operação técnica, a forma é fundamental: é o molde que determina a constituição do barro que vai formar o tijolo. As formas implícitas quebram esse dogma. $\mathrm{O}$ hábito de pressupô-las em troncos e madeiras a serem trabalhadas é tão antigo que se perde nas brumas do tempo, confundindo-se com lendas e poemas épicos. Em seu tradicional estilo enciclopédico, Simondon (op.cit.: 56) cita o herói Ulisses, que construiu sua própria casa ao redor de um leito nupcial, escavada em uma oliveira centenária. ${ }^{305} \mathrm{~A}$ cama foi como que "esculpida" com métodos de flexão e enxerto, de modo que os ramos se entrelaçassem naturalmente para formar a estrutura dos pés, estrado e dossel. $E$ esta foi a chave para Penélope reconhecê-lo quando o herói retornou depois de anos em combate e afirmou ser aquele leito irremovível.

304 Excerto no original: La prise de forme elle-même demande matière, forme et énergie, singularité. (tradução nossa).

305 "Grossa como coluna, vegetava / No pátio umbrosa e florida oliveira: / Densas pedras em roda, / em cima um teto, / Câmara edifiquei de unidas portas; / Já desgalhado, a bronze descasquei-lhe / Desde a raiz o tronco, e de esquadria / Artífice o puli, verrumei tudo, / Formando um pé, começo do meu leito; / Marfim neste embutindo e prata e ouro, / Táureas correias lhe teci vermelhas. / Esta a verdade. Ignoro se está firme / Esse leito, ou, serrando-se-lhe o tronco, / Por algum dos varões foi transplantado." (HOMERO 2009: LIVRO XXIII. Verso 140). 
Figura 28 - A estrutura do Platanen-kubus, com previsão de término em 2028

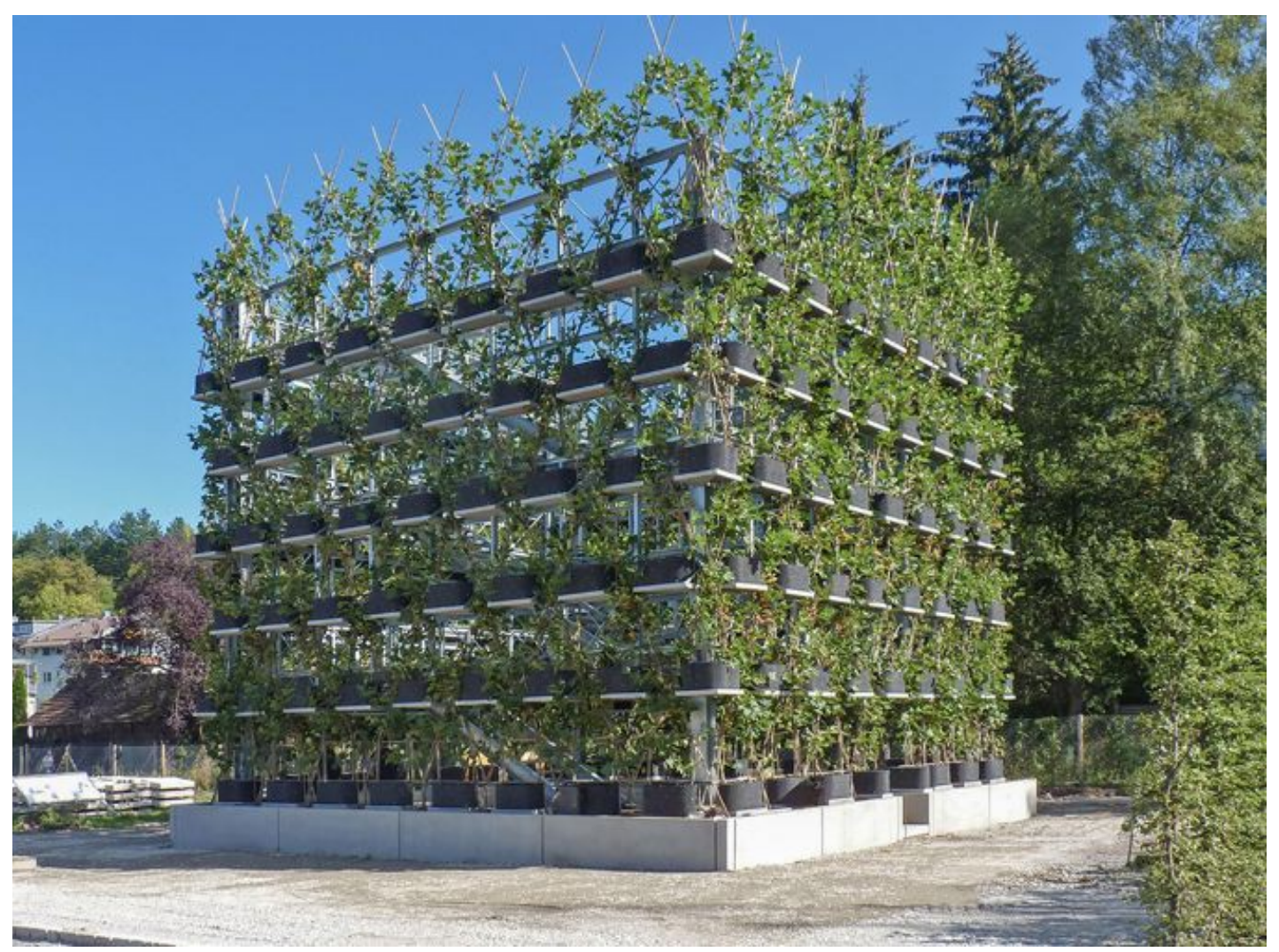

Fonte: https://www.designboom.com/architecture/egger-ferdinand-ludwig-baubotanik-nature-11-102016/

Por enquanto, construções em suportes vegetais servem apenas como introdução a um novo campo de pesquisa na arquitetura, embora seja possível antever a sua aplicação imediata na arquitetônica, ou o ensino de estruturas em geral (por ex. metodologias de armação de andaimes). Pergunta-se, então, qual o seu alcance filosófico, ou como podemos pensar novos conceitos de arquitetura em que a estabilidade de uma construção de concreto seja substituída pela plasticidade fenotípica das plantas, ou "por uma teoria energética e dinâmica das formas, não uma teoria estática e morfológica". ${ }^{306}$ Enquanto o ornato é considerado uma superfluidade na concepção funcional de um projeto de arquitetura, nas estruturas vivas arquitetônicas talvez seja uma forma de "obliterar" a correspondência entre forma e estrutura às custas de um ajuste externo, de uma calibragem energética, de uma adaptação. Na estética ecotécnica inscrita na técnica baubotanik, a própria noção de "morada" é subvertida, sem que seja preciso recorrer ao contorcionismo 306 Ver DOMINGUES, Ivan. Simondon, Cybernetics and Mechanology. Scientiae Studia, v.13, n.2, 2015, pp. 283-306. 
etimológico de Heidegger, bastando apenas lembrar que as palavras "arquitetura" e "anarquia" possuem uma raiz grega em comum, arkhé, que significa um princípio que ordena e regula a existência de todas as coisas. Mas há uma diferença fundamental: se os arquitetos são os mestres dos princípios, dos planos, dos projetos que serão porventura realizados, a anarquia "é a ausência positiva de um começo predeterminado, a falta de prescrições a priori dignas de prever o desenvolvimento futuro". ${ }^{307}$ Daí a necessidade de se inventar uma anarquitetura, uma técnica de construção habitacional suscetível a um processo de individuação permanente, capaz de "dispersar os significados soberanos de construção, edificação, habitação e abrigo, de modo que suas notas anarquitetônicas proliferem na forma de raízes e brotos acidentais." ${ }^{308}$

\subsection{Micélio}

As experiências com estruturas vivas em projetos de habitações ensaiam uma extrapolação para além do reino vegetal - mais especificamente, para o Reino Fungi. Várias espécies de fungos estão sendo testados no campo da biofabricação, muito em função de sua resistência e durabilidade. Vê-se que, durante o tempo de gestação, a tecnologia micelial apodera-se provisoriamente do pensamento artístico contemporâneo, como em Hy-Fi (2014), uma estrutura levantada no espaço PS1 do MoMA, em Nova York (ver Fig. 29). Projetado por David Benjamin, arquiteto pertencente ao escritório The Living, a instalação é na verdade uma torre de doze metros construída de tijolos orgânicos, biodegradáveis, elaborados por meio de uma cultura de fungos cultivada em resíduos agrícolas e moldados em fôrmas providas com serragem pasteurizada, técnica desenvolvida pela empresa Ecovative, que vem pesquisando tecnologias biológicas desde 2007, como a compostagem industrial com propriedades de automontagem. Na mesma linha, o artista e pesquisador Philip Ross, criador do conceito de mycotecture - um portmanteau composto das palavras mycelium (micélio, a parte vegetativa dos fungos, formada por uma massa emaranhada de filamentos, ou hifas) e architecture - levantou uma casa de chá na

307 Ver MARDER, Michael. Vegetal Anarchitectures. The Philosopher's Plant: a Los Angeles Review of Books Channel, 21 jun. 2016. Disponível em: <http://philosoplant.lareviewofbooks.org/? $\mathrm{p}=164>$. Acesso em: 22 jun. 2016.

$308 \mathrm{lbid}$. 
exposição de arte contemporânea na Kunsthalle Düsseldorf, totalmente estruturada com tijolos feitos de cogumelos lingzhi (Ganoderma lucidum), que, ao final do evento, foram extraídos diretamente das paredes para uma infusão de chá, servida cordialmente aos visitantes. No que concerne ao emprego massivo de tijolos à base de micélio na construção civil, a expectativa é pela realização do "salto quântico" exercitado pelos micologistas das empresas Ecovative Design e MycoWorks (administrada por Ross).

Figura 29 - Torre temporária de tijolos de micélio no MoMA PS1



Fonte: https://www.moma.org/calendar/exhibitions/3664 (Foto: Kris Graves)

Pode advir da "domesticação" do micélio, organismo vivo formado por uma rede ramificada de células filamentosas chamadas hifas, novos arquétipos tectônicos, bem como transformações da expressividade arquitetônica: a começar pela crença de que materiais de construção são, por necessidade, o produto da fabricação industrial, e não de um método de cultivo. Por que não pressupor um objeto tecno-ambiental construtivo capaz de crescer, deteriorar-se e, ato contínuo, crescer novamente? Daí o valor retornado à colônia fungosa que se desenvolve à 
medida que as extremidades das hifas entranham-se no substrato de alimentação (em geral, subprodutos agrícolas), ${ }^{309}$ aglutinando-se a ele simbioticamente e formando, ao longo de seu desenvolvimento, estruturas filamentosas entrelaçadas que se enrijecem por desidratação e lenhificam-se por ação do calor. ${ }^{310}$ Essas "placas" são empregadas, hoje em dia, na proteção térmica de residências, de acordo com as patentes registradas pela Ecovative Design, mas a tecnologia pode evoluir em breve para a composição de superfícies estruturais, e o prenúncio disso é a experiência de "arte-arquitetura" no MoMA PS1. Este é o momento oportuno, portanto, para se investir - epistemologicamente, ao menos - em projetos de mycotecture, ainda que sob a égide de disciplinas do gênero Desenvolvimento Integrado de Edifícios e BIM, ou seja, virtualmente, mas de qualquer modo anarquitetônico. Essa é, precisamente, a proposta de um grupo de pesquisadores da AA School of Architecture, de Londres, para se fabricar o protótipo de um parque recreacional (com anexos) em um campo de arroz na região de Kunming, capital de Yunnan, sul da China. ${ }^{311}$ Acima de tudo, o que a posiciona como proponente involuntária de uma estética ecotécnica é a junção entre o objeto técnico - uma idealização geométrica e computacional, por certo, mas pontuada por parcelas massivas de empirismo, que vão da cultura de fungos às técnicas de cofragem - e o meio associado, no caso, a palha de arroz, abundante subproduto da agricultura local. Por meio de uma estratégia extraída do design evolutivo selecionou-se a catenária $^{312}$ como a figura fundamental do projeto, forma inspirada nos autoenxertos e no drapeamento das raízes da figueira, e que orientará a solidificação dos microtúbulos miceliais ao formato colunar dos moldes. Embora esta abordagem

309 As células miceliais são envoltas por paredes formadas por camadas de proteínas e polissacarídeos, as quais as protegem de serem destruídas por excesso de líquido (citólise), concedendo-as juntamente propriedades mecânicas. Compare o crescimento controlado de duas espécies - Ganoderma lucidum e Pleurotus ostreatus - em diferentes tipos de substratos de celulose (em especial o Ágar Batata Dextrose) e como elas se sobressaem em comparação a outros polímeros alternativos aos plásticos à base de petróleo, como a celulose bacteriana e os polihidroxialcanoatos. Ver HANEEF, Muhammad; CESERACCIU, Luca; CANALE, Claudio, et al. Advanced Materials From Fungal Mycelium: Fabrication and Tuning of Physical Properties. Scientific Reports, v. 7, artigo 41292, 2017.

$310 \mathrm{lbid}$.

311 Cf. detalhes na brilhante documentação do projeto mycoFARMx em ZENG, ET AL., 2011.

312 "Em matemática, a catenária descreve uma família de curvas planas semelhantes às que seriam geradas por uma corda suspensa pelas suas extremidades e sujeitas à ação da gravidade". Ver Catenária. In: Wikipédia, a enciclopédia livre. [s.l.: s.n.], 2016. Disponível em: $<$ https://pt. wikipedia.org/w/index.php?title=Caten\%C3\%A1 ria\&oldid=47415142>. $\quad$ Acesso em: 22 jan. 2019. 
reporte à primeira vista aos inefáveis desenhos paramétricos, nota-se a presença indelével da noção de in situ. As formas não servem às idealizações e sim atendem às exigências da natureza local. Aqui é o ideal que serve ao natural, e não o oposto.

\subsubsection{Estruturas semivivas}

"A arquitetura orgânica é uma música viva, e não congelada, executada no presente contínuo" (PEARSON 2001: 24). Atribui-se a analogia entre manifestações da disciplina arquitetônica - tomada como o domínio das formas perenes ${ }^{313}$ - e efêmeros objetos temporais ${ }^{314}$ aos devaneios de "arquitetos filósofos". ${ }^{315}$ Entretanto, como suscitado nesse subcapítulo, o que está em causa é uma flexibilização normativa e a introdução de aspectos biológicos no mundo industrializado da construção civil. No setor das estruturas semivivas dão-se as mesmas prescrições do biodesign para estruturas vivas, bem como a "adaptação a padrões e procedimentos de crescimento biológico, multiplicando os fenômenos naturais dentro de um ambiente controlado determinado pelos parâmetros do projeto" (HEBEL 2017: 8). Semivivas, porque metabolizadas. Veremos que, a despeito de serem materiais de construção cultivados, a abordagem semiviva subentende, por exemplo, a carbonização de um bloco de madeira ou a reconfiguração das fibras do bambu, dois materiais sobre o qual dissertaremos. Por paradoxal que seja, a tradicional técnica de preservação da madeira chamada no Japão de yakisugi, que consiste em ligeiramente inflamar a superfície do bloco sem comprometê-lo em sua integridade, ressurge nos atuais escritórios de arquitetura como protocolo de proteção contra incêndios. ${ }^{316} \mathrm{Em}$ laboratórios da Associação Fraunhofer, na Alemanha, aventa-se a

313 "O universo teme o tempo, mas o tempo teme as pirâmides", provérbio egípcio. Epígrafe cit. in DUPUY 2011, p. 83.

314 Cf. a minuciosa análise de objetos temporais (no caso as notas e acordes musicais) sob a perspectiva fenomenológica de Husserl em STIEGLER 2009, pp. 188-243.

315 "Mas, a Música e a Arquitetura fazem-nos pensar em algo totalmente diverso delas próprias; acham-se em meio do mundo, quais monumentos de outro mundo; ou então, como exemplos, cá e lá disseminados, de uma estrutura e de uma duração que não pertencem aos seres, mas às formas e às leis. Parecem destinadas a diretamente lembrar-nos: - uma, a formação do universo; a outra, sua ordem e estabilidade. Invocam as construções do espírito, e sua liberdade, que busca essa ordem, reconstituindo-a de mil maneiras; desprezam as aparências particulares com as quais o mundo e o espirito de ordinário se ocupam: plantas, animais, pessoas...". Ver VALÉRY 1996, p. 81.

316 Wooden Skyscrapers Could be the Future for Cities. The Economist, 1 fev. 2018. Vídeo disponível em: <https://www.youtube.com/watch?v=2DPp2NcnTb0\&feature=youtu.be>. Acesso em: 17 jan. 2019. 
viabilidade de produção em grande escala da "espuma de madeira", uma evolução das lignoceluloses. E os caules de bambu (aqui, na versão projetada SPC, ou Structural Bamboo Products) retiram-se das vigas de apoio e andaimes de sustentação para tornarem-se o próprio material de construção. O primitivo moderniza-se na estética ecotécnica. Para lograr tal renovação releremos, se necessário, o manual do arquiteto descalço (LENGEN 2007), abstendo-nos, contudo, de qualquer propensão que rejeite as modernas inovações técnicas de índole imaginativa.

\subsection{Madeira}

É indicativo que, ano após ano, o Relatório Global de Emissões da ONU Meio Ambiente aponte a indústria de Arquitetura, Engenharia e Construção Civil (AEC) como a maior contribuinte das emissões globais de dióxido de carbono, ${ }^{317}$ abrangendo, para além das edificações em si, a "mineração e processamento de matérias-primas; transporte de materiais e trabalhadores; fabricação de cimento, tinta, calafetagem e isolamento de espuma; envio de resíduos de construção para aterros ou usinas de reciclagem; refrigerantes em condicionadores de ar, freezers e resfriadores; e, não esqueçamos, a desconstrução e reciclagem no final de vida de um edifício". ${ }^{318}$ (Por certo o cimento e o aço integram o topo da lista). À vista disso, arquitetos não-ortodoxos, como que inspirados por uma fantasiosa impostura helenística ${ }^{319}$ propõem a sua reposição por uma notória matéria-prima, porém inabitual nos canteiros urbanos: a madeira de reflorestamento. Julgam-na viável para a edificação de prédios de mais de 50 metros, e até mesmo arranha-céus. Em termos de estrutura e revestimentos, reputam de forma positiva as técnicas de derivados projetados, como a madeira laminada cruzada (CLT, na sigla em inglês), similar ao tradicional compensado, com a diferença que, naquele caso, as lamelas são aderidas perpendicularmente, em ângulo de 90 graus, camada por camada,

$317 \mathrm{Em} \mathrm{2017}$, a taxa foi de 37\%. Ver SULLIVAN, Joan. Buildings Made of Sky. Artists \& Climate Change, 18 out. 2018. Disponível em: <https://artistsandclimatechange.com/2018/10/18/buildingsmade-of-sky/>. Acesso em: 21 out. 2018.

$318 \mathrm{lbid}$.

319 "Em cartas e explicações, Valéry conta, ainda, com naturalidade, ter sabido, mais tarde, pelo helenista Bidez, que Eupalinos não fôra arquiteto, mas empreiteiro de obras do aqueduto de Atenas... Em contrapartida, omite, desde o título, o fantástico arquiteto, sem nome, construtor de flutuantes 'edifícios de madeira'". GUEDES, Joaquim. Geometria Habitada. In: VALÉRY 1996, p. 10. 
resultando em um produto sobremodo estável e resistente (inclusive ao fogo, a despeito do contrassenso). ${ }^{320} \mathrm{~A}$ própria dinâmica da montagem remete à construção alveolar do mundo natural, porque ao invés de lajes e colunas dos edifícios de concreto, tem-se a onipresença de placas de CLT, tanto nas paredes externas, como nas internas. Elas pertencem à mesma linhagem tecnológica da madeira laminada colada, conhecida pela abreviação anglo-saxônica glulam (glued laminated timber), originária de técnicas buriladas no século 19 , mas que vem sendo restituídas e remodeladas, entre outros, pelo escritório Waugh Thistleton Architects, de Londres, cujos afiliados defendem o "programa" high-rise como solução para o déficit habitacional das cidades do futuro. Somaremos a esse material um outro, supostamente mais "primitivo" e mais inclinado ao nível do rés-do-chão.

\subsection{Bambu}

Dentre todas as definições de estética, a que aqui nos parece menos obscura é a de como a experiência sensível constitui-se - ou é construída, se lançarmos mão de noções construtivistas da cibernética de segunda ordem. Nesse sentido, tal propósito construtivo seria, sob o ponto do vista de uma "fenomenologia ecotécnica", a combinação da intencionalidade cognitiva da parte do observador com os "caracteres posicionais do noema" (DUFRENNE 2015: 188). Esta constatação alinha-se com o juízo elementar de Carlson, segundo o qual o "essencial para a apreciação estética [de obras arquitetônicas] é o engajamento ativo, envolvendo o conhecimento cognitivo e a interação emocional entre o apreciador e o objeto de apreciação" (CARLSON 2005: 197). O uso de madeiras na construção civil - em que pese a edificação de "estabelecimentos seminaturais" (VALÉRY 1996: 59) - nos oferece um instrutivo exemplo dessa relação. Ainda que elas sejam de origem controlada, provenientes de reflorestamento, dispõe-se, antes, no quadro da estética discutida, outros insumos, como os produtos à base de bambu processado, os quais tornam-se lenhosos, similares à madeira de lei, após a lignificação, processo que exige o conhecimento de uma determinada técnica. Para protegê-los contra a umidade, pode-se revesti-los com resina de poliuretano ou, do modo recomendado

320 Ver 100 UK CLT Projects. Disponível em: <https://www.thinkwood.com/clt100book>. Acesso em: 24 jan. 2019. 
pela sabedoria popular, com "materiais não tóxicos, como estrume, creosoto ou bórax" (LENGEN 2007: 338). Não é porque a taquara e o bambu sejam materiais "primitivos" que não se possa integrá-los às variáveis paramétricas em projetos de estruturas parabólicas, ou mesmo hiperbólicas, uma forma com dupla curvatura espraiada em diferentes direções (MINKE 2012: 66). A propósito, sabe-se que os "chineses não têm o menor gosto pelos símbolos abstratos" (GRANET 2004: 352), mas foi na vila de Baoxi, na província chinesa de Zhejiang, que ocorreu em 2016 a primeira Bienal Internacional de Arquitetura de Bambu, ${ }^{321}$ plataforma experimental para estruturas geometricamente complexas, ligando o futuro das construções às tradições low tech dos campesinos (ver Fig. 30). Com efeito, a "madeira dos pobres" conquista o novo estatuto de "aço verde do século 21", ${ }^{322}$ denominação visivelmente avessa às pranchetas dos arquitetos de resorts e indispensável para integrá-la aos projetos urbanos, inclusive os de grande porte.

Figura 30 - Albergue de Anna Heringer na Bienal Internacional de Arquitetura de Bambu de Baoxi

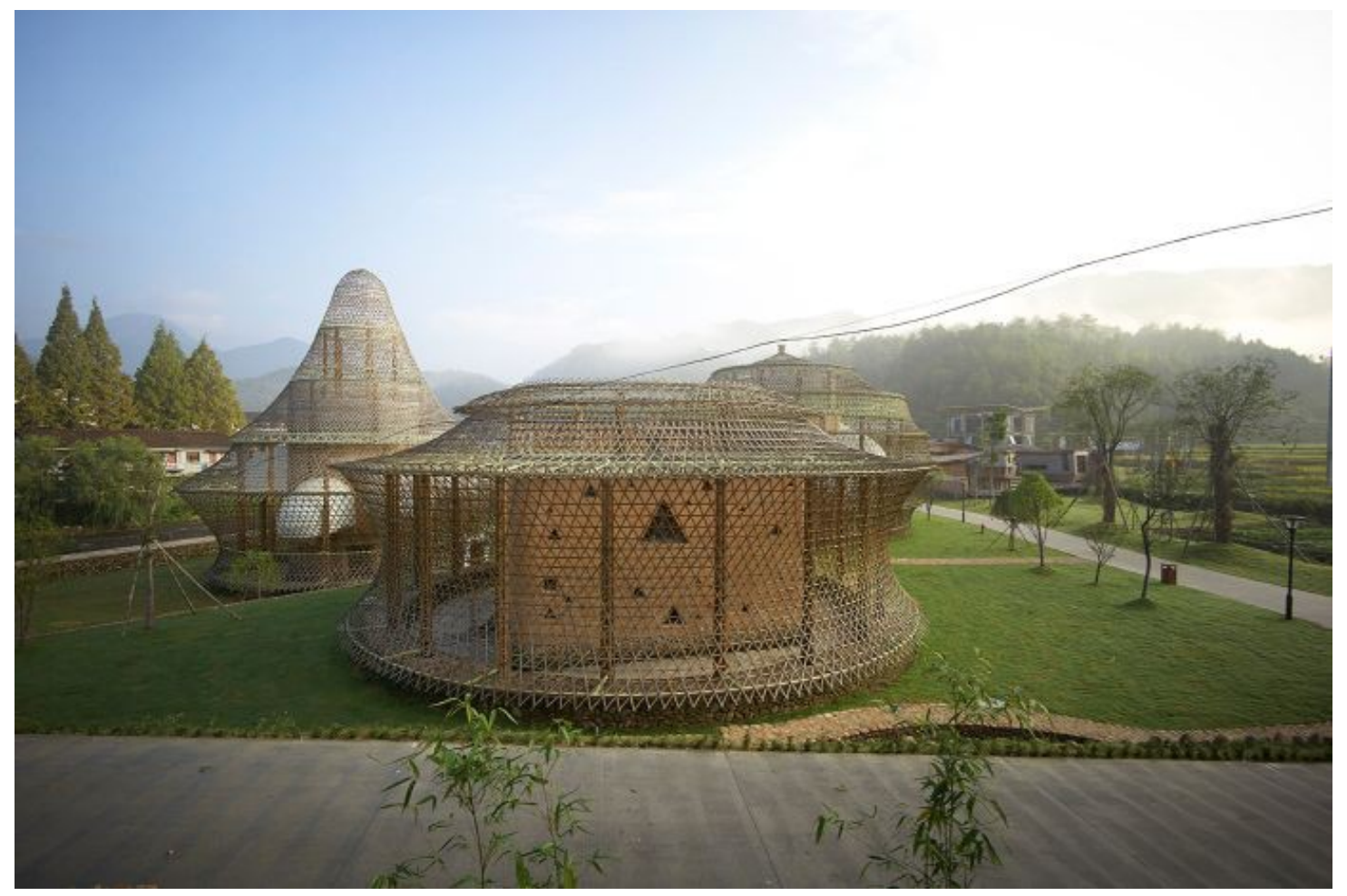

Fonte: https://www.archdaily.com/tag/baoxi (Foto: Julien Lanoo)

321 Ver mais detalhes no site do evento: International Bamboo Architecture Biennale. Disponível em: <http://www.bamboocommune.com/en/>. Acesso em: 19 jan. 2019.

322 Ver MELBOURNE-HAYWARD, Amelia. Bamboo Revival. Architecture Now, 30 set. 2016. Disponível em: </articles/bamboo-revival/>. Acesso em: 24 jan. 2019. 
É tendo como modelo os laminados de madeira que os laminados de bambu podem ser empregados como material de construção alternativo na forma de tábuas, colunas, vigas e painéis (MINKE 2012: 34-6). E é essa identidade material que, precisamente, assegura a "vitalidade semiviva" aos dois elementos recondicionados. $\mathrm{E}$ tanto um quanto o outro como que restauram, em meio ao abstraimento da construção civil contemporânea, a ordenação concreta da própria natureza naturante. "O homem", dirige-se o espectro de Sócrates ao espectro de Fedro no diálogo imaginado pelo poeta francês, "fabrica por abstração, ignorando e esquecendo grande parte das qualidades daquilo que emprega, atento unicamente às condições claras e nítidas que possam, na maior parte das vezes, ser simultaneamente satisfeitas, não por uma única, mas por muitas espécies de matéria" (VALÉRY 1996: 125). Mas o bambu (bem como a madeira) logram suspender essa tendência abstrativa do fabricador, devolvendo-lhe a capacidade de conciliar substância, forma e função (acrescentaríamos, em circunstâncias especiais, o item funcionamento). Esse modelo operatório coloca-o não em pé de igualdade com o Demiurgo, mas no mínimo em uma posição privilegiada. Deduz-se, por conseguinte, o reconhecimento da relevância do todo em proporção às partes, da conjuntura em relação às suas junturas. Assim como o imemorial marceneiro, o starchitect dos dias atuais é "inevitavelmente levado a produzir objetos cujo grau do conjunto é sempre inferior ao grau de cada uma de suas partes" (loc.cit.). Nota-se a ausência de um modo de compatibilidade entre formas anteriormente isoladas e uma denegação (voluntária ou não) da interconectividade ecológica, ou da extensa malha da natureza, na expressão de Timothy Morton. ${ }^{323} \mathrm{~A}$ construção concluída com madeiras (dos pobres ou não), por outro lado, apresenta o mesmo enredamento heterogêneo da árvore da qual elas foram extraídas, porque o conjunto ordenado pelo artífice, um objeto tecno-ambiental, não é "menos complexo que a textura das fibras da madeira";324 o fabricante, assim, não mais "reaproxima rudemente, em estranha ordem, pedaços de uma grande árvore que se haviam formado e desenvolvido em outras relações". ${ }^{325} \mathrm{Na}$ arquitetura orgânica inspirada pelo biodesign, o todo não é maior (emergência, transcendência holística), nem menor

323 Ver GRATTON, Peter. Tim Morton, The Ecological Thought. Speculations, v. 1, n. 1, 2010, pp. 192-99. 
("subscendência") que a soma de suas partes; ele inalteravelmente corresponde a elas.

\subsubsection{Arquitetura vernacular}

Ao caminhar pela vila de Koguva, em Muhu, ilha estoniana localizada no mar Báltico e última fortaleza de pagãos locais contra as Cruzadas do Norte (século 12), o escritor irlandês Darran Anderson observou o quanto as habitações daquele local pareciam ter-se consubstanciado com o meio ambiente, ${ }^{326}$ traço distintivo da arquitetura pré-moderna. A arquitetura tradicional, ou arquitetura histórica, defendida por historiadores da arquitetura, como o teórico belga Leon Krier, orientado na experiência passada das construções, ou da tectônica (derivação do grego, "relativo à construção"), deveria estar na ordem do dia das edificações atuais, seja na urbe ou na chamada hinterlândia. ${ }^{327}$ Ainda segundo Krier, as construções de uma povoação são como as cordas de um instrumento musical, ${ }^{328}$ as quais devem ser "afinadas" com relação ao meio circundante, e tal relação sinestésica entre arquitetura e música, como vimos em outra ocasião, evoca a ideia de tonalidade, descrita como a "qualidade da vibração" (MORTON 2007: 43). É essa vibração a principal qualidade de uma construção, e quando ela apresenta "esse fogo, ela se torna parte da natureza. Como ondas do mar, ou folhas de grama, suas partes são governadas pelo interminável jogo de repetição e variedade criado na presença do fato de que todas as coisas são transitórias" (ALEXANDER 1979: x-xi). Por si só, a qualidade eminente não é o bastante, porque ela invoca o suplemento de uma linguagem padrão, que, a despeito de ser universal, ramifica-se em idiomas. Propõese aqui buscar certos idiomas da arquitetura vernacular, ligando-os ao modelo da estética ecotécnica. Uma mostra prévia seriam os construtos poliédricos do Museu

326 ANDERSON, Darran. (@Oniropolis). "On a Baltic island that was the last stronghold of the Estonians against the crusaders. The architecture here is wonderful and seems to merge into the environment". 26 mai. 2018, 3:37 AM. Tweet.

327 Ver BRENNER, Neil. A Hinterlândia, Urbanizada? e-metropolis, $n^{\circ} 25$, ano 7, jun. 2016, pp. 611.

328 KRIER, Leon. Palestra proferida no Seminário Internacional La Arquitectura en la Era de la Austeridad, organizado pelo Premio Rafael Manzano Martos em colaboração com a escola de Arquitetura da Universidade de Notre Dame e a Universidade Politécnica de Madrid, jun. 2013. Vídeo disponível em <https://www.youtube.com/watch?v=iCRqcFvdn8o>. Acesso: 13 mar. 2017 
de Tecnologia Simples, ${ }^{329}$ em Madras, Índia, concebidos por Yona Friedman, arquiteto francês nascido na Hungria. Ao material orgânico - o bambu - veio somarse a folha de alumínio, aludindo à noções como intensificação não-material, arquitetura indígena e invenção. Singularizaremos, assim, uma "arquitetura sem arquitetos" (RUDOFSKY 1964) 330 dotada de uma "qualidade sem nome" (ALEXANDER op.cit.), partindo dos elementos em direção às estruturas.

\subsubsection{Elementos}

Os componentes arquitetônicos, de modo geral, sintetizam-se em unidades mínimas como colunas, arcos e balaustres. ${ }^{331}$ Veremos, no decorrer da análise morfológica, que é possível categorizar os elementos particulares das tradições de outro modo, decompondo-os, por exemplo, em recursos naturais (por ex. adobe, travertino), tecnologias (por ex. ventilação natural) e formas (por ex. pátios) (ASQUITH \& VELLINGA 2005: 16). Consideremos os dois últimos como elementos vernáculos por excelência, os "morfemas" da "linguagem" tradicional. É apto a constar deste repertório o promenoir ${ }^{32}$ do convento dominicano de Arbresle, cujas proporções de suas vidraçarias foram matematicamente calculadas por lannis Xenakis (SIMONDON 1992). E também as suas celas com loggia, cimentadas por Le Corbusier, devoto das medidas clássicas que mapeiam em "quantidades rítmicas, animadas por um mesmo impulso, para trazer a vida ao todo por meio de uma relação sutil e unificadora, para equilibrar, para resolver a equação" (CORBUSIER 1986: 163). Mas vê-se imediatamente, em contraposição ao classicismo (e, em certa medida, ao modernismo), que o elemento tradicional exige uma espécie de qualidade atemporal e não opera por quantidades, sobretudo quando o ganho de escala não é a finalidade. Quanto às tecnologias tradicionais é graças a elas que as formas dos elementos da arquitetura vernacular se expressam adequadamente e,

329 Ver FRIEDMAN, Yona. Museum of Simple Technology. Disponível em: <http://www.yonafriedman.nl/?page_id=514>. Acesso em: 18 maio 2015.

330 Aqui, a tradição é mais importante que a autoria, sem que seja "anônima".

331 Ver Architectural Elements. ClipArt ETC. Disponível em: <https://etc.usf.edu/clipart/galleries/800architectural-elements>. Acesso em: 1 fev. 2019.

332 Termo geral que significa um lugar coberto ou descoberto, cercado por arcos, colunas ou árvores. Ver Encyclopédie de Diderot. Disponível em: <http://encyclopédie.eu/index.php/beauxarts/1200047745-architecture/921119037-PROMENOIR>. Acesso em: 1 fev. 2019. 
para que isso transcorra, é preciso que os objetos tecno-ambientais sobre o qual dissertaremos comportem simultaneamente, em parcelas variáveis ou balanceadas, qualidades naturais, técnicas e artísticas. A tríade representa, respectivamente, função, funcionamento e forma; admitamos que a função assinalada distancie-se do princípio funcionalista e instrumental e abeire-se de uma "função latente" ${ }^{333}$ (sentido, significação) ou mesmo de um função ambiental, porque os seres produzidos pela natureza "crescem de tal modo que a matéria da qual são feitos, as formas que revestem, as funções que comportam, os meios de que dispõem para se comporem com as localidades e as estações climáticas, encontram-se invisivelmente ligados entre si através de secretas relações" (VALÉRY 1996: 121-22). Assim, os elementos elegidos a seguir, de acordo com esse critério, resumem-se a dois: a parede e a torre de vento.

\subsection{Parede}

A tecnologia de paredes trombe, concebida pelo arquiteto francês Félix Trombe em 1967, é um dos pontos fortes na interface entre arquitetura e energia alternativa, porque comporta uma estratégia passiva para aquecimento e ventilação natural de habitações. Ao integrá-la na fachada de uma residência rural em Santa Catarina, no Sinai (onde localiza-se o Mosteiro Ortodoxo de Santa Catarina), os pesquisadores Marwa Dabaieh e Ahmed Elbably, da Universidade Alemã do Cairo, propuseram, em uma região semiárida e fora de rede pública de energia, uma combinação heterogênea de objeto tecno-ambiental e máquina homeostática que, segundo a definição do biólogo chileno Humberto Maturana, é "um sistema que tem sua organização como variável que se mantém constante" (MATURANA \& VARELA GARCIA 1997: 71). A escolha da tinta cinza, em vez da tradicional tinta preta, para a pintura da parede posicionada atrás do caixilho de madeira (ver Fig 31, à esq.), uma coloração mais de acordo com o matiz das pedras empregadas na construção, inspira-se em princípios estéticos, bem como a colocação das cortinas sob as persianas externas, tornando-as menos visíveis. ${ }^{334}$ Ao formato seguiu-se a atenção à

333 RAPOPORT, Amos. Vernacular Design as a Model System. In: ASQUITH \& VELLINGA 2005, p.191.

334 Ver DABAIEH, Marwa; ELBABLY, Ahmed. Ventilated Trombe Wall as a Passive Solar Heating and Cooling Retrofitting Approach; a Low-tech Design for Off-grid Settlements in Semi-arid 
funcionalidade e eficiência do sistema. Para evitar o fenômeno da inversão térmica durante o inverno, planejou-se duas estratégias de isolamento: a primeira, na parte interna de um dos quartos, é na forma de painéis reversíveis e modulares feitos de lã de carneiro; a segunda - na parte externa, mais especificamente, dentro da caixa de ar, sobre a parede - é uma cortina do tipo persiana rolê, também feita de lã, com três milímetros de espessura. A vedação das aberturas de ventilação tem uma camada de alumínio, que absorve mais calor solar e intensifica a circulação do ar por meio do chamado efeito chaminé. Por fim, toda a vidração respalda-se em uma estrutura de vidros duplos, com seis milímetros de separação, os quais, por sua vez, foram esbranquiçados com um copolímero composto pela combinação de acrilonitrila, butadieno e estireno (ABS, na sigla em inglês), ${ }^{335}$ produto com propriedades de reflexão e refração da luz. Pode-se dizer que, sob a rubrica de uma adequação low tech, o padrão vernáculo parede - elemento que se afigura na construção ora como uma membrana plasmática, ora como uma carapaça demasiada rígida - adquire nesse exemplo renovadas qualidades.

Figura 31 - Parede Trombe em Santa Catarina, Egito

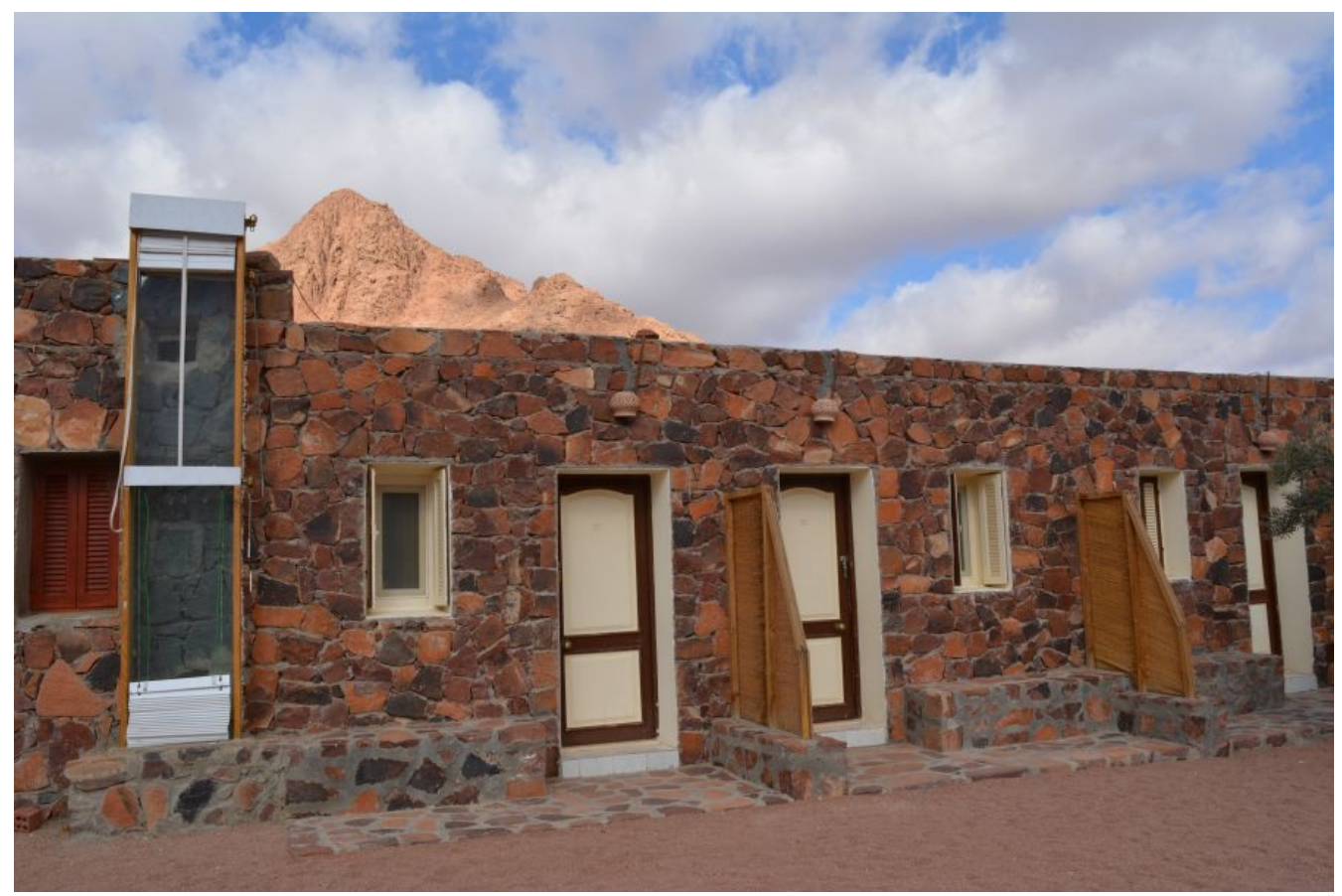

Fonte: https://phys.org/news/2016-02-18th-century-passive-solar-cooling.html

Climates. Solar Energy, v.122, 2015, pp. 820-33.

335 Ver Acrilonitrila butadieno estireno. In: Wikipédia, a enciclopédia livre. [s.l.: s.n.], 2018. Disponível em: <https://pt.wikipedia.org/w/index.php?title=Acrilonitrila_butadieno_estireno\&oldid=53533478>. Acesso em: 4 fev. 2019. 


\subsection{Torre de vento}

O tradicional elemento da torre de vento (ou apanhador de vento) é a concretização da tecnologia de ventilação natural, usufruída desde tempos imemoriais nas regiões do Norte da África e Oriente Médio, notadamente no Irã. Na cidade histórica de Yazd, declarada patrimônio da UNESCO em 2017, historiadores locais julgam o badgir como uma "invenção arquitetônica", ${ }^{336}$ o que pressupõe o antecedente de uma "descoberta científica" (STIEGLER 1998: 40-1), nesse caso, a dos gradientes de pressão. A esse discernimento local sucedeu, de acordo com o determinismo etnogeográfico de Leroi-Gourhan, o fenômeno da "diferenciação técnica, silenciosamente impulsionada pela tendência, [que] é efetuada, de fato, no nível étnico, por invenção ou por empréstimo" (op.cit.: 51). Daí o advento por difração, ao longo do espaço-tempo histórico, seja por conta de atos de reinterpretação ou reapropriamento, de diversos elementos análogos, como a chaminé solar, o lanternim, sheds e peitoris ventilados, comprovando que a "tradição vernacular pode mudar e se adaptar a novas circunstâncias sociopolíticas ou ambientais". ${ }^{337}$ Pode-se explicar o efeito chaminé, fenômeno patente na natureza, de modo compreensível: "o movimento de ar por impulsão térmica é ocasionado por gradientes verticais nas densidades e pressões do ar, advindos da diferença de temperatura"; se o ambiente dispõe de apenas uma abertura, "as pressões interna e externa serão iguais", contudo "se houver outra abertura na parte superior, haverá subpressão na parte inferior e sobrepressão na parte superior" e, por conseguinte, "o ar penetrará no ambiente pela abertura mais baixa e será eliminado pela abertura mais alta, estabelecendo um fluxo ascendente de ar". ${ }^{338}$ Ainda que simples seja o seu mecanismo, é notável como o funcionamento das torres de ventos tem sido pouco pesquisado até recentemente. ${ }^{339}$ Isso nos leva a conjecturar que talvez seja 336 Iran Program Presstv. Wind Towers. Vídeo disponível em: <https://www.youtube.com/watch? v=adTAx1uwahk>. Acesso em: 5 fev. 2019.

337 Ver ASQUITH \& VELLINGA 2005, p. 8, em oposição moderada ao purismo de Bernard Rudofsky (1964: 1), para quem a "arquitetura vernacular não passa por ciclos de moda. É quase imutável, na verdade, inimitável, pois serve ao seu propósito à perfeição".

338 Cf. NEVES, L. D. O. Chaminé Solar como Elemento Indutor de Ventilação Natural em Edificações. Tese de Doutorado - Universidade Estadual de Campinas, Faculdade de Engenharia Civil, Arquitetura e Urbanismo, Campinas, SP. 2012, p. 4.

339 Ver MEIR, Isaac A.; ROAF, Susan C. Towards New Methodologies for the Understanding and Optimization of the Performance of Vernacular Buildings. In: ASQUITH \& VELLINGA, op.cit., pp. 215-30. Os autores argumentam que a altura diversificada das torres de vento de Yazd não é o resultado exclusivo de influências climáticas, mas vincula-se à históricos fatores socioeconômicos. 
preciso não tomar a arquitetura vernacular à letra, justificando automaticamente a sua existência, porque isso restringiria os benefícios de reinterpretar (leia-se: compreender) ao invés de meramente reproduzir ou copiar a tecnologia. ${ }^{340} \mathrm{~A}$ esse respeito, devemos questionar, por exemplo, como o reduzido Fator de Visão do Céu, presente em espaços com alta densidade urbana (como em Yazd, por ex.), pode influenciar o desempenho de uma torre de vento, dado que o mesmo reduz a dispersão da radiação de onda longa, aumentando a massa térmica das construções. ${ }^{341} \mathrm{Em}$ suma, as torres de vento exigem um modelo de estética que ampare a cognição de fatos científicos e neutralize a "relutância em identificar as mudanças climáticas como uma questão de planejamento e projeto". ${ }^{342}$

\subsubsection{Estruturas}

É de uma estrutura mais basilar e integral que se espera ainda mais uma observância àquelas premissas de planejamento em que assentam os elementos básicos. Exatamente como o sugere o Sócrates de Valéry que, houvesse sido arquiteto, delinearia seus projetos "atento à localização, às luzes, às sombras e aos ventos; feita a escolha do terreno, de acordo com suas dimensões, sua exposição, seus acessos, terras contíguas, e a natureza profunda do subsolo..." (VALÉRY 1996: 175). Uma relação não hierárquica entre elemento e estrutura - entre parte e todo revela-se, por exemplo, nas construções vernáculas chinesas, nas quais "o prédio em si é menos importante do que a base que o sustenta e o telhado que o cobre" (GRANET 1997: 160). Dispõe-se então de números e proporções arquitetônicas que evoquem a relação do céu com a terra, tal como no procedimento de construção da residência do imperador (Ming Tang), que deveria repousar sobre uma base quadrada (representativa da Terra) e ser coberta por um telhado circular de colmo (simbolizando o Céu), ligado a ela por oito colunas (loc.cit.). Prova semelhante da dialética entre parte e todo encontra-se no fato de como a água é armazenada pela

340 Op.cit. Pergunta-se em qual das duas extremidades se encontra a moderna torre de vento do Instituto Masdar de Ciência e Tecnologia, na cidade planejada que está sendo construída no Emirado de Abu Dabi (Emirados Árabes Unidos), dado que jatos de névoa localizados no topo do elemento construtivo umidificam o fluxo de entrada de ar, tornando-o antinaturalmente mais fresco. 
população de diversas regiões do planeta, expresso em diversas obras vernaculares, escavadas ou torreadas, como atestam as soluções materializadas nas cisternas escalonadas da Índia (híbridos de tanques e templos), castelos d'água e tankhouses da Califórnia. Examinemos o quão a estrutura dos faróis marítimos, epítome da noção de ponto-chave, simboliza categoricamente a arquitetura vernacular sob as perspectivas estética, técnica e geográfica. E, por fim, o padrão relacional externo/externo das habitações.

\subsection{Caixa-d'água}

"A estética da caixa-d'água é, de há muito, um problema para os arquitetos. Para ser funcional, é preciso que ela seja mais alta do que o tudo que atende", observou Simondon (1992). Esta, para lograr a funcionalidade do efeito de pressão gravitacional, precisa ser construída em locais de proeminência, fazendo-se impactar sobre a paisagem, impropriedade semelhante à dos aerogeradores. Mas, relembremos, as "tradições vernaculares são dinâmicas e geradas através de uma interação contínua e dialética de estase e mudança, precedente e criatividade, estabilidade e inovação" (ASQUITH \& VELLINGA 2005: 19). Pode-se conceber, nesse sentido, formas inauditas. Por exemplo, as plantas e os animais que vivem em ambientes hostis têm muito a nos ensinar sobre o manejo de recursos hídricos, devido às suas características em escala micro e macro. Ao pesquisar os exoesqueletos de escaravelhos da Namíbia, o sistema integrado de coleta de vapores de cactus e folhas de lótus, os arquitetos italianos Arturo Vittori e Andreas Vogler, do estúdio Architecture and Vision, reconstituíram a caixa-d'água em uma engenhoca ecotécnica feita a mão que permite a coleta e armazenagem de água da chuva, além de ser capaz de condensar o orvalho da manhã, em autonomia aos métodos elétricos. Inspirados na geometria dos cupinzeiros, sistemas favoráveis ao fluxo de ar interno, e na figueira local Warka, arquétipo de encontros sociais nas aldeias etíopes na região montanhosa do nordeste do país, a torre de dez metros de altura dos italianos colhe todos os dias até 26,4 litros de chuva e orvalho e pode armazenar até 264 litros de água potável (ver Fig. 32). Ao invés da biomimética, pôs- 
se em prática o biodesign através do prolongamento do mundo natural (precedência da mimese de processos sobre a mimese de formas) em adição ao emprego de materiais vivos, como bambu, cânhamo e plásticos derivados de fontes renováveis de biomassa (bioplástico). Nada mais razoável que, estruturas hídricas construídas com substancias dessa natureza, obtenham o atributo de "suturas absorvíveis", ou seja, estruturas com a capacidade de se dissolver no ambiente de forma natural ao longo do tempo, como os geotêxteis de Philip Beesley. ${ }^{343}$ Mais que um projeto de renovação da arquitetura vernacular, as torres Warka são o modelo de como os saberes locais de tribos tradicionais não se contrastam com a filosofia inventiva das novas tecnologias sociais, visto que elas são projetadas para serem administradas e operadas pelos próprios aldeões.

Figura 32 - Torre Warka projetada por Arturo Vittori e Andreas Vogler

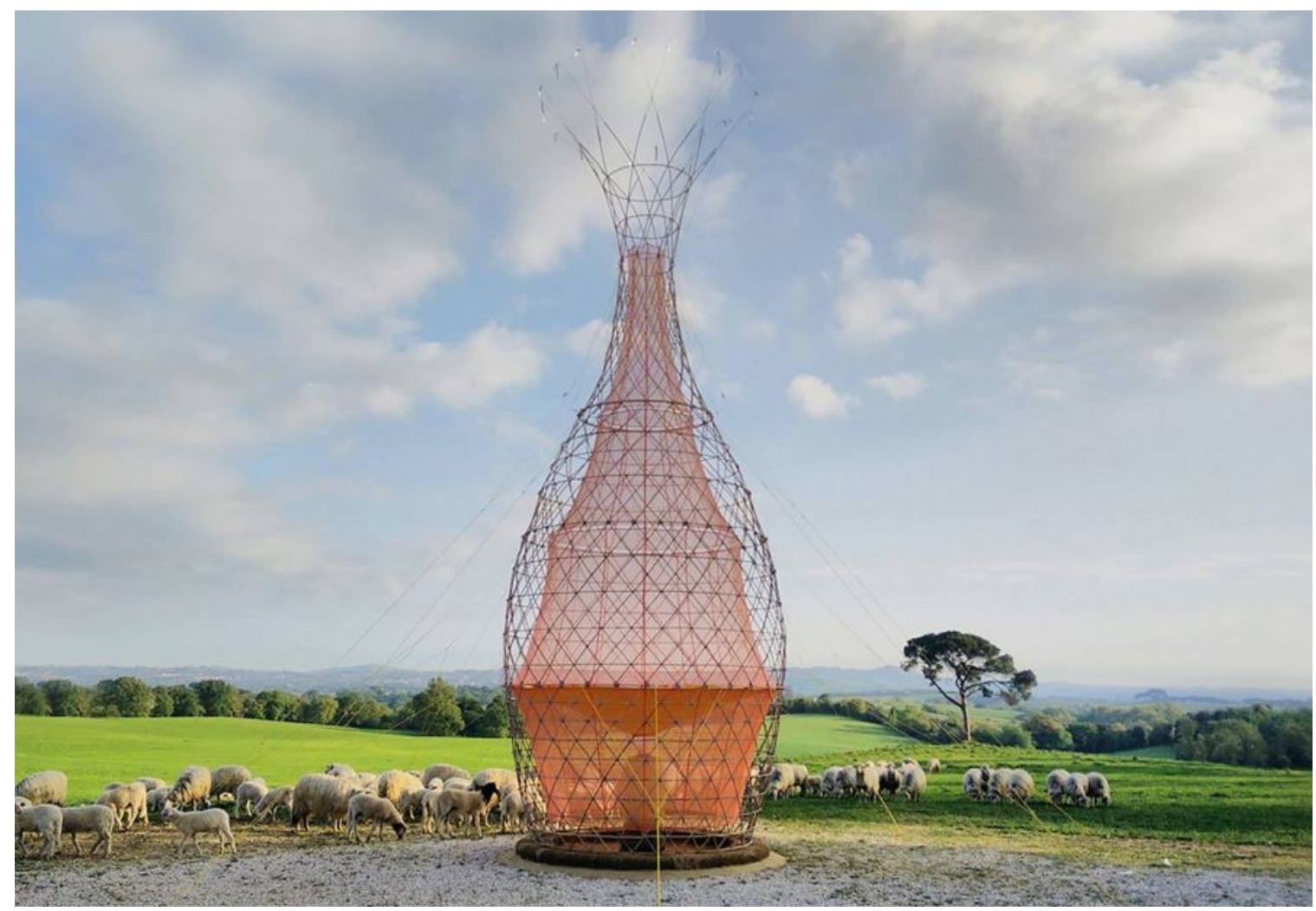

Fonte: http://www.architectureandvision.com/portfolio/073-warka-water-2012/ 


\subsection{Farol}

É provável que o farol se configure como a mais explícita das construções funcionais, tendo conservado a sua forma essencial desde os tempos do Farol de Alexandria, edificado entre 280 e 247 a.C. Caso se pretenda elaborar uma análise genética dessa estrutura vernacular a partir da era moderna, o farol de Eddystone, localizado a 9 milhas $(14 \mathrm{~km})$ a sudoeste de Rame Head, Reino Unido, faz-se o modelo ideal para essa iniciativa. Tendo sido construído e destruído ao longo de séculos, a sua variante mais duradoura, inaugurada em 1759 pelo engenheiro John Smeaton, foi construída com blocos de granito interligados e chameados nos alicerces para assegurar uma maior estabilidade. A fixação da estrutura de 18 metros de altura sobre vários tipos de rochas de modo inteiriço exigiu múltiplas soluções de engenharia que originaram uma lexicografia de novos termos (screwpile, skeleton, sparkplug, etc). ${ }^{344}$ Em sua versão contemporânea, Eddystone é revestido com cimento impermeável, enquanto a parte interna combina um complexo sistema de encaixes, cavilhas de mármore, soldaduras de junção e cantarias. O seu formato é considerado o ícone indiferenciado de todas as realizações posteriores de torres costeiras. ${ }^{345}$ Ligado diretamente à topografia de promontórios dominantes e havendo-se fortificado para resistir às contingências climáticas, o farol genérico, graças às técnicas desenvolvidas por Smeaton, conquistou a qualificação "estética da era das máquinas", 346 sendo belo e "pitoresco sem a intenção de sê-lo", 347 em especial "porque está inserido em um ponto-chave do mundo geográfico e humano" (SIMONDON 1969: 185). Ele constitui uma espécie de interconexão entre o objeto técnico ("o farol é meramente um suporte arquitetônico para um mecanismo de iluminação"), ${ }^{348}$ objeto de uso (como o "vestuário, a mobília, a casa") (DUFRENNE

344 Ver MILLINGTON, Steve. The Modern Lighthouse - A Sculpture by Accident. In: STRANG; EDENSOR; PUCKERING 2018, pp. 92-7. Para citar um dos exemplos referente aos faróis assentados sobre estacas parafuso (screwpile) inseridas em fundos marinhos ou fluviais: "trata-se de um tubo metálico com uma ou mais chapas de aço em formato helicoidal (espiral) soldadas na extremidade". Ver NEDEL, Mateus. Dimensionamento e previsão de carga para estacas parafusos ou helicoidais. Monografia apresentada à Especialização em Estruturas de Concreto e Fundações, Universidade Cidade de São Paulo, 2016.

$345 \mathrm{lbid}$.

346 Ibid.

347 MARE cit. in ibid.

348 Cf. MILLINGTON, op.cit. 
2015: 242$)^{349}$ e objeto belo, que "pode ser belo sem o querer, isto é, sem solicitar a sua estetização e, também, sem perder as suas outras virtudes - encanto, funcionalidade, inteligibilidade - quando é estetizado, pois ele então as exprime no sensível" (op.cit.: 243).

Figura 33 - Farol de Adziogol, construído por Vladimir Shukhov

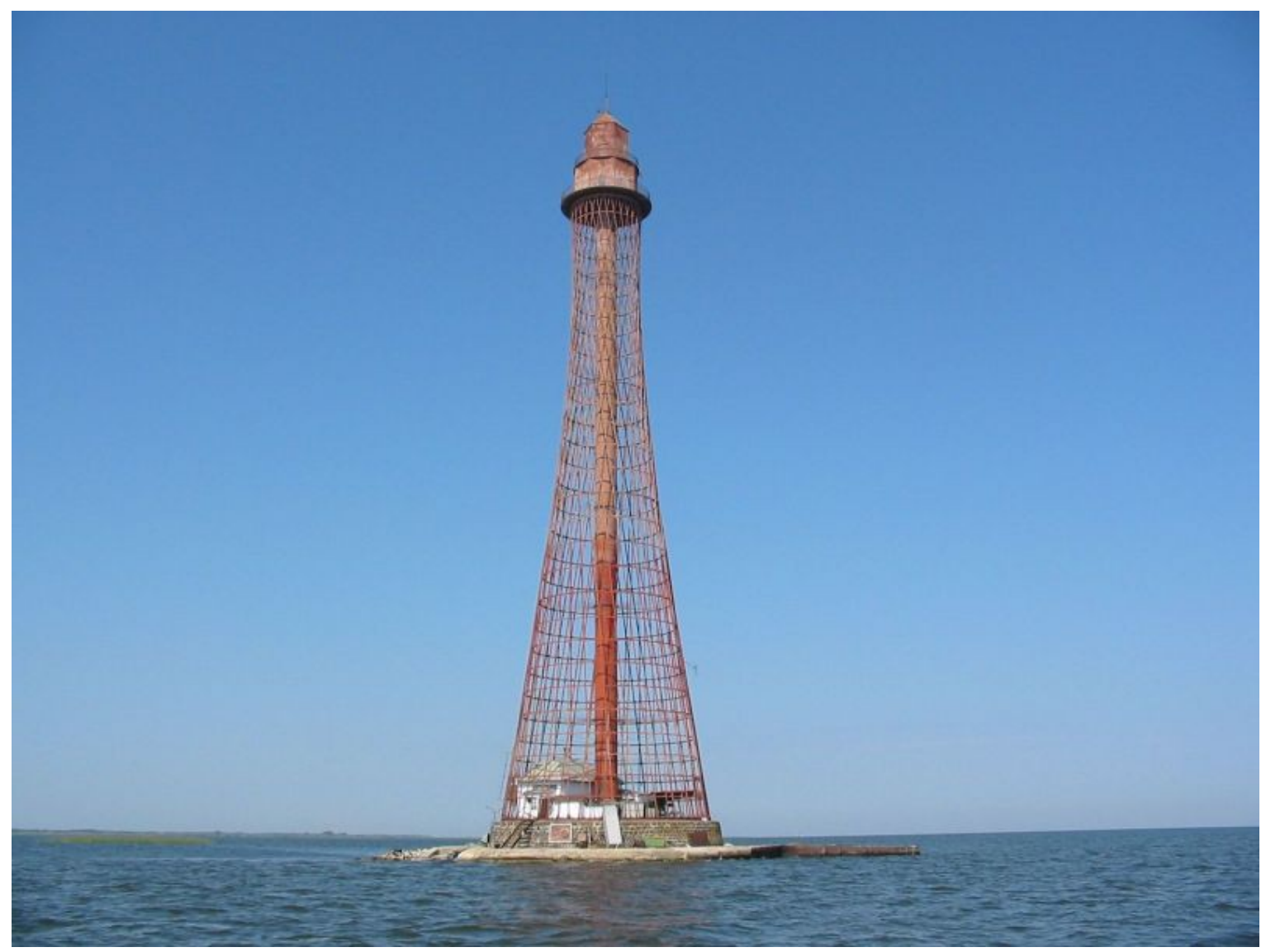

Fonte: http://www.arch.mcgill.caprofsijpkesarch-struct-2010shukhov

Considerados como objetos técnicos, chega-se à estetização dos faróis através do modelo cognitivo de Carlson, pois é "aqui que certa cultura técnica é necessária para apreciar o objeto [de uso]" (op.cit.: 252) ${ }^{350}$ e o "sentido que aparece neles deve ser este uso: a função deve manifestar-se na estrutura" (op.cit.: 249). Com efeito, aprendemos que tais objetos são de uso, uma vez que servem para abrigar um sistema de tecnologia visual constituído, entre outros subobjetos, pelas lentes de Fresnel, que canalizam a luz das lâmpadas em feixes extensos através de 349 Sob esse aspecto, ver também o verbete Moradias Anexas (A Lighthouse Lexicon) em JONES 2013, p. 58.

350 Retificaríamos a sentença escrevendo: "certa cultura ecotécnica". 
prismas de vidro polido dispostos em uma moldura de bronze. ${ }^{351}$ Partindo da ideia da casa xinguana antropomorfa, comparada a um corpo humano, pode-se dizer que o aparelhamento ótico dos faróis faz com que o mar tenha "seus próprios olhos", ${ }^{352}$ e que eles se comuniquem com os marinheiros em uma "única língua: os lampejos de luz", 353 validando a observação do fictício arquiteto Eupalinos segundo a qual, "dentre os edifícios ... uns são mudos; outros falam; e outros enfim, mais raros, cantam" (VALÉRY 1996: 54-5). ${ }^{354}$ A antropomorfização faz com que a distinção entre figura e fundo, sucedida após a idade da magia, seja irremediavelmente suspensa. O objeto híbrido do farol recebe, portanto, a "sua propriedade estética sobretudo do mundo, quando a ele se integra, [e] é na natureza e por ela que ele acaba de se tornar natural" (DUFRENNE 2015: 254), compelindo o desparecimento, durante a sua "evolução técnica natural", da diferença entre physis e techné ao engendrar um "terceiro ambiente" (STIEGLER 1998: 77): o meio associado. Note-se, por exemplo, o farol de Adziogol, construído em 1911 no estuário do rio Dnieper, Ucrânia, por Vladimir Shukhov (ver Fig. 33). Trata-se, no jargão técnico, de uma construção de 64 metros de altura que incorpora diversos tipos de estruturas, tais como hiperboloides, treliçadas, tensionadas e sistemas gridshell (superfícies geometricamente resistentes). É uma inovação no modelo de Smeaton que não somente subtrai qualquer forma de ornamento, bem como do próprio "espaço interior", entregando-se a uma espécie de abstração inspirada no Construtivismo Soviético. ${ }^{355}$ Julgamos, contudo, que a tênue rede tridimensional de aço-carbono, com resistência máxima às ventanias da região, ajusta-se materialmente ao ambiente no processo de concretização de suas propriedades eletroquímicas, ${ }^{356}$ o que o faz tender cada vez mais à naturalidade (op.cit.: 81).

351 Ver JONES 2013, p. 88-9. Tituladas assim em homenagem ao físico francês Augustin Fresnel que, em 1822, concebeu a primeira de suas lentes em forma de colmeia.

352 MOR'VRAN. Direção: Jean Epstein. França: Compagnie Universelle Cinématographique (CUC), 1931. (26 min).

353 LES FEUX de la mer. Direção: Jean Epstein. França: Les Films Etienne Lallier, 1948. (20 min).

354 Acrescentaríamos: "e, uns, enxergam".

355 Cf. MILLINGTON, op.cit.

356 Principalmente no que se refere às estratégias de preservação contra a corrosão de suas hastes. Ver NYKYFORCHYN, H; KUTNYI, Andrij; STUDENT, Oleksandra; et al. Structure and Properties of the Steels of Hyperboloid Gridshell Shukhov's Towers After Long-Term Operation. Materials Science, v. 49, 2014. 


\subsection{Habitação}

Para bem entender a relação entre habitações vernaculares e a estética ecotécnica, partamos do próprio termo ecologia, porque ecologia é o "pensamento da morada" e, portanto, do mundo (oikos adicionado a logos). Pode-se extrair daí a reflexão sobre as categorias do interno e externo, sobre como a relação entre espaço interior e exterior representa um dos padrões originários da arquitetura, e é deles que se trata na obra de Alexander, que os descreve como a "relação entre contexto, forças e relações no espaço" (ALEXANDER 1979: 259), relações estas que parecem ter sido olvidadas nos atuais projetos habitacionais, considerando-se a atenção excessiva do homem contemporâneo ao "transvio de fluxos de ar e impurezas de um lugar para outro". ${ }^{357}$ Oposto ao descerramento puro, ou ao menos a construção de áreas não hermeticamente fechadas, como na arquitetura japonesa tradicional, em que o plano aberto (em paralelo com a estrutura esquelética, componentes modulares, portas corrediças etc.) permanece em seu repertório há séculos (RUDOFSKY 1964). Habitações assim são, simultaneamente (e paradoxalmente), sistemas fechados e abertos, sugerindo uma analogia com os sistemas vivos. "Os organismos são organizacionalmente fechados, os tecidos são organizacionalmente fechados, as células são organizacionalmente fechadas, bem como muitos outros sistemas. Porém, afora as mônadas e o ponto que repetia 'eu' no livro Planolândia, de Edwin Abott, eles também são informacionalmente abertos. Assim, eles podem, de acordo com o domínio abordado, conversar, interagir ou coontogenizar". ${ }^{358}$ A solução da aporia evoca aquela proposta por Sócrates a Mênon, na qual o "ser humano não recebe seu conhecimento do mundo exterior, do mundo finito dos objetos, mas o encontra em si mesmo". ${ }^{359}$ Resolve-se, portanto, o dilema do interno e externo através de uma reminiscência.

357 Ver MORTON, Timothy. Architecture Without Nature. In: tarp: Architecture Manual - Not Nature, Primavera, 2012, pp. 20-5.

358 Ver PASK, Gordon. Different Kinds of Cybernetics. In: VIJVER 1992, pp. 11-31.

359 Ver BARNET, Belinda. Technical Machines and Evolution. CTHEORY, 16 mar. 2004. Disponível em: <http://ctheory.net/ctheory_wp/technical-machines-and-evolution/>. Acesso em: 19 fev. 2019. 
Figura 34 - Projeto do escritório Rintala Eggertsson para o festival SALT

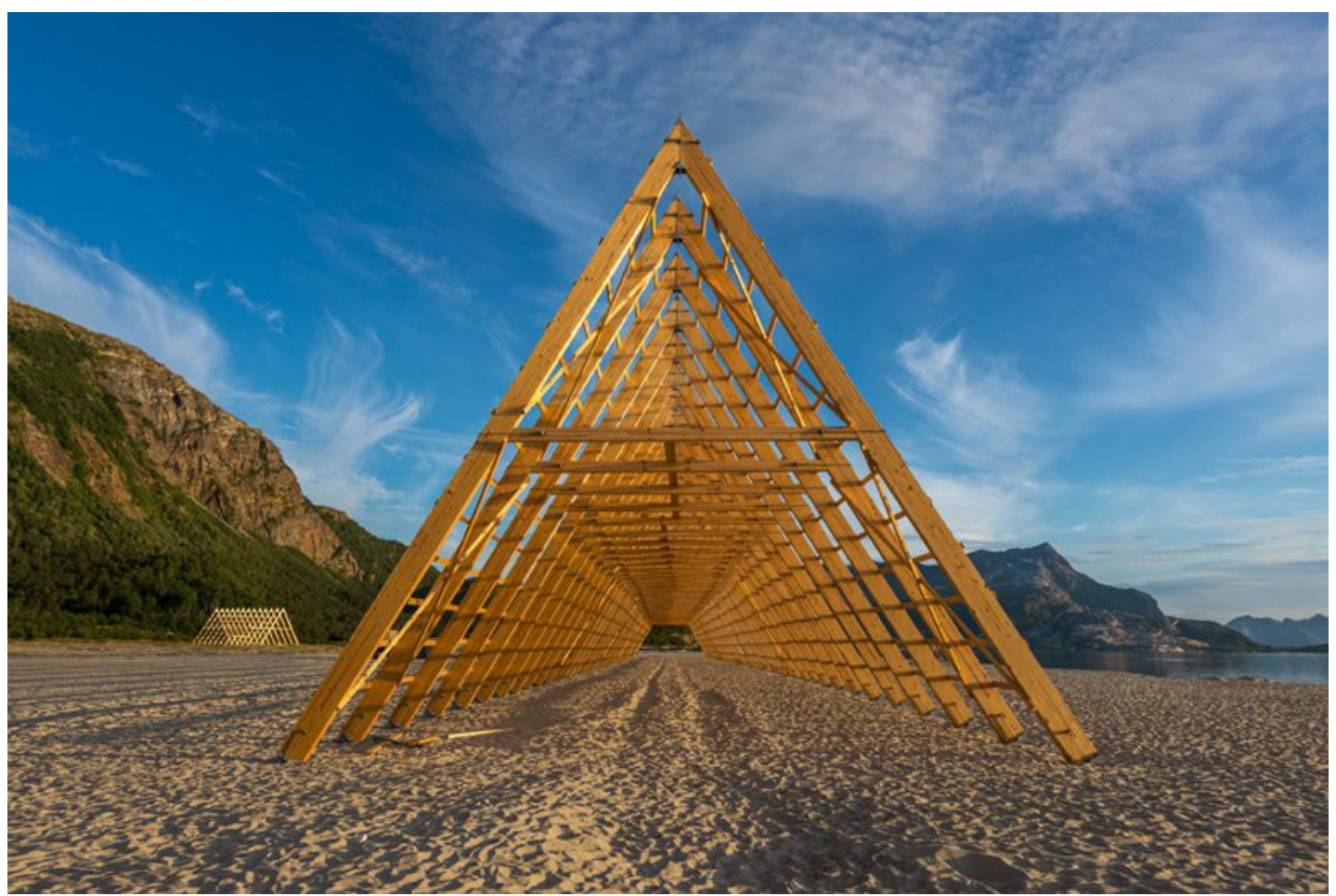

Fonte: https://www.archdaily.com/office/rintala-eggertsson-architects (Foto: Gunnar Holmstad)

Consideremos, por exemplo, uma das três estruturas construídas em 2014 para um festival de arte na região do Ártico, ${ }^{360}$ ocorrido em uma ilha ao norte da Noruega (ver Fig. 34). A maior delas - um espaço voltado para projetos de arte, concertos, peças teatrais e leitura de textos - é uma moldura de madeira inclinada inspirada no fiskehjell, uma grelha de secagem de peixes que integra o repertório da arquitetura vernacular norueguesa, ao lado do rorbu, um tipo tradicional de habitação costeira para pescadores. Não é difícil encontrar semelhanças entre as "pirâmides de Sandhornøya" projetadas pelo arquiteto finlandês Sami Rintala e o kozolec, estrutura de madeira destinada à secagem do feno e do milho, forma distintiva de arquitetura vernacular eslovena, de acordo com os historiadores daquele país. Sabe-se que a associação entre objetos "típicos" e identidade nacional é uma construção artificial, o gesto imaginativo de comunidades com rompantes nacionalistas (ANDERSON 2008), fato que nos convida de volta ao argumento do mito da reminiscência. De fato, as duas formas são, a princípio, objetos técnicos, mas com o potencial de converter-se em objetos de uso, no caso do kozolec, por exemplo, se uma das tipologias (a da dupla) for encoberta por um manto, pode 360 Ver detalhes em SALT. Disponível em: <https://www.salted.no/>. Acesso em: 21 fev. 2019. 
fornecer proteção para implementos agrícolas ou mesmo servir de abrigo temporário. ${ }^{361} \mathrm{O}$ principal interesse de aproximar o ambiente interno ao externo, nos dois casos "arquetípicos" é, por certo, de ordem conceitual, e não prática; e não seria a aporia do sistema semiaberto a metáfora mais entusiástica do condicionamento térmico do ambiente interno e outras técnicas de ventilação natural presentes na arquitetura bioclimática? Devemos, por fim, ver nos dois casos apresentados de habitação vernacular uma diferenciação sem oposição entre physis, techné e oikos, ou melhor, a copossibilidade de uma individuação mútua entre os três termos.

\subsubsection{Arquitetura paisagista}

Para constatar evidências de uma estética ecotécnica nas práticas e técnicas de paisagismo convém, antes de mais nada, procurar esclarecer os motivos pelos quais utilizaremos, nessa seção, o termo arquitetura de paisagem, ao invés do vocábulo protocolar "arquitetura paisagista", ou, como é subscrito nas revistas de banca voltadas à jardinagem: paisagismo. Primeiro, faz-se imperativo apontar que, na França e na Espanha, os profissionais paisagistas sequer estão autorizados a grafar a palavra "arquiteto" em seus títulos, passando a se autodenominar, respectivamente, paysagistes ou paisajistas (HOLDEN \& LIVERSEDGE 2014: 16). ${ }^{362}$ Tal conduta, repercutida também no Brasil, distancia uma espécie de arquitetura da paisagem construtivista de outras áreas, como a arte, a ciência e a gestão da paisagem (op.cit.: 15), aproximando-a do design de interiores (no caso, de exteriores) e esvaziando-a de outros sentidos mais amplos. Segundo, porque nos é indispensável conservar na íntegra a palavra paisagem em nosso prospecto, de acordo com a proposta mesológica que, como falávamos na seção Pensamento ecológico do primeiro capítulo, acopla à ciência ecológica dimensões subjetivas, notadamente aquelas de índole fenomenológica. A prática da arquitetura de paisagem seria, nesse sentido, uma forma de "pensar através da paisagem", na

361 Ver APPLEGATE, Toby Martin. The Kozolec: Material Culture, Identity, and Social Practice in Slovenia. Dissertação de mestrado, Universidade do Tennessee, 2008, p. 35.

362 É possível notar, no Brasil, a prática do paisagismo sendo exercida não tão-somente por arquitetos, mas por engenheiros agrônomos. 
expressão de Augustin Berque, uma maiêutica reflexiva entre o homem e seu meio, um diálogo construtivo entre uma natureza desnaturada e um artífice destituído de hubris. Contudo, seria um erro afirmar que a arquitetura da paisagem seria avessa às convenções do paisagismo popular, sendo-lhe meritórias as atividades corriqueiras da jardinagem e a ideia dos parques públicos, tão antiga quanto à cultura mesopotâmica (op.cit:: 20). Certamente, compreende também a área de manejo florestal, à qual são integradas tecnologias para a conservação e criação de paisagens, contudo sem ressaltar o seu aspecto extrativista, de caráter "sustentável". Essas tecnologias, quando circunstanciadas a partir do próprio vocábulo tecnologia, anunciam um logos que é, como vimos em outra ocasião, uma forma de conhecimento, bem como o campo do "metron, em atenção voltada ao 'tal como é' de um ser (a sua physis)" (STIEGLER 1998: 186). Trata-se, portanto, de se buscar aqui, por meio de um olhar estético e técnico, a medida adequada de florestas reflorestadas, jardins e parques: naturezas intrinsecamente desnaturadas, ou ecotécnicas por natureza.

\subsubsection{Florestas}

Para que a meta de dois graus definida pela comunidade internacional seja cumprida, e o planeta consiga se resguardar de uma possível catástrofe ambiental, relatórios do Painel Intergovernamental sobre Mudanças Climáticas demonstram a inevitabilidade de se criar tecnologias de emissão negativa de carbono, formas artificiais de captura e armazenamento de gás carbônico. ${ }^{363}$ Elas enquadram-se na esfera da geoengenharia que, segundo Clive Hamilton, propugna a "intervenção, de forma deliberada e em larga escala, nos sistemas climáticos, com o objetivo de contrapor o aquecimento global ou alguns dos seus efeitos". ${ }^{364}$ Contudo, ainda não se provou factível, ou financeiramente viável, o desenvolvimento pleno de um dispositivo que sequestre e deposite o principal gás de efeito estufa em formações geológicas profundas, e apostá-lo como único recurso indica "mecanismos

363 Ver Carbon capture and storage. In: Wikipedia. [s.l.: s.n.], 2019. Disponível em: $<$ https://en. wikipedia.org/w/index.php?title=Carbon_capture_and_storage\&oldid=887123970 $>$. Acesso em: 11 mar. 2019.

364 Ver TADDEI, Renzo. Alter Geoengenharia. Trabalho apresentado no colóquio internacional Os Mil Nomes de Gaia - Do Antropoceno à Idade da Terra, em 16 de setembro de 2014, na Fundação Casa de Rui Barbosa, Rio de Janeiro. 
psicológicos de cinismo e autoengano". ${ }^{365}$ Por conseguinte, confere-se atenção redobrada às alternativas, como a "tecnologia" de captura de carbono mais eficiente em termos de custo até o presente momento: as florestas. ${ }^{366}$ Considere-se que, por exemplo, "uma árvore pode armazenar uma média de cerca de 48 quilos de dióxido de carbono em um ano", uma forma de solução natural que, no conjunto, pode contribuir com $37 \%$ da meta climática. ${ }^{367}$ A restauração florestal, por exemplo, será capaz de sequestrar 9,28 gigatoneladas de dióxido de carbono até 2050, e uma de suas técnicas são as agroflorestas multiestratificadas, sistema capaz de se autoperpetuar $^{368}$ em um processo de crescimento orientado, em analogia às outras individuações de seres viventes que, independente de seus "aspectos estéticos", caracterizam-se como "a criação de conjuntos organizados com base em um esquema autoconstitutivo relacionado ao aumento do dinamismo e dos dados iniciais que dependem do acaso" (SIMONDON 2005: 189). ${ }^{369}$

$\mathrm{Na}$ presente conjuntura de exploração do ambiente pelo agronegócio, só podemos enaltecer alternativas com a da agrofloresta, "sistema que reúne as culturas de importância agronômica em consórcio com a floresta". ${ }^{370}$ Trata-se de um plantio de intercalação, ou o entremetimento de duas naturezas: o "desenho de instalação de uma agrofloresta é composto de várias faixas, sendo de dois tipos, distribuídas de forma intercalar: a faixa de adubação verde, geralmente denominada 'faixa de capim' ou 'entrelinha' e a faixa de diversidade, também denominada de 'canteiro' ou 'linha'". ${ }^{371}$ Mas há outras alternativas de performance da "natureza", nas quais verifica-se uma inter-relação mais evidente entre forma e estrutura, condição que nos parece significativa para alcançarmos a paisagem ecotécnica.

\section{Ibid.}

366 GROOT, Han de. The Best Technology for Fighting Climate Change Isn't a Technology. Scientific American, 5 dez. 2018.2 Disponível em: $<$ https://blogs.scientificamerican.com/observations/the-best-technology-for-fighting-climate-changeisnt-a-technology/>. Acesso em: 11 fev. 2019.

367 Ibid.

368 Ver SEOANE, C. E. S.; FROUFE, L. C. M.; AMARAL-SILVA, J.; ARANTES, A. C. V.; STEENBOCK, W. Conservação Ambiental Forte Alcançada Através de Sistemas Agroflorestais Multiestratificados: Agroflorestas e a Restauração Ecológica de Florestas. Cadernos de Agroecologia, Vol 9, No. 4, 2014, p. 3.

369 Excerto no original: l'identité du processus d'accroissement, qui serait création d'ensembles organisés à partir d'un schème autoconstitutif relevant d'un dynamisme d'accroissement et de données initiales dépendent du hasard. (tradução nossa).

370 Ver Agrofloresta. In: Wikipédia, a enciclopédia livre. [s.l.: s.n.], 2018. Disponível em: <https://pt. wikipedia.org/w/index.php?title=Agrofloresta\&oldid=53021981>. Acesso em: 13 mar. 2019.

371 SEOANE, C. E. S., ET AL., op.cit. 
Suponhamos, em primeiro lugar, que seja possível descrever tal "natureza" a partir da acoplagem entre gestalt e estrutura. Esta última, "um conjunto de constantes funcionais" não é meramente idealista, "porque depende da forma para se manifestar; ela se informa para a percepção". ${ }^{372}$ É o caso do satoyama (de sato, aldeia, e yama, montanha), estilo tradicional de agricultura japonesa fundada na ideia de uma paisagem florestal mista para a produção de vegetais e criação de animais. A antropóloga estadunidense Anna Lowenhaupt Tsing, em seu livro The Mushroom at the End of the World, aponta como as florestas de posse comunal (irirai), quando propositadamente "perturbadas" por humanos, tornam-se a medida de uma racionalidade na reabilitação da "produção" de matsutake, cogumelo comestível adverso ao cultivo programado. Os distúrbios provocados por humanos sobre o organismo florestal são, em verdade, uma gestalt instituída a uma estrutura. Ademais, Tsing observa que,

\begin{abstract}
...restaurar florestas para o cogumelo impulsiona um conjunto de outros seres vivos: pinheiros, carvalhos, ervas de sub-bosque, insetos, pássaros. A restauração requer perturbação, mas uma perturbação que aumente a diversidade e o funcionamento saudável dos ecossistemas. Alguns deles ... florescem com as atividades humanas... Essa expressão me permitiu considerar como as paisagens, em geral, são produtos de um design não intencional, isto é, uma sobreposição de atividades de produção de mundo efetuada por diversos agentes, humanos e não humanos (TSING 2015: 152; grifo da autora).
\end{abstract}

372 RAMOS, Silvana de Souza. Palestra proferida no Colóquio Internacional: Gilbert Simondon, os sentidos da individuação (mesa 5 - A individuação ético-política). Faculdade de Filosofia, Letras e Ciências Humanas, USP. 7 dez. 2018. Vídeo disponível em: <https://www.youtube.com/watch? v=BdDSBNXUmAQ\&feature=youtu.be $>$. Acesso em: 12 mar. 2019. 
Figura 35 - Fotograma de O Meu Vizinho Totoro (1988)

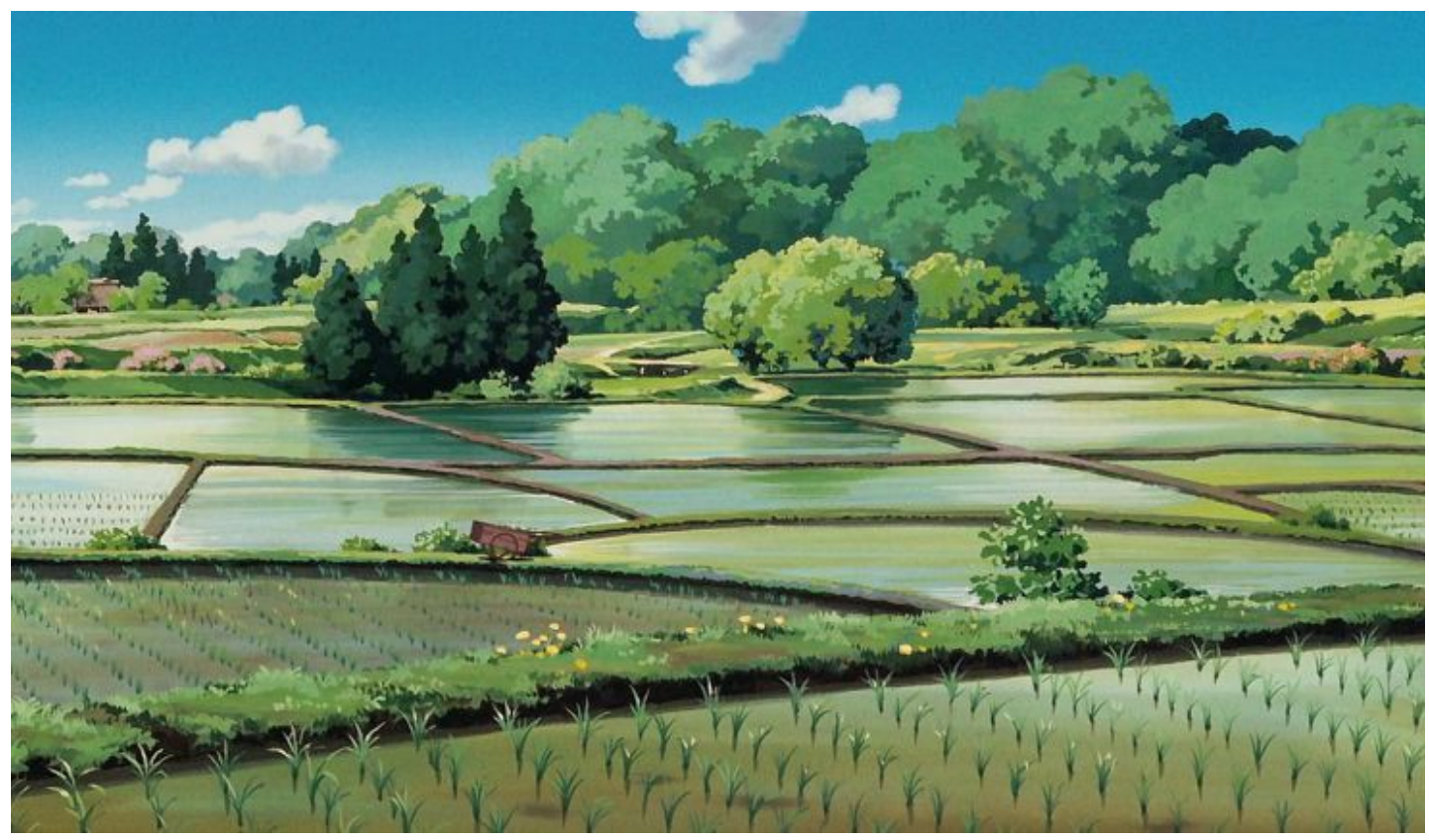

Fonte: https://wallpapertag.com/my-neighbor-totoro-wallpaper (Direitos autorais: Studio Ghibli, 1988)

É para o lado da restauração, e não da preservação, que pende a técnica do satoyama. A diferença é significativa. O conservacionismo é herança direta do ambientalismo nacionalista que deu origem aos parques nacionais nos EUA, paisagens selvagens dignas de proteção contra a interferência de humanos (notadamente a de povos indígenas) e salvaguardadas por meio de territórios confinados, intocados. A composição (e recomposição por intervenção) do satoyama - ilustrado com precisão de pesquisa e atenção aos detalhes no filme de animação O Meu Vizinho Totoro (1988), dirigido por Hayao Miyazaki e produzido pelo Studio Ghibli (ver Fig. 35) -, ao contrário, por ser uma paisagem de borda, no formato de mosaico, nos leva a superar a tradicional noção de "mãe natureza" em favor de uma "natureza ciborgue, a qual rejeita os valores coloniais ... da pureza e fragilidade, pondo em seu lugar a possibilidade de uma vida libertada". ${ }^{373}$ Tal é, portanto, a finalidade dessa técnica de silvicultura e construção da paisagem: proporcionar a emergência de uma natureza ecotécnica, renunciando ao "deixai fazer" liberal em nome de um "deixar-se fazer" perpetrado por diversos agentes. Por certo, "programas ecológicos de restauração em todo o mundo valem-se da ação humana 373 OUT OF THE WOODS. Lies of the Land: Against and Beyond Paul Kingsnorth's Völkisch Environmentalism. libcom.org, 31 mar. 2017. Disponível em: <http://libcom.org/blog/lies-land-againstbeyond-paul-kingsnorth's-völkisch-environmentalism-31032017>. Acesso em: 19 mar. 2019. (grifo nosso). 
para reorganizar paisagens naturais, mas o que distingue a revitalização do satoyama ... é a ideia de que as atividades humanas pertencem à floresta, da mesma forma que as atividades não humanas" (TSING, loc.cit.). Ademais, as florestas dessa "paisagem mental"374 servem como fornecedoras de lenha, fertilizantes naturais, cogumelos, bem como compatibilizam-se, no ritmo calculado das estações, com o complexo sistema de riachos, açudes e reservatórios, cujas águas inundam os terraços de arrozais no momento oportuno. Pode-se haurir um sentido nessas intervenções.

Certamente, o sentido do satoyama é concebido a partir da intenção cognitiva de agentes humanos, embora haja "o sentido próprio do elemento, [que] pertence à coisa mesma" (DUFRENNE 2015: 240). Nesse caso, talvez não seria exagero incluir elementos de uma sobrenatureza ao rol de agentes não humanos, ou ao menos a imagem reflexa dos espíritos da floresta, argumento não naturalista explorado com maestria no filme supracitado de Miyazaki. Seria o ente mitológico que habita uma cavidade secreta da canforeira gigante, descoberto pela protagonista Mei, o índice de que a "floresta é inteligente [e que] ela tem um pensamento igual ao nosso"? (VALENTIM 2018: 257). O pensamento do homem branco supõe "sistematicamente que, 'a floresta cresceu sozinha', que 'ela cobre o solo sem razão', ou seja, que ela 'está morta'". ${ }^{375}$ Entretanto, consoante a cosmovisão dos povos ameríndios, todo e qualquer fenômeno ou episódio decorrido no seio da floresta "não é sem razão" (op.cit.: 255), e sempre comporta um sentido. A floresta está, amiúde, viva (e funcional). A todos, pois, cabe uma função no sistema do satoyama; inclusive - e aqui ausentamo-nos do território da extramundanidade e introduzimo-nos no da intramundanidade - os objetos técnicos. ${ }^{376}$ Consideremos, assim, uma "arquitetura

374 Ver MATSUYAMA, Hiroko. Satoyama: Japanese Mindscape of Nature. Patternz.jp, 10 jan. 2017. Disponível em: <https://www.patternz.jp/satoyama-japanese-mindscape-nature/>. Acesso em: 19 mar. 2019.

375 Nas palavras de Davi Kopenawa e Bruce Albert (A Queda do Céu, 2015), cit. in VALENTIM 2018, p. 255.

376 O auge da representação florestal-ciborguiana é terra0, projeto criado por estudantes da Universidade de Berlim e referido poeticamente como uma "floresta cibernética". Trata-se, em linhas gerais, de um bosque que possui uma identidade digital, ou um avatar, capaz de realizar capital vendendo licenças de corte controlado de seus próprios recursos. As transações são efetuadas através de processos automatizados em um DAO (do inglês decentralized autonomous organization), plataforma cujas regras são especificadas através de contratos inteligentes executados e validados por uma tecnologia do tipo blockchain. A cada seis meses, a identidade digital da floresta calcula seu valor de mercado com base em um sistema de imagens enviadas por satélite e determina a quantidade disponível de madeira negociável. O projeto inspira-se na nova Constituição equatoriana, na qual constam os "Direitos da Natureza", ou a Natureza como titular de direitos (compreende-se, na 
paisagista computacional" no âmbito da engenharia florestal, por meio da qual seja possível "mergulhar" a floresta em "sinais eletromagnéticos [para] medir ... [e] contabilizar ... pássaros ativos, besouros, texugos ou outros participantes ... É o wi-fi como uma ferramenta para análise ecológica: ... um radar animal". ${ }^{377} \mathrm{~A}$ imagem da "natureza ciborgue" não difere muito de atuais áreas verdes literalmente permeadas por redes digitalizadas de sensores que examinam plantas em crescimento, movimentos de animais, cursos de água e o próprio ar. ${ }^{378}$ Pode-se evidentemente especular como seria, por assim dizer, um satoyama ciborgue.

\subsubsection{Jardins}

O jardim, como espaço planejado e constituído, é o resultado de um processo histórico e um "desdobramento de tendências divergentes e ramificadas". ${ }^{379}$ Admitamos que, providos ou não da presença de instalações, os jardins sejam áreas colocadas entre parênteses, espécie de mundo natural vedado e disposto no centro da cultura. Ao dissertar sobre La Chartreuse du Val de Bénédiction, monastério construído pelo Papa Inocêncio VI em Villeneuve lez Avignon, o filósofo checo (naturalizado brasileiro) Vilém Flusser, em posse de categorias clássicas, vincula os jardins aos templos, espaços voltados à contemplação, tanto espiritual como paisagista. ${ }^{380}$ Para os epicuristas, chamados na antiga Grécia de oi apo ton keton (aqueles do Jardim), a ética via-se ligada à estética, tanto que o acesso à primeira era prescrito pela última. ${ }^{381} \mathrm{O}$ deleite supremo proporcionado pelas sensações de prazer não hedonista (leia-se: o Bem Absoluto) seria informado por uma vida

visão dos estudantes alemães, o direito de propriedade). Bem como no componente de não dissociação entre natureza e cultura, ou a outorga à natureza do título de "departamento do aparelho cultural", nas palavras de Vilém Flusser. Ver HAMPSHIRE, Max; KOLLING, Paul; SEIDLER, Paul. terra0: Can an Augmented Forest Own and Utilise Itself? Universität der Künste Berlin, 2016. Disponível em <https://terra0.org/assets/pdf/terra0_white_paper_2016.pdf>. Acesso 20 mar. 2019.

377 Ver MANAUGH, Author Geoff. Computational Landscape Architecture. BLDGBLOG, 1 fev. 2019 Disponível em: <http://www.bldgblog.com/2019/02/computational-landscape-architecture/>. Acesso em: 21 mar. 2019.

378 Ver HARRIS, Mark. A Web of Sensors Enfolds an Entire Forest to Uncover Clues to Climate Change. IEEE Spectrum: Technology, Engineering, and Science News. Disponível em: $<$ https://spectrum.ieee.org/green-tech/conservation/a-web-of-sensors-enfolds-an-entire-forest-touncover-clues-to-climate-change>. Acesso em: 21 mar. 2019.

379 Ver FLUSSER, Vilém. Gärten. In: FLUSSER \& RÖTZER 1993, pp. 46-52.

380 Ver FLUSSER, Vilém. A Utopia of Gardens: Epicurus versus Marx (versão original em inglês), publicado em francês ("Les jardins de l'utopie") in La Chartreuse, Villeneuve-Lez-Avignon, JulhoOutubro 1980, p. 101.

$381 \mathrm{lbid}$. 
esteticamente orientada, a qual dá mostras de sabedoria (filosofia), ${ }^{382}$ porque uma vida não examinada não vale a pena ser vivida, na famosa expressão socrática. Em contrapartida, certas visões de mundo suplantam o conceito do jardim como ambiente circundante, tornando-o algo passível de manipulação (por ex. o extrativismo capitalista, segundo o marxismo). É aqui que a mesologia rompe como perspectiva cosmológica e estética, mas em sua segunda encarnação, protagonizada por "Uexküll e Watsuji Tetsurô, ambos os quais estabeleceram a necessidade de distinção fundamental entre os dados ambientais (Umgebung e shizen kankyo) e o meio (Umwelt e fûdo) para evitar qualquer reducionismo naturalista e cientificista". ${ }^{383}$ O sumo herdeiro dessas duas visões é, decerto, Augustin Berque, para quem o ambiente circundante (o meio, ou milieu) seria, a princípio, construído por um corpo que articula natureza e cultura, ou melhor, que media elementos ecológicos, técnicos e simbólicos. Pode-se dizer que o modo como os arquitetos paisagistas do extremo oriente "pensam através da paisagem", na expressão do geógrafo francês, fornece indícios de qual a função de um jardim de acordo com a estética ecotécnica.

A originalidade dos arquitetos de paisagem japoneses, por exemplo, decorre do fato de que, para eles, um "jardim ... é tudo menos uma simples intrusão humana em uma paisagem natural" (CARLSON 2002: 166). É certo que, no entanto, não se inserem na categoria destinada, por exemplo, aos earthworks (loc.cit.). Propõe-se, à vista disso, que sejam objetos tecno-ambientais atraídos mais pela força ou influência dos objetos naturais do que dos objetos de arte. Partamos do princípio de que a assimetria observada em alguns daqueles jardins fornece soluções paisagistas razoáveis, como notou o diplomata e poeta holandês Constantijn Huygens (1596-1687), o primeiro a desinteressar-se pelo convencional cumprimento das proporções ideais do homem de Vitrúvio na arquitetura de paisagem, insurgência executada quando do planejamento de seu jardim particular próximo a Haia, conhecido como Hofwijck (título também de um de seus poemas). Tal prática foi amparada e disseminada uma geração depois pelo historiador e ensaísta inglês William Temple, o qual "importou" do Japão o conceito paisagista de irregularidade 
intencional, ou sharawadgi. ${ }^{384}$ Certos jardins daquele país insular, observara Huygens, são informes e incompreensíveis, tais como as estampas dos quimonos de seus habitantes, ${ }^{385}$ como se eles atendessem à abordagem estética zen budista do wabi-sabi, a qual refere-se à busca pela beleza no impermanente, no imperfeito e nos elementos rústicos. ${ }^{386} \mathrm{~A}$ palavra sharawadgi é ainda hoje tema de debate, contudo faz-se crer que a sua origem esteve associada à disputa pela supremacia dos ideários paisagistas ingleses, em oposição aos franceses, vista a irregularidade dos terrenos no interior da Inglaterra. ${ }^{387}$ No entanto, disputas estético-políticas à parte, os sharawadgi distinguem-se dos jardins de passeio (kaiyu-shiki) pela sua variabilidade e incorreção, resolvendo assim o dilema de Carlson (2002: 165), segundo o qual objetos naturais e artísticos são, em termos relativos, esteticamente fáceis de assimilar, enquanto os objetos situados no entremeio, ao contrário, não o são. Se seguíssemos por uma via alternativa, substituindo os jardins de passeio do filósofo estadunidense pelos jardins irregulares, reconstituiríamos a função natural ${ }^{388}$ dos últimos - mais suscetível às reivindicações da estética ecotécnica.

384 Ver KUITERT, Wybe. Japanese Robes, Sharawadgi, and the Landscape Discourse of Sir William Temple and Constantijn Huygens. Garden History, v. 41, 2013, pp. 157-176.

$385 \mathrm{lbid}$.

$386 \mathrm{Em}$ uma célebre anedota zen, possivelmente apócrifa, conta-se que o então jovem Sen no Rikyu, futuro mestre do wabi-sabi, desejou aprender o Caminho do Chá. O mestre Takeno Joo ordenou-lhe então que, para passar no "exame de admissão", teria de varrer com afinco o jardim do templo. Ao verificar o trabalho concluído do pleiteante, o mestre considerou que tudo estava em perfeita ordem e então sacudiu os galhos de uma árvore próxima, fazendo com que diversas folhas caíssem ao acaso no solo. Essa seria a demonstração cabal de que nada deve estar perfeitamente em ordem; apenas suficientemente em ordem. Cf. KOREN 2008, p. 79.

387 KUITERT, op.cit.

388 Para recapitular o sentido do termo "função" segundo o modelo da estética ecotécnica, empregaremos o exemplo de uma árvore: para um arquiteto pragmático, ela teria a atribuição de fornecer sombra aos homens ou protegê-los dos ventos oceânicos. Todavia, no contexto ecológico, a sua atividade natural é, dentre outras coisas, capturar gás carbônico da atmosfera, servir de "central de comunicação" à rede de micélios, reduzir a erosão do solo etc. 
Figura 36 - Jardim Suminoe, de Mirei Shigemori (1966)

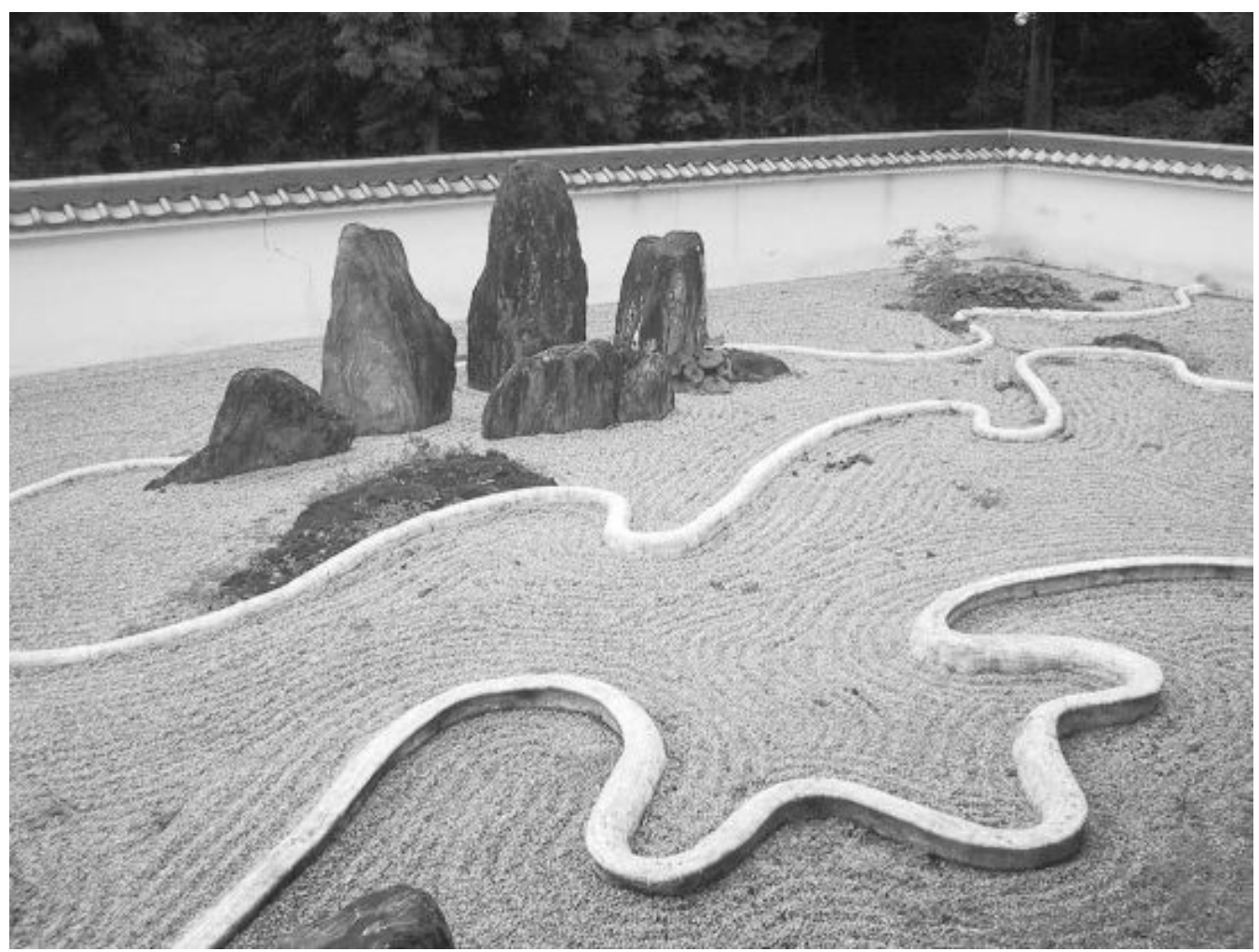

Fonte: TSCHUMI 2006

Uma outra categoria, com vocação mais técnica (no sentido de poiesis associada à metron), poderia compreender o jardim de pedras japonês (karesansui), celebrado e retratado em diversas expressões culturais do Japão, ${ }^{389}$ um estilo de jardim que, ao abdicar de lagos e córregos, faz representações simbólicas de paisagens naturais usando arranjos de pedra, areia branca, musgo e, em alguns casos, esculturas de rochas. Concebido no período Muromachi (1333-1568), os "jardins secos" (chamados também de "paisagens secas") podem ser descritos como objetos intermediários (situados entre objetos de arte e naturais) destinados a reproduzir não a aparência real da natureza, mas a sua essência, afirmando-se também como um objeto fenomenológico, porque "pensar o fenômeno é distinguir a aparência do aparecer, a experiência do objeto do objeto em si" (STIEGLER 2009: 193). Com efeito, a experiência sensória propiciada por um karesansui, na visão do construtor de paisagens Mirei Shigemori (1896-1975), invoca a memória da natureza e os espíritos nativos da mitologia xintoísta (kami). ${ }^{390}$ No projeto do Jardim Suminoe 389 Ver, por exemplo, Bashun (Pai e Filha, no Brasil), filme japonês de 1949 dirigido por Yasujiro Ozu.

390 Ver TSCHUMI, Christian A. Between Tradition and Modernity: The Karesansui Gardens of Mirei 
(ver Fig. 36), construído próximo à cidade de Sasayama, ele roçou metodicamente o solo de cascalho com o ancinho, desvelando o padrão ondulante das águas marítimas da baía, e organizou as esculturas de pedras sob a influência de iwakura (formações rochosas divinas), referenciando desta forma o deus do mar. ${ }^{391} \mathrm{O}$ seu modo de produção é, portanto, poético, na acepção grega da palavra, uma produção não exploradora, que não compele a physis, nem a provoca desafiadoramente, mas a conduz em seu "fazer-se" originário. De fato, a sua techné poderia ser "compreendida como physis, como produzir que faz aparecer" e, nessa perspectiva, "a physis desabrocha espontaneamente e não está a serviço exclusivo dos agenciamentos humanos". 392

\subsubsection{Parques}

Em documentário ${ }^{393}$ dirigido por Kalyanee Mam vemos uma pescadora da ilha de Koh Sralau, no Camboja, visitando os Jardins da Baía, parque construído sobre um aterro marítimo em Singapura, cidade-Estado insular ao sul da Península Malaia. O parque é, de fato, um microcosmo da "cidade-jardim", apodo do colosso urbano edificado sobre um pântano drenado e que ostenta uma linha costeira cercada em quase a sua totalidade por concreto. No documentário ficamos sabendo que, para expandir o seu território, Singapura tornou-se um dos maiores importadores de areia do mundo, notadamente do Camboja. E é essa a contradição revelada no filme, porque os impressivos agrupamentos de jardins verticais do parque, modelados em forma de árvores e que pontuam uma paisagem de ficção científica, assentam-se sobre uma massa terrestre escavada de costas e estuários próximos aos mangues que compõem o modo vida de pescadores artesanais cambojanos, a visitante incluída: "Essa terra é minha terra", decreta com desânimo. O fato de os arquitetos de paisagem terem concebido uma "simulação ecológica de proporções épicas", contendo dois dos maiores conservatórios climatizados do mundo, denota que "para

Shigemori. Landscape Journal, v. 25, n. 1, 2006, pp. 108-25.

$391 \mathrm{lbid}$.

392 Ver COCCO, Ricardo. A Questão da Técnica em Heidegger. Controvérsia, v.2, n.1, 2006, pp. $34-54$.

393 LOST World. Direção: Kalyanee Mam. Produção: Emmanuel Vaughan-Lee. Go Project Films, 2018. Disponível em: <https://www.youtube.com/watch?v=NSRY_aYmfFo>. Acesso em: 22 mar. 2019. 
fazer a vida prosperar lá, nada fazem para mitigar as forças que estão permitindo a vida morrer em outros lugares". ${ }^{394}$ Os Jardins da Baía remontam a um artifício, a um modelo. Trata-se de um recurso estético no qual a tecnologia não vai de encontro com a natureza, ao contrário, colide-se com ela. Não comporta, como mencionamos anteriormente, a solidariedade constitutiva entre techné e physis que, por intermédio da poiesis - o denominador comum em produções heterônomas (alopoiese) e a capacidade de determinados entes de produzirem a si próprios (autopoiese) - forma uma das premissas da estética ecotécnica. O contraste entre o parque de Singapura e um parque hipoteticamente ecotécnico é o mesmo contraste entre modelo e exemplo, sugerido por Eduardo Viveiros de Castro, sendo os exemplos "técnicas ... que funcionam como incentivos para fazer algo 'diferentemente parecido' com o exemplo inspirador, que é sempre uma versão ou transformação de outro exemplo, assim como os mitos são apenas versões de um outro sem modelo original". ${ }^{395} \mathrm{O}$ que seria, por conseguinte, um parque ecotécnico?

Veremos, em que pese o desafio de se investigar o "exemplo" segundo Viveiros de Castro, que a resposta talvez se encontre a dois mil quilômetros ao norte, em Bangkok, Tailândia, capital que, devido aos impactos das mudanças climáticas, submerge a uma taxa de dois centímetros ao ano. ${ }^{396}$ Outrora repleta de canais, a ponto de ser chamada de "Veneza do Oriente", atualmente tais "coletores pluviais" encontram-se pavimentados para dar espaço à expansão urbana, deixando-a vulnerável a inundações catastróficas. É esse fato que levou a arquiteta de paisagem tailandesa Kotchakorn Voraakhom a conceber, conforme o critério do seu "design anfíbio", um parque público no centro da cidade, situado no campus da Universidade Chulalongkorn. Capaz de conter quase um milhão de litros de água durante inundações severas, o parque é formado por componentes que funcionam como um sistema, sendo o principal deles o teto verde lateral em forma de plano inclinado que, por força da gravidade, escoa a carga d'água em direção às várzeas centrais e à lagoa de retenção, localizada na parte menos elevada da outra

394 Ver MYERS, Natasha. Edenic Apocalypse: Singapore's End-of-Time Botanical Tourism. In: DAVIS \& TURPIN 2015, pp. 31-42.

395 Ver VIVEIROS DE CASTRO, Eduardo. On Models and Examples: Engineers and Bricoleurs in the Anthropocene. Current Anthropology, v. 60, n. 3, 2019 (no prelo).

396 Ver Sinking Bangkok Among Cities To Be Hardest Hit By Climate Change. ASIA TODAY News \& Events, 9 set. 2018. Disponível em: <http://www.asiatoday.com/pressrelease/sinkingbangkok-among-cities-be-hardest-hit-climate-change>. Acesso em: 9 abr. 2019. 
extremidade. A morfologia do "exemplo", via de regra, teve como "modelo" as raízes da Coreutéria (Koelreuteria paniculata) e as bochechas do macaco. ${ }^{397}$ Mas ao apresentar o projeto em uma conferência TED, ${ }^{398}$ Voraakhom, como que se apropriando da prática da bricolagem, na analogia de Viveiros de Castro, pareceu invocar uma amostra mais significativa, mais propensa ao "modo de criatividade não originalmente programado que se baseia em materiais heterogêneos já disponíveis (como o conhecimento enciclopédico armazenado na cultura e na linguagem do criador de mitos)", ${ }^{399}$ recordando para a plateia que, durante a infância, sua maior diversão era alargar as fissuras no concreto do estacionamento ao lado de sua casa para dar espaço às plantas que laboriosamente cresciam por entre as estreitas frestas. Assim como elas, o parque centenário da universidade, que ocupa uma fração mínima do espaço urbano, irrompe à superfície sob o peso do novo normal climático.

397 Essa árvore tem um "sistema radicular muito significativo, de longo alcance, e seus galhos se projetam, criando sombras para o entorno ecológico". Já a referência aos símios remete ao "rei Bhumibol, monarca da Tailândia de 1946 até ... 2016, [que] costumava usar a metáfora das bochechas dos macacos para descrever como Bangkok poderia se adaptar às enchentes. Assim como um macaco retém o alimento na boca até sentir necessidade de engoli-lo, também a cidade deve ser capaz de reter a água da enchente até que ela lhe seja útil". Ver D'ARCY, Patrick. When Bangkok floods (and it floods a lot), this park does something amazing. TED Ideas, 20 jul, 2018. Disponível em: <https://ideas.ted.com/when-bangkok-floods-and-it-floods-a-lot-this-park-doessomething-amazing/>. Acesso em: 9 abr. 2019.

398 VORAAKHOM, Kotchakorn. Palestra proferida no TEDWomen 2018, Palm Springs (Califórnia), nov. 2018. Vídeo disponível em: <https://bit.ly/2U2sMQF>. Acesso em: 9 abr. 2019.

399 VIVEIROS DE CASTRO, op.cit. 
Figura 37 - Planta do Parque Centenário Chulalongkorn

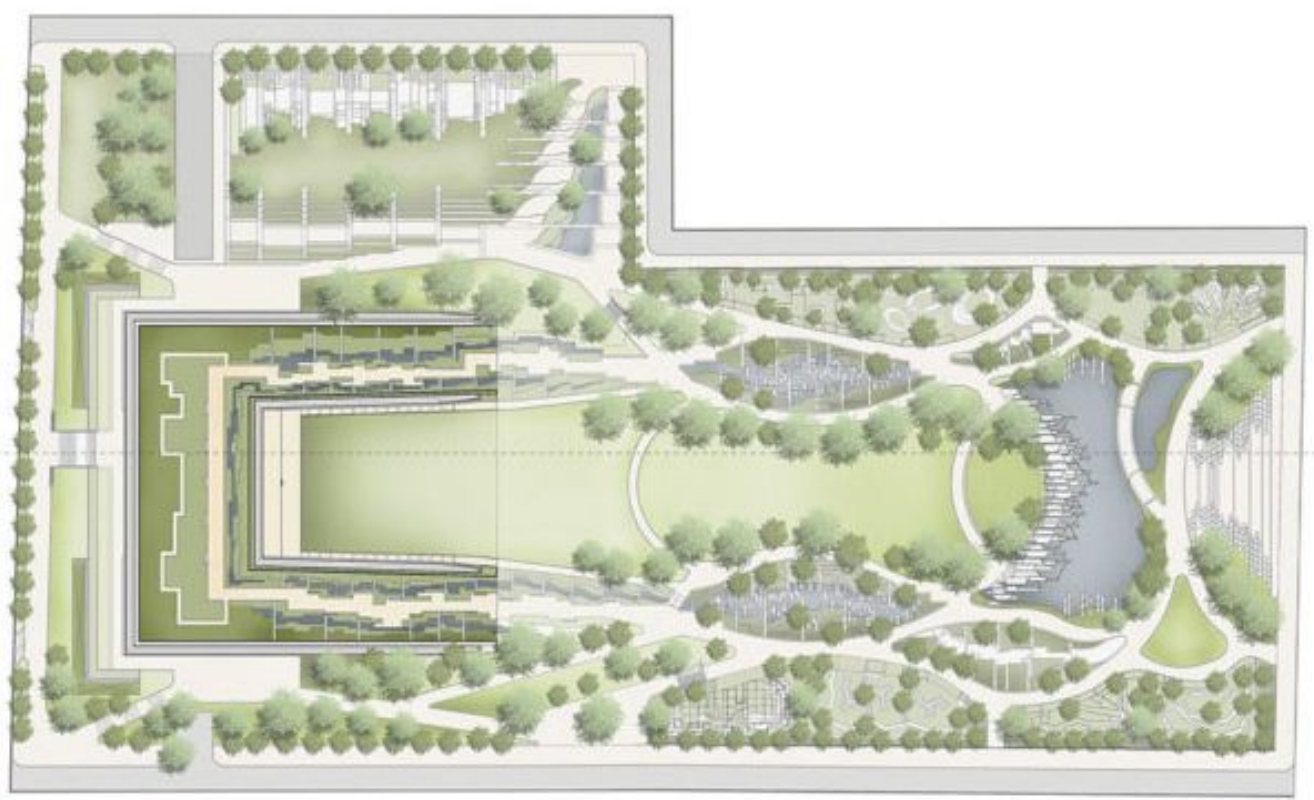

Fonte: https://worldlandscapearchitect.com/chulalongkorn-centenary-park-green-infrastructure-for-thecity-of-bangkok/

Podemos supor que o parque seja um prolongamento das bricolagens experimentadas por Voraakhom ao longo de sua infância, decorrência mais de exemplos memoriais do que de modelos previamente designados. O parque em si é também um objeto tecno-ambiental, por combinar de modo indeterminado forma, funcionamento e função e por manter a proporção exata entre figura (plano inclinado) e fundo (subsidência topográfica). Quanto às suas representações projetuais, ao lado dos inexoráveis ambientes virtuais em $3 \mathrm{D},{ }^{400}$ a arquiteta tailandesa procurou preservar técnicas tradicionais de arquivos de arquitetura de paisagem, como a planta em vista aérea confeccionada ao estilo das villas documentadas no arquivo histórico Catena (ver Fig. 37). ${ }^{401}$ Ao mesmo tempo, estabeleceu-se a centralidade (para não dizer: a precedência) da ideia de lugar, componente essencial no campo do projeto arquitetônico-urbanístico. ${ }^{402}$ Ela fez aflorar em seu projeto o sentido da aura do sítio, o genius loci, a partir de uma

400 Cf. Parque Centenário da Universidade de Chulalongkorn. Vídeo disponível em: <https://www.youtube.com/watch?v=i31bU7A2Los\&feature=youtu.be>. Acesso em: 9 abr. 2019.

401 Como, por exemplo, a vista panorâmica dos jardins da Villa d'Este, Tivoli, assinada por Etienne Dupérac. Ver em <http://catena.bgc.bard.edu/este/index.htm>. Acesso em: 10 abr. 2019.

402 Ver CASTELLO, Lineu. Da Sustentabilidade da Subjetividade: o Projeto IBA Emscher Park. vitruvius, arquitextos 042.01: ano 04, nov. 2003. Disponível em: <http://www.vitruvius.com.br/revistas/read/arquitextos/04.042/636>. Acesso em: 10 abr. 2019. 
convergência entre o elemento físico-espacial e a ativação subjetiva, sintetizada na produção de sentido, resultado da soma da percepção estética (pré-sentido) e da intenção cognitiva (geração de sentido por meio de conhecimento adquirido). No caso do parque centenário, o gênio faz-se presente nas oito "salas paisagistas", cada uma delas voltada a um programa distinto, como a horta de ervas, o anfiteatro, a caminhada meditativa e a área de leitura.

\subsection{ESTÉTICA ECOTÉCNICA E INFRAESTRUTURAS}

Passemos agora ao segundo campo expandido, a saber, o campo das infraestruturas. No texto curatorial da exposição de arte contemporânea Infrastructural Territory: The Spatial Foundation of National Discourse, ocorrida em 2018 nos espaços da OCAT Xangai, ${ }^{403}$ chamou-nos a atenção a citação de um mote do urbanista australiano Richard Weller: "A paisagem em si é um veículo pelo qual todas as evoluções ecológicas acontecem. Ela é o futuro da infraestrutura". ${ }^{404}$ A frase reforça a concepção dos curadores, segundo a qual a "paisagem não deve se limitar ao 'ambiente natural' não cultivado, uma vez que a sua integração às infraestruturas está se tornando um componente crítico dos territórios humanos", 405 reflexão que, no fundo, coincide parcialmente com a visão que exploraremos no presente subcapítulo. (Parcialmente, porque faz-se necessário discutir de partida a escala daquela integração). Assim, permitimo-nos falar de uma "infraestrutura de paisagem", ao modo da arquitetura de paisagem comentada no subcapítulo anterior. Em vez dos panegíricos dirigidos por Brian Hayes (2006) ao estetismo das infraestruturas legadas, aquelas que se pode reconhecer de fato em condições de decadência e colapso, ${ }^{406}$ voltamo-nos para outras formas de adequação infraestrutural, apoiadas em tecnologias naturais e invenções que estabeleçam novas formas de coerência com o mundo (CHABOT 2003: ix). Decompomos o 403 Grupo de espaços culturais patrocinados pela Overseas Chinese Town Enterprises Co., estatal chinesa que atua na área da industria cultural.

404 Ver Infrastructural Territory - The Spatial Foundation of National Discourse (OCAT Shanghai). Ran Dian Magazine, [s.d]. Disponível em: <http://www.randianonline.com/np_event/infrastructural-territorythe-spatial-foundation-of-national-discourse-ocatshanghai/>. Acesso em: 17 abr. 2019.

405 Ibid.

406 Ver a matéria Infraestrutura dos EUA Sob Risco de Colapso. Deutsche Welle, 19 jul. 2017. Disponivel em: <https://www.dw.com/pt-br/infraestrutura-dos-eua-sob-risco-de-colapso/a-39750416>. Acesso em: 18 abr. 2019. 
conjunto de rubricas em quatro grandes setores: engenharia, telecomunicações, energia e recursos hídricos. A análise é, decerto, orientada pela bússola estética, mas sugere nas entrelinhas a imprescindibilidade de modificação - ou mesmo de plena substituição - do regime sociotecnológico vigente.

\subsubsection{Setor de engenharia}

Uma passagem notável de Sobre a tecno-estética: Carta a Jacques Derrida é a descrição aficionada da ponte Garabit sobre o rio Truyère, a fusão perfeita das categorias técnica e estética. Pode-se dizer, consoante a Simondon (1992), que a obra arqueada de Gustave Eiffel representa o arquétipo da chamada arte estrutural, que tem como principais ideais a elegância, a economia e a eficiência, encaixandose quase unanimemente com a nossa tríade composta por forma, função e funcionamento. ${ }^{407}$ Honramos a crítica de que uma estrutura projetada para ser eficiente automaticamente torna-se admirável, uma crendice tão ou mais reducionista quanto a de que, para se construir "uma estrutura bela, exige-se a assistência de um consultor em estética" (BILLINGTON 1985: xvi), sem as credenciais do engenheiro. Também outrora não se enfatizou a funcionalidade em detrimento da estética, ${ }^{408}$ fato esse verificável nos traçados da ponte Nihonbashi em Tóquio, construída no início do período Edo (1603-1868) e sobre a qual erigiu-se uma via expressa durante a década de 1960, transformando o popular marco fotogênico em uma "monstruosidade". ${ }^{409} \mathrm{E}$, da mesma forma, não é à toa que Thomas Telford e Robert Maillart são normalmente designados - antes mesmo que

407 Não se deve entender a diferença entre eficiência e eficácia no sentido da administração organizacional moderna. No contexto tecnológico, os dois termos são quase sinônimos. Apesar da diferenciação que o engenheiro estadunidense David Billington (1985) faz entre estruturas (estáticas) e máquinas (dinâmicas), sugerindo que enquanto a primeira é eficiente (cumpre satisfatoriamente uma função), a segunda é eficaz (executa uma tarefa otimamente), recorremos ao modo como Simondon (1969: 55) descreve a eficácia (efficacité) do sistema de refrigeração do gerador de Guimbal, a qual poderia perfeitamente ser definida como uma operação eficientemente eficaz. Daí a nossa convicção em afirmarmos, em alguns casos, que tal ou qual estrutura é funcional (não no sentido de atender a uma função, mas no de estar funcionando corretamente) ou não.

408 Essa reflexão converge com outra, lavrada por SolarpunkAnarchist (@SolarpunkA): "Forma deve seguir a função quando se trata de design. Mas isso não significa abraçar uma estética monótona onde tudo é feito de concreto cinza. Parte da função prática de um projeto é ser sensualmente atraente." 19 abr. 2019, 3:33 AM. Tweet. (grifo nosso).

409 Ver o editorial Let Nihonbashi Bridge Rise Again. The Japan Times, 8 mar. 2014. Disponível em: <https://www.japantimes.co.jp/opinion/2014/03/08/editorials/let-nihonbashi-bridge-rise-again/>. Acesso em: 1 nov. 2018. 
Ihes seja conferido o título oficial de engenheiros de pontes - por termos como "artistas estruturais" (op.cit.). Contudo, se as pontes ferroviárias ou rodoviárias encarnam o espírito da tecno-estética de Simondon, convém prevenir que a adequação técnica celebrada pela estética ecotécnica reivindica o que poderíamos chamar de uma Nova Matriz Energética. Cabe-nos, portanto, sustentar iniciativas "ásperas" de redução de dióxido de carbono (ou emissões equivalentes), ${ }^{410}$ esmiuçando estruturas que não dão suporte aos meios de transporte subordinados aos combustíveis fósseis (petróleo, carvão mineral e gás natural), mas formas "verdes", identificadas aqui como pontes pedonais (vivas ou não) e serviços públicos e tecnológicos voltados para as chamadas cidades caminháveis.

\subsubsection{Pontes pedonais}

Devido ao amplo valor social e simbólico das pontes convencionais, ${ }^{411}$ a literatura sobre pontes pedonais é reconhecidamente esparsa (BAUS, ET AL. 2007: 6). Por isso elas desde logo assinalam uma tipologia própria que, desde o século 18, vem se destacando do universo das pontes de larga escala, louvadas pelo pensamento das Luzes por representar o avanço tecnológico (op.cit.: 11). Diferente das passarelas, os engenheiros de pontes pedonais devem antecipar o fato de que os transeuntes não simplesmente as transporão, mas poderão eventualmente se deter sobre a elevação, com a intenção de admirar o entorno, daí a importância de se projetar balaustradas, parapeitos e corrimãos seguros e eficientes (op.cit.: 12). Conciliar harmonicamente natureza e tecnologia, combinando-as através de noções como "verdade da construção" e "estética da economia", faz-se um desafio recorrente e parece ter sido o devir de engenheiros de pontes pedonais do Reino dos Jardins de Dessau-Wörlitz (jardim à inglesa situado na região de Gartenreich, Alemanha), que deixam transparecer o conhecimento técnico dos que se dedicam a estruturas destinadas não somente ao fluxo de pedestres (op.cit.: 28-30). Apesar de

410 Ver SPRINGETT, Jay. The Coming Asperity. Medium | Anomalous Engineering, 13 nov. 2013. Disponível em: <https://medium.com/anomalous-engineering/the-coming-asperity-5bf9407bd010>. Acesso em: 3 nov. 2018.

411 Aqui iremos nos restringir ao termo pontes pedonais (conhecidas popularmente como pinguelas) - ao invés de passarelas - para demarcar as estruturas projetadas não para o tráfego rodoviário ou ferroviário. Entendemos as últimas mais como estruturas de separação, certamente direcionadas à travessia de pedestres, porém sendo, ao menos em nosso entendimento, uma subclasse das pontes pedonais. 
sua aparente frivolidade, essas estruturas requisitam rigorosos testes de vibração forçada, como os verificados recentemente na avaliação da ponte pedonal de Metagarup sobre o rio Swan, em Perth, Austrália. ${ }^{412}$ Nota-se assim que, ao lado do estudo do comportamento dinâmico das forças de tração, o critério de seleção de materiais é crucial e acha-se na intersecção de decisões geométricas, estéticas e de funcionalidade, sejam as estruturas de épocas passadas ou modernas, estas últimas construídas geralmente como se fossem pontes catenárias ou atirantadas. ${ }^{413}$ Quanto às modernas, o engenheiro suíço Robert Maillart, especialista em construção de pontes de grande porte, transpôs a sua estética de estruturas arqueadas para as pontes pedonais (ver Fig. 38), as quais similarmente abstém-se dos pilares de suporte, tornando inconsútil a transição entre a monolítica estrutura de concreto e o chão firme (op.cit.: 56).

Figura 38 - Ponte pedonal de Töss, em Winterthur-Wülflingen, de Robert Maillart

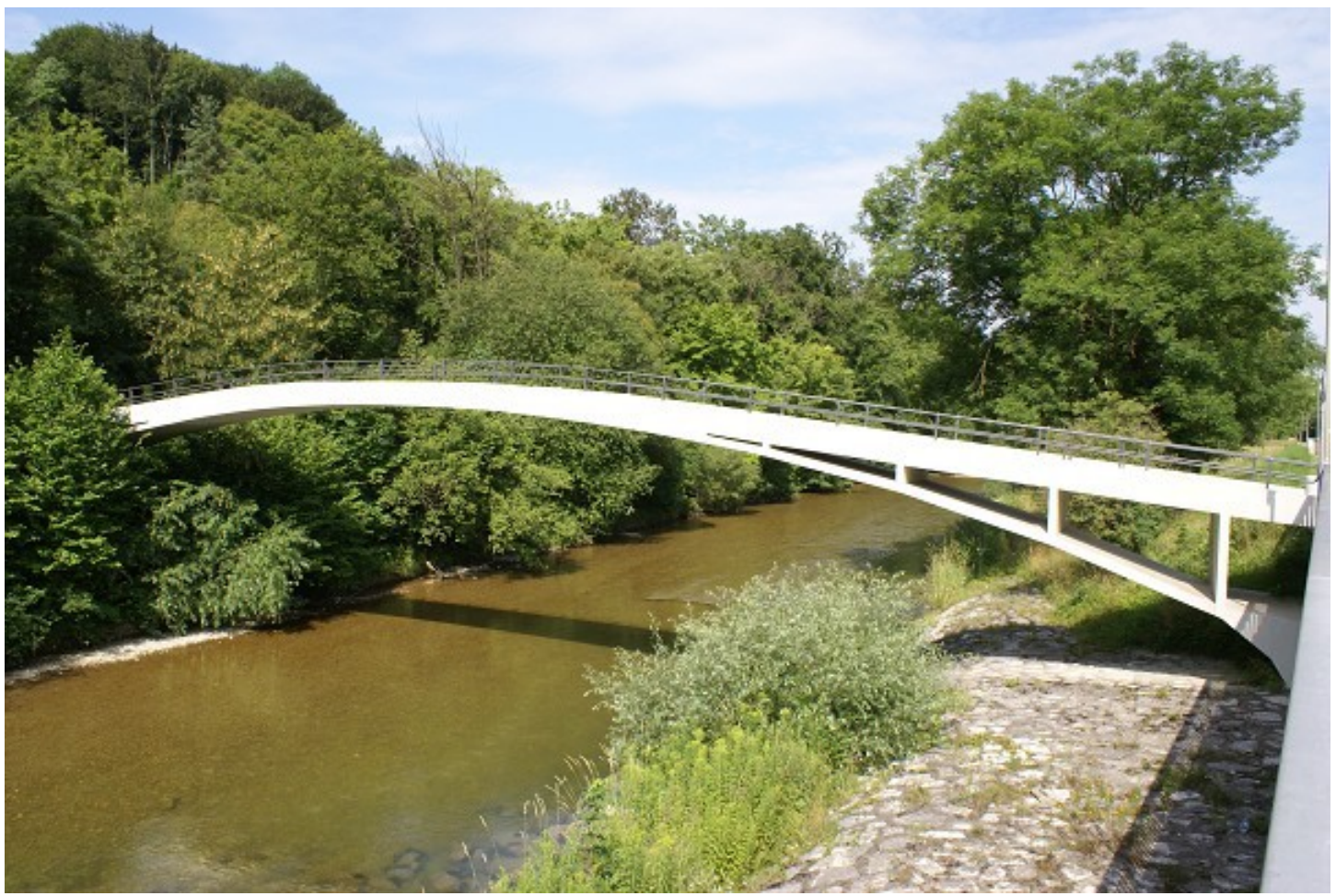

Fonte: https://structurae.net/structures/toss-footbridge (Foto: Markus Widmer)

412 Ver ZIMMERMAN, Josh. Bridge Undergoes First People Test. PerthNow, 7 jul. 2018. Disponível em: <https://www.perthnow.com.au/sport/perth-stadium/hundreds-walk-across-matagarup-bridge-aspart-of-dynamic-tuning-test-ng-b88888779z>. Acesso em: 8 nov. 2018.

413 Ver COSTA, Diogo Cândido da. Análise do Comportamento Dinâmico de uma Ponte Pedonal. Dissertação para obtenção do grau de Mestre em Engenharia Civil na Área de Especialização em Estruturas. Instituto Superior de Engenharia de Lisboa, 2012. 
O mesmo princípio de escolha de materiais repete-se na história das pontes pedonais da China, em especial aquelas construídas em madeira. E são as pinguelas em forma de arco, presumivelmente elementares, as que mais se consagram por repousar em sofisticadas técnicas e tecnologias. Pode-se vê-las retratadas naquelas pinturas em seda dispostas em pergaminhos horizontais, como o rolo Quingming, de Zhang Zeduan, pintor chinês que viveu durante o período Song, dinastia que governou a China de 960 a 1279; bem como no rolo Kidai Shoran, ${ }^{414}$ datado de 1805, na superfície do qual é possível apreciar a Ponte Imagawa (Imagawabashi), uma das menores pontes pedonais do Período Edo. As pinguelas de estrutura de madeira oferecem muitas vantagens, como coordenação ambiental (por ex. O uso de pinus e o eucalipto), tênue peso próprio, ${ }^{415}$ alta capacidade de carga, excelente durabilidade e abundância de formas. ${ }^{416}$ Mas para que estas estruturas tenham pleno rendimento em sua função de armação conectiva, faz-se necessária a aplicação de técnicas milenares, com base em sistemas de encaixe e cavilhas, envolvimento de vigas treliçadas e montagens do tipo caixa e espiga. ${ }^{417}$ Para cumpri-las, os Mestres Carpinteiros põem à prova números e proporções racionais, medidas verificadas, por exemplo, no projeto da ponte em forma de arco-íris pintada por Zeduan, composta por 21 grupos de estruturas em forma de arco organizadas em paralelo. ${ }^{418}$ Mas, como assoma o sinólogo francês Marcel Granet (2004: 175), os chineses abstêm-se de ver nos números os "sinais abstratos e imperativos da quantidade", sendo uma grandeza que serve unicamente "para indicar relações e proporções, permitindo a manipulação das relações e uma certa folga nas proporções" (grifo do autor). Talvez seja por esse motivo que ainda existam hoje mais de cem pontes arqueadas de madeira construídas ao longo de vários períodos dinásticos, expressando uma

414 Uma versão digital do Kidai Shoran, de autor desconhecido, foi mostrada na exposição Emoção Art.ficial 1.0, promovida em 2001 pelo Instituto Itaú Cultural, São Paulo. O projeto é assinado pelo coletivo alemão Art+Com, formado por Ralph Ammer, Joachim Sauter e Tobias Schmidt.

415 Termo que significa a carga de uma estrutura imposta pelo seu próprio peso. Cf. Self Weight. SkyCiv Documentation. Disponível em: <https://skyciv.com/documentation/structural-3d/applyingloads/self-weight/>. Acesso em: 27 nov. 2018.

416 Ver FU, Meizhen; LIU, Yongjian; LI, Na; et al. Application of Modern Timber Structure in Short and Medium Span Bridges in China. Journal of Traffic and Transportation Engineering, v. 1, n. 1, 2014, pp. 72-80.

417 Ver Caixa e espiga. In: Wikipédia, a enciclopédia livre. [s.l.: s.n.], 2013. Disponível em: $<$ https://pt.wikipedia.org/w/index.php?title=Caixa_e_espiga\&oldid=34873387>. Acesso em: 9 nov. 2018.

418 FU, ET AL., op.cit. 
variedade de formas e linhagens estruturais, sendo reconhecidas como Patrimônio Cultural Imaterial da Humanidade pela UNESCO. ${ }^{419}$

Figura 39 - Ponte de raízes vivas na vila de Nongriat

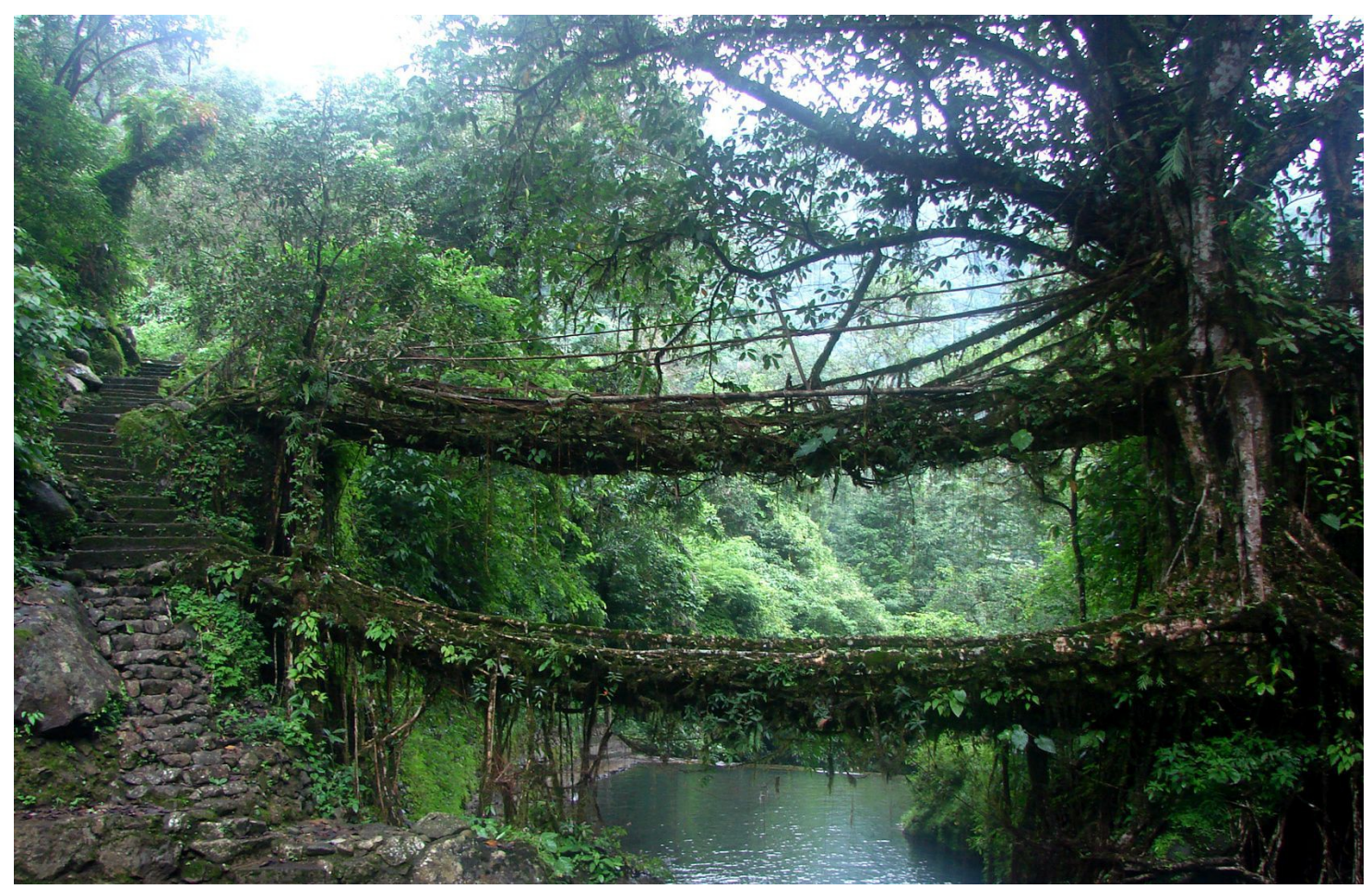

Fonte: http://www.brokennature.org/living-root-bridge-ecosystems-india/ (Foto: Sanjeev Shankar)

Cabe introduzirmos neste instante uma técnica de construção de pinguelas que se compatibiliza de forma exata aos moldes da estética ecotécnica: as pontes de raízes vivas da Índia, conhecidas localmente como jingkieng jri. Trata-se de uma técnica de arborescultura aprimorada através do conhecimento etnobotânico dos povos Khasi e Jaintia, estabelecidos no estado indiano de Meghalaya. Em linhas gerais, o processo de "construção" da ponte começa com um arranjo transversal de raízes aéreas de árvores-da-borracha (Ficus elastica) sobre um desfiladeiro ou um rio. Em cada uma das margens, elas são distribuídas sobre troncos de palmeiras (especificamente as da espécie Areca catechu), as quais fornecerão nutrientes e proteção contra as intempéries das monções, além de funcionarem como um sistema de orientação do movimento gravitrópico positivo das raízes, em que a zona inferior cresce mais lentamente que a superior. O conjunto é, então, escorado 419 UNESCO. Traditional Design and Practices for Building Chinese Wooden Arch Bridges. [s.l.: s.n., s.d.]. Vídeo disponível em: <https://www.youtube.com/watch?v=um6DQxKb9Q8>. Acesso em: 27 nov. 2018. 
temporariamente por uma armação de bambu, até a estabilização definitiva do processo de crescimento subjacente das longarinas e corrimãos, que envolve a constante junção por entrelaçamento das fibras das seções, método chamado de inosculação (semelhante ao enxerto). ${ }^{420}$ Parece plausível pressupor que dessas técnicas surge a condição de possibilidade de uma estética ambiental de modelo cognitivo, posto que investigar o crescimento e a fisiologia da árvore-da-borracha, "especialmente a morfologia e biomecânica das fibras das raízes, juntamente com a sua inosculação, é um pré-requisito para compreender, aprimorar e replicar o desempenho dessas estruturas". ${ }^{421} \mathrm{Em}$ comparação com as pontes suspensas de ferro e concreto, ou mesmo as vernaculares de bambu, a resistência (e, principalmente, a resiliência) das pontes de raízes vivas é extremamente exitosa, haja vista a durabilidade da ponte double deck situada próxima ao vilarejo de Nongriat, uma estrutura "madura" que se consolidou no decorrer de 30 anos (ver Fig. 39).

\subsubsection{2 "Caminhabilidade"}

Na véspera do feriado do Dia de Ação de Graças de 2018, o ABCNews.com, serviço de notícias da ABC News (subsidiária da Disney Interactive Media Group) publicou um vídeo ${ }^{422}$ em sua página no Instagram: o registro de um monumental engarrafamento automotivo na Rodovia 405, no ponto de saída da cidade de Los Angeles, em Orange County, exatamente após a finalização do reparo de alargamento desse trecho ao custo de 1,6 bilhão de dólares. É inegável a conclusão preliminar de tal visão: obras de alargamento de rodovias e vias expressas não funcionam, para além do sentido coloquial da palavra "funcionamento". Como explicar essa incongruência? O urbanista estadunidense Jeff Speck aponta, entre outras razões, para o fenômeno da demanda induzida, que é "quando o aumento do suprimento de rodovias reduz o custo de condução, fazendo com que mais pessoas

420 Ver SHANKAR, Sanjeev. Living Root Bridges: State of knowledge, Fundamental Research and Future Application. Texto para a conferência IABSE - Structural Engineering: Providing Solutions to Global Challenges. Genebra, 2015.

$421 \mathrm{Ibid}$. Adicionaríamos, nesse sentido, o verbo "apreciar" aos que antecedem ao substantivo "desempenho".

422 HOLIDAY TRADITION: Bumper-to-bumper traffic in Los Angeles on Tuesday night as Americans get a head start on Thanksgiving travel. $A B C$ News on Instagram, 21 nov. 2018. Disponível em: <https://www.instagram.com/p/BqbOzp-BrkM/>. Acesso em: 3 dez. 2018. 
dirijam, eliminando qualquer redução no congestionamento" (SPECK 2012: 82). À primeira vista, o impacto não intencional dessa clássica resolução de engenheiros de tráfego é semelhante ao paradoxo de Jevons, segundo o qual o aumento de eficiência de uso de um determinado recurso (que, em tese, teria que poupá-lo) promove precisamente o oposto do previsto, em virtude da ampliação simétrica da respectiva demanda. Outro estudo, mencionado por Speck, revelou que, em média, o aumento de $10 \%$ de novas pistas em vias urbanas induz o aumento imediato de $4 \%$ em quilômetros rodados de cada veículo, número que atinge $10 \%$ em poucos anos, neutralizando o plano inicial de defluxo com uma espécie de efeito rebote (op.cit.). Consideremos, à vista das estatísticas expostas, a existência de dois modelos confrontáveis de engenharia urbana: um que efetiva a expansão do suburbanismo motorizado e outro que ativa a concentração do urbanismo "caminhável" (acrescente-se aqui o emprego de tecnologias voltadas ao uso de bicicletas como meio transporte). Optaremos por explorar, por coerência temática, o segundo modelo, analisando quais medidas, técnicas e estratégias elevam os índices de caminhabilidade (walkability) em contextos urbanos.

O ponto de partida desse debate é, decerto, a intercambialidade entre estética e técnica, mútuo resumido, por exemplo, no valor que o Ministério dos Transportes da Dinamarca confere aos elementos paisagísticos e arquiteturais assentados ao longo de rodovias públicas. ${ }^{423}$ Sob esse aspecto, o desafio do "designer de estradas" (resultado da miscigenação entre um engenheiro e um paisagista, espécie de quimera do ministério) é contrabalançar os princípios do design (simplicidade, escala, equilíbrio, ritmo, contraste e unidade) com os princípios da engenharia (segurança, eficiência e economia), ${ }^{424}$ cabendo relembrar que "quando o objeto técnico é belo, é porque está inserido no mundo natural ou humano, como a realidade estética" (SIMONDON 1969: 187). Nessa perspectiva, para ser esteticamente aceitável, uma rodovia deve "refletir em sua localização e projetar um reconhecimento do ambiente natural e social existente pelo qual passa". ${ }^{425}$ Quanto

423 Isso não significa que o peso atribuído pelo governo dinamarquês aos dois termos tenha sido sempre isonômico. Há, ao que parece, uma crítica velada aos excessos de solicitude estética em detrimento dos avanços tecnológicos: "Esse conservadorismo estético ajudou a preservar a beleza original da paisagem, mas também pode obstruir a inovação. A arquitetura rodoviária deve criar novos valores estéticos baseados em condições existentes". Cf. EGEBJERG, ET AL. 2002, p. 14.

424 Ver LANPHEAR, F. Aesthetics of Highway Design. Purdue Road School, 1967. Disponível em: $<$ https://docs.lib.purdue.edu/roadschool/1967/proceedings/14>.

$425 \mathrm{lbid}$. 
ao referido modelo de urbanismo caminhável - o qual inclina-se mais para ciclovias e calçadas amplas (e por que não incluir ecopistas e ecovias, usando a curiosa terminologia encontrada em projetos de engenheiros portugueses?) - dele irradiase, em primeiro lugar, um princípio estético. Esta afirmação explica-se, em parte, pela comparação entre um mapa de "zoneamento euclidiano", no qual grandes áreas de única utilidade situam-se apartadas (configuração urbana conhecida, nos Estados Unidos, como sprawl); e um mapa representando uma área marcada por uma ocupação intensa, mas organizada (como o mapa do borough de Manhattan, por exemplo). Na analogia inspirada na história da arte feita por Jeff Speck (discípulo de Andrés Duany e Elizabeth Plater-Zyberk, fundadores do movimento Novo Urbanismo), enquanto a primeira planta assemelha-se a um trabalho de Mark Rothko, cujas telas abstratas exprimem superfícies compostas por partes espaçadas e monocromáticas, a segunda remete a uma pintura de Georges Seurat, pioneiro do movimento pontilhista. ${ }^{426} \mathrm{Em}$ suma, uma das "tecnologias" habilitadoras da cidade caminhável é o adensamento urbano, o uso intensivo do espaço, de tal modo que não se justifique o emprego imoderado de "dispositivos prostéticos" (epíteto dos automóveis, na expressão de Speck).

426 SPECK, Jeff. Palestra proferida no TEDxMidAtlantic, out. 2013. Vídeo disponível em: <https://www.ted.com/talks/jeff_speck_4_ways_to_make_a_city_more_walkable>. Acesso em: 10 dez. 2018. 
Figura 40 - Estreitamento de via pública em Oklahama City, EUA

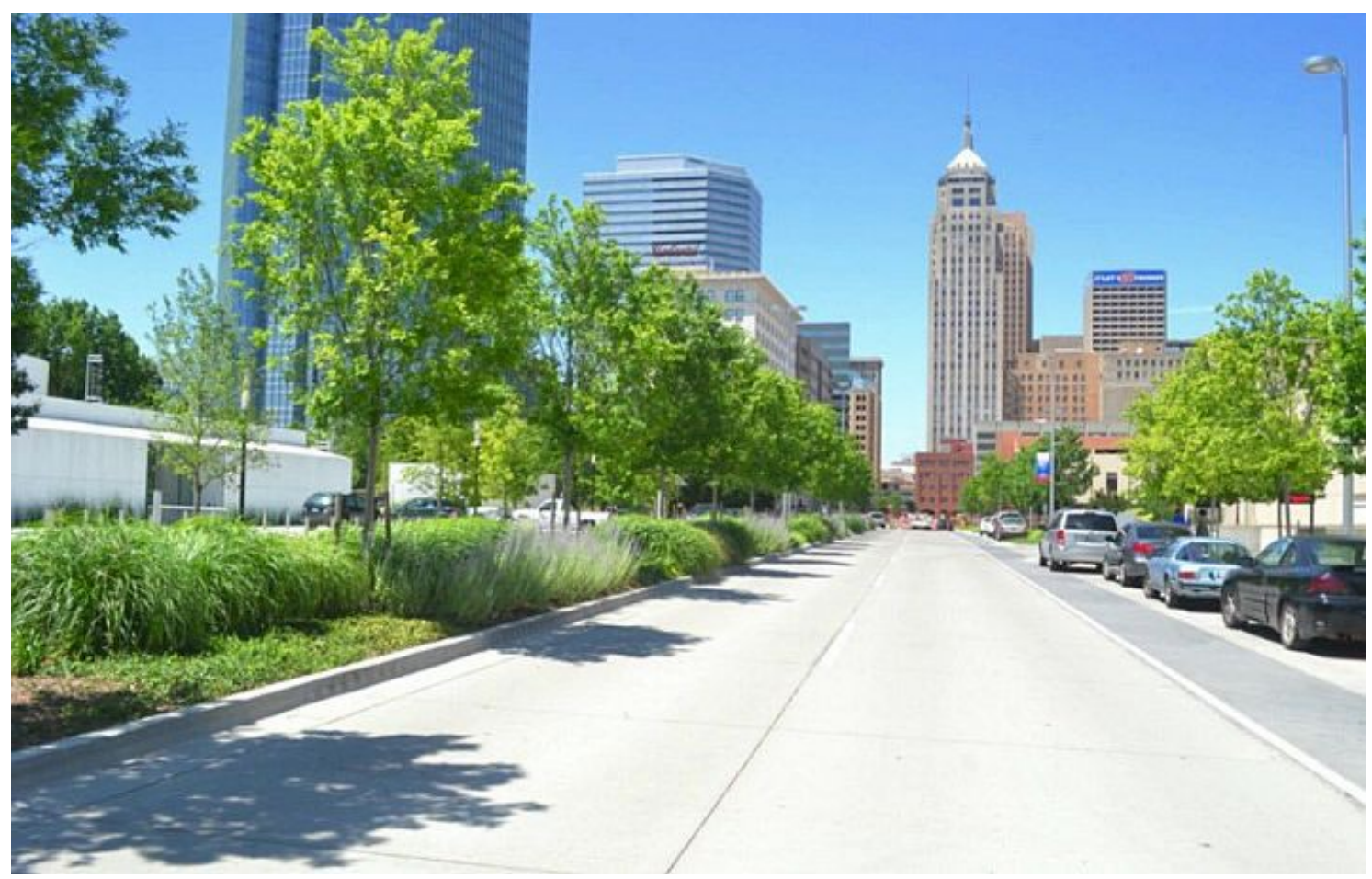

Fonte: https://www.ted.com/talks/jeff_speck_4_ways_to_make_a_city_more_walkable

Até a plena consolidação do urbanismo como disciplina de planejamento das cidades, os principais argumentos para a construção de metrópoles propícias para transeuntes eram principalmente de ordem estética e social (SPECK 2012: 37). Passou-se, então, a recorrer aos seus aspectos técnicos, donde o interesse de urbanistas pela Teoria Geral das Cidades Caminháveis, desenvolvida por Jeff Speck (op.cit.). Vista como uma série de providências para o cumprimento de sua formalização física, a teoria é resumida em quatro eixos temáticos, os quais assumem o papel de verdadeiras causas eficientes. Sucede então que, para se obter o êxito de um projeto de cidade "caminhável", o planejador deve oferecer aos 
pedestres: a) um motivo para caminhar; ${ }^{427}$ b) segurança; ${ }^{428}$ c) conforto; ${ }^{429}$ e, por fim, d) um entorno significativo e humano. ${ }^{430}$ Acaso não estariam enquadrados os quatro eixos em uma infraestrutura pedonal esteticamente ecotécnica? É certo que, por exemplo, o aspecto de segurança compõe-se de especificidades técnicas, como a determinação do raio de curvatura de esquinas visando a salvaguarda de pedestres e a implementação de neckdowns, medida que reduz a largura da via nos pontos de travessia de interseções. ${ }^{431}$ Há, de outra parte, indícios de precauções ecológicas no aspecto de conforto, principalmente tendo em conta que o plantio de árvores por toda a extensão de vias públicas impele a redução de velocidade dos automóveis, além de combater os efeitos das ilhas de calor. ${ }^{432}$ Ao compará-los com 0 "solucionismo" tecnológico de empresas como a Boring Company, do empresário Elon Musk, ${ }^{433}$ tem-se a obrigação de reconhecer a simplicidade dos eixos propostos

427 Aqui insere-se a questão habitacional e uma apologia às cidades com redes de ruas interconectadas, onde todos os locais são de fácil acesso em razão do tamanho compacto de quadras e ruas. Há de se recompensar o pedestre com uma jornada proveitosa e balanceada, no sentido de fazê-lo complementar a sua caminhada com o uso eficiente de transportes públicos. Cf. SPECK, op.cit., p. 71.

428 Talvez este seja o mais técnico dos quatro eixos, por incluir elementos de engenharia que auxiliam na proteção do pedestre, tais como "tamanho do quarteirão, largura da pista, rotatórias, direção do fluxo, sinalização, geometria da pista, e uma série de outros fatores". Cf. op.cit. Eles pertencem às chamadas técnicas de traffic calming ("moderação do tráfego"), conjunto de medidas para aumentar a segurança dos deslocamentos de pedestres e ciclistas, tais como refúgios e ilhas de mediana. Algumas delas foram aplicadas por Jeff Speck no redesenho de ruas do centro de Oklahama City, EUA (ver Fig. 40).

429 O conforto de uma caminhada depende, em última instância, do senso de espaço e orientação do pedestre. Speck fundamenta essa hipótese com a teoria da perspectiva-refúgio, articulada pelo geógrafo Jay Appleton e pelo ecologista E. P. Odum. Em suma, refere-se a um comportamento ancestral do Homo sapiens que, na fronteira da savana e da floresta, obtinha uma posição privilegiada de observação em perspectiva desobstruída das redondezas a partir de um ponto seguro, ou seja, de um local de refúgio. O urbanista Thomas Campanella, da Universidade da Carolina do Norte, observa que a "lembrança da borda da floresta pode explicar por que elementos arquitetônicos e urbanísticos que evocam este espaço - colunatas, galerias, arcadas, varandas e até alpendres são tão cativantes." Cf. cit. in op.cit. p. 213. Pode-se incluir neste rol locais que ofereçam aos pedestres arredores bem definidos, mas providos com "rotas de fuga".

430 Isso implica em sinais de humanidade intervalados no percurso da caminhada (praças, restaurantes etc.). E, mais importante: sem a presença do brutalismo e das pernósticas obras assinadas por starchitects. Op.cit., p. 237.

431 Ver PACHECO, Priscila. Quatro Modelos de Interseções que Priorizam Pedestres. TheCityFix Brasil, 1 jun. 2015. Disponível em: <http://thecityfixbrasil.com/2015/06/01/4-modelos-de-intersecoesque-priorizam-pedestres/>. Acesso em: 19 dez. 2018.

432 Ver Ilha de calor. In: Wikipédia, a enciclopédia livre. [s.l.: s.n.], 2018. Disponível em: <https://pt.wikipedia.org/w/index.php?title=llha_de_calor\&oldid=53472458>. Acesso em: 20 dez. 2018. 433 Aqui referimo-nos ao Boring Tunnel, projeto para a construção de uma rede de túneis afilados específicos para veículos elétricos autônomos munidos com um conjunto extra de rodas, disparados a velocidades de até $240 \mathrm{~km} / \mathrm{h}$. Ver MARSHALL, Aarian. Elon Musk Unveils the Boring Company's Car-Flinging Tunnel. Wired, 2018. Disponível em: <https://www.wired.com/story/elon-musk-boringcompany-car-flinging-tunnel/>. Acesso em: 20 dez. 2018. Anunciado de forma errônea como um modal de transporte público, o empreendimento de Musk vem suscitando críticas de urbanistas. Sem precisar recorrer ao argumento da demanda induzida, pode-se refutar a iniciativa da empresa 
por Jeff Speck para resolver os complexos problemas de mobilidade das metrópoles. Mas, na atual conjuntura dos cenários climáticos e tecnológicos, talvez seja preferível retroceder alguns passos para avançar outros tantos, diminuindo a celeridade do que se entende por inovação e priorizando estratégias adequadas de "retroinovação".

\subsubsection{Setor de telecomunicações}

Começamos essa reflexão sobre a infraestrutura de telecomunicações dividindo-a em duas partes: comunicação e informação (essa última associada à computação). Tal estratégia analítica, por suposição, proporciona o conhecimento sucinto de um dos conjuntos técnicos mais complexos da atualidade: a telemática que, na descrição precisa da Wikipedia, é o "conjunto de tecnologias da informação e da comunicação resultante da junção entre os recursos das telecomunicações (telefonia, satélite, cabo, fibras ópticas etc.) e da informática (computadores, periféricos, softwares e sistemas de redes)". ${ }^{434}$ As formas abrangentes de comunicação inter-humana distinguem-se de motivações meramente econômicas e laborais, incumbindo-se como o modo de expressão dos pensamentos técnico, religioso e estético (SIMONDON 1969: 201, 252-3). Assim, o arquétipo da comunicabilidade sintetiza-se no modelo many-to-many, ou a transmissão de informação originada de muitas fontes para muitos destinatários. Por isso, a solidez do consórcio entre comunicação e informação afirma-se com o advento da internet, a rede mundial de computadores. Para facilitar o processo de interconectividade entre máquinas distintas e díspares, a Organização Internacional para a Normalização definiu que sua arquitetura seria modular, uma estrutura instituída em camadas sobrepostas, originando-se da camada física e estendendo-se em progressão para outras seis. A última camada desse padrão, chamado de Interconexão de Sistemas Abertos (do inglês Open Systems Interconnection, ou

somente com números. Por exemplo, a linha 3 do metrô em Budapeste permite a circulação de um trem a cada 150 segundos nos horários de pico, com capacidade de comportar 28.200 pessoas por hora. Para replicar essa eficácia com carros de cinco lugares, o projeto Boring Tunnel precisaria fazer circular o número absurdo de três Teslas a cada 2 segundos (ou 94 carros / min). VITÉZY, Dávid (@vitdavid). 19 dez. 2018, 12:19 PM. Tweet.

434 Ver Telemática. In: Wikipédia, a enciclopédia livre. [s.l.: s.n.], 2017. Disponível em: <https://pt. wikipedia.org/w/index.php?title=Telem\%C3\%A1tica\&oldid=49956433>. Acesso em: 2 out. 2018. 
OSI), corresponde às aplicações, ou seja, ao que é visto e interagido por humanos; em suma, é o domínio das páginas e aplicativos. A nos atermos aos elementos da estética ecotécnica nessa camada específica, excetuaremos como exemplo os 500.000 sites mais populares, os quais comportam, segundo diferentes métodos de medição, tamanhos médios de até $2.9 \mathrm{MB},{ }^{435}$ sendo responsáveis pelo consumo de $10 \%$ da produção global de eletricidade. ${ }^{436}$ A personificação de uma estética adaptada aos novos tempos manifesta-se, portanto, no projeto da revista Lowtech, ${ }^{437}$ cuja página estática tem $0.77 \mathrm{MB}$ e está hospedada em um servidor em Barcelona alimentado por energia solar. Apesar da relevância imposta por essa última camada, a que iremos nos dedicar adiante é a que comporta uma constituição material e concreta, determinando as especificações físicas dos dispositivos de comunicação e das redes em si.

\subsubsection{Computação natural}

Em editorial para uma edição de revista acadêmica sobre o futuro da computação, Andrew Adamatzky, professor do departamento de ciência da computação da Universidade do Oeste da Inglaterra, em Bristol, escreve: "[Nesta edição] não tentamos prever o futuro, mas contemplar o papel da computação em tecnologias futuras, imaginando como as coisas poderão acontecer. O futuro da computação é polimorfo e evasivo". ${ }^{438}$ Dentro desse espírito, identificamos a intencionalidade fenomenológica e construtivista da declaração, a ponto de revertemos a sua qualidade especulativa em uma proposta estética no presente. Assim, propomos descobrir uma realidade alternativa na qual o paradigma da Inteligência Artificial, que em vigor constitui um marco histórico da tecnologia contemporânea, seja substituída por outro, o da Computação Natural, grupo de estratégias computacionais acopladas ao mundo natural. Sob esse aspecto, a

435 Cf. Page Weight. Disponível em: <https://httparchive.org/reports/page-weight>. Acesso em: 3 out. 2018.

436 JONES, Vera P. Internet Uses More Than $10 \%$ of the World's Electricity. Inside Scandinavian Buseiness, 14. Mar. 2019. Disponível em: <https://www.insidescandinavianbusiness.com/article.php? id=356>. Acesso em: 29 mai. 2019.

437 Conteúdos da publicação são parte integrante de nossa bibliografia. Ver $L O W \leftarrow T E C H$ MAGAZINE. Disponível em: <https://solar.lowtechmagazine.com>. Acesso em: 3 out. 2018.

438 ADAMATZKY, Andrew. Editorial: Computing 2065. International Journal of Unconventional Computing, Vol. 13, pp. 185-86. (grifo nosso). 
computação LoNo (low-power/no-power, ou baixa-potência/sem-energia) adequa-se precisamente aos dois adjetivos mencionados por Adamatzky, sobretudo por acolher dispositivos lógicos que não demandam grandes quantidades de eletricidade (ou mesmo nenhuma), tais como dispositivos de controle de fluídos, moléculas, reagentes químicos, partículas, macromoléculas (proteínas, DNA, RNA ou células), e até mesmo plantas e animais. Consideremos, primeiramente, a "fluônica", neologismo usado pelo cientista da computação estadunidense Charles Reid para descrever a pesquisa em computadores que usam fluidos, em vez de eletricidade, para operar circuitos e executar operações lógicas. ${ }^{439}$ Desde muito cedo, a ciência da computação já voltava a sua atenção aos computadores hidráulicos. ${ }^{440}$ Qual é o mecanismo de seu funcionamento? Esbocemos assim: "Suponhamos que, em vez de uma corrente de elétrons, usássemos uma corrente de líquido ... e tentássemos realizar essas operações mecanicamente, ao invés de eletricamente. No lugar da grade [elétrica de controle], os jatos de fluido, precisamente controlados e direcionados para o fluxo principal a partir das laterais, modulam ou desviam o fluxo. Assim, pode-se conseguir uma amplificação ou 'ligar' e 'desligar' o fluxo". ${ }^{441}$ Essa é a exata descrição de um transistor, componente eletrônico usado principalmente como amplificador e interruptor de sinais elétricos; neste caso, porém, os processos não ocorrem em uma placa de circuito impresso, mas em microcanais quimicamente gravados em plástico Dycril por uma técnica chamada Optiform. ${ }^{442}$

O próximo ponto de inflexão corresponde às fontes que alimentam esses sistemas. No caso das portas lógicas hidráulicas, entende-se por "fonte de energia" um forte jato de fluido bombeado através da entrada em uma das extremidades dos microcanais. Segundo Reid, "a computação fluônica requer uma força motriz

439 Ver REID, Charles. LoNo Computing. Arquivo digital pessoal disponível em: <https://charlesreid1.blue/wiki/Lono_Computing>. Ver em especial a apresentação em PowerPoint: Low-Power/No-Power \#LoNo Computing - Concepts and Conceptualizations. Acesso em: 24 ago. 2018.

440 Esse é o contexto, por exemplo, da computação analógica e do computador hidráulico do russo Vladimir Lukyanov, a primeira máquina computacional do mundo criada para resolver equações diferenciais parciais. Em 1936, tinha como finalidade resolver o problema das rachaduras no concreto, correlacionado aos regimes de temperatura, composição dos materiais e diversas condições externas. Ver SOLOVYEVA, O. Máquinas Computadoras Movidas a Água. Ciência \& Vida, n.4, 2000 (conteúdo em russo). Disponível em: <http://www.nkj.ru/archive/articles/7033/>. Acesso em: 4 out. 2018.

441 Ver ANGRIST, Stanley W. Fluid Control Devices. Scientific American. Dezembro, 1964, pp. 808.

442 Ibid. 
mecânica (em oposição a uma força motriz potencial elétrica, como a voltagem), que pode assumir várias formas: energia de pressão e volume (compressão), energia cinética (movimento), energia interna (reações e calor) ou energia potencial (gravidade)". ${ }^{443}$ Talvez essa seja a própria representação do que convencionalmente chamamos de estética ecotécnica: redobrar técnica e natureza a partir de uma intensificação não-material do padrão energético, sem furtar-se às leis, ritmos e operações da natureza. Reid nos oferece, por exemplo, uma ordenação tecnológica na qual "montanhas, rios, barragens, lagos e torres artificiais propiciam enorme energia potencial gravitacional, da mesma forma que os supercomputadores têm fontes de energia que geram enormes tensões, permitindo que eles realizem cálculos gigantescos". ${ }^{444}$ A atração gravitacional emerge, assim, como uma fornecedora alternativa de energia, colocando-se no lugar das tradicionais fontes de cargas elétricas, alimentando "computadores fluônicos" com forças extraídas de "poderosas torrentes de neve derretida no topo de uma montanha, ou [d]a água da chuva capturada e armazenada nos telhados de arranha-céus". ${ }^{445}$ É aqui que a força da gravidade produz um determinado efeito de cascata na corrente aquosa que, ao trespassar por componentes microfluídicos, logra realizar "operações matemáticas". ${ }^{446} \mathrm{Na}$ visão de Reid, no lugar das fazendas de servidores das quatro grandes empresas representantes do "capitalismo de plataformas", ${ }^{447}$ teríamos assim um conjunto técnico constituído por uma rede de "supercomputadores gravitacionais maciços". ${ }^{448}$ Assim como o teórico estadunidense Jeremy Rifkin (STIEGLER 2013: 92), Reid tem o mérito de postular que problemas atuais de geração de energia nunca são distintos de questões associadas às redes de comunicação e informação, ${ }^{449}$ sobretudo quando o "mundo geográfico e o mundo dos objetos técnicos que já existem são postos em relação em uma concretização orgânica, definida por sua função relacional" (SIMONDON 1969: 56 ). ${ }^{450}$

443 REID, op.cit.

444 Ibid.

$445 \mathrm{lbid}$.

446 Ibid.

447 Expressão criada por Nick Srnicek para se referir às quatro grandes empresas de tecnologia que atualmente dominam a internet: Google, Apple, Facebook e Amazon. Ver Platform Capitalism - P2P Foundation. Disponível em: <https://wiki.p2pfoundation.net/Platform_Capitalism>. Acesso em: 12 out. 2018.

448 REID, op.cit.

449 Ou "sistemas hipomnéticos", de acordo com o jargão usado por Bernard Stiegler.

450 Excerto no original: C'est de façon semblable que le monde géographique et le monde des objets 
Para posicionar um sistema de computação natural na área de telecomunicações para além dos modelos ortodoxos de exploração do potencial microeletrônico da matéria, é preciso reavaliar algumas experiências anteriores que não merecem ser olvidadas. Na década de 1960, por exemplo, o ciberneticista britânico Stafford Beer realizou uma série de testes em lagoas de Derbyshire e Surrey propondo-se a modelar uma "máquina ultraestável", nos moldes do homeostato descrito por William Ross Ashby em 1948, a saber, um aparato capaz de adaptar-se às inconstâncias do meio circundado, um sistema de auto-organização dotado de circuitos não previamente projetados. No diagrama, ${ }^{451}$ vê-se um sistema de controle ligado ao "módulo" do mundo geográfico, território propenso à uma infinidade de situações e variações, daí a necessidade de "restringi-lo" ou "granulálo". ${ }^{452}$ A "mídia" computacional é o próprio nicho ecológico no qual seria possível sobrepor funções cibernéticas, como se fossem sinais em uma onda portadora de informação. É de fato um computador biológico "composto de organismos simples: colônias de Daphnia, um crustáceo de água doce ([Gordon] Pask considerou o Aedes aegypti, a larva do mosquito da febre amarela), de Euglena protozoa e todo o ecossistema da lagoa" (PICKERING 2010: 233). Beer: "Muitos experimentos foram feitos com as pulgas de água [Daphnia]. Limalhas de ferro foram colocadas sobre folhas mortas no tanque, sendo por elas ingeridas o suficiente a ponto de reagirem a um determinado campo magnético". ${ }^{453}$ Além disso, as criaturas da colonia, operando juntas em uma zona localizada entre a emissão de luz e o fotorreceptor, funcionam como um computador de Reação-Difusão no qual "intensidades luminosas podem converter repulsão em atração", passando-se por um sistema "quasi-químico de precipitação, em que 0 é um produto e 1 é um reagente" (ADAMATZKY 2012: 22). Nota-se que os seres biológicos de Beer, quando estimulados ou inibidos, alteram seus estados, de forma análoga à dinâmica espaçotemporal de excitação que ocorre em uma reação oscilante do tipo Belousov-Zhabotinsky.

techniques déjà existants sont mis en rapport dans une concrétisation qui est organique, et qui se definit par sa fonction relationnelle. (tradução nossa).

451 Cf. BEER, Stafford. A Progress Note on Research Into a Cybernetic Analogue of Fabric. In: HARNDEN \& LEONARD 1994, p. 26.

452 Para reduzir a diferença entre os dois sistemas, Beer ilustra a discriminação de variações relevantes, a possibilidade de poder transpor comportamentos de um sistema para o outro, a sua capacidade de aproximar-se do equilíbrio dinâmico e o grau de riqueza da interação em seu conjunto. 453 Cf. BEER op.cit., p. 29. 
Figura 41 - Eletrodos ligados a um cacto do gênero Schlumbergera em experimento de implementação de portas lógicas em um fitocomputador

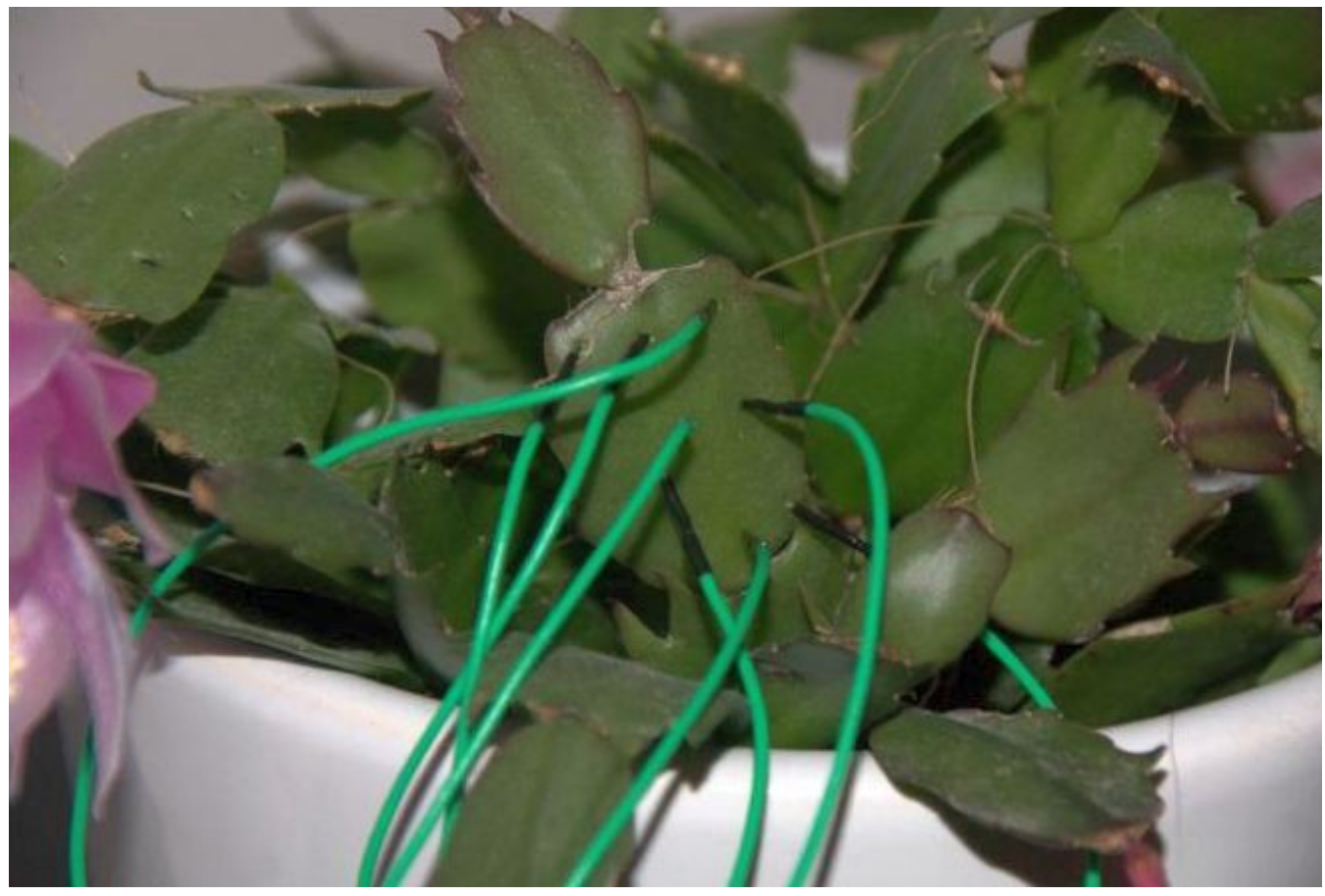

Fonte: STEPNEY ET AL., 2018

O cientista Andrew Adamatzky é um entusiasta de formas não convencionais de computação, e um dos que insistem no fato de que todo o Universo, do infinitamente pequeno ao infinitamente grande, é governado por informação e computação. ${ }^{454}$ Parece-nos essencial, particularmente sob a ótica de uma estética ecotécnica, a sua concepção de fitocomputação, ou seja, a possibilidade de modificar as "propriedades biofísicas das plantas para torná-las dispositivos eletrônicos orgânicos", ou mesmo "persuadir" vegetais a resolver tarefas em domínios que lhes sejam homomórficos, admitindo a existência de um "sistema de posicionamento" na região apical da raiz, cuja tarefa é resolver problemas semelhantes aos propostos pela teoria dos grafos, como descobrir o menor caminho entre dois pontos, evitando colisões. ${ }^{455}$ Nesse modelo científico que procura descrever a relação empírica de fenômenos biológicos e físicos verificou-se um tipo de padrão de comportamento exploratório das raízes, o qual é "determinado pelo ambiente, especificamente a qualidade do nutriente e dureza do substrato, secura, 454 Cf. AKL, Selim G. Information and Computation: The Essence of It All. International Journal of Unconventional Computing, Vol. 13, No. 3, 2017, pp. 187-194.

455 ADAMATZKY, Andrew; HARDING, Simon; EROKHIN, Victor; et al. Computers from Plants We Never Made: Speculations. In: STEPNEY ET AL., 2018. 
etc. Além disso, as raízes são sensíveis à iluminação e mostram um comportamento de fototropismo negativo quando expostas à luz, campos elétricos, gradientes de temperatura, diversas moléculas voláteis e, portanto, permitem a entrada de informações paralelas e não-destrutivas". ${ }^{456}$ Ainda segundo Adamatzky, em fitocomputadores morfológicos, "os dados são representados pela configuração inicial das raízes e configurações de fontes de atrativos e repelentes". ${ }^{457}$ É possível, portanto, "induzir" o comportamento das raízes através de elementos químicos, do mesmo modo que os fragmentos de onda de osciladores químicos e os crustáceos de Beer, em uma analogia advinda do fototropismo botânico. Questiona-se, doravante, quais tarefas o fitocomputador solucionará em uma situação concreta. Como vimos, as raízes das plantas, em princípio, conseguem resolver um dos problemas clássicos da teoria dos grafos, chamado de árvore de extensão mínima. Admita-se como hipótese, por exemplo, a implantação em uma determinada área geográfica de uma rede de comunicação, na qual todos os nós devem ser conectados pelas arestas mais curtas possíveis, ou seja, as que possuem o menor tributo numérico (no linguajar da ciência da computação: o menor peso). Tal máquina biológica, por meio de um algoritmo de Kruskal, seria assim capaz de encontrar, em meio a uma "floresta" de opções, uma "árvore" particular na qual a totalidade dos tributos, dada pela soma das extensões das arestas, é mínima.

Chegamos ao ponto onde é preciso retomar, ao menos de passagem, algumas implicações estéticas dos exemplos. Se supormos que o logos computacional é de ordem inteligível - e não sensível - e se o fenômeno computacional manifesta-se no centro da relação dialética entre o abstrato e o concreto, isto é, entre os procedimentos simbólicos e os circuitos eletrônicos, ${ }^{458} \mathrm{em}$ que parte deste quadro geral situar-se-ia o elemento sensório? Em nosso modelo construtivista-fenomenológico, primeiro atribui-se uma maior prioridade à remoção das camadas de abstração daquela relação e, posteriormente, direciona-se a intencionalidade cognitiva do sujeito aos caracteres de um objeto material ao sabor de diversas contingências. Não existe nenhuma oposição entre os dois termos, 
como no modelo de "pré-programação determinista de probabilidades", ${ }^{459}$ identificado na arquitetura computacional de von Neumann. Não subscrevemos que o sensível, consoante Stiegler na esteira de Aristóteles, "seja oposto ao inteligível [pois] a sensibilidade é o regime de individuação específico do movimento da alma sensível" (STIEGLER 2013: 125).

Para seguir adiante em direção a uma realidade de computação natural não convencional, é válido descrever brevemente uma experiência de treinamento de materiais do tipo evolution-in-materio (EIM), na qual um cacto é transformado inteiramente em um circuito eletrônico, sendo o substituto de componentes tradicionais dos computadores, como transistores, resistores e capacitores (ver Fig. 41). Ao conectar oito eletrodos às saídas digitais de uma placa Mecobo e inseri-los em folhas de Schlumbergera (tipo de cacto brasileiro conhecido como "cacto de Natal"), Adamatzky notou que, ao enviar inputs por intermédio de um resistor limitador de corrente, obtinha como resposta da planta modulações locais capazes de produzir portas lógicas booleanas (ou seja, com valores 0 e 1). ${ }^{460}$ Trata-se, acreditamos, de um fitocomputador com destino ao estado da arte. Em virtude dos limites da atual matriz energética, pode-se perguntar, a pretexto de conclusão, se a computação natural seria uma opção viável no atual estágio tecnológico. Talvez, se desvinculamo-la das modalidades correntes de computação - por ex. velocidade, escala e universalidade - e inserimo-la na categoria das tecnologias transformacionais (STIEGLER op.cit.: 104), contudo sem equivocá-la com biotecnologia e nanotecnologia, áreas que já foram absorvidas pelo processo de hiperindustrialização, protagonista do colapso ambiental em curso.

\subsubsection{Antenas}

Nessa altura, introduzimos a segunda parte que integra o sistema de telecomunicações, composta por dispositivos para irradiar ou receber ondas de rádio, segundo a descrição do Instituto de Engenheiros Eletricistas e Eletrônicos, ${ }^{461}$

459 Cf. FAZI, M. Beatrice. Incomputable Aesthetics: Open Axioms of Contingency. Computational Culture: a journal of software studies, 15 jan. 2016. Disponível em: $<$ http://computationalculture.net/article/incomputable-aesthetics-open-axioms-of-contingency $>$. Acesso em: 17 out. 2018.

460 ADAMATZKY ET AL., op.cit.

461 IEEE Standard for Definitions of Terms for Antennas. IEEE Std 145-2013 (Revision of IEEE Std 
estando à frente nessa categoria as torres e antenas de rádio, as mais conspícuas de todas as estruturas feitas pelo homem, na palavra do estudioso de infraestruturas Brian Hayes (2006). O autor se vale como exemplo a Sutro Tower, torre de antena de TV e rádio de 295 metros, erguida em 1973 na Califórnia. É possível que a colossal criatura de três cabeças e tripés listrados de vermelho e branco, espécie de Cérbero radiotransmissor que guarda a entrada da baía de São Francisco, não merecesse o mesmo tratamento estético que a "floresta de metal" das torres transmissoras de Villebon, em virtude exatamente de sua excessiva conspicuidade. A tecno-estética evoca, recordemos aqui, uma distinção (ou a diferença que faz a diferença) entre a figura e o fundo, funda-se em um efeito equilibrado de contrastes de planos, mesmo que o fundo da natureza seja coberto por procuração por uma outra figura técnica, como no caso daquelas embarcações da Marinha equipadas com radares: "a antena do radar é bela quando vista do convés do navio, governando a superestrutura mais alta; colocado no chão, não é mais do que um chifre deveras grosso, montado em um pivô; era belo como a conclusão estrutural e funcional daquele conjunto que é o navio, mas não é belo em si e sem referência a um universo" (SIMONDON 1968: 185-186). ${ }^{462}$ Sucede assim que o projeto da torre de telecomunicações de Salerno, assinado pelo arquiteto Suleiman Alhadidi, pode cumprir com a função de referente de áreas adjacentes, uma vez que sua estrutura de arcos empilhados fornecerá diferentes impressões visuais de diferentes pontos geográficos da baía de Bellaria. Contudo, os dois exemplos mencionados acima amoldam-se ao eidos tecnológico e infraestrutural da contemporaneidade, ou seja, à uma imagem estabilizada por uma cultura técnica dominante (STIEGLER 2009: 149162). ${ }^{463}$ Acomodaremos a nossa redução e nossa intencionalidade cognitiva aos projetos de telecomunicação comunitária, exercitando contra o eidos estável uma variação imaginária que inventa objetos tecnologicamente adequados, aspirando projetá-los como imagens metaestáveis em nossas consciências.

145-1993), 2014, p. $1-50$.

462 Excerto no original: L'antenne du radar est belle quand elle est vue du pont du navire, surmontant la plus haute superstructure; posée au sol, elle n'est plus qu'un cornet assez grossier, monté sur un pivot; elle étrait belle comme achèvement structural et fonctionnel de cet ensemble qu'est le navire, mais elle n'est pas belle en elle-même et sans référence à un univers. (tradução nossa).

463 Bernard Stiegler associa ao eidos tecnológico da modernidade as tecnologias transformacionais, em especial a biotecnologia. Induzimos, a partir de seu argumento, que haveria outros eidos. 
Figura 42 - Antena Skywire Loop

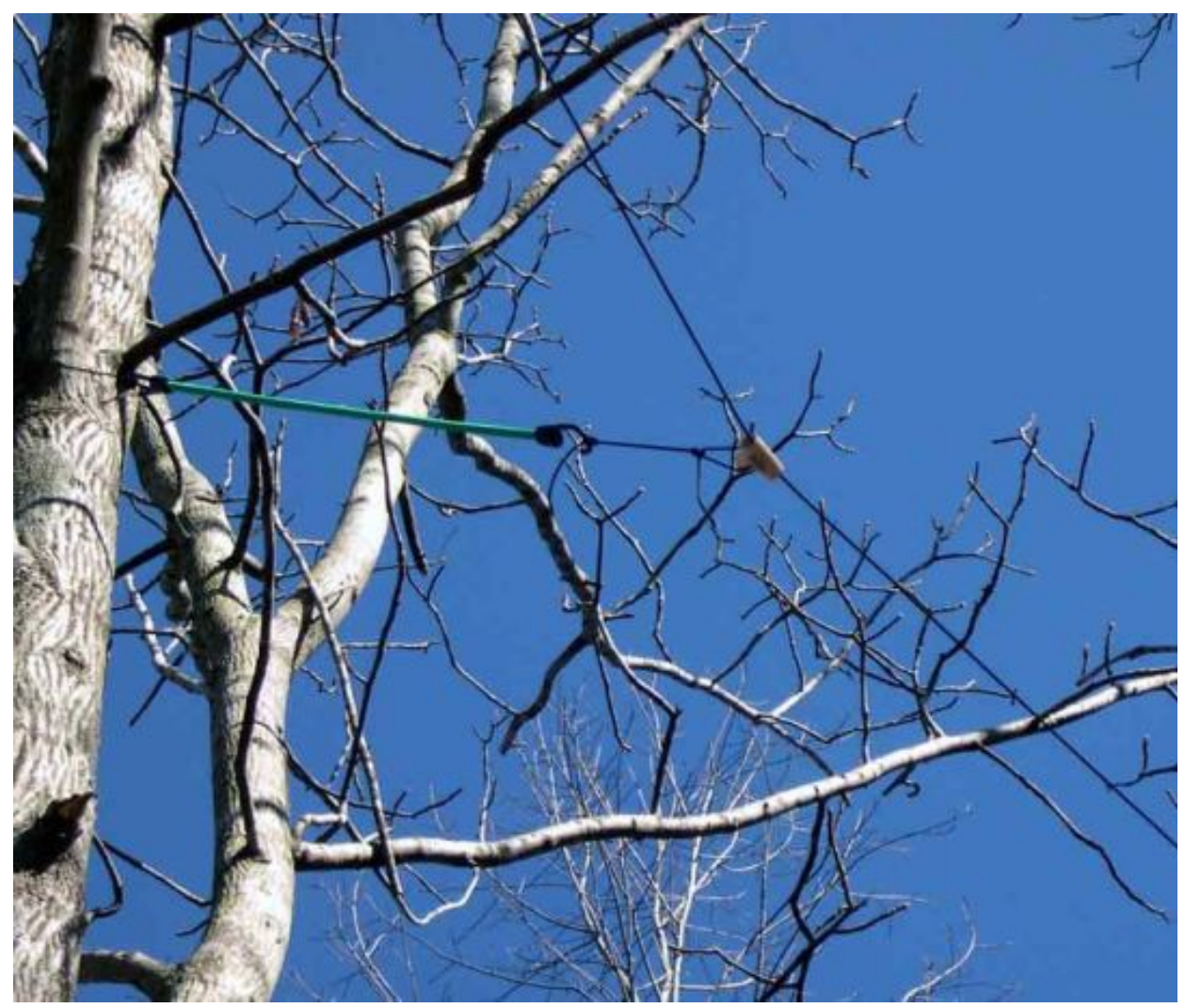

Fonte: $h$ ttp://www.donkeith.com/n4kc/article.php? $p=12$

Quando dizemos "projetos de telecomunicação comunitária", subentende-se a ideia de decentralização, efetivada nas chamadas redes ad hoc, que são redes destituídas de um "calcanhar de Aquiles", ou seja, de um ponto de acesso especial em direção ao qual todas as comunicações convergem e desde o qual elas são difundidas aos nós. Além disso, os projetos comunitários envolvem dois fatores: a interligação de múltiplas redes físicas (internetworking), tendo por referência os princípios arquiteturais da internet, consubstanciados na padronização de protocolos de encaminhamento de dados; e o consumo energético proporcionalmente pequeno, recordando, com o auxílio de Simondon, que, diferentemente da qualidade do rendimento termodinâmico, as "características de desempenho dos canais de informação não tem a ver com a energia e, muitas vezes, o bom desempenho informacional caminha de mãos dadas com o baixo desempenho energético" (SIMONDON 1969: 132). ${ }^{464}$ Retomemos a questão das antenas de uma rede ad hoc

464 Excerto no original: Ces caractéristiques de rendement des canaux d'information ne sont pas des caractéristiques énergétiques, et très souvent un bon rendement en information va de pair avec un mauvais rendement énergétique ... (tradução nossa). 
sem fio, portanto. Primeiro, pode-se implementá-las com o método do rádio pacote (packet radio), que se vale do protocolo AX.25, o qual permite a troca de dados entre os nós a 9600 bits/seg. Ao invés de antenas dipolo de meia onda, os técnicos recomendam ${ }^{465}$ o uso da antena de loop de onda completa (full wave), uma antena multibanda de longo alcance em forma de losango, construída a partir de um cabo coaxial enlaçado em copas de árvores por cordas de nylon (ver Fig. 41). Essa ordenação nasce da arte aprimorada pela comunidade radioamadora, dedicada a troca de textos e pequenos arquivos em uma rede real time ${ }^{466}$ capaz de resistir a furacões e outros desastres causados por mudanças climáticas. ${ }^{467}$ Tem-se aqui, portanto, o modelo de um sistema de telecomunicações com elevada capacidade de auto-organização, constituído por antenas skywire conectadas (supostamente) a fitocomputadores e computadores fluônicos programados para calcular o roteamento de pacotes e enviar informações. Quanto à conectividade ecológica inerente a tal sistema, aludimos que o ciberneticista britânico Gordon Pask estabeleceu uma analogia entre redes sociológicas e redes naturais (por ex. uma rede micorrízica), ${ }^{468}$ asseverando-nos de que, "se um observador deseja usar quaisquer potencialidades auto-organizadoras que a rede possa ter, então ele deve olhar para ela como se fosse um praticante de História Natural". 469 O modelo, por enquanto, é um experimento mental, mas um que pode prevalecer na linhagem das tecnologias transformacionais.

465 Cf. KEITH, Don. N4KC's Skywire Horizontal Loop Antenna. Disponível em: <http://www.donkeith.com/n4kc/article.php?p=12>. Acesso em: 23 out. 2018.

466 Cf. Radioamador: O Rádio Pacote. Teleco, [s.d.]. Disponível em: <http://www.teleco.com.br/tutoriais/tutorialrede/pagina_3.asp>. Acesso em: 23 out. 2018.

467 Ver PEIRANO, Marta. Radioaficionados al Rescate: Tecnologías del Siglo XIX que Sobreviven a Huracanes y a Trump. Eldiario.es, 28 set. 2017. Disponível em: $<$ http://www.eldiario.es/internacional/Radioaficionados-tecnologias-XIX-catastrofes-

XXI_0_691181094.html>. Acesso em: 29 set. 2017.

468 Rédes de micélios fúngicos micorrízicos que conectam duas ou mais plantas, reconhecidos como mediadores de interações florestais através de seus efeitos na sobrevivência, crescimento e habilidade competitiva das árvores. É chamada, coloquialmente, de Wood Wide Web. Ver a aplicação da teoria de redes na agência entre a rede micorriza em uma floresta de Pseudotsuga menziesii (espécie de conífera nativa do oeste da América do Norte) em BEILER, Kevin J.; DURALL, Daniel M.; SIMARD, Suzanne W.; et al. Architecture of the Wood-wide Web: Rhizopogon spp. Genets Link Multiple Douglas-fir Cohorts. New Phytologist, v. 185, n. 2, 2010, pp. 543-53.

469 Cf. PASK, Gordon. The Natural History of Networks. In: YOVITS \& CAMERON 1960, pp. $232-$ 263. 


\subsubsection{Setor energético}

\subsubsection{Sistemas micro-hídricos}

Nos anais do setor energético, não há dúvida de que os países da antiga União Soviética tinham uma profunda admiração pelas usinas hidrelétricas, conferindo-lhes a dimensão de símbolo máximo do progresso civilizatório. Pode-se confirmar essa tese em diversas expressões cinematográficas do realismo soviético, ainda que houvesse tantas voltadas em examinar os conflitos entre modernidade e tradição, representados em atos de resistência às megabarragens. ${ }^{470}$ Teríamos bons motivos para citar Ivan, de 1932, dirigido por Alexander Dovzhenko, mas decidimonos pela "ode ao mar" (Poema o more, 1958) realizado por sua esposa Yuliva Solntseva, película sobre a construção de uma usina hidrelétrica na bacia do rio Dnieper, na Ucrânia. O "mar" do título é, em verdade, o reservatório de Kakhovka, cuja imensidão chega a suscitar a metáfora pelágica. Essa peça de propaganda sobre as virtudes do industrialismo soviético fabula a possibilidade de se realmente "construir" um mar, mesmo que à custa do morejar de camponeses, os quais devem ser realocados antes que suas aldeias fiquem submersas pela brutal inundação. É impossível deixar de recordar aqui antigos mitos, como o do dilúvio que, se no "Antigo Testamento era um ato da abominação de Deus, nesta obra é a realização gloriosa e milagrosa do gênio humano coletivo". ${ }^{471}$ A certa altura da narrativa, ouvese o engenheiro Grekov dizer que, por se comportar como "seres anárquicos", os rios devem ser controlados por diques e usinas, submetendo assim physis à techné, a essência aos acidentes. A despeito de sua territorialização, o ethos desenvolvimentista consolidado em centrais hidroelétricas expande-se para outras culturas e espaços-tempos. Tome-se o caso da usina de Belo Monte, na bacia do Rio Xingu. Segundo Márcio Santilli, sócio fundador do Instituto Socioambiental (ISA), os maiores afetados pelo polêmico empreendimento - pequenos agricultores, ribeirinhos e índios - são exatamente os maiores excluídos dos supostos benefícios desse tipo de projeto hiperbólico, pois para o governo e empresas do setor elétrico,

470 Ver em especial Proshchanie (1983), dirigido por Elem Kliniv.

471 Ver KARTASHOV, Andrei. Of Sun and Rivers: Yuliya Solntseva's Ukrainian Trilogy. Notebook | MUBI, 25 ago. 2017. Disponível em: <https://mubi.com/notebook/posts/of-sun-and-rivers-yuliyasolntseva-s-ukrainian-trilogy>. Acesso em: 4 set. 2018. 
"seria muito alto o custo do rebaixamento da alta tensão para que a energia gerada pela usina pudesse ser usufruída pelas comunidades locais", obrigando-as ao uso de geradores a diesel. ${ }^{472}$ É trágico que hoje tem-se a urgência de soluções energéticas desse porte, quando respostas menos superlativas e de baixo impacto ambiental, direcionadas para o consumo líquido de energia nulo (net zero), se aprimoram a cada dia, tanto técnica como financeiramente.

Em oposição à matriz corrente é preciso que entrem em cena engenheiros visionários e artistas, como o inglês Nick Laessing, que participou em 2016 de uma exposição na Kunsthalle Wien, ${ }^{473}$ Áustria, com o protótipo de um gerador de energia livre, espécie de máquina de movimento perpétuo que produz mais energia que consome para funcionar, patenteado nos anos 1980 pelo inventor estadunidense John Bedini. Apesar da simplicidade de sua constituição - um ímã, algumas bobinas de cobre e um prego - a física envolvida no protótipo ainda não é admitida por engenheiros que se dizem sérios, sendo destinada aos anais das pseudociência e da economia geral de Georges Bataille, para quem a queima excedente de energia em uma dada sociedade deve resultar na democratização da luxúria, e não em guerras genocidas. ${ }^{474} \mathrm{Em}$ retrospecto, aprende-se a glória das menores escalas. Por exemplo, no curso do rio Adda, afluente do rio Pó, sob o rochedo que escora o Castelo de Visconteo, em Trezzo sull'Adda, encontra-se a miniusina hidrelétrica de Taccani, projetada no final do século 19 pelo arquiteto Gaetano Moretti e construída com as pedras típicas do local, conhecidas como ceppo, fazendo com que o conjunto se integre perfeitamente ao cenário circundante, em ressonância aos princípios de uma autêntica estética ecotécnica. A usina de Taccani contrasta com os grandes empreendimentos atuais, todos aglutinados em torno de uma ultrapassada filosofia da energia, ${ }^{475}$ a da geração centralizada, em oposição direta à autogeração, ou geração distribuída e descentralizada, nos moldes da antiga usina italiana (e das energias renováveis). Não se trata aqui de recorrer ao modelo das pequenas centrais hidrelétricas $(\mathrm{PCH})$ que, segundo definição da Agência Nacional de Energia

472 Ver SANTILLI, Márcio. Revolução na Matriz Ética do Setor Elétrico. ISA - Instituto Socioambiental, 18 fev. 2016. Disponível em: <https://www.socioambiental.org/pt-br/blog/blog-doppds/revolucao-na-matriz-etica-do-setor-eletrico>. Acesso em: 23 fev. 2016.

473 KUNSTHALLE WIEN. Nick Laessing - The Promise of Total Automation. Viena, 2016. Disponível em: <https://www.youtube.com/watch?v=jkOdhOWYD9c>. Acesso em: 20 fev. 2017.

474 Ver GEERTS, Robert-Jan; GREMMEN, Bart; JACOBS, Josette; et al. Towards a Philosophy of Energy. Scientiae Studia, v.12, n.SPE, 2014, pp. 105-127.

475 Idem., p. 113. 
Elétrica (ANEEL), são "usinas de pequeno porte com capacidade instalada maior do que $3 \mathrm{MW}$ e no máximo $30 \mathrm{MW".}{ }^{476}$ No modelo ecotécnico, enaltecemos, ante a experiência de Taccani, produções domésticas em torno de $700 \mathrm{~W}$, efetuadas por sistemas micro-hídricos que podem ser interligados - ou não - à rede elétrica oficial. ${ }^{477}$ Estima-se ${ }^{478}$ que a turbina de fluxo cruzado Banki-Mitchell seja a mais adequada para regimes de vazões variáveis, o que nos permite induzir que seu existir técnico seja marcado por um processo adaptativo, ${ }^{479}$ levando-nos com isso a indagar se a relação do artefato com seu "ambiente associado" seja análoga à da turbina de Guimbal, conquanto em menor escala e sem a presença do reservatório de óleo.

\subsubsection{Vela solar}

A ideia de que os raios solares são passíveis de domesticação para fins energéticos não é nova e pode ser retraçada nas visões de utopistas como John Adolphus Etlzler, imigrante alemão que, no século 19, propôs o estabelecimento de comunidades tecnocráticas em regiões do continente americano, todas elas alimentadas energeticamente através do "vapor gerado pelo calor do sol, por meio de refletores concentrados, ou espelhos convexos de um artefato simples" (ETZLER 1836: 208). Outros Ihe seguiram os passos. Augustin Mouchot, e seu assistente Abel Pifre, encantaram os visitantes da Exposição Universal de 1878 com uma máquina de gelo movida a energia solar. ${ }^{480} \mathrm{Na}$ época, o desafio desse modal se colocava não em sua geração, mas em como conservá-lo, problema que se estende aos dias de

476 Mesmo porque não existe diferença, em termos de impacto ambiental, entre megarrepresas e múltiplas represas pequenas, devido ao efeito acumulativo das últimas. Ver SALISBURY, Claire. Pequenas Hidrelétricas são um Grande Problema Global Negligenciado pela Ciência e pela Política. Mongabay, 13 abr. 2018 Disponível em: <https://pt.mongabay.com/2018/04/pequenashidreletricas-sao-um-grande-problema-global-negligenciado-pela-ciencia-pela-politica/>. Acesso em: 20 fev. 2019.

477 Ver DUARTE, Samuel Gouveia. Moinhos de Ponte de Lima: Topologias de Interface, 2011. Dissertação (Mestrado em Engenharia Eletrônica Industrial e Computadores) - Universidade do Minho, Braga, Portugal.

478 Ver JÚNIOR, Antonio Gonçalves de Mello. A Turbina de Fluxo Cruzado (Michell-Banki) como Opção para Centrais Hidráulicas de Pequeno Porte, 2000. Dissertação (Mestrado em Energia) Universidade de São Paulo.

479 Ver LOPES, Wendell Evangelista Soares. Gilbert Simondon e uma Filosofia Biológica da Técnica. Scientiae Studia, v. 13, n. 2, p. 307-334, 2015.

480 Ver COLLINS, Paul. The Beautiful Possibility. CABINET, Primavera 2002. Disponível em: $<$ http://cabinetmagazine.org/issues/6/beautifulpossibility.php>. Acesso em: 21 set. 2018. 
hoje sob a expressão "energia intermitente", ou seja, a impossibilidade de se fornecê-la continuamente devido a fatores não controláveis (noite, dias nublados, etc.). A motivação por detrás das primeiras experiências com energia solar era a expectativa do "pico do carvão" e o eventual término de sua produção, ansiedade que desdobra-se aos dias de hoje. De modo geral, as formas alternantes de geração (e conservação) de energia solar servem atualmente como uma espécie de placa de Petri para uma cultura de objetos tecno-ambientais, tanto por parte de engenheiros como de artistas. No contrapé do que investigamos no capítulo 2, aqui artistas travestem-se de engenheiros, como é o caso do dinamarquês Olafur Eliasson, que lançou na Tate Modern de Londres, em 2012, Little Sun, ${ }^{481}$ projeto de fornecimento de lâmpadas LED recarregáveis com energia solar à comunidades carentes da África. Em todo o caso, inclinamo-nos nesse momento a favor de propostas com traços apropriados (SCHUMACHER 1973), ou que possa ser o germe de uma tendência técnica (STIEGLER 1998), como é o caso de SunZilla, sistema composto por uma bateria, um inversor (dispositivo elétrico que converte a corrente contínua em um sinal de corrente alternada, com capacidade de percorrer maiores distancias em razão da voltagem mais alta) e uma "vela solar" (ver Fig. 43), capaz de abastecer uma residência ou integrar o conjunto técnico de uma micro-rede.

Figura 43 - Vela Solar SunZilla

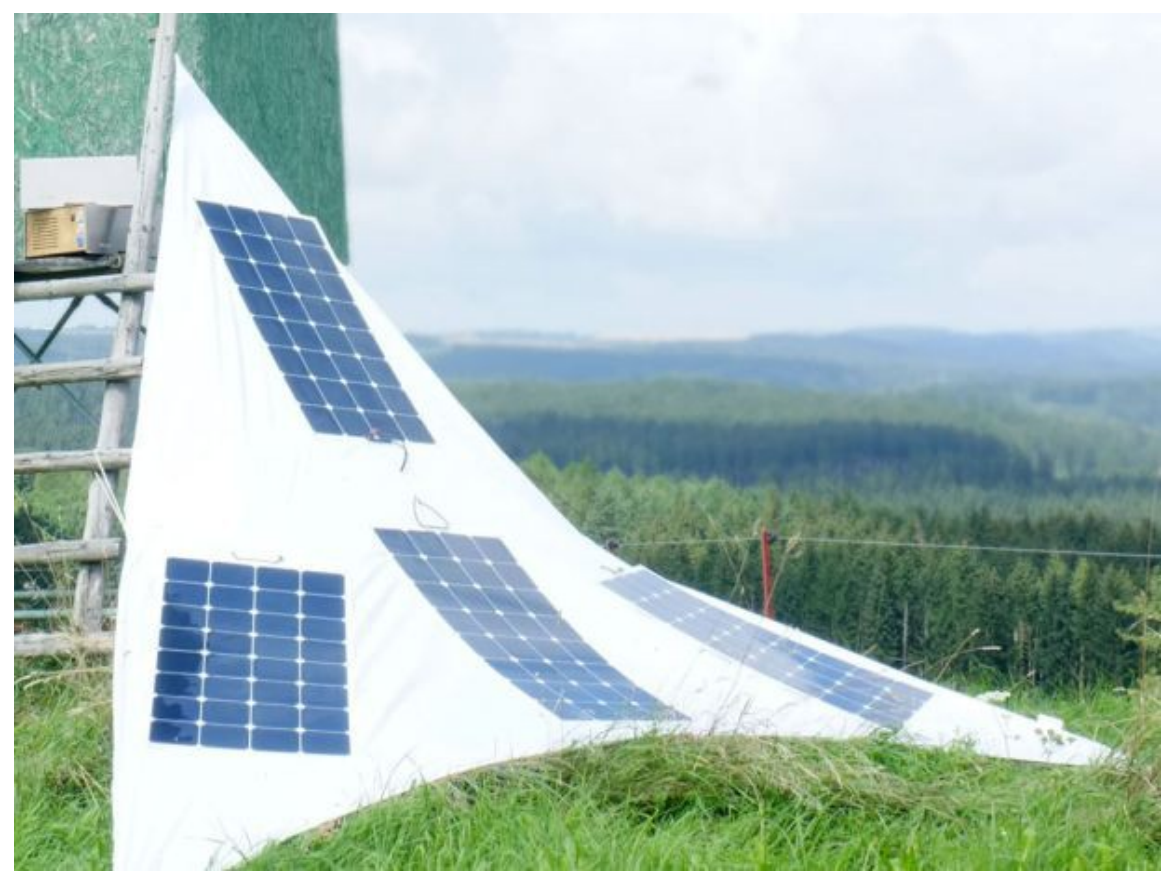

Fonte: https://sunzilla.de

481 Ver detalhes em Little Sun. Disponível em: <http://littlesun.com>. Acesso em: 11 maio 2016. 
Mais real que o pensamento desejante dos entusiastas da energia livre é a apreensão de que, na transição energética global de combustíveis fósseis para a energia limpa, as instalações da segunda possam perder a oportunidade histórica por motivos estéticos, devido ao impacto visual de seus dispositivos sobre o meio ambiente local. A questão dos aerogeradores é patente, mas a dos painéis solares também é inquietante. A boa-nova é o avanço da tecnologia de filmes finos na composição da terceira geração de células solares, as quais são classificadas de acordo com seus tipos: sistemas híbridos (orgânico/inorgânico) ou puramente orgânicos, como as células solares sensibilizadas por corante (DSSC, do inglês Dye Sensitized Solar Cell), materiais usados, por exemplo, pela artista canadense Sarah Hall, especialista na confecção de placas solares em forma de vitrais. Tais células também já começam a integrar diversos trabalhos inscritos na Land Art Generator Initiative, ou LAGI, plataforma responsável por concursos de projetos de estações de energia alternativa, concebido em 2009 pelos artistas Elizabeth Monoian e Robert Ferry, de Pittsburgh, EUA. Unindo a lógica dos sistemas integrados com a vertente contemporânea da arte pública, o concurso, que acontece no formato de bienal, oferece em paralelo um programa educacional acerca dos detalhes essenciais das tecnologias de geração de energia renovável (FERRY \& MONOIAN 2012). Observando as plantas técnicas dos projetos nos sentimos como se estivéssemos folheando os esboços sequenciais de um cenário de filme de ficção científica, mesmo cientes de que uma das normas basilares da LAGI é a de que o projeto deve ser realizável (em vez de apenas teórico e/ou estético). A assimilação de novas tecnologias no campo da energia solar amplia-se a cada edição da plataforma, de modo que dilemas estéticos possam ser solucionados. Acrescentamos nesse sentido a aplicação em projetos inscritos da célula solar de filme fino (Thin-Film Solar Cell, abreviadamente TFSC, em inglês), segunda geração de placas fotovoltaicas elaboradas a partir de películas de espessura nanométrica, cuja maleabilidade torna-as ideal para balões solares, ${ }^{482}$ projeto que, quando implementado, servirá como alternativa às gigantescas usinas solares térmicas.

482 Ver o projeto Solar Cloud, de Gabriel Muñoz Moreno (Social Cooperation Architects) em LAGI2016. Disponível em: <http://landartgenerator.org/LAGI-2016/kxyz2846/>. Acesso em: 20 set. 2018. 


\subsubsection{Energia biofotovoltaica}

Ao lado do modal solar, consolida-se outro com qualidades biológicas, mas que não vincula-se à tradicional bioenergia, esta obtida através da biomassa (cana, por ex.). Algumas propostas, em especial as que envolvem o uso de biodiesel de algas, nos fazem também renunciar ao estrito mundo da cibernética de primeira ordem - no qual os sistemas, vivos ou não, criam estratégias mecânicas em torno de um objetivo inabalável -, em nome de alguns princípios biológicos, congruentes com o fenômeno do tropismo, ou o deslocamento estimulado de uma planta em direção a uma fonte volante de energia. Em um exercício de futurecraft, imaginamos um futuro em que a principal fonte de energia utilizada no mundo seja a da tecnologia biofotovoltaica (BPV), ${ }^{483}$ esquematizada idealmente nas chamadas "placas solares vivas". Essa forma de energia apoia-se no princípio de funcionamento das células de combustível, dispositivos que transformam energia química em elétrica, mas ao invés de se usar o hidrogênio como propelente, lança mão de bactérias, organismos fotossintéticos que dispõem da energia luminosa para oxidar a água em que estão imersas e produzir elétrons. Tais partículas são então transportadas do ânodo para o cátodo, gerando assim uma corrente elétrica. Decerto que tal sistema insere-se nas operações de aquisição de forma (prise de forme) que, como recorda Simondon (2005: 46-47), não estariam restritas à oficina do oleiro ou do ceramista segundo o senso comum, podendo ocorrer no interior de uma válvula eletrônica (no caso apresentado por ele, um tríodo), fazendo a nuvem de elétrons desprendida durante a reação de oxidação da água o papel da massa de argila, a qual se converte em tijolo assim que se desprende de seu molde. Esse vínculo é possível graças à analogia entre o molde e a modulação da grade, a qual inverte o sinal da corrente contínua no circuito de baixa voltagem para o sinal da corrente alternada no de alta voltagem. ${ }^{484}$ A grade moduladora é, portanto, um "molde variável". Nesse sentido, "moldar é modular de forma definitiva; [e] modular é

483 Ver BIOLOGICAL PHOTOVOLTAICS. An Introduction to Biological Photovoltaics, 2013. Vídeo disponível em: <https://www.youtube.com/watch?v=uPNDOw041Q8>. Acesso em: 22 fev. 2017.

484 Para se visualizar como a grade de comando funciona como o "molde" de uma corrente entre dois circuitos, ver uma animação realizada com o aplicativo EveryCircuit em SIMPLY ELECTRONICS. What is a Relay? - Electronics Basics 8. Vídeo disponível em: <https://www.youtube.com/watch? v=n9renPKEtUc>. Acesso em: 24 set. 2018. 
moldar continuamente e de modo perpetuamente variável" (loc.cit.). ${ }^{485}$ Mas enquanto Simondon realiza a analogia entre a grade de controle que separa os dois circuitos e o molde do oleiro - procurando inserir os dois termos em um regime energético que se sobressaia do hilemorfismo (doutrina segundo a qual matéria e forma cessam de individuar a partir de sua "união estável") -, tomamos a licença poética de estendêla, no caso dos dispositivos biofotovoltaicos, à membrana eletrolítica polimérica, película condutora de prótons que separa os compartimentos do ânodo e do cátodo e que, por estar isolada eletronicamente, atua como um "modulador" - não de tensão, obviamente, mas em razão de sua função seletora.

Figura 44 - Ânodo do projeto Musgo Voltaico (IAAC)

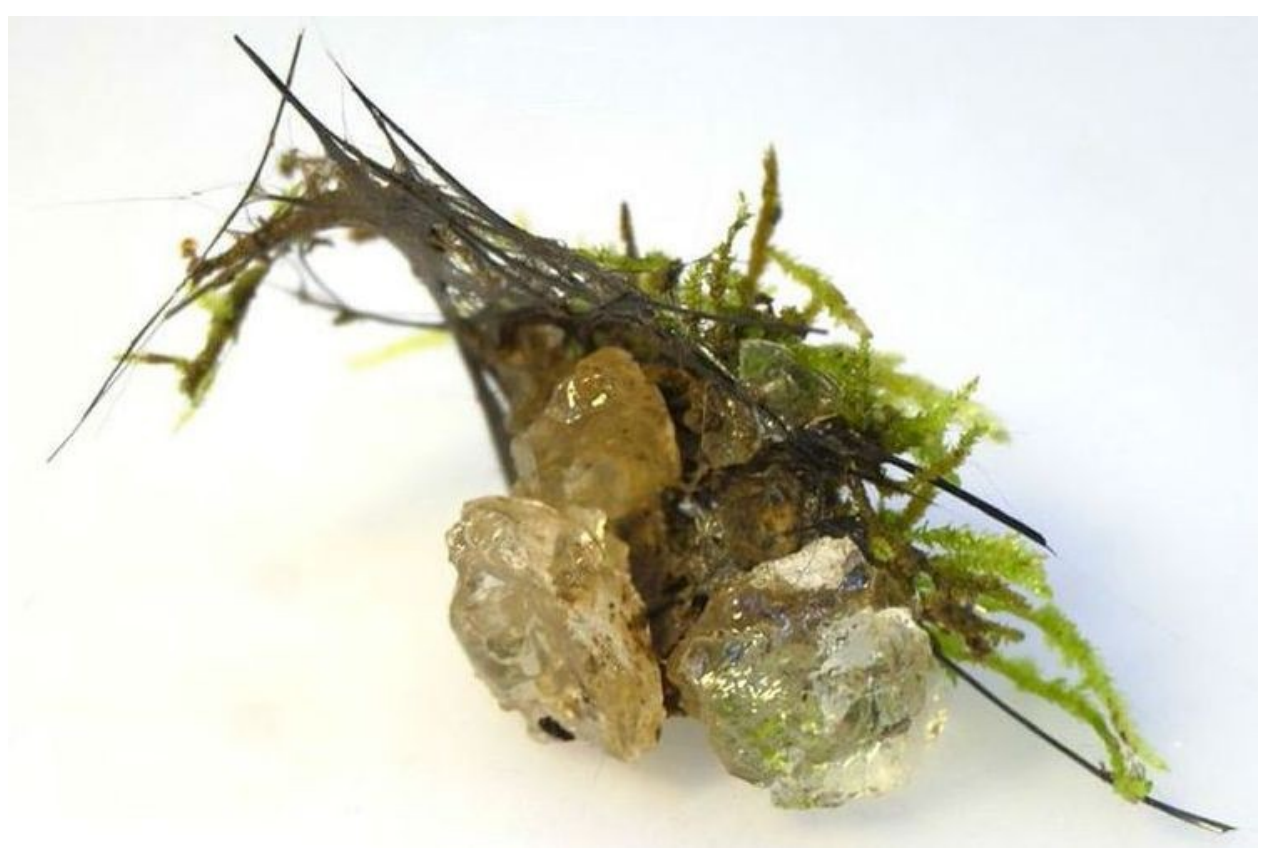

Fonte: https://iaac.net/research-projects/self-sufficiency/moss-voltaics/

Alternativas inovadoras dessa tecnologia estão sendo experimentadas no Instituto de Arquitetura Avançada da Catalunha, centro de pesquisa e educação voltado para as cidades do século 21. Praticadas com bom senso, tornam-se plausíveis as imagens de uma "cidade inteligente" em um futuro próximo, mas uma que seja realmente inteligente, na provocação de Bernard Stiegler (2018: 119-123), isto é, um exorganismo que acompanhe as constantes transformações dos indivíduos organológicos que a habitam (leia-se: nós), seres que passam

485 Excerto no original: Mouler est moduler de manière définitive ; moduler est mouler de manière continue et perpétuellement varible. (tradução nossa). 
simultaneamente por processos de individuação psíquica, técnica e social. Desconsideremos, nesse ponto, a automação e o processamento e análise de grandes quantidades de informação, elementos imprescindíveis para os arautos da $\mathrm{CI}$. Essa inteligência urbana, ao menos na visão do IAAC, depende primordialmente de uma abordagem estética, ou seja, da solução de consagrados problemas "ecofenomenológicos" (separação entre ecologia e cultura, por ex.), donde se reivindica uma "estética evolucionária", com potencial adaptativo. ${ }^{486}$ Tomemos o projeto Musgo Voltaico, ${ }^{487}$ sistema modular de painéis de BPV que dá um passo adiante da tendência arquitetônica conhecida por "muros verdes". Aqui, o musgo usa a energia solar para converter o dióxido de carbono da atmosfera em matéria orgânica, cujos componentes são decompostos por bactérias. Os elétrons liberados por elas nesse processo são capturados por um ânodo singular (ver Fig. 44): uma estrutura formada pelo material biológico do musgo, cubos de hidrogel (um polímero superabsorvente de água) e fibras de carbono. ${ }^{488}$ O sistema bioelétrico é complementado operacionalmente por um cátodo, o catalisador e a "ponte salina" que permite à carga positiva (geralmente prótons) migrar do material biológico anódico para o cátodo. Por fim, agrupa-se todos os elementos no interior de tijolos construídos com a técnica de colagem de barbotina (processo empregado na produção de peças cerâmicas em larga escala), recipientes que, além de servir de material de construção, criam um microclima específico para o crescimento do musgo. Cada unidade produz modestos 0,35 volts, porém a sua potencialidade reside no "efeito solidário de funcionamento do conjunto" (SIMONDON 1969: 25). ${ }^{489}$ A tecnologia BPV ainda não atingiu a maturidade de eficiência requerida para a sua "adoção" (STIEGLER 1998: 58), por ser ainda obscuro o processo através do qual as bactérias libertam os elétrons do interior de seus organismos. Mas a forma desse sistema energético - tanto molecular quanto molar - é por certo ecotécnica.

486 Cf. CARLO, Ilaria Di. The Aesthetics of Sustainability. IAAC BITS, 7.1.3. Setembro, 2016. 487 Ver Moss Voltaics - The Institute for Advanced Architecture of Catalonia. Disponível em: <https://iaac.net/research-projects/self-sufficiency/moss-voltaics/>. Acesso em: 21 abr. 2018.

488 O compósito, diríamos, consiste em um objeto tecno-ambiental por excelência!

489 Nessa expressão, o filósofo francês refere-se ao sistema de refrigeração a ar do motor a explosão, mais coparticipante do conjunto que o sistema de arrefecimento a água. Cremos que uma solidariedade análoga ocorra em nosso exemplo. 
Figura 45 - Windstalk (Atelier DNA)

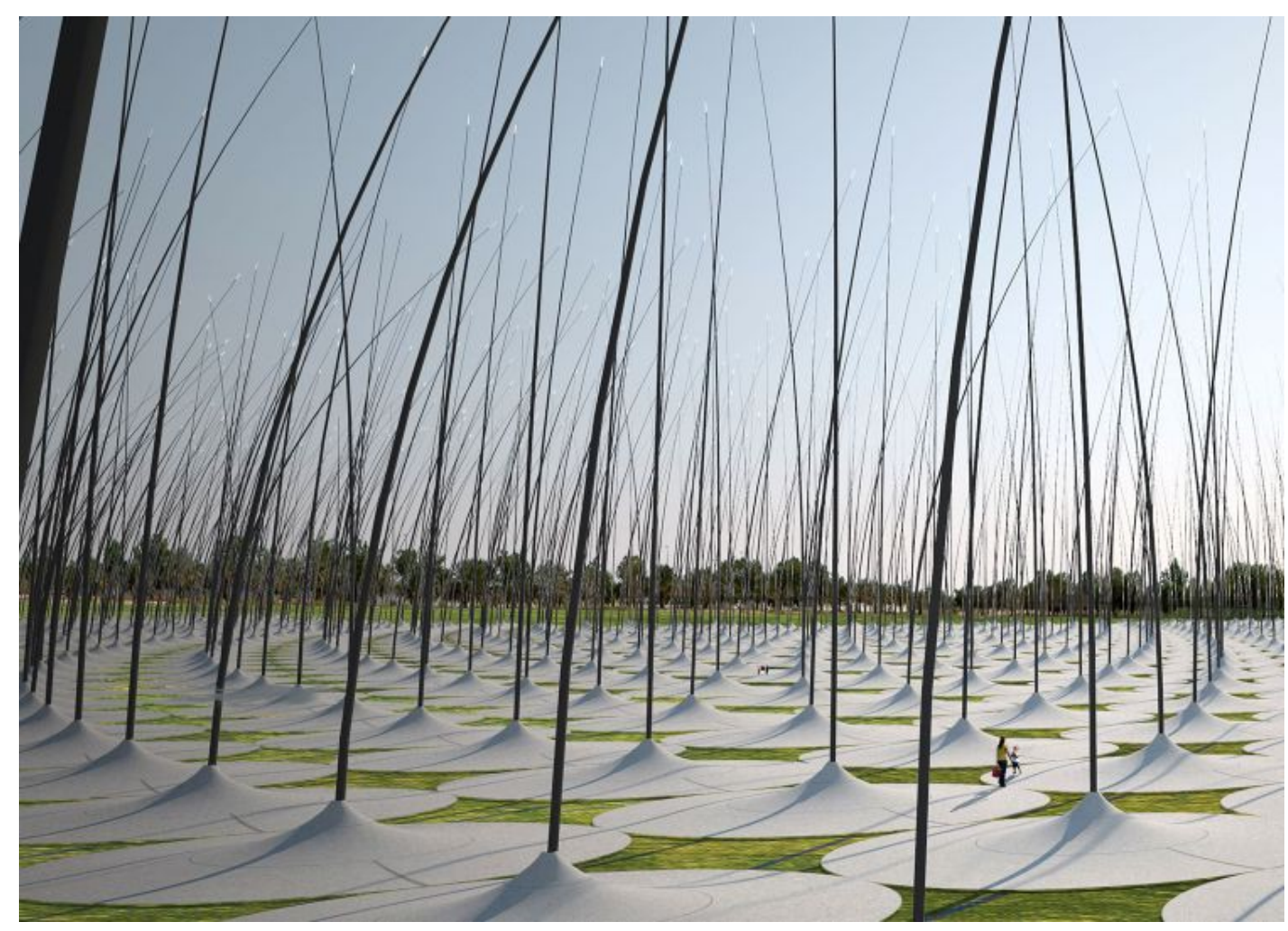

Fonte: http://landartgenerator.org/competition2010.html

\subsubsection{Turbinas eólicas piezoelétricas}

Como vimos em outra situação, a polêmica sobre a forma dos objetos técnicos ligados às fontes alternativas parece concentrar-se no segmento eólico, em virtude da predominância física e visual dos parques de aerogeradores em nosso campo de visão. Tais dispositivos, segundo seus detratores, capturam de modo abarcador a nossa atenção, corrompendo a apreciação estética da paisagem. $\mathrm{Na}$ França, por exemplo, a Sociedade para a Proteção de Paisagens e Estética questiona se as características das atuais turbinas eólicas são mesmo mandatórias, e se essa proeminência não seria "deformadora". 490 Mas a opção de esculpi-las em forma de árvores, em nosso entendimento, configura um processo de "customização" que, retomando Simondon, agrega elementos supérfluos ao objeto técnico (SIMONDON 1969: 24). Uma de suas caraterísticas essenciais é o de estar fundamentado em uma espécie de organização analítica, sempre deixando o

490 Ver LAURENSON, John. Turbina Eólica em Forma de Árvore. Deutsche Welle, 7 abr. 2015. Disponível em: <http://www.dw.com/pt-br/turbina-e\%C3\%B3lica-em-forma-de-\%C3\%A1rvore/a18359728>. Acesso em: 17 jan. 2017. 
caminho aberto a novas possibilidades, considerando-se que "tais possibilidades são a manifestação externa de uma contingência interna" (loc.cit.). O vínculo entre os aspectos não essenciais e a natureza do objeto é negativo, como no caso dos automóveis. Eis aí um bom exemplo do caráter não essencial da customização (sur mesures): quanto mais a indústria automotiva atende às exigências dos usuários, mais o objeto técnico é sobrecarregado, "a carroceria torna-se mais pesada pelos acessórios, as formas não correspondem mais à estrutura que permite a melhor filtragem da entrada de ar ... [isso] vai contra a essência do ser técnico, é como um peso morto que é imposto do exterior" (op.cit.: 24-25). ${ }^{491}$ Ademais, considerações funcionais e mecânicas são tão prioritárias quanto influências econômicas, como o custo por quilowatt de capacidade, que vem diminuindo a cada ano na área de energia renovável. ${ }^{492}$ Nesse sentido, observe-se as novas propostas de turbina eólica de eixo horizontal (HAWT, na sigla em inglês, ou horizontal-axis wind turbine), hastes incrustadas por material piezoelétrico, o qual tem a capacidade de gerar tensão elétrica por força de pressão mecânica. Um dos projetos selecionados na edição de 2010 da Land Art Generator Initiative alavanca o potencial estético dessa tecnologia: trata-se de Windstalk, ${ }^{493}$ do Atelier DNA, laboratório de design baseado em Nova York. Cada haste da matriz (ver Fig. 44), organizada segundo o padrão de filotaxia das flores do disco de girassol, contém placas cerâmicas, entre as quais situam-se os eletrodos. Quando o vento a faz oscilar, a pilha de discos piezoelétricos

491 Hoje a questão dos opcionais é menos importante que o desempenho dos motores. Veja-se, na evolução dos sistemas de carburação, a diferença entre o motor do Ford Modelo T (produzido entre 1908 e 1927) - que ao invés de bombas dependia da gravidade para conduzir o combustível ao carburador - da sofisticada injeção eletrônica do Power Unit, como é chamado o motor dos carros de F1. Nesse quesito específico, ver LAVRINC, Damon. An Illustrated Guide to F1's Radical New Engine. Wired, 2014. Disponível em: <https://www.wired.com/2014/01/illustrated-guide-f1-2014/>. Acesso em: 28 set. 2018. No mundo moderno, os motores de carros de passeio funcionam a uma taxa de $98 \%$ de eficiência. Entretanto, existe um objeto técnico de grande relevância na atualidade que desempenha a uma taxa de $1 \%$ (ou até $0,01 \%$ ): os aplicativos. Objetos extremamente "inchados", sua ineficiência é compensada por hardwares cada vez mais robustos (para se ter uma ideia, há páginas que pesam mais que o antigo Windows 95 , que comportava meros $30 \mathrm{Mb}$ ). Tudo isso faz lembrar que os softwares controlam cada vez mais o funcionamento dos veículos de última geração, o que nos leva de volta à discussão sobre se estes "assessórios" não poderiam ser classificados como itens de customização, sendo dessa forma inessenciais... Para uma reflexão sobre a progressiva ineficiência dos programas de computador, ver PROKOPOV, Nikita. Software Disenchantment. Tonsky.me, 17 set. 2018. Disponível em: <http://tonsky.me/blog/disenchantment/>. Acesso em: 28 set. 2018.

492 Cf. Levelized Cost of Energy 2017. Lazard.com. Disponível em: <https://www.lazard.com/perspective/levelized-cost-of-energy-2017/>. Acesso em: 27 set. 2018.

493 Ver Windstalk - Atelier DNA NY (Dario Nunez Ameni e Thomas Siegl). Disponível em: <https://atelierdna.com/portfolio/windstalk/>. Acesso em: 27 set. 2018. 
é comprimida, gerando energia cinética até o gerador de torque localizado em sua base que, por sua vez, a converte em energia elétrica. Diferente das turbinas em forma de árvores, as HAWT do Atelier DNA reproduzem um evento da natureza (gramíneas ondulando ao vento), sem procurar imitá-lo.

\subsubsection{Setor hídrico}

\subsubsection{Cultura dos canais}

$\mathrm{Na}$ forma como é executada a gestão hídrica no Japão, algumas das concepções estéticas de seu povo tornam-se manifestas, influenciando as diversas políticas de transformação ripária, ou métodos de "construção de rios". Lá, por exemplo, o planejamento hídrico de regulação de bacias subdivide-se basicamente em duas estratégias, ou diretrizes: a solução modernista, tecnocrática e desenvolvimentista consubstanciada nos planos de sanmen-bari, ou a concretagem dos três lados dos canais (fundo e margens); ${ }^{494}$ e a governança orientada a natureza, chamada de Tashizengata Kawazukuri, a qual introduziu no campo das políticas públicas uma eco-estética de paisagismo hídrico. ${ }^{495}$ Essas duas formas de gestão das bacias hidrográficas, por mais dicotômicas que pareçam, predispõem, cada uma à sua maneira, um ponto de vista estético. Augustin Berque, por exemplo, já havia descrito como a concretagem dos rios japoneses curiosamente convertiamnos, aos olhos da população local, em objetos belos. ${ }^{496}$ Pode-se notar a invocação plástica desse canais, uns e outros estabilizados lateralmente por gabiões, em expressões culturais nipônicas, ${ }^{497}$ fazendo as vezes de recurso "solucionista"

494 Ver WALEY, Paul. Following the Flow of Japan's River Culture. Japan Forum, v. 12, n. 2, 2000, pp. 199-217.

495 Ver os detalhes sobre essa ética de governança - e sua malversação - em CHAKRABORTY, Abhik. Promises Unfulfilled: Tashizengata Kawazukuri and Environment-Oriented River Basin Governance in Japan. Asia Pacific World 3(2), 2012, pp. 83-107.

496 "O Japão me reservou outros ensinamentos. Por exemplo esta expressão - tirada de uma recente pesquisa sociológica - de um camponês a respeito de um córrego vizinho: 'Ele ficou bonito depois que o canalizaram!'. Não há ambiguidade na palavra empregada: utsukushii quer dizer 'belo'. E sem ironia, para espanto dos pesquisadores (é preciso dizer que no Japão não se canaliza com mão leve: sanmen-bari, calibrar os rios em 'três planos', é transformá-los em dois muros e um fundo em concreto armado). Eles achavam que o sanmen-bari não era belo... Mas para o morador, o bonito era não ter mais que ceifar as margens dos meandros caprichosos do antigo córrego... Ele ficou limpo e arrumado, por que não belo?". Ver BERQUE, Augustin. Paysage, Milieu, Histoire. In: BERQUE 1994, pp. 12-29.

497 Ver, por exemplo, diversos planos de fundo de histórias em quadrinhos ilustradas por Jiro 
tecnológico. A contrapelo das duas visões, cultiva-se a imagem de um nostálgico cenário ribeirinho (furusato no kawa), carregado de simbolismos ancestrais, dela resultando a chamada "cultura dos rios" (kawa no bunka), afeiçoada ao nativismo dos antigos arrozais espalhados por planícies aluviais. ${ }^{498}$ Logo, enumera-se não duas, mas três narrativas de gestão de controle hídrico no Japão, todas condicionadas por políticas de combate às enchentes, bem como por justificativas estetizantes: a primeira, tecnológica e centralizadora, é herdeira do modernismo e do conceito de crescimento econômico; a segunda, de matiz preservacionista e econacionalista, aspira à restauração dos rios originais e de um passado anterior às influências ocidentais; e a terceira, espécie de caminho do meio entre os dois polos, detém um perfil conservacionista, porém sem abster-se do uso da tecnologia dentro de certos limites (tsukurasete morau) ${ }^{499}$

A filosofia (ou ética) do Tashizengata Kawazukuri, aprimorada pelo engenheiro Seki Masakazu, é um termo híbrido, uma fusão de Tayosei (variedade) e Shizen (natureza). ${ }^{500}$ Heterogêneo, semelhantemente, quando da sua execução, misturando no mesmo crisol os idiomas do rewilding e da biodiversidade, assim como a linguagem das novas técnicas de engenharia hídrica, em particular a restauração de meandros em cursos de água (respeitando os intercursos de correntezas e remansos), o paisagismo em margens inclinadas e a recriação de planícies aluviais. ${ }^{501} \mathrm{Em}$ suma, é um formato de gestão de sistemas fluviais com design humano, que procura encontrar a justa medida entre tecnologia e ecologia. Pode-se aventar que ele sustém algumas características da estética ecotécnica, principalmente se considerarmos certos projetos com a sua marca como sendo objetos tecno-ambientais. Tome-se, por exemplo, os onipresentes parques hidrofílicos, definição que os distinguem de parques aquáticos, voltados a um tipo de entretenimento de outra espécie. $\mathrm{O}$ ápice paradigmático do modelo é o parque shinsui Komatsugawa, ${ }^{502}$ situado no distrito de Edogawa, próximo à Tóquio, através

Taniguchi, em particular O Homem Que Caminha (São Paulo: Devir Livraria, 2017), manga que narra oito passeios de uma mesma personagem por sua cidade natal.

498 WALEY, op.cit.

499 CHAKRABORTY, op.cit.

$500 \mathrm{lbid}$.

501 Ver WALEY, Paul. What's a River Without Fish? Symbol, Space and Ecosystem in the Waterways of Japan. In: PHILO \& WILBERT 2000, pp. 161-183.

502 Ver Komatsugawa Shinsui Koen [s.l.: s.n., s.d.]. Vídeo disponível em: <https://www.youtube.com/watch?v=0vWEcnGOxFo>. Acesso em: 6 ago. 2018. 
do qual serpenteia um curso d'água que flui por "bosques de bambu, praias de cascalho, barrancos e cachoeiras, artisticamente posicionados para sugerir as quatro estações e simbolizar algumas das características mais célebres da paisagem japonesa, um equivalente urbano moderno de um jardim do século 17". 503 Os parques hidrofílicos são, com efeito, projetos de regularização fluvial urbana, mas que privilegiam em maior grau os aspectos afetivos (shinsui koen, em tradução livre, significa "afeto pela água"), do que os funcionais, criando paisagens estéticas com alto valor de amenidade. ${ }^{504}$ Mas esse tipo de paisagismo fluvial, que reforça o sentido de uma "eco-estética", ${ }^{505}$ não está infenso a críticas, ${ }^{506}$ como as que delatam a possibilidade de implementá-los somente em reduzidas extensões urbanas, e não em toda a bacia hidrográfica.

E é aqui que a filosofia gerencial dos parques hídricos intercambia-se com premissas da estética ecotécnica, em particular as que culminam no entendimento sobre a relação entre objetos técnicos, naturais e de arte - ou aqueles que se posicionam no gradiente dos objetos intermediários. Adiciona-se às técnicas orientadas a natureza o tecnicismo do poder construtor para obter-se um nexo "hidrosocial" desprovido da funcionalidade propiciada pela natureza pristina, daquele "deixar-se fazer" próprio do mundo natural. Perguntamos se, ao serem destituídos de sua função originária, ou nativa, os parques estariam do mesmo modo comprometidos em exercer a sua função "natural-ambiental" (na acepção de Carlson); cremos que não; logo, há que vê-los como influenciadores de uma cultura específica: a cultura dos rios. Pode-se argumentar que as duas funções primordiais do Tashizen Kawazukuri - mitigação das enchentes e estímulo à biodiversidade tenham sido promessas não cumpridas. ${ }^{507}$ Contudo, parece-nos que os parques hídricos, emblemas da maneira como o povo japonês aprecia a natureza, tornam-se, no mínimo, sinédoques de uma paisagem hídrica em processo de desaparição. O plantio de cerejeiras ao longo do canal de Shinkawa, por exemplo, é uma legítima ode ao pensamento estético unificador, o motivo inspirador de cantos líricos: ${ }^{508}$ a 503 lbid.

504 Ver WALEY, Paul; ÅBERG, E Ulrika. Finding Space for Flowing Water in Japan's Densely Populated Landscapes. Environment and Planning A: Economy and Space, v. 43, n. 10, 2011, pp. 2321-2336.

$505 \mathrm{lbid}$

506 CHAKRABORTY, op.cit.

507 Ibid.

508 As redes de canais construídas em tempos pré-modernos arrebatam por si só traços poéticos. 
"poesia do acordo" (DUFRENNE 2015: 205). Ela alastra-se no pacto da engenharia humana com o mundo natural, na prática concomitante do paisagismo de aterros e da reativação de bacias de retenção. É como se a tecnologia empregada na construção dos parques hídricos fosse um remédio contra a própria tecnologia (ou seus excessos). Nesse sentido, os espaços de "afeto por água" são, arriscaríamos a dizer, uma espécie de símbolo da Gelassenheit, a compostura serena frente à alienação proporcionada pelos objetos técnicos: "Gostaria de dar a esta atitude de um simultâneo sim e não ao mundo tecnológico um nome antigo: serenidade frente às coisas" (INWOOD 2002: 35-7), profetizava Heidegger (1966) em seu discurso $O$ Homem na Era Atômica, proferido em Messkirch, no ano de $1955 .{ }^{509}$ De volta ao Japão atual, a gestão hídrica orientada a natureza (ou "naturezacultura"?) precisa sobressair-se dos ataques de seus críticos, assumindo determinantemente o fato de que o pensamento meditativo pressupõe o cálculo (STIEGLER 2018: 105).

\subsubsection{Templos da água}

No período pré-colonial, o manejo hídrico em Bali era um desafio extraordinariamente complexo de engenharia. Sumariamente, a maioria dos sistemas de irrigação balinesa tem início em lagos sagrados, quando não em açudes represados, que desviam parte do seu fluxo para galerias subterrâneas artificiais. Os túneis emergem mais ou menos um quilômetro a jusante, onde a água é levada por um labirinto de canais e aquedutos até a encosta onde se encontram os terraços de plantação de arroz. A coordenação de todo o sistema é completamente descentralizada, sendo gerenciada em âmbito local por cooperativas autônomas de produtores, os subak. Na realidade, não são absolutamente autônomas, e sim subordinadas aos "templos da água", edificações sagradas situadas em cada ponto nevrálgico do sistema, que têm como função definir os caminhos das águas traçados por divindades (como a Deusa do Templo do Lago da Cratera), responsáveis

Ver, em mídia cinematográfica, TAKAHATA, Isao. The Story of Yanagawa's Canals. [s.l.: s.n., s.d.]. Disponível em: <http://www.imdb.com/title/tt0094345/>. Acesso em: 11 ago. 2018.

$509 \mathrm{Em}$ certo trecho do documentário The Magus of Messkirch (1989), dirigido por Rudiger Safranski, ouve-se a voz do narrador dizer como sobreveio ao filósofo alemão a noção de Gelassenheit: "Heidegger encontra o seu Tao". 
também pelos arrozais (sawahs) e a purificação da terra da poluição (ver Fig. 46). Não é à toa que o nome balinês para a religião local é agama tirtha, a religião da água sagrada, ${ }^{510}$ em que cerimônias sagradas coexistem com a computação de padrões de cultivo e cronogramas de irrigação, garantindo a segurança hídrica de centenas de zonas de plantio. Trata-se de um arranjo "tecno-teológico" cujas variáveis são as características fisiológicas do arroz, o clima local, os sistemas de calendário balinês e o papel dos templos. ${ }^{511}$ Há, contudo, um complicador adicional na coordenação coletiva de uma das datas-chave desse complexo, marcada pela celebração da primeira colheita do ano: o uso, pelos subaks, de dois calendários distintos (sendo um deles lunissolar) para que se fixe a chamada Lua Cheia do Décimo Mês. A disparidade calendárica é resolvida estimando-se quando a estação chuvosa está prestes a terminar, conforme evidenciado por sinais naturais, como o aparecimento de um musgo particular sobre uma árvore venerável, o crescimento da grama Dasa, ou até mesmo a mudança na cor do mar. ${ }^{512}$ Assim, a efeméride é "calculada" por intermédio de diferenças ambientais, produto de uma unidade de sobrevivência (e não de competição, como queria Darwin) composta por organismos e o seu meio. É por isso que a ecologia revela-se como sendo "o estudo da interação e sobrevivência de ideias e programas (isto é, diferenças, complexos de diferenças, etc.) em circuitos", na perspectiva de Gregory Bateson (2000: 491).

O funcionamento ótimo do circuito é essencial para que os subaks agendem o retorno das chuvas, os padrões de cultivo e, especialmente, os períodos uniformes de repouso de terras cultiváveis (pousio). ${ }^{513}$ Caso isso se cumpra, verifica-se que "(a) as necessidades de chuva e sol do arroz são otimizadas; (b) a colheita é cronometrada para a estação seca; (c) populações de pragas são minimizadas" 514 (porque intercala-se o plantio de arroz e vegetais repelentes às espécies nocivas). Logo, essa tecnologia social e hídrica constituída por canais, tuneis e aquedutos é meticulosamente representada pelos sacerdotes dos templos com diagramas, mandalas e ciclos de rituais interligados por dois tipos de calendários. Noções típicas computacionais, como variáveis de ambiente (path), são marcadas nos

510 Ver LANSING, J. Stephen. Balinese "Water Temples" and the Management of Irrigation. American Anthropologist, v. 89, n. 2, 1987, pp. 326-341.

$511 \mathrm{lbid}$.

$512 \mathrm{lbid}$.

$513 \mathrm{lbid}$.

$514 \mathrm{lbid}$. 
diagramas, nos quais se entrevê que os terraços dependem dos fluxos dos canais que, por sua vez, dependem do fluxo da represa que, finalmente, depende do fluxo dos rios. O antropólogo Stephen Lansing (2009) percebeu que, neste esquema de "dependência da trajetória", os canais exercem o papel de hardware, enquanto os templos, o de software (op.cit:: xvii), ou seja, o sistema funciona como um computador que calcula o uso coletivo da água sagrada a montante e o individual a jusante (op.cit:: 56). Como a irrigação depende da precipitação sazonal, a escolha dos cronogramas de irrigação de cada unidade próxima aos lagos vulcânicos afeta a disponibilidade de água de seus vizinhos rio-abaixo. Isso irá compor um sistema de contrabalanças. Por exemplo, se os subaks a montante têm a dádiva da oferta de água e os vizinhos a justante, contrariamente, põem-se à sua mercê, todos partilham algo: a necessidade de manejo integrado de pragas. Ora, se os padrões de colheita são escalonados, os terraços ao longo da planície são inundados sincronicamente, assolando o biossistema de insetos nocivos em toda a província. Tal procedimento, como vimos, é apenas um módulo do código. Ademais, a materialização física desse "programa" assemelha-se ao processo de construção de nichos, ${ }^{515}$ que é a "modificação pelos organismos dos componentes bióticos e abióticos do ambiente, por meio de interações tróficas e 'trabalho', incluindo atividades metabólicas, fisiológicas, comportamentais ou de escolhas feitas naquele ambiente". ${ }^{516}$ Trata-se, portanto, da evolução de uma técnica efetiva de poiesis, e não de sua adaptação às mudanças históricas, políticas ou climáticas.

515 Ver LANSING, J. Stephen; FOX, Karyn M. Niche Construction on Bali: The Gods of the Countryside. Philosophical Transactions of the Royal Society of London B: Biological Sciences, v. 366, n. 1566, 2011, pp. 927-34.

516 Ver TREVISAN, Camila et al. Seleção Natural no Trampolim: Como a Teoria da Construção de Nicho Balança Nosso Entendimento da Evolução. Revista Jovens Cientistas, ano 1, número 3, 2014, pp. 36-7. 
Figura 46 - Canal de subak velado por divindade

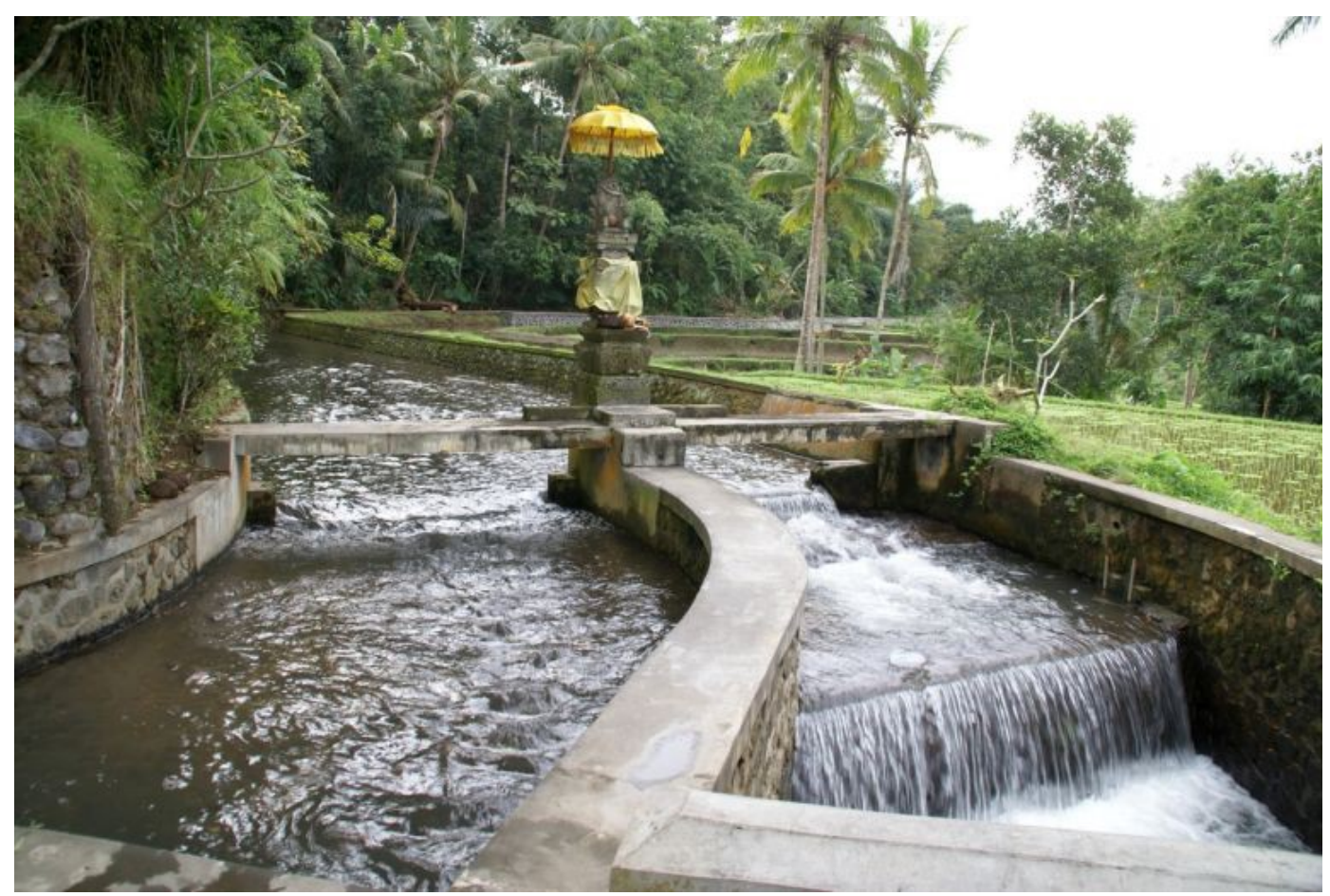

Fonte: https://anthropology.ua.edublogsprimatereligion20140205how-is-religion-useful

Essa tecnologia de distribuição hídrica, não restrita a Bali, mas extensiva a toda Indonésia, pode ser explicada como um mecanismo de programação de cultivo em larga escala, que vem operando ininterruptamente por 900 anos. ${ }^{517}$ Essa extrapolação como que ratifica algumas intuições de Leroi-Gourhan, a principal delas consistindo na relação de um sistema técnico com outros sistemas - ou como uma tendência técnica universal (os sistemas de irrigação, por exemplo) é "envelopada" culturalmente por grupos étnicos, que a concretizam, ou seja, convertem-na em um fato técnico (STIEGLER 1994: 43-69). Os operadores dos subaks, entretanto, identificam-se não somente como um sistema sociocultural, agroecológico e político-administrativo específico, mas como uma rede de "meios associados" (no vocabulário de Simondon), "um inextricável espaço tecno-geográfico no qual a individuação tecnológica claramente intervém na dinâmica geofísica como uma ruptura" (STIEGLER 2011: 196). Soma-se à análise dessa máquina agroecológica a categorização de suas "peças", a saber, as principais instalações do sistema de controle de irrigação. Cada unidade de subak compõe-se 517 Ver ROTH, Dik. The Subak in Diaspora: Balinese Farmers and the Subak in South Sulawesi. Human Ecology, v. 39, n. 1, 2011, pp. 55-68. 
necessariamente de uma barragem (pengalapan), valas (jelinjing) e ductos (cakangans), sendo a altura dos últimos idênticos para várias fazendas, tendo em vista proporcionar a equidade do fluxo d'água. ${ }^{518} \mathrm{~A}$ teoria da hidrodinâmica, neste caso, é superada pelas condições da "matéria funcional" (não na acepção industrial), (loc.cit.) "uma vez que a questão funcional nunca é apenas a aplicação de uma função física [à realidade prática], mas [é resultado] de um complexo organizacional, mesmo quando este não for propriamente orgânico" (loc.cit.). O fato técnico tornase, portanto, um fato sociocultural, porque o "meio tecno-geográfico inclui também a geografia humana" (loc.cit.). Lamentavelmente, o emaranhamento da conexão entre o pensamento religioso de cunho ecológico e o pensamento puramente técnico distintivo desse sistema foi quase completamente erradicado com a chegada dos colonizadores holandeses e, décadas depois, com o advento da Revolução Verde, a disseminação de práticas modernas no campo que visam o aumento da produção agrícola. A funcionalidade do tradicional sistema de irrigação em Bali, concluímos, mostra como a hidrosfera do planeta pode ser interpretada como uma "máquina universal", sensível a oscilações molares e moleculares.

\subsubsection{Linhas chaves}

O pensamento simondoniano sobre os pontos-chave acomoda-se de forma adequada em um dos princípios agrícolas da permacultura, o conceito de keyline design (ou planejamento em linhas chave), metodologia topográfica para controle do fluxo da água, em que o problema da infiltração da água pluvial se coloca no estudo projetivo de canteiros, terraços e banhados por toda a extensão longitudinal das encostas. Antes de se definir as linhas chaves, faz-se necessário descobrir os pontos chave que as equilibram, locais em que o vale exibe a sua inclinação mais íngreme e onde a sua parte côncava torna-se convexa. Esse método, desenvolvido nos anos 1950 pelo geólogo australiano P. A. Yeomans, delineia o "perfil" de uma paisagem por meio de curvas de nível (ou isolinhas), linhas de contorno que conectam pontos-chave em um relevo latitudinal. Contudo, os pontos singulares do

518 Ver Subak: Bali Traditional Water Management System (irrigation). Disponível em: <http://www.baliglory.com/2016/04/subak-bali.html>. Acesso em: 23 ago. 2018. 
keyline, ao invés de incumbir-se da condição de privilegiados (como o notório cume da montanha), detém uma aparência fugidia, escapam à nossa atenção, limitam-se a detecção por intermédio de dispositivos técnicos, analógicos e digitais, como instrumentos a laser ou até mesmo o Google Earth. ${ }^{519} \mathrm{Em}$ conformidade com as revelações da natureza, desenha-se no mapa os pontos-chave que, como vimos, são os locais que marcam uma mudança na relação do vale com seus cumes adjacentes, ou seja, é o ponto em que o declive torna-se mais plano, extensão talhada a exercer a função de escoadouro para bacias hidrográficas ou de captação. Liga-se, ato contínuo à fase de campo, tais pontos de inflexão com as linhas planas a declive, fazendo-as curvar à medida que a inclinação altera-se a partir das cumeeiras. ${ }^{520}$ Mesmo as regiões menos acidentadas e montanhosas apresentam essas características topológicas, mas de modo menos acentuado (ver Fig. 47).

519 Ver WALLACE, William. Free Permaculture Design Analysis Tool Tutorial. Permies, 2017. Disponível em: <https://permies.com/t/71351/permaculture-projects/Free-Permaculture-DesignAnalysis-Tool>. Acesso em: 28 ago. 2018.

520 Para a visualização das etapas de localização de keypoints e keylines (no caso, para programas de manejo e reflorestamento), ver a sequência de diagramas no texto Applying Keyline to Ripping, Sowing and Tree Planting. Earth Integral, 20 abr. 2013. Disponível em: <https://earthintegral.com/2013/04/20/applying-keyline-to-ripping-sowing-and-tree-planting/>. Acesso em: 24 ago. 2018. 
Figura 47 - As "curvas estéticas" de keylines (em verde) no layout de uma fazenda sueca

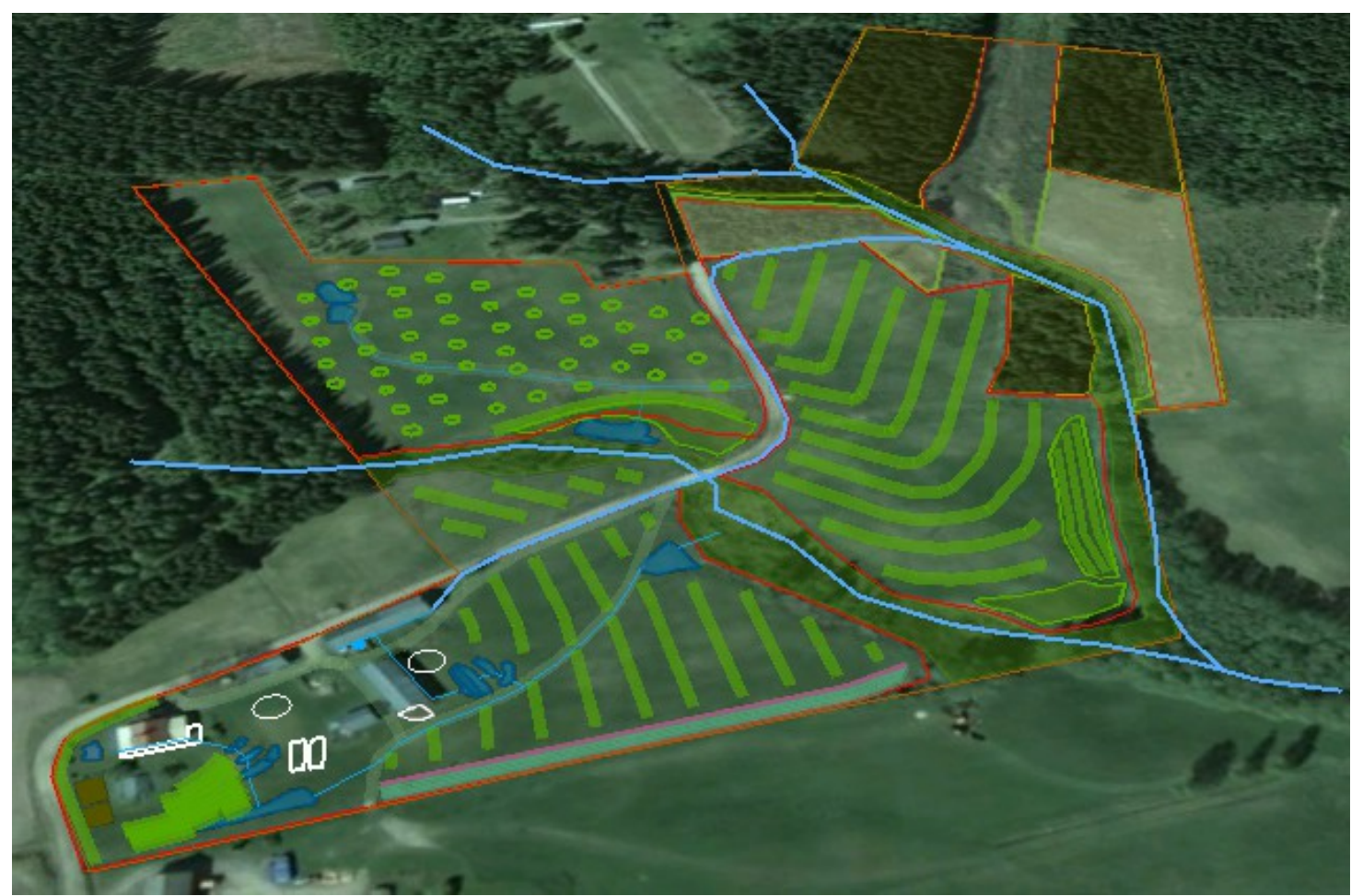

Fonte: http://www.ridgedalepermaculture.com/blog/keyline-design-in-cold-climate-sweden

Apesar da aparente imposição geometrizante, a solução das keylines é topológica e não euclidiana. Uma topologia em regime físico, mas com traços de uma individuação física. Ao invés de apoiar-se na estrutura topológica primordial de interioridade e exterioridade, o processo de espacialização das linhas chave opera em localidades côncavas e convexas, quer dizer, em uma zona liminar entre elas. Pode-se estabelecer uma analogia entre a topologia dos acidentes geográficos e a topologia dos campos eletromagnéticos, neste contexto entre as linhas de contorno das keylines e as radiações, assinalando a falsa distinção que há entre a frequência ondulatória e o seu inverso, o comprimento de onda; e, com relação ao segundo termo, poder constatar um outro tipo de anverso, como "uma depressão semelhante à das colinas que retêm em seu cimo um acúmulo de água" (GRANET 1997: 237). ${ }^{521}$ Simondon sempre insistiu que as duas realidades dos seres físicos luminosos "não são idênticas nem heterogêneas, mas contíguas", bastando-lhes ultrapassar seus limites por um método de transdução, amadurecendo no processo uma "topologia da transdutividade" (SIMONDON 2005: 107). Esse mesmo padrão de contiguidade

521 Nesta citação, o sinólogo francês refere-se ao pensador Confúcio, que tinha no topo de seu crânio um rebaixamento, fisiologia esta que rendeu-lhe o nome de família "outeiro côncavo", imagem inspiradora para nossa analogia de inversões topológicas. 
revela-se no planejamento das keylines, precisamente quando, na confecção do modelo, as linhas superiores e inferiores desviam-se de seus respectivos contornos, por força da acentuação dos declives. Em suma, na aplicação tradicional desses padrões, tudo é uma questão de compensar, no controle do terreno, os níveis das curvas ascendentes e das curvas descendentes. Ademais, o método é um expoente de adequação tecnológica, porque tira partido, de forma passiva, da força da gravidade na distribuição hidrométrica das vazões, guiando-as para áreas de captação através de canais, de preferência escavados por implementos agrícolas do gênero arado subsolador. Contudo, recorrer às leis da física na condução das águas pluviais não configura uma situação de ciência aplicada; reconhece-se aqui o vir-aser comunitário com a replicação e transmissão de conhecimentos geométricos ancestrais, porque "a passagem do levantamento topográfico para a geometria só é possível através da produção de idealidades irredutíveis à experimentação" (STIEGLER 1996: 131). 


\section{CONCLUSÃO}

O pensamento ecológico, oculto em potência no interior da fase técnica exposta por Simondon, é um dos sinais para se compreender a hipótese da presente tese. Tal pensar em hiato, previsto pelo filósofo francês, mas não contemplado por ele, se fez ouvido nos dias atuais e, convictos de sua relevância, cedemos-lhe a sua manifestação. Ele colocou-se em paridade com o pensamento tecnológico, inicialmente de forma conflituosa, mas logo depois consentindo com a mediação de um pensamento estético - e não fortuitamente, porque os esquemas sempre pertenceram ao fundo original sobre o qual perfilam. O primeiro desfecho de tal articulação é que o pensamento ecológico convém com o pensamento mesológico, um pensamento que compreende, segundo Augustin Berque, uma escala ontológica da realidade constituída de três níveis, sendo o físico não redutível ao biológico e ao humano. ${ }^{522}$ É nítida a convergência do momento estrutural de Watsuji, comentada no primeiro capítulo, com a congruência estrutural dos viventes, de Maturana e Varela (2010: 108), segundo a qual "uma pertubação do meio não contém em si uma especificação de seus efeitos sobre o ser vivo. Este, por meio de sua estrutura, é que determina quais as mudanças que ocorrerão em resposta". E também com Uexküll, para quem o meio não determina as variações, apenas dispõe os seres em condições de interpretá-lo (ou, por que não dizer?: construí-lo), segundo suas próprias proclividades. O acoplamento dinâmico entre indivíduos e meio, é imperativo ressaltar, está presente em três esferas do sistema Terra (a saber: hidrosfera, atmosfera e biosfera), consoante as novas teorias do materialismo vital (BENNETT 2010). O pensamento ecológico, o da conectividade total entre os seres do meio ambiente, se faz presente junto ao tecnológico, mas com um semblante mesológico, com pendor mais para o meio do que para o ambiente.

A empresa implicada na definição de uma estética ecotécnica não seria possível sem a investigação, por mais efêmera que fosse, sobre a relação entre figura e fundo e, por conseguinte, sobre o fenômeno da percepção. Expusemos, nessa peripécia filosófica, pormenores em dois registros, tanto do construtivismo cibernético de segunda ordem, como da fenomenologia de Merleau-Ponty, na interpretação de Simondon e Dufrenne, mas reconhecemos - e acautelamos - que 522 Ver tabela 6.1 em BERQUE 2013, p. 57. 
seria reconhecidamente hercúlea a tarefa de circunstanciar um eventual construtivismo fenomenológico, ou uma "fenomenologia construtiva", segundo as aspirações de Husserl (MERLEAU-PONTY 1999: 1). Os problemas da fenomenologia, a despeito de todo o seu histórico, estão longe de ser resolvidos. $O$ nosso propósito, portanto, foi tão-somente matizar duas essências do pensamento estético: a questão da forma e da percepção. "A forma é adequada ao sentido, escreve Dufrenne (2015: 202), se se realiza a imanência do sentido ao sensível", isso tratando-se de um objeto de arte, mas poderíamos expandir tal sentido a todos os objetos belos, sejam eles declaradamente estéticos - ou não, como os objetos tecno-ambientais analisados no terceiro capítulo. Pode-se inferir, quanto ao sentido de certos objetos tecno-ambientais analisados, que o conteúdo da forma assenta-se nos confins do horizonte e o conteúdo do fundo é - não sem surpresa - a própria figura. Entendemos que o sentido preconizado por Dufrenne é dado sobretudo por formas ajustadas adequadamente ao fundo, ou seja, ao "real inexaurível" (op. cit.: 200), simbolizado pelo fundo, versão visual do meio multisensorial: a natureza em pleno movimento e consagração. Dinamismo evidente inclusive nas formas, pois "tão importante quanto o problema da forma (Gestalt) é o da formação (Gestaltung)" (ARGAN 1992: 272). (Formação: sinônimo de construção, e mesmo de individuação). Pode-se dizer que o pensamento estético é indissociável da reticulação formada por figura e fundo e que não se restringe a um domínio limitado, como a arte, posto que é uma "tendência fundamental do ser humano" ${ }^{523}$

O pensamento tecnológico é assinalado, em primeira instância, pela rubrica de um pensamento técnico, favorável à tecnicidade dos objetos técnicos. Contudo, não nos dispusemos erradicar em definitivo o logos inscrito na palavra "tecnologia", porquanto nos pareceu adequado manter um grau de racionalidade na instituição de uma mecanologia educacional e de uma intencionalidade cognitiva. Rasuramos o logos da palavra tecnologia somente em reação à sua mistificação, promovida pela crença no desenvolvimento técnico exponencial, expresso na assíntota da singularidade tecnológica e do transumanismo, hipóteses caras aos magos do Vale do Silício. Eis, portanto, o primeiro encargo. O segundo, não menos importante, procura revelar um pensamento que ofereça um significado mais ecológico que antropológico ao processo técnico, em suma, aos processos de fabricação. A 523 Ver DUHEM, Ludovic. Simondon y la Cuestión Estética. Demarcaciones, n.4, 2016. 
essência da operação técnica restringe-se, segundo os ensinamentos tradicionais, na causa eficiente: produtor, artesão, mecânico. Diferencia-se da causa eficiente de um objeto natural, que é o seu próprio ser, emergido da necessidade peculiar de uma natureza naturante disposta a desdobrar-se, multiplicar-se, desenvolver-se. Mas a causa eficiente da operação técnica é, por assim dizer, a sua causa final. Elas se confundem, segundo Aristóteles e seus arautos modernos. Daí o legado da instrumentalidade do objeto técnico, cuja razão de existir é o de ser o expediente destinado a fins específicos. Não é de nossa conta refutar aqui tais causas. Faz-se mister, na definição de uma estética ecotécnica, contemplar as funções, os funcionamentos e as formas dos objetos. Mantemos apenas a convicção de que a poiesis técnica deva assemelhar-se à poiesis da physis, como se as duas estivessem de comum acordo, associadas (o termo "meio associado", examinado por Simondon, nos vem à cabeça), cooperativadas, o homem sendo mais um "parteiro" do que um extrativista. Não se trata de uma biomimese, como vimos em diversas seções ao longo da tese, movimento por demais apegado às formas, mas de uma mimese operativa: o modelo (ou o exemplo, como nos ensina Eduardo Viveiros de Castro) é a própria constituição dos indivíduos. Diversos autores já lançaram a proposta conceitual de que a natureza naturante, por meio da causa eficiente das técnicas, operadas pelo homem (uma de suas criaturas, reconheçamos), obtém produtos variados (naturezas naturadas), reconhecidos como resultados de uma genuína causa final. Nesse sentido, as técnicas não estariam a serviço de um projeto de manipulação dos objetos naturais, de sua exploração ilimitada, mas de sua revelação (quase no sentido heideggeriano), como se a causa final de um engenheiro, a causa eficiente, fosse não apenas construir uma ponte ou um viaduto funcional, mas um objeto belo, acabado.

Os dilemas da estética ambiental de Allen Carlson, como vimos, não são absolutamente ordinários. Para se combater a noção de desinteresse, ele recorre à conceitualização do sujeito; para desfazer-se de quaisquer traços teístas da estética positiva, a atenção volta-se ao objeto constituído. Vimos, na seção sobre o assunto, como se estrutura a estratégia orientada ao objeto, um produto posicionado a meio caminho entre a arte pura e a natureza "adâmica", sendo, por conseguinte, funcional. Já a estética de Arnold Berleant é menos cognitiva e mais 
fenomenológica. Mas mesmo o retorno às próprias coisas se abre à significação, a uma forma revestida de informação, pois "todo fenômeno traz consigo um sentido, ao mesmo tempo porque o sujeito está sempre presente no dado para organizá-lo e comentá-lo e porque o dado jamais se oferece como bruto e insignificante à maneira dos sense-data que o empirismo imagina" (DUFRENNE 2015: 196). O real sensível torna-se uma espécie de "realidade aumentada" se the for justaposto um conhecimento que o ative, não o rechace. A projeção cognitiva não se confunde com o cientificismo ou mesmo com o correlacionismo, ideia descrita como "a afirmação de uma relação de pressuposição recíproca entre o pensamento e o ser" (DANOWSKI \& VIVEIROS DE CASTRO 2015: 47). Arroubos ontológicos à parte, recapitulamos que a ontologia insinua-se nesse trabalho como uma espécie de radiação cósmica de fundo - por apreço aos modos de ser examinados por Simondon. A correlação, se tivermos impreterivelmente de acedê-la, é entre o pensamento e o sensível, ou melhor, entre dois momentos da percepção, intercalados por uma intelecção não expansionista.

Uma das inspirações da estética ecotécnica é, por certo, a tecno-estética, expressão explicitamente manifestada por Simondon somente às vésperas de sua morte. Mas isso não significa que seu espectro não tenha rondado diversas passagens de sua obra. É razoável inquirir: quais objetos técnicos se enquadrariam dentro da noção de tecno-estética? Numa vista d'olhos seletiva sobre o texto de Simondon exclusivamente voltado ao tema - a sua carta a Jacques Derrida defrontamo-nos com o seguinte "inventário": capelas, tratores, carros de corrida, passeios, lógias, prédios, muralhas, igrejas, telhados, tubulações, cabos, lambris, torres, viadutos, antenas, alicates, tesourões, chaves de bicicleta, limas, foices, enxós, tornos, brocas, pianos, harpas, pincéis, broxas, facas, parafusos, radares, carros de passeio, pinturas sfumato, manequins, basic foods, eletricidade, antenas, motores, baterias, caixas d'água, estradas e casas enxaimel. Em meio a exemplos retirados da engenharia mecânica e civil, elementos da arquitetura, instrumentos musicais e utensílios variegados, nota-se a inclusão de artigos aparentemente alheios ao conjunto, como fenômenos naturais, técnicas de engenharia alimentar, vestuário e, em discrição absoluta, uma referência ao mundo das artes plásticas, um parágrafo com a análise a respeito do "sorriso incoativo" da Gioconda. Prova cabal 
de que a região situada entre arte e tecnologia é - sempre foi, convenhamos - uma zona de conflito. Vários pensadores - como Kant, Hegel e Heidegger - eram convictos de que a arte é irredutível à técnica, sendo a sua combinação uma incompatibilidade, quase um erro de categoria, mas, no íntimo, reconheciam-na como imprescindível à praxis artística. ${ }^{524} \mathrm{~A}$ tecno-estética ergueu-se para reconciliálas em definitivo. Bem como o corpo e o utensílio, sendo ele próprio uma ferramenta, no modelo de uma organologia. ${ }^{525}$ A eletricidade e os dispositivos de visualização... Enfim. O que se pode extrair desse programa, que não deve ter impressionado Derrida, ${ }^{526}$ é a gênese de uma axiologia na qual a proposição de beleza expressa na junção da técnica e da estética é demonstrada por meio de um funcionamento efetivo de um objeto, seja operacional ou estrutural. Tal como os objetos tecnoambientais dissertados no segundo e terceiro capítulos.

Como assinalamos no início do trabalho, a estética ecotécnica se acha no entremeio de duas outras estéticas, mas estaria ela em outras posições intermédias, como aquela que Simondon propõe: entre técnica e religião? Sim, porque o esquema genético da estética ecotécnica seria, sob determinada perspectiva, um 'quasi-espelho' do primeiro desdobramento do sistema simondoniano, difratando-se em virtude de sua individuação ocorrer no interior da fase técnica. E, de fato, é. Com a exceção de que, ao invés de abarcar todo o domínio da religião - por si só vasto -, nosso esquema integra apenas um aspecto dela, o da ecologia. $E$ não seria a ecologia, hoje, uma forma de teologia? Tome-se, a título de prova, a encíclica Laudato si, do Papa Francisco, sobre o cuidado que a humanidade deve tomar com relação à casa comum... 


\section{REFERÊNCIAS}

ADAMATZKY, Andrew. Reaction-Diffusion Automata: Phenomenology, Localisations, Computation. New York: Springer, 2012.

ADAMATZKY, Andrew; THERESA, Schubert. Experiencing The Unconventional: Science In Art. Singapura: World Scientific, 2015.

ADAMATZKY, Andrew; MARTÍNEZ, Genaro J. (orgs.). Designing Beauty: The Art of Cellular Automata. [s.I.]: Springer International Publishing, 2016.

ALEXANDER, Christopher. The Timeless Way of Building. New York: Oxford University Press, 1979.

ALLEN, Jamie; HOWSE, Martin (orgs.). SR_TRANSMEDIALE READER - For: Earth Observatory Array Activation Workshop (EOAAW) at Silent Green 24th Februrary 2017. Basel: Shift Register, 2017a.

ALLEN, Jamie; HOWSE, Martin (orgs.). Earth Observatory Array Elements Treak Cliff (EOA-TC). Basel: Shift Register, 2017b.

ALLEN, Jamie; HOWSE, Martin (orgs.). Earth Observation Source (EOS) Workshop, Hyytiälä Forestry Field Sation - September, 2017. Basel: Shift Register, 2017c.

ALLEN, Jamie; HOWSE, Martin (orgs.). ShR_Montreal - Response - Snowfall Permafrost - Collection \& Retention - Hydrometers - Reflection of Snow Measurement. Basel: Shift Register, 2017d.

ANDERSON, Benedict. Comunidades Imaginadas. São Paulo: Companhia das Letras, 2008.

ANDRADE, Oswald de. A Utopia Antropofágica: A Antropofagia ao Alcance de Todos. São Paulo: Globo Livros, 1990.

APPRICH, Clemens et. al. (orgs). Provocative Alloys: A Post-Media Anthology. [s.l.]: Mute Publishing \& Leuphana University, 2013.

ARAÚJO, Hermetes Reis de (org.). Tecnociência e Cultura: Ensaios Sobre o Tempo Presente. Estação Liberdade: São Paulo, 1998.

ARGAN, Giulio Carlo. Arte Moderna. São Paulo: Companhia das Letras, 1992.

ARMSTRONG, Rachel. Vibrant Architecture: Matter as a CoDesigner of Living Structures. Berlin: Walter de Gruyter GmbH \& Co KG, 2015. 
ASQUITH, Lindsay; VELLINGA, Marcel (eds.). Vernacular Architecture in the 21st Century: Theory, Education and Practice. London; New York: Taylor \& Francis, 2005.

BARDIN, Andrea. Epistemology and Political Philosophy in Gilbert Simondon. Dordrecht: Springer Netherlands, 2015.

BARTHÉLÉMY, Jean-Hugues. Cahiers Simondon, nº 3. Paris: L'Harmattan, 2011.

BATAILLE, Georges. Prehistoric Painting: Lascaux, or The Birth of Art. Genebra: Skira, 1955.

BATESON, Gregory. Steps to an Ecology of Mind: Collected Essays in Anthropology, Psychiatry, Evolution, and Epistemology. Chicago: University of Chicago Press, 2000.

BAUS, Ursula; SCHLAICH, Mike; DECHAU, Wilfried. Footbridges: Construction, Design, History. Basel : Boston: Birkhauser Verlag AG, 2007.

BEESLEY, Philip (org.). Hylozoic Ground: liminal responsive architecture. Cambridge: Riverside Architectural Press, 2010a.

BEESLEY, Philip (org.). Kinetic Architectures and Geotextile Installations. Cambridge: Riverside Architectural Press, 2010b.

BELISÁRIO, Adriano (org.). Tecnomagia. Rio de Janeiro: Imotirõ, 2014.

BENNETT, Jane. Vibrant Matter: a political ecology of things. Durham; London: Duke University Press, 2010.

BERLEANT, Arnold. The Aesthetics of Environment. Philadelphia: Temple University Press, 1995.

BERQUE, Augustin (org.); CONAN, Michel; DONADIEU, Pierre; LASSUS, Bernard; ROGER, Alain. Cinq Propositions Pour une Théorie du Paysage. Ceyzérieu: Editions Champ Vallon, 1994.

BERQUE, Augustin. EI Pensamiento Paisajero. Madrid: Editorial Biblioteca Nueva, 2009.

BERQUE, Augustin. Thinking Through Landscape. London; New York: Routledge, 2013.

BILLINGTON, David P. The Tower and the Bridge: The New Art of Structural Engineering. Princeton, New Jersey: Princeton University Press, 1985.

BISHOP, Claire. Participation. London, Cambridge: Whitechapel, MIT Press, 2006. 
BOEVER, Arne De; MURRAY, Alex; ROFFE, Jon (orgs.). Gilbert Simondon: Being and Technology. Edinburgh: Edinburgh University Press, 2013.

BOOKCHIN, Murray. Post-scarcity Anarchism. Montreal; Buffalo: Black Rose Books, 1986.

BONNEMAISON, Sarah; EISENBACH, Ronit. Installations by Architects:

Experiments in Building and Design. New York: Princeton Architectural Press, 2009.

BRASIL. Vamos cuidar do Brasil com escolas sustentáveis: educando-nos para pensar e agir em tempos de mudanças socioambientais globais. Elaboração Teresa Moreira. MEC/MMA. Brasília, 2012.

BROGLIO, Ron. Technologies of the Picturesque: British Art, Poetry, and Instruments, 1750-1830. Cranbury: Associated University Presse, 2008.

CANAVAN, Gerry; ROBINSON, Kim Stanley. Green Planets: Ecology and Science Fiction. Middletown, Connecticut: Wesleyan University Press, 2014.

CANDLIN, Fiona; GUINS, Raiford. The Object Reader. London; New York: Routledge, 2009.

CANGUILHEM, Georges. Knowledge of Life. New York: Fordham Univ Press, 2008.

CANN Du Charlotte, KINGSNORTH, Paul, SMITH, Tom, WHEELER, Steve (orgs.). Dark Mountain \#8: Technê, 2015.

CARLSON, Allen. Aesthetics and the Environment: The Appreciation of Nature, Art and Architecture. New York: Psychology Press, 2002.

CHABOT, Pascal. The Philosophy of Simondon: Between Technology and Individuation. London; New York: A\&C Black, 2013.

CHIDESTER, David; LINENTHAL, Edward T. (orgs.). American Sacred Space. Indiana University Press: Bloomington, 1995.

COMBES, Muriel. Gilbert Simondon and the Philosophy of Transindividual. London: The MIT Press, 2013.

CORBUSIER, Le. Towards a New Architecture. New York: Dover Publication, Inc., 1986.

CUTCLIFFE, Stephen H.; POST, Robert C. In Context: History and the History of Technology: Essays in Honor of Melvin Kranzberg. Bethlehem, Pa.: Lehigh University Press, 1989. 
DANOWSKI, Déborah; VIVEIROS DE CASTRO, Eduardo. Há Mundo Por Vir? Ensaio Sobre os Medos e os Fins. Desterro [Florianópolis]: Cultura e Barbárie: Instituto Socioambiental, 2014.

DAVIS, Heather. TURPIN, Etienne (orgs.). Art in the Anthropocene: Encounters Among Aesthetics, Politics, Environments and Epistemologies. London: Open Humanities Press, 2015.

DEANE-DRUMMOND, Celia; BERGMANN, Sigurd; SZERSZYNSKI, Bronislaw. Technofutures, Nature and the Sacred: Transdisciplinary Perspectives. New York: Routledge, 2016.

DE BOEVER, Arne; MURRAY, Alex; ROFFE, Jon; WOODWARD, Ashley (orgs.). Gilbert Simondon: Being and Technology. Edinburgh University Press, 2012.

DELEUZE, Gilles; GUATTARI, Felix. A Thousand Plateaus: Capitalism and Schizophrenia. Trad. Brian Massumi. Minneapolis: University of Minnesota Press, 1987.

DUFRENNE, Mikel. The Phenomenology of Aesthetic Experience; [tradução Edward S. Casey]. Evanston: Northwestern University Press, 1973.

DUFRENNE, Mikel. Estética e Filosofia; [tradução de Roberto Figurelli]. São Paulo: Perspectiva, 2015.

DUPUY, Jean-Pierre. O Tempo das Catástrofes: Quando o Impossível é uma Certeza. São Paulo: Realizações Editora, 2011.

EDWARDS, Paul N. A Vast Machine: Computer Models, Climate Data, and the Politics of Global Warming. Cambridge, Massachusetts; London, England: The MIT Press, 2013.

EGEBJERG, Ulla (org.). Beautiful Roads: a Handbook of Road Architecture. Copenhagen: Danish Road Directorate, 2002.

ETZLER, John Adolphus. The Paradise Within the Reach of All Men, Without Labour, by Powers of Nature and Machinery?: An Address to All Intelligent Men. London: John Brooks, 1836.

FERRY, Robert; MONOIAN, Elizabeth. A Field Guide to Renewable Energy Technologies. Pittsburgh: Society for Cultural Exchange, 2012.

FLORIDI, Luciano. Information: A Very Short Introduction. [s.I.]: OUP Oxford, 2010.

FLUSSER, Vilém; RÖTZER, Florian. Dinge und Undinge: Phänomenologische Skizzen. München: Carl Hanser, 1993.

FOSTER, Hal. O Complexo Arte-arquitetura. São Paulo: Cossaf Naify, 2015. 
FOSTER, John. After Sustainability: Denial, Hope, Retrieval. Nova York: Routledge, 2014.

FRAMPTON, Kenneth. Modern Architecture: a Critical History. London: Thames and Hudson, 1985.

GILCHRIST, Bruce; JOELSON, Jo. Remote Performances in Nature and Architecture. New York: Routledge, 2016.

GILLE, Bertrand. History of Techniques: Techniques and civilizations. New York: Gordon and Breach Science Publishers, 1986.

GILPIN, William. Observations on the River Wye: And Several Parts of South Wales, \&c. Relative Chiefly to Picturesque Beauty, Made in the Summer of the Year 1770. London: A. Strahan, 1800.

GLEICK, James. A Informação: Uma História, uma Teoria, uma Enxurrada. São Paulo: Companhia das Letras, 2013.

GRANET, Marcel. O Pensamento Chinês. Rio de Janeiro: Contraponto, 1997.

GRAUGAARD, Jeppe Dyrendom. Transforming Sustainabilities: Grassroots Narratives in an Age of Transition. An Ethnography of the Dark Mountain Project. A thesis submitted to the School of Environmental Sciences of the University of East Anglia for the degree of Doctor of Philosophy, 2014.

GREER, John Michael. The Ecotechnic Future: Envisioning a Post-Peak World. Gabriola Island: New Society Publishers, 2009.

GUERRA, Tonino. Instant Light: Tarkovsky Polaroids. London: Thames \& Hudson, 2006.

GUZIK, Ariel. Holoturian. London: Arts Catalyst, 2015.

HARNDEN, Roger; LEONARD, Allenna (orgs.). How Many Grapes Went into the Wine: Stafford Beer on the Art and Science of Holistic Management. Chichester ; New York: Wiley, 1994.

HAYES, Brian. Infrastructure: The Book of Everything for the Industrial Landscape. New York; London: W. W. Norton \& Company, 2006.

HEBEL, Dirk E.; HEISEL, Felix. Cultivated Building Materials. Basel; Boston: Birkhäuser, 2017.

HEGEL, G.W.F. Introductory Lectures on Aesthetics. Londres: Penguin Books, 1993.

HEIDEGGER, Martin. Discourse on Thinking. New York: Harper \& Row, 1966. 
HEIDEGGER, Martin. The Question Concerning Technology, and Other Essays. New York, NY: Harper Torchbooks, 1977.

HEIDEGGER, Martin. Basic Writings: Second Edition, Revised and Expanded. New York: HarperCollins, 1993.

HOLDEN, Robert; LIVERSEDGE, Jamie. Landscape Architecture: An Introduction. London: Laurence King Publishing, 2014.

HOMERO. Odisséia; [tradução de Manoel Odorico Mendes]. Atena Editora: São Paulo. 2009.

HOTTOIS, Gilbert. Simondon et la Philosophie de la "Culture Technique". Bruxelles: De Boeck Université, 1993.

HUISMAN, Denis; PATRIX, Georges. A Estética Industrial. São Paulo: Difusão Européia, 1967.

INWOOD, Michael. Dicionário Heidegger. Rio de Janeiro: Zahar, 2002.

JAMESON, Fredric. A Virada Cultural: Reflexões Sobre o Pós-modernismo. Rio de Janeiro: Editora Civilização Brasileira, 2006.

JONAS, Hans. O Princípio Responsabilidade: Ensaio de uma Ética para a Civilização Tecnológica. Rio de Janeiro: Contraponto, 2006.

JONES, Ray. Lighthouse Encyclopedia: The Definitive Reference. Guilford, Conn: Globe Pequot Press, 2013.

KASTNER, Jeffrey; WALLIS, Brian. Land and Environmental Art. London; New York, NY: Phaidon Press, 2010.

KOREN, Leonard. Wabi-sabi for Artists, Designers, Poets \& Philosophers. Point Reyes, California: Imperfect Publishing, 2008.

KWON, Miwon. One Place After Another: Site-specific Art and Locational Identity. Cambridge \& London: MIT Press, 2004.

LANSING, J. Stephen. Priests and Programmers: Technologies of Power in the Engineered Landscape of Bali. Princeton: Princeton University Press, 2009.

LENGEN, Johan van. The Barefoot Architect. Bolinas, Califórnia: Shelter Publications, Inc., 2007.

LEROI-GOURHAN, André. Gesture and Speech. Cambridge \& London: MIT Press, 1993. 
LEOPOLD, Aldo. A Sand County Almanac, and Sketches Here and There. New York: Oxford University Press, 1989.

MACHADO, Arlindo. Arte e Mídia. Rio de Janeiro: Jorge Zahar, 2010.

MAIERS, Michael. Atalanta Fugiens. [s.I.]: Old Book Publishing Limited, 2015.

MARCONI, Marina de Andrade; LAKATOS, Eva Maria. Fundamentos de Metodologia Científica. São Paulo: Atlas, 2003.

MATURANA R., Humberto; VARELA GARCIA, Francisco J. De Máquinas e Seres Vivos: Autopoiese - a Organização do Vivo. Porto Alegre: Artes Medicas,1997.

MATURANA R., Humberto; VARELA GARCIA, Francisco J. A Árvore do Conhecimento: As Bases Biológicas da Compreensão Humana. São Paulo: Palas Athena, 2010.

MINKE, Gernot. Building with Bamboo: Design and Technology of a Sustainable Architecture. Basel: Birkhauser Architecture, 2012.

MONTAG, Daro (Org.). Artful Ecologies: Art, Nature and Environment Conference 2006. Falmouth, Cornwell, England: Festerman, 2008.

MORTON, Timothy. Ecology Without Nature: Rethinking Environmental Aesthetics. Cambridge MA: Harvard University Press, 2007.

MORTON, Timothy. The Ecological Thought. Reprint edition. Cambridge, Mass.; London: Harvard University Press, 2010.

MORTON, Timothy. Dark Ecology: For a Logic of Future Coexistence. [s.I.]:

Columbia University Press, 2016.

MÜLLER, Albert; MÜLLER, Karl H. An Unfinished Revolution?: Heinz Von Foerster and the Biological Computer Laboratory, BCL, 1958-1976. Vienna: Edition Echoraum, 2007.

MUSEUM OF MODERN ART (New York, N.Y.). Cubism and Abstract Art. New York: The Museum of Modern Art, 1936.

MUSIL, Robert. Flypaper. London: Penguin UK, 2013.

NETTESHEIM, Heinrich Cornelius Agrippa von. Três Livros De Filosofia Oculta. São Paulo: Madras, 2008.

NIETZSCHE, Friedrich. Aurora. São Paulo: Editora Escala, 2008.

PARIKKA, Jussi. A Geology of Media. Minneapolis. London: University of Minnesota Press, 2015. 
PAUL, Christiane. A Companion to Digital Art. Hoboken, New Jersey: WileyBlackwell, 2016.

PEARSON, David. New Organic Architecture: The Breaking Wave. London: Gaia Books Limited, 2001.

PETERS, John Durham. The Marvelous Clouds: Toward a Philosophy of Elemental Media. Chicago ; London: University Of Chicago Press, 2015.

PINTO, Álvaro Vieira. O Conceito de Tecnologia (Volume I, capítulo III: A técnica). Rio de Janeiro: Editora Contraponto, 2005.

PLATÃO. Ílon. Belo Horizonte: Autêntica, 2011.

PLATÃO. Hípias Maior; [tradução de Carlos Alberto Nunes]. Editora da Universidade Federal do Pará, 1980.

PHILO, Chris; WILBERT, Chris (orgs.). Animal Spaces, Beastly Places. London; New York: Routledge, 2000.

PICKERING, Andrew. The Cybernetic Brain: Sketches of Another Future. [s.I.]: University of Chicago Press, 2010.

PRICE, Sir Uvedale; LAUDER, Sir Thomas Dick. Sir Uvedale Price, On the Picturesque. Londres: Caldwell, Lloyd, 1842.

PYNCHON, Thomas. Arco-íris da Gravidade; [tradução de Paulo Henriques Britto]. São Paulo: Companhia das Letras, 1998.

RANCIĖRE, Jacques. Dissensus: On Politics and Aesthetics. London: Bloomsbury Publishing, 2015.

RAY, Priyadaranjan. History of Chemistry in Ancient and Medieval India: Incorporating the History of Hindu Chemistry. Calcutá: Indian Chemical Society, 1956.

REBOUÇAS, Julia; VOLZ, Jochen (eds.). Catálogo da $32^{a}$ Bienal de São Paulo Incerteza Viva. São Paulo: Bienal de São Paulo, 2016.

REIZNER, Jason M. Südthüringer-Wald-Institut: Knowledge Sharing for the End of the World. 2012. 60 f. Dissertação (Mestrado em Mídia Arte / Design de Mídia). Fakultät Medien. Bauhaus-Universität Weimar, Alemanha.

RIVKIN, Julie; RYAN, Michael. Literary Theory: An Anthology. Malden, MA: Blackwell Pub, 2004.

RYKER, Lori; HALL, Audrey. Off The Grid Homes: Case Studies for Sustainable Living. Salt Lake City, Utah: Gibbs Smith, 2007. 
ROBINSON, Kim Stanley. Red Mars. London: Voyager, 1995.

RUDOFSKY, Bernard. Architecture Without Architects: A Short Introduction to Non-pedigreed Architecture. Garden City, New York: Doubleday \& Company, Inc., 1964.

SAHLINS, Marshall. Cultura e Razão Prática. Rio de Janeiro: Zahar, 2003.

SARTI, Alessandro; MONTANARI, Federico GALOFARO, Francesco (orgs.). Morphogenesis and Individuation. Cham: Springer International Publishing, 2015.

SCHRODINGER, Erwin. What is Life?: With Mind and Matter and Autobiographical Sketches. Cambridge: Cambridge University Press, 2012.

SCHULZ, Bruno. Ficção Completa. São Paulo: Cosac \& Naify, 2012.

SCHUMACHER, E. F. Small Is Beautiful: Economics as if People Mattered. New York, NY: Harper Perennial, 2010.

SELIGMAN, Paul. The "Apeiron" of Anaximander: A Study in the Origin and Function of Metaphysical Ideas. London: The Athlone Press, 1962.

SEPP, Hans Rainer; EMBREE, L. (orgs.). Handbook of Phenomenological Aesthetics. Dordrecht: Springer Netherlands, 2009.

SHARR, Adam. Heidegger's Hut. Cambridge, Massachusetts: MIT Press, 2006.

SHELLEY, Mary. Frankenstein, ou o Moderno Prometeu; (Tradução de Bruno Gambarotto). São Paulo: Hedra, 2013.

SHERIF, Mostafa Hashem. Ad Hoc Networks: 5th International ICST Conference, ADHOCNETS 2013, Barcelona, Spain, October 2013, Revised Selected Papers. [s.l.]: Springer, 2014.

SIMONDON, Gilbert. Du Mode d'Existence des Objets Techniques. Paris: AubierMontaigne, 1969.

SIMONDON, Gilbert. Sobre a Tecno-estética: Carta a Jacques Derrida; [tradução de Stella Senra]. Les Papiers du Collège de Philosophie, $n^{\circ}$ 12, 1992. In: ARAÚJO, 1998.

SIMONDON, Gilbert. L'individuation à la Lumière des Notions de Forme et d'Information. Grenoble: Jérôme Millon, 2005.

SIMONDON, Gilbert. El modo de Existencia de los Objetos Técnicos. Buenos Aires: Prometeo Libros, 2008a. 
SIMONDON, Gilbert. Imagination et Invention. Paris: Les Editions de la transparence, 2008b.

SIMONDON, Gilbert. Imaginación e Invención: (1965-1966). Buenos Aires: Cactus, 2008c.

SIMONDON, Gilbert. La Individuación a la Luz de las Nociones de Forma y de Información. Buenos Aires: La Cebra y Cactus, 2009.

SPECK, Jeff. Walkable City: How Downtown Can Save America, One Step at a Time. New York: Farrar, Straus and Giroux, 2012.

STEPNEY, Susan; ADAMATZKY, Andrew (Orgs.). Inspired by Nature. Cham: Springer International Publishing, 2018, v. 28, p. 357-387.

STIEGLER, Bernard. Technics and Time, 1: The Fault of Epimetheus. California: Stanford University Press, 1998.

STIEGLER, Bernard. Technics and Time, 2: Disorientation. California: Stanford University Press, 2009.

STIEGLER, Bernard. Technics and Time, 3: Cinematic Time and the Question of Malaise. California: Stanford University Press, 2011.

STIEGLER, Bernard. What Makes Life Worth Living: On Pharmacology; [tradução de Daniel Ross]. Cambridge: Polity Press, 2013.

STIEGLER, Bernard. States of Shock: Stupidity and Knowledge in the 21st Century. Cambridge; Malden, MA: Polity, 2015.

STIEGLER, Bernard. The Neganthropocene. London: Open Humanites Press, 2018.

STRANG, Veronica; EDENSOR, Tim; PUCKERING, Joanna (orgs.). From the Lighthouse: Interdisciplinary Reflections on Light. London; New York: Routledge, 2018.

TARDE, Gabriel. Underground Man. Westport, Connecticut: Hyperion Press, Inc., 1974.

TSING, Anna Lowenhaupt. The Mushroom at the End of the World: On the Possibility of Life in Capitalist Ruins. Princeton \& Oxford: Princeton University Press, 2015.

TUFNELL, Ben. Land Art. London; New York: Tate Publishing, 2007.

URSPRUNG, Phillip. Allan Kaprow, Robert Smithson, and the Limits to Art. University of California Press, 2013. 
VALENTIM, Marco Antonio. Extramundanidade e Sobrenatureza: Ensaios de Ontologia Infundamental. Florianópolis: Cultura e Bárbarie, 2018.

VALÉRY, Paul. Eupalinos ou O Arquiteto. Edição: Edição bilíngue francês / português. Rio de Janeiro: Editora 34, 1996.

VERNADSKY, Vladimir I. The Biosphere. New York, NY: Springer New York, 1998.

VIJVER, Gertrudis van de (org.). New Perspectives on Cybernetics: SelfOrganization, Autonomy and Connectionism. Dordrecht: Springer, 1992.

ZENG, Jack; THAMWISET, Sukhumam Bo; PHIRIYAPHONGSAK, Walee; GUO, Xin. mycoFARMX. London: Architectural Association, 2011.

ZIELINSKI, Siegfried. Deep Time of the Media: Toward an Archaeology of Hearing and Seeing by Technical Means. London: MIT Press, 2006.

YANEVA, Albena; ZAERA-POLO, Alejandro (eds.). What is Cosmopolitical Design? Farnham: Ashgate, 2015.

YOVITS, M. C.; CAMERON, S (orgs.). Self-Organizing Systems. Oxford: Pergamon Press, 1960.

WARK, McKenzie. Molecular Red. New York: Verso Books, 2015.

WATSUJI, Tetsuro. Antropología del Paisaje: Climas, Culturas y Religiones.

Salamanca: Sígueme, 2006.

WIENER, Norbert. Cybernetics or Control and Communication in the Animal and the Machine. Cambridge: MIT Press, 1961.

WULF, Andrea. The Invention of Nature: Alexander von Humboldt's New World. New York: Knopf Doubleday Publishing Group, 2015. 